UNIVERSIDADE DE SÃO PAULO

DEPARTAMENTO DE ENGENHARIA DE TRANSPORTES

FERNANDA PILATI SOBREIRO

EFEITO DA ADIÇÃO DE ÁCIDOS FOSFÓRICOS NO COMPORTAMENTO REOLÓGICO DE LIGANTES ASFÁLTICOS PUROS E MODIFICADOS COM COPOLÍMERO SBS 
FERNANDA PILATI SOBREIRO

\section{EFEITO DA ADIÇÃO DE ÁCIDOS FOSFÓRICOS NO COMPORTAMENTO REOLÓGICO DE LIGANTES ASFÁLTICOS PUROS E MODIFICADOS COM COPOLÍMERO SBS}

Tese apresentada à Escola de Engenharia de São Carlos, da Universidade de São Paulo, como parte dos requisitos para obtenção do Título de Doutor em Ciências, Programa de Pós-Graduação em Engenharia de Transportes. Área de Concentração: Infraestrutura de Transportes.

Orientador: Prof. Dr. Glauco Tulio Pessa Fabbri.

\section{São Carlos}

2014 
AUTORIZO A REPRODUÇÃO E DIVULGAÇÃO TOTAL OU PARCIAL DESTE TRABALHO, POR QUALQUER MEIO CONVENCIONAL OU ELETRÔNICO, PARA FINS DE ESTUDO E PESQUISA, DESDE QUE CITADA A FONTE.

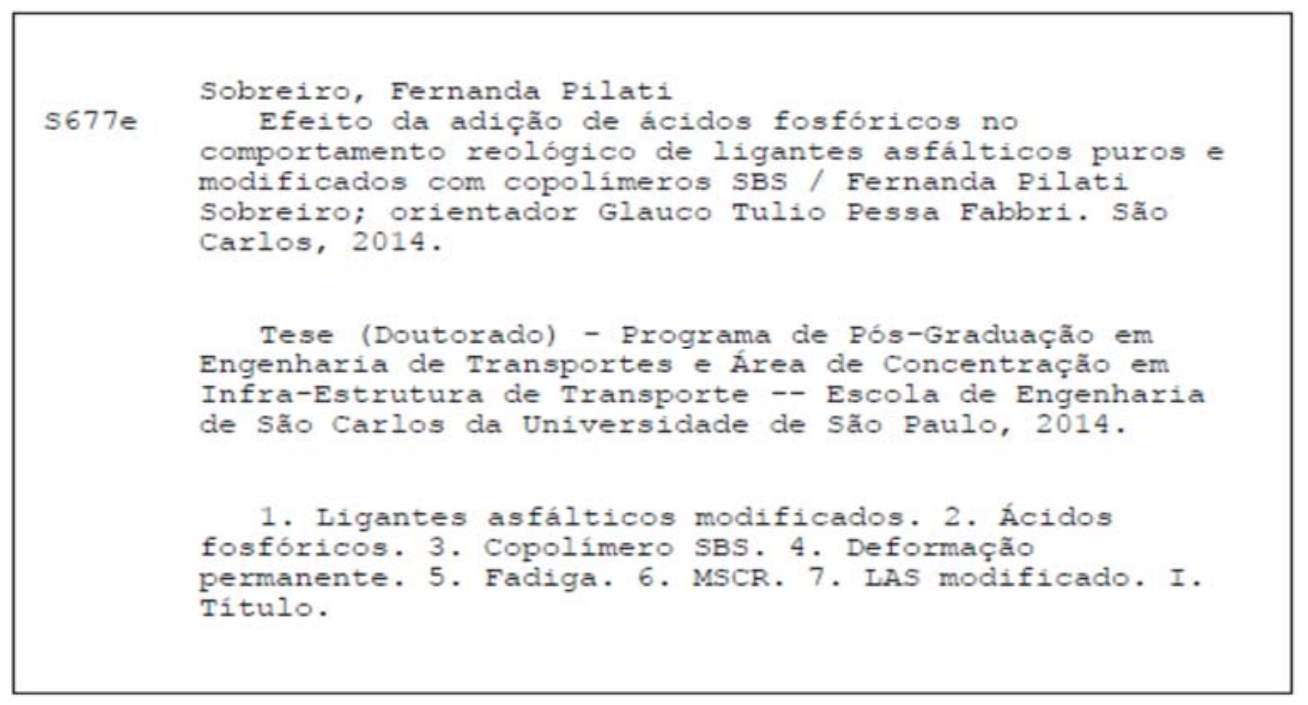




\section{FOLHA DE JULGAMENTO}

Candidata: Engerıheirc FERNANDA PILATI \$OBREIRO

Titulo da tese: 'Efeito da adiça de úcidos fosóricos no comporamento reológico de ligantes asfálticos puros e modificocos corr copolimeros \$3S

Doto da detesc: 27/03/2014

Comissôo Julgadora:

Resultado:

Prcf. Dr. Glauco Túllo Pessa Fabbri (Orientador)

(Escola de Engenharia de Sōo Carlo5/LSP)

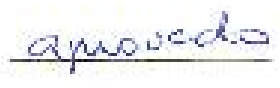

Prot. Associado Adelberto Leandro Faxina

(Escola de Engenthor a de Säo Corlos/USP)

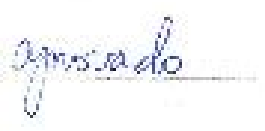

Prota. Titular Liedi Légi Barianl Bernuccl

(Escola Politécnica/EP-USP)

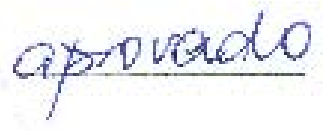

Prota. Dra. Anne Slivia Palcheco Pebxoto

Aprasabe-

Universidade Eslaciual Poulista "Súlio de Mesquiru Fino"/UNESP-Bcurul

Prof. Dr. John Kennedy Guedes Rodrigues

$\frac{1}{1}(200001) 0$

(Universidade Federal de Compiza Grande/UFCG)

Coordenodo: do Programa do Pós-Graduaçāo om Engerihario de Transportes:

Prof. Associodo Antônio Nélson Rodrigues da Sllva

Presidente da Comissôo de Pós-Groduocúo:

Pref. Tituor Denis Vinicius Coury 
Dedico este trabalho

Aos meus amáveis e eternos pais Laurindo e Deonila Pilati, que, no decorrer de todo este processo, proporcionaramme, além de extenso carinho e amor, os conhecimentos da integridade e da perseverança. Por essa razão, gostaria de dedicar e reconhecer a vocês minha imensa gratidão e sempre amor. Um agradecimento especial aos meus queridos irmãos Emerson e Rubiane Pilati, que permaneceram sempre ao meu lado, em todos os momentos.

Ao meu querido amor Vinicius Amorim Sobreiro, que além de me fazer feliz, ajudou-me, durante toda esta caminhada, compreendendo-me e ensinando-me para que eu conquistasse um lugar ao sol.

E especialmente à minha maravilhosa avó Theresa Roza Guindani, que mesmo distante sempre me incentivou em todos os momentos.

À todos vocês, meu muito obrigado. 
" Há homens que lutam um dia e são bons, há outros que lutam um ano e são melhores, há os que lutam muitos anos e são muito bons. Mas há os que lutam toda a vida e estes são imprescindíveis"

(Bertold Brecht) 


\section{Resumo}

SOBREIRO, Fernanda Pilati. Efeito da adição de ácidos fosfóricos no comportamento reológico de ligantes asfálticos puros e modificados com copolímero SBS. 2014. 346 fl. Tese (Doutorado em Engenharia de Transportes) - Escola de Engenharia de São Carlos, Universidade de São Paulo, São Carlos.

A adição de modificadores no ligante asfáltico visando melhorar o seu comportamento é uma prática comum atualmente. Existem vários tipos de modificadores, entre eles o mais utilizado nas rodovias federais brasileiras é o copolímero SBS. Além dos polímeros, o ácido polifosfórico (PPA) é outro tipo de modificador que produz boas características quando adicionado ao ligante asfáltico. Apesar do efeito positivo, sabe-se que este material é importado, o que dificulta sua aquisição e pode tornar o produto final muito caro. Tendo em vista a possibilidade de se trabalhar com um produto de mesma base, mas de origem nacional, o que o tornaria o modificador mais acessível, optou-se por verificar o comportamento da adição de ácido fosfórico (PA85) ao ligante asfáltico. Sendo assim, o propósito desta tese é analisar o efeito da adição de ácidos fosfóricos no comportamento reológico de ligantes asfálticos puros e modificados com o copolímero SBS. Para tanto, realizou-se ensaios empíricos e reológicos com o intuito de verificar o comportamento destes materiais. $\mathrm{Na}$ primeira parte da pesquisa, dois ligantes asfálticos de base, CAP50/70 de classificação PG64XX, (Replan e Lubnor), foram modificados somente com a adição dos dois ácidos (PPA e PA85), enquanto na segunda parte esses ligantes asfálticos de base foram modificados com o copolímero SBS com ou sem a presença dos ácidos. Os ensaios avaliados foram penetração, ponto de amolecimento, viscosidade rotacional, ensaio de fluência e recuperação sob tensão múltipla (MSCR), LAS modificado, e estabilidade à estocagem. De maneira geral, a adição dos modificadores melhora o comportamento dos ligantes asfálticos, tendo em vista que melhoram a recuperação, ficam menos sensíveis à deformação permanente e são mais tolerantes à fadiga. Pode-se constatar que o tipo de ligante asfáltico de base influencia diretamente o comportamento dos materiais, independente dos modificadores adicionados. A adição dos modificadores foi mais expressiva no ligante asfáltico proveniente da Replan. Em relação aos ácidos, conclui-se que a adição do PA85 foi satisfatória, uma vez que apresentou comportamento semelhante ao do ácido PPA, porém com efeito um pouco menos expressivo. A adição dos ácidos melhorou a estabilidade à estocagem dos ligantes asfálticos modificados, e pode-se constatar que a adição de um destes modificadores permite a redução do teor do copolímero SBS. Quanto à capacidade de suporte de tráfego, a adição de altos teores desses 
modificadores não é viável, devido ao fato de apresentarem suporte similar a ligantes asfálticos modificados com teores baixos e intermediários.

Palavras-chave: ligantes asfálticos modificados; ácidos fosfóricos, copolímero SBS, deformação permanente, fadiga, MSCR, LAS modificado. 


\section{A6stract}

SOBREIRO, Fernanda Pilati. Effect of phosphoric acid in the rheological behavior of pure and modified asphalt binders with SBS copolymer .2014. 346 pp. Doctorate's Thesis (Transportation Engineering) - Engineering School of São Carlos, University of São Paulo, São Carlos.

The addition of modifiers in asphalt binder to improve its behavior is a common practice nowadays. There are many types of modifiers, among them the most used in the Brazilian federal highways is the SBS copolymer. In addition to polymers, polyphosphoric acid (PPA) is another type of modifier that produces good characteristics when added to asphalt binder. Despite the positive effects, it is known that this material is imported, which makes its purchase as well as the final product very expensive. Considering the opportunity to work with a product with the same basic component, but of national origin, which would make it the most affordable modifier, the present study decided to verify the behavior of the addition of phosphoric acid (PA85) to the asphalt binder. Therefore, the purpose of this thesis is to analyze the effect of the addition of phosphoric acid to the rheological behavior of pure and modified asphalt binders with the SBS copolymer. For both, empirical and rheological tests were conducted in order to verify the behavior of these materials/substances. In the first part of the research, two asphalt binders base CAP50/70 asphalt binder graded PG64-XX (Replan and Lubnor) were modified only with the addition of the two acids (PPA and PA85), while in the second part of these asphalt binders base were modified with SBS copolymer with or without the presence of acids. The tests evaluated penetration, softening point, rotational viscosity, multiple stress creep and recovery (MSCR), LAS modified, and storage stability. In general, the addition of the modifiers enhances the behavior of the asphalt binders, for they improve recovery, are less susceptible to rutting and are more resistant to fatigue. It was found that the type of asphalt binder base directly influences the behavior of materials, regardless of added modifiers. The addition of modifiers was greater in the asphalt binder from the Replan. Compared to acids, it is concluded that the addition of PA85 was satisfactory, since the performance was similar to the PPA acid behavior, but with slightly less significant effect. The addition of acid improved the storage stability of the modified asphalt binders, and it was found that the addition of such modifiers allows reducing the content of the SBS copolymer. Regarding the ability to support traffic, the addition of high levels of these modifiers is not feasible because they show similar support for modified asphalt binders with low and intermediate levels.

Keywords: modified asphalt binders; phosphoric acids, SBS copolymer, rutting, fatigue, MSCR, LAS modified. 


\section{Lista de Ilustrações}

Figura 1 - Esquema de ligantes tipo (A) Sol e tipo (B) Gel. 48

Figura 2 - Distribuição dos grupos químicos no asfalto. 49

Figura 3 - Porcentagem dos componentes asfálticos para ligantes asfálticos diferentes. _ 50 Figura 4 - Frações SARA para ligantes diferentes antes a após envelhecimento a curto prazo. 51

Figura 5 - Representação do modelo de estrutura coloidal segundo Yen. 51

Figura 6 - Estrutura molecular do ácido ortofosfórico (A) e ácido pirofosfórico (B). 57

Figura 7 - Rigidez do ligante asfáltico com diferentes tipos de ácidos fosfóricos. 58

Figura 8 - Deformação permanente. 64

Figura 9 - Trinca por fadiga. 65

Figura 10 - Esquema das tensões e deformações durante a realização do ensaio. 69

Figura 11 - Localização das deformações em um ciclo do ensaio MSCR. 70

Figura 12 - Relação entre a compliância não-recuperável e o percentual de recuperação a $3200 P a$. 72

Figura 13- Incremento da deformação (em degraus) no ensaio LAS. 73

Figura 14 - Modelo de fadiga. 74

Figura 15 - Incremento linear de deformação no ensaio LAS modificado. 76

Figura 16 - Resultados do LAS modificado e do time sweep. 76

Figura 17 - Taxa de crescimento da fissura em função do comprimento da fissura. 77

Figura 18 - Região delimitada pelo experimento com misturas para presente pesquisa. 82

Figura 19 - Misturas estudadas inicialmente. 83

Figura 20 - Misturas utilizados, sendo (a) baixo cisalhamento e (b) alto cisalhamento. 85

Figura 21 - Estufa do filme fino rotativo (RTFOT). 87

Figura 22 - Estufa de vaso pressurizado (PAV) marca Prentex, modelo 9300. 88

Figura 23 - Esquema básico do ensaio de penetração (a) e foto do equipamento (b). 89

Figura 24 - Equipamento para ensaio de anel e bola, ou ponto de amolecimento. 90

Figura 25 - Esquema ilustrativo do experimento de Newton para determinação da viscosidade. 92

Figura 26 - Viscosímetro Brookfield modelo DVII+Pro. 93

Figura 27 - Reômetro de Cisalhamento Dinâmico AR 200Ex - TA Instruments. 95

Figura 28 - Reômetro de cisalhamento dinâmico (DSR) e amostra do ensaio LAS modificado.

Figura 29 - Penetração Retida dos ligantes asfálticos modificados com ligante base Replan. 
Figura 30 - Penetração Retida dos ligantes asfálticos modificados com ligante base Lubnor.

Figura 31 - Determinação das temperaturas de usinagem e compactação (TUC). 108

Figura 32 - Recuperação $(R)$ do ligante asfáltico proveniente da Replan modificado com PPA.

Figura 33 - Compliância Não Recuperável $\left(\mathrm{J}_{n r}\right)$ do ligante asfáltico proveniente da Replan modificado com PPA.

Figura 34 - Recuperação $(R)$ do ligante asfáltico proveniente da Replan modificado com PA85.

Figura 35 - Compliância Não Recuperável $\left(J_{n r}\right)$ do ligante asfáltico proveniente da Replan modificado com PA85.

Figura 36 - Modelagem da Recuperação, na temperatura de $64^{\circ} \mathrm{C}$ e nível de tensão de 100Pa, para os ácidos PPA e PA85 com ligante asfáltico de base Replan.

Figura 37 - Modelagem da Compliância não recuperável, na temperatura de $64^{\circ} \mathrm{C}$ e no nível de tensão de 100Pa, para os ácidos PPA e PA85 com ligante asfáltico de base Replan._118 Figura 38 - Recuperação $(R)$ do ligante asfáltico proveniente da Lubnor modificado com PPA.

Figura 39- Compliância não recuperável $\left(\mathrm{J}_{n r}\right)$ do ligante asfáltico proveniente da Lubnor modificado com PPA.

Figura 40- Recuperação (R) do ligante asfáltico proveniente da Lubnor modificado com PA85.

Figura 41 - Compliância não recuperável $\left(J_{n r}\right)$ do ligante asfáltico proveniente da Lubnor modificado com PA85.

Figura 42 - Modelagem da Recuperação, na temperatura de $64^{\circ} \mathrm{C}$ e nível de tensão de 100Pa, para os ácidos PPA e PA85 com ligante asfáltico de base Lubnor.

Figura 43 - Modelagem da Compliância não recuperável, na temperatura de $64^{\circ} \mathrm{C}$ e no nível de tensão de 100Pa, para os ácidos PPA e PA85 com ligante asfáltico de base Lubnor._126 Figura 44 - Valores de $a_{f}$ para amostras com adição de PA85 no ligante asfáltico Replan, envelhecido no RTFOT.

Figura 45 - Valores de $a_{f}$ para amostras com adição de PPA no ligante asfáltico Replan, envelhecido no RTFOT.

Figura 46 - Variação do número de ciclos na ruptura em função da amplitude de deformação para os ligantes asfálticos da Replan envelhecidos no RTFOT modificados com PA85.

Figura 47 - Variação do número de ciclos na ruptura em função da amplitude de deformação para os ligantes asfálticos da Replan envelhecidos no PAV modificados com PA85. 
Figura 48 - Variação do número de ciclos na ruptura em função da amplitude de deformação para os ligantes asfálticos da Replan envelhecidos no RTFOT modificados com PPA.

Figura 49 - Variação do número de ciclos na ruptura em função da amplitude de deformação para os ligantes asfálticos da Replan envelhecidos no PAV modificados com PPA.

Figura 50 - Variação do número de ciclos na ruptura em função da amplitude de deformação para os ligantes asfálticos da Lubnor envelhecidos no RTFOT modificados com PA85.

Figura 51 - Variação do número de ciclos na ruptura em função da amplitude de deformação para os ligantes asfálticos da Lubnor envelhecidos no PAV modificados com PA85.

Figura 52 - Variação do número de ciclos na ruptura em função da amplitude de deformação para os ligantes asfálticos da Lubnor envelhecidos no RTFOT modificados com PPA.

Figura 53 - Variação do número de ciclos na ruptura em função da amplitude de deformação para os ligantes asfálticos da Lubnor envelhecidos no PAV modificados com PPA.

Figura 54 - Efeitos de interação entre fatores na penetração.

Figura 55 - Efeitos de interação entre fatores no ponto de amolecimento.

Figura 56 - Efeitos de interação entre fatores na viscosidade rotacional.

Figura 57 - Efeitos de interação entre fatores na Recuperação.

Figura 58- Efeitos de interação entre fatores na compliância não recuperável. 146

Figura 59 - Efeitos de interação entre fatores na resistência à fadiga.

Figura 60 - Perda de massa para ligantes modificados com 2,5SBS e os ácidos (Replan).

Figura 61 - Perda de massa para ligantes modificados com 5,0SBS e os ácidos (Replan).

Figura 62 - Perda de massa para ligantes modificados com 2,5SBS e os ácidos (Lubnor).

Figura 63 - Perda de massa para ligantes modificados com 5,0SBS e os ácidos (Lubnor).

Figura 64 - Taxa de crescimento da fissura (da/dN) x a do ligante asfáltico 5,0SBS.

Figura 65 - Gráfico de Superfície de Resposta e efeito dos componentes. 172

Figura 66 - Superfície de Resposta (a) e efeito de componentes (b) para penetração na condição virgem das misturas com PA85 (Replan). 
Figura 67 - Superfície de Resposta (a) e efeito de componentes (b) para penetração na condição virgem das misturas com PPA (Replan).

Figura 68 - Superfície de Resposta (a) e efeito de componentes (b) para penetração na condição RTFOT das misturas com PA85(Replan).

Figura 69 - Superfície de Resposta (a) e efeito de componentes (b) para penetração na condição RTFOT das misturas com PPA (Replan).

Figura 70 - Superfície de Resposta (a) e efeito de componentes (b) para a penetração na condição virgem das misturas com PA85 (Lubnor).

Figura 71 - Superfície de Resposta (a) e efeito de componentes (b) para a penetração na condição virgem das misturas com PPA (Lubnor).

Figura 72 - Superfície de Resposta (a) e efeito de componentes (b) para a penetração na condição RTFOT das misturas com PA85 (Lubnor).

Figura 73 - Superfície de Resposta (a) e efeito de componentes (b) para a penetração na condição RTFOT das misturas com PPA (Lubnor).

Figura 74 - Superfície de Resposta (a) e efeito de componentes (b) para penetração retida das misturas com PA85(Replan). 186

Figura 75 - Superfície de Resposta (a) e efeito de componentes (b) para penetração retida das misturas com PPA (Replan).

Figura 76 - Superfície de Resposta (a) e efeito de componentes (b) para a penetração retida das misturas com PA85 (Lubnor). 188

Figura 77 - Superfície de Resposta (a) e efeito de componentes (b) para a penetração retida das misturas com PPA (Lubnor). 188

Figura 78 - Superfície de Resposta (a) e efeito de componentes (b) para ponto de amolecimento na condição virgem das misturas com PA85 (Replan).

Figura 79 - Superfície de Resposta (a) e efeito de componentes (b) para ponto de amolecimento na condição virgem das misturas com PPA (Replan).

Figura 80 - Superfície de Resposta (a) e efeito de componentes (b) para ponto de amolecimento na condição RTFOT das misturas com PA85(Replan).

Figura 81 - Superfície de Resposta (a) e efeito de componentes (b) para ponto de amolecimento na condição RTFOT das misturas com PPA (Replan).

Figura 82 - Superfície de Resposta (a) e efeito de componentes (b) para o incremento do ponto de amolecimento das misturas com PA85(Replan). 194

Figura 83 - Superfície de Resposta (a) e efeito de componentes (b) para o incremento do ponto de amolecimento das misturas com PPA (Replan). 195

Figura 84 - Superfície de Resposta (a) e efeito de componentes (b) para o ponto de amolecimento na condição virgem das misturas com PA85 (Lubnor). 196 
Figura 85 - Superfície de Resposta (a) e efeito de componentes (b) para o ponto de amolecimento na condição virgem das misturas com PPA (Lubnor).

Figura 86 - Superfície de Resposta (a) e efeito de componentes (b) para o ponto de amolecimento na condição RTFOT das misturas com PA85 (Lubnor).

Figura 87 - Superfície de Resposta (a) e efeito de componentes (b) para o ponto de amolecimento na condição RTFOT das misturas com PPA (Lubnor).

Figura 88 - Superfície de Resposta (a) e efeito de componentes (b) para incremento do ponto de amolecimento das misturas com PA85 (Lubnor).

Figura 89 - Superfície de Resposta (a) e efeito de componentes (b) para incremento do ponto de amolecimento das misturas com PPA (Lubnor).

Figura 90 - Superfície de Resposta (a) e efeito de componentes (b) para Viscosidade à $135^{\circ} \mathrm{C}$ com amostras virgens das misturas com PA85 (Replan).

Figura 91 - Superfície de Resposta (a) e efeito de componentes (b) para Viscosidade à $135^{\circ} \mathrm{C}$ com amostras virgens das misturas com PPA (Replan).

Figura 92 - Superfície de Resposta (a) e efeito de componentes (b) para Viscosidade à $135^{\circ} \mathrm{C}$ com amostras envelhecidas RTFOT das misturas com PA85(Replan).

Figura 93 - Superfície de Resposta (a) e efeito de componentes (b) para Viscosidade à $135^{\circ} \mathrm{C}$ com amostras envelhecidas RTFOT das misturas com PPA.

Figura 94 - Superfície de Resposta (a) e efeito de componentes (b) para a viscosidade à $135^{\circ} \mathrm{C}$ com amostras virgens das misturas com PA85 (Lubnor).

Figura 95 - Superfície de Resposta (a) e efeito de componentes (b) para a viscosidade à $135^{\circ} \mathrm{C}$ com amostras virgens das misturas com PPA (Lubnor).

Figura 96 - Superfície de Resposta (a) e efeito de componentes (b) para a viscosidade à $135^{\circ} \mathrm{C}$ com amostras envelhecidas RTFOT das misturas com PA85(Lubnor).

Figura 97 - Superfície de Resposta (a) e efeito de componentes (b) para a viscosidade à $135^{\circ} \mathrm{C}$ com amostras envelhecidas RTFOT das misturas com PPA (Lubnor). 208

Figura 98 - Superfície de Resposta (a) e efeito de componentes (b) da diferença dos pontos de amolecimento entre topo e fundo das misturas com PA85 (Replan). 214

Figura 99 - Superfície de Resposta (a) e efeito de componentes (b) da diferença dos pontos de amolecimento entre topo e fundo das misturas com PPA (Replan).

Figura 100 - Superfície de Resposta (a) e efeito de componentes (b) da diferença dos pontos de amolecimento entre topo e fundo das misturas com PA85 (Lubnor).

Figura 101 - Superfície de Resposta (a) e efeito de componentes (b) da diferença dos pontos de amolecimento entre topo e fundo das misturas com PPA (Lubnor).

Figura 102 - Superfície de Resposta (a) e efeito de componentes (b) para a Recuperação (\%) à $64^{\circ} \mathrm{C}$ na tensão de $100 \mathrm{~Pa}$ das misturas com PA85 (Replan). 
Figura 103 - Superfície de Resposta (a) e efeito de componentes (b) para a Recuperação (\%) à $64^{\circ} \mathrm{C}$ na tensão de $3200 \mathrm{~Pa}$ das misturas com PA85 (Replan). 219

Figura 104 - Superfície de Resposta (a) e efeito de componentes (b) para a Recuperação (\%) à $64^{\circ} \mathrm{C}$ na tensão de $100 \mathrm{~Pa}$ das misturas com PPA (Replan). 220

Figura 105 - Superfície de Resposta (a) e efeito de componentes (b) para a Recuperação (\%) à $64^{\circ} \mathrm{C}$ na tensão de $3200 \mathrm{~Pa}$ das misturas com PPA (Replan). 221

Figura 106 - Superfície de Resposta (a) e efeito de componentes (b) para a Compliância não recuperável $\left(\mathrm{kPa}^{-1}\right)$ à $64^{\circ} \mathrm{C}$ na tensão de 100Pa das misturas com PA85 (Replan)._222 Figura 107 - Superfície de Resposta (a) e efeito de componentes (b) para a Compliância não recuperável ( $\left.\mathrm{KPa}^{-1}\right)$ à $64^{\circ} \mathrm{C}$ na tensão de 3200Pa das misturas com PA85 (Replan)._222 Figura 108 - Superfície de Resposta (a) e efeito de componentes (b) para a Compliância não recuperável $\left(\mathrm{KPa}^{-1}\right)$ à $64^{\circ} \mathrm{C}$ na tensão de 100Pa das misturas com PPA (Replan). 223 Figura 109 - Superfície de Resposta (a) e efeito de componentes (b) para a Compliância não recuperável ( $\left.\mathrm{KPa}^{-1}\right)$ à $64^{\circ} \mathrm{C}$ na tensão de 3200Pa das misturas com PPA (Replan). _ 224 Figura 110 - Superfície de Resposta (a) e efeito de componentes (b) para a Recuperação (\%) à $64^{\circ} \mathrm{C}$ na tensão de $100 \mathrm{~Pa}$ das misturas com PA85 (Lubnor). 225

Figura 111 - Superfície de Resposta (a) e efeito de componentes (b) para a Recuperação (\%) à $64^{\circ} \mathrm{C}$ na tensão de 3200Pa das misturas com PA85(Lubnor). 226

Figura 112 - Superfície de Resposta (a) e efeito de componentes (b) para a Recuperação (\%) à $64^{\circ} \mathrm{C}$ na tensão de 100Pa das misturas com PPA(Lubnor). 226

Figura 113 - Superfície de Resposta (a) e efeito de componentes (b) para a Recuperação (\%) à $64^{\circ} \mathrm{C}$ na tensão de $3200 \mathrm{~Pa}$ das misturas com PPA(Lubnor). 227

Figura 114 - Superfície de Resposta (a) e efeito de componentes (b) para a Compliância não recuperável $\left(\mathrm{kPa}^{-1}\right)$ à $64^{\circ} \mathrm{C}$ na tensão de 100Pa das misturas com PA85 (Lubnor).__ 228 Figura 115 - Superfície de Resposta (a) e efeito de componentes (b) para a Compliância não recuperável $\left(\mathrm{KPa}^{-1}\right)$ à $64^{\circ} \mathrm{C}$ na tensão de 3200Pa das misturas com PA85(Lubnor). _229 Figura 116 - Superfície de Resposta (a) e efeito de componentes (b) para a Compliância não recuperável $\left(\mathrm{KPa}^{-1}\right)$ à $64^{\circ} \mathrm{C}$ na tensão de 100Pa das misturas com PPA(Lubnor). 229 Figura 117 - Superfície de Resposta (a) e efeito de componentes (b) para a Compliância não recuperável $\left(\mathrm{KPa}^{-1}\right)$ à $64^{\circ} \mathrm{C}$ na tensão de $3200 \mathrm{~Pa}$ das misturas com PPA(Lubnor). _ 230 Figura 118 - Superfície de Resposta (a) e efeito de componentes (b) para o LAS modificado (af) à $25^{\circ} \mathrm{C}$ na condição de RTFOT das misturas com PA85, para o ligante asfáltico da Lubnor. 235

Figura 119 - Superfície de Resposta (a) e efeito de componentes (b) para o LAS modificado (af) à $25^{\circ} \mathrm{C}$ na condição de RTFOT das misturas com PPA, para o ligante asfáltico da Lubnor. 236 
Figura 120 - Superfície de Resposta (a) e efeito de componentes (b) para o LAS modificado (af) à $25^{\circ} \mathrm{C}$ na condição de PAV das misturas com PA85, para o ligante asfáltico da Lubnor.

Figura 121 - Superfície de Resposta (a) e efeito de componentes (b) para o LAS modificado (af) à $25^{\circ} \mathrm{C}$ na condição de PAV das misturas com PPA, para o ligante asfáltico da Lubnor.

Figura 122 - Viscosidade Ligante Replan na condição Virgem com adição do ácido PA85.

Figura 123 - Viscosidade Ligante Replan na condição Virgem com adição do ácido PPA. 261

Figura 124 - Viscosidade Ligante Replan na condição RTFOT com adição do ácido PA85.

Figura 125 - Viscosidade Ligante Replan na condição RTFOT com adição do ácido PPA.

Figura 126 - Viscosidade Ligante Lubnor na condição Virgem com adição do ácido PA85.

Figura 127 - Viscosidade Ligante Lubnor na condição Virgem com adição do ácido PPA. 263

Figura 128 - Viscosidade Ligante Lubnor na condição RTFOT com adição do ácido PA85.

Figura 129 - Viscosidade Ligante Lubnor na condição RTFOT com adição do ácido PPA.264 Figura 130 - Efeito do envelhecimento na variação do número de ciclos na ruptura em função da amplitude de deformação para o REPLAN puro. 281

Figura 131 - Efeito do envelhecimento na variação do número de ciclos na ruptura em função da amplitude de deformação para o REPLAN + 0,5\%PA85.

Figura 132 - Efeito do envelhecimento na variação do número de ciclos na ruptura em função da amplitude de deformação para o REPLAN + 0,5\%PPA.

Figura 133 - Efeito do envelhecimento na variação do número de ciclos na ruptura em função da amplitude de deformação para o REPLAN +1,0\%PA85.

Figura 134 - Efeito do envelhecimento na variação do número de ciclos na ruptura em função da amplitude de deformação para o REPLAN +1,0\%PPA.

Figura 135 - Efeito do envelhecimento na variação do número de ciclos na ruptura em função da amplitude de deformação para o REPLAN +1,5\%PA85.

Figura 136 - Efeito do envelhecimento na variação do número de ciclos na ruptura em função da amplitude de deformação para o REPLAN +1,5\%PPA.

Figura 137- Variação do número de ciclos na ruptura em função da amplitude de deformação para os ligantes asfálticos da Replan envelhecidos no RTFOT modificados 2,5 SBS e PA85. 
Figura 138 - Variação do número de ciclos na ruptura em função da amplitude de deformação para os ligantes asfálticos da Replan envelhecidos no RTFOT modificados 2,5 SBS e PPA. 285

Figura 139 - Variação do número de ciclos na ruptura em função da amplitude de deformação para os ligantes asfálticos da Replan envelhecidos no PAV modificados 2,5 SBS e PA85.

Figura 140 - Variação do número de ciclos na ruptura em função da amplitude de deformação para os ligantes asfálticos da Replan envelhecidos no PAV modificados 2,5 SBS e PPA.

Figura 141 - Variação do número de ciclos na ruptura em função da amplitude de deformação para os ligantes asfálticos da Replan envelhecidos no RTFOT modificados 5,0 SBS e PA85. 287

Figura 142 - Variação do número de ciclos na ruptura em função da amplitude de deformação para os ligantes asfálticos da Replan envelhecidos no RTFOT modificados 5,0 SBS e PPA. 287

Figura 143 - Variação do número de ciclos na ruptura em função da amplitude de deformação para os ligantes asfálticos da Replan envelhecidos no PAV modificados 5,0 SBS e PA85.

Figura 144 - Variação do número de ciclos na ruptura em função da amplitude de deformação para os ligantes asfálticos da Replan envelhecidos no PAV modificados 5,0 SBS e PPA. 288

Figura 145 - Variação do número de ciclos na ruptura em função da amplitude de deformação para os ligantes asfálticos da Lubnor envelhecidos no RTFOT modificados 2,5 SBS e PA85.

Figura 146 - Variação do número de ciclos na ruptura em função da amplitude de deformação para os ligantes asfálticos da Lubnor envelhecidos no RTFOT modificados 2,5 SBS e PPA. 289

Figura 147 - Variação do número de ciclos na ruptura em função da amplitude de deformação para os ligantes asfálticos da Lubnor envelhecidos no PAV modificados 2,5 SBS e PA85.

Figura 148 - Variação do número de ciclos na ruptura em função da amplitude de deformação para os ligantes asfálticos da Lubnor envelhecidos no PAV modificados 2,5 SBS e PPA. 290

Figura 149 - Variação do número de ciclos na ruptura em função da amplitude de deformação para os ligantes asfálticos da Lubnor envelhecidos no RTFOT modificados 5,0 SBS e PA85. 291 
Figura 150 - Variação do número de ciclos na ruptura em função da amplitude de deformação para os ligantes asfálticos da Lubnor envelhecidos no RTFOT modificados 5,0 SBS e PPA.

Figura 151 - Variação do número de ciclos na ruptura em função da amplitude de deformação para os ligantes asfálticos da Lubnor envelhecidos no PAV modificados 5,0 SBS e PA85.

Figura 152 - Variação do número de ciclos na ruptura em função da amplitude de deformação para os ligantes asfálticos da Lubnor envelhecidos no PAV modificados 5,0 SBS e PPA.

Figura 153 - Efeito do envelhecimento na variação do número de ciclos na ruptura em função da amplitude de deformação para o LUBNOR puro.

Figura 154 - Efeito do envelhecimento na variação do número de ciclos na ruptura em função da amplitude de deformação para o LUBNOR + 0,5\%PA85.

Figura 155 - Efeito do envelhecimento na variação do número de ciclos na ruptura em função da amplitude de deformação para o LUBNOR + 0,5\%PPA.

Figura 156 - Efeito do envelhecimento na variação do número de ciclos na ruptura em função da amplitude de deformação para o LUBNOR + 1,0\%PA85.

Figura 157 - Efeito do envelhecimento na variação do número de ciclos na ruptura em função da amplitude de deformação para o LUBNOR + 1,0\%PPA.

Figura 158 - Efeito do envelhecimento na variação do número de ciclos na ruptura em função da amplitude de deformação para o LUBNOR + 1,5\%PA85.

Figura 159 - Efeito do envelhecimento na variação do número de ciclos na ruptura em função da amplitude de deformação para o LUBNOR + 1,5\%PPA.

Figura 160 - Superfície de Resposta (a) e efeito de componentes (b) para Viscosidade à $143^{\circ} \mathrm{C}$ na condição virgem para misturas com $P P A$.

Figura 161 - Superfície de Resposta (a) e efeito de componentes (b) para Viscosidade à $143^{\circ} \mathrm{C}$ na condição virgem para misturas com PA85.

Figura 162 - Superfície de Resposta (a) e efeito de componentes (b) para Viscosidade à $143^{\circ} \mathrm{C}$ na condição RTFOT para misturas com PPA.

Figura 163 - Superfície de Resposta (a) e efeito de componentes (b) para Viscosidade à $143^{\circ} \mathrm{C}$ na condição RTFOT para misturas com PA85.

Figura 164 - Superfície de Resposta (a) e efeito de componentes (b) para Viscosidade à $155^{\circ} \mathrm{C}$ na condição virgem para misturas com PA85.

Figura 165 - Superfície de Resposta (a) e efeito de componentes (b) para Viscosidade à $155^{\circ} \mathrm{C}$ na condição virgem para misturas com PPA.

Figura 166 - Superfície de Resposta (a) e efeito de componentes (b) para Viscosidade à $155^{\circ} \mathrm{C}$ RTFOT para misturas com PA85. 
Figura 167 - Superfície de Resposta (a) e efeito de componentes (b) para Viscosidade à $155^{\circ} \mathrm{C}$ RTFOT para misturas com PPA. 300

Figura 168 - Superfície de Resposta (a) e efeito de componentes (b) para Viscosidade à $163^{\circ} \mathrm{C}$ para amostras virgens das misturas com PA85. 301

Figura 169 - Superfície de Resposta (a) e efeito de componentes (b) para Viscosidade à $163^{\circ} \mathrm{C}$ para amostras virgens das misturas com PPA.

Figura 170 - Superfície de Resposta (a) e efeito de componentes (b) para Viscosidade à $135^{\circ} \mathrm{C}$ RTFOT das misturas com PA85.

Figura 171 - Superfície de Resposta (a) e efeito de componentes (b) para Viscosidade à $135^{\circ} \mathrm{C}$ RTFOT das misturas com PPA.

Figura 172 - Superfície de Resposta (a) e efeito de componentes (b) para Viscosidade à $177^{\circ} \mathrm{C}$ para amostras virgens das misturas com PA85. 303

Figura 173 - Superfície de Resposta (a) e efeito de componentes (b) para Viscosidade à $177^{\circ} \mathrm{C}$ para amostras virgens das misturas com PPA.

Figura 174 - Superfície de Resposta (a) e efeito de componentes (b) para Viscosidade à $177^{\circ} \mathrm{C}$ RTFOT das misturas com PA85.

Figura 175 - Superfície de Resposta (a) e efeito de componentes (b) para Viscosidade à $177^{\circ} \mathrm{C}$ RTFOT das misturas com PPA.

Figura 176 - Superfície de Resposta (a) e efeito de componentes (b) para perda de massa das misturas com PA85 (Replan). 305

Figura 177 - Superfície de Resposta (a) e efeito de componentes (b) para perda de massa das misturas com PPA (Replan) 305

Figura 178 - Superfície de Resposta (a) e efeito de componentes (b) para a Recuperação (\%) à $52^{\circ} \mathrm{C}$ na tensão de 100PA das misturas com PA85. 306

Figura 179 - Superfície de Resposta (a) e efeito de componentes (b) para a Recuperação (\%) à $52^{\circ} \mathrm{C}$ na tensão de $3200 \mathrm{PA}$ das misturas com PA85. 306

Figura 180 - Superfície de Resposta (a) e efeito de componentes (b) para a Recuperação (\%) à $52^{\circ} \mathrm{C}$ na tensão de $100 \mathrm{PA}$ das misturas com PPA. 307

Figura 181 - Superfície de Resposta (a) e efeito de componentes (b) para a Recuperação (\%) à $52^{\circ} \mathrm{C}$ na tensão de 3200PA das misturas com PPA. 307

Figura 182 - Superfície de Resposta (a) e efeito de componentes (b) para a Compliância não recuperável $\left(\mathrm{kPa}^{-1}\right)$ à $52^{\circ} \mathrm{C}$ na tensão de $100 \mathrm{~Pa}$ das misturas com PA85. 308 Figura 183 - Superfície de Resposta (a) e efeito de componentes (b) para a Compliância não recuperável $\left(\mathrm{KPa}^{-1}\right)$ à $52^{\circ} \mathrm{C}$ na tensão de 3200Pa das misturas com PA85. 308 Figura 184 - Superfície de Resposta (a) e efeito de componentes (b) para a Compliância não recuperável $\left(\mathrm{kPa}^{-1}\right)$ à $52^{\circ} \mathrm{C}$ na tensão de 100PA das misturas com PPA. 309 
Figura 185 - Superfície de Resposta (a) e efeito de componentes (b) para a Compliância não recuperável $\left(\mathrm{KPa}^{-1}\right)$ à $52^{\circ} \mathrm{C}$ na tensão de 3200PA das misturas com PPA.

Figura 186 - Superfície de Resposta (a) e efeito de componentes (b) para a Recuperação (\%) à $58^{\circ} \mathrm{C}$ na tensão de 100PA das misturas com PA85.

Figura 187 - Superfície de Resposta (a) e efeito de componentes (b) para a Recuperação (\%) à $58^{\circ} \mathrm{C}$ na tensão de 3200PA das misturas com PA85.

Figura 188 - Superfície de Resposta (a) e efeito de componentes (b) para a Recuperação (\%) à $58^{\circ} \mathrm{C}$ na tensão de $100 P A$ das misturas com PPA.

Figura 189 - Superfície de Resposta (a) e efeito de componentes (b) para a Recuperação (\%) à $58^{\circ} \mathrm{C}$ na tensão de 3200PA das misturas com PPA.

Figura 190 - Superfície de Resposta (a) e efeito de componentes (b) para a Compliância não recuperável $\left(\mathrm{kPa}^{-1}\right)$ à $58^{\circ} \mathrm{C}$ na tensão de 100Pa das misturas com PA85.

Figura 191 - Superfície de Resposta (a) e efeito de componentes (b) para a Compliância não recuperável $\left(\mathrm{KPa}^{-1}\right)$ à $58^{\circ} \mathrm{C}$ na tensão de $3200 \mathrm{~Pa}$ das misturas com PA85.

Figura 192 - Superfície de Resposta (a) e efeito de componentes (b) para a Compliância não recuperável $\left(\mathrm{kPa}^{-1}\right)$ à $58^{\circ} \mathrm{C}$ na tensão de 100PA das misturas com PPA.

Figura 193 - Superfície de Resposta (a) e efeito de componentes (b) para a Compliância não recuperável $\left(\mathrm{KPa}^{-1}\right)$ à $58^{\circ} \mathrm{C}$ na tensão de 3200PA das misturas com PPA.

Figura 194 - Superfície de Resposta (a) e efeito de componentes (b) para a Recuperação (\%) à $70^{\circ} \mathrm{C}$ na tensão de 100PA das misturas com PA85.

Figura 195 - Superfície de Resposta (a) e efeito de componentes (b) para a Recuperação (\%) à $70^{\circ} \mathrm{C}$ na tensão de 3200PA das misturas com PA85.

Figura 196 - Superfície de Resposta (a) e efeito de componentes (b) para a Recuperação (\%) à $70^{\circ} \mathrm{C}$ na tensão de 100PA das misturas com PPA.

Figura 197 - Superfície de Resposta (a) e efeito de componentes (b) para a Recuperação (\%) à $70^{\circ} \mathrm{C}$ na tensão de $3200 P A$ das misturas com PPA.

Figura 198 - Superfície de Resposta (a) e efeito de componentes (b) para a Compliância não recuperável $\left(\mathrm{kPa}^{-1}\right)$ à $70^{\circ} \mathrm{C}$ na tensão de 100PA das misturas com PA85.

Figura 199 - Superfície de Resposta (a) e efeito de componentes (b) para a Compliância não recuperável $\left(\mathrm{kPa}^{-1}\right)$ à $70^{\circ} \mathrm{C}$ na tensão de 3200PA das misturas com PA85.

Figura 200 - Superfície de Resposta (a) e efeito de componentes (b) para a Compliância não recuperável $\left(\mathrm{kPa}^{-1}\right)$ à $70^{\circ} \mathrm{C}$ na tensão de 100PA das misturas com PPA.

Figura 201 - Superfície de Resposta (a) e efeito de componentes (b) para a Compliância não recuperável $\left(\mathrm{KPa}^{-1}\right)$ à $70^{\circ} \mathrm{C}$ na tensão de 3200PA das misturas com PPA.

Figura 202 - Superfície de Resposta (a) e efeito de componentes (b) para a Recuperação (\%) à $76^{\circ} \mathrm{C}$ na tensão de 100PA das misturas com PA85. 
Figura 203 - Superfície de Resposta (a) e efeito de componentes (b) para a Recuperação (\%) à $76^{\circ} \mathrm{C}$ na tensão de 3200PA das misturas com PA85.

Figura 204 - Superfície de Resposta (a) e efeito de componentes (b) para a Recuperação (\%) à $76^{\circ} \mathrm{C}$ na tensão de 100PA das misturas com PPA. 319

Figura 205 - Superfície de Resposta (a) e efeito de componentes (b) para a Recuperação (\%) à $76^{\circ} \mathrm{C}$ na tensão de 3200PA das misturas com PPA. 319

Figura 206 - Superfície de Resposta (a) e efeito de componentes (b) para a Compliância não recuperável $\left(\mathrm{KPa}^{-1}\right)$ à $76^{\circ} \mathrm{C}$ na tensão de 100PA das misturas com PA85. 320

Figura 207 - Superfície de Resposta (a) e efeito de componentes (b) para a Compliância não recuperável $\left(\mathrm{kPa}^{-1}\right)$ à $76^{\circ} \mathrm{C}$ na tensão de 3200PA das misturas com PA85.

Figura 208 - Superfície de Resposta (a) e efeito de componentes (b) para a Compliância não recuperável $\left(\mathrm{kPa}^{-1}\right)$ à $76^{\circ} \mathrm{C}$ na tensão de 100PA das misturas com PPA. 321

Figura 209 - Superfície de Resposta (a) e efeito de componentes (b) para a Compliância não recuperável $\left(\mathrm{kPa}^{-1}\right)$ à $76^{\circ} \mathrm{C}$ na tensão de 3200PA das misturas com $P P A$.

Figura 210 - Superfície de Resposta (a) e efeito de componentes (b) para a viscosidade à $143^{\circ} \mathrm{C}$ das misturas com PA85.

Figura 211 - Superfície de Resposta (a) e efeito de componentes (b) para a viscosidade à $143^{\circ} \mathrm{C}$ das misturas com PPA.

Figura 212 - Superfície de Resposta (a) e efeito de componentes (b) para a viscosidade à $143^{\circ} \mathrm{C}$ das misturas com PA85. 323

Figura 213 - Superfície de Resposta (a) e efeito de componentes (b) para a viscosidade à $143^{\circ} \mathrm{C}$ das misturas com PPA.

Figura 214 - Superfície de Resposta (a) e efeito de componentes (b) para a viscosidade à $155^{\circ} \mathrm{C}$ das misturas com PA85.

Figura 215 - Superfície de Resposta (a) e efeito de componentes (b) para a viscosidade à $155^{\circ} \mathrm{C}$ das misturas com PPA.

Figura 216 - Superfície de Resposta (a) e efeito de componentes (b) para a viscosidade à $155^{\circ} \mathrm{C}$ das misturas com PA85.

Figura 217 - Superfície de Resposta (a) e efeito de componentes (b) para a viscosidade à $155^{\circ} \mathrm{C}$ das misturas com PPA. 325

Figura 218 - Superfície de Resposta (a) e efeito de componentes (b) para a viscosidade à $163^{\circ} \mathrm{C}$ das misturas com PA85.

Figura 219 - Superfície de Resposta (a) e efeito de componentes (b) para a viscosidade à $163^{\circ} \mathrm{C}$ das misturas com PPA. 326

Figura 220 - Superfície de Resposta (a) e efeito de componentes (b) para a viscosidade à $163^{\circ} \mathrm{C}$ das misturas com PA85. 
Figura 221 - Superfície de Resposta (a) e efeito de componentes (b) para a viscosidade à $163^{\circ} \mathrm{C}$ das misturas com PPA.

Figura 222 - Superfície de Resposta (a) e efeito de componentes (b) para a viscosidade à $177^{\circ} \mathrm{C}$ das misturas com PA85. 328

Figura 223 - Superfície de Resposta (a) e efeito de componentes (b) para a viscosidade à $177^{\circ} \mathrm{C}$ das misturas com PPA. 328

Figura 224 - Superfície de Resposta (a) e efeito de componentes (b) para a viscosidade à $177^{\circ} \mathrm{C}$ RTFOT das misturas com PA85. 329

Figura 225 - Superfície de Resposta (a) e efeito de componentes (b) para a viscosidade à $177^{\circ} \mathrm{C}$ RTFOT das misturas com PPA. 329

Figura 226 - Superfície de Resposta (a) e efeito de componentes (b) para perda de massa das misturas com PA85 (Lubnor). 330

Figura 227 - Superfície de Resposta (a) e efeito de componentes (b) para perda de massa das misturas com PPA (Lubnor) 330

Figura 228 - Superfície de Resposta (a) e efeito de componentes (b) para a Recuperação (\%) à $52^{\circ} \mathrm{C}$ na tensão de 100PA das misturas com PA85.

Figura 229 - Superfície de Resposta (a) e efeito de componentes (b) para a Recuperação (\%) à $52^{\circ} \mathrm{C}$ na tensão de 3200PA das misturas com PA85.

Figura 230 - Superfície de Resposta (a) e efeito de componentes (b) para a Recuperação (\%) à $52^{\circ} \mathrm{C}$ na tensão de 100PA das misturas com PPA. 332

Figura 231 - Superfície de Resposta (a) e efeito de componentes (b) para a Recuperação (\%) à $52^{\circ} \mathrm{C}$ na tensão de 3200PA das misturas com PPA. 332

Figura 232 - Superfície de Resposta (a) e efeito de componentes (b) para a Compliância não recuperável $\left(\mathrm{KPa}^{-1}\right)$ à $52^{\circ} \mathrm{C}$ na tensão de 100Pa das misturas com PA85. 333

Figura 233 - Superfície de Resposta (a) e efeito de componentes (b) para a Compliância não recuperável $\left(\mathrm{KPa}^{-1}\right)$ à $52^{\circ} \mathrm{C}$ na tensão de $3200 \mathrm{~Pa}$ das misturas com PA85.

Figura 234 - Superfície de Resposta (a) e efeito de componentes (b) para a Compliância não recuperável $\left(\mathrm{kPa}^{-1}\right)$ à $52^{\circ} \mathrm{C}$ na tensão de 100PA das misturas com PPA.

Figura 235 - Superfície de Resposta (a) e efeito de componentes (b) para a Compliância não recuperável $\left(\mathrm{KPa}^{-1}\right)$ à $52^{\circ} \mathrm{C}$ na tensão de 3200PA das misturas com PPA.

Figura 236 - Superfície de Resposta (a) e efeito de componentes (b) para a Recuperação (\%) à $58^{\circ} \mathrm{C}$ na tensão de 100PA das misturas com PA85.

Figura 237 - Superfície de Resposta (a) e efeito de componentes (b) para a Recuperação (\%) à $58^{\circ} \mathrm{C}$ na tensão de 3200PA das misturas com PA85. 335

Figura 238 - Superfície de Resposta (a) e efeito de componentes (b) para a Recuperação (\%) à $58^{\circ} \mathrm{C}$ na tensão de $100 P A$ das misturas com PPA. 336 
Figura 239 - Superfície de Resposta (a) e efeito de componentes (b) para a Recuperação (\%) à $58^{\circ} \mathrm{C}$ na tensão de 3200PA das misturas com PPA. 336

Figura 240 - Superfície de Resposta (a) e efeito de componentes (b) para a Compliância não recuperável $\left(\mathrm{kPa}^{-1}\right)$ à $58^{\circ} \mathrm{C}$ na tensão de $100 \mathrm{~Pa}$ das misturas com PA85.

Figura 241 - Superfície de Resposta (a) e efeito de componentes (b) para a Compliância não recuperável $\left(\mathrm{KPa}^{-1}\right)$ à $58^{\circ} \mathrm{C}$ na tensão de $3200 \mathrm{~Pa}$ das misturas com PA85.

Figura 242 - Superfície de Resposta (a) e efeito de componentes (b) para a Compliância não recuperável $\left(\mathrm{kPa}^{-1}\right)$ à $58^{\circ} \mathrm{C}$ na tensão de 100PA das misturas com PPA.

Figura 243 - Superfície de Resposta (a) e efeito de componentes (b) para a Compliância não recuperável $\left(\mathrm{KPa}^{-1}\right)$ à $58^{\circ} \mathrm{C}$ na tensão de 3200PA das misturas com PPA.

Figura 244 - Superfície de Resposta (a) e efeito de componentes (b) para a Recuperação (\%) à $70^{\circ} \mathrm{C}$ na tensão de 100PA das misturas com PA85. 339

Figura 245 - Superfície de Resposta (a) e efeito de componentes (b) para a Recuperação (\%) à $70^{\circ} \mathrm{C}$ na tensão de 3200PA das misturas com PA85. 339

Figura 246 - Superfície de Resposta (a) e efeito de componentes (b) para a Recuperação (\%) à $70^{\circ} \mathrm{C}$ na tensão de 100PA das misturas com PPA. 340

Figura 247 - Superfície de Resposta (a) e efeito de componentes (b) para a Recuperação (\%) à $70^{\circ} \mathrm{C}$ na tensão de 3200PA das misturas com PPA. 340

Figura 248 - Superfície de Resposta (a) e efeito de componentes (b) para a Compliância não recuperável $\left(\mathrm{kPa}^{-1}\right)$ à $70^{\circ} \mathrm{C}$ na tensão de 100PA das misturas com PA85. 341

Figura 249 - Superfície de Resposta (a) e efeito de componentes (b) para a Compliância não recuperável $\left(\mathrm{kPa}^{-1}\right)$ à $70^{\circ} \mathrm{C}$ na tensão de 3200PA das misturas com PA85. 341

Figura 250 - Superfície de Resposta (a) e efeito de componentes (b) para a Compliância não recuperável $\left(\mathrm{KPa}^{-1}\right)$ à $70^{\circ} \mathrm{C}$ na tensão de 100PA das misturas com PPA.

Figura 251 - Superfície de Resposta (a) e efeito de componentes (b) para a Compliância não recuperável $\left(\mathrm{kPa}^{-1}\right)$ à $70^{\circ} \mathrm{C}$ na tensão de 3200PA das misturas com PPA.

Figura 252 - Superfície de Resposta (a) e efeito de componentes (b) para a Recuperação (\%) à $76^{\circ} \mathrm{C}$ na tensão de 100PA das misturas com PA85. 343

Figura 253 - Superfície de Resposta (a) e efeito de componentes (b) para a Recuperação (\%) à $76^{\circ} \mathrm{C}$ na tensão de 3200PA das misturas com PA85. 343

Figura 254 - Superfície de Resposta (a) e efeito de componentes (b) para a Recuperação (\%) à $76^{\circ} \mathrm{C}$ na tensão de $100 \mathrm{PA}$ das misturas com PPA. 344

Figura 255 - Superfície de Resposta (a) e efeito de componentes (b) para a Recuperação (\%) à $76^{\circ} \mathrm{C}$ na tensão de 3200PA das misturas com PPA. 344

Figura 256 - Superfície de Resposta (a) e efeito de componentes (b) para a Compliância não recuperável $\left(\mathrm{KPa}^{-1}\right)$ à $76^{\circ} \mathrm{C}$ na tensão de 100PA das misturas com PA85. 345 
Figura 257 - Superfície de Resposta (a) e efeito de componentes (b) para a Compliância não recuperável $\left(\mathrm{kPa}^{-1}\right)$ à $76^{\circ} \mathrm{C}$ na tensão de 3200PA das misturas com PA85. 345

Figura 258 - Superfície de Resposta (a) e efeito de componentes (b) para a Compliância não recuperável $\left(\mathrm{kPa}^{-1}\right)$ à $76^{\circ} \mathrm{C}$ na tensão de 100PA das misturas com PPA. 346

Figura 259 - Superfície de Resposta (a) e efeito de componentes (b) para a Compliância não recuperável $\left(\mathrm{kPa}^{-1}\right)$ à $76^{\circ} \mathrm{C}$ na tensão de 3200PA das misturas com PPA. 346 


\section{Lista de Tabelas}

Tabela 1 - Graus do Ácido Fosfórico. 56

Tabela 2 - Classificação quanto ao valor de Jnr de acordo com o critério proposto pelo FHWA. 71

Tabela 3 - Percentual de recuperação de acordo com o critério proposto pelo FHWA. 71

Tabela 4 - Composição das misturas estudadas. 80

Tabela 5 - Porcentagem dos componentes das misturas. 82

Tabela 6 - Propriedades físicas e métodos de ensaio. 83

Tabela 7 - Caraterísticas físicas do CAP 50-70 Replan. 84

Tabela 8 - Caraterísticas físicas do CAP 50-70 Lubnor. 84

Tabela 9 - Variáveis de processamento dos ligantes asfálticos. 86

Tabela 10 - Dados referentes ao ensaio de Viscosidade rotacional. 94

Tabela 11 - Grau de desempenho das amostras. 97

Tabela 12 - Grau de desempenho contínuo dos ligantes asfálticos. 98

Tabela 13 - Quantidades de ácidos necessárias para aumentar o PG. 98

Tabela 14 - Valores de penetração e graus de modificação dos ligantes asfálticos para o ligante base Replan.

Tabela 15 - Valores de penetração e graus de modificação dos ligantes asfálticos com ligante base Lubnor.

Tabela 16 - Valores de Ponto de Amolecimento e Gmod dos ligantes asfálticos proveniente da Replan. 102

Tabela 17 - Valores de Ponto de Amolecimento e Gmod dos ligantes asfálticos proveniente da Lubnor.

Tabela 18 - Incremento do Ponto de Amolecimento $\left({ }^{\circ} \mathrm{C}\right)$ após envelhecimento em curto prazo.

Tabela 19 - Comparação da viscosidade (cP) Virgem e RTFOT (PA85), para ligante Replan. 105

Tabela 20 - Comparação da viscosidade (cP) Virgem e RTFOT (PPA), para ligante Replan. 105

Tabela 21 - Aumento percentual da viscosidade com aumento do teor dos modificadores, para ligante Replan. 105

Tabela 22 - Aumento percentual do valor de viscosidade após envelhecimento, para ligante Replan. 
Tabela 23 - Comparação da viscosidade (cP) Virgem e RTFOT (PA85), para ligante Lubnor.

Tabela 24 - Comparação da viscosidade (cP) Virgem e RTFOT (PPA), para ligante Lubnor.

Tabela 25 - Aumento percentual da viscosidade com aumento do teor dos modificadores, para ligante Lubnor. 107

Tabela 26 - Aumento percentual do valor de viscosidade após envelhecimento, para ligante Lubnor. 108

Tabela 27 - Temperaturas de usinagem e de compactação dos ligantes asfálticos - Replan.

Tabela 28 - Temperaturas de usinagem e de compactação dos ligantes asfálticos - Lubnor.

Tabela 29 - Perda de Massa (\%) dos ligantes asfálticos estudados.

Tabela 30 - Percentuais de recuperação $(R)$ do ligante asfáltico proveniente da Replan modificado com PPA.

Tabela 31 - Compliância Não Recuperável (Jnr) do ligante asfáltico proveniente da Replan modificado com PPA.

Tabela 32 - Percentuais de recuperação $(R)$ do ligante asfáltico proveniente da Replan modificado com PA85.

Tabela 33 - Compliância não recuperável (Jnr) do ligante asfáltico proveniente da Replan modificado com PA85.

Tabela 34 - Diferenças percentuais entre as compliâncias não-recuperáveis $\left(J_{n r}\right)$ do ligante asfáltico proveniente da Replan.

Tabela 35 - Percentuais de recuperação $(R)$ do ligante asfáltico proveniente da Lubnor modificado com PPA.

Tabela 36 - Compliância não recuperável $\left(J_{n r}\right)$ do ligante asfáltico proveniente da Lubnor modificado com PPA.

Tabela 37 - Percentuais de recuperação $(R)$ do ligante asfáltico proveniente da Lubnor modificado com PA85.

Tabela 38 - Compliância não recuperável (Jnr) do ligante asfáltico proveniente da Lubnor modificado com PA85.

Tabela 39 - Diferenças percentuais entre as compliâncias não-recuperáveis $\left(J_{n r}\right)$ do ligante asfáltico proveniente da Lubnor.

Tabela 40 - Classificação dos ligantes asfálticos segundo o critério de tráfego do FHWA, para o ligante asfáltico base Lubnor.

Tabela 41 - Classificação dos ligantes asfálticos segundo o critério de tráfego do FHWA, para o ligante asfáltico base Replan. 
Tabela 42 - Comprimento da fissura na ruptura $\mathrm{a}_{f}(\mathrm{~mm})$ para todos os ligantes asfálticos. 130 Tabela 43 - Parâmetro A e B para o ligante asfáltico proveniente da Replan puro e modificados.

Tabela 44 - Parâmetro A e B para o ligante asfáltico proveniente da Lubnor puro e modificados.

Tabela 45 - Análise da significância dos fatores e suas interações na penetração. 139

Tabela 46 - Análise da significância dos fatores e suas interações no ponto de amolecimento.

Tabela 47 - Análise da significância dos fatores e suas interações na viscosidade rotacional.

Tabela 48 - Análise da significância dos fatores e suas interações na Recuperação.

Tabela 49- Análise da significância dos fatores e suas interações na compliância não recuperável.

Tabela 50 - Análise da significância dos fatores e suas interações no LAS modificado $\left(a_{f}\right)$.

Tabela 51 - Resultados de Penetração (dmm) e Penetração Retida (\%) para os ligantes asfálticos modificados (Replan).

Tabela 52 - Resultados de Penetração (dmm) e Penetração Retida (\%) para os ligantes asfálticos modificados (Lubnor).

Tabela 53 - Resultados do Ponto de Amolecimento $\left({ }^{\circ} \mathrm{C}\right)$ e Incremento $\left({ }^{\circ} \mathrm{C}\right)$ para os ligantes asfálticos modificados (Replan).

Tabela 54 - Resultados do Ponto de Amolecimento $\left({ }^{\circ} \mathrm{C}\right)$ e Incremento $\left({ }^{\circ} \mathrm{C}\right)$ para os ligantes asfálticos modificados (Lubnor).

Tabela 55 - Viscosidade (Pa.s) dos ligantes asfálticos modificados com SBS e PA85 na condição virgem (Replan).

Tabela 56 - Viscosidade (Pa.s) para os ligantes asfálticos modificados com SBS e PPA na condição virgem (Replan).

Tabela 57 - Viscosidade (Pa.s) para os ligantes asfálticos modificados com SBS e PA85 na condição RTFOT (Replan). 155

Tabela 58 - Viscosidade (Pa.s) para os ligantes asfálticos modificados com SBS e PPA na condição RTFOT (Replan). 155

Tabela 59 - Viscosidade (Pa.s) para os ligantes asfálticos modificados com SBS e PA85 na condição virgem (Lubnor).

Tabela 60 - Viscosidade (Pa.s) para os ligantes asfálticos modificados com SBS e PPA na condição virgem (Lubnor).

Tabela 61 - Viscosidade (Pa.s) para os ligantes asfálticos modificados com SBS e PA85 na condição RTFOT (Lubnor). 
Tabela 62 - Viscosidade (Pa.s) para os ligantes asfálticos modificados com SBS e PPA na condição RTFOT

Tabela 63 - Temperatura $\left({ }^{\circ} \mathrm{C}\right)$ de Usinagem e Compactação dos Ligantes Modificados

(Replan).

Tabela 64 - Temperatura $\left({ }^{\circ} \mathrm{C}\right)$ de Usinagem e Compactação dos Ligantes Modificados (Lubnor).

Tabela 65- Diferença do Ponto de Amolecimento $\left({ }^{\circ} \mathrm{C}\right)$ entre topo e fundo das amostras de todos os ligantes asfálticos.

Tabela 66 - Valores de Recuperação (\%) dos ligantes asfálticos modificados (Replan). _ 164

Tabela 67 - Valores de Compliância não recuperável $\left(\mathrm{KPa}^{-1}\right)$ dos ligantes asfálticos modificados (Replan).

Tabela 68 - Diferenças percentuais entre as compliâncias não-recuperáveis (Jnr) dos ligantes asfálticos provenientes da Replan.

Tabela 69 - Classificação dos ligantes asfálticos modificados (Replan) segundo critério de tráfego do FHWA.

Tabela 70 - Valores de Recuperação (\%) dos ligantes asfálticos modificados (Lubnor). _ 168

Tabela 71 - Valores de Compliância não recuperável $\left(\mathrm{KPa}^{-1}\right)$ dos ligantes asfálticos modificados (Lubnor).

Tabela 72 - Diferenças percentuais entre as compliâncias não-recuperáveis $\left(J_{n r}, d_{i f f r}\right)$ dos ligantes asfálticos provenientes da Lubnor.

Tabela 73 - Classificação segundo critério de tráfego do FHWA dos ligantes asfálticos modificados (Lubnor).

Tabela 74 - Comprimento da fissura na ruptura $a_{f}(\mathrm{~mm})$ para todos os ligantes asfálticos (Replan).

Tabela 75 - Comprimento da fissura na ruptura $a_{f}(\mathrm{~mm})$ para todos os ligantes asfálticos (Lubnor).

Tabela 76 - Parâmetro $A_{35}$ e $B$ para o ligante asfáltico proveniente da Replan puro e modificados, na condição virgem e RTFOT.

Tabela 77 - Valores de Nf para os ligantes modificados (Replan) em diversas amplitudes de deformação (\%), na condição envelhecida em curto prazo (RTFOT).

Tabela 78 - Valores de Nf para os ligantes modificados (Replan) em diversas amplitudes de deformação (\%), na condição envelhecida em longo prazo (PAV). 174

Tabela 79 - Parâmetro $A_{35}$ e $B$ para o ligante asfáltico proveniente da Lubnor puro e modificados.

Tabela 80 - Valores de Nf para os ligantes modificados (Lubnor) em diversas amplitudes de deformação (\%), na condição envelhecida em curto prazo (RTFOT). 176 
Tabela 81 - Valores de Nf para os ligantes modificados (Lubnor) em diversas amplitudes de deformação (\%), na condição envelhecida em longo prazo (PAV). 176

Tabela 82 - Modelos de regressão referente à propriedade penetração. 190

Tabela 83 - Modelos de regressão referentes ao ponto de amolecimento. 200

Tabela 84 - Valores máximos de viscosidade (Pa.s) nas condições virgem e RTFOT (Replan).

Tabela 85 - Valores máximos de viscosidade (Pa.s) nas condições virgem e RTFOT (Lubnor).

Tabela 86 - Variação média de Viscosidade (Pa.s) para 1\% de aumento na proporção dos modificadores (Replan).

Tabela 87 - Variação média de Viscosidade (Pa.s) para 1\% de aumento na proporção dos modificadores (Lubnor).

Tabela 88 - Modelos de regressão referente à propriedade Viscosidade.

Tabela 89 - Variação média da perda de massa para 1\% de aumento na proporção dos modificadores

Tabela 90 - Modelos de regressão da Perda de Massa. 213

Tabela 91 - Modelos de regressão da Estabilidade à estocagem.

Tabela 92 - Variação média da recuperação e compliância não recuperável para 1\% de aumento na proporção dos modificadores, para os ligantes asfálticos de base Replan. _ 231 Tabela 93 - Variação média da recuperação e compliância não recuperável para 1\% de aumento na proporção dos modificadores, para os ligantes asfálticos de base Lubnor. _ 231 Tabela 94 - Modelos de regressão da Recuperação e Compliância não recuperável dos ligantes modificados (Replan).

Tabela 95 - Modelos de regressão da Recuperação e Compliância não recuperável dos ligantes modificados (Lubnor).

Tabela 96 - Modelos de regressão da tolerância à fadiga ( $\left.a_{f}\right)$. 238

Tabela 97 - Efeitos dos componentes nas propriedades monitoradas para os ligantes asfálticos modificados (Replan).

Tabela 98 - Efeitos dos componentes nas propriedades monitoradas para os ligantes asfálticos modificados (Lubnor). 


\section{Sumário}

DEDICATÓRIA - -

EPÍGRAFE ---

RESUMO -

ABSTRACT - XIII

LISTA DE ILUSTRAÇÕES -.-XX

LISTA DE TABELAS--XXX

1. INTRODUÇÃO 41

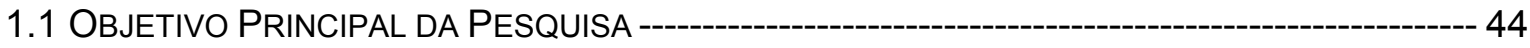

1.2 Programa LaboratorIAL da PESQUISA -ב- 44

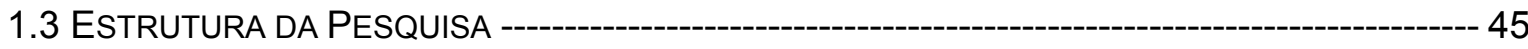

2. REVISÃO DE LITERATURA--:- 47

2.1 LIGANTES ASFÁLTICOS--- 47

2.1.1 Composição Química do Ligante Asfáltico --

2.2 INFLUÊNCIA DE MODIFICADORES NO LIGANTE ASFÁLTICO - 52

2.2.1 Ligantes Modificados com polímero Tipo SBS ------------------------------ 53

2.2.2 Ligantes Modificados com Componentes Fosfóricos --------------------- 56

2.2.3 -- Ligantes Asfálticos e Misturas Asfálticas Modificados com Copolímero SBS e Ácidos Fosfóricos. --

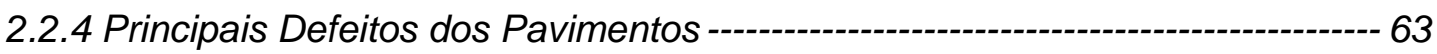

2.2.5 Apontamentos Sobre Reologia Aplicada aos Ligantes Asfálticos -------------- 66

2.2.6 Avaliação da Deformação Permanente e Tolerância ao dano por Fadiga ---- 67

2.2.6.1 Ensaio de Fluência e Recuperação sob Tensão Múltipla (MSCR)----- 68

2.2.6.2 Ensaio para Avaliação da Tolerância ao Dano por Fadiga ------------ 72

2.2.6.3 Ensaio LAS Modificado---_---- 75

3. MATERIAIS E MÉTODOS -- 79

3.1 DELINEAMENTO DO EXPERIMENTO -- 79

3.1.1 Ligantes Asfálticos Modificados com Ácidos Fosfóricos -------------------- 79 
3.1.2 Ligantes Asfálticos Modificados com Ácidos Fosfóricos e Copolímero SBS. 81

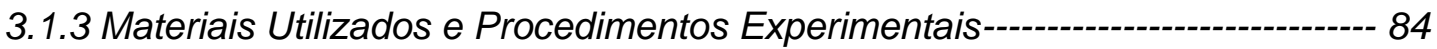

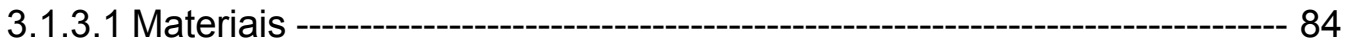

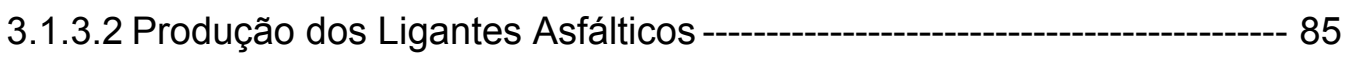

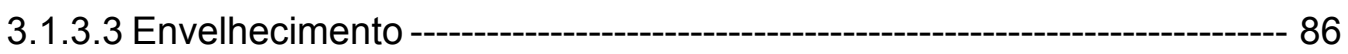

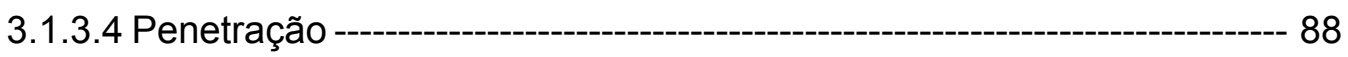

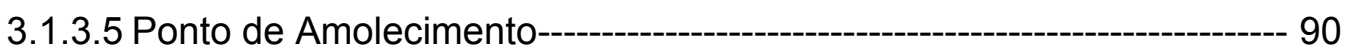

3.1.3.6 Estabilidade à Estocagem-- 91

3.1.3.7 Viscosidade Rotacional ou Brookfield------------------------------ 92

3.1.3.8 Ensaio de Fluência e Recuperação sob Tensão Múltipla (MSCR) ---- 94

3.1.3.9 Linear Amplitude Sweep (LAS Modificado) --------------------------------- 95

4. RESULTADOS E DISCUSSÕES - 97

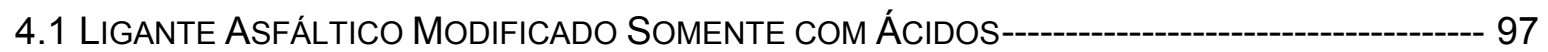

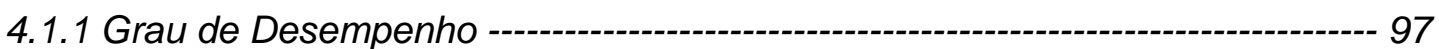

4.1.2 Ensaio de Penetração -- 99

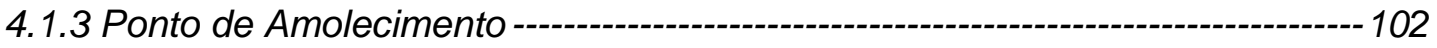

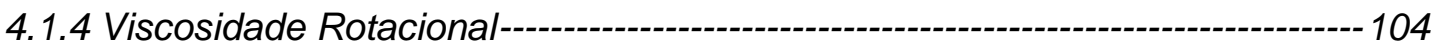

4.1.5 Temperatura de Usinagem e Compactação ---------------------------------------108

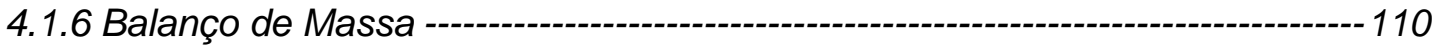

4.1.7 Ensaio de Fluência e Recuperação sob Tensão Múltipla (MSCR)------------111

4.1.8 Ensaio Tolerância ao Dano por Fadiga ------------------------------------------128

4.1.8.1 Análise do índice de tolerância ao dano pelo parâmetro at-------------128

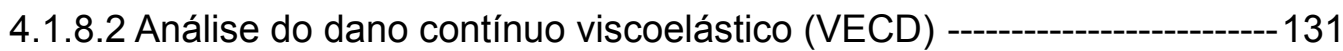

4.1.9 Resultados das Análises Estatísticas do Experimento Fatorial -----------------139

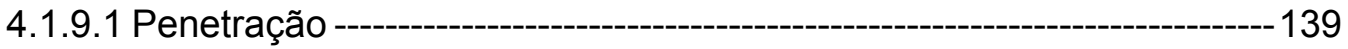

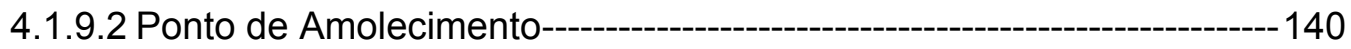

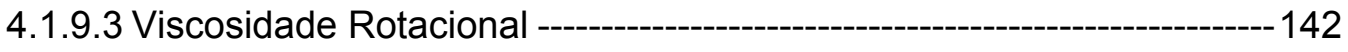

4.1.9.4 Recuperação-------------------------------------------------------------------------143

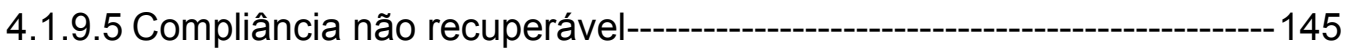

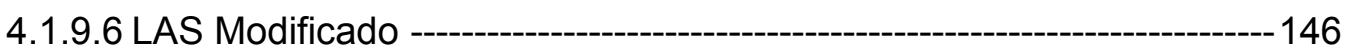

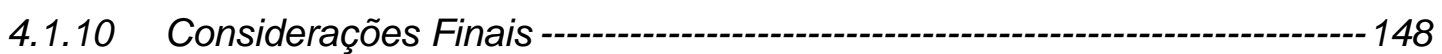

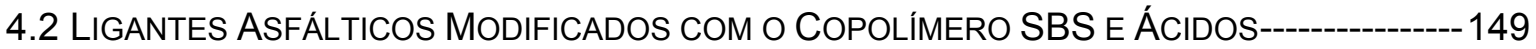

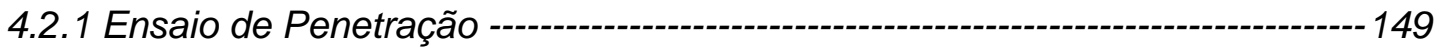

4.2.2 Ensaio de Ponto de Amolecimento--

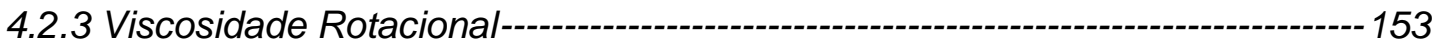

4.2.4 Temperatura de Usinagem e Compactação ---------------------------------157 


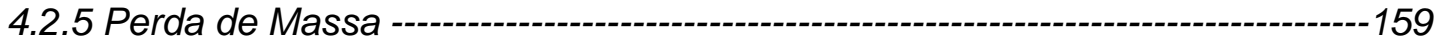

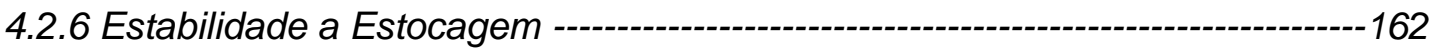

4.2.7 Ensaio de Fluência e Recuperação sob Tensão Múltipla (MSCR) -------------164

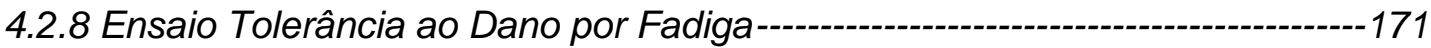

4.2.8.1 Análise do índice de tolerância ao dano pelo parâmetro af-------------171

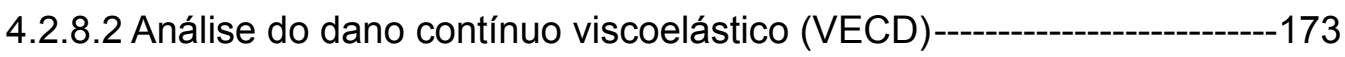

4.2.9 Análise Estatística do Experimento com Misturas -------------------------------177

4.2.9.1 Ensaio de Penetração --- 179

4.2.9.2 Ponto de Amolecimento---------------------------------------------190

4.2.9.3 Viscosidade Rotacional --

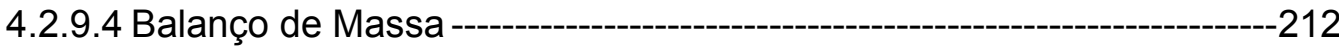

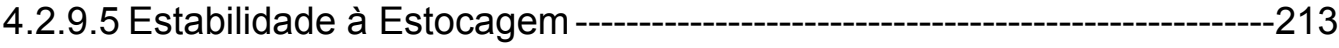

4.2.9.6 Ensaio de Fluência e Recuperação sob Tensão Múltipla (MSCR)----217

4.2.9.7 Análise do índice de tolerância ao dano pelo parâmetro af-------------235

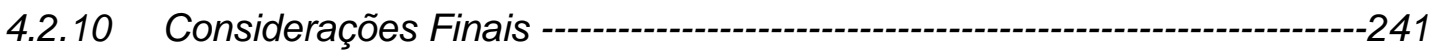

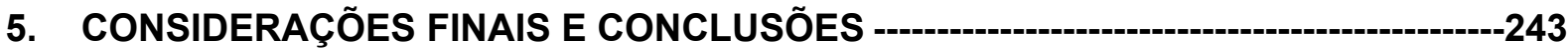

5.1APONTAMENTOS SOBRE OS LIGANTES ASFÁLTICOS MODIFICADOS SOMENTE COM ÁCIDOS243

5.2 APONTAMENTOS SOBRE OS LIGANTES ASFÁLTICOS MODIFICADOS COM O COPOLÍMERO SBS COM OU SEM A PRESENÇA DOS ÁCIDOS.---

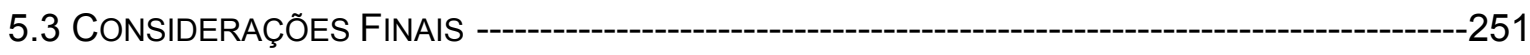

6. REFERÊNCIAS BIBLIOGRÁFICAS --

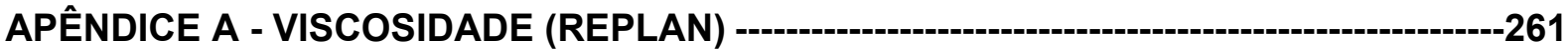

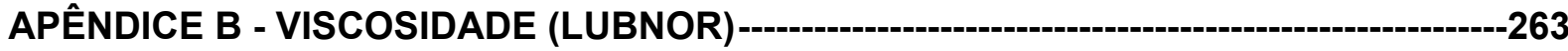

APÊNDICE C - DADOS DE RECUPERAÇÃO E COMPLIÂNCIA NÃO RECUPERÁVEL PARA LIGANTES ASFÁLTICOS PUROS E MODIFICADOS (REPLAN E LUBNOR).-----265 APÊNDICE D - EFEITO DO ENVELHECIMENTO NA NF EM FUNÇÃO DA AMPLITUDE DE

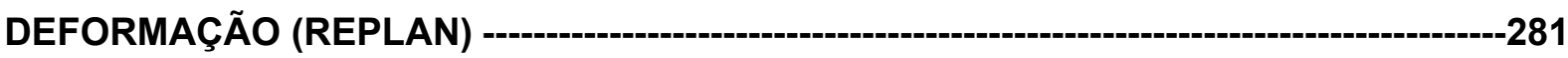

APÊNDICE E- VARIAÇÃO DO NF EM FUNÇÃO DA AMPLITUDE DE DEFORMAÇÃO

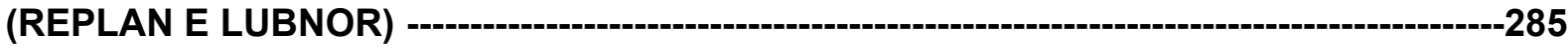

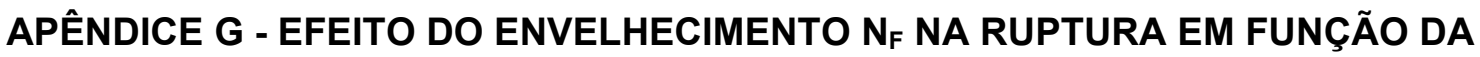
AMPLITUDE DE DEFORMAÇÃO (LUBNOR).

APÊNDICE H- GRÁFICO DE SUPERFÍCIE E EFEITO DE COMPONENTES (REPLAN E LUBNOR) 


\section{Introdução}

As rodovias possibilitam a integração econômica entre as regiões do país e proporcionam grandes benefícios para a sociedade, sendo um dos principais sistemas de transportes utilizados para o deslocamento de pessoas e bens. Portanto, é importante que essa infraestrutura seja mantida de forma adequada e satisfatória, para que os problemas relacionados a ela não interfiram nos custos operacionais dos veículos, tampouco elevem os preços dos serviços e bens comercializados.

Vários são os fatores que influenciam e propiciam a degradação das rodovias, entre os quais se destacam: (a) aumento do volume de tráfego; (b) excesso de carga transportada por eixo; (c) pressão de enchimento dos pneus elevada; e (d) pouco planejamento e realizações de intervenções/conservações. Todos esses fatores aliados às condições ambientais, às quais são submetidas as rodovias brasileiras, fazem com que a sua vida útil diminua. Para tentar solucionar e/ou diminuir o efeito desses fatores, visando melhorar as condições estruturais e funcionais das rodovias, deve-se fiscalizar, mediante postos de pesagens, as cargas transportadas por eixo pelos veículos, assim como realizar levantamentos das condições das rodovias periodicamente para que, desta maneira, seja realizado um planejamento de conservações, intervenções e restaurações necessário para as rodovias. Outra forma, bastante explorada, é a busca por materiais que melhorem a durabilidade e o comportamento dos materiais que compõem a estrutura do pavimento, proporcionando um aumento na sua vida útil.

Dentro desse contexto, visando melhorar a condição funcional e estrutural das rodovias, uma alternativa é a busca pela maior durabilidade dos revestimentos asfálticos. Sendo assim, uma das possibilidades é realizar estudos com os materiais que compõem o revestimento asfáltico, ligante asfáltico e materiais pétreos, com objetivo de melhorar as características do produto final e, consequentemente, proporcionar um melhor desempenho da capa asfáltica. No que diz respeito ao ligante asfáltico, diversos estudos são realizados, principalmente com a adição de modificadores, para verificar seu comportamento e a possibilidade de obter características melhores que as dos ligantes asfálticos não modificados. 
Recentemente, a adição de modificadores ao ligante asfáltico, principalmente a de polímeros ${ }^{1}$, tem sido expressiva devido à busca por revestimentos que suportem o elevado volume de tráfego e que consigam atender as exigências de conforto e segurança para os usuários. Além disso, destaca-se que a utilização de polímeros no ligante asfáltico tem sido promissora nos últimos anos, uma vez que proporciona um melhor desempenho da mistura asfáltica devido ao aumento da resistência a deformação permanente e a trincas por fadiga e, dessa maneira, permite reduzir os custos de manutenção e conservação das rodovias e aumentar sua vida útil. Cabe salientar ainda que a adição de agentes modificadores no ligante asfáltico visa melhorar suas propriedades e, consequentemente, propiciar um desempenho satisfatório desse material dentro de uma ampla faixa de temperaturas, que corresponda às de serviço do pavimento.

Nesse âmbito, é importante destacar que conhecer o comportamento de ligantes asfálticos é imprescindível, pois há relação direta com a qualidade do revestimento asfáltico. Apesar da mistura asfáltica ser composta por materiais pétreos (agregados) e material betuminoso (ligante asfáltico), esse último, por ser um material termoviscoelástico, tem características que influenciam diretamente na resposta da mistura asfáltica à ação do tráfego. Portanto, tenta-se, mediante estudo das características do ligante asfáltico, prever o comportamento da mistura asfáltica frente às ações que o revestimento asfáltico é submetido.

Atualmente, existem vários tipos de polímeros, naturais ou sintéticos, sendo estudados para modificação de ligantes asfálticos, entre os quais podem ser citados: (a) Borracha moída de pneu;(b) Borracha de estireno-butadieno (SBR); (c) copolímero2tribloco de estirenobutadieno-estireno (SBS); (d) copolímero tribloco de estireno-etileno/butadieno-estireno (SEBS); (e) copolímero etileno-acetato de polivinila (EVA), entre outros. Segundo Herrington et al. (1999), os ligantes asfálticos podem ser modificados com adição de ácidos como, por exemplo, o anidrido maleico, ácido fumárico e ácido polifosfórico (PPA).

Leite et al., (2004) comentam que a utilização de ácido polifosfórico na modificação de ligantes asfálticos é uma prática existente há aproximadamente cinco anos nos EUA e que é possível melhorar o desempenho dos ligantes asfálticos mediante a modificação química proporcionada pelo ácido polifosfórico. Segundo Baumgardneret al., (2005), o mecanismo de modificação do ligante asfáltico com o ácido polifosfórico depende das características químicas do ligante asfáltico de base.

Destaca-se, ainda, que o ácido polifosfórico é um modificador que pode ser adicionado sozinho ao ligante asfáltico ou juntamente com outros tipos de modificadores. Ainda segundo

\footnotetext{
${ }^{1}$ Polímeros são macromoléculas caracterizadas por seu tamanho, estrutura química e interação intra e intermoleculares. Possuem unidades químicas ligadas por covalência, repetidas ao longo da cadeia denominadas de meros (Mano \& Mendes, 1999).

${ }^{2}$ Denomina-se copolímero quando o polímero tem mais de um tipo de mero. Tem-se um copolímero em bloco quando alternamse sequências de unidades químicas iguais (Mano \& Mendes, 1999).
} 
Martin e Baumgardner (2006), o ácido polifosfórico pode preservar algumas características do ligante modificado mesmo com a redução da proporção do polímero modificador, ou seja, ele permite reduzir a proporção do polímero adicionado ao ligante asfáltico, mas consegue obter características tão adequadas quanto às do ligante asfáltico modificado apenas com o polímero. Além do ácido polifosfórico, estudos realizados por Arnold (2008) apontam que qualquer grau de ácido fosfórico (de 50 a 100\%) poderia ser adicionado como modificador de ligantes asfálticos. No entanto, deve-se levar em conta que graus muito baixos podem acarretar problemas ao serem misturados com o ligante asfáltico, devido à alta temperatura necessária para mistura e à parcela de água contida no material.

Mesmo sabendo do efeito positivo da adição do ácido polifosfórico ao ligante asfáltico, destaca-se o fato de se trabalhar com um produto importado, o que dificulta sua aquisição e pode tornar o produto final muito caro. Tendo em vista a possibilidade de se trabalhar com um produto de mesma base, mas de origem nacional, o que o tornaria um modificador mais acessível, optou-se por verificar o comportamento da adição de ácido fosfórico (PA85) ao ligante asfáltico. Ademais, sabendo-se do bom comportamento da adição do ácido com outros tipos de polímero, também foi planejado a verificação do comportamento dos ácidos fosfórico (PA85) e polifosfórico (PPA) juntamente com o copolímero SBS, uma vez que este é o polímero mais utilizado nas rodovias federais brasileiras. Salienta-se também a influência do tipo de ligante asfáltico de base, visto que a composição química pode influenciar nas modificações que ocorrem no ligante asfáltico modificado com o ácido. Dessa maneira, optouse por modificar dois tipos de ligantes diferentes, a saber: (a) um proveniente do estado de São Paulo (Replan) e outro, (b) proveniente do Ceará (Lubnor).

Resumidamente, pretende-se analisar o comportamento reológico de dois ligantes asfálticos modificados com componentes fosfóricos e com adição do copolímero SBS, visando verificar a possibilidade da substituição do ácido polifosfórico (PPA) pelo ácido fosfórico (PA85), assim como verificar seu comportamento com a adição do copolímero SBS. 


\subsection{Objetivo Principal da Pesquisa}

Com base no contexto apresentado na seção anterior, o principal objetivo neste trabalho é analisar o efeito da adição de agentes fosfóricos (ácidos fosfórico e polifosfórico) no comportamento reológico de diferentes ligantes asfálticos puros e modificados com o copolímero SBS. Visando o cumprimento desses objetivos, têm-se como objetivos secundários:

- Analisar a possibilidade de substituir o ácido polifosfórico - PPA (produto importado), pelo ácido fosfórico - PA85 (produto nacional utilizado na indústria alimentícia);

- Analisar o efeito dos ácidos fosfóricos (PPA e PA85) sobre as propriedades reológicas de ligantes asfálticos diferentes (Replan e Lubnor);

- Analisar os efeitos principais dos ácidos (fosfóricos e polifosfórico) sobre propriedades reológicas de ligantes asfálticos puros e modificados pelo copolímero SBS, virgens e envelhecidos;

- Estabelecer limites de proporções dos ácidos fosfóricos e polifosfórico, com base em limites de especificações de propriedades reológicas do ligante asfáltico; e

- Avaliar a hipótese de que os ácidos pesquisados podem promover determinadas modificações químicas no ligante asfáltico, de modo a proporcionar ligantes asfálticos com maior estabilidade à estocagem, com maior resistência ao efeito do envelhecimento e com propriedades reológicas adequadas nas temperaturas de ocorrência dos principais defeitos dos pavimentos.

\subsection{Programa Laboratorial da Pesquisa}

Para alcançar os objetivos expostos, o programa laboratorial da pesquisa foi dividido em duas etapas: (a) um experimento fatorial para análise das misturas ${ }^{3}$ modificadas somente com ácidos (PPA e PA85); e (b) para as misturas com adição dos ácidos (PPA e PA85) e copolímero SBS, o planejamento para as formulações foram realizadas com base na técnica de experimentos com misturas, conforme apresentado por Cornell (2002). Para o experimento

\footnotetext{
${ }^{3}$ Entende-se mistura como formulações realizadas com as diferentes proporções de ligante asfáltico + ácido; ligante asfáltico +SBS, ou ligante asfáltico + SBS+ácido. 
fatorial, a influência dos fatores e suas interações nas propriedades monitoras foram analisadas estatisticamente mediante análise de variância (ANOVA), para um nível de significância de $95 \%$ e, para o experimento com misturas as análises de resultados foram realizadas através dos gráficos de superfície de resposta e efeito de componentes.

Os ligantes asfálticos dos dois experimentos foram submetidos a ensaios laboratoriais para determinação de propriedades empíricas e fundamentais, na condição virgem, envelhecida a curto prazo (RTFOT) e/ou envelhecida a longo prazo (PAV), dependendo da propriedade avaliada, seguindo as especificações Superpave. Para análise do comportamento reológico foram verificados a penetração à $25^{\circ} \mathrm{C}$, o ponto de amolecimento, a viscosidade Brookfield em cinco temperaturas (135; 143; 155; 163 e $170^{\circ} \mathrm{C}$ ) com amostras virgens e envelhecidas a curto prazo; a fluência e a recuperação sob múltipla tensão (MSCR) avaliada em cinco temperaturas $\left(52 ; 58 ; 64 ; 70\right.$ e $\left.76^{\circ} \mathrm{C}\right) \mathrm{com}$ amostras envelhecidas a curto prazo, e a tolerância ao dano por fadiga (LAS) na temperatura de $25^{\circ} \mathrm{C}$, com amostras na condição envelhecida a curto e a longo prazo. Além desses ensaios, também foi realizado o de estabilidade à estocagem.

\subsection{Estrutura da Pesquisa}

Além desta introdução, este texto está estruturado da seguinte forma: no capítulo 2 , de maneira breve, é apresentada uma revisão de literatura sobre a composição de ligantes asfálticos, os agentes modificadores do ligante asfáltico de interesse da presente pesquisa (ácido fosfórico, polifosfórico e copolímero SBS) e algumas considerações sobre a influência desses modificadores nas propriedades reológicas dos ligantes asfálticos, assim como de misturas asfálticas.

O capítulo 3 apresenta os materiais utilizados neste trabalho, assim como os aspectos metodológicos que conduziram a parte experimental e a descrição dos ensaios realizados para avaliação dos materiais. No capítulo 4 são apresentados os dados e, consequentemente, os resultados e análises da pesquisa. Finalmente, no capítulo 5 são apresentadas as conclusões e as sugestões para trabalhos futuros. 


\section{Revisão de Literatura}

\subsection{Ligantes Asfálticos}

O ligante asfáltico, amplamente utilizado na pavimentação de rodovias, é um material bastante complexo com uma grande variedade de compostos orgânicos. É originado do petróleo, podendo ser obtido por evaporação natural de depósitos localizados na superfície da terra (asfaltos naturais) ou por destilação em unidades industriais (refinarias de petróleo).

É um material impermeável à água e pouco reativo, não obstante, sofre um processo de envelhecimento por oxidação lenta, devido ao contato com o ar e a água, isto porque o ligante asfáltico é formado por moléculas orgânicas e estas reagem com o oxigênio do meio ambiente (oxidação) proporcionando maior rigidez ao material.

O ligante asfáltico tem comportamento viscoelástico, ou seja, apresenta características elásticas e viscosas ao mesmo tempo. Quando é submetido a altas temperaturas se comporta como um fluido viscoso, e em baixas temperaturas apresenta comportamento próximo ao sólido elástico. Sabe-se que o pavimento, durante sua vida útil, está submetido a temperaturas intermediárias, portanto apresenta os dois tipos de comportamentos.

O ligante asfáltico tem função aglutinante e impermeabilizante na mistura asfáltica. A função aglutinante visa proporcionar ligação entre os agregados, que possibilita uma mistura asfáltica capaz de resistir à ação mecânica de desagregação produzida pela ação do tráfego. Quanto à função de impermeabilização, garante ao pavimento vedação eficaz contra a penetração de água, minimizando o efeito nocivo, que pode comprometer a estrutura do pavimento.

Atualmente é comum a utilização de agentes modificadores no ligante asfáltico visando melhorar as suas propriedades e, assim, propiciar um melhor desempenho dos revestimentos a longo prazo.

\subsubsection{Composição Química do Ligante Asfáltico}

Ligantes asfálticos são materiais complexos de hidrocarbonetos contendo vários compostos químicos, sendo a maioria com peso molecular relativamente alto. Análises realizadas em ligantes asfálticos originados de diferentes petróleos mostram que a maioria 
desses materiais contém de 82 a $88 \%$ de carbono, de 8 a $11 \%$ de hidrogênio, de 0 a $6 \%$ de enxofre, de 0 a 1,5\% de oxigênio e de 0 a $1 \%$ de nitrogênio. Essa composição pode variar de acordo com o material de origem, o processo de fracionamento, as modificações induzidas no processo e o envelhecimento do material durante sua vida útil (SHELL, 2003). Considerando variáveis como tamanho molecular e tipo de hidrocarbonetos presentes no asfalto, torna-se notável a complexidade da composição desse material (CORBERTT, 1969). O ligante asfáltico pode ser definido como um material praticamente não volátil, viscoso e impermeável derivado do petróleo bruto, sendo completamente ou quase totalmente solúvel em tolueno, e muito viscoso ou quase sólido em temperatura ambiente. Diante da complexidade da sua composição química, pesquisadores elaboraram métodos para separar os ligantes asfálticos mediante sua solubilidade em solventes específicos.

Um modelo coloidal da estrutura do ligante asfáltico foi proposto por Pfeiffer \& Saal (1939) para tentar esclarecer as diferenças das propriedades reológicas desse material. A pesquisa determinou que o ligante asfáltico pode ser classificado de 3 (três) maneiras: Tipo SOL, tipo GEL e SOL-GEL, representados na Figura 1.

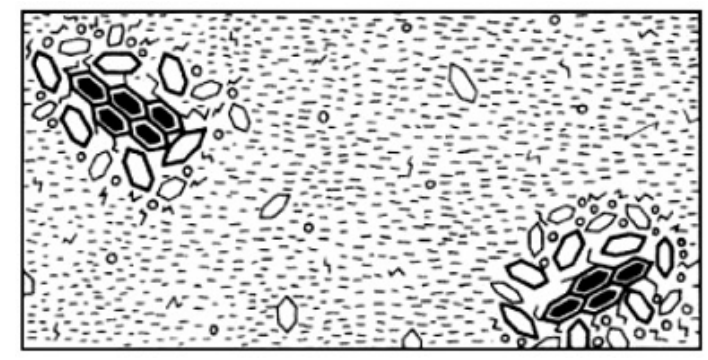

(A) Estrutura Tipo SOL

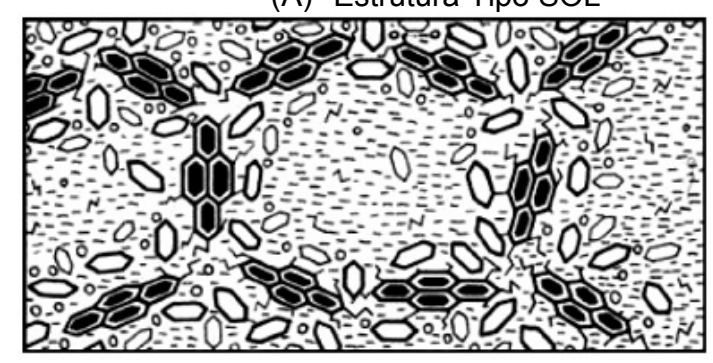

(B) Estrutura Tipo GEL

Figura 1 - Esquema de ligantes tipo (A) Sol e tipo (B) Gel. Fonte: Adaptado SHELL (2003).

Na presença suficiente de resinas e aromáticos de adequada dispersão, os asfaltenos são totalmente dispersos/peptizados e resultam em micelas com mobilidade dentro do ligante asfáltico, o que forma a estrutura tipo SOL. No entanto, se a quantidade de resinas e aromáticos não são suficientes para dipersar as micelas, os asfaltenos podem se associar. Isto permite a formação de estruturas irregulares da unição das micelas em que os vazios são preenchidos com fluidos de constituintes mistos, constituindo estruturas do tipo GEL (SHELL, 2003). 
A maioria dos ligantes asfálticos apresentam comportamento intermediário, uma vez que sua estrutura é uma mistura de micelas existentes no ligante asfáltico do tipo SOL e da estrutura do ligante asfáltico do tipo GEL, sendo assim, estes ligantes asfálticos apresentam estruturas do tipo GEL-SOL. Os ligantes asfálticos com estrutura tipo SOL apresentam comportamento newtoniano, enquanto os ligantes asfálticos com estrutura do tipo GEL tem comportamento não-newtoniano (LESUEUR, 2009).

Dentre esses métodos, um bastante comentado na literatura é a do químico Corbertt (1969), que aponta que o ligante asfáltico é dividido em quatro famílias genéricas (ASTM D 4124-01), a saber: saturados, aromáticos, resinas e asfaltenos, estrutura que o pesquisador denomina frações SARA, conforme ilustrado na Figura 2. Os asfaltenos são separados primeiro por precipitação com adição de n-heptano, e os outros constituintes, denominados de maltenos, são solúveis no n-heptano e separados por cromatografia de adsorção (MASSON, et al. 2001; SHELL, 2003).

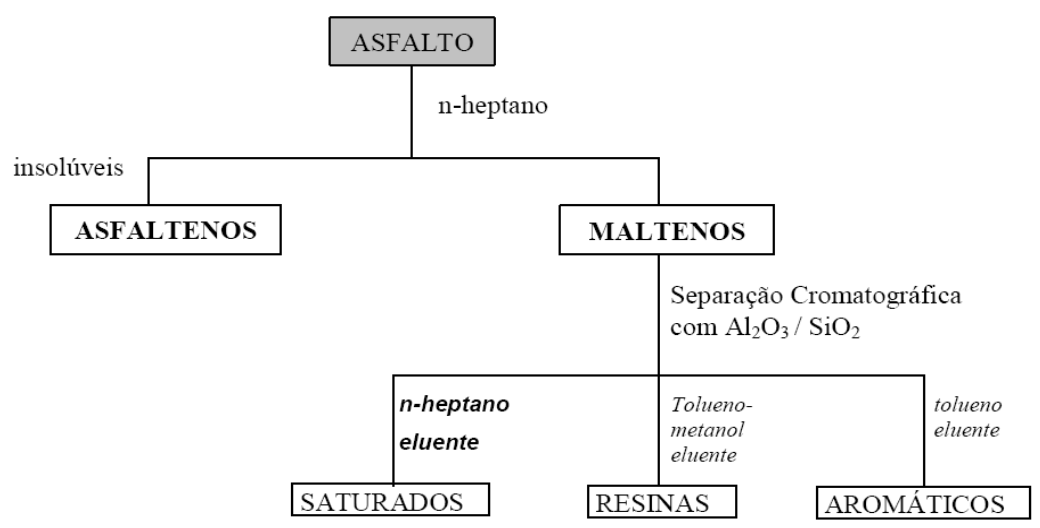

Figura 2 - Distribuição dos grupos químicos no asfalto.

Fonte: Corbertt, (1969).

Os asfaltenos são materiais aromáticos complexos com peso molecular elevado e constituem de $5 \%$ a $25 \%$ do ligante. O teor de asfaltenos tem grande influência nas características reológicas do ligante asfáltico. O aumento no teor de asfaltenos produz um ligante asfáltico mais consistente, mais viscoso, com valores de penetração mais baixos e ponto de amolecimento maior. Quanto à fase maltênica, os saturados são cadeias lineares e ramificadas de hidrocarbonetos, com peso molecular similar ao dos aromáticos, e constituem de $5 \%$ a $20 \%$ do ligante asfáltico. As resinas atuam como agentes dispersantes dos asfaltenos e, assim como estes, são compostos por hidrogênio e carbono, com pequenas quantidades de oxigênio, enxofre e nitrogênio. Os aromáticos compreendem o menor peso molecular dos compostos do ligante asfáltico, representam a maior proporção do meio de dispersão dos asfaltenos, constituem cerca de $40 \%$ a $65 \%$ do total do ligante asfáltico (SHELL, 2003). 
Segundo Corbertt (1969), as frações aromáticas melhoram as propriedades físicas, os saturados influenciam negativamente na susceptibilidade térmica, as resinas melhoram a ductilidade e dispersão dos asfaltenos que, por sua vez, proporcionam um aumento da viscosidade e tornam os asfaltos menos susceptíveis a variações de temperatura.

Estudos realizados por Mortazavi \& Moulthrop (1993) avaliaram trinta e dois (32) tipos diferentes de ligantes asfálticos dos Estados Unidos e Canadá; a seleção desses materiais almejou caracterizar ligantes asfálticos com comportamentos diferentes (bons ou ruins) baseados em estudos preliminares (laboratoriais) ou situações de campo.

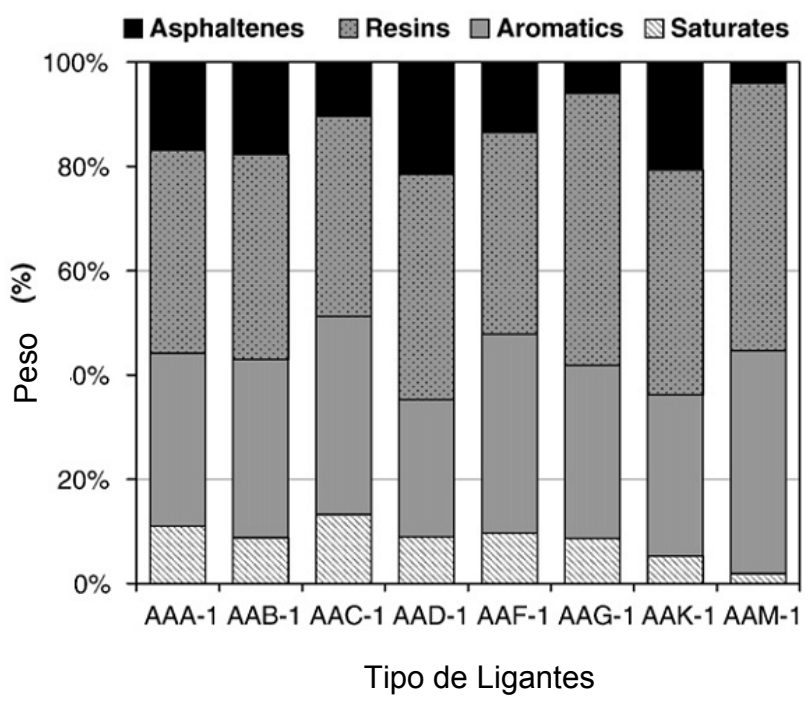

Figura 3 - Porcentagem dos componentes asfálticos para ligantes asfálticos diferentes. Fonte: Leuser (2009) adaptado de Mortazavi \& Moulthrop (1993).

Quanto à composição quimíca, pode-se observar, na Figura 3, que os saturados constituem de $5 \%$ a $15 \%$ do ligante asfáltico, os aromáticos e resinas estão presentes na proporção de 30 a $45 \%$ de cada e os asfaltenos representam de $5 \%$ a $20 \%$. Desta maneira, confirma-se que a variação dos componentes dos ligantes asfálticos está diretamente relacionada ao tipo de material de origem.

A estrutura do ligante asfáltico é complexa e resulta do processo da organização das moléculas. As moléculas podem expandir irreversivelmente com o envelhecimento químico mediante a soma das reações de oxidação e polimerização, e em menor grau, pela evaporação dos componentes mais leves. O resultado desse envelhecimento proporciona um endurecimento do material, o que aumenta a probabilidade de sua fissuração (SHELL, 2003). Salienta-se, ainda, que a susceptibilidade de um ligante asfáltico ao envelhecimento depende do material de origem e do processo de produção. Na Figura 4 pode-se observar que o processo de envelhecimento leva a uma diminuição dos teores de aromáticos, um aumento 
dos teores de resina e asfaltenos e que os saturados permanecem inalterados devido a sua baixa reatividade química.
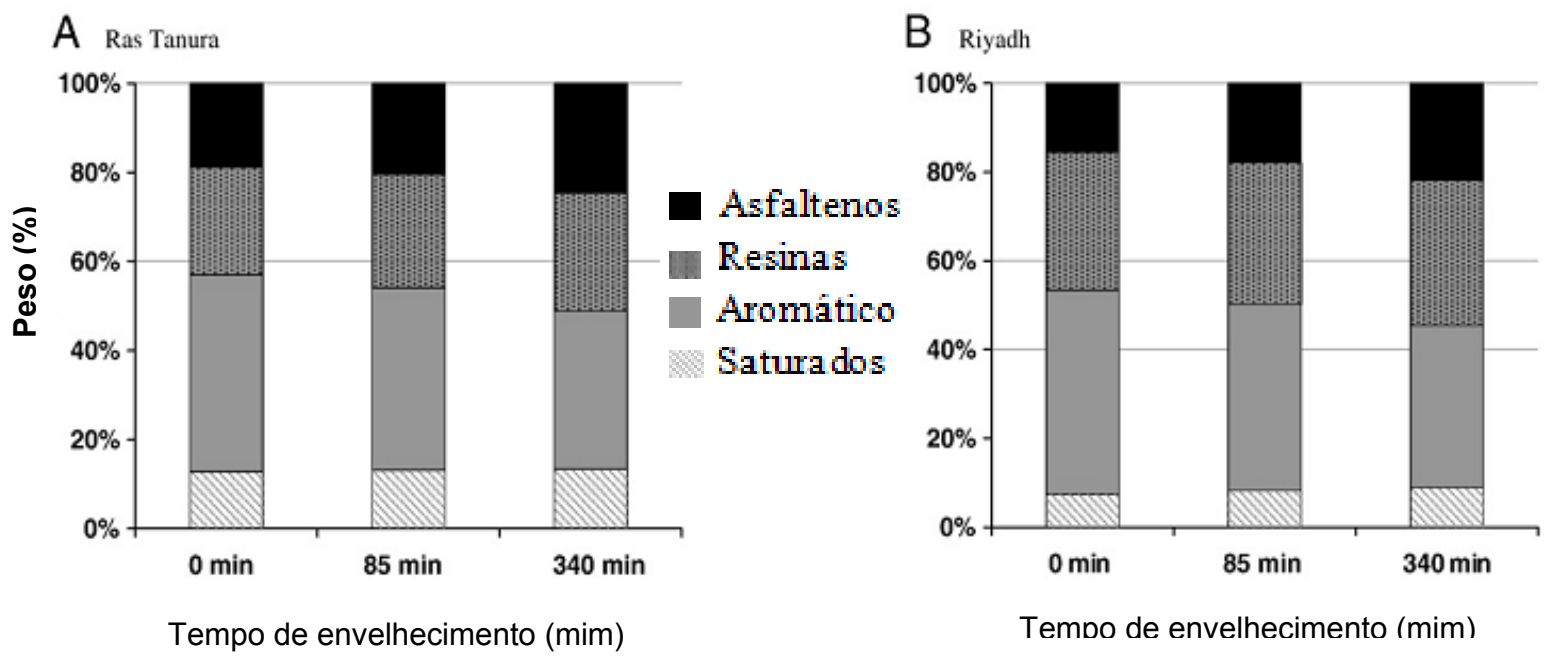

Figura 4 - Frações SARA para ligantes diferentes antes a após envelhecimento a curto prazo.

Fonte: Adaptado de Leusser (2009).

No modelo proposto por Yen ${ }^{4}$ apud Leite (1999), o CAP é um sistema coloidal, constituído pela suspensão de micelas de asfaltenos, peptizadas por resinas em meio oleoso (saturados e aromáticos), formando um equilíbrio, conforme apresentado na Figura 5. Segundo Silva (2005), o equilíbrio desse sistema está intimamente relacionado com as propriedades físicas e reológicas do ligante asfáltico, além de ser extremamente importante na previsão da estabilidade coloidal do asfalto e de sua compatibilidade com aditivos.

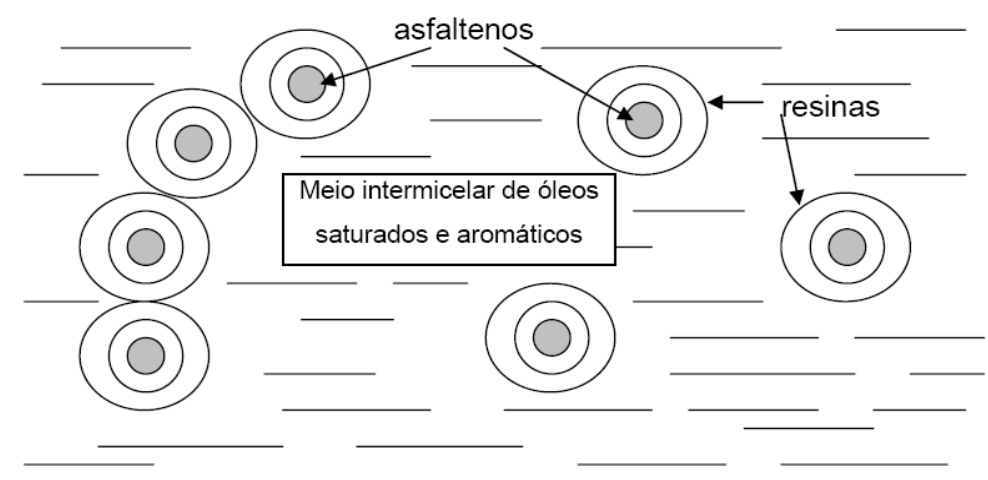

Figura 5 - Representação do modelo de estrutura coloidal segundo Yen. Fonte: Silva (2005).

Considerando sua estrutura química, pode-se dizer que o ligante asfáltico é um sistema coloidal consistindo de micelas de asfaltenos de alto peso molecular dispersas ou

\footnotetext{
${ }^{4}$ Yen. T.F. Asphaltene/Resin plus oil inteconversion: an investigation into colloidal model of asphaltene. Proceddings of WorkshopThe chemical components and structure of asphaltic materials - Rome 1991.
} 
dissolvidas em um meio oleoso (maltenos) de baixo peso molecular, ou seja, é uma dispersão coloidal de micelas de asfaltenos na fase maltênica (LESUEUR, 2009).

Segundo Silva (2005), o modelo estrutural do programa SHRP não considera válido o conceito de asfaltenos e maltenos, classificando as frações asfálticas em polares e nãopolares. O modelo propõe que as forças intra e intermoleculares são responsáveis pela formação de redes tridimensionais que resultam em características elásticas ou viscosas, uma vez que com o aumento da temperatura ou ação de forças cisalhantes ocorre destruição destas interações e consequente redução da elasticidade e aumento de suas características viscosas.

Em geral, os ligantes asfálticos são classificados pela penetração, porém ligantes asfálticos de mesma classificação não apresentam, necessariamente, a mesma composição química e o mesmo comportamento físico e reológico quando misturados com polímeros e ácidos (LOEBER et al., 1998). Apesar de ser uma prática comum, a modificação de ligantes asfálticos, mediante adição de modificadores diversos, tem interação e compatibilidade com o ligante asfáltico de base como fatores importantes, pois influenciam diretamente no comportamento mecânico do material final. Altos teores de asfaltenos diminuem a compatibilidade do polímero com o ligante asfáltico e a aromaticidade dos maltenos devem permanecer entre certos limites para atingir um bom nível de compatibilidade (LESUEUR, 2009).

\subsection{Influência de Modificadores no Ligante Asfáltico}

A utilização de polímeros como modificadores de ligantes asfálticos é uma prática bastante comum, visto que essa modificação proporciona melhorias no desempenho da camada asfáltica, devido ao aumento da resistência à deformação permanente e à fadiga, bem como a redução dos efeitos prejudiciais do envelhecimento do ligante asfáltico. No entanto, apesar dos efeitos positivos dessa incorporação, tem-se um comprometimento da trabalhabilidade da mistura durante a construção, tornando o processo executivo mais complexo.

Uma das alternativas para tentar solucionar esse problema é adicionar aditivos que melhorem o manuseio do material, atuando na redução da viscosidade do ligante asfáltico. Dentre esses materiais pode-se citar o ácido polifosfórico, que tem sido indicado por ser um agente capaz de aumentar a qualidade do ligante asfáltico modificado com polímero, proporcionando a redução do modificador adicionado, o que permite uma redução da viscosidade e, consequentemente, uma melhor trabalhabilidade do produto final. 
Com o intuito de relatar a influência dos modificadores no ligante asfáltico, os subitens apresentados a seguir apresentam os efeitos da adição dos modificadores copolímero SBS e ácidos fosfóricos no ligante asfáltico.

\subsubsection{Ligantes Modificados com copolímero Tipo SBS}

Para Silva, et al., (2002), o copolímero SBS é um copolímero tribloco de estireno e butadieno, um exemplo de elastômero termoplástico, composto por domínios rígidos de poliestireno (PS) dispersos em uma matriz flexível elastomérica de polibutadieno (PB). Estes domínios de poliestireno funcionam como pontos de ligação das extremidades das cadeias do polibutadieno, proporcinando ao material propriedades de resistência e elasticidade. O componente poliestireno é responsável pelo aumento da consistência, consequentemente, ponto de amolecimento mais elevado, enquanto o componente polibutadieno confere à mistura um aumento da elasticidade (Robinson, 2004).

Ao se adicionar o copolímero SBS ao ligante asfáltico, a fase elastomérica do polímero absorve os maltenos do ligante asfáltico e aumenta seu volume inicial em até 9 vezes (LU \& ISACSSON, 1997). Como as cadeias poliméricas tem peso molecular similar ou maior que os asfaltenos, ambas competem pelo poder solvente da fase maltênica do ligante asfáltico e uma separação de fase pode ocorrer se a quantidade de maltenos dispersos for insuficiente. Esta separação de fase é um indicativo da incompatibilidade do ligante asfáltico de base com o polímero, que pode ser melhorada com a adição de óleos aromáticos. No entanto, um teor muito elevado de aromáticos pode dissolver os blocos de poliestireno e comprometer os benefícios do copolímero SBS (AIREY, 2003; KANABAR, 2010).

Segundo Wen, et al., (2002) esta separação de fase pode acontecer devido à diferença de solubilidade e densidade entre o copolímero SBS e o ligante asfáltico de base. Durante a estocagem em altas temperaturas, partículas do copolímero SBS dispersas no ligante asfáltico são acumuladas e flutuam no topo do ligante asfáltico, fazendo com que, ao se avaliar a estabilidade à estocagem, mediante ensaio de ponto de amolecimento, os valores obtidos para o topo do material são superiores quando comparados ao restante, por causa da maior concentração do copolímero SBS.

Uma concentração aceitável do copolímero SBS, em peso, para modificação do ligante asfáltico, está entre 3 a $5 \%$, e sua adição no ligante asfáltico forma uma rede polimérica contínua que permite modificar significativamente as propriedades do material (LU \& ISACSSON, 1998; AIREY, 2003; KANABAR, 2010). Polímeros elastoméricos como o copolímero SBS modificam a reologia do ligante asfáltico melhorando o componente elástico 
e reduzindo o componente viscoso; sendo assim, o material tem melhor recuperação elástica depois da remoção de uma carga aplicada, reduzindo, dessa maneira, o risco de deformação permanente (ROBINSON, 2004).

No tocante aos ensaios convencionais, a modificação do ligante com adição do copolímero SBS proporciona uma redução da penetração, devido ao aumento da rigidez; aumento do ponto de amolecimento, o que torna-se favorável, pois minimiza possíveis problemas de plastificação e deformação do pavimento por escoamento dos ligantes asfálticos (FERNANDES,et al., 2008). Estudos realizados por Airey (2003) para avaliar as propriedades dos ligantes asfálticos modificados com o copolímero SBS apontam redução nos valores de penetração relativamente uniforme com o aumento do teor do modificador. No entanto, para o ponto de amolecimento foi constatado um aumento significativo para altas concentrações do modificador ( $5 \%$ a $7 \%)$.

Quanto às propriedades reológicas, pesquisas realizadas por Airey (2003) e Fernandes, et al., (2008) observaram uma melhora na resistência do ligante asfáltico à deformação permanente (maiores valore de $G^{*}$ ), bem como uma melhora na resposta elástica (menores valores de $\delta$ ). Menores variações nos valores de $\delta$ com a temperatura foram observadas para o ligante asfáltico modificado com o copolímero SBS em relação ao ligante asfáltico base, indicando uma menor suceptibilidade térmica do material. Essas alterações são dependentes do tipo de ligante asfáltico de base e da compatibilidade entre ligante asfáltico e polímero. A pesquisa de Airey (2003) ainda destaca que, em linhas gerais, os ligantes asfálticos paraníficos têm mostrado maior grau de modificação com a adição do copolímero SBS quando comparados aos ligantes asfálticos naftênicos, em condições de altos teores de modificador e altas temperaturas.

Quanto à viscosidade, estudos realizados por Lu e Isacsson (1997b) e Wen, et al., (2002) mostram que o aumento dessa propriedade não é diretamente proporcional à concentração do modificador. Foi observado comportamento diferente com teores acima de $3 \%$, fazendo com que os pesquisadores concluíssem que o copolímero SBS não é um aditivo inerte, podendo existir certas interações entre as moléculas do copolímero SBS e entre este modificador e o ligante asfáltico. O pequeno aumento da viscosidade para ligantes asfálticos modificados com teores inferiores a $3 \%$ provavelmente ocorre pela fraca interação ente as partículas do copolímero SBS.

Outro ponto de interesse é conhecer o comportamento dos ligantes modificados com o copolímero SBS em relação ao envelhecimento que ocorre no material na usina e na sua aplicação em campo. Quanto às propriedades convencionais, pesquisas realizadas por Domingos e Faxina (2013) destacam que a adição do copolímero SBS no ligante asfáltico reduz a sensibilidade do ligante asfáltico ao envelhecimento a curto prazo quanto à penetração retida e ao incremento do ponto de amolecimento. 
A pesquisa realizada por $\mathrm{Wu}$, et al. (2008) mostrou que antes do envelhecimento à longo prazo, os valores do ponto de amolecimento dos ligantes asfálticos modificados com SBS são superiores aos do ligante asfáltico de base, devido a estrutura da cadeia polimérica do ligante asfáltico modificado. Com o aumento do tempo de envelhecimento nesta pesquisa, até o período de 500 horas, o ponto de amolecimento do ligante asfáltico de base aumentou consideravelmente, enquanto o ligante asfáltico modificando esta propriedade diminuiu. A partir desse limite de horas, ambos os materiais tiveram aumentados os valores desta propriedade, gradualmente, com o tempo de envelhecimento exposto. Os pesquisadores acreditam que esses fatos podem ser explicados porque no ligante asfáltico de base, mais asfaltenos, com alto peso molecular, são formados devido ao processo de envelhecimento, permitindo o aumento da propriedade. Para os ligantes asfálticos modificados com o copolímero SBS, a degradação do polímero e a oxidação do ligante asfáltico de base ocorrem ao mesmo tempo, sendo que o primeiro tende a diminuir a propriedade e o segundo tende a aumentá-la. Este comportamento é dependente do tipo de ligante de base, assim como da estrutura do copolímero SBS.

Ainda nesse contexto, estudos realizados por Lu e Isacsson (1997) apontam que o envelhecimento do ligante asfáltico aumenta a resistência à deformação permanente de ligantes asfálticos modificados com o copolímero SBS com teores de até 3\%. No entanto, para ligantes asfálticos com teores superiores ( $6 \%$ a $9 \%$ ) esse efeito é dependente da temperatura. Para temperaturas superiores a $60^{\circ} \mathrm{C}$ foi constatada uma diminuição da resistência à deformação permanente nesse material. Quanto à resposta elástica, os ligantes asfálticos modificados com baixos teores de copolímero SBS (3\%) apresentaram um aumento pequeno devido ao envelhecimento. Para teores superiores (6\% a $9 \%)$, o envelhecimento, para altas temperaturas, diminuiu a resposta elástica do material.

Quanto ao dano por fadiga, estudos feitos por Bahia, et al, (1999) mostram que o efeito do envelhecimento a longo prazo aumenta este dano, em baixos níveis de deformação. Já em estudos realizados por Soenen \& Eckmann (2004), constatou-se que amostras envelhecidas apresentam maior resistência à fadiga em baixos níveis de deformação, porém para altos níveis de deformação estas são mais propensas ao dano por fadiga, ou seja, o dano por fadiga aumenta com o aumento da deformação.

Cabe destacar, ainda, que estudo realizado por Nuñez (2013) avaliou o dano por fadiga de ligantes asfálticos modificados com vários tipos de polímeros, entre eles o copolímero SBS. Pode-se observar, em linhas gerais, que ao considerar baixos níveis de deformação (3\%), o efeito da modificação melhora o comportamento à fadiga dos ligantes asfálticos, em relação ao ligante asfáltico base e, ao considerar altos níveis de deformação no material $(30 \%)$, o efeito da modificação se mostra benéfico apenas para alguns tipos de modificadores. No entanto, para os ligantes modificados com o copolímero SBS, o 
comportamento apresentado, para altas deformações, foi inferior ao ligante asfáltico de base, para as duas condições de envelhecimento (RTFOT e PAV) e temperaturas $\left(25^{\circ} \mathrm{C}\right.$ e $\left.35^{\circ} \mathrm{C}\right)$ avaliadas.

\subsubsection{Ligantes Modificados com Componentes Fosfóricos}

A primeira patente (US37512785) descrevendo as modificações do ligante asfáltico com adição de ácido fosfórico foi publicada em 1973. Sendo assim, desde o início dos anos 70 , esse tipo de modificador é adicionado ao ligante asfáltico com o objetivo de obter ligantes asfálticos com maior resistência à deformação permanente, sem prejudicar a resistência à formação de trincas de origem térmica (BAUMGARDNET et al, 2005).

A modificação do ligante asfáltico pode ser realizada com qualquer grau de ácido fosfórico. Comercialmente podem ser encontrados graus diferentes de ácido fosfórico contendo diferentes quantidades de ácido ortofosfórico, tais como 50, 75, 85 e 100\%. No entanto, os ácidos polifosfóricos contêm, por exemplo, quantidades de 105 e 115\% de ácido (ARNOLD, 2008).

O composto básico para produção do ácido polifosfórico (PPA) é o pentóxido de fósforo $\left(\mathrm{P}_{2} \mathrm{O}_{5}\right)$ e o ácido fosfórico $\left(\mathrm{H}_{3} \mathrm{PO}_{4}\right)$. O fósforo é oxidado em pentóxido de fósforo, que se cristaliza como $\mathrm{P}_{4} \mathrm{O}_{10}$ e após a sua reação com a água, é produzido o ácido fosfórico. O PPA é um oligômero de $\mathrm{H}_{3} \mathrm{PO}_{4}$, sendo disponível em vários graus. No entanto, o grau pode gerar confusão, pois pode exceder os $100 \%$. Para melhor explicar esse fato, alguns exemplos são mostrados na Tabela 1.

Tabela 1 - Graus do Ácido Fosfórico.

\begin{tabular}{c|c|c|c}
\hline Ácido Fosfórico & Fórmula & $\mathbf{P}_{\mathbf{2}} \mathbf{O}_{\mathbf{5}} \mathbf{( \% )}$ & Ácido Fosfórico (\%) \\
\hline Orto & $\mathrm{H}_{3} \mathrm{PO}_{4}$ & 72,4 & 100 \\
& & 75,9 & 105 \\
Piro & $\mathrm{H}_{4} \mathrm{P}_{2} \mathrm{O}_{7}$ & 79,4 & 110 \\
Tri & $\mathrm{H}_{5} \mathrm{P}_{3} \mathrm{O}_{10}$ & 82,6 & 114 \\
\hline
\end{tabular}

Fonte: Adaptado de Masson, (2008).

Na Tabela 1, observa-se que o ácido ortofosfórico (100\%) contém $72,4 \%$ de $\mathrm{P}_{2} \mathrm{O}_{5}$, o qual é calculado a partir da relação do peso molecular de $\mathrm{P}_{2} \mathrm{O}_{5} / \mathrm{H}_{3} \mathrm{PO}_{4}$. Seguindo o mesmo raciocínio para o ácido pirofosfórico $\left(\mathrm{H}_{4} \mathrm{P}_{2} \mathrm{O}_{7}\right)$ tem-se a relação $\mathrm{P}_{2} \mathrm{O}_{5} / \mathrm{H}_{4} \mathrm{P}_{2} \mathrm{O}_{7}$ que obtém $79,4 \%$ de $\mathrm{P}_{2} \mathrm{O}_{5}$. O grau de ácido fosfórico é obtido pela relação entre os teores de $\mathrm{P}_{2} \mathrm{O}_{5}$ do ácido em

${ }^{5}$ S Alexander. (1973). US3751278 - Method of treating asphalt. 
questão com o $\mathrm{P}_{2} \mathrm{O}_{5}$ do ácido ortofosfórico (100\%). Sendo assim, para o ácido pirofosfórico a relação 79,4/72,4 determina o grau de ácido fosfórico de 110\% (Masson , 2008). O mesmo método é aplicado para os demais graus de ácidos.

A produção de PPA proporciona uma distribuição de comprimentos de cadeias, onde o número de unidades de repetições varia de uma cadeia para outra. Na Figura 6 pode-se observar a estrutura molecular do ácido ortofosfórico $\left(\mathrm{H}_{3} \mathrm{PO}_{4}\right)$ e o ácido pirofosfórico $\left(\mathrm{H}_{4} \mathrm{P}_{2} \mathrm{O}_{7}\right)$ de cadeia superior. O aumento do comprimento da cadeia conduz a uma "rede", o que explica o aumento da viscosidade para ácidos de maiores graus.

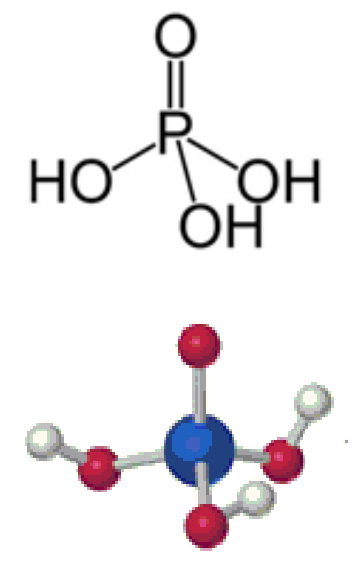

(A) $\mathrm{H}_{3} \mathrm{PO}_{4}$

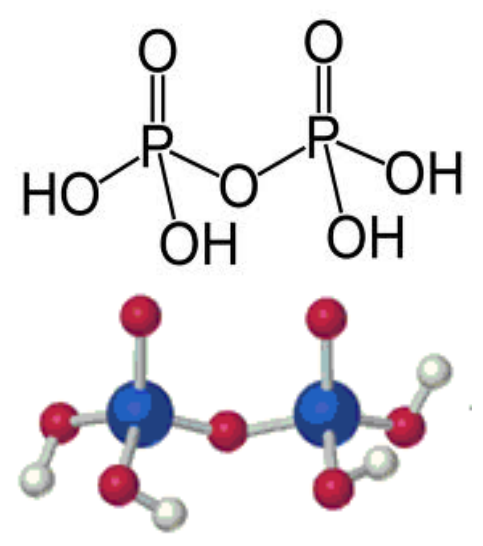

(B) $\mathrm{H}_{4} \mathrm{P}_{2} \mathrm{O}_{7}$

Figura 6 - Estrutura molecular do ácido ortofosfórico $(A)$ e ácido pirofosfórico (B).

Estudos para avaliar diferentes concentrações de ácidos fosfóricos (50, 75, 85, 100 105 e 115\%) em diferentes tipos de ligantes asfálticos, realizados por Arnold, et al., (2009), demonstram, como pode-se observar na Figura 7, que o comportamento das misturas com adição de diferentes graus de ácidos foi semelhante, aumentando a rigidez do material. Foi constatado que o aumento no enrijecimento do material após adição do ácido é dependente do tipo de ligante asfáltico utilizado (THOMAS \& TURNER, 2008; ARNOLD., 2008; ARNOLD, et al., 2009 e FHWA, 2012).

Observa-se, ainda na Figura 7, que a maior rigidez foi apresentada pelo material com a adição do ácido de 50\%; segundo os autores, isso é atribuído à presença de ácidos fortes como fluorídrico e sulfúrico neste material. No entanto, a natureza corrosiva desse ácido impede que esse tipo de material seja utilizado na indústria do asfalto. Os mesmos autores ainda salientam que para os ácidos mais diluídos (menores concentrações de $\mathrm{P}_{2} \mathrm{O}_{5}$ ) é necessário cuidado na sua adição ao ligante asfáltico em altas temperaturas, devido à parcela de água do material.

A modificação de ligantes asfálticos por ácido polifosfórico não é uma prática recente. Desde a década de 1970, ligantes asfálticos têm sido modificados com ácido polifosfórico, na 
tentativa de aumentar a viscosidade sem reduzir substancialmente a penetração (BAUMGARDNET, et al., 2005). Mais recentemente, o ácido polifosfórico tem sido empregado para ampliar a faixa de temperatura de trabalho dos ligantes asfálticos, isto é, o grau de desempenho segundo a especificação Superpave. Segundo Filippis, et al., (1995); Baumgardnet, et al., (2005) e Feeet al., (2010), a adição de ácido polifosfórico pode proporcionar melhoria das propriedades reológicas do ligante asfáltico nas temperaturas altas, sem afetar o PG do material nas temperaturas baixas.

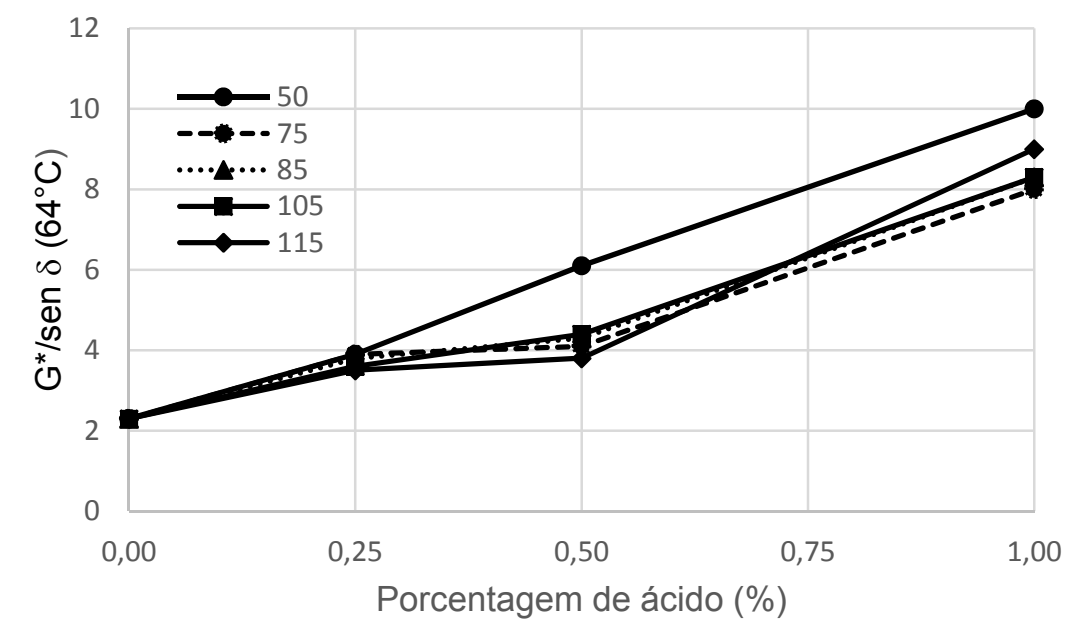

Figura 7 - Rigidez do ligante asfáltico com diferentes tipos de ácidos fosfóricos. Fonte: Adaptado de Arnold (2008).

O mecanismo de interação entre o ácido polifosfórico e o ligante asfáltico ainda não é totalmente conhecido. No entanto, Fee, et al., (2010) chamaram a atenção para a teoria que sugere que o ácido polifosfórico reage com vários grupos funcionais do ligante asfáltico, quebrando os aglomerados de asfaltenos e permitindo que as unidades individuais dos mesmos consigam uma melhor dispersão na fase maltênica. Uma vez dispersos, as unidades individuais dos asfaltenos são relativamente mais eficazes na formação de grandes redes e afetam as características físicas e reológicas do ligante asfáltico. Estudos realizados por Leite, et al., (2004) indicam que na adição do ácido polifosfórico ao ligante asfáltico ocorre uma associação dos asfaltenos com fósforo e o aumento considerável do peso molecular dos asfaltenos.

Cabe salientar que Orange, et al., (2004) apontam a neutralização ácido-base e a reação de esterificação como as duas principais reações envolvidas na mistura do ácido polifosfórico ao ligante asfáltico. Sendo assim, o ácido pode modificar a composição química, aumentando o teor de asfaltenos e de resinas mediante essas reações. Ainda neste contexto, pesquisa realizada por Cao, et al., (2010) avaliou a composição química do ligante asfáltico modificado com $1,5 \%$ de ácido polifosfórico; o estudo mostrou que a adição desse material promove uma aparente conversão de saturados em asfaltenos. Os autores concluiram que o 
maior teor de asfaltenos produz um ligante asfáltico mais rígido, com valores de penetração inferior e ponto de amolecimento superior ao ligante asfáltico puro. Diante do exposto, o que se sabe é que a modificação do ligante asfáltico com a adição do ácido polifosfórico depende das características do ligante asfáltico de base, no entanto, não se sabe exatamente como esse fenômeno acontece.

Em estudos realizados por Giavarini et al., (2000) observou-se alterações na composição SARA nos ligantes asfálticos modificados com o ácido polifosfórico. Os autores entendem que ocorre a conversão de parte das resinas em asfaltenos e dos saturados e aromáticos em resinas, resultando num produto menos homogêneo e com alta estabilidade coloidal. Salientam, ainda, que este comportamento pode ocorrer devido à formação de uma estrutura transiente do tipo GEL altamente flexível. Ainda segundo Giavarini et al. 1996, a estabilidade de um ligante asfáltico modificado com polímero não está relacionada somente à diferença de densidade e de viscosidade entre o ligante asfáltico de base e do modificador. A estrutura do ligante asfáltico também é importante e misturas estáveis são obtidas quando uma estrutura GEL se forma no ligante asfáltico. Os autores afirmam que a adição do ácido polisfofórico melhora a homogeneização entre o ligante asfáltico e o polímero, proporcionando a formação de uma estrutura GEL com melhores características reológicas e maior estabilidade.

Para Kodratet al. (2007), a incorporação do ácido polifosfórico ao ligante asfáltico pode ser feita de 3 (três) maneiras diferentes, a saber: (a) como catalisador no processo de sopragem, quando o ligante asfáltico é submetido a aquecimento e mistura na presença de um gás; (b) adicionado com um aditivo puro, sem a modificação do ligante asfáltico por sopragem, e (c) atuando com um acelerador da reação entre terpolímero ${ }^{6}$ reativo e o ligante asfáltico, permitindo a redução do teor do polímero.

De maneira geral, pode-se supor que o ácido polifosfórico atue como defloculante da fração de asfaltenos, evitando sua associação, e tem como finalidade permitir a redução da concentração do polímero, propiciando melhores condições de processamento, de viscosidade e de estabilidade à estocagem (Edwards, et al. 2006). Pesquisas realizadas por Leite et al., (2004) apontam que a adição de ácido polifosfórico no ligante asfáltico mostrou que é possível obter características superiores ao ligante original, e assim ter um produto com menor susceptibilidade térmica e melhor grau de desempenho Superpave.

O efeito do ácido polifosfórico é mais intenso sobre a viscosidade, estabilidade e rigidez em ligantes asfálticos de natureza naftênica, enquanto sua influência sobre a recuperação elástica é maior para ligantes asfálticos com natureza aromática (Martin \& Baumgardner, 2006). Sendo assim, como seu efeito está diretamente atrelado à composição

${ }^{6}$ Polímero formado por 3 (três) monômeros diferentes. 
química do tipo de ligantes asfáltico de base, atuando em características importantes do produto final, é difícil afirmar qual tipo de ligante asfáltico de base seria mais adequado.

Quanto às propriedades empíricas do ligante asfáltico, a adição de PPA aumenta o ponto de amolecimento do material, reduz a penetração, aumenta a viscosidade e melhora a susceptibilidade térmica (Cao, et al., 2010; Filippis, et al., 1995; Leite, al., 2004; Trakarnpruk \& Chanathup, 2005). No tocante às condições envelhecidas do material, o ligante asfáltico modificado com PPA se apresentou mais estável do que ligantes asfálticos não modificados (Filippis, et al., 1995). Estudos realizados por Shulga et al, (2012) também avaliaram a susceptibilidade ao envelhecimento de ligantes asfálticos de diferentes fontes modificados com PPA e observaram que a adição de PPA aumenta a penetração retida dos ligantes asfálticos, o que indica uma menor susceptibilidade ao envelhecimento.

Estudos realizados por Trakarnpruk \& Chanathup (2005), visando comparar a adição de três diferentes ácidos (polifosfórico, fosfórico e cítrico) ao ligante asfáltico, apontam que o ligante asfáltico modificado com o ácido polifosfórico apresentou o melhor comportamento reológico, seguido pelo ácido fosfórico e, por fim, o ácido cítrico, que apresentou comportamento bem inferior aos demais.

Pesquisas realizadas por Filippis et al., (1995) mostram que o efeito da adição de componentes fosfóricos ao ligante asfáltico é similiar ao proporcionado pelo processo de sopragem. Observou-se uma maior porcentagem de material peptizado, permitindo uma estrutura mais próxima da GEL; no entanto, constatou-se efeitos menos expressivos sobre a penetração e nas propriedades em baixas temperaturas. Notou-se um aumento significativo na resistência ao envelhecimento à curto prazo, o que indica que a adição deste modificador melhora a resistência a este tipo de envelhecimento, também constatado por estudos realizados por Giavarini et al., (2000).

Em relação ao comportamento dos ligantes asfálticos modificados com ácido polifosfórico frente a sua tolerância à deformação permanente, estudos realizados por Fee et al., (2010) e Domingos \& Faxina, (2013) observaram que a adição de ácido polifosfórico reduziu a compliância não-recuperável e aumentou a recuperação dos ligantes asfálticos. A adição do ácido polifosfórico é favorável à resistência à deformação permanente em temperaturas altas e/ou tráfego lento. No entanto, em baixas temperaturas, o efeito do ácido é inexpressivo, o que pode refletir em pouca influência sobre a resistência à formação de trincas de origem térmica (FAXINA et al., 2009). Os ligantes asfálticos modificados com o PPA são mais rígidos e mais elásticos nas temperaturas altas e intermediárias do pavimento (FAXINA, 2010).

Quanto à tolerância à fadiga, estudo feito com dois tipos de ligantes asfálticos e adição de 4 teores de ácido polifosfórico $(0,0 ; 0,5 ; 1,5$ e 2,0\%), realizados por Pamplona (2013) verificou que a adição do ácido polifosfórico torna o ligante asfáltico mais tolerante à fadiga, e 
que o envelhecimento termo-oxidativo tem efeito positivo nesta propriedade. No entanto, em temperaturas mais elevadas os materiais apresentaram menor tolerância à fadiga. Cabe destacar, ainda, que o efeito da adição de PPA é claramente influenciado pela composição química dos ligantes asfálticos e o mecanismo predominante de reação entre o PPA e o ligante asfáltico varia de acordo com as frações SARA do ligante asfáltico.

\subsubsection{Ligantes Asfálticos e Misturas Asfálticas Modificados com Copolímero SBS e Ácidos Fosfóricos.}

Como já salientado, os ligantes asfálticos podem ser modificados com adição do copolímero SBS, com ou sem a presença de ácidos fosfóricos. A adição do ácido polifosfórico permite que se utilize menos polímero na mistura para alcançar o mesmo grau de desempenho (Pulzic \& Williamson, 2002; Orange, et al., 2004; e Martin \& Baumgardner, 2006). Estudos realizados por Domingos e Faxina (2013) mostram que a adição de baixos teores de ácido polifosfórico $(0,5 \%)$ ao ligante asfáltico com adição do copolpímero SBS possibilitou diminuir o teor do copolímero SBS de $4,5 \%$ para $3 \%$, preservando o seu PG (Performance Grade), mesmo com a redução da quantidade do polímero.

Estudos realizados por D'Angelo (2009) apontam que a interação entre o SBS e o ácido polifosfórico é benéfica. Ainda com base nesses estudos, foi observado que a adição de pequenas proporções de ácido $(0,5 \%)$ juntamente com o SBS aumenta significativamente o PG em relação à adição somente do polímero. Segundo D'Angelo (2009) e FHWA (2012), a combinação desses dois modificadores auxilia na formação de uma rede polimérica no ligante asfáltico, que proporciona uma melhora na resistência à deformação permanente e, também, na resposta elástica do material.

Quanto à análise referente à recuperação elástica e a susceptibilidade à deformação permanente, a pesquisa realizada por Domingos \& Faxina (2013) destaca que ligantes asfálticos modificados com o copolímero SBS, juntamente com o ácido polifosfórico, apresentam melhor comportamento frente à susceptibilidade à deformação permanente quando comparados com ligantes asfálticos modificados somente com o copolímero SBS, mesmo apresentando 1,5\% a menos deste modificador. No entanto, à luz desta propriedade, os melhores resultados foram obtidos pelo ligante asfáltico modificado somente com o ácido polifosfórico.

No que se refere à vida de fadiga, estudos realizados por Nuñez (2013) mostram que a incorporação do ácido polifosfórico juntamente com o copolímero SBS aos ligantes asfálticos proporciona aumento da vida de fadiga, diminuição da sensibilidade à temperatura 
e aumento da sensibilidade aos níveis de deformação em relação a misturas somente com o copolímero SBS.

No que diz respeito à contribuição do ligante asfáltico no comportamento das misturas asfálticas, pode-se dizer que a adição dos modificadores pode proporcionar uma maior recuperação elástica e uma menor susceptibilidade à deformação permanente das misturas. Um dos métodos utilizados para reaproveitar a mistura asfáltica existente para recuperação da pista de rolamento é a reciclagem da camada asfáltica. Misturas asfálticas com ligantes modificados com o copolímero SBS foram testadas na pesquisa realizada por Kim et al, (2009) com adição de $0,15 \%, 25 \%$ e $35 \%$ de material reciclado, incorporado como material pétreo na mistura asfáltica. Quando avaliadas a deformação permanente e as trincas por fadiga dessas misturas, foi observado que todas as misturas, independente do teor de material reciclado adicionado, apresentaram respostas semelhantes entre si, bem como próximas da mistura de referência. Sendo assim, o modificador (copolímero SBS) não afeta negativamente esse tipo de procedimento, permitindo boas características do produto final.

Ao avaliar as propriedades mecânicas de misturas asfálticas produzidas com ligantes asfálticos modificados com diferentes teores de ácido polifosfórico, Grande (2011) observou uma melhora na rigidez, na flexibilidade, na resistência à tração e na susceptibilidade ao dano por umidade para misturas com adição deste modificador. Já para misturas com ligantes asfálticos modificados pelo copolímero SBS, com ou sem a presença de ácido, mas com o mesmo grau de desempenho (PG 76-XX), os resultados apresentados por Nuñez et al. (2012) mostram que todas as misturas também apresentaram aumento de rigidez e aumento na resistência à tração, sendo que a mistura com SBS+PPA teve um aumento de 50\% no valor da resistência à tração quando comparada com a mistura de referência. Após o condicionamento para avaliação do dano à umidade, verificou-se que as misturas são poucos suscetíveis à umidade, atentendo os critérios especificados na norma.

No entanto, quando essas propriedades foram avaliadas para misturas com ligantes asfálticos modificados com o copolímero SBS, sem a presença de ácido (4,25\% SBS) e com a presença do ácido polifosfórico (0,5\%PPA+2,5\%SBS), Bernnet \& Martin (2012) concluíram que os resultados, referentes a resistência à fadiga e à deformação permanente, foram semelhantes para as misturas avaliadas. Cabe destacar, ainda, que apesar do resultado semelhante da deformação permanente, ensaios que avaliaram somente os ligantes asfálticos modificados (MSCR) apontaram maior tolerância à deformação permanente para misturas com o copolímero SBS. Do mesmo modo, no que diz respeito à resistência à fadiga, avaliações realizadas por Maldonado et al., (2012) não observaram mudanças significativas em relação a essa propriedade, mesmo com a redução do teor de SBS em misturas com presença do ácido polifosfórico. 
Quanto à adição do ácido polifosfórico, assim como a adição deste combinado ao copolímero SBS, em misturas asfálticas, alguns testes em pistas experimentais foram realizados e não apontaram problemas (Kodrat, et al, 2007; e FHWA, 2012). Os locais apresentaram poucas deformações permanentes e fissuras. Os testes verificaram que a dosagem adequada para o PPA é de 1,0 a 1,5\%. Valores superiores podem ser utilizados, porém é necessário se fazer avaliações de deformação permanente e fadiga para verificar a interação entre o ácido e a estrutura pétrea da mistura (FHWA, 2012). Misturas betuminosas com ligante asfáltico modificado com ácido apresentam resultados satisfatórios quanto ao recobrimento dos agregados e de resistência à tração (LEITE et al., 2004).

Pesquisas realizadas em Ontário, mediante pista experimental, sugerem que o uso do ácido polifosfórico pode prevenir as trincas longitudinais que podem ocorrer entre as faixas de tráfego, dependendo da formulação utilizada. A pista experimental foi construída no Canadá, no ano de 2003, e sua avaliação 3 (três) anos mais tarde, não apresentou nenhum tipo de trincamento, ressaltando o bom desempenho das misturas modificadas.

\subsubsection{Principais Defeitos dos Pavimentos}

Segundo Joliet \& Mallot (2000), o comportamento das misturas asfálticas é afetado tanto pela consistência e reologia dos ligantes asfálticos, quanto pelas características da matriz pétrea. Desse modo, a mistura asfáltica, desde sua aplicação até o final de sua vida de serviço, é afetada por vários fatores que proporcionam defeitos que prejudicam o desempenho do pavimento. Estes defeitos podem ser classificados de duas maneiras, podem estar associados a problemas estruturais ou apenas funcionais. Um defeito de classe estrutural está atrelado à diminuição da capacidade do pavimento no suporte de cargas, em perder sua integridade estrutural. Os problemas funcionais estão associados às condições de segurança e trafegabilidade do pavimento em termos de rolamento.

Existem vários tipos de defeitos de pavimentos flexíveis, que são especificados e definidos pela norma DNIT 005/2003 - TER. No entanto, os principais defeitos encontrados nas rodovias brasileiras são: (a) deformação permanente e (b) trincas por fadiga. Vários são os fatores que podem proporcionar os defeitos do pavimento, como projeto, execução das diferentes camadas (aplicação dos materiais), suporte das camadas que compõem o pavimento, entre outros.

O defeito de deformação permanente pode ser definido como o acúmulo de pequenas quantidades de deformações não recuperáveis resultantes da aplicação das cargas dos veículos, ilustrado na Figura 8. Segundo o DNER (1997), a deformação permanente em 
misturas asfálticas ocorre em duas parcelas: (1) o afundamento plástico e (2) o afundamento de consolidação. Segundo o glossário de termos técnicos DNIT 005/2003 - TER "O afundamento plástico é a deformação permanente que ocorre em uma ou mais camadas dos pavimentos flexíveis ou semi-rígidos, ou ainda no subleito". No que diz respeito ao revestimento asfáltico, a denominação plástico se refere ao seu comportamento viscoelástico. O DNER (1997) ainda define o afundamento por consolidação como "a deformação permanente que ocorre nos pavimentos flexíveis ou semi-rígidos, devido à consolidação diferencial que se verifica em camadas do pavimento ou subleito".

A deformação permanente reflete-se em afundamentos de trilha de roda nos pavimentos. Entende-se que o pavimento é um sistema de múltiplas camadas, e que esses afundamentos podem ser oriundos de qualquer uma das camadas. De maneira geral, podese dizer que o fenômeno da deformação permanente acontece em consequência da deformação viscosa do ligante asfáltico, juntamente com a deformação plástica da estrutura mineral (material pétreo) da mistura asfáltica, isto para problemas de caráter estrutural. Destaca-se também que este tipo de defeito pode ser caracterizado por problemas somente funcionais, e não está ligado a quaisquer problemas estruturais do pavimento.

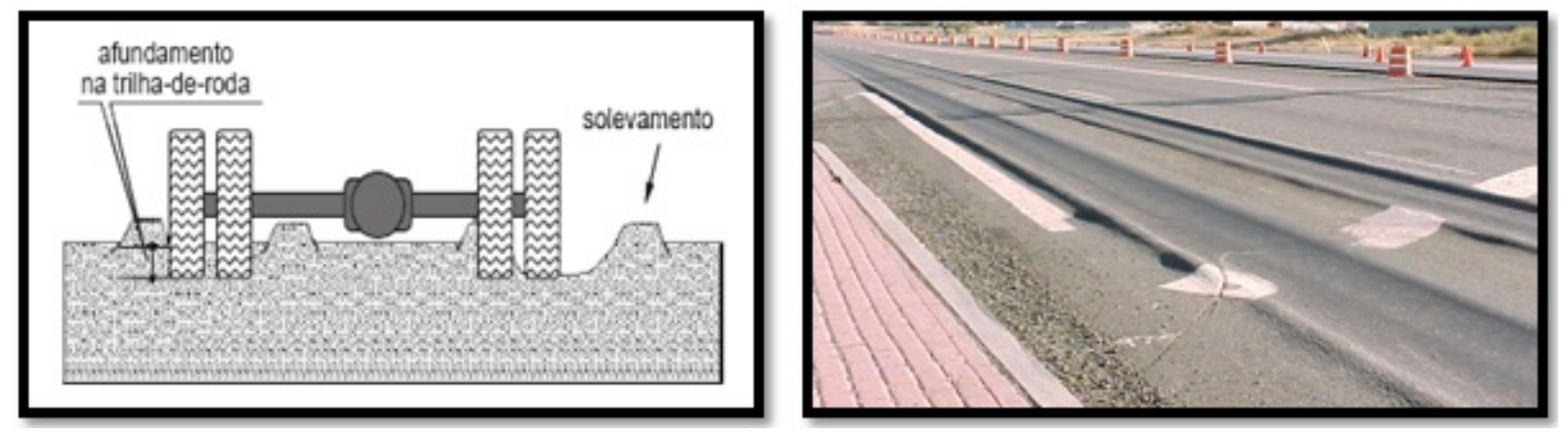

Figura 8 - Deformação permanente.

Esse tipo de defeito é característico de altas temperaturas, formado por contribuições de pequenas deformações. Em relação ao ligante asfáltico, para tentar proporcionar resistência cisalhante maior para mistura asfáltica, seria necessário utilizar um ligante asfáltico mais consistente e elástico para que quando aplicado um carregamento, o ligante asfáltico apresente um comportamento mais elástico, permitindo que retorne a sua posição original, evitando a deformação plástica do material. Um dos principais problemas gerados por esse tipo de defeito é a aquaplanagem, quando uma lâmina de água é formada nos afundamentos de trilha de roda, ocasionando uma redução de segurança aos usuários.

Outro defeito bastante encontrado nas rodovias brasileiras são as trincas por fadiga do revestimento asfáltico sob a ação de cargas repetidas de tráfego. Esse fenômeno pode ser entendido como a deteriorização de um material que está submetido a tensões (carga do 
tráfego) e deformações repetidas, o que resulta em trincas; depois de um determinado número de solicitações (repetição do carregamento), ou seja, ocorre a perda de resistência do material quando é solicitado repetidamente por uma carga. Na Figura 9, pode-se observar o fenômeno de trincas por fadiga, denomidado também como fenda existente no revestimento, facilmente detectável, com abertura superior à da fissura, podendo apresentar-se sob a forma de trinca isolada ou trinca interligada.

Segundo Shell (2003), a fadiga de um pavimento flexível resulta em trincamento, que, por sua vez, consiste em duas fases principais: (a) trincamento inicial e (b) propagação das trincas. As trincas surgem mediante as tensões de tração geradas no pavimento. No entanto, não somente pelas cargas geradas pelo tráfego, mas também pela variação de temperatura e práticas de construções. Quando uma carga é aplicada, ela gera tensões horizontais de tração na fibra inferior do revestimento asfáltico. Sendo assim, o material que compõe a camada asfáltica deve suportar várias aplicações de carga, em nível de tensão inferiores a resistência à tração estática, sem romper.
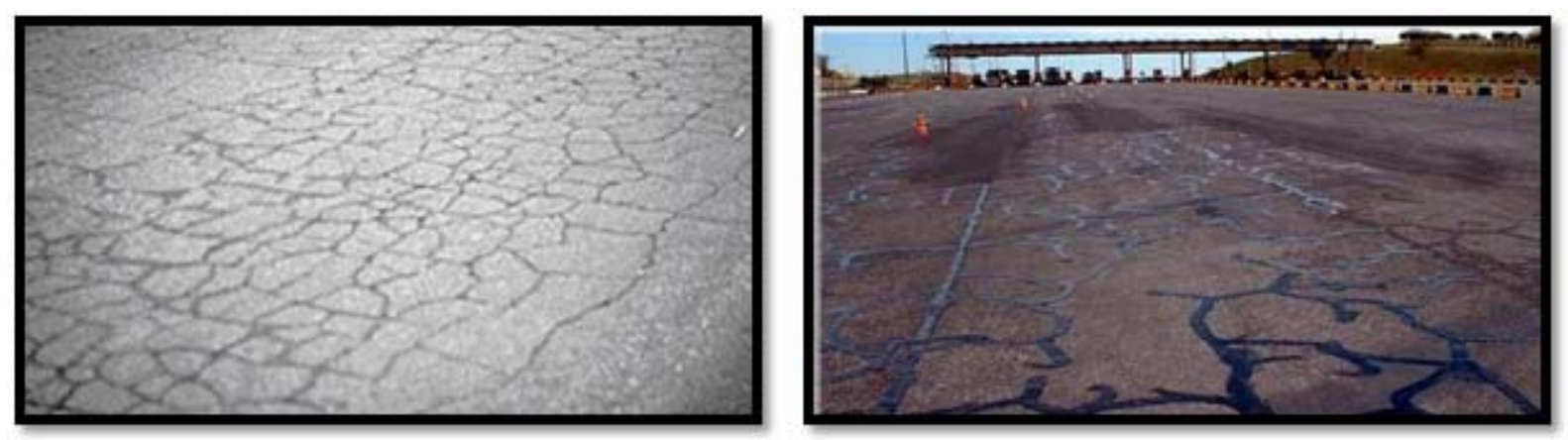

Figura 9 - Trinca por fadiga.

Esse tipo de defeito é acelerado em condições de baixas temperaturas, fazendo com que a mistura asfáltica torne-se mais rígida e suporte menos as repetições das cargas. Para se prevenir as trincas por fadiga, deve-se compatibilizar a espessura das camadas e a rigidez dos materiais que as compõem, e verificar a resiliência que seja suficiente para as deflexões normais.

Cabe destacar que, considerando os dois principais defeitos aqui comentados, quando provenientes de problemas funcionais, a trinca por fadiga é o defeito que demanda maior quantidade de recursos quando se trata de restauração de rodovias, e ainda atrelado à sua grande quantidade faz dele o principal defeito das rodovias brasileiras. O controle deste tipo de defeito é muito importante, principalmente porque pode expor as camadas inferiores à umidade, e isto pode proporcionar uma diminuição da capacidade estrutural das demais camadas que compõem o pavimento, podendo ocasionar outros tipos de problemas. 
No intuito de melhorar o comportamento da mistura asfáltica, almejando escolher materiais adequados para minimizar os defeitos precoces do pavimento, podem ser estudados os materiais que a compõem. No tocante ao ligante asfáltico, à luz dos defeitos dos pavimentos, ele pode ser avaliado no que diz respeito a sua contribuição à deformação permanente e tolerância à fadiga mediante ensaios proveniente da reologia dos ligantes asfálticos, expostos a seguir.

\subsubsection{Apontamentos Sobre Reologia Aplicada aos Ligantes Asfálticos}

A definição de reologia como "estudo da deformação e fluxo da matéria" foi proposta pela Sociedade Americana de Reologia por ocasião de sua fundação, em 1929. O primeiro encontro realizado pelos membros dessa sociedade foi com a intenção de discutir sobre as propriedades e comportamentos de materiais divergentes como o asfalto, lubrificantes, tintas, plásticos e borrachas, assim como as demais disciplinas que pudessem estar envolvidas no assunto (BARNES et al., 1993).

Segundo Malkin (1994), a reologia é uma ciência com interesses nas propriedades mecânicas de vários sólidos e líquidos semelhantes, assim como de produtos naturais. $\mathrm{O}$ autor salienta que para atingir suas metas, a reologia trabalha com modelos que representam o comportamento desses materiais de interesse. De maneira geral, o comportamento dos materiais está relacionado à tensão e deformação (ou mudança de forma), assim como ao tempo de aplicação de carga e tempo de experimento.

O comportamento reológico do ligante asfáltico é complexo, tendo em vista que está submetido a uma ampla variação de temperatura, carregamento dinâmico do tráfego, exposição a diferentes frequências de carregamento, bem como ao efeito de envelhecimento que proporciona modificações químicas no material. Atrelado a isso, quando o ligante asfáltico é modificado, se torna mais sensível a todos esses fatores, dificultando, ainda mais, a caracterização das suas propriedades.

Dentro desse contexto, estudos realizados pelo Strategic Highway Research Program - SHRP, iniciado em 1987 e concluído em 1994, tinham como objetivo identificar as propriedades físicas do ligante asfáltico que são relacionados ao desempenho do pavimento e aos métodos para determinar tais propriedades (Bahia \& Anderson, 1995).

Para atingir os objetivos, foi realizada uma revisão de literatura com diversos materiais e pavimentos. Segundo Bahia (1993), as revisões indicam que os tipos de defeitos ou "falhas" do pavimento são conhecidos como deformação permanente, trincas por fadiga e trincas térmicas, e esses são os principais problemas que os pesquisadores relacionavam com as 
propriedades físicas dos ligantes asfálticos. O autor salienta também que o envelhecimento é o principal fator na mudança das propriedades do ligante asfáltico durante a vida útil (vida de serviço) do pavimento e que afeta diretamente seu desempenho.

Com o desenvolvimento do programa SHRP, a compreensão do comportamento reológico dos ligantes asfálticos teve grandes avanços. A utilização de equipamentos, tais como os reômetros de cisalhamento dinâmico e de flexão permitiram a determinação de propriedades fundamentais dos materiais, que se tornaram base para especificações de ligantes asfálticos baseadas em desempenho.

As novas especificações são conhecidas como Superpave e apresentam procedimentos diferenciados de ensaios de ligantes e misturas asfálticas. Em relação à avaliação de ligantes asfálticos, são enfatizadas as propriedades reológicas mediante ensaios mais representativos do que os ensaios denominados empíricos, como por exemplo, penetração, ponto de amolecimento, viscosidade SayboltFurol, recuperação elástica e ductilidade.

A classificação dos ligantes asfálticos pela especificação SUPERPAVE é realizada mantendo o valor do parâmetro de avaliação da característica fixa e a verificação de qual temperatura de uso aquele material atende o valor especificado. A classificação é estabelecida pelo "grau de desempenho" (Performance Grade - PG), ou seja, em graus de temperaturas máxima e mínima em que o ligante asfáltico apresenta determinadas propriedades. Nessa classificação, a temperatura máxima (primeiro número) representa a temperatura mais alta do pavimento, com base nas temperaturas durante os sete dias consecutivos mais quentes do ano, e a temperatura mínima (segundo número) representa a menor temperatura que atua no mesmo ponto do pavimento no dia mais frio do ano. $O$ intervalo entre as classes são de $6^{\circ} \mathrm{C}$ nas temperaturas.

\subsubsection{Avaliação da Deformação Permanente e Tolerância ao dano por Fadiga}

Neste item serão comentados os ensaios que visam avaliar o comportamento dos ligantes asfálticos no que diz respeito aos dois principais defeitos do pavimento: deformação permanente e trincas por fadiga. Sendo assim serão apresentados os ensaios utilizados para caracterização e avaliação dos ligantes asfálticos com relação à tolerância à deformação permanente e ao dano por fadiga. 


\subsubsection{Ensaio de Fluência e Recuperação sob Tensão Múltipla (MSCR)}

Inicialmente, para avaliar a resistência dos ligantes asfálticos à deformação permanente, a especificação Superpave adotou o parâmetro $G^{*} / \sin \delta$. Esse parâmetro combina a resistência total do ligante asfáltico à deformação sob carregamento do tráfego, representado pelo $G^{*}$ (módulo complexo de cisalhamento), e o ângulo de fase $(\delta)$ que representa a distribuição relativa da resposta total do ligante asfáltico entre um componente em fase e outro defasado. O componente em fase, conhecido como $G^{\prime}$, representa o componente elástico, que pode ser relacionado com a quantidade de energia armazenada a cada ciclo de carregamento; enquanto o componente defasado $\left(G^{\prime \prime}\right)$ está relacionado à quantidade de energia dissipada em cada ciclo de carregamento, representando assim o comportamento viscoso. Dentro desse contexto, pode-se compreender que a contribuição do ligante asfáltico na resistência à deformação permanente da mistura asfáltica acontece mediante uma resistência total maior (valores superior de $G^{*}$ ) ou de uma elasticidade maior (menores valores de $\delta$ ) (Bahia \& Anderson, 1995).

Enquanto o $G^{*} / \sin \delta$ é um parâmetro utilizado para determinar os efeitos viscosos e elásticos dos materiais, ele não foi adequado para avaliar os benefícios dos modificadores dos ligantes asfálticos, uma vez que o impacto no ângulo de fase foi pequeno em relação ao valor total do $G^{*} / \sin \delta$ (Asphalt Institute, 2010). Além disso, Delgadillo et al., (2006) comentam que os testes realizados para avaliar a deformação permanente dos ligantes asfálticos eram realizados com baixas tensões, o que permitia a simplificação do ensaio. No entanto, os mesmos autores salientam que ao evitar testes em tensões mais altas, o ligante asfáltico se comporta como um material viscoelástico linear e a deformação se torna proporcional à tensão. Sendo assim, uma dúvida foi gerada com relação à caracterização da resistência à deformação permanente dos ligantes asfálticos com aplicação de baixas tensões, pois as tensões e deformações no ligante asfáltico podem ser superiores às do limite de comportamento linear, podendo alcançar o comportamento não-linear do material.

Estudos realizados por Bahia et al.,(2001) avaliaram duas hipotéses para propor um procedimento de ensaio que indicasse melhor a contribuição do ligante asfáltico na deformação permanente da mistura asfáltica, a saber: (a) a deformação do ligante asfáltico é maior do que a utilizada em regime oscilatório; (b) o carregamento cíclico utilizado com completa reversão na tensão ou na deformação não seria o método mais adequado para determinar a contribuição do ligante asfáltico na resistência da mistura asfáltica à deformação permanente, pois na mistura a deformação é causada por um carregamento ciclíco e é de natureza irreversível. Em relação ao primeiro item (a), os pesquisadores concluíram que os ensaios de regime oscilatório não indicavam de maneira satisfatória a resistência à 
deformação permanente, e mediante estudos para o item (b), foi desenvolvido o ensaio de fluência repetida e recuperação (repeated creep and recovery test - RCRT), que almejava verificar o comportamento dos ligantes asfálticos à deformação permanente. Esse ensaio consistia em aplicar uma tensão de cisalhamente entre 30 e 300Pa por 100 ciclos, sendo cada ciclo constituido de tempo de carregamento de 1s e tempo de repouso de 9s.

Com o aperfeiçoamento do RCRT, a Administração Rodoviária Federal dos Estados Unidos (FHWA) desenvolveu o ensaio de fluência e recuperação sob tensão múltipla (MSCR), com o intuito de caracterizar a resistência dos ligantes asfálticos à deformação permanente. Este ensaio é realizado no reômetro de cisalhamento dinâmico (DSR), de acordo com a norma ASTM D7405, com tensão controlada de 1s em amostra do ligante asfáltico, sendo removida em seguida e permitindo que o material repouse por um período de 9s. São realizados ensaios com dois níveis de tensão (100 Pa e 3200 Pa), conforme ilustra a Figura 10, em 10 ciclos para cada tensão.

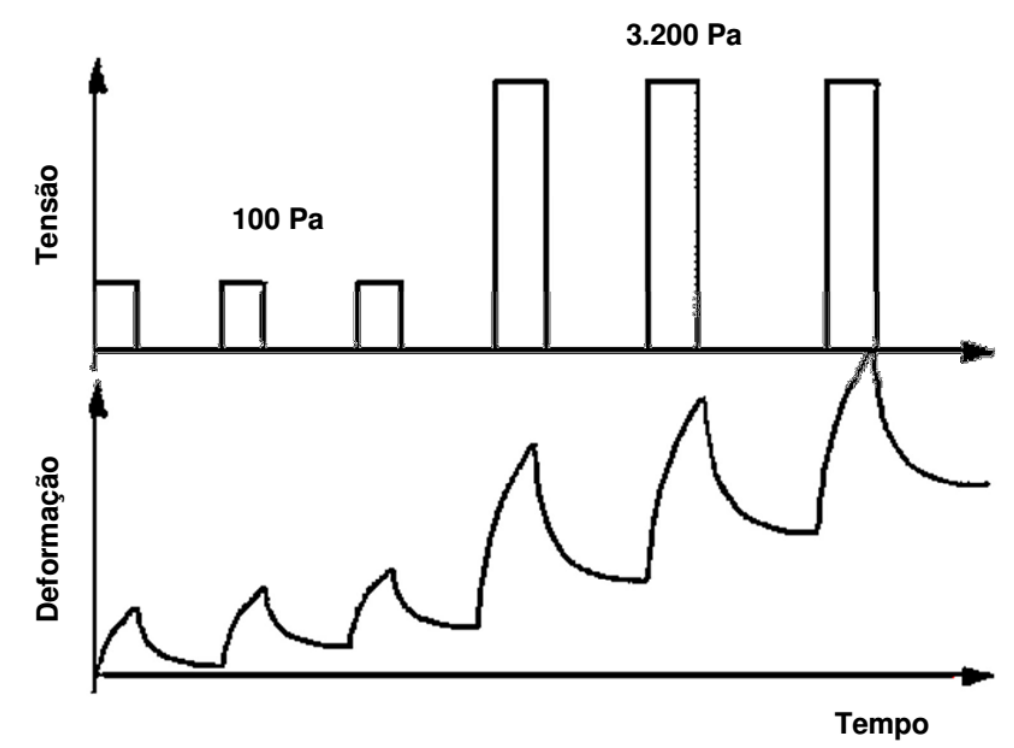

Figura 10 - Esquema das tensões e deformações durante a realização do ensaio.

Fonte: D'Angelo \& Dongré (2009).

Mediante o ensaio de MSCR são determinadas duas propriedades. o percentual de recuperação $(R)$ e a compliância não-recuperável $\left(J_{n r}\right)$. A determinação dessas propriedades são feitas atráves de 3 (três) leituras de deformações do ligante asfáltico para cada um dos 10 ciclos de fluência e recuperação. São elas: (I) Início do período de fluência de cada ciclo $\left(\varepsilon_{0}\right)$, medido no tempo 0 segundo, (II) Final do período de fluência de cada ciclo $\left(\varepsilon_{c}\right)$, medido no tempo de 1 segundo; e (III) Final do período de recuperação de cada ciclo $\left(\varepsilon_{\mathrm{r}}\right)$, medido no tempo de 10 segundos. Na Figura 11, pode-se observar os pontos de localização das deformações em 2 (dois) ciclos de fluência e recuperação. 


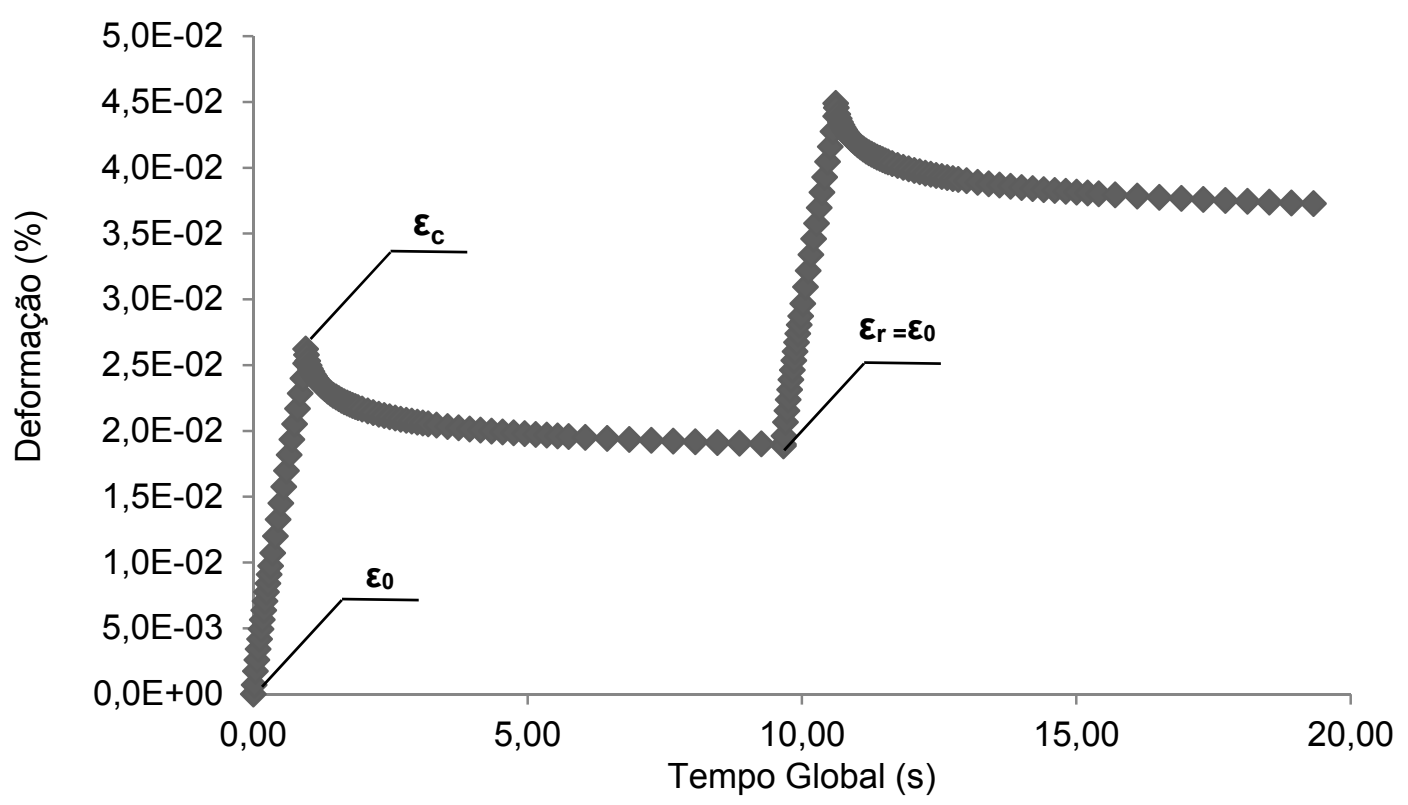

Figura 11 - Localização das deformações em um ciclo do ensaio MSCR.

A compliância não-recuperável é calculada pela razão entre a deformação nãorecuperável do ligante asfáltico e a tensão aplicada, de modo que as deformações do material passam a ser normalizadas pelo valor da tensão., conforme Equação 1 abaixo.

$$
J_{n r}(\sigma, N)=\frac{\left(\varepsilon_{r}-\varepsilon_{o}\right)}{\sigma}
$$

O percentual de recuperação é obtido pela razão entre a deformação recuperável e a deformação total do material, sendo expresso em porcentagem. O percentual de recuperação $(\% R)$ é calculada de acordo com a Equação 2, apresentada a seguir:

$$
\% R(\sigma, N)=\frac{\left[\left(\varepsilon_{c}-\varepsilon_{0}\right)-\left(\varepsilon_{r}-\varepsilon_{0}\right)\right] \times 100}{\left(\varepsilon_{c}-\varepsilon_{0}\right)}
$$

Onde $R(\sigma, N)$ é o percentual de recuperação e $\operatorname{Jnr}(\sigma, N)$ é a compliância nãorecuperável na tensão $\sigma(\sigma=100 \mathrm{~Pa}$ ou $3.200 \mathrm{~Pa})$ para o ciclo de fluência e recuperação número $\mathrm{N}$ (onde $1 \leq \mathrm{N} \leq 10$ ). Para cada temperatura de ensaio, é obtida a média aritmética dos valores de \%R e Jnr nos dez ciclos do ensaio, para cada tensão de cisalhamento.

Devido aos estudos realizados com o MSCR, uma nova classificação foi desenvolvida, baseada nos valores limites de Jnr considerando materiais na condição envelhecida a curto prazo (RTFOT) para diferentes níveis de carregamento de tráfego $\mathrm{S}$ (padrão), $\mathrm{H}$ (Pesado), $\mathrm{V}$ 
(muito pesado) e E (extremamente pesado), conforme apresentado na Tabela 2 (D'ANGELO, 2010).

Tabela 2 - Classificação quanto ao valor de Jnr de acordo com o critério proposto pelo FHWA.

Fonte: AASHTO M3207.

\begin{tabular}{cccc}
\hline Propriedade & $\begin{array}{c}\text { Limite máximo } \\
\left(\mathrm{kPa}^{-1}\right)\end{array}$ & Tipo de tráfego & $\begin{array}{c}\text { Número de passadas de um } \\
\text { eixo padrão }\end{array}$ \\
\hline & 4,0 & Padrão $(\mathrm{S})$ & $<10$ milhões \\
$\mathrm{Jn}_{\mathrm{n} \text { a 3.200Pa na }}$ & 2,0 & Pesado $(\mathrm{H})$ & $>10$ milhões \\
temperatura do PG & 1,0 & Muito pesado $(\mathrm{V})$ & $>30$ milhões \\
& 0,5 & $\begin{array}{c}\text { Extremamente } \\
\text { pesado }(\mathrm{E})\end{array}$ & $>100$ milhões \\
\hline
\end{tabular}

Valores mínimos do percentual de recuperação são recomendados para os ligantes asfálticos de acordo com o valor da compliância não-recuperável, conforme Tabela 3. Segundo Asphalt Institute (2010), esse percentual fornece uma indicação da resposta elástica retardada do ligante asfáltico, sendo que valores elevados indicam uma componente elástica significativa no material na temperatura de realização do ensaio MSCR.

Tabela 3 - Percentual de recuperação de acordo com o critério proposto pelo FHWA.

Fonte: D'Angelo J. , (2010)

\begin{tabular}{cc}
\hline Jnr a 3.200 Pa (kPa-1) & $\%$ R mínimo (\%) \\
\hline $1,01-2,0$ & 30 \\
$0,51-1,0$ & 35 \\
$0,251-0,50$ & 45 \\
$0,125-0,25$ & 50 \\
\hline
\end{tabular}

Os valores mínimos do percentual de recuperação também podem ser apresentados na forma gráfica, como mostrado na Figura 12. Os ligantes asfálticos com pares ordenados (Jnr, R) acima da curva são considerados de alta elasticidade, e aqueles com pares ordenados (Jnr, R) abaixo da curva são considerados de baixa elasticidade.

Para assegurar que o material não seja demasiadamente sensível a mudanças no nível de tensão, a relação entre as compliâncias não-recuperáveis a 100 Pa (Jnr100) e a $3.200 \mathrm{~Pa}$ (Jnr3200), não deve superar os $75 \%$.

\footnotetext{
7 AMERICAN ASSOCIATION OF STATE HIGHWAY AND TRANSPORTATION OFFICALS. AASHTOM320: Standard Specification for Performance-Graded Asphalt Binder. Washington, D.C.
} 


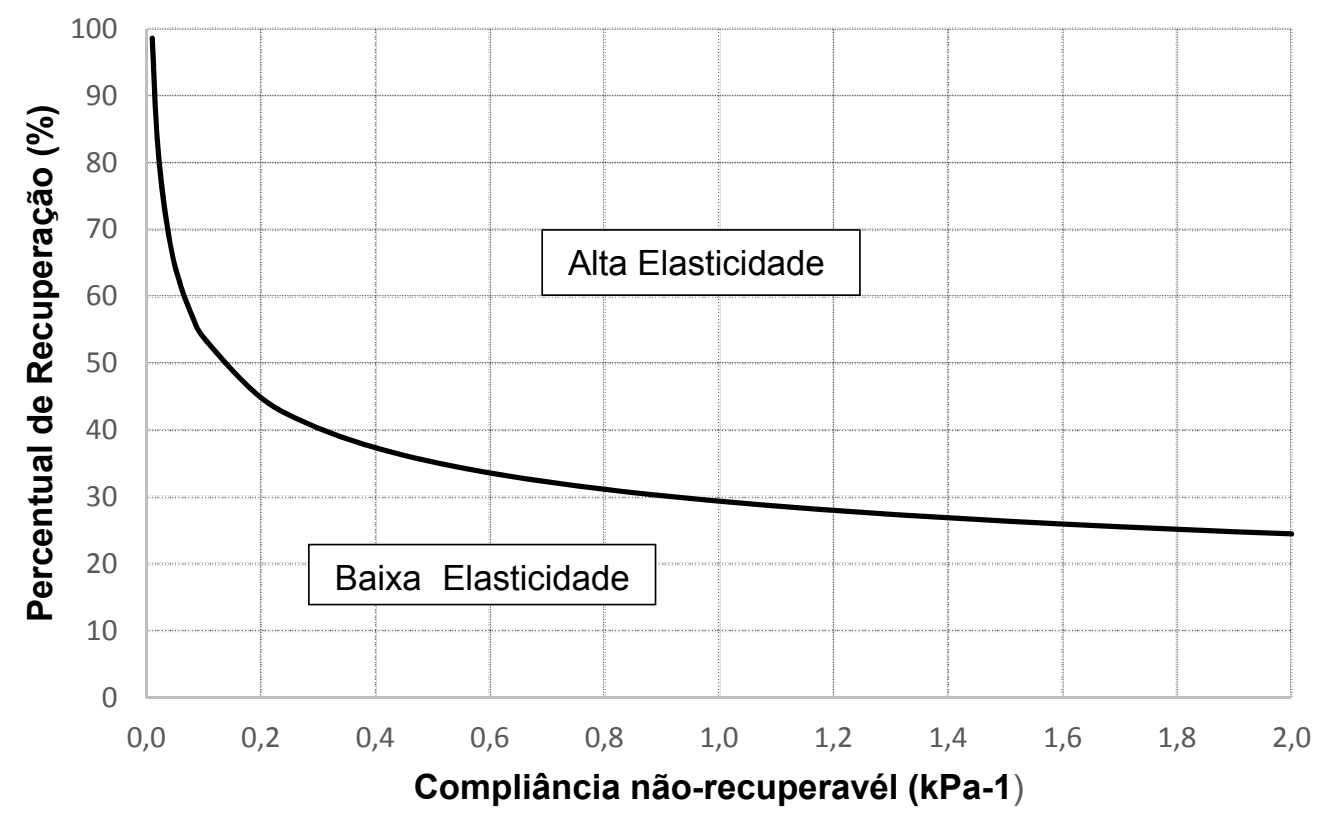

Figura 12 - Relação entre a compliância não-recuperável e o percentual de recuperação a 3200Pa.

\subsubsection{Ensaio para Avaliação da Tolerância ao Dano por Fadiga}

Nos estudos realizados pelo SHRP, foi adotado como critério para especificação da fadiga de ligantes asfálticos o parâmetro $G^{*} \sin \delta\left(G^{\prime \prime}\right)$, indicador da energia total dissipada durante carregamento cíclico, sendo obtido com o material envelhecido a longo prazo (PAV), em temperaturas intermediárias do pavimento. (Bahia \& Anderson, 1995). Esse parâmetro foi adotado devido à necessidade de simplicidade e facilidade de obtenção (Anderson, et al., 2001). No entanto, depois da implementação da especificação Superpave foi constatado que esse parâmetro não era eficiente para representar a resistência do ligante asfáltico ao trincamento por fadiga, pois o ensaio era realizado na faixa de viscoelasticidade linear, em níveis baixos de deformação, sendo que esse tipo de dano ocorre na região de viscoelasticidade não-linear com altas deformações (Bahia, et al., 1999).

Na tentativa de melhorar as deficiências apontadas do ensaio anterior, o projeto NCHRP 9-10 (National Highway Reseach Program) apresentou o teste de varredura de $G^{*}$ em função do tempo, conhecido como Time Sweep. O ensaio é baseado na definição de dano por fadiga, como a degradação da integridade do material pela ação de cargas repetidas. O ensaio apresenta boa correlação com resultados obtidos com avaliações de fadiga em misturas asfálticas, no entanto ele é bastante demorado, em virtude do tempo necessário para levar o material à falha, inviabilizando sua utilização em especificações (Bahia et al., 2001). 
No intuito de acelerar o ensaio para determinação da resistência à fadiga de ligantes asfálticos, foi desenvolvido, por Johnson (2010), um ensaio denominado LAS (Linear Amplitude Sweep), que possui uma etapa de varredura de frequência e outra de varredura de amplitude de deformação. Na etapa de varredura de frequência, as propriedades viscoelásticas na região não linear são determinadas para estabelecer um quadro de referência apropriado para avaliar o acúmulo do dano na amostra. Na etapa de varredura de amplitude de deformação é realizado um ensaio, no qual o material é levado à fratura, e os parâmetros do modelo de fadiga são determinados. A teoria utilizada por este método, para análise dos dados e determinação do modelo de fadiga dos ligantes asfálticos, é do dano viscoelástico contínuo (VECD-Viscoelastic Continuum Damage), que utiliza o desvio do comportamento viscoelástico linear e a redução na rigidez da amostra para caracterizar o aumento do dano. No que diz respeito à amplitude de deformação, é considerado, no ensaio, que o raio da amostra não é alterado durante a execução do ensaio, porém estudos realizados por Hintz (2012) apontam que isso não acontece e a autora concluiu que a redução do $G^{*}$ não é um indicar do dano por fadiga.

O ensaio proposto por Johnson (2010) é realizado no reômetro de cisalhamento dinâmico (DSR), com amostras envelhecidas a curto prazo (RTFOT) ou a longo prazo (PAV). Para esse ensaio a amostra é colocada na geometria de $8 \mathrm{~mm}$ com distância de $2 \mathrm{~mm}$ entre placas. Neste ensaio, o carregamento é feito com incrementos progressivos de deformações para acelerar o dando. Na primeira etapa a varredura de frequência (entre 0,1 e $30 \mathrm{~Hz}$ ) é feita para determinar as propriedades reológicas na região de viscoelasticidade linear, com amplitude de deformação de $0,1 \%$. Na segunda etapa, é realizada uma varredura de amplitude de deformação entre $0,1 \%$ e $30 \%$ com frequência de $10 \mathrm{~Hz}$. Na Figura 13, pode-se observar o carregamento, que é feito em intervalos de 10 segundos com amplitude de deformação constante, sendo cada intervalo seguido de outro com amplitude de deformação maior.

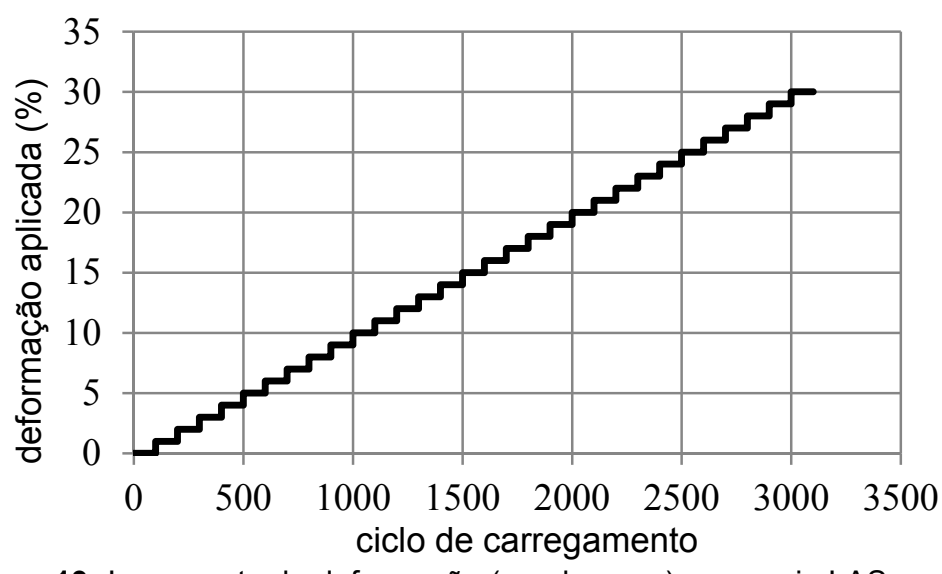

Figura 13- Incremento da deformação (em degraus) no ensaio LAS.

Fonte: Johnson (2010). 
Na Figura 14 é ilustrado o gráfico para determinação do modelo de fadiga mediante o princípio de dano contínuo viscoelástico, obtido com os resultados da varredura de amplitude de deformação e da caracterização reológica do material na região de viscoelasticidade linear. Este modelo é derivado da relação entre a carga aplicada e a vida de fadiga do material.

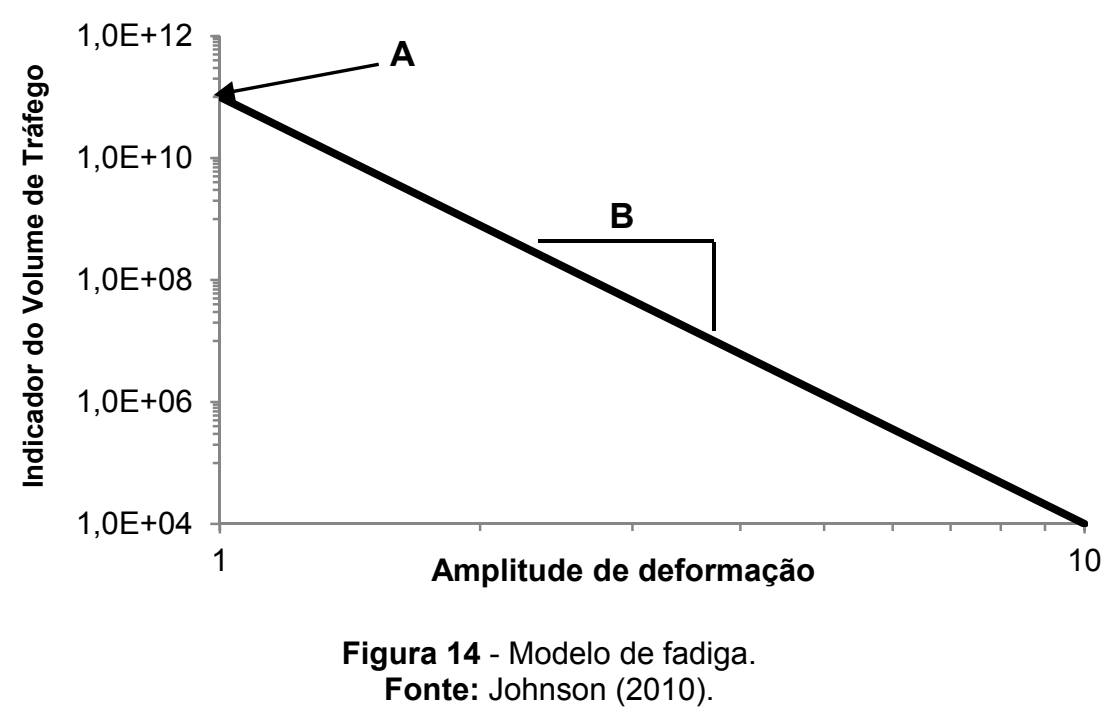

A vida de fadiga $\left(\mathrm{N}_{\mathrm{f}}\right)$ pode ser determinada pela Equação 3, apresentada abaixo, que demonstrou ter boa correlação entre as misturas asfálticas e ligantes asfálticos.

$$
\mathrm{N}_{\mathrm{f}}=\mathrm{A} \times\left(\gamma_{\text {máx }}\right)^{\mathrm{B}}
$$

Sendo A e B parâmetros característicos do material e Ymáx a deformação máxima esperada para uma dada estrutura do pavimento.

O cálculo do parâmetro B é realizado mediante Equação 4:

$$
B=2 \times \alpha
$$

onde $\alpha=1+1 / \mathrm{m}$, sendo $\mathrm{m}$ a inclinação da reta do gráfico log-log do módulo de armazenamento $\left(\left|G^{*}\right| \times \cos \delta\right)$ versus frequência.

Através da fórmula, apresentada na Equação 5, é calculado o parâmetro A:

$$
A=\frac{f\left(D_{f}\right)^{k}}{k\left(\pi I_{D} C_{1} C_{2}\right)^{\alpha}}
$$


sendo $f$ é a frequência $(10 \mathrm{~Hz}), D_{\mathrm{f}}$ é o valor de $\mathrm{D}(\mathrm{t})$ na ruptura, $\mathrm{k}$ é definido como $k=1+(1-$ $\left.C_{2}\right) \propto$, ID é o valor inicial de $\left|\mathrm{G}^{*}\right|$, em MPa, do intervalo de amplitude de deformação de $1,0 \%$. Os coeficientes $C_{0}, C_{1}$ e $C_{2}$ podem ser determinados a partir do modelo da relação entre $\left|G^{*}\right| \sin \delta$ e $\mathrm{D}(\mathrm{t})$, onde $\mathrm{D}(\mathrm{t})$ é o dano acumulado na amostra, calculado de acordo com a Equação 6.

$$
D(t)=\sum_{\mathrm{i}=1}^{\mathrm{N}}\left[\pi \mathrm{I}_{\mathrm{D}} \gamma_{0}^{2}\left(\left|\mathrm{G}^{*}\right| \operatorname{sen} \delta_{\mathrm{i}-1}-\left|\mathrm{G}^{*}\right| \operatorname{sen} \delta_{\mathrm{i}}\right)\right]^{\frac{\alpha}{1+\alpha}}\left(\mathrm{t}_{\mathrm{i}}-\mathrm{t}_{\mathrm{i}-1}\right)^{\frac{1}{1+\alpha}}
$$

\subsubsection{Ensaio LAS Modificado}

Pesquisa realizada por Hintz (2012) propõe modificações no ensaio e na análise dos resultados propostos por Johnson (2010), denominado de LAS modificado. A autora tinha como hipótese, em seus estudos, que a fratura é a responsável pela aparente redução no módulo complexo durante o ensaio de varredura de $\mathrm{G}^{*}$ em função do tempo (time sweep). Em relação à análise dos dados, Hintz (2012) propôs utilizar o modelo baseado na fratura ao invés do modelo usado por Johnson (2010), com base na teoria do dano contínuo viscoelástico, isto porque foi verificado que ocorrem microfraturas durante o ensaio e que o raio da amostra não permanece constante ao longo do processo de fadiga do material. Outra observação realizada por Hintz (2010) foi a de que o ensaio LAS, proposto por Johnson (2010), não representava um ensaio real de fadiga devido às mudanças bruscas na amplitude de deformação no carregamento do ensaio, o que proporcionava degraus na amplitude de deformação.

A modificação proposta por Hintz (2012) no procedimento de ensaio está atrelada ao formato da sequência de amplitudes de deformação, mostrado na Figura 15. No LAS modificado, a amplitude de deformação aumenta linearmente em cada ciclo de carga em vez de aumentar em forma de degraus. Assim, a pesquisadora pretendia eliminar as trincas na periferia da amostra ainda na fase de condicionamento. A sequência de carregamento, proposta por Hintz (2012), consiste no mesmo número de ciclos (tempo de ensaio) e na mesma faixa de amplitudes de deformação propostos por Johnson (2010). 


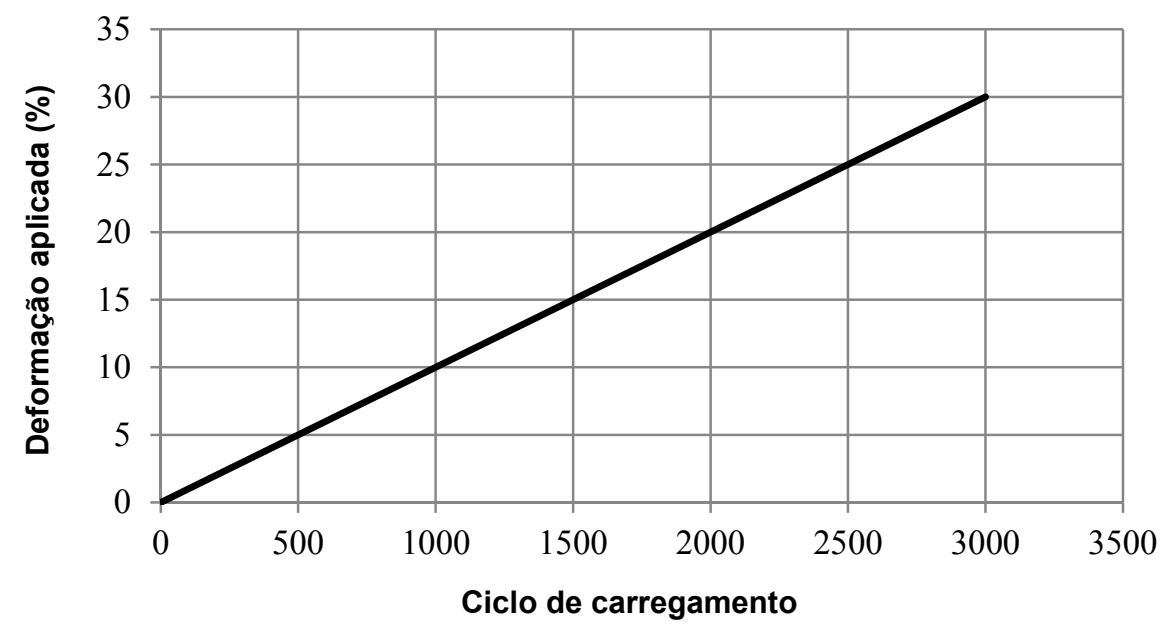

Figura 15 - Incremento linear de deformação no ensaio LAS modificado. Fonte: Hintz (2012).

Os estudos realizados por Hintz (2012) compararam o incremento da taxa da propagação da fissura em função do comprimento da fissura. Os resultados destes ensaios foram comparados com o time sweep $\left(\mathrm{N}_{\mathrm{f}}\right)$ observando uma tendência similar, conforme ilustrado na Figura 16.

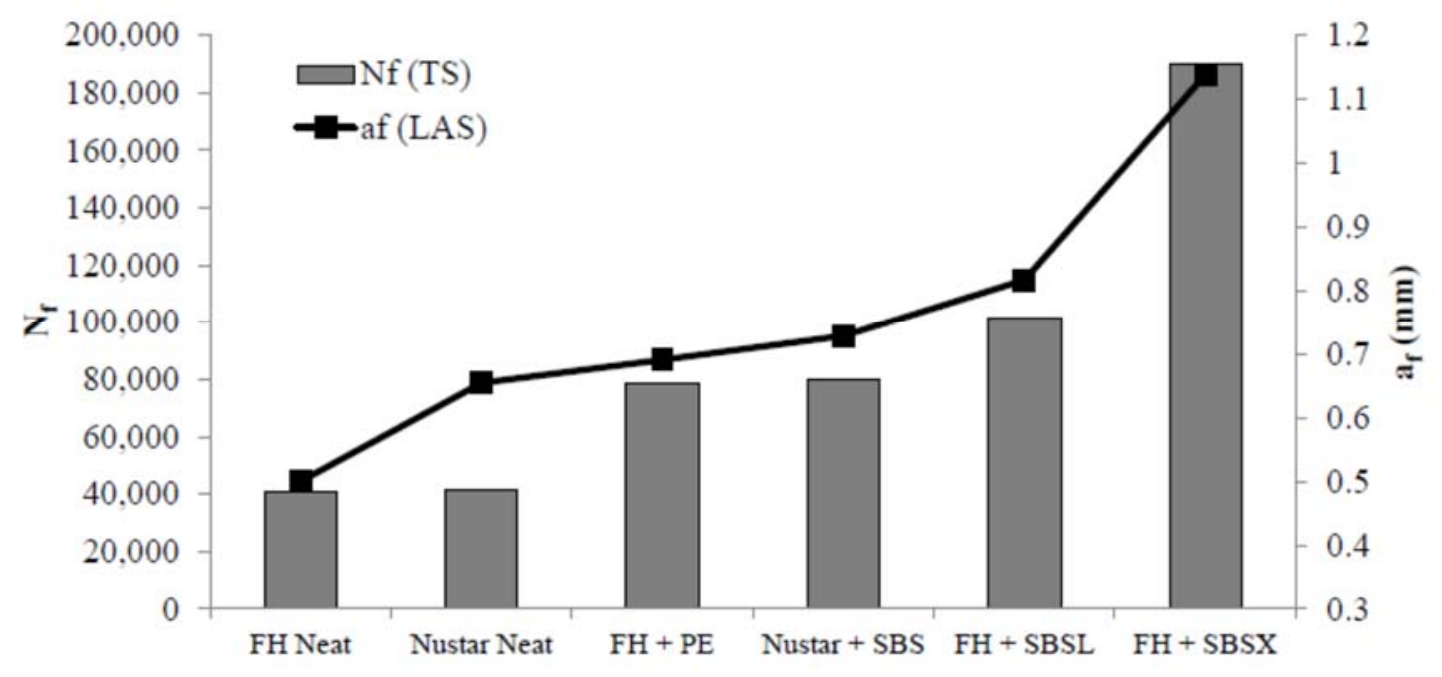

Figura 16 - Resultados do LAS modificado e do time sweep.

Fonte Hintz (2012).

No método proposto for Hintz (2012) foi escolhido o critério de comprimento da fissura $\left(\mathrm{a}_{\mathrm{f}}\right)$ como o parâmetro selecionado para o determinar à tolerância ao dano a fadiga. Este parâmetro corresponde ao valor de comprimento da fissura no local mínimo da curva da taxa de crescimento da fissura em função do seu comprimento, ilustrado na Figura 17. Sendo assim, é desejável um comprimento maior da fissura, indicando que o ligante asfáltico pode resistir a uma fissura maior antes da rápida propagação. 


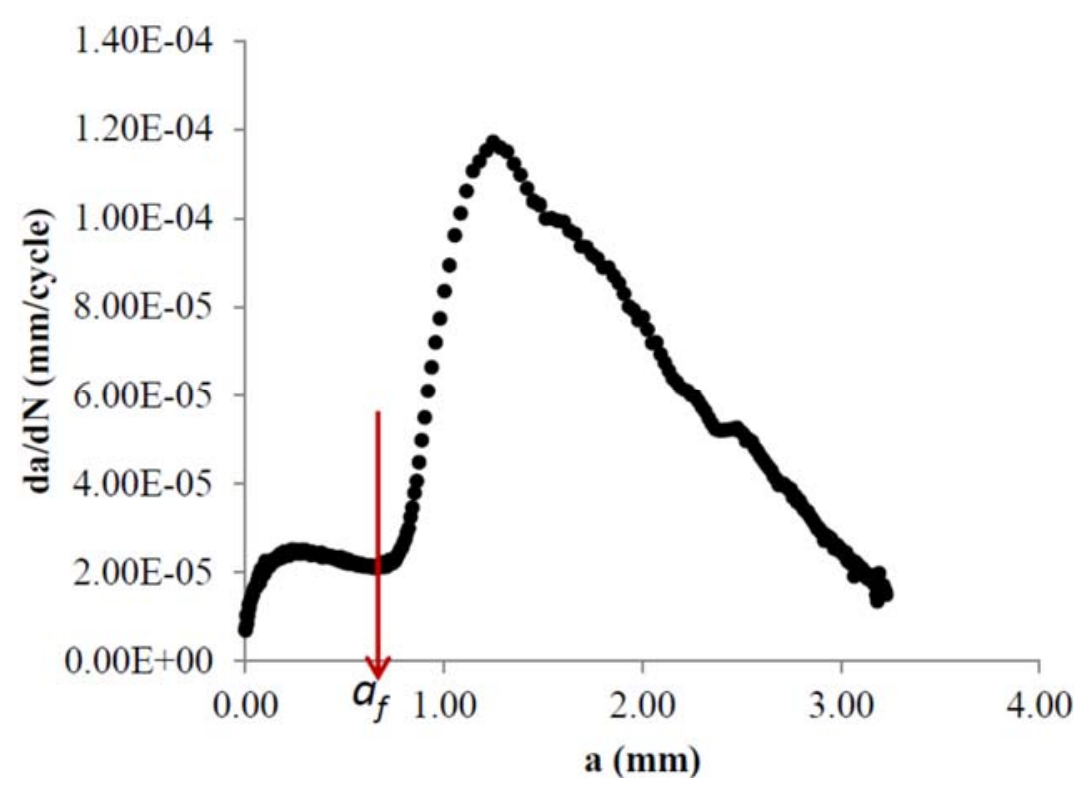

Figura 17 - Taxa de crescimento da fissura em função do comprimento da fissura. Fonte: Hintz (2012).

Em 2013, foi lançada, a norma AASHTO TP 101-12-UL que considera as modificações propostas por Hintz (2012) e propõe dois tipos de análises: o dano contínuo viscoelástico proposto por Johnson (2010), considerando as propriedades reológicas e a varredura de amplitude e, análise proposta por Hintz (2012) mediante resultados da varredura de amplitude.

Em estudos relacionados à fadiga de materiais asfálticos, considera-se que o fenômeno ocorre por deformação controlada, partindo do princípio que a maioria dos pavimentos são esbeltos, e dessa forma, a camada asfáltica deforma acompanhando a deformação das camadas inferiores. É intuitivo se pensar que a redução da rigidez dos ligantes asfálticos proporciona um aumento na resistência à fadiga, no entanto, alguns estudos como VALLERGA et al., (1972); HARVEY E TSAI, (1997); HINTZ et al., (2011), apontam um aumento da resistência à fadiga com aumento da rigidez do material.

Com o intuito de avaliar o comportamento dos materiais selecionados, no próximo capítulo serão apresentados os procedimentos e métodos adotados para ensaios de caracterização dos ligantes asfálticos, assim como os procedimentos adotados para avaliação da sua suscetibilidade à deformação permanente e tolerância à fadiga. 


\section{Materiais e Métodos}

Neste capítulo são apresentados os materiais e métodos utilizados, assim como a descrição das atividades laboratoriais que auxiliaram no desenvolvimento desta pesquisa. $A$ parte experimental foi realizada em duas fases, sendo a primeira referente ao estudo dos ligantes asfálticos modificados com os ácidos em questão (PPA e PA85) e, a segunda parte, a modificação dos ligantes asfálticos com os ácidos e o copolímero SBS.

\subsection{Delineamento do Experimento}

Como o objetivo do presente estudo é analisar o efeito da adição de agentes fosfóricos, aqui representados pelo ácido polifosfórico (PPA) e fosfórico (PA85), no comportamento reológico de ligantes asfálticos puros e modificados com o copolímero SBS, foram desenvolvidos dois experimentos, o primeiro referente à análise da modificação dos ligantes asfálticos somente com adição dos ácidos (experimento fatorial) e, o segundo, para verificação dos ligantes asfálticos modificados com os ácidos e o copolímero SBS (experimento com misturas).

\subsubsection{Ligantes Asfálticos Modificados com Ácidos Fosfóricos}

A primeira fase da pesquisa comtempla a análise da modificação dos ligantes asfálticos com os ácidos (PPA e PA85). Essa etapa é constituída por um experimento fatorial completo composto por quatro fatores (tipo de ácido, teor de ácido, tipo de ligante e envelhecimento), sendo cada fator considerado com níveis diferentes, a saber:

- O fator tipo de ácido tem 2 níveis (PPA e PA85);

- O fator teores de ácido tem 4 níveis $(0,0 ; 0,5 ; 1,0$ e 1,5\%)

- O fator tipo de ligante asfálticos tem 2 níveis (REPLAN e LUBNOR); e

- O envelhecimento com 2 níveis (sem envelhecimento; RTFOT e/ou PAV). 
O fator "tipo de ácido", considerado em dois níveis (PPA e PA85), busca analisar o comportamento dos ligantes asfálticos modificados com os dois diferentes ácidos, com objetivo de responder se é possível utilizar o PA85 em substituição ao PPA, ou seja, se existe algum tipo de equivalência de efeitos.

O fator "teor de ácido", em 4 níveis, tem como objetivo analisar a influência da concentração dos modificadores nas propriedades monitoradas.

O fator "tipo de ligante", variando em dois níveis, visa identificar a influência da adição dos ácidos em ligantes base diferentes, uma vez que a adição do ácido promove reação química com o ligante asfáltico e pode variar seu efeito de modificação dependendo do tipo de ligante base utilizado.

Finalmente, o fator "envelhecimento" procura avaliar o efeito do envelhecimento a curto prazo e a longo prazo nos diferentes tipos de ligantes asfálticos. Cabe destacar que, em todas as propriedades analisadas, têm-se dois condicionamentos, ou seja, dois níveis (Virgem RTFOT ou RTFOT / PAV), sendo a escolha definida dependendo da propriedade avaliada.

No total, nessa primeira fase da pesquisa, foram realizadas as misturas de 12 ligantes asfálticos modificados diferentes, descontando as 2 com ligante asfáltico puro. Na Tabela 4 , a seguir, pode-se observar a composição das misturas que foram feitas.

\begin{tabular}{cc} 
Tabela 4 - Composição das misturas estudadas \\
\hline Ligante REPLAN & Ligante LUBNOR \\
\hline CAP Puro & CAP Puro \\
CAP + 0,5 PPA & CAP + 0,5 PPA \\
CAP + 1,0PPA & CAP + 1,0 PPA \\
CAP + 1,5PPA & CAP + 1,5 PPA \\
CAP + 0,5 PA85 & CAP + 0,5 PA85 \\
CAP + 1,0 PA85 & CAP + 1,0 PA85 \\
CAP + 1,5 PA85 & CAP + 1,5 PA85 \\
\hline
\end{tabular}

Com base nesses apontamentos, nessa primeira fase tem-se como objetivo verificar a hipótese de que é possível substituir o ácido importado (PPA) pelo ácido nacional (PA 85), no que diz respeito à aplicação como único modificador do ligante asfáltico. Para verificar essa suposição, depois de feitas as misturas dos componentes, foram realizados alguns ensaios para verificar as novas propriedades do material. A influência dos fatores e suas interações nas propriedades monitoradas foram analisadas estatisticamente mediante análise de variância (ANOVA), para um nível de significância de 5\%, com o auxílio do software Minitab $16^{\odot}$. 


\subsubsection{Ligantes Asfálticos Modificados com Ácidos Fosfóricos e Copolímero SBS.}

$\mathrm{Na}$ segunda fase, que tem como objetivo analisar o efeito dos ácidos juntamente com o modificador copolímero SBS, o experimento foi delineado com base na técnica estatística de "experimento com misturas" (Cornell, 2002). Nesse tipo de experimento, a análise é realizada mediante gráficos de efeitos dos componentes e superfície de resposta.

De maneira resumida, a técnica de experimentos com misturas propõe que as variáveis escolhidas para representar o problema em questão sejam proporções, admitindo a condição de dependência entre as variáveis. Consequentemente, ela pode ser aplicada em experimentos onde se pode atribuir às alterações verificadas nas propriedades das amostras a variações nas proporções dos componentes adotadas. Dentro desse contexto, as amostras são denominadas de "misturas", enquanto os fatores analisados no experimento são chamados de "componentes".

Observando esses apontamentos, na presente pesquisa foram avaliados três componentes; o ligante asfáltico, os ácidos (PPA e PA85) e o copolímero SBS. Com base na definição e diferenciação de experimentos com misturas e fatoriais, apresentada por Cornell (2002), o modelo adotado será composto de três componentes $X_{1} ; X_{2}$ e $X_{3}$, visando à obtenção de uma função de segunda ordem ou quadrática.

Onde:

$$
\begin{array}{ll}
X_{1} & \text { Representará o CAP; } \\
X_{2} & \text { Representará o copolímero SBS; e } \\
X_{3} & \text { Representará o ácido (PPA e PA85). }
\end{array}
$$

Os componentes devem apresentar quantidades maiores ou iguais a zero e o somatório das proporções utilizadas igual à unidade. Cabe salientar que, as proporções dos componentes estudados foram escolhidas devido à utilização já conhecida, em casos práticos ou de estudos já realizados. As restrições impostas para a presente pesquisa, ou seja, as limitações dos componentes para composição das misturas são apresentas nas inequações (1):

$$
\begin{aligned}
& 0,935 \leq X_{1} \leq 1,000 \quad(C A P) \\
& 0,000 \leq X_{2} \leq 0,05 \quad(S B S) \\
& 0,000 \leq X_{3} \leq 0,015 \quad(\text { Ácido) }
\end{aligned}
$$


O experimento com mistura também auxilia na determinação da seleção de misturas que irão representar ou descrever o espaço amostral referente às restrições impostas. Para este estudo, a região delimitada pelo experimento com misturas pode ser observada na Figura 18, e o detalhamento das misturas está exposto na Tabela 5. Observa-se que o espaço amostral ficou definido por nove misturas determinadas pela técnica de experimento com misturas.

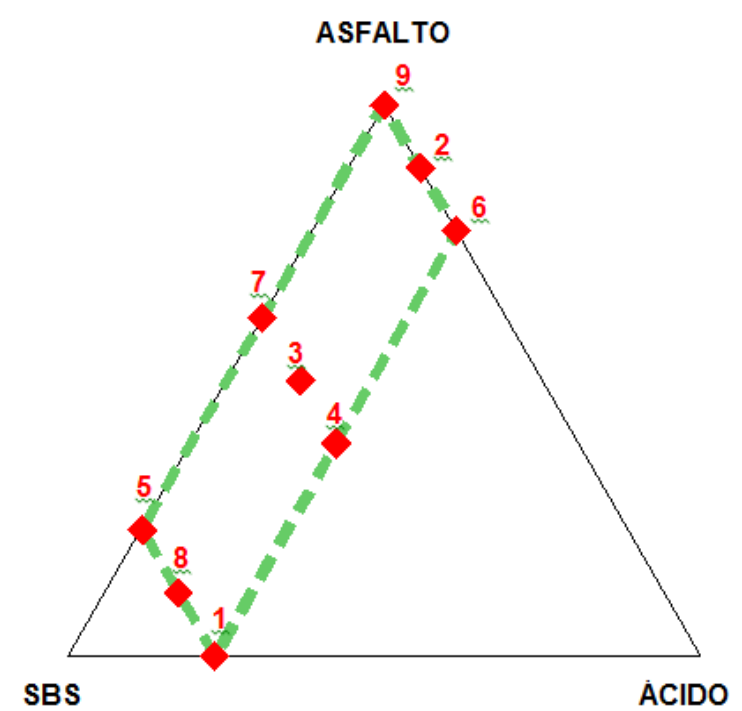

Figura 18 - Região delimitada pelo experimento com misturas para presente pesquisa.

\begin{tabular}{cccc} 
Tabela 5 - Porcentagem dos componentes das misturas. \\
\hline \multirow{4}{*}{ Misturas } & \multicolumn{3}{c}{ Proporção dos Componentes (\%) } \\
& $\boldsymbol{X}_{\mathbf{1}}$ (CAP) & $\boldsymbol{X}_{\mathbf{2}}$ (SBS) & $\boldsymbol{X}_{\mathbf{3}}$ (Ácido) \\
\hline 1 & 93,50 & 5,00 & 1,50 \\
2 & 99,25 & 0,00 & 0,75 \\
3 & 96,75 & 2,50 & 0,75 \\
4 & 96,00 & 2,50 & 1,50 \\
5 & 95,00 & 5,00 & 0,00 \\
6 & 98,50 & 0,00 & 1,50 \\
7 & 97,50 & 2,50 & 0,00 \\
8 & 94,25 & 5,00 & 0,75 \\
9 & 100,00 & 0,00 & 0,00 \\
\hline
\end{tabular}

As amostras são selecionadas devido às restrições impostas e ao grau do modelo a ser ajustado. Destaca-se que, um número mínimo de misturas é exigido para dar suporte ao modelo escolhido para explicar a propriedade avaliada. No presente estudo, considerando as restrições já apresentadas e o ajuste do modelo quadrático, ainda segundo Cornell (2002), o número mínimo de misturas a serem realizadas é 6 (seis), obtido conforme a Equação 6, onde $q$ representa o número de componentes (3) e $m$ corresponde ao grau do polinômio

$$
\frac{(q+m-1) !}{m !(q-1) !}=\frac{(3+2-1) !}{2 !(3-1) !}=6
$$


Com base nessa especificação, inicialmente, foram produzidas sete misturas (mínimo mais uma), conforme apresentado na Figura 19. No entanto, cabe destacar que, caso não se obtenha um bom ajuste do modelo, no intuito de melhorá-lo, pode-se optar por produzir um maior número de misturas (acima do mínimo estabelecido) ou aumentar o número de repetições dos ensaios por mistura estudada.

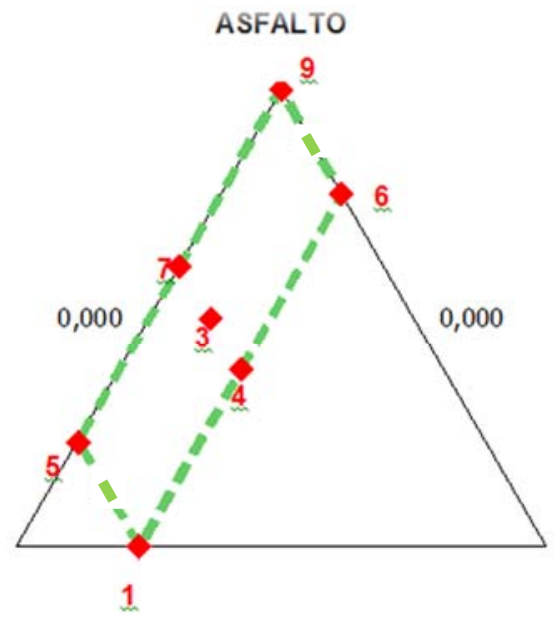

SBS

ACIDO

Figura 19 - Misturas estudadas inicialmente.

Depois da realização de alguns ensaios, optou-se por estudar todas as misturas (nove) determinadas pela técnica de experimento com misturas, para que dessa maneira, fosse realizada a análise completa da região experimental delimitada. Consequentemente, para caracterização das misturas, foram selecionados os ensaios apontados na Tabela 6 . Os ensaios visaram verificar as propriedades reológicas empíricas e fundamentais, visto que as empíricas ainda são utilizadas pelas normas brasileiras.

Tabela 6 - Propriedades físicas e métodos de ensaio.

\begin{tabular}{lc}
\hline \multicolumn{1}{c}{ Propriedade } & Método de Ensaio \\
\hline Penetração Virgem /-RTFOT & ASTM D5 \\
Ponto de Amolecimento Virgem-/ RTFOT & ASTM D36 \\
Viscosidade Aparente (Brookfield) & ASTM D4402 \\
135-143-150-163-177 $\left({ }^{\circ} \mathrm{C}\right)$ & ASTM D 2872 \\
Balanço de Massa & ASTM D 5892 \\
Estabilidade à Estocagem (para misturas com SBS) & ASTM D7405 \\
MSCR (RTFOT) & AASTHO TP 101-12-UL \\
Tolerância ao dano por Fadiga (RTFOT e PAV) & \\
\hline
\end{tabular}




\subsubsection{Materiais Utilizados e Procedimentos Experimentais}

\subsubsection{Materiais}

No presente trabalho foram utilizados dois ligantes asfálticos de base (CAP 50/70), a saber: (a) Replan (Refinaria do Planalto Paulista) de Paulínia/SP; e (b) Lubnor (Refinaria de Petróleo da Petrobrás) de Fortaleza/CE. As características físicas, na condição virgem e envelhecido a curto prazo (RTFOT), do CAP Replan estão apresentadas na Tabela 7, e do CAP Lubnor, na Tabela 8.

Tabela 7 - Caraterísticas físicas do CAP 50-70 Replan.

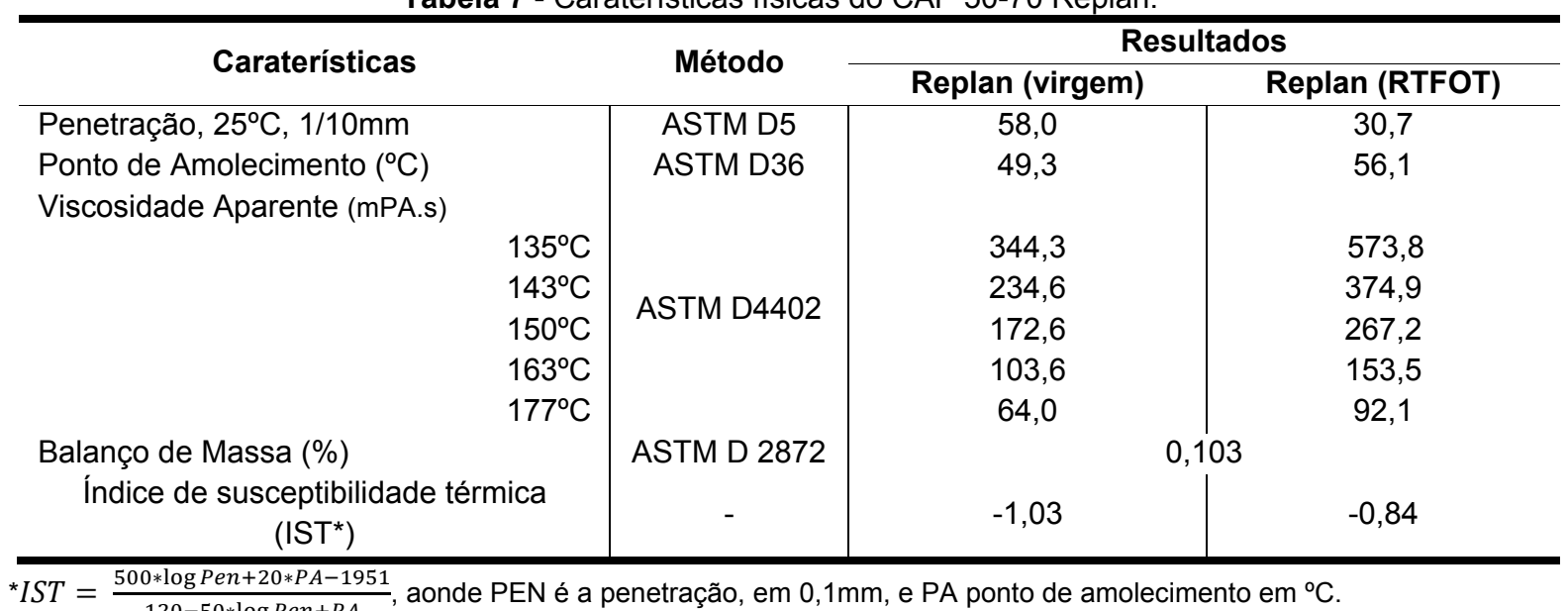

Tabela 8 - Caraterísticas físicas do CAP 50-70 Lubnor.

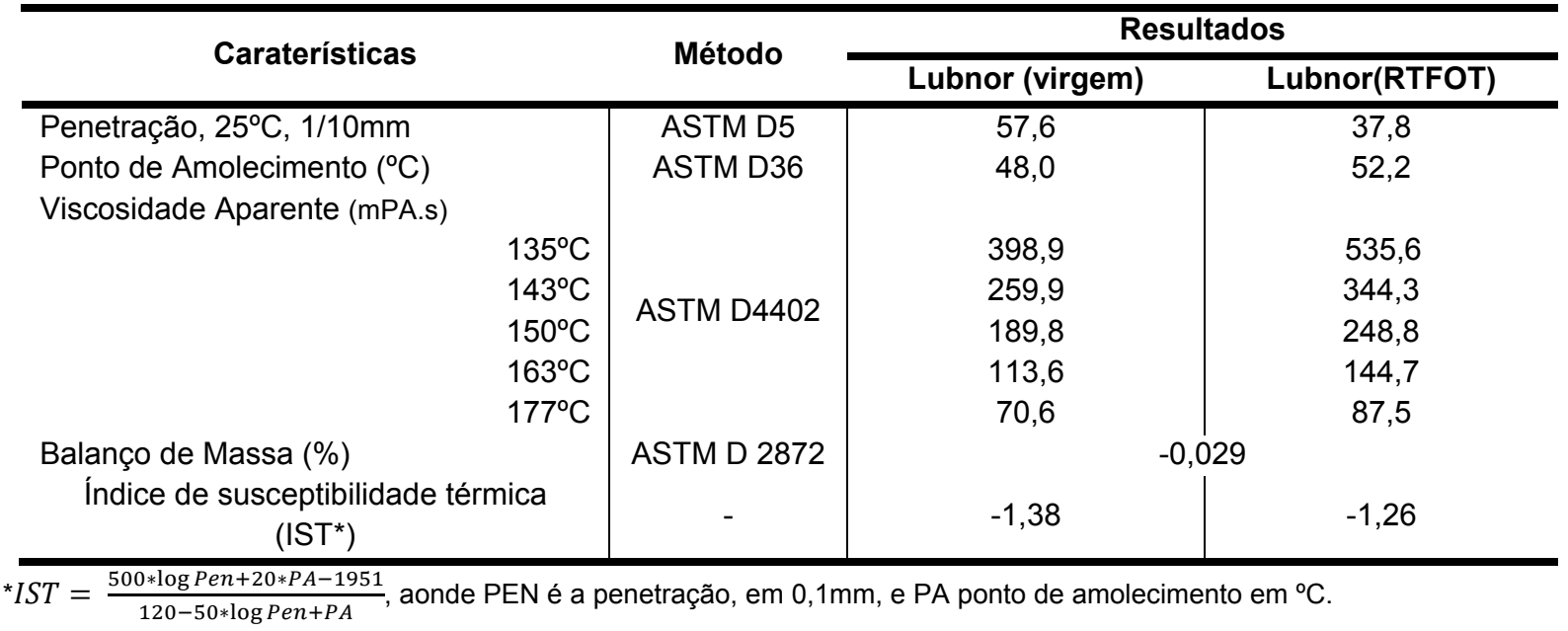


Além dos dois ligantes asfálticos, apresentados anteriormente, os modificadores utilizados no trabalho foram os seguintes, a saber:

a) Ácido polifosfórico (PPA), comercialmente conhecido como Innovalt E-200, fornecido pela Innophos Inc dos EUA;

b) Ácido fosfórico (PA85), fornecido pela empresa Serquímica Indústria e Comércio de Produtos Químicos Ltda; e

c) Copolímero SBS do tipo TR-1101, adquirido da Kraton Polymers do Brasil, fornecidos pela empresa Betunel dotado das seguintes características técnicas: teor de poliestireno de $31 \%$, densidade igual a 0,94 , resistência à tração de $33 \mathrm{MPa} e$ alongamento na ruptura igual a $880 \%$.

\subsubsection{Produção dos Ligantes Asfálticos}

No que diz respeito à produção dos ligantes asfálticos modificados, foram utilizados dois tipos de misturadores, a saber: (a) misturador de baixo cisalhamento da marca Fisatom, modelo 722D; e (b) misturador de alto cisalhamento da marca Silverson, modelo L4R. Os misturadores são apresentados na Figura 8. Dependendo do modificador a ser adicionado, foram determinadas as variáveis de processamento da mistura, que estão apresentadas na Tabela 9.

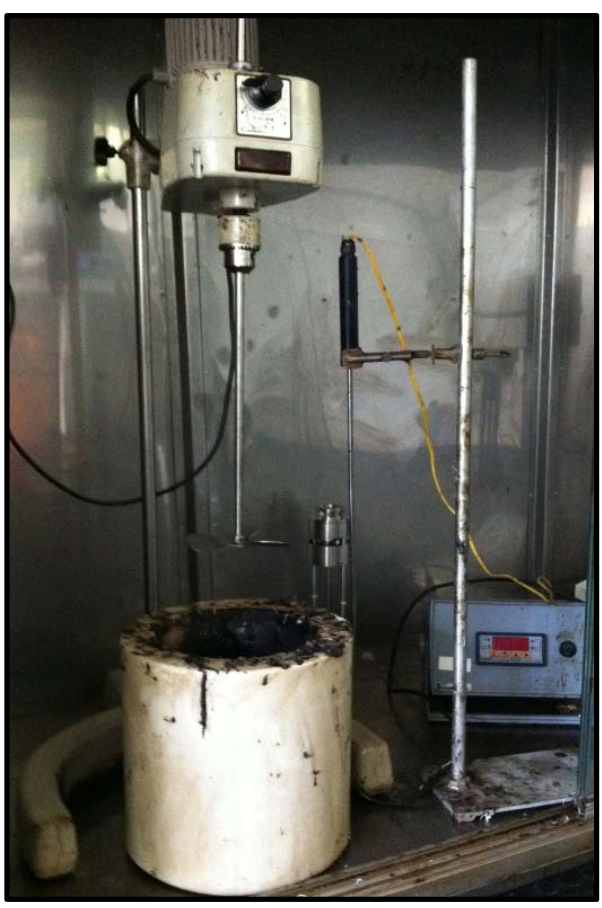

(a)

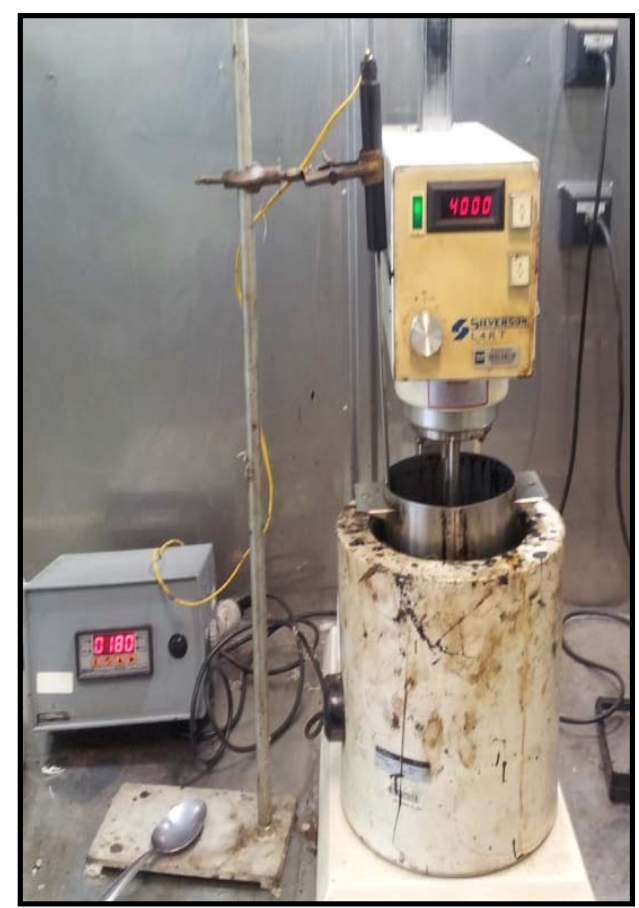

(b)

Figura 20 - Misturas utilizados, sendo (a) baixo cisalhamento e (b) alto cisalhamento. 
Tabela 9 - Variáveis de processamento dos ligantes asfálticos.

\begin{tabular}{c|c|c|c|c}
\hline \multirow{2}{*}{ Ligantes Asfálticos } & \multicolumn{4}{c}{ Variáveis de Processamento } \\
\cline { 2 - 5 } & Cisalhamento & Rotação $(\mathbf{r p m})$ & Temperatura $\left.{ }^{\circ} \mathbf{C}\right)$ & 130 \\
\hline CAP + Ácidos & Baixo & 300 & 180 & 30 \\
\hline CAP + SBS & Alto & 4000 & 180 & 120 com Ácidos aos 60 \\
\hline CAP + SBS + Ácidos & Alto & 4000 & Tempo \\
\hline
\end{tabular}

\subsubsection{Envelhecimento}

Para Shell (2003), o envelhecimento do ligante asfáltico do revestimento ocorre em três etapas: (a) durante o processo de usinagem e representa $60 \%$ do envelhecimento total sofrido pelo ligante; (b) durante o transporte, espalhamento e compactação, que representa $20 \%$ do envelhecimento total sofrido pelo ligante; e (c) o envelhecimento que ocorre durante a vida útil do revestimento devido à ação do meio ambiente, que corresponde a $20 \%$ do envelhecimento total. Grande parte desse processo acontece durante o chamado "envelhecimento em curto prazo", que corresponde ao processo sofrido durante a mistura, estocagem, transporte e aplicação. Nessas etapas, o ligante é submetido simultaneamente aos três fatores necessários para que ocorra o envelhecimento acelerado: altas temperaturas, elevada área superficial de agregados em relação ao volume de ligante (baixa espessura de película) e exposição ao ar (mistura solta) (TONIAL, 2001).

A simulação desse envelhecimento é realizada mediante ensaio conhecido como RTFOT (Rolling Thin Film Oven Test), estufa de filme fino rotativo ou película delgada rotacional. Esse ensaio simula o envelhecimento por oxidação e evaporação de forma severa por estar continuamente expondo nova porção do ligante ao efeito do ar. O envelhecimento é avaliado mediante comparação dos resultados dos ensaios realizados com as amostras envelhecidas em relação as amostras virgens. Na Figura 21 é apresentado um exemplo do equipamento RTFOT.

É válido destacar que nesse ensaio, uma fina película de asfalto de $35 \mathrm{~g}$ é continuamente girada dentro de um recipiente de vidro a $163^{\circ} \mathrm{C}$ por 85 minutos, com uma injeção de ar a cada 3 a 4 segundos. O ensaio foi realizado mediante a norma ASTM D28728. O efeito desse envelhecimento é avaliado com base nas alterações das propriedades medidas (ensaios de caracterização) antes e após esse procedimento. Cabe destacar que, de maneira opcional, pode-se realizar o ensaio de balanço de massa. Essa avaliação é feita em comparação com o percentual de massa original.

\footnotetext{
${ }^{8}$ ASTM D2872- Standard Test Method for effect of heat and air on a moving film of asphalt - rolling thin-film oven test.
} 
Há muitos mecanismos envolvidos no envelhecimento dos ligantes asfálticos, porém dois são mais relevantes: a perda de componentes voláteis (saturados e aromáticos) e a reação química do asfalto com o oxigênio do ar. O material avaliado pode apresentar tanto ganho quanto perda de massa, indicado com sinal positivo ou negativo, respectivamente. Materiais com baixos teores de componentes leves apresentam ganho de massa, porém materiais com altos teores de voláteis geralmente apresentam perda de massa. Isso se deve ao fato que, os componentes leves dos materiais volatilizam, proporcionando perda de massa (evaporação), enquanto a reação entre o oxigênio e o material causa ganho de massa (oxidação).

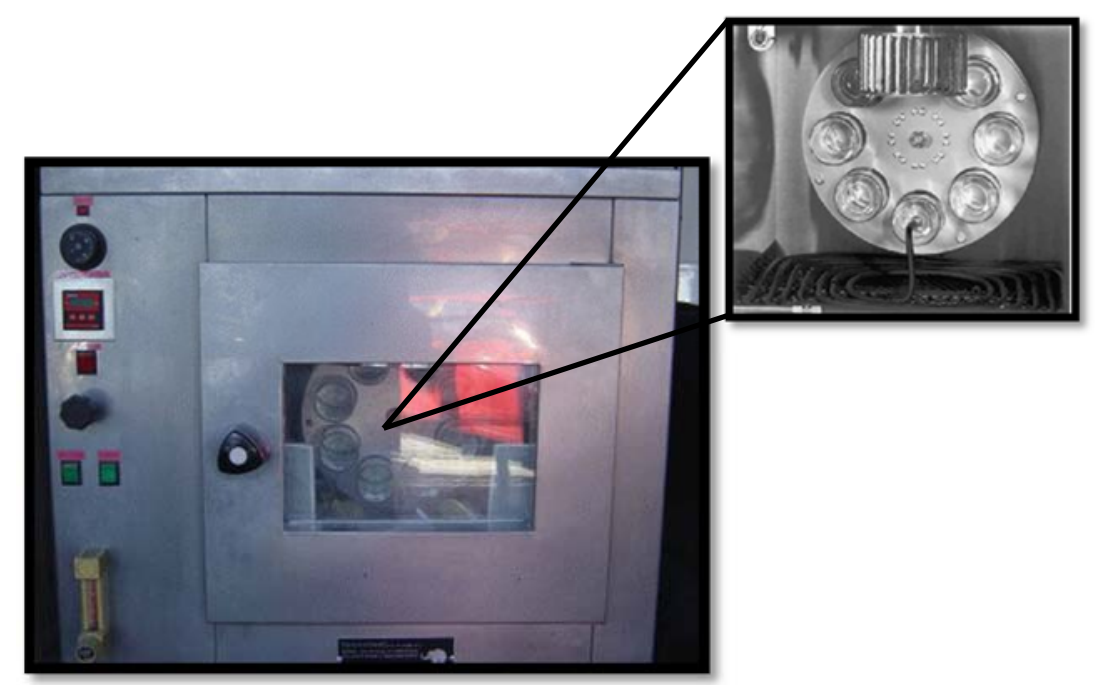

Figura 21 - Estufa do filme fino rotativo (RTFOT).

Uma vez que o pavimento esteja concluído, o processo de envelhecimento do ligante da mistura asfáltica em serviço, chamado de longo prazo, se torna mais lento, porém não cessa. A simulação do endurecimento oxidativo que ocorre no ligante asfáltico ao longo da vida útil do pavimento (podendo simular sua vida de serviço) é realizado pelo vaso de envelhecimento sob pressão. O equipamento que simula esse envelhecimento é denominado de PAV. Na Figura 22 é apresentado um exemplo desse tipo de equipamento. 


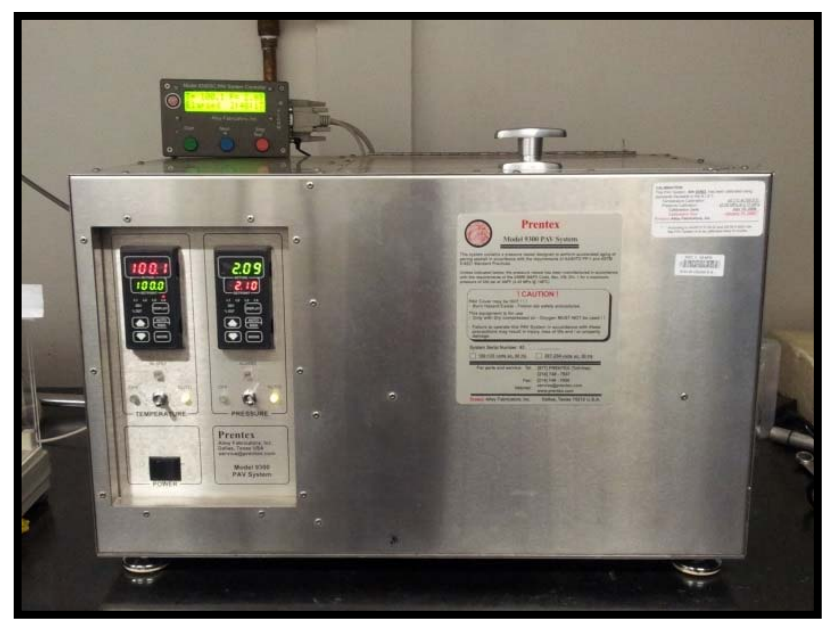

Figura 22 - Estufa de vaso pressurizado (PAV) marca Prentex, modelo 9300.

O condicionamento é descrito pela norma ASTM 6521-03a9 ${ }^{9}$ Para realização dessa simulação, uma dada parcela da amostra do RTFOT (50g) é colocada em pratos de aço inoxidável e envelhecida sob temperaturas de $100^{\circ} \mathrm{C}$ durante o período de 20 horas em um vaso pressurizado com ar sob pressão de 2,10MPa. Após esse procedimento, as amostras são levadas a estufa de vácuo a $170^{\circ} \mathrm{C}$ e $15 \mathrm{kPa}$ por 30 minutos para retirar as bolhas.

Após os condicionamentos, envelhecimento em curto e em longo prazo, os ensaios de interesse são realizados. No presente trabalho, foram realizados na condição virgem e envelhecido a curto prazo (RTFOT) os ensaios de penetração, ponto de amolecimento e viscosidade Brookfield. No entanto, seguindo instruções de norma o ensaio referente a tolerância a deformação permanente (MSCR) foi realizado com amostras na condição envelhecida a curto prazo (RTFOT), enquanto o ensaio do LAS modificado, que avalia a tolerância ao dano por fadiga, foi realizado com amostras envelhecidas nos dois procedimentos (RTFOT e PAV). Os detalhes desses ensaios estão descritos nos itens seguintes.

\subsubsection{Penetração}

É caracterizado como um ensaio empírico. É obtido mediante aparelho denominado penetrômetro, conforme apresentado na Figura 23 e seu valor é estabelecido em décimos de milímetro, pelo valor de penetração de uma agulha padronizada, a $25^{\circ} \mathrm{C}$, após 5 segundos, sob ação de uma carga estabelecida de $100 \mathrm{~g}$. Pode-se realizar esse ensaio em outras temperaturas, mais altas ou mais baixas. Em cada ensaio, três medidas individuais de penetração são realizadas. A média dos três valores é anotada e aceita, se a diferença entre

\footnotetext{
${ }^{9}$ ASTM 6521-03a Standard practice for accelerated aging of asphalt binder using a pressurized aging vessel - PAV.
} 
as três medidas não exceder um limite especificado em norma. Entende-se que a consistência do CAP é maior quanto menor for a penetração da agulha. É válido destacar que este ensaio é realizado segundo a norma ASTM D5 ${ }^{10}$.

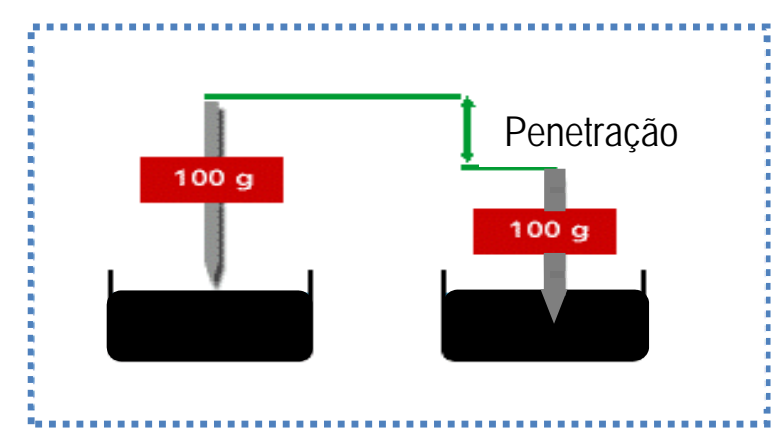

(a)

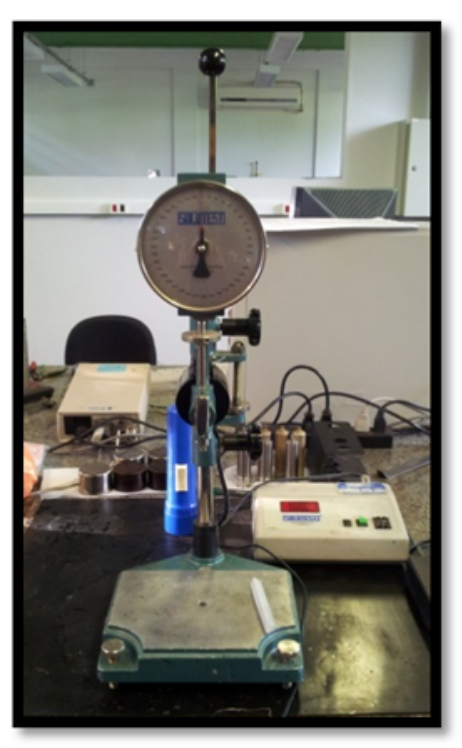

(b)

Figura 23 - Esquema básico do ensaio de penetração (a) e foto do equipamento (b).

Além dos valores de penetração encontrados, pode-se mediante este ensaio analisar o valor de penetração retida dos ligantes asfálticos, que é calculada pela razão entre a penetração do ligante asfáltico na condição envelhecida em curto prazo (Pen RTFOT) e a penetração do mesmo material na condição virgem (Pen Virgem), conforme mostrado na Equação 7.

$$
\text { Penetração Retida }(\%)=\frac{\text { Pen RTFOT }}{\text { Pen Virgem }} * 100
$$

Consequentemente, valores baixos de penetração retida indicam alta sensibilidade ao envelhecimento em curto prazo.

\footnotetext{
${ }^{10}$ ASTM D5 - Standard Test Method for Penetration of Bituminous Materials.
} 


\subsubsection{Ponto de Amolecimento}

De maneira semelhante ao ensaio de penetração, o ponto de amolecimento é caracterizado como um ensaio empírico, conhecido como anel e bola. Ele fornece o valor da temperatura na qual a consistência de um ligante asfáltico passa do estado semissólido para o estado líquido. O ensaio é realizado com uma bola de aço com dimensões e peso especificados, colocada no centro de uma amostra de asfalto que está dentro de um anel metálico padronizado. O conjunto é colocado em um banho de água e/ou glicerina (dependente do ponto de amolecimento do material) dentro de um béquer. $O$ banho é aquecido a uma taxa de ganho de temperatura controlada e, quando o asfalto amolecer o suficiente para a esfera e o asfalto deslocar-se até o fundo do béquer e atingir a placa do fundo do conjunto, a temperatura é anotada. O teste é conduzido com duas amostras do mesmo material. Se a diferença de temperaturas entre as duas amostras exceder $2^{\circ} \mathrm{C}$, o ensaio deve ser refeito.

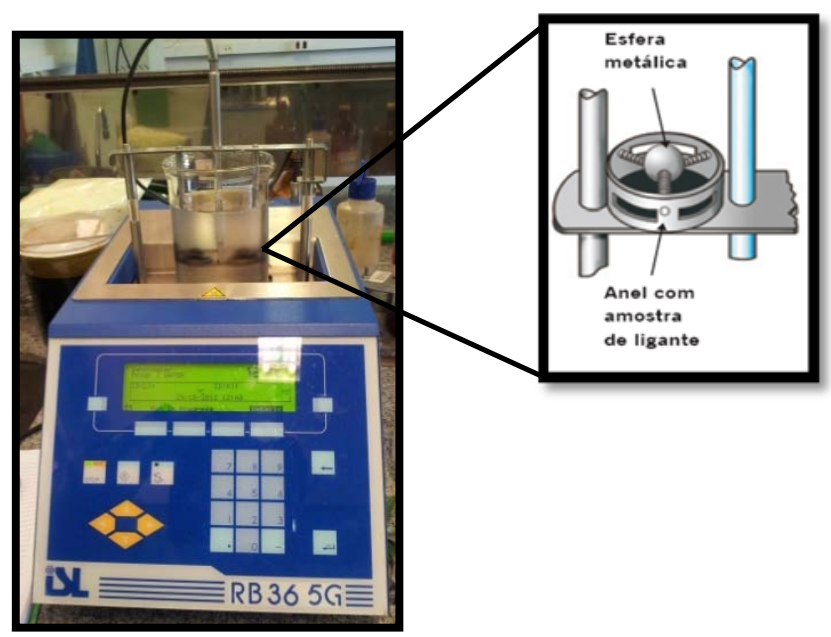

Figura 24 - Equipamento para ensaio de anel e bola, ou ponto de amolecimento.

O ensaio foi realizado pela norma ASTM D36 ${ }^{11}$. Na Figura 24 pode-se verificar o equipamento utilizado. Esse ensaio é classificatório em especificações brasileiras e, geralmente, é empregado para estimar a suscetibilidade térmica.

No ensaio de ponto de amolecimento pode-se analisar o incremento do ponto de amolecimento dos ligantes asfálticos (Ic Pa), que é calculado pela diferença entre o ponto de amolecimento dos ligantes asfálticos na condição envelhecida em curto prazo (Pa RTFOT) e

\footnotetext{
${ }^{11}$ ASTM D36 - Standard Test Method for Softening of Bitumen (ring-and-ball appatarus). 
o ponto de amolecimento do material na condição virgem ( $\mathrm{Pa}$ Virgem), como mostra a Equação 8. Altos valores de Ic $\mathrm{Pa}$ apontam sensibilidade elevada do ligante asfáltico ao envelhecimento em curto prazo.

$$
I c_{P a}=P a_{R T F O T}-P a_{V i r g e m}
$$

Foi avaliado tanto para o ensaio de penetração quanto para o ponto de amolecimento o grau de modificação $\left(G_{\text {mod }}\right)$ do ligante asfáltico, calculado pela razão entre o valor da propriedade avaliada do material modificado $\left(P_{\text {mod }}\right)$ e o valor da propriedade para o material

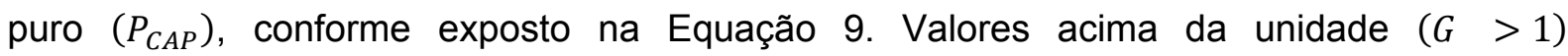
correspondem a um aumento da propriedade para o ligante asfáltico modificado quando comparado ao ligante asfáltico puro, enquanto valores inferiores à unidade $\left(G_{m o d}<1\right)$ apontam uma redução da propriedade para o material modificado em relação ao ligante asfáltico puro.

$$
G_{\text {mod }}=\frac{P_{\text {mod }}}{P_{C A P}}
$$

\subsubsection{Estabilidade à Estocagem}

Esse ensaio tem por objetivo avaliar a compatibilidade entre o polímero e o ligante asfáltico durante estocagem sem agitação a altas temperaturas. Essa avaliação é realizada mediante comparação entre os valores de ponto de amolecimento, obtidos das partes superiores e inferiores de um tubo preenchido pela amostra, após submetido ao condicionamento especificado pela norma ASTM D5892-0012. De maneira geral, o ensaio compreende em preencher tubos, já colocados no raque, com as amostras a serem estudadas. Depois coloca toda essa estrutura na estufa a $163 \pm 5^{\circ} \mathrm{C}$ durante $48 \pm 1 \mathrm{~h}$, após este período leva o material imediatamente para ao freezer com temperatura de $-6,7 \pm 5^{\circ} \mathrm{C}$, deixando os tubos sempre na vertical, durante um período de $4 \mathrm{~h}$. Depois de remover as amostras, deve-se cortá-las em 3 partes iguais, colocar a parte de topo e fundo em recipientes separadas dentro de uma estufa para retirada do material. Após este procedimento, deve-se realizar o ensaio de ponto de amolecimento com as amostras ensaiadas. A avaliação da estabilidade à estocagem é realizada pela diferença do ponto de amolecimento do topo e do fundo. Sendo que, as normas americanas e europeias estabelecem para ligante asfálticos

\footnotetext{
12 ASTM D5892-00 Standard test method for type IV polymer modified asphalt cement use in pavement construction.
} 
modificados com o copolímero SBS limite que variam entre 2 a $5^{\circ} \mathrm{C}$ no máximo para essa diferença. Esse limite determina que o material pode ser estocagem sem a necessidade de agitação.

\subsubsection{Viscosidade Rotacional ou Brookfield}

A viscosidade é fator importante para obras rodoviárias, pois determina as temperaturas para bombeamento, usinagem, lançamento e compactação das misturas asfálticas na rodovia. Pode ser entendida como a propriedade física que caracteriza a resistência ao escoamento de um fluído simples.

Para melhor entender esse fenômeno, considera-se um fluído confinado entre duas placas paralelas e planas, conforme ilustrado na Figura 25. Ele é submetido ao movimento da placa superior em relação à inferior (fixa). À medida que a placa móvel é deslocada, gera-se um gradiente de velocidade do fluído que vai desde zero na interface com a placa fixa até o valor máximo na interface da placa móvel. Quanto maior a força imposta na placa móvel, maior será o gradiente de velocidade do fluído.

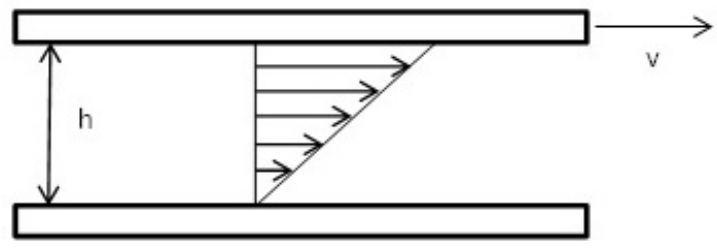

Figura 25 - Esquema ilustrativo do experimento de Newton para determinação da viscosidade.

A força por unidade de área necessária para manter o escoamento do fluído é denominada tensão de cisalhamento $(F / A)$, enquanto que o deslocamento relativo das partículas ou moléculas do fluído é denominado de taxa de cisalhamento ou gradiente de velocidade. Sendo assim, a viscosidade é a relação entre a tensão de cisalhamento e o gradiente de velocidade (Navarro, 1997).

Os materiais que apresentam viscosidade constante para qualquer taxa de cisalhamento são chamados de líquidos Newtonianos e sua viscosidade é conhecida como Viscosidade Newtoniana. No entanto, para alguns materiais a relação entre a tensão de cisalhamento e a taxa de cisalhamento não é constante, sendo chamados de fluídos nãonewtoniano (Malkin, 1994). Esses últimos, por sua vez, apresentam a viscosidade dependente do cisalhamento aplicado ou do tempo da sua aplicação (NAVARRO, 1997). 
Os líquidos não newtonianos podem ser classificados como: (a) Pseudoplásticos (viscosidade diminui com a taxa de cisalhamento); (b) Dilatante (viscosidade aumenta com a taxa de cisalhamento); (c) Fluído de Binghan (existência de um valor residual para a tensão de cisalhamento, o qual deve ser excedido para que o material apresente um fluxo viscoso); e, (d) Plásticos ou fluído de Herschel-Burlkley (considera a tensão residual acrescida da lei da potência ${ }^{13}$ ) (BARNES, et al. 1993; NAVARRO, 1997). Diante do exposto, nota-se que a viscosidade dos materiais pode ser significativamente afetada por variáveis como a taxa de cisalhamento, a temperatura, a pressão e o tempo de cisalhamento sofrido pela amostra (BARNES, et al; 1993).

O ensaio de viscosidade rotacional, no presente trabalho, foi realizado no equipamento viscosímetro Brookfield modelo DVII+Pro (Figura 26) acoplado a um controlador de temperatura Thermosel. O ensaio de viscosidade rotacional foi monitorado nas temperaturas de $135^{\circ} \mathrm{C}, 143^{\circ} \mathrm{C}, 150^{\circ} \mathrm{C}, 163^{\circ} \mathrm{C}$ e $177^{\circ} \mathrm{C}$. As taxas de cisalhamento adotadas para o ensaio foram definidas para que as porcentagens de torque estabelecidas pela norma ASTM $\mathrm{D} 4402^{14}$ ) fossem respeitadas (inferiores a $98 \%$ e superiores a $10 \%$ ). Salienta-se ainda que, para manter os limites estabelecidos e a mesma taxa de cisalhamento aplicada para todos os ligantes, foram utilizados dois "splindes", $n^{\circ} 21$ e n' 27 , e alterado, conforme formulações da norma, a velocidade de rotação do equipamento, apresentadas na Tabela 10.
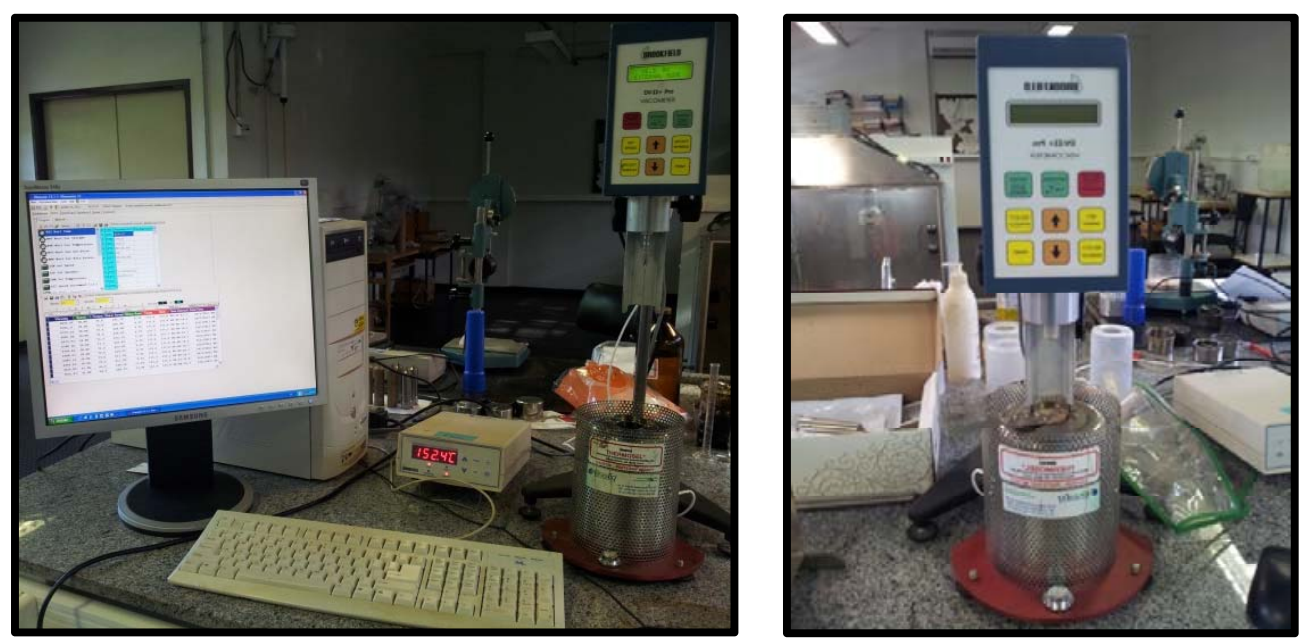

Figura 26 - Viscosímetro Brookfield modelo DVII+Pro.

\footnotetext{
${ }^{13}$ Lei da Potência: ao examinar alguns fluídos sob escoamento cisalhante, Waale apud Navarro (1997) verificou que eles apresentavam comportamentos diferentes dos Newtonianos e percebeu que a relação entre a tensão de cisalhamento e a taxa de deformação não era linear e que a inclinação variava de forma não linear com a taxa de deformação e propôs o modelo considerando um índice de potência $\left(\tau=K * \gamma^{n}\right)$ onde $n$ é o índice de potência e $K$ índice de consistência do fluído.

${ }^{14}$ ASTM D4402 - Standard Test Method for Viscosity Determination of Asphalt at Elevated Temperatures Using a Rotational Viscometer.
} 
Tabela 10 - Dados referentes ao ensaio de Viscosidade rotacional.

\begin{tabular}{cccc}
\hline \multirow{2}{*}{ Temperatura $\left({ }^{\circ} \mathrm{C}\right)$} & \multicolumn{2}{c}{ Velocidade $(\mathbf{r p m})$} & \multirow{2}{*}{ Taxa de Cisalhamento $\left(\mathbf{s}^{-1}\right)$} \\
\cline { 2 - 3 } & Spindle 21* & Spindle $\mathbf{2 7}^{\text {** }}$ & \\
\hline 135 & 10 & 28 & 9 \\
143 & 15 & 41 & 14 \\
155 & 20 & 55 & 19 \\
163 & 30 & 82 & 28 \\
177 & 50 & 137 & 47 \\
\hline *Taxa de cisalhamento $=0,93^{*} \mathrm{~N}$. &
\end{tabular}

Foram realizados três ensaios por amostra, almejando controlar a variabilidade dos resultados, assim como realizar as análises estatísticas selecionadas para o presente trabalho. As viscosidades finais, para cada temperatura, foram determinadas com a média de 10 leituras determinadas pelo equipamento.

Também foi verificado o incremento da viscosidade, que é calculada pela razão entre a viscosidade na condição envelhecida em curto prazo $\left(V_{R T F O T}\right)$ e a viscosidade virgem $\left(V_{\text {Virgem }}\right)$, conforme Equação 10. O incremento da viscosidade aponta quantas vezes a viscosidade na condição envelhecida em curto prazo (RTOFT) é maior do que esta propriedade na condição virgem, ou seja, quantas vezes a viscosidade aumentou devido ao envelhecimento. Ligantes asfálticos que apresentam sensibilidade maior ao envelhecimento em curto prazo, têm valores de $I_{v}$ superiores.

$$
I_{V}=\frac{V_{R T F O T}}{V_{\text {Virgem }}}
$$

\subsubsection{Ensaio de Fluência e Recuperação sob Tensão Múltipla (MSCR)}

Esse ensaio foi realizado no Reômetro de Cisalhamento Dinâmico AR 200Ex - TA Instruments, ilustrado na Figura 27. Para esse ensaio é utilizada geometria de $25 \mathrm{~mm}$ com gap de $1 \mathrm{~mm}$ entre as placas. Segundo a norma ASTM D7405 - 10a ${ }^{15}$, o ensaio é realizado mediante tensão controlada, de 100Pa e 3200Pa, onde uma carga constante é aplicada por tempo de 1s, e após sua remoção o material fica em repouso por um tempo de 9s. Foram rodados 10 ciclos de fluência e recuperação para 5 temperaturas diferentes $(52,58,64,70$ e $\left.76^{\circ} \mathrm{C}\right)$ em dois níveis de tensão (100Pa e 3200Pa). Foram mantidos os tempos de carregamento e de repouso e o número de ciclos, conforme citado, para cada nível de tensão aplicado.

\footnotetext{
${ }^{15}$ ASTM D7405 - 10a - Standard Test Method for Multiple Stress Creep and Recovery (MSCR) of Asphalt Binder Using a Dynamic Shear Rheometer.
} 
Para esse ensaio foram verificados parâmetros que indicam a resposta elástica retardada do ligante asfáltico, por meio do percentual de recuperação - $\mathrm{R}$ (\%); avaliação da tolerância do material à deformação permanente, mediante compliância não-recuperável; e análise da sensibilidade dos material com a mudança do nível de tensão, mediante o $\left(J_{n r, \text { diff. }}\right)$, conforme já detalhado no capítulo 2 deste trabalho.
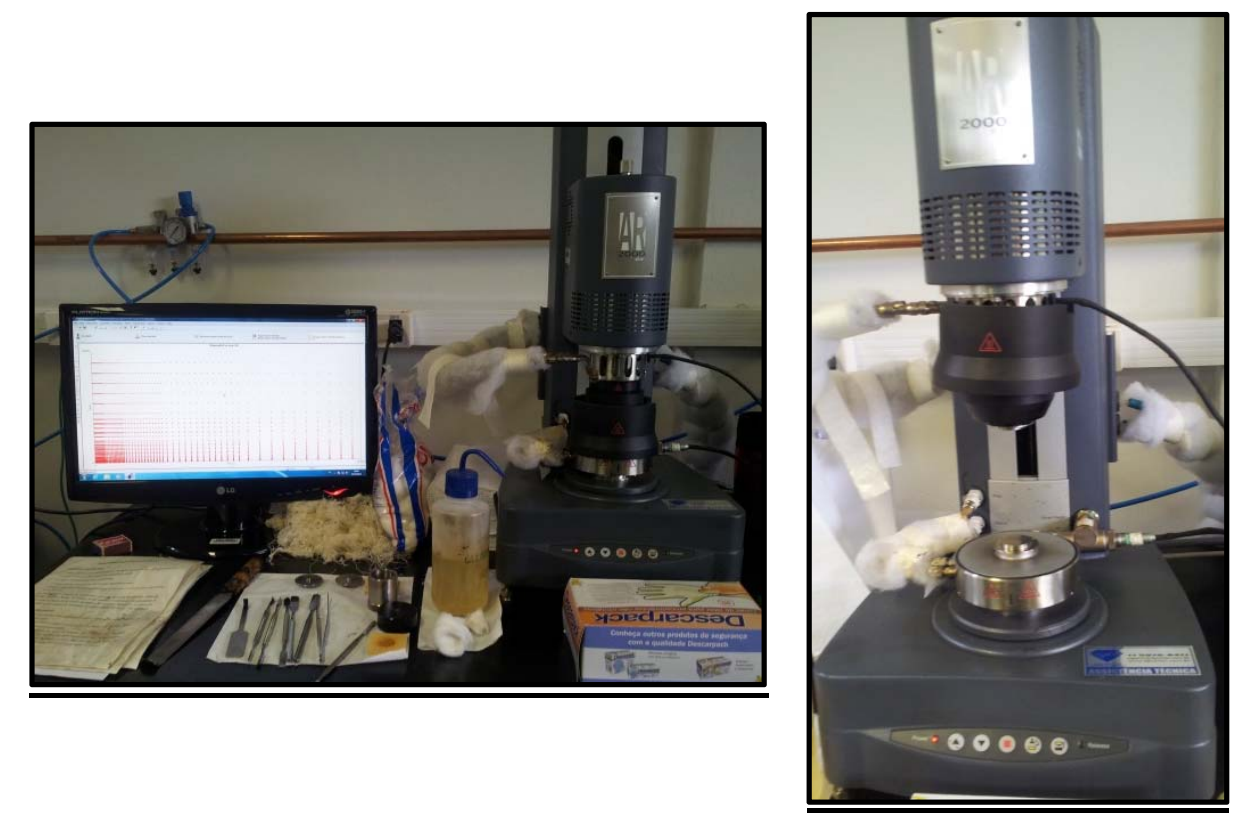

Figura 27 - Reômetro de Cisalhamento Dinâmico AR 200Ex - TA Instruments.

\subsubsection{Linear Amplitude Sweep (LAS Modificado)}

O ensaio foi realizado utilizando o Reômetro de Cisalhamento Dinâmico AR 200Ex TA Instruments, conforme Figura 28, na geometria de placas paralelas de $8 \mathrm{~mm}$, com o gap de $2 \mathrm{~mm}$ entre as placas.

Este ensaio é dividido em duas etapas: (i) uma varredura de frequência de 0,2 a $30 \mathrm{~Hz}$, a uma amplitude de deformação de $0,1 \%$ e (ii) uma varredura de amplitude de deformação, com aumento linear, variando de 0 a $30 \%$ de deformação, a uma frequência fixa de $10 \mathrm{~Hz}$, no intervalo de tempo de 300 segundos. Os ensaios foram realizados a uma temperatura de $25^{\circ} \mathrm{C}$, nas amostras envelhecidas em curto prazo (RTFOT) e em longo prazo (PAV). Nesse ensaio, o comprimento da trinca (af) na ruptura por fadiga é monitorado. 

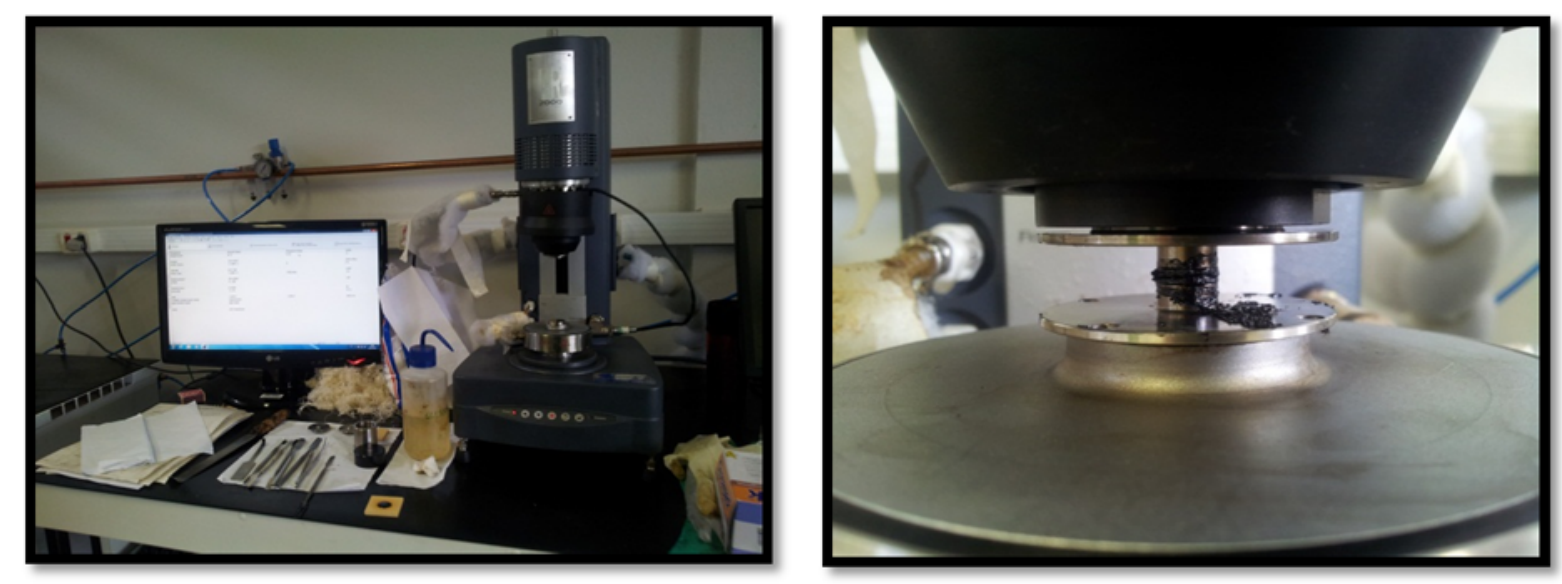

Figura 28 - Reômetro de cisalhamento dinâmico (DSR) e amostra do ensaio LAS modificado.

Cabe destacar que, para os ligantes asfálticos mais modificados, devido ao fato de não se observar a ruptura do material e, consequentemente, não obter o ponto mínimo da curva para definir o valor de af, optou-se por realizar o ensaio com a amplitude de deformação de $50 \%$. Já para ligantes asfálticos muito modificados, como $5 \%$ SBS $+1,5 \%$ Ácido, foi realizado o ensaio com amplitude de deformação de $80 \%$. 


\section{Resultados e Discussões}

\subsection{Ligante Asfáltico Modificado Somente com Ácidos}

Nesta seção são apresentados os resultados referentes aos ensaios realizados com os dois tipos de ligantes asfálticos de base selecionados (Replan e Lubnor) modificados com a adição do ácido polifosfórico (PPA) e do ácido fosfórico (PA85). Também são apresentadas as análises feitas com o auxílio do ANOVA, para verificar a influência dos fatores e suas interações nas propriedades monitoradas.

\subsubsection{Grau de Desempenho}

O grau de desempenho ou Performance Grade (PG) das amostras foi obtido com base nos valores do parâmetro $\mathrm{G}^{*} / \operatorname{sen} \delta$ das amostras virgens, de acordo com o novo critério da especificação Superpave. A Tabela 11 apresenta o grau de desempenho das amostras avaliadas, para os dois tipos de ligantes asfálticos de base.

Tabela 11 - Grau de desempenho das amostras.

\begin{tabular}{cccccc}
\hline \multirow{2}{*}{ Ligante } & Típo de & \multicolumn{4}{c}{ Teor de Ácido (\%) } \\
\cline { 5 - 7 } & Ácido & 0 & 0,5 & 1,0 & 1,5 \\
\hline \multirow{2}{*}{ Replan } & PA85 & \multirow{2}{*}{64} & 64 & 70 & 76 \\
& PPA & & 64 & 70 & 76 \\
\hline \multirow{2}{*}{ Lubnor } & PA85 & \multirow{2}{*}{64} & 64 & 70 & 70 \\
& PPA & & 64 & 70 & 70 \\
\hline
\end{tabular}

Pode-se observar que, a adição de pequenos teores de qualquer ácido não altera o PG do ligante de base, todos continuam com PG 64. Para o ligante de base Replan o aumento dos teores dos ácidos proporciona o aumento do grau de desempenho, fato não observado para as amostras modificadas com o ligante asfáltico da Lubnor. Nota-se que para este ligante asfáltico a adição de 1,0\% e 1,5\% dos ácidos produziu o mesmo valor de PG, ambos os teores elevaram apenas o grau de desempenho quando comparados ao ligante asfáltico de base puro. 
Outro item avaliado é o grau de desempenho contínuo, apresentado na Tabela 12. Para a adição de $0,5 \%$ de qualquer ácido em ambos os ligantes asfálticos de base, nota-se que estes ligantes asfálticos modificados estão mais próximos do PG 70. Ainda para este teor de ácido percebe-se um grau de desempenho similar para os ligantes asfálticos modificados com PPA e PA85. Para o teor de 1,0\% notam-se valores mais próximos do PG 76 para o ligante asfáltico de base Replan, e neste teor observam-se maiores valores de grau de desempenho contínuo para o ligante asfáltico modificados com o PPA. No entanto, para o mesmo teor de ácido, as amostras modificadas com ligante asfáltico Lubnor apresentam grau de desempenho contínuo ainda próximo do PG70. No teor de 1,5\%, para o ligante asfáltico de base Replan, o grau de desempenho contínuo está mais próximo do PG 82, enquanto para o ligante asfáltico de base Lubnor tem-se esta classificação próxima do PG 76. Sendo assim, o ligante asfáltico proveniente da Replan, apresentou um aumento mais expressivo no grau de desempenho com o aumento das quantidades dos ácidos.

Tabela 12 - Grau de desempenho contínuo dos ligantes asfálticos.

\begin{tabular}{llcccc}
\hline \multirow{2}{*}{ Ligante } & Tipo de & \multicolumn{4}{c}{ Teor de Ácido (\%) } \\
\cline { 3 - 6 } & Ácido & 0 & 0,5 & 1,0 & 1,5 \\
\hline \multirow{2}{*}{ Replan } & PA85 & \multirow{2}{*}{68,42} & 69,61 & 73,53 & 80,54 \\
& PPA & & 69,78 & 75,57 & 80,15 \\
\hline \multirow{2}{*}{ Lubnor } & PA85 & \multirow{2}{*}{67,42} & 68,79 & 70,76 & 74,02 \\
& PPA & & 69,43 & 72,09 & 74,90 \\
\hline
\end{tabular}

A quantidade de ácido necessária para elevar o PG de cada ligante asfáltico de base em um nível está mostrada na Tabela 13. Para o ligante asfáltico de base Replan elevar o PG 64 para PG 70 são necessários $0,55 \%$ de PA85 e 0,52\% de PPA. No entanto, para elevar o PG em dois níveis (PG 64 para PG 76) são necessários 1,08\% de PA85 e 1,10\% de PPA. Pode-se dizer que para este ligante asfáltico de base, os dois ácidos necessitam de proporções similares para alterar o nível do PG. Já para as amostras modificadas com o ligante asfáltico de base Lubnor, observa-se que o PPA tem efeito mais expressivo do que o PA85 para alterar o nível de PG 64 para PG 70, necessitando menor porcentagem do modificador.

Tabela 13 - Quantidades de ácidos necessárias para aumentar o PG.

\begin{tabular}{llcc}
\hline \multirow{2}{*}{ Ligante } & Tipo de & \multicolumn{2}{c}{ PG } \\
\cline { 3 - 4 } & Ácido & $\mathbf{7 0}$ & $\mathbf{7 6}$ \\
\hline \multirow{2}{*}{ Replan } & PA85 & 0,55 & 1,08 \\
& PPA & 0,52 & 1,10 \\
\hline \multirow{2}{*}{ Lubnor } & PA85 & 0,81 & - \\
& PPA & 0,61 & - \\
\hline
\end{tabular}


O ligante asfáltico proveniente da Replan se mostrou mais sensível à adição dos ácidos, aumentando a temperatura alta do PG com o menor teor de ácido. Destaca-se ainda, que os teores estudados no presente trabalho, até 1,5\%, não foram suficientes para alterar o grau de desempenho dos ligantes asfálticos proveniente da Lubnor para um PG76. Os resultados apresentados corroboram com a teoria de que o efeito da adição dos ácidos é dependente do tipo de ligante asfáltico de base utilizado.

\subsubsection{Ensaio de Penetração}

Os resultados de penetração e grau de modificação dos asfálticos modificados com as adições de ácidos polifosfórico e fosfórico no ligante de base Replan, na condição virgem e envelhecido em curto prazo, estão apresentados na Tabela 14. Pode-se observar que, de maneira geral, a adição desses modificadores proporciona uma redução dos valores de penetração, indicando uma maior rigidez desses materiais quando comparados com o ligante asfáltico base (Replan CAP 50/70) na temperatura de $25^{\circ} \mathrm{C}$. Nota-se também, como já esperado, valores inferiores para esta propriedade com o envelhecimento em curto prazo.

Tabela 14 - Valores de penetração e graus de modificação dos ligantes asfálticos para o ligante base Replan.

\begin{tabular}{lcccc}
\hline & \multicolumn{2}{c}{ Material Virgem } & \multicolumn{2}{c}{ Material RTFOT } \\
Ligante Asfáltico & PEN $(\mathrm{dmm})$ & Gmod & PEN $(\mathrm{dmm})$ & Gmod \\
\hline CAP 50/70 & 56 & 1,00 & 31 & 1,00 \\
0,5PA85 & 54 & 0,97 & 30 & 0,97 \\
1,0PA85 ${ }^{\text {a }}$ & 48 & 0,85 & 27 & 0,86 \\
1,5PA85 $^{\text {b }}$ & 41 & 0,71 & 25 & 0,80 \\
0,5PPA $^{\text {a }}$ & 47 & 0,85 & 27 & 0,86 \\
1,0PPA $^{\text {b }}$ & 41 & 0,73 & 26 & 0,83 \\
1,5PPA & 36 & 0,63 & 24 & 0,80 \\
\hline $\mathbf{a}, \mathbf{b}$ : Apresentam os mesmos valores para propriedade de penetração.
\end{tabular}

No entanto, observa-se que a adição de baixo teor de PA85 (0,5\%) apresenta valor similar de penetração ao do ligante asfáltico de base na condição virgem e envelhecido em curto prazo, ou seja, a adição de baixos teores desse modificador não altera o comportamento do ligante asfáltico de base à luz dessa propriedade. Ainda pode-se observar que, a adição de PPA proporciona uma redução mais expressiva nos valores de penetração do que os ligantes modificados com PA85. Em termos amplos, considerando todos os teores, pode-se destacar que a redução média dos valores de penetração dos ligantes asfálticos modificados com PPA em relação aos ligantes asfálticos modificados com PA85 é de aproximadamente 
$13 \%$ na condição virgem e de aproximadamente $9 \%$ na condição envelhecida a curto prazo. Destaca-se ainda que os resultados de penetração, nas duas condições, apontam comportamentos similares, considerando a tolerância da norma de $\pm 2\left(10^{-1} \mathrm{~mm}\right)$, para o ligante asfáltico modificado com 0,5PPA e 1,0PA85, e para o ligante asfáltico modificado com 1,0PPA e 1,5PA85. Sendo assim, pode-se dizer que para utilizar o PA85 como modificador e obter o mesmo valor de penetração de ligantes asfálticos modificados com PPA é necessário um adicional de $0,5 \%$ de PA85.

Ainda observando os resultados da Tabela 14, no que diz respeito aos valores de grau de modificação, nota-se que para todos os modificadores, independente do teor, os valores de grau de modificação são inferiores a 1 (um), o que representa que os valores de penetração dos ligantes asfálticos modificados são menores do que os valores de penetração do material puro. Quando se comparam os valores de grau de modificação dos materiais virgens e envelhecidos em curto prazo, pode-se perceber que o efeito dos modificadores diminui com o envelhecimento. Isso pode ser notado, ao se observar a variação do grau de modificação após o envelhecimento dos materiais, sendo que esse efeito é maior para os teores de $1,5 \%$ com variação de 0,10 para o PA85 e 0,17 para o PPA.

$\mathrm{Na}$ Figura 29, é indicado o efeito do envelhecimento na penetração, na forma de penetração retida, que corresponde à razão entre a penetração da amostra envelhecida (RTFOT) pela penetração da amostra virgem, expressa em porcentagem.

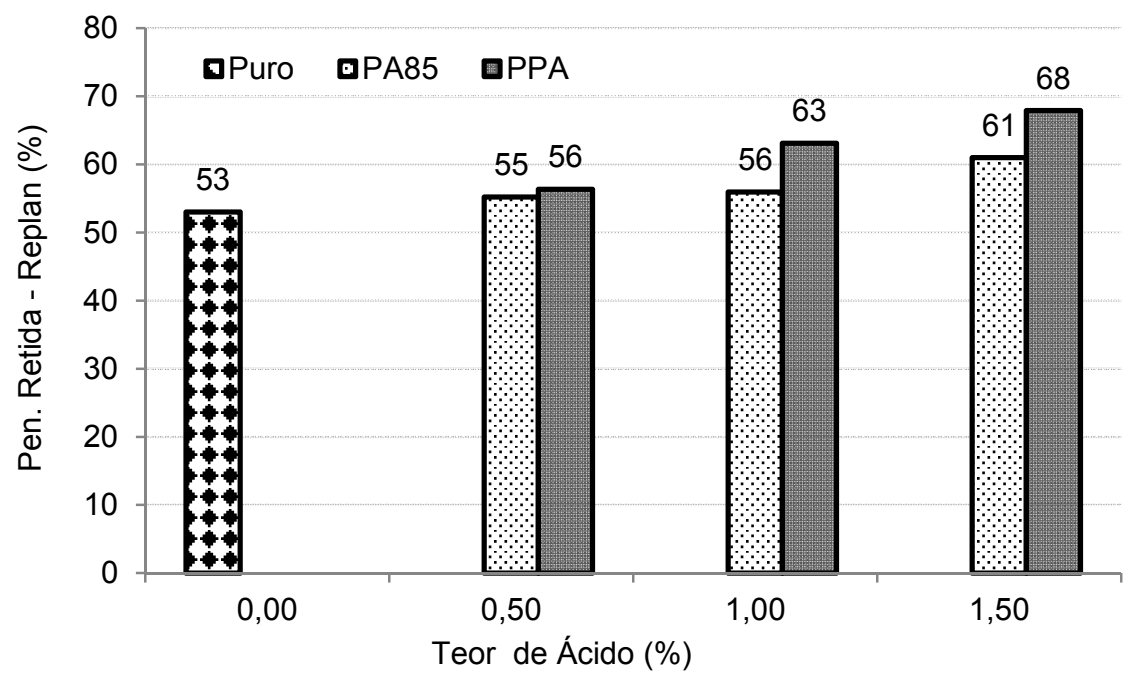

Figura 29 - Penetração Retida dos ligantes asfálticos modificados com ligante base Replan.

Considerando o Regulamento Técnico 03/2005 da ANP tem-se: (A) para ligantes asfálticos com penetração de 50 a 70 dmm, o valor de penetração retida mínima de 55\%; e (B) para materiais com penetração de 30 a $45 \mathrm{dmm}$ o valor mínimo de penetração retida de $60 \%$. Na situação A encontra-se a mistura com adição de $0,5 \%$ de PA85, as demais se 
enquadram na situação B. Pode-se observar que as misturas, com exceção dos ligantes asfálticos modificados com 1,0\% e 1,5\% de PPA, apesar de atenderem a especificação supracitada, apresentam limites próximos aos exigidos. As misturas com adição de PA85 apresentaram menores valores de penetração retida, o que representa misturas mais sensiveis ao envelhecimento.

Na Tabela 15 estão apresentados os resultados de penetração e grau de modificação dos asfálticos modificados com a adição dos ácidos polifosfórico e fosfórico ao ligante de base Lubnor, na condição virgem e envelhecido em curto prazo. Como já esperado, as adições dos modificadores, em qualquer teor, apontam reduções nos valores de penetração quando comparados com o ligante base. O envelhecimento do material proporciona um aumento no enrijecimento, observado pela redução dos valores de penetração. Diferentemente do que foi observado para os ligantes asfálticos modificados com ligante de base Replan, neste caso, independente do modificador e do teor, nota-se pequena alteração no comportamento dos materiais. Pode-se observar ainda, considerando os limites estabelecidos pela norma de \pm 2 $\left(10^{-1} \mathrm{~mm}\right)$, que os valores de penetração são similares para os teores de $0,5 \%, 1,0 \%$ e 1,5\%, independente do modificador utilizado, tanto para condição virgem quanto envelhecida em curto prazo.

Tabela 15 - Valores de penetração e graus de modificação dos ligantes asfálticos com ligante base Lubnor.

\begin{tabular}{lcccc}
\hline \multirow{2}{*}{ Ligante Asfáltico } & \multicolumn{2}{c}{ Material Virgem } & \multicolumn{2}{c}{ Material RTFOT } \\
\cline { 2 - 5 } & PEN $(\mathrm{dmm})$ & Gmod & PEN $(\mathrm{dmm})$ & Gmod \\
\hline CAP 50/70 & 58 & 1,00 & 38 & 1,00 \\
0,5PA85 & 53 & 0,92 & 33 & 0,88 \\
1,0PA85 & 40 & 0,70 & 31 & 0,83 \\
1,5PA85 & 35 & 0,61 & 28 & 0,74 \\
0,5PPA & 50 & 0,88 & 33 & 0,88 \\
1,0PPA & 39 & 0,67 & 30 & 0,80 \\
1,5PPA & 33 & 0,57 & 26 & 0,68 \\
\hline
\end{tabular}

Em termos gerais, considerando todos os teores, pode-se destacar que, a redução média dos valores de penetração dos ligantes asfálticos modificados com PPA em relação aos ligantes asfálticos modificados com PA85 é de aproximadamente $5 \%$ na condição virgem e de aproximadamente $9 \%$ na condição envelhecida em curto prazo.

Na Figura 30 é apresentada a penetração retida dos ligantes asfálticos provenientes da Lubnor. Para estas amostras observa-se que na situação $A$ se enquadram as misturas com adição 0,5\% de PA85 e PPA, as demais se encontram na situação B. Todas as misturas apresentaram valores de penetração retida acima de $60 \%$, que representam valores dentro 
dos limites estabelecidos. Outro item interessante para as misturas com o ligante asfáltico Lubnor é que para concentrações de 1,0\% e 1,5\% o comportamento dos dois ácidos é igual.

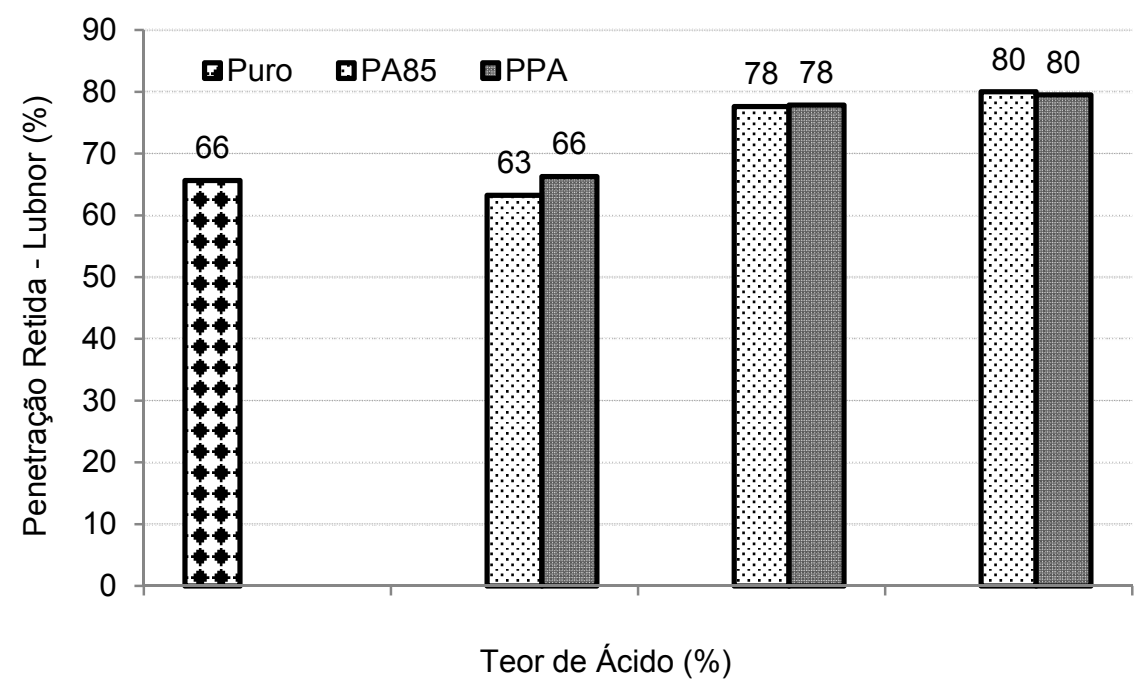

Figura 30 - Penetração Retida dos ligantes asfálticos modificados com ligante base Lubnor.

Ao se comparar a Figura 29 e Figura 30 pode-se dizer que, com valores menores de penetração retida, as misturas realizadas com o ligante asfáltico proveniente da Replan são mais sensíveis ao envelhecimento.

\subsubsection{Ponto de Amolecimento}

A Tabela 16 mostra os valores médios de ponto de amolecimento dos ligantes asfálticos provenientes da Replan, na condição virgem e envelhecida em curto prazo, assim como seus respectivos graus de modificação.

Tabela 16 - Valores de Ponto de Amolecimento e Gmod dos ligantes asfálticos proveniente da Replan.

\begin{tabular}{lcccc}
\hline & \multicolumn{2}{c}{ Material Virgem } & \multicolumn{2}{c}{ Material RTFOT } \\
\cline { 2 - 5 } Ligante Asfáltico & $\mathrm{Pa}\left({ }^{\circ} \mathrm{C}\right)$ & $\mathrm{Gmod}$ & $\mathrm{Pa}\left({ }^{\circ} \mathrm{C}\right)$ & $\mathrm{Gmod}$ \\
& 49 & 1,00 & 56 & 1,00 \\
\hline CAP 50/70 & 52 & 1,05 & 58 & 1,03 \\
0,5PA85 & 55 & 1,12 & 62 & 1,10 \\
1,0PA85 & 58 & 1,17 & 69 & 1,23 \\
1,5PA85 & 52 & 1,04 & 58 & 1,04 \\
0,5PPA & 57 & 1,16 & 64 & 1,15 \\
1,0PPA & 62 & 1,25 & 74 & 1,32 \\
1,5PPA & & & & \\
\hline
\end{tabular}


Pode-se observar, de maneira geral, que os materiais modificados aumentam o ponto de amolecimento nas duas condições testadas (virgem e envelhecida em curto prazo), indicando uma maior rigidez destes materiais em relação ao ligante asfáltico de base. Notase para essa propriedade, na condição virgem, que os valores de ponto de amolecimento para teores baixos e intermediários de ácidos $(0,5 \%$ e $1,0 \%)$ são similares para ambos modificadores (PPA e PA85). No entanto, para proporções maiores (1,5\%), o efeito da adição do PPA é um pouco mais expressivo, uma vez que as amostras com este modificador apresentam valores superiores desta propriedade. Pode ser observado o mesmo comportamento para as amostras submetidas ao envelhecimento em curto prazo. Em média o aumento do valor do ponto de amolecimento, na condição virgem, proporcionado pelo aumento dos teores dos ácidos PA85 e PPA, foi de aproximadamente $6 \%$ e $9 \%$, respectivamente. Enquanto este aumento, na condição envelhecida em curto prazo, foi de aproximadamente $10 \%$ para amostras com PA85 e aproximadamente $13 \%$ para amostras com PPA.

Quanto ao grau de modificação, nota-se que somente as amostras com adição de 1,5\% dos ácidos aumentaram o grau de modificação após o envelhecimento em curto prazo, indicando menor sensibilidade ao envelhecimento no que se refere ao enrijecimento do material devido à adição dos ácidos. Já para os teores baixos e intermediários (0,5\% e 1,0\%) que apresentam valores menores de grau de modificação após envelhecimento, apontam efeito pouco expressivo da adição do modificador ao envelhecimento em curto prazo.

Tabela 17 - Valores de Ponto de Amolecimento e Gmod dos ligantes asfálticos proveniente da Lubnor.

\begin{tabular}{lcccc}
\hline \multirow{2}{*}{ Ligante Asfáltico } & \multicolumn{2}{c}{ Material Virgem } & \multicolumn{2}{c}{ Material RTFOT } \\
\cline { 2 - 5 } & $\mathrm{Pa}\left({ }^{\circ} \mathrm{C}\right)$ & Gmod & $\mathrm{Pa}\left({ }^{\circ} \mathrm{C}\right)$ & Gmod \\
\hline CAP 50/70 & 47 & 1,00 & 52 & 1,00 \\
0,5PA85 & 49 & 1,05 & 55 & 1,04 \\
1,0PA85 & 52 & 1,10 & 57 & 1,09 \\
1,5PA85 & 53 & 1,13 & 60 & 1,14 \\
0,5PPA & 49 & 1,05 & 56 & 1,07 \\
1,0PPA & 52 & 1,11 & 57 & 1,10 \\
1,5PPA & 55 & 1,18 & 62 & 1,19 \\
\hline
\end{tabular}

Na Tabela 17 são apresentados os valores de ponto de amolecimento e grau de modificação das amostras produzidas com o ligante asfáltico de base proveniente da Lubnor. Nota-se que, da mesma forma que nos dados de penetração, os valores referentes ao ponto de amolecimento são semelhantes para os ácidos e seus respectivos teores, sendo que, em média, o aumento na proporção dos teores faz com que o valor do ponto de amolecimento, na condição virgem, aumente para amostras com PA85 e PPA, em 4\% e 5\%, respectivamente. 
Para ambos os ácidos, o aumento no ponto de amolecimento, quando comparado com seus valores na condição virgem, é de aproximadamente $12 \%$.

Quanto ao grau de modificação, pode-se destacar que os valores apresentados na condição virgem e na condição envelhecida são semelhantes, o que indica que estas misturas são pouco sensíveis ao envelhecimento no que se refere ao enrijecimento adquirido com adição dos modificadores. Ao se comparar o tipo de ligante de origem, nota-se que o asfalto da Replan é mais afetado pela adição do ácido, pois os valores de ponto de amolecimento são superiores ao das misturas com o ligante Lubnor.

$\mathrm{Na}$ Tabela 18 são apresentados os incrementos do ponto de amolecimento para os dois ligantes asfálticos de base. Analisando os dados, considerando a aplicação do valor máximo de $8^{\circ} \mathrm{C}$ para incremento do ponto de amolecimento (diferença entre os pontos de amolecimento do material envelhecido em curto prazo e o material na condição virgem), especificado pelo Regulamento Técnico 03/2005 da ANP, apenas os ligantes asfálticos modificados com 1,5\% de PA85 e PPA produzidos com o ligante asfáltico de base Replan não seriam adequados. No entanto, todas as misturas originadas do ligante base Lubnor atendem ao regulamento técnico. Com exceção da amostra com adição de 1,0\% de PA85 no ligante asfáltico da Replan, os ligantes asfálticos modificados com PPA foram mais sensíveis ao processo de envelhecimento em curto prazo. Para o ligante asfáltico de base Lubnor, com exceção das amostras com $1,0 \%$ dos ácidos que apresentam valores semelhantes, as amostras com PPA foram mais sensíveis ao envelhecimento. Sendo assim, nota-se pelos valores maiores de incremento do ponto de amolecimento, para qualquer teor e tipo de ácido, que o ligante Replan é mais sensível ao efeito do envelhecimento.

Tabela 18 - Incremento do Ponto de Amolecimento $\left({ }^{\circ} \mathrm{C}\right)$ após envelhecimento em curto prazo.

\begin{tabular}{ccccc}
\hline \multicolumn{4}{c}{ Replan } & \multicolumn{3}{c}{ Lubnor } \\
\hline Teor & PA85 & PPA & PA85 & PPA \\
\hline $\mathbf{0 , 5}$ & 6,0 & 6,7 & 5,1 & 6,4 \\
$\mathbf{1 , 0}$ & 7,4 & 5,8 & 5,5 & 5,6 \\
$\mathbf{1 , 5}$ & 11,2 & 12,3 & 6,7 & 7,3 \\
\hline
\end{tabular}

\subsubsection{Viscosidade Rotacional}

Na Tabela 19 e Tabela 20 são apresentados os valores da viscosidade rotacional para as amostras com adição dos ácidos PA85 e PPA na condição virgem e envelhecida em curto prazo, respectivamente, produzidas com o ligante asfáltico de base Replan. Nota-se que à medida que se aumenta o teor do modificador (de $0,5 \%$ para $1,5 \%$ ), tem-se um aumento na viscosidade do material, o que já era esperado, pelo maior consistência apresentada pelos 
materiais modificados. Os gráficos referentes à viscosidade, nas duas condições estudadas, para as amostras modificadas no ligante asfáltico proveniente da Replan estão apresentados no Apêndice A.

Nestas tabelas pode-se observar que, para baixos teores de ácido $(0,5 \%)$, os valores de viscosidade são similares para os dois modificadores, tanto na condição virgem quanto na envelhecida em curto prazo. No entanto, para teores intermediários e altos, nota-se efeito mais expressivo do PPA nesta propriedade, pois as amostras com esse modificador apresentam maiores valores de viscosidade. Cabe destacar que, adotando como referência a especificação Superpave, que limita a viscosidade ao máximo de $3 \mathrm{~Pa} . \mathrm{s}$ a $135^{\circ} \mathrm{C}$, nenhum dos ligantes asfálticos modificados ultrapassou este limite.

Tabela 19 - Comparação da viscosidade (Pa.s) Virgem e RTFOT (PA85), para ligante Replan.

\begin{tabular}{crrrrrrrr}
\hline \multirow{2}{*}{ Temperatura } & \multicolumn{2}{c}{ Puro } & \multicolumn{2}{c}{ 0,5PA85 } & \multicolumn{2}{c}{ 1,0PA85 } & \multicolumn{2}{c}{ 1,5PA85 } \\
& Virgem & RTFOT & Virgem & RTFOT & Virgem & RTFOT & Virgem & RTFOT \\
\hline 135,0 & 0,344 & 0,545 & 0,415 & 0,732 & 0,535 & 1,118 & 0,692 & 1,913 \\
143,0 & 0,235 & 0,357 & 0,279 & 0,466 & 0,344 & 0,691 & 0,438 & 1,116 \\
150,0 & 0,173 & 0,258 & 0,203 & 0,329 & 0,246 & 0,474 & 0,309 & 0,734 \\
161,7 & 0,104 & 0,148 & 0,120 & 0,199 & 0,142 & 0,253 & 0,174 & 0,370 \\
175,5 & 0,064 & 0,088 & 0,073 & 0,115 & 0,085 & 0,141 & 0,102 & 0,195 \\
\hline
\end{tabular}

Tabela 20 - Comparação da viscosidade (Pa.s) Virgem e RTFOT (PPA), para ligante Replan.

\begin{tabular}{ccccccccc}
\hline \multirow{2}{*}{ Temperatura } & \multicolumn{2}{c}{ Puro } & \multicolumn{3}{c}{ 0,5PPA } & \multicolumn{1}{c}{ 1,0PPA } & \multicolumn{1}{c}{ 1,5PPA } \\
& Virgem & RTFOT & Virgem & RTFOT & Virgem & RTFOT & Virgem & RTFOT \\
\hline 135,0 & 0,344 & 0,545 & 0,444 & 0,724 & 0,659 & 1,283 & 0,928 & 2,643 \\
143,0 & 0,235 & 0,357 & 0,296 & 0,466 & 0,417 & 0,793 & 0,576 & 1,427 \\
150,0 & 0,173 & 0,258 & 0,213 & 0,329 & 0,295 & 0,538 & 0,397 & 0,932 \\
161,7 & 0,104 & 0,148 & 0,125 & 0,184 & 0,166 & 0,282 & 0,215 & 0,461 \\
175,5 & 0,064 & 0,088 & 0,075 & 0,107 & 0,097 & 0,154 & 0,122 & 0,235 \\
\hline
\end{tabular}

Para melhor visualizar o aumento da viscosidade com o aumento da quantidade do modificador, é apresentado na Tabela 21 o quanto a viscosidade aumentou em relação à viscosidade do ligante puro, em porcentagem. O maior aumento no valor da viscosidade foi proporcionado pelo PPA, independente da temperatura e teor, quando comparado ao modificar PA85. O maior aumento, entre todos os ligantes asfálticos modificados, é observado para temperatura de $135^{\circ} \mathrm{C}$ com viscosidade de $169,4 \%$ superior a viscosidade do ligante puro.

Tabela 21 - Aumento percentual da viscosidade com aumento do teor dos modificadores, para ligante Replan.

\begin{tabular}{ccccccc}
\hline Temperatura & 0,5PA85 & 1,0PA85 & 1,5PA85 & 0,5PPA & 1,5PPA & 1,5PPA \\
\hline 135,0 & 20,7 & 55,4 & 100,9 & 29,0 & 91,3 & 169,4 \\
143,0 & 19,0 & 46,5 & 86,8 & 26,1 & 77,9 & 145,7 \\
150,0 & 17,9 & 42,8 & 79,3 & 23,2 & 70,6 & 129,9 \\
161,7 & 16,1 & 36,9 & 67,8 & 20,4 & 60,4 & 107,6 \\
175,5 & 14,5 & 32,6 & 59,1 & 17,8 & 52,3 & 90,4 \\
\hline
\end{tabular}


$\mathrm{Na}$ Tabela 22 são apresentados os valores de aumento percentuais da viscosidade após o envelhecimento. Cabe destacar que, diferentemente do que mostraram os dados referentes ao ensaio do ponto de amolecimento, com exceção do ligante asfáltico modificado com 1,5\% de PA85, as demais amostras com adição deste modificador sofreram, no caso da viscosidade, maior influência do envelhecimento, pois apresentaram valores percentuais, relação entre viscosidade do material virgem e a viscosidade do material envelhecido, superior às porcentagens obtidas para os ligantes asfálticos com adição do PPA.

Tabela 22 - Aumento percentual do valor de viscosidade após envelhecimento, para ligante Replan.

\begin{tabular}{cccccccc}
\hline Temperatura & Puro & 0,5PA85 & 1,0PA85 & 1,5PA85 & 0,5PPA & 1,0 PPA & 1,5PPA \\
\hline 135,0 & 58,4 & 76,2 & 108,8 & 176,6 & 63,0 & 94,7 & 184,9 \\
143,0 & 52,3 & 67,0 & 101,1 & 154,6 & 57,4 & 90,0 & 147,5 \\
150,0 & 49,3 & 61,7 & 92,4 & 137,3 & 54,8 & 82,5 & 134,9 \\
161,7 & 42,5 & 65,1 & 78,6 & 112,7 & 47,8 & 69,7 & 114,2 \\
175,5 & 37,7 & 57,2 & 65,7 & 91,7 & 41,5 & 58,2 & 92,8 \\
\hline
\end{tabular}

No entanto, é importante destacar que, mesmo sofrendo maior influência do envelhecimento, para essa propriedade, os valores de viscosidade das misturas com PPA, para qualquer teor e qualquer temperatura, ainda são superiores aos valores de viscosidade das misturas com PA85, indicando que misturas com esse tipo de modificador são mais rígidas.

$\mathrm{Na}$ Tabela 23 e Tabela 24 pode-se observar os valores de viscosidade referentes ao ligante asfáltico modificado com ácido PA85 e PPA para o ligante de origem Lubnor, respectivamente. É constatado, como já esperado, o aumento da viscosidade com o aumento dos teores de ambos os modificadores. Para este ligante asfáltico de base também é observado que o efeito da adição do PPA é mais expressivo do que a adição do PA85, nas duas condições estudadas, tendo em vista maiores valores de viscosidade nas amostras com este modificador. Destaca-se que, no tocante à limitação imposta pela especificação Superpave (máximo de 3 Pa.s a $135^{\circ} \mathrm{C}$ ), todas as amostras se enquadraram.

Tabela 23 - Comparação da viscosidade (Pa.s) Virgem e RTFOT (PA85), para ligante Lubnor.

\begin{tabular}{ccccccccc}
\hline \multirow{2}{*}{ Temperatura } & \multicolumn{2}{c}{ Puro } & \multicolumn{2}{c}{ 0,5PA85 } & \multicolumn{2}{c}{ 1,0PA85 } & \multicolumn{2}{c}{ 1,5PA85 } \\
& Virgem & RTFOT & Virgem & RTFOT & Virgem & RTFOT & Virgem & RTFOT \\
\hline 135,0 & 0,393 & 0,529 & 0,438 & 0,641 & 0,497 & 0,825 & 0,561 & 1,022 \\
143,0 & 0,257 & 0,343 & 0,286 & 0,390 & 0,325 & 0,519 & 0,363 & 0,648 \\
150,0 & 0,188 & 0,248 & 0,208 & 0,293 & 0,234 & 0,366 & 0,262 & 0,450 \\
161,7 & 0,114 & 0,145 & 0,122 & 0,167 & 0,137 & 0,205 & 0,154 & 0,246 \\
175,5 & 0,071 & 0,088 & 0,074 & 0,098 & 0,083 & 0,118 & 0,093 & 0,139 \\
\hline
\end{tabular}


Tabela 24 - Comparação da viscosidade (Pa.s) Virgem e RTFOT (PPA), para ligante Lubnor.

\begin{tabular}{ccccccccc}
\hline Temperatura & \multicolumn{2}{c}{ Puro } & \multicolumn{2}{c}{ 0,5PPA } & \multicolumn{2}{c}{ 1,0PPA } & \multicolumn{2}{c}{ 1,5PPA } \\
& Virgem & RTFOT & Virgem & RTFOT & Virgem & RTFOT & Virgem & RTFOT \\
\hline 135,0 & 0,393 & 0,529 & 0,466 & 0,643 & 0,533 & 0,863 & 0,660 & 1,217 \\
143,0 & 0,257 & 0,343 & 0,303 & 0,404 & 0,345 & 0,544 & 0,425 & 0,748 \\
150,0 & 0,188 & 0,248 & 0,220 & 0,289 & 0,250 & 0,383 & 0,306 & 0,513 \\
161,7 & 0,114 & 0,145 & 0,131 & 0,166 & 0,146 & 0,212 & 0,174 & 0,276 \\
175,5 & 0,071 & 0,088 & 0,082 & 0,099 & 0,089 & 0,122 & 0,103 & 0,154 \\
\hline
\end{tabular}

$\mathrm{Na}$ Tabela 25 é apresentado, em porcentagem, quanto a viscosidade aumentou em relação à viscosidade do ligante puro, com o aumento da quantidade do modificador. O maior aumento no valor da viscosidade foi proporcionado pelo modificar PPA, independente da temperatura e teor, quando comparado ao modificar PA85. O maior aumento, entre todas as misturas, é observado para temperatura de $135^{\circ} \mathrm{C}$ com viscosidade de $69 \%$ superior a viscosidade do ligante puro. Apesar dos valores de viscosidade do ligante asfáltico proveniente da Lubnor puro serem um pouco mais elevados quando comparado com os valores apresentados pelo ligante asfáltico proveniente da Replan puro, ao comparar a Tabela 21 com a Tabela 25 nota-se que o efeito dos modificadores é bem mais expressivo para amostras produzidas com o ligante asfáltico de base proveniente da Replan, que apresentaram porcentagens mais elevadas para o aumento da viscosidade com o aumento do teor dos modificadores.

Tabela 25 - Aumento percentual da viscosidade com aumento do teor dos modificadores, para ligante Lubnor.

\begin{tabular}{ccccccc}
\hline Temperatura & 0,5PA85 & 1,0PA85 & 1,5PA85 & 0,5PPA & 1,0PPA & 1,5PPA \\
\hline 135,0 & 14,0 & 27,2 & 42,9 & 20,9 & 38,3 & 69,0 \\
143,0 & 13,8 & 27,1 & 41,7 & 20,7 & 36,0 & 66,8 \\
150,0 & 12,2 & 25,3 & 40,2 & 19,9 & 34,2 & 62,7 \\
161,7 & 8,8 & 20,9 & 36,2 & 18,3 & 28,9 & 52,5 \\
175,5 & 7,6 & 17,4 & 33,5 & 19,1 & 24,7 & 44,8 \\
\hline
\end{tabular}

Na Tabela 26 são apresentados os valores de aumento percentuais da viscosidade após o envelhecimento. Apesar das misturas com adição de PA85 sofreram, no caso da viscosidade, maior influência do envelhecimento, apresentando valores percentuais superiores às porcentagens obtidas para misturas com adição do PPA, nota-se que para as amostras produzidas com o ligante asfáltico de base Lubnor, estes percentuais são mais próximos, principalmente no teor de $1,5 \%$, quando comparado com os percentuais das amostras modificadas com o ligante asfáltico de base Replan, apontando que a sensibilidade ao efeito do envelhecimento é menor para este ligante asfáltico de base. 
Tabela 26 - Aumento percentual do valor de viscosidade após envelhecimento, para ligante Lubnor.

\begin{tabular}{cccccccc}
\hline Temperatura & Puro & 0,5PA85 & 1,0PA85 & 1,5PA85 & 0,5PPA & 1,0 PPA & 1,5PPA \\
\hline 135,0 & 34,5 & 46,6 & 66,0 & 82,4 & 38,0 & 61,8 & 84,4 \\
143,0 & 33,6 & 36,4 & 59,9 & 78,8 & 33,1 & 57,8 & 76,1 \\
150,0 & 32,1 & 40,7 & 56,3 & 71,6 & 31,5 & 53,2 & 67,9 \\
161,7 & 26,6 & 37,4 & 49,7 & 59,9 & 27,1 & 44,9 & 58,3 \\
175,5 & 23,5 & 32,2 & 42,7 & 48,9 & 19,9 & 37,4 & 48,7 \\
\hline
\end{tabular}

Quanto à sensibilidade ao envelhecimento, à luz da propriedade viscosidade rotacional, ligantes asfálticos proveniente da Replan modificados apresentam maior sensibilidade quando comparados com ligantes asfálticos provenientes da Lubnor, corroborando com as demais propriedades, pois apresentam valores superiores do aumento percentual do valor de viscosidade após envelhecimento em curto prazo.

\subsubsection{Temperatura de Usinagem e Compactação}

Os cálculos das temperaturas de usinagem e de compactação (TUCs) dos ligantes asfálticos virgens foram realizados com base nos limites tradicionais de viscosidade rotacional, sendo eles: $0,17 \pm 0,02$ Pa.s para a usinagem e 0,28 \pm 0,03 Pa.s para a compactação, conforme ilustrado na Figura 31.

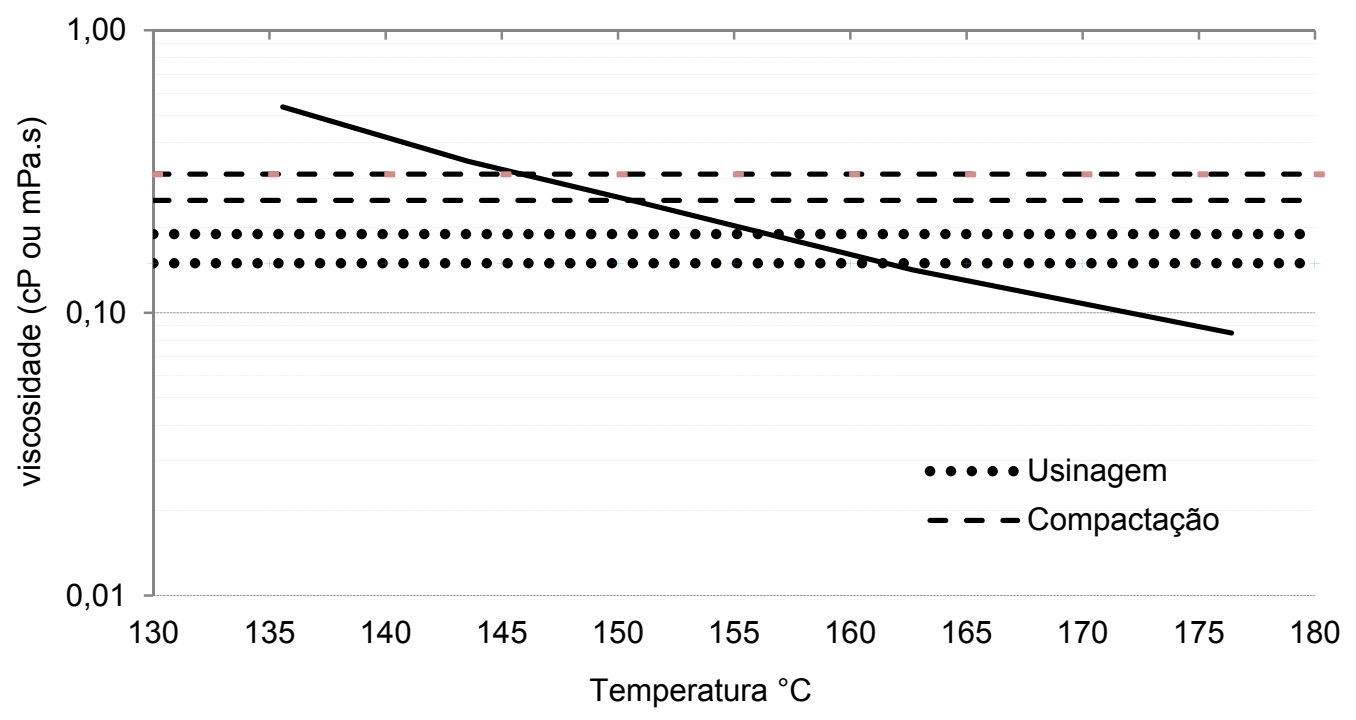

Figura 31 - Determinação das temperaturas de usinagem e compactação (TUC).

Os dados referentes às temperaturas de usinagem e compactação das amostras estudadas estão apresentados na Tabela 27 e Tabela 28, para os ligantes asfálticos provenientes da Replan e Lubnor, respectivamente. As temperaturas de usinagem e 
compactação dos ligantes modificados estão acima dos valores encontrados para o ligante asfáltico de base, independente do modificador utilizado. Nota-se, para amostras produzidas com o ligante asfáltico proveniente Replan, que para teores baixos $(0,5 \%)$ dos modificadores, as temperaturas de usinagem e compactação para ambos os modificadores são próximas, e para teores intermediários a altos tem-se temperaturas um pouco mais elevadas para as amostras modificadas com PPA.

Tabela 27 - Temperaturas de usinagem e de compactação dos ligantes asfálticos - Replan.

\begin{tabular}{|c|c|c|c|c|c|c|c|c|}
\hline \multirow{3}{*}{ Teor } & \multicolumn{4}{|c|}{ Usinagem } & \multicolumn{4}{|c|}{ Compactação } \\
\hline & \multicolumn{2}{|c|}{ PA85 } & \multicolumn{2}{|c|}{ PPA } & \multicolumn{2}{|c|}{ PA85 } & \multicolumn{2}{|c|}{ PPA } \\
\hline & Intervalo & Média & Intervalo & Média & Intervalo & Média & Intervalo & Média \\
\hline 0,00 & $148-154$ & 151 & 148-154 & 151 & $137-142$ & 140 & $137-143$ & 140 \\
\hline 0,50 & $153-158$ & 156 & $153-158$ & 156 & $142-147$ & 145 & $143-147$ & 145 \\
\hline 1,00 & $157-162$ & 160 & $160-165$ & 163 & $145-150$ & 148 & $149-154$ & 152 \\
\hline 1,50 & $161-166$ & 164 & $165-170$ & 168 & $151-155$ & 153 & $155-159$ & 157 \\
\hline
\end{tabular}

No entanto, para amostras produzidas com ligante asfáltico de base Lubnor pode-se observar que as temperaturas de usinagem e compactação ficaram praticamente iguais para teores baixos e intermediários dos ácidos, sendo que para teores altos $(1,5 \%)$ têm-se valores um pouco superiores para as amostras modificadas com PPA. Uma vez que a viscosidade do ligante asfáltico de base Lubnor é um pouco mais elevada, têm-se para este ligante asfáltico temperaturas de usinagem e compactação um pouco superiores. No entanto, quando se modificou os ligantes asfálticos com adição dos ácidos, mostrou-se que o efeito da adição dos modificadores foi mais expressivo para o ligante asfáltico de base Replan, para os quais as temperaturas de usinagem e compactação, foram um pouco maiores, principalmente para amostras com teores intermediários e altos.

Tabela 28 - Temperaturas de usinagem e de compactação dos ligantes asfálticos - Lubnor.

Usinagem

Compactação

\begin{tabular}{ccccc|cccc}
\hline & \multicolumn{2}{c}{ PA85 } & \multicolumn{2}{c|}{ PPA } & \multicolumn{2}{c}{ PA85 } & \multicolumn{2}{c}{ PPA } \\
\cline { 2 - 9 } & Intervalo & Média & Intervalo & Média & Intervalo & Média & Intervalo & Média \\
\hline 0,00 & $150-155$ & 153 & $150-155$ & 153 & $138-144$ & 141 & $138-144$ & 141 \\
0,50 & $153-158$ & 156 & $153-158$ & 155 & $142-148$ & 145 & $143-148$ & 145 \\
1,00 & $158-162$ & 160 & $158-163$ & 160 & $144-149$ & 147 & $146-150$ & 148 \\
1,50 & $157-164$ & 161 & $160-166$ & 163 & $146-151$ & 149 & $150-155$ & 153 \\
\hline
\end{tabular}

No entanto, levando em consideração a especificação do DNIT 031/2006 ${ }^{16}$ referente à temperatura do ligante para concreto asfáltico, adota-se que a temperatura do ligante asfáltico

\footnotetext{
${ }^{16}$ DNIT 031/2006-ES - Pavimento Flexível - Concreto Asfáltico.
} 
não deve ser inferior a $107^{\circ} \mathrm{C}$ nem exceder a $177^{\circ} \mathrm{C}$. Neste sentido, todos os ligantes asfálticos modificados, independente da procedência do ligante asfáltico de base, dos modificadores e teores adicionados atendem esse critério.

No que vale considerar a especificação referente a concretos asfálticos modificados com polímero (DNER ES-385/99 ${ }^{17}$ ), que aceitam limites superiores destas temperaturas, devido ao aumento de viscosidade de material, recomendam que a temperatura conveniente para aquecimento do ligante asfáltico é de $150^{\circ} \mathrm{C}$ acrescida de $3^{\circ} \mathrm{C}$ para cada $1 \%$ de polímero, não podendo ultrapassar a temperatura de $180^{\circ} \mathrm{C}$; e a temperatura recomendável para a compactação mistura é de $140^{\circ} \mathrm{C}$ acrescida de $3^{\circ} \mathrm{C}$ para cada $1 \%$ de polímero. Sendo assim, a temperatura recomendada para usinagem seria de $155^{\circ} \mathrm{C}$ e de compactação de $145^{\circ} \mathrm{C}$. Apesar das misturas não ultrapassarem o limite máximo de $180^{\circ} \mathrm{C}$, somente as amostras com baixas concentrações de ácidos $(0,5 \%)$ atenderiam as recomendações das normas citadas.

\subsubsection{Balanço de Massa}

Os resultados da perda de massa para os dois ligantes asfálticos de base estão apresentados na Tabela 29. Todos os ligantes asfálticos modificados apresentam maiores perdas de massa quando comparados aos ligantes asfálticos de base. Para todas as amostras observa-se uma maior perda com o aumento do teor dos modificadores. As amostras modificadas com o PA85 apresentaram perdas maiores do que aquelas modificadas com o PPA. Pode-se observar também que as amostras produzidas com o ligante asfáltico de base proveniente da Replan apresentam perdas superiores quando comparadas com as amostras feitas com o ligante asfáltico de base da Lubnor.

Tabela 29 - Perda de Massa (\%) dos ligantes asfálticos estudados.

\begin{tabular}{ccccc}
\hline \multirow{2}{*}{ Teor } & \multicolumn{2}{c}{ Replan } & \multicolumn{2}{c}{ Lubnor } \\
\cline { 2 - 5 } & PA85 & PPA & PA85 & PPA \\
\hline 0,00 & $-0,074$ & $-0,074$ & $-0,028$ & $-0,028$ \\
0,50 & $-0,210$ & $-0,199$ & $-0,061$ & $-0,033$ \\
1,00 & $-0,256$ & $-0,229$ & $-0,108$ & $-0,057$ \\
1,50 & $-0,270$ & $-0,257$ & $-0,134$ & $-0,094$ \\
\hline
\end{tabular}

No entanto, considerando o limite de perda de massa de $0,50 \%$ especificado pelo Regulamento Técnico 03/2005 18 da Agência Nacional do Petróleo, Gás Natural e Biocombustíveis (ANP), todos os CAPs modificados atendem a exigência estabelecida.

\footnotetext{
${ }^{17}$ DNER 385/1999- Pavimentação - Concreto Asfáltico com asfalto polímero.

${ }^{18}$ AGÊNCIA NACIONAL DO PETRÓLEO, GÁS NATURAL E BIOCOMBUSTíVEIS. (2005). Regulamento Técnico 03/2005: Cimento Asfáltico de Petróleo. Brasília, DF.
} 


\subsubsection{Ensaio de Fluência e Recuperação sob Tensão Múltipla (MSCR)}

Os resultados referentes aos ensaios MSCR são avaliados pela recuperação média do ligante asfáltico e pelos valores médios da compliância não-recuperável $\left(\mathrm{J}_{\mathrm{nr}}\right)$ nas tensões de 100PA e 3200PA. Por recomendações da Asphalt Institute (2010a), as análises devem ser realizadas na temperatura na qual o ligante asfáltico estará sendo solicitado durante sua vida útil. O documento aponta como temperatura máxima de análise, dependento do PG do ligante asfáltico, a temperatura de $70^{\circ} \mathrm{C}$. Ao analisar dados de levantamentos deflectométricos realizados, atendendo ao Edital 0448/10-00 do DNIT, em aproximadamente $30.000 \mathrm{Km}$ da malha rodoviária do Brasil, foi constatado que a temperatura, apontam que a temperatura do pavimento não ultrapassa a $64^{\circ} \mathrm{C}$. Apesar disso, e a título de análise, os dados aqui apresentados contemplam todas as cinco temperaturas de análise, $52^{\circ} \mathrm{C}, 58^{\circ} \mathrm{C}, 64^{\circ} \mathrm{C}, 70^{\circ} \mathrm{C} \mathrm{e}$ $76^{\circ} \mathrm{C}$, e são destacados os dados referente a temperatura de $64^{\circ} \mathrm{C}$.

$\mathrm{Na}$ Tabela 30 estão apresentados os valores percentuais da recuperação para as amostras produzidas com o ligante de base da Replan e modificados com o PPA. A adição dos modificadores proporciona um aumento da recuperação do material, independente do teor adicionado e da temperaturas para o nível de tensão de $100 \mathrm{~Pa}$.

Tabela 30 - Percentuais de recuperação $(\mathrm{R})$ do ligante asfáltico proveniente da Replan modificado com
\begin{tabular}{cccccccccccc}
\hline \multirow{3}{*}{ Teor } & \multicolumn{1}{c}{$300 \mathrm{~Pa}(\%)$} \\
\cline { 2 - 11 } & $52^{\circ} \mathrm{C}$ & $58^{\circ} \mathrm{C}$ & $\mathbf{6 4}{ }^{\circ} \mathbf{C}$ & $70^{\circ} \mathrm{C}$ & $76^{\circ} \mathrm{C}$ & $52^{\circ} \mathrm{C}$ & $58^{\circ} \mathrm{C}$ & $\mathbf{6 4}{ }^{\circ} \mathbf{C}$ & $70^{\circ} \mathrm{C}$ & $76^{\circ} \mathrm{C}$ \\
\hline Puro & 12,54 & 6,05 & $\mathbf{1 , 2 4}$ & 0,00 & 0,00 & 8,99 & 0,55 & $\mathbf{0 , 0 0}$ & 0,00 & 0,00 \\
0,50 & 28,73 & 19,98 & $\mathbf{1 3 , 6 3}$ & 5,35 & 0,67 & 24,38 & 10,91 & $\mathbf{1 , 0 4}$ & 0,00 & 0,00 \\
1,00 & 55,41 & 46,77 & $\mathbf{3 6 , 9 2}$ & 26,82 & 17,82 & 52,49 & 38,06 & $\mathbf{1 9 , 8 3}$ & 4,81 & 0,00 \\
1,50 & 75,44 & 70,82 & $\mathbf{6 3 , 2 1}$ & 53,70 & 43,02 & 74,85 & 67,91 & $\mathbf{5 5 , 3 8}$ & 35,61 & 14,10 \\
\hline
\end{tabular}

No entanto, ao analisar o comportamento referente à recuperação para tensão de $3200 \mathrm{~Pa}$, para todos os teores, há melhora do comportamento do material até a temperatura de $58^{\circ} \mathrm{C}$, a partir desta temperatura a recuperação do material só é beneficiada com adição de teores de $1,0 \%$ na temperatura de $70^{\circ} \mathrm{C}$ e de $1,5 \%$ na temperatura de $76^{\circ} \mathrm{C}$, pois nos outros teores o valor da recuperação é zero. Sendo assim, sabendo-se que o percentual de recuperação identifica a resposta elástica do ligante asfáltico, um valor nulo para esta propriedade indica que a deformação acumulada no material não sofre qualquer recuperação. Analisando a recuperação na temperatura de interesse $\left(64^{\circ} \mathrm{C}\right)$, percebe-se um aumento significativo desta propriedade quando comparada as amostras modificadas com o CAP puro no nível de tensão de 100PA, enquanto no nível de tensão de 3200PA nota-se um aumento somente com adições intermediárias ou altas do modificador PPA. 


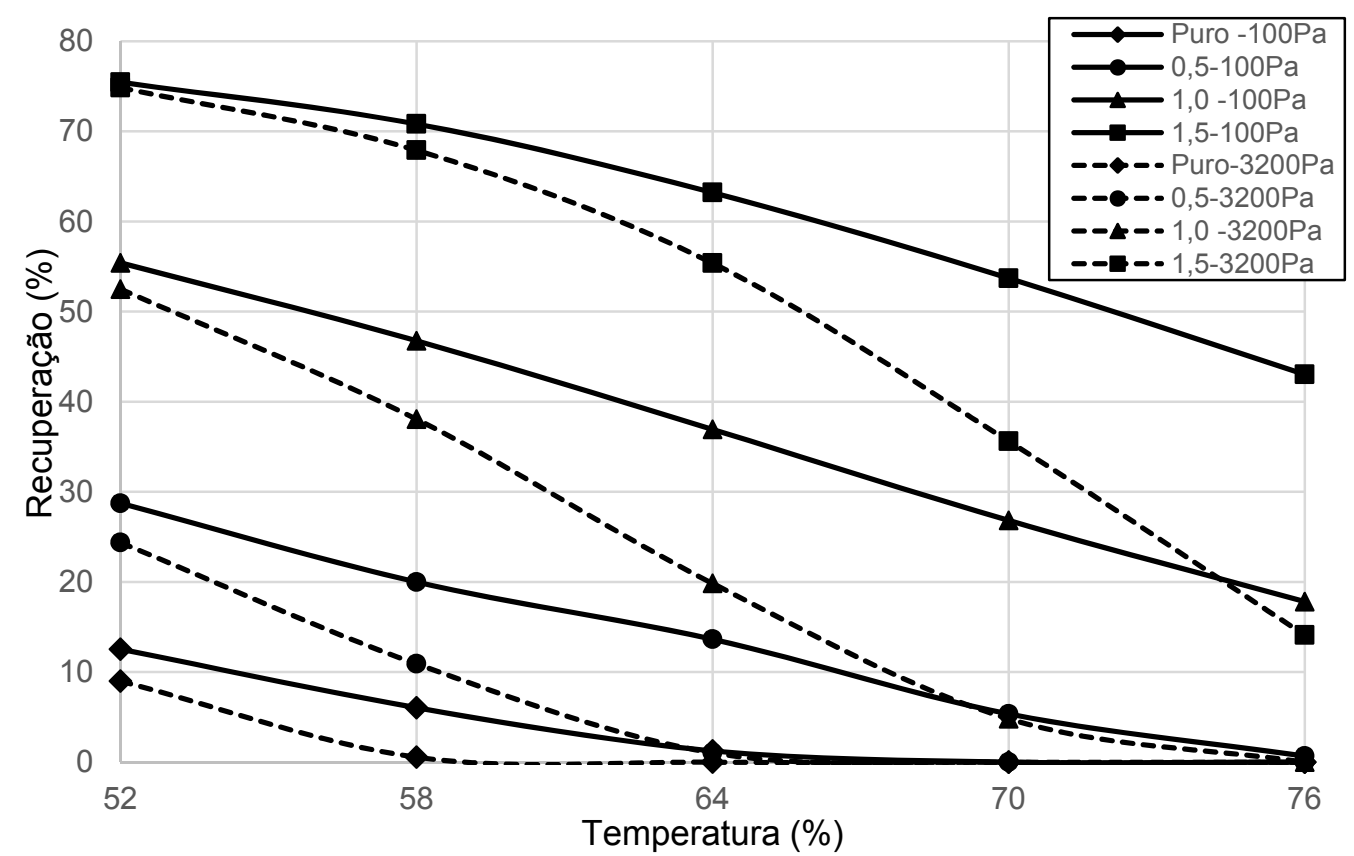

Figura 32 - Recuperação (R) do ligante asfáltico proveniente da Replan modificado com PPA.

Na Figura 32 é ilustrado as variações de recuperação para as amostras produzidas com o ligante de base Replan modificados com o PPA. Pode-se observar que a recuperação diminui com o aumento da temperatura e da tensão. A diferença entre os valores de recuperação nos níveis de tensão de $100 \mathrm{~Pa}$ e $3200 \mathrm{~Pa}$ aumenta gradativamente com o aumento da temperatura, ou seja, menores diferenças estão na temperatura de $52^{\circ} \mathrm{C}$ e as maiores diferenças estão na temperatura de $76^{\circ} \mathrm{C}$. Para exemplificar, tem-se como menor diferença o percentual de 0,8 para a amostra com adição de 1,5\% de PPA na temperatura de $52^{\circ} \mathrm{C}$, enquanto na temperatura de $76^{\circ} \mathrm{C}$, a mesma amostra teve uma redução de $33,7 \%$ na recuperação. No entanto, para este ligante asfáltico de base e com adição do modificar PPA, os teores baixos a intermediários apresentaram as maiores reduções da recuperação, chegando a $82 \%$ para o teor de $1,0 \%$ na temperatura de $76^{\circ} \mathrm{C}$. Nas temperaturas mais altas a adição de pequenos teores do modificador $(0,5 \%)$ não tem efeito nesta propriedade.

$\mathrm{Na}$ Tabela 31 estão apresentados os valores de compliância não recuperável $\left(\mathrm{J}_{\mathrm{nr}}\right)$ das amostras produzidas com o ligante asfáltico proveniente da Replan modificadas com o PPA. Os valores de compliância não recuperável, independente da tensão, aumentam com o aumento da temperatura e diminuem com adição do modificador PPA. Uma vez que o valor de $J_{n r}$ está relacionado à suscetibilidade do ligante asfáltico à deformação permanente, podese dizer que o CAP Puro apresenta a maior suscetibilidade e que a amostra com maior adição de PPA $(1,5 \%)$ possui a menor, ambos em qualquer situação de temperatura e de nível de tensão. 
Tabela 31 - Compliância Não Recuperável (Jnr) do ligante asfáltico proveniente da Replan modificado com PPA.

\begin{tabular}{ccccccccccc}
\hline \multirow{2}{*}{ Teor } & \multicolumn{4}{c}{$100 \mathrm{~Pa}\left(\mathrm{KPa}^{-1}\right)$} & \multicolumn{5}{c}{$3200 \mathrm{~Pa}\left(\mathrm{KPa}^{-1}\right)$} \\
\cline { 2 - 10 } & $52^{\circ} \mathrm{C}$ & $58^{\circ} \mathrm{C}$ & $\mathbf{6 4}{ }^{\circ} \mathrm{C}$ & $70^{\circ} \mathrm{C}$ & $76^{\circ} \mathrm{C}$ & $52^{\circ} \mathrm{C}$ & $58^{\circ} \mathrm{C}$ & $\mathbf{6 4}{ }^{\circ} \mathbf{C}$ & $70^{\circ} \mathrm{C}$ & $76^{\circ} \mathrm{C}$ \\
\hline Puro & 0,33 & 0,92 & $\mathbf{2 , 4 2}$ & 5,93 & 13,49 & 0,34 & 1,02 & $\mathbf{2 , 7 6}$ & 6,77 & 15,18 \\
0,50 & 0,17 & 0,47 & $\mathbf{1 , 4 4}$ & 3,47 & 7,08 & 0,18 & 0,53 & $\mathbf{1 , 7 5}$ & 4,33 & 8,85 \\
1,00 & 0,06 & 0,15 & $\mathbf{0 , 3 8}$ & 0,97 & 2,34 & 0,06 & 0,17 & $\mathbf{0 , 5 1}$ & 1,43 & 3,67 \\
1,50 & 0,01 & 0,03 & $\mathbf{0 , 0 8}$ & 0,21 & 0,52 & 0,01 & 0,04 & $\mathbf{0 , 1 0}$ & 0,30 & 0,86 \\
\hline
\end{tabular}

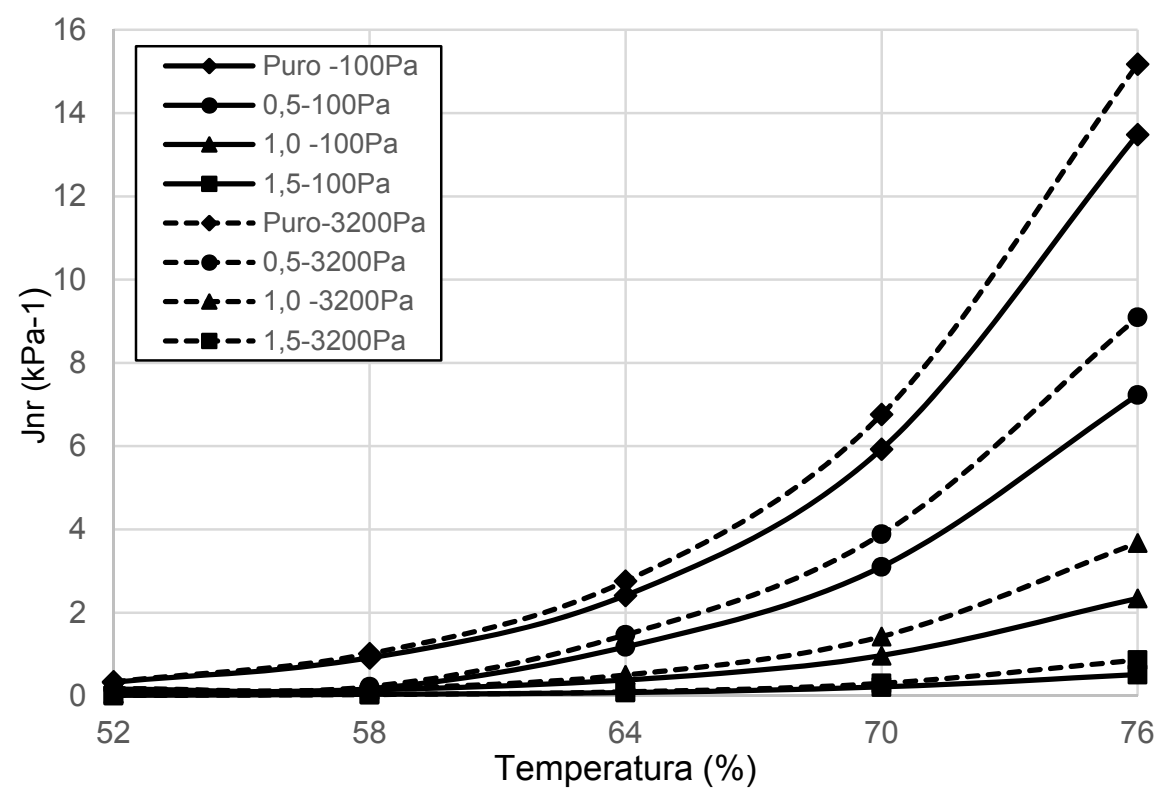

Figura 33 - Compliância Não Recuperável $\left(\mathrm{J}_{\mathrm{nr}}\right)$ do ligante asfáltico proveniente da Replan modificado com PPA.

Quanto à variação dos valores de compliância não recuperáveis dos níveis de tensão, de $100 \mathrm{~Pa}$ e $3200 \mathrm{~Pa}$, apresentados na Figura 33, pode-se observar o mesmo comportamento para todas as misturas. A temperatura e o nível de tensão têm efeito proporcional ao teor de modificador adicionado, aumentam o valor do Jnr das amostras. A sensibilidade à mudança ao nível de tensão é dependente da temperatura. Para baixas temperaturas (até $58^{\circ} \mathrm{C}$ ) o aumento da concentração dos modificadores diminui a sensibilidade ao nível de tensão, enquanto para temperaturas maiores a adição de modificadores aumento esta sensibilidade.

Tabela 32 - Percentuais de recuperação (R) do ligante asfáltico proveniente da Replan modificado com PA85.

\begin{tabular}{ccccccccccc}
\hline \multirow{2}{*}{ Teor } & \multicolumn{1}{c}{$100 \mathrm{~Pa}(\%)$} & \multicolumn{6}{c}{$3200 \mathrm{~Pa}(\%)$} \\
\cline { 2 - 10 } & $52^{\circ} \mathrm{C}$ & $58^{\circ} \mathrm{C}$ & $\mathbf{6 4}{ }^{\circ} \mathbf{C}$ & $70^{\circ} \mathrm{C}$ & $76^{\circ} \mathrm{C}$ & $52^{\circ} \mathrm{C}$ & $58^{\circ} \mathrm{C}$ & $\mathbf{6 4}{ }^{\circ} \mathbf{C}$ & $70^{\circ} \mathrm{C}$ & $76^{\circ} \mathrm{C}$ \\
\hline Puro & 12,54 & 6,05 & $\mathbf{1 , 2 4}$ & 0,00 & 0,00 & 8,99 & 0,55 & $\mathbf{0 , 0 0}$ & 0,00 & 0,00 \\
0,50 & 28,19 & 18,65 & $\mathbf{9 , 9 8}$ & 4,50 & 0,00 & 23,54 & 10,37 & $\mathbf{0 , 0 0}$ & 0,00 & 0,00 \\
1,00 & 47,84 & 38,41 & $\mathbf{2 8 , 5 0}$ & 19,24 & 10,57 & 44,28 & 28,91 & $\mathbf{1 2 , 1 5}$ & 1,03 & 0,00 \\
1,50 & 65,44 & 58,26 & $\mathbf{4 8 , 6 7}$ & 38,17 & 28,28 & 64,26 & 53,20 & $\mathbf{3 5 , 6 2}$ & 15,68 & 2,29 \\
\hline
\end{tabular}


$\mathrm{Na}$ Tabela 32 estão apresentados os dados referentes aos percentuais de recuperação (R) para as amostras produzidas com o ligante de base da Replan e modificados com o PA85. Assim como nas amostras modificadas com PPA, estas apresentam maiores valores de recuperação com o aumento do teor da adição do ácido, porém verifica-se uma redução no valor da recuperação com o aumento da temperatura e do nível de tensão. Os menores valores de recuperação são apresentados pela amostra com o ligante asfáltico de base e os maiores valores de recuperação são apresentados pelas amostras com adição de $1,5 \%$ de PA85, independente da temperatura e do nível de tensão aplicado. No entanto, ao analisar o comportamento referente à recuperação para tensão de $3200 \mathrm{~Pa}$, a adição de todos os teores, melhora o comportamento do material até a temperatura de $58^{\circ} \mathrm{C}$, a partir desta temperatura a recuperação do material só é beneficiada com adição de teores de 1,0\% na temperatura de $70^{\circ} \mathrm{C}$ e de $1,5 \%$ na temperatura de $76^{\circ} \mathrm{C}$, pois nos outros teores o valor da recuperação é zero.

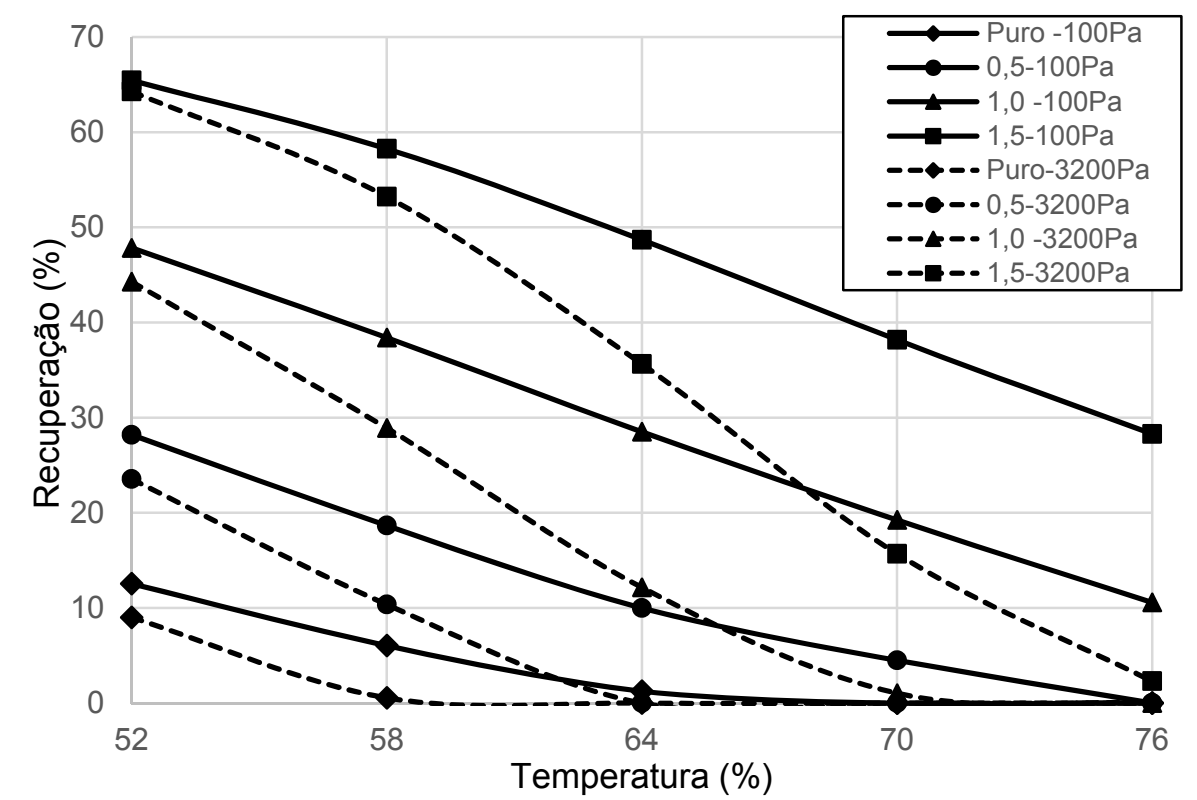

Figura 34 - Recuperação $(R)$ do ligante asfáltico proveniente da Replan modificado com PA85.

Quando comparados os valores da Tabela 30 e da Tabela 32 pode-se observar que apesar do mesmo comportamento, os valores de recuperação apresentados para as amostras com adição de PPA são maiores, independente dos teores adicionados, que os encontrados para as amostras com adição de PA85, embora ambos apresentem melhor comportamento, em termos de recuperação, que os ligantes asfálticos puros.

Na Figura 34 são ilustradas as variações de recuperação para as amostras produzidas com o ligante de base Replan modificados com o PA85. Assim como para as amostras modificadas com o PPA, a recuperação diminui com o aumento da temperatura e da tensão. A diferença entre os valores de recuperação nos níveis de tensão de $100 \mathrm{~Pa}$ e $3200 \mathrm{~Pa}$ 
aumenta gradativamente com o aumento da temperatura, ou seja, menores diferenças estão na temperatura de $52^{\circ} \mathrm{C}$ e as maiores diferenças estão na temperatura de $76^{\circ} \mathrm{C}$. Para exemplificar, tem-se como menor diferença o percentual de 1,8 para a amostra com adição de $1,5 \%$ de PA85 na temperatura de $52^{\circ} \mathrm{C}$, enquanto na temperatura de $76^{\circ} \mathrm{C}$, a mesma amostra teve uma redução de 58,9\% na recuperação. No entanto, para este ligante asfáltico de base e com adição do modificador PA85, os teores baixos a intermediários apresentaram as maiores reduções da recuperação, chegando a 94\% para o teor de 1,0\% na temperatura de $76^{\circ} \mathrm{C}$. Em temperatura alta $\left(76^{\circ} \mathrm{C}\right)$, a adição de teores baixos e intermediários do modificador $(0,5 \%$ e $1,0 \%)$ não tem efeito nesta propriedade, pois os valores de recuperação são zero. Quando comparados os dados da Figura 32 e da Figura 34, observa-se uma mesma tendência, porém diferenças maiores para as amostras com adição de PA85, sendo mais sensível à mudança do nível de tensão.

$\mathrm{Na}$ Tabela 33 estão apresentados os valores de compliância não recuperável $\left(\mathrm{J}_{\mathrm{nr}}\right)$ das amostras produzidas com o ligante asfáltico proveniente da Replan modificadas com o PA85. Assim como nas amostras modificadas com PPA, os valores de compliância não recuperável, independente da tensão, aumentam com o aumento da temperatura e diminuem com adição do modificador PA85. Nota-se, neste caso, que para teores de 1,0\% nas temperaturas de $52^{\circ} \mathrm{C}$ e $58^{\circ} \mathrm{C}$, para os dois níveis de tensão, os valores de $\mathrm{J}_{\mathrm{nr}}$ são similares. Levando em consideração que o valor de Jnr está relacionado à suscetibilidade do ligante asfáltico à deformação permanente, pode-se dizer que o CAP puro apresenta a maior suscetibilidade e que a amostra com adição de alta concentração de PA85 (1,5\%) possui a menor, ambos em qualquer situação de temperatura e de nível de tensão.

Tabela 33 - Compliância não recuperável (Jnr) do ligante asfáltico proveniente da Replan modificado com PA85.

\begin{tabular}{ccccccccccc}
\hline \multirow{2}{*}{ Teor } & \multicolumn{4}{c}{$100 \mathrm{~Pa}\left(\mathrm{KPa}^{-1}\right)$} & \multicolumn{5}{c}{$3200 \mathrm{~Pa}\left(\mathrm{KPa}^{-1}\right)$} \\
\cline { 2 - 10 } & $52^{\circ} \mathrm{C}$ & $58^{\circ} \mathrm{C}$ & $64^{\circ} \mathrm{C}$ & $70^{\circ} \mathrm{C}$ & $76^{\circ} \mathrm{C}$ & $52^{\circ} \mathrm{C}$ & $58^{\circ} \mathrm{C}$ & $64^{\circ} \mathrm{C}$ & $70^{\circ} \mathrm{C}$ & $76^{\circ} \mathrm{C}$ \\
\hline 0,00 & 0,33 & 0,92 & $\mathbf{2 , 4 2}$ & 5,93 & 13,49 & 0,34 & 1,02 & $\mathbf{2 , 7 6}$ & 6,77 & 15,18 \\
0,50 & 0,16 & 0,17 & $\mathbf{1 , 1 8}$ & 3,10 & 7,23 & 0,17 & 0,52 & $\mathbf{1 , 4 7}$ & 3,89 & 9,10 \\
1,00 & 0,08 & 0,21 & $\mathbf{0 , 5 4}$ & 1,37 & 3,46 & 0,08 & 0,24 & $\mathbf{0 , 7 0}$ & 1,92 & 4,97 \\
1,50 & 0,03 & 0,07 & $\mathbf{0 , 1 9}$ & 0,49 & 1,22 & 0,03 & 0,08 & $\mathbf{0 , 2 4}$ & 0,73 & 2,04 \\
\hline
\end{tabular}

No que diz respeito à variação dos valores de compliância não recuperável nos níveis de tensões de 100Pa e 3200Pa, apresentados na Figura 35, pode-se observar o mesmo comportamento para todas as misturas. O aumento da temperatura e do nível de tensão proporciona um aumento no valor do $J_{\mathrm{nr}}$, independente do teor de ácido acionado $A$ sensibilidade à mudança ao nível de tensão é dependente da temperatura. Para baixas temperaturas (até $58^{\circ} \mathrm{C}$ ) o aumento da concentração dos modificadores diminui a 
sensibilidade ao nível de tensão, enquanto para temperaturas maiores a adição de modificadores aumento esta sensibilidade.

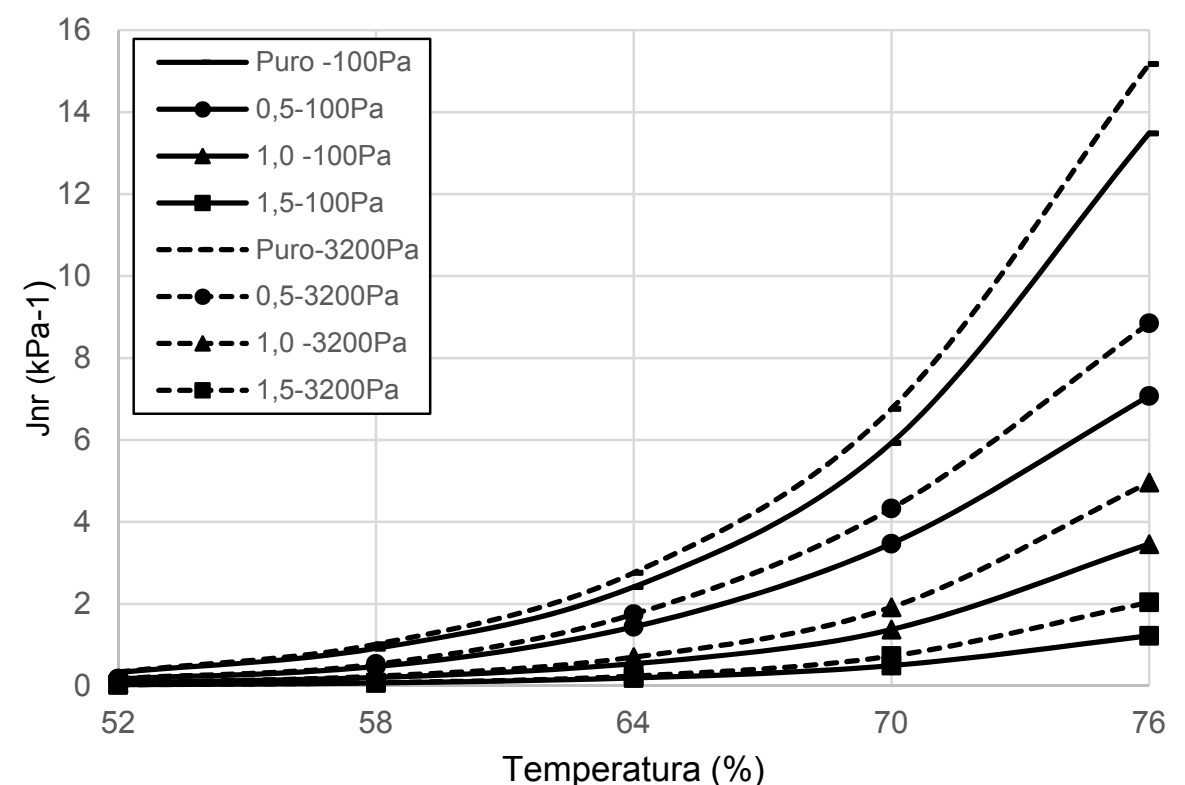

Figura 35 - Compliância Não Recuperável $\left(\mathrm{J}_{n r}\right)$ do ligante asfáltico proveniente da Replan modificado com PA85.

A Tabela 34 apresenta as diferenças percentuais entre as compliâncias $\left(\mathrm{J}_{\mathrm{nr}}, \mathrm{d}_{\text {iff }}\right)$ para o ligante asfáltico de base proveniente da Replan e os ligantes asfálticos modificados com PPA e PA85, na condição envelhecida a curto prazo. Os ligantes asfálticos avaliados não apresentam diferenças percentuais superiores ao valor de $75 \%$ estipulado pela norma AASHTO MP19, sendo que as amostras com adição de 1,5\% de PPA e 1,5\% de PA85 são os ligante asfálticos com valor de $J_{\mathrm{nr}}, \mathrm{d}_{\mathrm{iff}}$ mais próximo deste valor, com 67,26\% e 67,08\%, respectivamente. As menores diferenças percentuais, quando analisado o grupo com adição do modificador PPA, é representada pelo ligante asfáltico de base, com exceção para a temperatura de $58^{\circ} \mathrm{C}$.

Para o grupo com adição de PA85, pode perceber que o ligante de base apresenta menores diferenças percentuais somente nas temperaturas acima de $64^{\circ} \mathrm{C}$, sendo que para temperaturas inferiores, a mistura com adição de 1,5\% de PA85 apresentou menos sensibilidade à tensão. Ao analisar o $\mathrm{J}_{\mathrm{nr}}, \mathrm{d}_{\text {iff }}$ na temperatura do pavimento adotado no presente trabalho $\left(64^{\circ} \mathrm{C}\right)$, nota-se que a sensibilidade à tensão aumenta com o aumento dos teores dos ácidos até $1,0 \%$, porém a mesma diminui com a adição de concentrações de $1,5 \%$, independente do modificador utilizado. Ao comparar os dois grupos, de maneira geral, notase que as amostras com adição de PPA são mais sensíveis à tensão do que as amostras modificadas com PA85, com teores baixos e intermediários. No entanto, para altos teores deste modificador as amostras se mostraram mais sensíveis, pois apresentam diferenças percentuais maiores. 
Tabela 34 - Diferenças percentuais entre as compliâncias não-recuperáveis ( $\left.\mathrm{J}_{\mathrm{nr}}\right)$ do ligante asfáltico proveniente da Replan.

\begin{tabular}{ccccccccccc}
\hline \multirow{2}{*}{ Teor Jnr diff (\%) para amostras com PPA } & \multicolumn{7}{c}{ Jnr .diff $(\%)$ para amostras com PA85 } \\
\cline { 2 - 10 } & $52^{\circ} \mathrm{C}$ & $58^{\circ} \mathrm{C}$ & $\mathbf{6 4}^{\circ} \mathbf{C}$ & $70^{\circ} \mathrm{C}$ & $76^{\circ} \mathrm{C}$ & $52^{\circ} \mathrm{C}$ & $58^{\circ} \mathrm{C}$ & $\mathbf{6 4}{ }^{\circ} \mathbf{C}$ & $70^{\circ} \mathrm{C}$ & $76^{\circ} \mathrm{C}$ \\
\hline 0,00 & 4,93 & 11,43 & $\mathbf{1 4 , 3 4}$ & 14,08 & 12,54 & 4,93 & 11,43 & $\mathbf{1 4 , 3 4}$ & 14,08 & 12,54 \\
0,50 & 6,25 & 27,11 & $\mathbf{2 4 , 5 0}$ & 25,31 & 25,87 & 6,85 & 13,27 & $\mathbf{2 1 , 6 4}$ & 24,78 & 25,08 \\
1,00 & 5,22 & 15,99 & $\mathbf{3 2 , 0 4}$ & 47,30 & 56,78 & 6,13 & 15,76 & $\mathbf{2 9 , 5 3}$ & 39,80 & 43,43 \\
1,50 & 1,40 & 8,53 & $\mathbf{1 9 , 9 3}$ & 44,05 & 67,26 & 2,31 & 10,59 & $\mathbf{2 6 , 1 7}$ & 47,73 & 67,08 \\
\hline
\end{tabular}

$\mathrm{Na}$ tentativa de identificar o padrão de equivalência entre os teores de PPA e PA85 para a propriedade de recuperação, foi realizada uma modelagem, na temperatura de $64^{\circ} \mathrm{C} \mathrm{e}$ no nível de tensão de 100Pa. Na Figura 36 é apresentado o gráfico de modelagem dessa propriedade para ambos os ácidos. Mediante as formulações encontradas pode-se constatar que, à luz da recuperação, a adição de $0,5 \%$ de PPA corresponde a 0,6\% de PA85, e a adição de $1,0 \%$ de PPA corresponde a $1,2 \%$ de PA85, e por fim a adição de $1,5 \%$ de PPA corresponde a $1,8 \%$ de PA85, ou seja, para obtenção de mesmos valores de recuperação, há necessidade de $20 \%$ a mais de PA85 em relação à quantidade de PPA, aproximadamente.

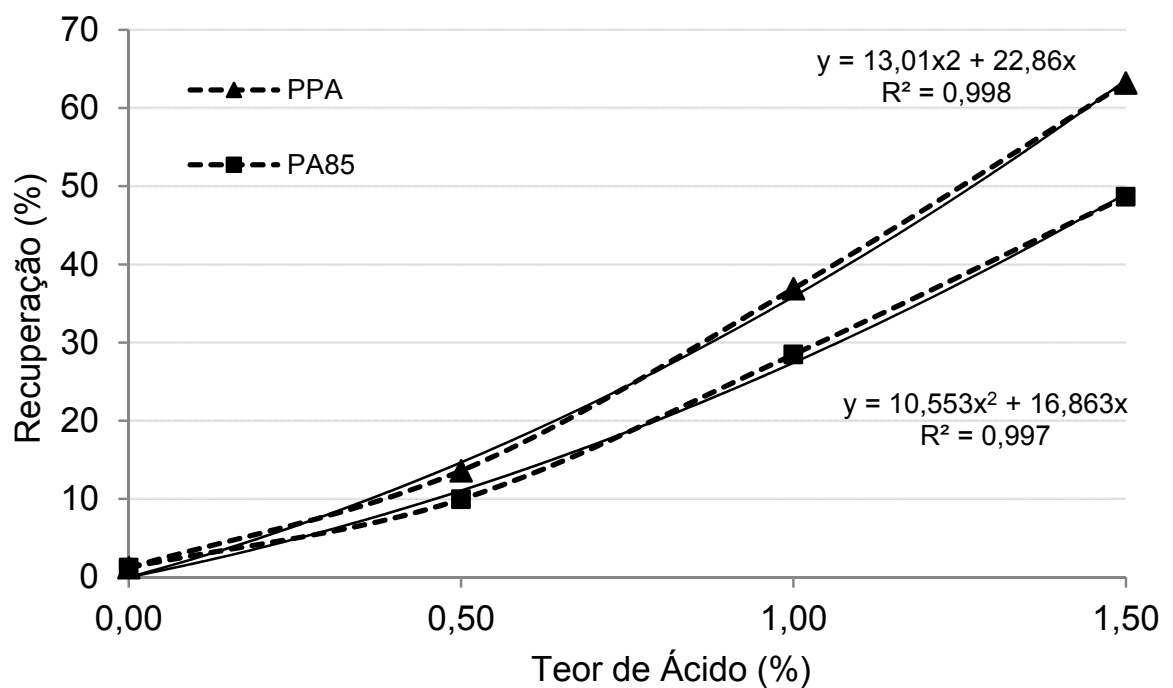

Figura 36 - Modelagem da Recuperação, na temperatura de $64^{\circ} \mathrm{C}$ e nível de tensão de $100 \mathrm{~Pa}$, para os ácidos PPA e PA85 com ligante asfáltico de base Replan.

De maneira similar, para identificar o padrão de igualdade entre os teores de PPA e PA85 para a compliância não recuperável, foi realizada uma modelagem, na temperatura de $64^{\circ} \mathrm{C}$ e na tensão de 100Pa. Na Figura 37 é apresentado o gráfico de modelagem (métodos dos mínimos quadrados) dessa propriedade para ambos os ácidos. Mediante as formulações encontradas pode-se constatar que, para a compliância não recuperável, as proporções foram similares às encontradas para propriedade de recuperação sendo para a adição de $0,5 \%$ de 
PPA corresponde a $0,6 \%$ de PA85, e a adição de $1,0 \%$ de PPA corresponde a $1,2 \%$ de PA85, e por fim a adição de $1,5 \%$ de PPA corresponde a 1,9\% de PA85.

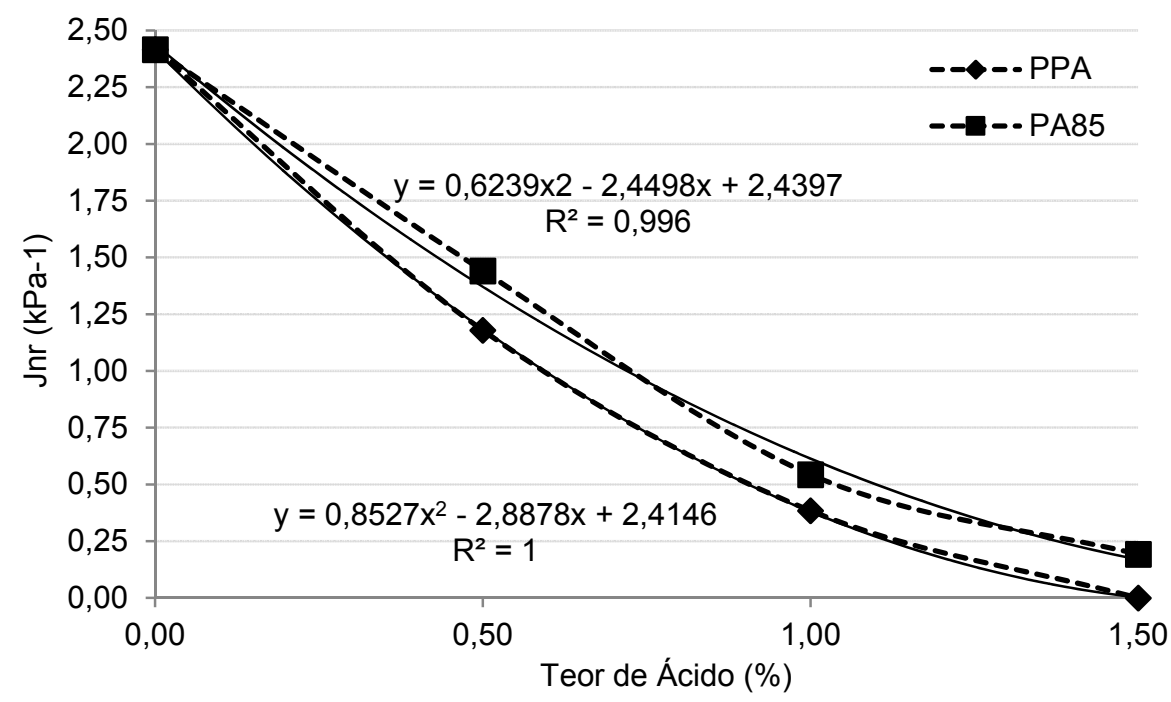

Figura 37 - Modelagem da Compliância não recuperável, na temperatura de $64^{\circ} \mathrm{C}$ e no nível de tensão de 100Pa, para os ácidos PPA e PA85 com ligante asfáltico de base Replan.

$\mathrm{Na}$ Tabela 35 estão apresentados os dados referentes aos percentuais de recuperação (R) para as amostras produzidas com o ligante de base da Lubnor e modificados com o PPA. De maneira geral, a adição dos modificadores proporciona um aumento da recuperação do material, e o aumento do nível da tensão e da temperatura diminui o valor da recuperação. $O$ ligante asfáltico de base só apresentou recuperação na temperatura de $52^{\circ} \mathrm{C}$. A única amostra que apresentou recuperação em todas as temperaturas foi com a adição de 1,5\% de PPA, no nível de tensão de 100Pa. Para o nível de tensão de 3200Pa não foi obtido nenhum valor de recuperação em temperaturas acima de $70^{\circ} \mathrm{C}$. Considerando a temperatura do pavimento de $64^{\circ} \mathrm{C}$, observa-se que para o nível de tensão de 100Pa apenas a adição de teores acima de $1,0 \%$ apresentam valores de recuperação. Para o nível de tensão de $3200 \mathrm{~Pa}$, somente ligantes asfálticos modificados com teor de $1,5 \%$ de PPA apresentam valores de recuperação.

Tabela 35 - Percentuais de recuperação $(R)$ do ligante asfáltico proveniente da Lubnor modificado com PPA.

\begin{tabular}{ccccccccccc}
\hline \multirow{2}{*}{ Teor } & \multicolumn{1}{c}{$100 \mathrm{~Pa}(\%)$} & \multicolumn{6}{c}{$3200 \mathrm{~Pa}(\%)$} \\
\cline { 2 - 11 } & $52^{\circ} \mathrm{C}$ & $58^{\circ} \mathrm{C}$ & $64^{\circ} \mathrm{C}$ & $70^{\circ} \mathrm{C}$ & $76^{\circ} \mathrm{C}$ & $52^{\circ} \mathrm{C}$ & $58^{\circ} \mathrm{C}$ & $64^{\circ} \mathrm{C}$ & $70^{\circ} \mathrm{C}$ & $76^{\circ} \mathrm{C}$ \\
\hline 0,00 & 1,79 & 0,00 & $\mathbf{0 , 0 0}$ & 0,00 & 0,00 & 0,56 & 0,00 & $\mathbf{0 , 0 0}$ & 0,00 & 0,00 \\
0,50 & 10,92 & 4,15 & $\mathbf{0 , 0 0}$ & 0,00 & 0,00 & 4,15 & 0,10 & $\mathbf{0 , 0 0}$ & 0,00 & 0,00 \\
1,00 & 23,47 & 14,13 & $\mathbf{7 , 4 3}$ & 1,13 & 0,00 & 20,08 & 7,99 & $\mathbf{0 , 0 0}$ & 0,00 & 0,00 \\
1,50 & 42,41 & 31,36 & $\mathbf{2 0 , 7 0}$ & 12,36 & 4,03 & 39,20 & 23,98 & $\mathbf{8 , 9 1}$ & 0,00 & 0,00 \\
\hline
\end{tabular}


Na Figura 38 são ilustradas as variações de recuperação para as amostras produzidas com o ligante de base Lubnor modificados com o PPA. A recuperação diminui com o aumento da temperatura e da tensão. A diferença entre os valores de recuperação nos níveis de tensão de $100 \mathrm{~Pa}$ e $3200 \mathrm{~Pa}$ aumenta gradativamente com o aumento da temperatura, ou seja, menores diferenças estão na temperatura de $52^{\circ} \mathrm{C}$ e as maiores diferenças estão na temperatura de $76^{\circ} \mathrm{C}$. Para exemplificar, tem-se como menor diferença o percentual de $7,6 \%$ para a amostra com adição de $1,5 \%$ de PPA na temperatura de $52^{\circ} \mathrm{C}$, enquanto na temperatura de $76^{\circ} \mathrm{C}$, a mesma amostra teve uma redução de $56,9 \%$ na recuperação. No entanto, para este ligante asfáltico de base e com adição do modificador PPA, os teores baixos a intermediários apresentaram as maiores reduções da recuperação, chegando a 97,7\% para o teor de $0,5 \%$ na temperatura de $58^{\circ} \mathrm{C}$. Nas temperaturas superiores a $58^{\circ} \mathrm{C}$, a adição de teores baixos e intermediários do modificador (0,5\% e 1,0\%) não têm efeito nesta propriedade, pois não apresentam recuperação.

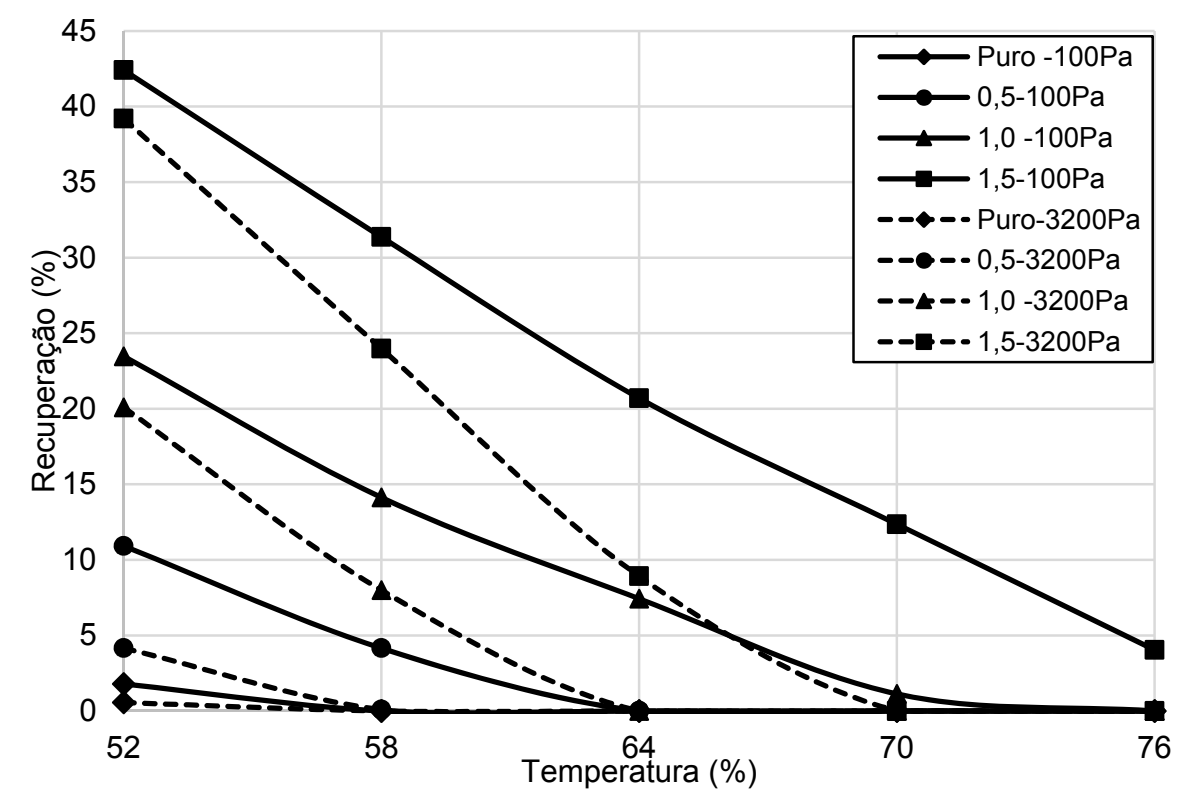

Figura 38 - Recuperação $(R)$ do ligante asfáltico proveniente da Lubnor modificado com PPA.

Ao comparar os dados de recuperação das amostras com adição de PPA para os dois tipos de ligante asfálticos utilizados, Tabela 30 e Tabela 35, pode-se perceber que o efeito da adição do ácido é mais expressivo para o ligante de base Replan, pois apresenta valores superiores de recuperação, isto porque é observado um melhor comportamento, no que se refere à recuperação, do ligante asfáltico da Replan quando comparado ao ligante asfáltico proveniente da Lubnor. No entanto, é importante destacar que, mesmo com valores inferiores de recuperação, a adição do ácido ao ligante asfáltico Lubnor melhora seu comportamento, à luz desta propriedade. Quanto às variações de recuperação, pode-se observar que as amostras produzidas com o ligante asfáltico proveniente da Lubnor são mais sensíveis ao 
nível de tensão, uma vez que as variações encontradas para estas amostras foram superiores às encontradas nas amostras produzidas com o ligante asfáltico de base Replan.

$\mathrm{Na}$ Tabela 36 estão apresentados os valores de compliância não recuperável $\left(\mathrm{J}_{n r}\right)$ das amostras produzidas com o ligante asfáltico proveniente da Lubnor modificadas com o PPA. Pode-se observar que, para temperaturas até $58^{\circ} \mathrm{C}$, para qualquer teor de ácido, os valores são similares para os dois níveis de tensões. A partir desta temperatura tem-se um aumento dos valores de $\mathrm{J}_{\mathrm{nr}}$. Ao considerar que o valor de $\mathrm{J}_{\mathrm{nr}}$ está relacionado à suscetibilidade do ligante asfáltico à deformação permanente, pode-se dizer que o CAP puro apresenta a maior suscetibilidade e que a amostra com adição de alta concentração de PPA (1,5\%) possui a menor, ambos em qualquer temperatura e nível de tensão.

Tabela 36 - Compliância não recuperável $\left(\mathrm{J}_{\mathrm{nr}}\right)$ do ligante asfáltico proveniente da Lubnor modificado com PPA.

\begin{tabular}{ccccccccccc}
\hline \multirow{2}{*}{ Teor } & \multicolumn{4}{c}{$100 \mathrm{~Pa}\left(\mathrm{KPa}^{-1}\right)$} & \multicolumn{5}{c}{$3200 \mathrm{~Pa}\left(\mathrm{KPa}^{-1}\right)$} \\
\cline { 2 - 10 } & $52^{\circ} \mathrm{C}$ & $58^{\circ} \mathrm{C}$ & $\mathbf{6 4}{ }^{\circ} \mathbf{C}$ & $70^{\circ} \mathrm{C}$ & $76^{\circ} \mathrm{C}$ & $52^{\circ} \mathrm{C}$ & $58^{\circ} \mathrm{C}$ & $\mathbf{6 4} 4^{\circ} \mathbf{C}$ & $70^{\circ} \mathrm{C}$ & $76^{\circ} \mathrm{C}$ \\
\hline 0,00 & 0,55 & 1,48 & $\mathbf{3 , 6 1}$ & 8,33 & 17,77 & 0,57 & 1,53 & $\mathbf{3 , 8 2}$ & 8,83 & 18,88 \\
0,50 & 0,35 & 0,95 & $\mathbf{2 , 3 8}$ & 5,53 & 12,08 & 0,37 & 1,03 & $\mathbf{2 , 6 3}$ & 6,19 & 13,54 \\
1,00 & 0,19 & 0,54 & $\mathbf{1 , 3 8}$ & 3,31 & 7,47 & 0,20 & 0,60 & $\mathbf{1 , 6 2}$ & 4,00 & 9,01 \\
1,50 & 0,08 & 0,24 & $\mathbf{0 , 6 5}$ & 1,64 & 3,93 & 0,09 & 0,27 & $\mathbf{0 , 7 9}$ & 2,14 & 5,19 \\
\hline
\end{tabular}

Em relação à variação dos valores de compliância não recuperáveis em função dos níveis de tensões (100Pa e 3200Pa), apresentados na Figura 39, pode-se observar o mesmo comportamento para todas as misturas. De maneira geral, a variação dos valores de $J_{\mathrm{nr}}$ para todos os ligantes asfálticos é bem próxima, porém em valores absolutos, tem-se que para esta propriedade, que a amostra com o ligante asfáltico modificado com 1,5\% de PPA foi a mais sensível à mudança do nível de tensão, apresentando maiores diferenças entre os valores de $\mathrm{J}_{\mathrm{nr}}$, enquanto o ligante asfáltico de base é o que apresenta as menores diferenças nos valores de $J_{n r}$, indicando uma menor sensibilidade ao incremento do nível de tensão de 100 para 3.200 $\mathrm{Pa}$. 


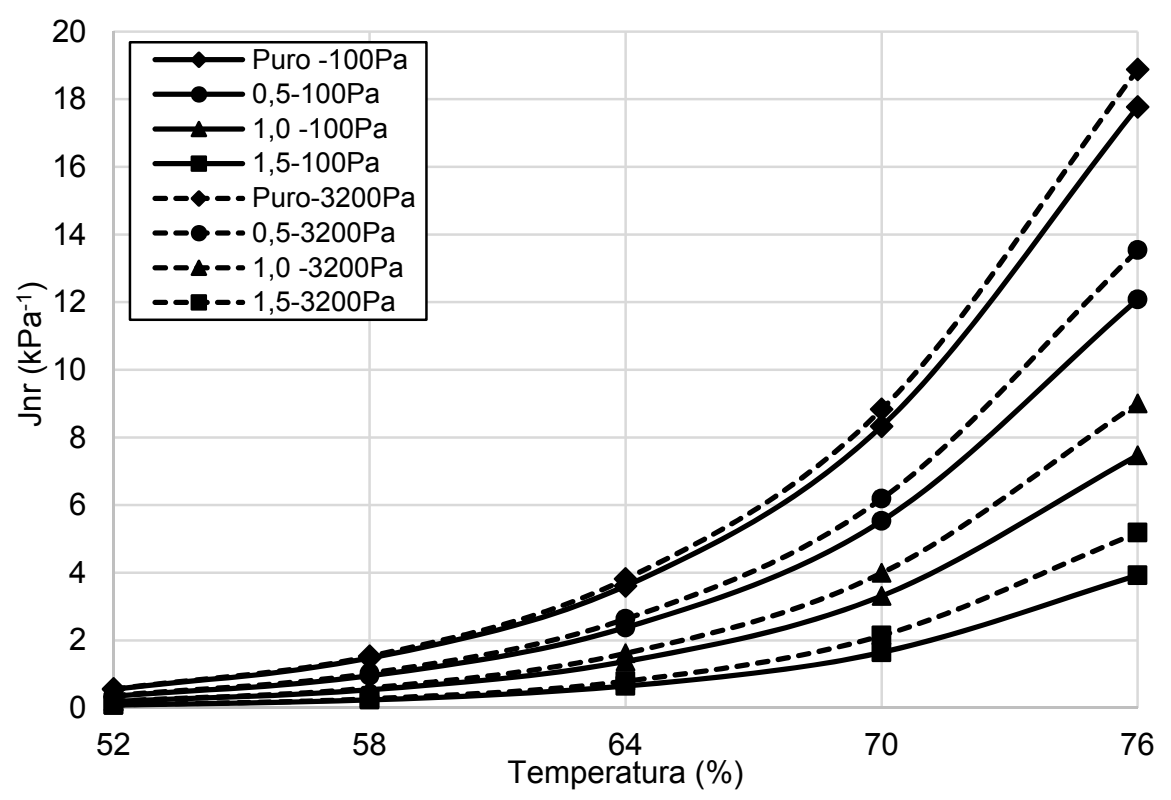

Figura 39- Compliância não recuperável (Jnr) do ligante asfáltico proveniente da Lubnor modificado com PPA.

$\mathrm{Na}$ Tabela 37 estão apresentados os dados referentes aos percentuais de recuperação (R) para as amostras produzidas com o ligante de base da Lubnor e modificados com o PA85. Assim como para o ligante asfáltico modificado com o PPA, a adição desse modificador proporciona um aumento da recuperação do material, e os aumentos do nível da tensão e da temperatura diminuem o valor dessa propriedade. A única amostra que apresentou recuperação em todas as temperaturas foi a com adição de 1,5\% de PA85, no nível de tensão de 100Pa. Para o nível de tensão de 3200Pa não foram obtidos valores de recuperação em temperaturas acima de $70^{\circ} \mathrm{C}$. Considerando a temperatura do pavimento de $64^{\circ} \mathrm{C}$, observase que para o nível de tensão de 100Pa, somente as amostras com teores intermediários a altos dos modificador apresentam valores de recuperação. Para o nível de tensão de $3200 \mathrm{~Pa}$, somente ligantes asfálticos modificados com teor de 1,5\% de PA85 apresentam valores de recuperação.

Tabela 37 - Percentuais de recuperação $(R)$ do ligante asfáltico proveniente da Lubnor modificado com PA85.

\begin{tabular}{ccccccccccc}
\hline \multirow{3}{*}{ Teor } & \multicolumn{1}{c}{$100 \mathrm{~Pa}(\%)$} & \multicolumn{6}{c}{$3200 \mathrm{~Pa}(\%)$} \\
\cline { 2 - 10 } & $52^{\circ} \mathrm{C}$ & $58^{\circ} \mathrm{C}$ & $\mathbf{6 4}{ }^{\circ} \mathbf{C}$ & $70^{\circ} \mathrm{C}$ & $76^{\circ} \mathrm{C}$ & $52^{\circ} \mathrm{C}$ & $58^{\circ} \mathrm{C}$ & $\mathbf{6 4}{ }^{\circ} \mathbf{C}$ & $70^{\circ} \mathrm{C}$ & $76^{\circ} \mathrm{C}$ \\
\hline 0,00 & 1,79 & 0,00 & $\mathbf{0 , 0 0}$ & 0,00 & 0,00 & 0,56 & 0,00 & $\mathbf{0 , 0 0}$ & 0,00 & 0,00 \\
0,50 & 10,27 & 4,15 & $\mathbf{0 , 0 0}$ & 0,00 & 0,00 & 6,87 & 0,00 & $\mathbf{0 , 0 0}$ & 0,00 & 0,00 \\
1,00 & 22,36 & 13,68 & $\mathbf{6 , 2 0}$ & 1,63 & 0,00 & 17,75 & 6,34 & $\mathbf{0 , 0 0}$ & 0,00 & 0,00 \\
1,50 & 33,20 & 23,44 & $\mathbf{1 4 , 1 0}$ & 6,76 & 0,75 & 30,35 & 16,03 & $\mathbf{3 , 6 3}$ & 0,00 & 0,00 \\
\hline
\end{tabular}

Ao analisar os dados de recuperação apresentados nas Tabela 35 e Tabela 37 podese observar comportamentos semelhantes para as adições dos ácidos PPA e PA85 para a propriedade de recuperação. No entanto, os valores de recuperação são superiores para os 
ligantes asfálticos modificados com o PPA. No tocante aos valores encontrados na temperatura de $64^{\circ} \mathrm{C}$, os resultados apontam efeito dos ácidos a partir da adição de $1,0 \%$ destes modificadores, sendo que, a adição de ácido PPA produz valores de recuperação 1,19 e 1,46 vezes maiores que os apresentados com o ácido PA85 no nível de tensão de 100Pa, para os teores de 1,0\% e 1,5\%, respectivamente. A maior diferença foi observada para o nível de tensão de $3200 \mathrm{~Pa}$ e para teores de $1,5 \%$ de ácidos, sendo que adição de PPA proporcionou resultados de recuperação 2,45 vezes maiores que a adição de PA85.

Ao comparar os percentuais de recuperação do ligante asfáltico proveniente da Lubnor com os percentuais de recuperação do ligante asfáltico proveniente da Replan pode-se observar que adição de ácido é mais efetiva para o ligante asfáltico de base Replan, uma vez que os valores encontrados de recuperação são maiores do que os apresentados no ligante asfáltico de base Lubnor.

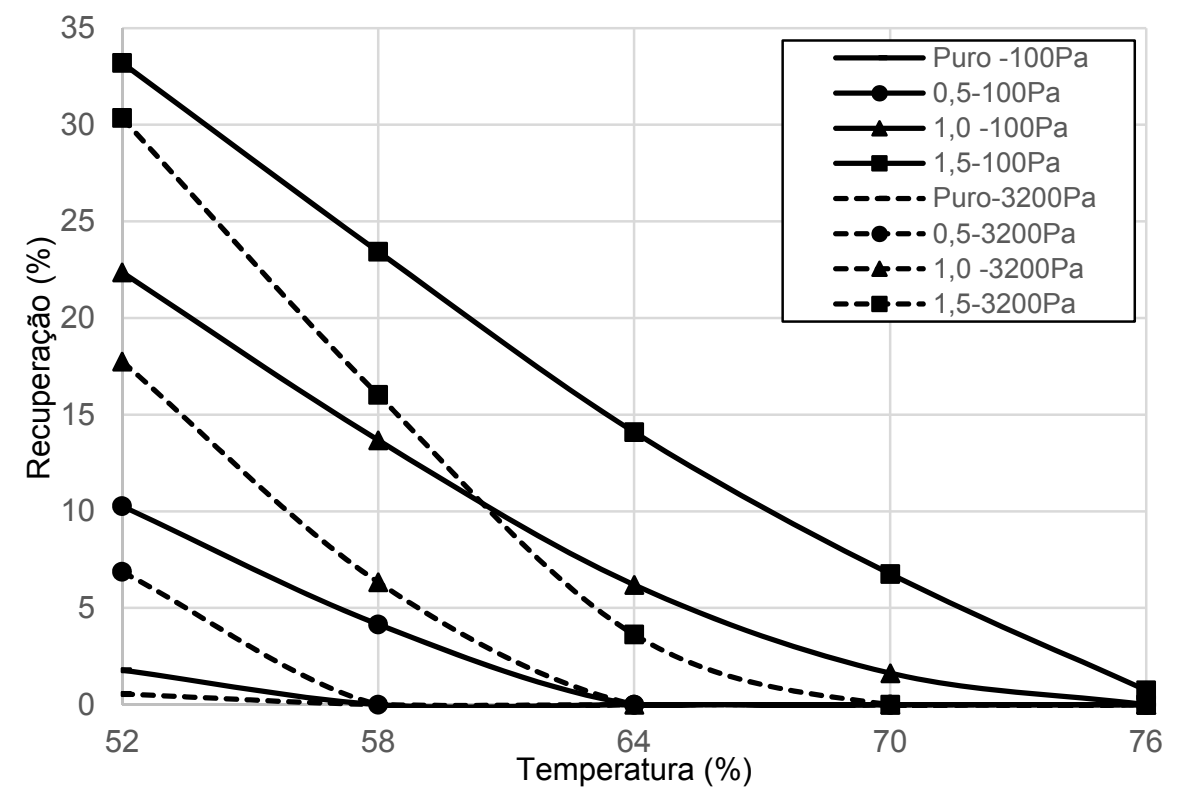

Figura 40- Recuperação (R) do ligante asfáltico proveniente da Lubnor modificado com PA85.

Na Figura 40 são ilustradas as variações de recuperação para as amostras produzidas com o ligante de base Lubnor modificados com o PA85. Assim como para as amostras modificadas com o PPA, a recuperação diminui com os aumentos da temperatura e da tensão. A variação percentual da recuperação nos níveis de tensão de 100Pa e 3200Pa aumenta gradativamente com o aumento da temperatura, ou seja, menores diferenças estão na temperatura de $52^{\circ} \mathrm{C}$ e as maiores diferenças estão na temperatura de $76^{\circ} \mathrm{C}$. A utilização do ácido é benéfica para o comportamento da recuperação, uma vez que, os ligantes asfálticos modificados apresentam recuperação maiores do que o ligante asfáltico de base para todas as temperaturas. Para o nível de tensão de $100 \mathrm{~Pa}$, quanto maior o grau de modificação do ligante asfáltico, melhor é o comportamento desse material frente ao aumento da temperatura, 
sendo que o ligante asfáltico modificado com 0,5\% de PA85 apresenta recuperação até a temperatura de $58^{\circ} \mathrm{C}$, enquanto com $1,0 \%$ de PA85 apresenta recuperação até $70^{\circ} \mathrm{C}$ e por fim, a adição de 1,5\% de PA85 apresenta recuperação em todas as temperaturas avaliadas. No entanto, para o nível de tensão de 3200Pa segue o mesmo comportamento, porém com adição de $1,5 \%$ de PA85 apresenta valores de recuperação até a temperatura de $64^{\circ} \mathrm{C}$.

Na Tabela 38 estão apresentados os valores de compliância não recuperável (Jnr) das amostras produzidas com o ligante asfáltico proveniente da Lubnor modificadas com o PA85. Da mesma maneira que as amostras modificadas com PPA, os valores de compliância não recuperável, independente da tensão, aumentam com o aumento da temperatura e diminuem com adição de maiores concentrações do modificador PA85. Nota-se, neste caso, que para teores de $1,0 \%$ nas temperaturas de $52^{\circ} \mathrm{C}$ a $64^{\circ} \mathrm{C}$, para os dois níveis de tensões, os valores de Jnr são similares.

Tabela 38 - Compliância não recuperável (Jnr) do ligante asfáltico proveniente da Lubnor modificado com PA85.

\begin{tabular}{ccccccccccc}
\hline \multirow{2}{*}{ Teor } & \multicolumn{4}{c}{$100 \mathrm{~Pa}(\%)$} \\
\cline { 2 - 11 } & $52^{\circ} \mathrm{C}$ & $58^{\circ} \mathrm{C}$ & $\mathbf{6 4} 4^{\circ} \mathbf{C}$ & $70^{\circ} \mathrm{C}$ & $76^{\circ} \mathrm{C}$ & $52^{\circ} \mathrm{C}$ & $58^{\circ} \mathrm{C}$ & $\mathbf{6 4} \mathbf{4}^{\circ} \mathbf{C}$ & $70^{\circ} \mathrm{C}$ & $76^{\circ} \mathrm{C}$ \\
\hline 0,00 & 0,55 & 1,48 & $\mathbf{3 , 6 1}$ & 8,33 & 17,77 & 0,57 & 1,53 & $\mathbf{3 , 8 2}$ & 8,83 & 18,88 \\
0,50 & 0,37 & 1,00 & $\mathbf{2 , 4 8}$ & 5,72 & 12,44 & 0,39 & 1,08 & $\mathbf{2 , 7 5}$ & 6,43 & 14,02 \\
1,00 & 0,21 & 0,23 & $\mathbf{1 , 5 0}$ & 3,60 & 8,13 & 0,23 & 0,25 & $\mathbf{1 , 7 5}$ & 4,28 & 9,75 \\
1,50 & 0,13 & 0,36 & $\mathbf{0 , 9 4}$ & 2,31 & 5,42 & 0,13 & 0,40 & $\mathbf{1 , 1 3}$ & 2,89 & 6,81 \\
\hline
\end{tabular}

Levando em consideração que o valor de Jnr está relacionado à suscetibilidade do ligante asfáltico à deformação permanente, pode-se dizer que o CAP puro apresenta a maior suscetibilidade e que a amostra com adição de alta concentração de PA85 (1,5\%) possui a menor, ambos em qualquer situação de temperatura e de nível de tensão, apresentando mesmo comportamento que os ligantes asfálticos modificados com PPA.

Na Figura 41 é apresentada a variação dos valores de compliância não recuperável para os dois níveis de tensão, 100Pa e 3200Pa, do ligante asfáltico da Lubnor modificado com PA85. Pode-se observar o mesmo comportamento para todas as misturas. De maneira geral, as variações dos valores de $\mathrm{J}_{\mathrm{nr}}$ para todos os ligantes asfálticos são similares, sendo o ligante asfáltico de base o que apresentou menor suscetibilidade ao incremente do nível de tensão e os ligantes asfálticos modificados com o ácido apresentaram valores maiores de $J_{\mathrm{nr}}$, $\mathrm{d}_{\mathrm{iff}}$, o que indica que a adição de ácido acarreta ligantes asfálticos modificados mais sensíveis à mudança no nível de tensão. 


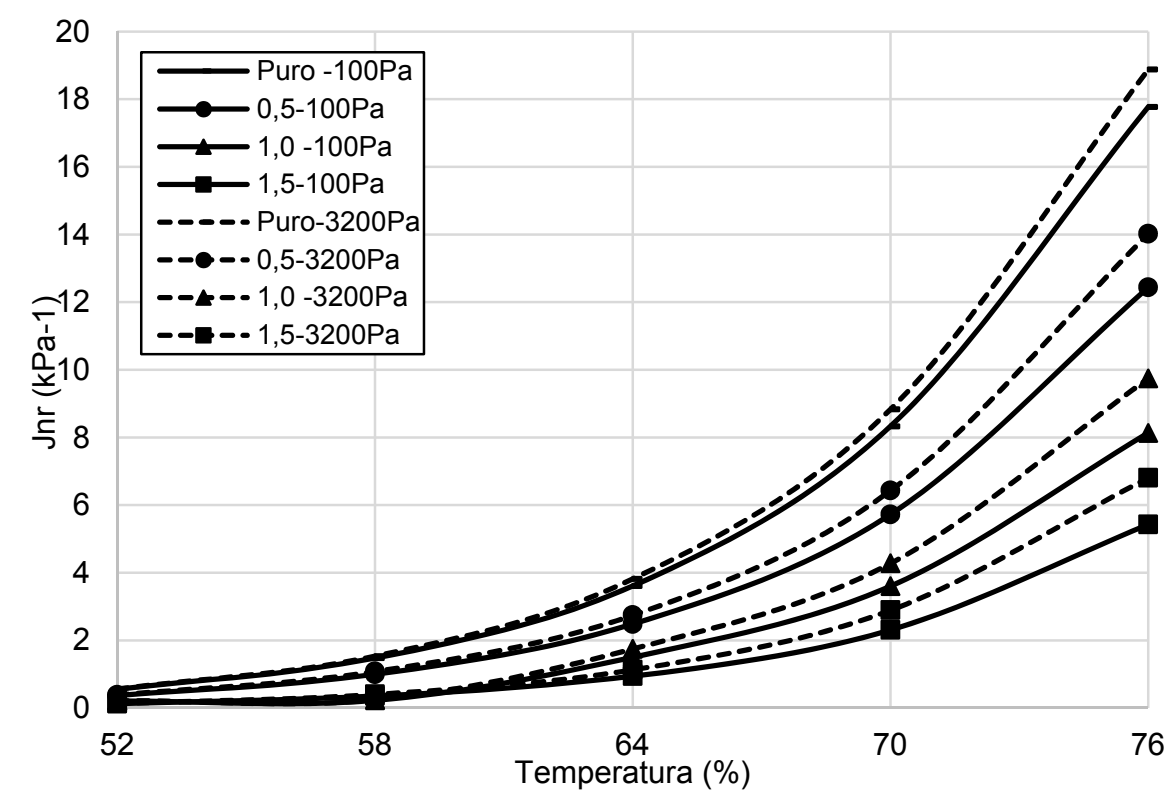

Figura 41 - Compliância não recuperável (Jnr) do ligante asfáltico proveniente da Lubnor modificado com PA85.

$\mathrm{Na}$ Tabela 39 são apresentadas as diferenças percentuais entre as compliâncias $\left(\mathrm{J}_{\mathrm{nr}}, \mathrm{d}_{\mathrm{iff}}\right)$ para o ligante asfáltico de base proveniente da Lubnor e os ligantes asfálticos modificados com PPA e PA85, na condição envelhecida em curto prazo.

Tabela 39 - Diferenças percentuais entre as compliâncias não-recuperáveis $\left(\mathrm{J}_{\mathrm{nr}}\right)$ do ligante asfáltico proveniente da Lubnor.

\begin{tabular}{ccccccccccc}
\hline \multirow{2}{*}{ Teor } & $J_{\mathrm{nr}} . \mathrm{d}_{\text {iff }}(\%)$ para amostras com PPA & \multicolumn{3}{c}{$\mathrm{J}_{\mathrm{nr}} . \mathrm{d}_{\text {iff }}(\%)$ para amostras com PA85 } \\
\cline { 2 - 10 } & $52^{\circ} \mathrm{C}$ & $58^{\circ} \mathrm{C}$ & $\mathbf{6 4} \mathbf{4}^{\circ} \mathbf{C}$ & $70^{\circ} \mathrm{C}$ & $76^{\circ} \mathrm{C}$ & $52^{\circ} \mathrm{C}$ & $58^{\circ} \mathrm{C}$ & $\mathbf{6 4}{ }^{\circ} \mathbf{C}$ & $70^{\circ} \mathrm{C}$ & $76^{\circ} \mathrm{C}$ \\
\hline 0,00 & 2,38 & 3,74 & $\mathbf{5 , 7 7}$ & 6,04 & 6,23 & 2,38 & 3,74 & $\mathbf{5 , 7 7}$ & 6,04 & 6,23 \\
0,50 & 4,96 & 7,93 & $\mathbf{1 0 , 6 6}$ & 11,96 & 12,10 & 5,32 & 8,45 & $\mathbf{1 0 , 5 6}$ & 12,39 & 12,76 \\
1,00 & 5,21 & 10,92 & $\mathbf{1 7 , 7 3}$ & 20,62 & 20,55 & 7,04 & 10,71 & $\mathbf{1 6 , 5 9}$ & 18,75 & 19,81 \\
1,50 & 5,79 & 12,68 & $\mathbf{2 1 , 6 3}$ & 30,50 & 32,16 & 4,50 & 12,83 & $\mathbf{2 0 , 0 8}$ & 25,32 & 25,51 \\
\hline
\end{tabular}

É importante salientar que, os ligantes asfálticos avaliados não apresentam diferenças percentuais superiores ao valor de $75 \%$ estipulado pela norma AASHTO MP19, sendo que as amostras com adições de 1,5\% de PPA e 1,5\% de PA85 são os ligante asfálticos com valor de $\mathrm{J}_{\mathrm{nr}}$, $\mathrm{d}_{\text {iff }}$ mais elevados, apesar de distantes do valor estipulado pela norma. As menores diferenças percentuais, quando analisado o grupo com adição do modificador PPA, são ligante asfáltico de base. Para o grupo com adição de PA85, o ligante de base também apresenta as menores diferenças percentuais em todas as temperaturas. Ao analisar o $\mathrm{J}_{\mathrm{nr}}, \mathrm{d}_{\mathrm{iff}}$ na temperatura do pavimento adotado no presente trabalho $\left(64^{\circ} \mathrm{C}\right)$, nota-se que a sensibilidade à tensão aumenta com o aumento do teor dos ácidos. Ao comparar os dois grupos, pode-se observar que as amostras com adição de PPA são mais sensíveis à tensão do que as amostras modificadas com PA85, pois apresentam diferenças percentuais maiores. 
Quando comparado o comportamento dos dois tipos de ligante asfálticos utilizados em relação à sensibilidade ao incremento do nível de tensão, Tabela 34 e Tabela 39 pode-se afirmar que o ligante asfáltico de base proveniente da Replan é mais sensível à mudança de tensão do que o ligante asfáltico de base da Lubnor, tendo em vista os valores superiores de $\mathrm{J}_{\mathrm{nr}}$, $\mathrm{d}_{\text {iff. }}$ Quanto à adição dos modificadores, de maneira geral, o ligante asfáltico proveniente da Lubnor e modificado com $1,5 \%$ de ácido apresentou os maiores valores de $\mathrm{J}_{\mathrm{nr}}, \mathrm{d}_{\text {iff, }}$, apontando que este ligante modificado é o mais sensível ao aumento do nível de tensão. No entanto, para o ligante asfáltico proveniente da Replan modificado com os ácidos não se observa um comportamento definido, sendo variável com o tipo e teor do ácido e a temperatura.

$\mathrm{Na}$ tentativa de identificar o padrão de igualdade entre os teores de PPA e PA85 para a propriedade de recuperação, foi realizada uma modelagem, na temperatura de $64^{\circ} \mathrm{C}$ e no nível de tensão de 100Pa.

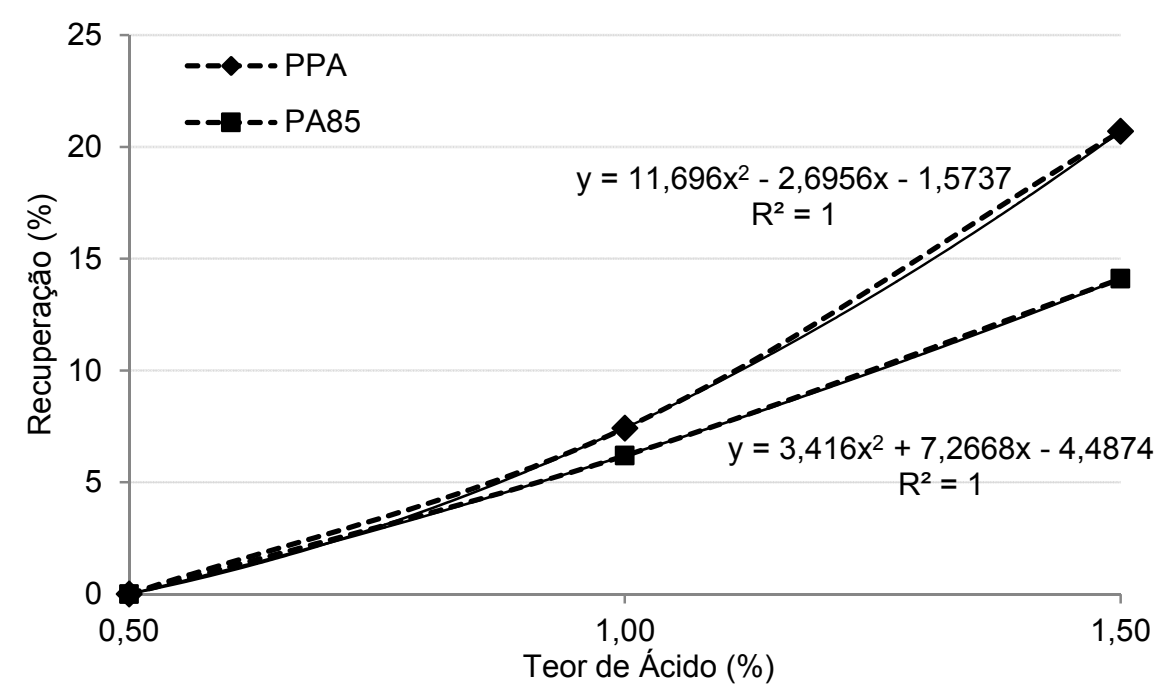

Figura 42 - Modelagem da Recuperação, na temperatura de $64^{\circ} \mathrm{C}$ e nível de tensão de $100 \mathrm{~Pa}$, para os ácidos PPA e PA85 com ligante asfáltico de base Lubnor.

Na Figura 42 é apresentado o gráfico de modelagem dessa propriedade para ambos os ácidos, para o ligante asfáltico de base proveniente da Lubnor. Mediante as formulações encontradas pode-se constatar que, à luz da recuperação, que a adição de 1,0\% de PPA corresponde a $1,1 \%$ de PA85, e por fim que a adição de 1,5\% de PPA corresponde a 1,9\% de PA85. Sendo assim, a variação percentual no teor dos ácidos foi de $0,1 \%$ e $0,4 \%$ respectivamente. Cabe destacar que, no teor de $0,5 \%$ o valor da recuperação para os dois ácidos é zero.

Na tentativa de identificar o padrão de igualdade entre os teores de PPA e PA85 para a compliância não recuperável, foi realizada uma modelagem, na temperatura de $64^{\circ} \mathrm{C}$ e na 
tensão de 100Pa. Na Figura 43 é apresentado o gráfico de modelagem dessa propriedade para ambos os ácidos. Mediante as formulações encontradas pode-se constatar que, para a compliância não recuperável, as proporções foram similares às encontradas para propriedade de recuperação sendo que a adição de $0,5 \%$ de PPA corresponde a $0,53 \%$ de PA85, e a adição de $1,0 \%$ de PPA corresponde a $1,1 \%$ de PA85, e por fim, a adição de 1,5\% de PPA corresponde a $1,9 \%$ de PA85. Sendo assim, a variação percentual no teor dos ácidos foi de $0,03 \%, 0,1 \%$ e $0,4 \%$ respectivamente.

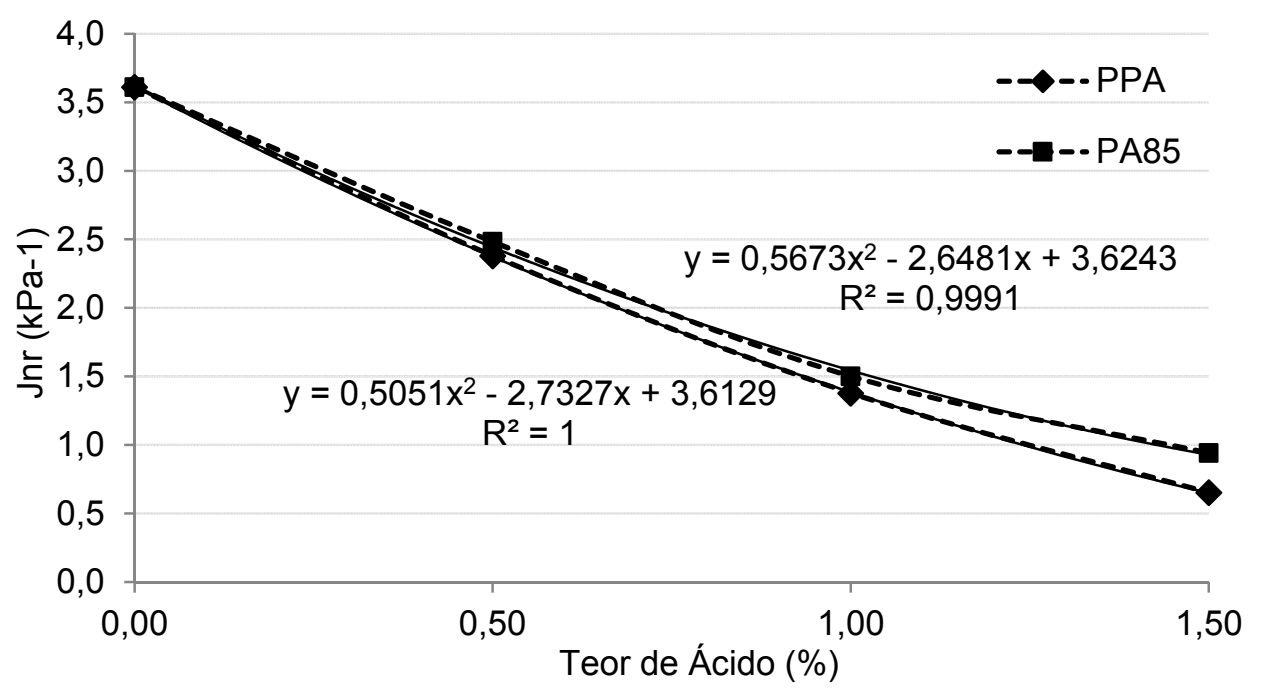

Figura 43 - Modelagem da Compliância não recuperável, na temperatura de $64^{\circ} \mathrm{C}$ e no nível de tensão de 100Pa, para os ácidos PPA e PA85 com ligante asfáltico de base Lubnor.

Com o intuito de classificar os ligantes asfálticos selecionados para presente pesquisa quanto ao critério de tráfego do FHWA que leva em consideração os valores de Jnr a 3200Pa e na temperatura máxima do pavimento na condição de envelhecido em curto prazo, a Tabela 40 apresenta a classificação dos ligantes asfálticos provenientes da Lubnor. Com exceção da temperatura de $52^{\circ} \mathrm{C}$, pode-se dizer que para esse ligante asfáltico de base a adição de ambos os modificadores, à luz do suporte de tráfego, seria interessante somente os ligantes asfálticos modificados com adições acima de 1,0\%. Ao analisar a temperatura de interesse $\left(64^{\circ} \mathrm{C}\right)$, notase que o para o teor de 1,0\% dos ácidos, ambos suportam um tráfego pesado (número de solicitações maior que 10 milhões). No entanto, o ligante asfáltico modificado com $1,5 \%$ de PPA pode suportar um tráfego muito pesado (número de solicitações maior que 30 milhões), enquanto o ligante asfáltico modificado com 1,5\% de PA85 suportaria um tráfego pesado. 
Tabela 40 - Classificação dos ligantes asfálticos segundo o critério de tráfego do FHWA, para o ligante asfáltico base Lubnor.

\begin{tabular}{ccccccccccc}
\hline \multirow{2}{*}{ Teor } & \multicolumn{9}{c}{$\mathrm{PPA}$} \\
\cline { 2 - 11 } & $52^{\circ} \mathrm{C}$ & $58^{\circ} \mathrm{C}$ & $\mathbf{6 4}{ }^{\circ} \mathbf{C}$ & $70^{\circ} \mathrm{C}$ & $76^{\circ} \mathrm{C}$ & $52^{\circ} \mathrm{C}$ & $58^{\circ} \mathrm{C}$ & $\mathbf{6 4} 4^{\circ} \mathbf{C}$ & $70^{\circ} \mathrm{C}$ & $76^{\circ} \mathrm{C}$ \\
\hline 0,00 & $\mathrm{~V}$ & $\mathrm{H}$ & $\mathbf{S}$ & - & - & $\mathrm{V}$ & $\mathrm{H}$ & $\mathbf{S}$ & - & - \\
0,50 & $\mathrm{E}$ & $\mathrm{H}$ & $\mathbf{S}$ & - & - & $\mathrm{E}$ & $\mathrm{H}$ & $\mathbf{S}$ & - & - \\
1,00 & $\mathrm{E}$ & $\mathrm{V}$ & $\mathbf{H}$ & $\mathrm{S}$ & - & $\mathrm{E}$ & $\mathrm{E}$ & $\mathbf{H}$ & - & - \\
1,50 & $\mathrm{E}$ & $\mathrm{E}$ & $\mathbf{V}$ & $\mathrm{S}$ & - & $\mathrm{E}$ & $\mathrm{E}$ & $\mathbf{H}$ & $\mathrm{S}$ & - \\
\hline
\end{tabular}

Onde: $\mathrm{S}=$ padrão; $\mathrm{H}=$ pesado; $\mathrm{V}=$ muito pesado e $\mathrm{E}=$ extremamente pesado.

$\mathrm{Na}$ Tabela 41 estão apresentadas as classificações dos ligantes asfálticos provenientes da Replan. Para temperatura de $52^{\circ} \mathrm{C}$ o comportamento de todos os ligantes asfálticos é igual com suporte de um tráfego extremamente pesado (número de solicitações maior que 100 milhões), independente do modificador. Na temperatura de interesse $\left(64^{\circ} \mathrm{C}\right)$ pode-se observar que, de maneira geral, para este ligante asfáltico de base a adição de ambos os ácidos foi benéfica para o suporte de tráfego. Apenas os modificados com o PPA não apresentaram diferenças nos teores de $0,5 \%$ e $1,0 \%$.

Quando comparados os dois ligantes asfálticos, nota-se um melhor comportamento em relação ao suporte de tráfego para o ligante asfáltico de base proveniente de Replan, mesmo sem modificação. Enquanto para o ligante asfáltico proveniente da Lubnor o teor de modificador mínimo, para se obter melhores resultados de suporte de tráfego, é de 1,0\%, para o ligante asfáltico de base proveniente da Replan qualquer adição deste modificador proporciona melhoria no suporte de tráfego.

Tabela 41 - Classificação dos ligantes asfálticos segundo o critério de tráfego do FHWA, para o ligante asfáltico base Replan

\begin{tabular}{|c|c|c|c|c|c|c|c|c|c|c|}
\hline \multirow{2}{*}{ Teor } & \multicolumn{5}{|c|}{ PPA } & \multicolumn{5}{|c|}{ PA85 } \\
\hline & $52^{\circ} \mathrm{C}$ & $58^{\circ} \mathrm{C}$ & $64^{\circ} \mathrm{C}$ & $70^{\circ} \mathrm{C}$ & $76^{\circ} \mathrm{C}$ & $52^{\circ} \mathrm{C}$ & $58^{\circ} \mathrm{C}$ & $64^{\circ} \mathrm{C}$ & $70^{\circ} \mathrm{C}$ & $76^{\circ} \mathrm{C}$ \\
\hline 0,00 & $E$ & $\mathrm{H}$ & $S$ & - & - & $E$ & $\mathrm{H}$ & $S$ & - & - \\
\hline 0,50 & $E$ & $E$ & H & $S$ & - & $E$ & V & H & - & - \\
\hline 1,00 & $E$ & $E$ & H & $\mathrm{H}$ & S & $E$ & $E$ & V & $\mathrm{H}$ & - \\
\hline 1,50 & $E$ & $E$ & $E$ & $E$ & V & $E$ & $E$ & $E$ & V & $S$ \\
\hline
\end{tabular}

Onde: $\mathrm{S}=$ padrão; $\mathrm{H}=$ pesado; $\mathrm{V}=$ muito pesado e $\mathrm{E}=$ extremamente pesado.

Em relação aos ácidos, no ligante asfáltico de base Lubnor, observa-se que a adição de 1,5\% de PA85 não melhorou esta propriedade, comportamento diferente do suporte de tráfego apresentado pelo ligante asfáltico modificado com PPA. No entanto, para o ligante asfáltico de base proveniente da Replan o comportamento do ligante asfáltico modificado com $1,0 \%$ de PA85 apresentou suporte de tráfego superior quando comparado ao ligante asfáltico 
modificado com o mesmo teor de PPA. Porém, é importante salientar, que a adição de qualquer modificador melhora o comportamento do material, quando comparado com o ligante asfáltico de base.

\subsubsection{Ensaio Tolerância ao Dano por Fadiga}

\subsubsection{Análise do índice de tolerância ao dano pelo parâmetro af}

Este ensaio foi analisado com base no modelo de fratura. No critério de ruptura Hintz (2012) propôs analisar a determinação da tolerância ao dano por meio do ponto mínimo da taxa de crescimento da fissura $\left(a_{f}\right)$, que corresponde ao ponto anterior ao rápido aumento na taxa de crescimento da fissura. É desejável se obter um comprimento da fissura na falha maior, uma vez que, isto indica que o ligante asfáltico resiste a um fissuramento maior antes da rápida propagação da fissura.

Para ilustrar a determinação dos valores do $a_{f}$, na Figura 44 e Figura 45, estão apresentadas a variação do crescimento da fissura em função do número de ciclos versus o comprimento da fissura do Replan modificados com o ácido PA85 e PPA, respectivamente, a $25^{\circ} \mathrm{C}$, nas condições de envelhecimento em curto prazo.

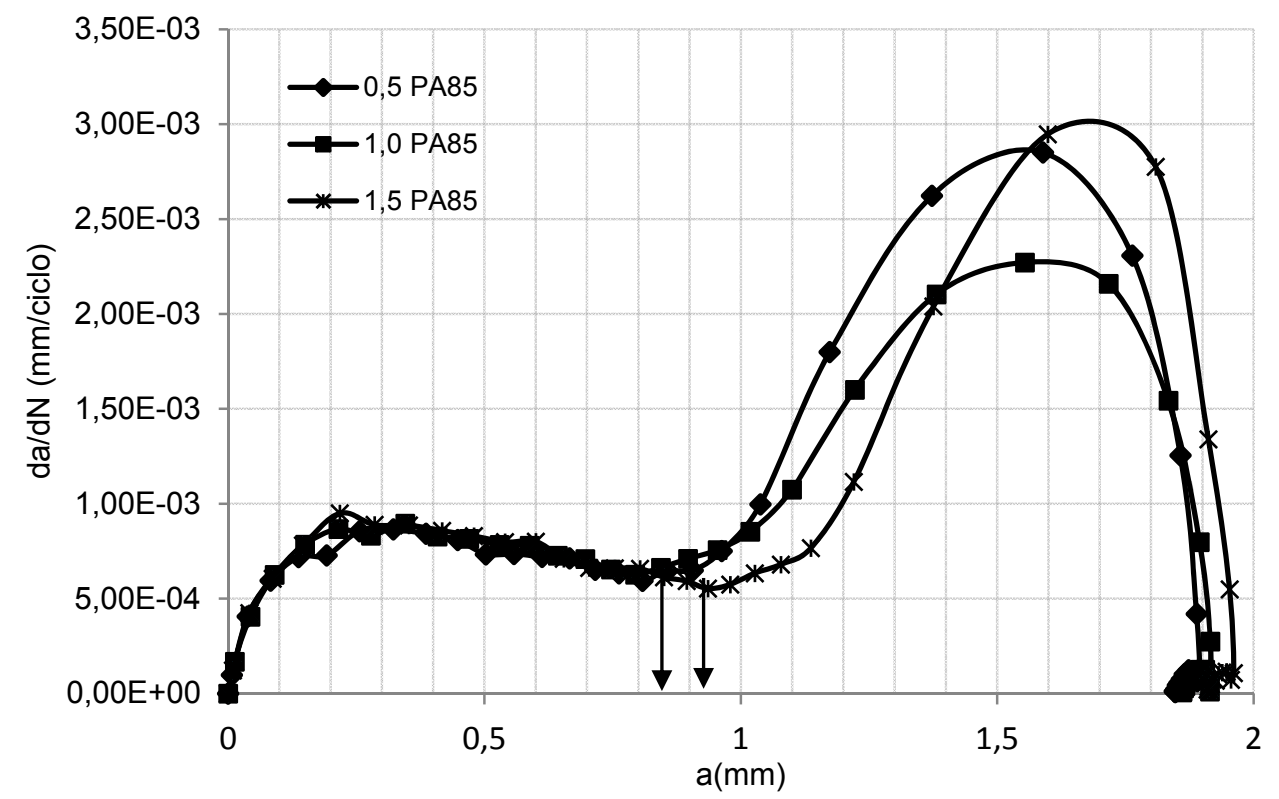

Figura 44 - Valores de af para amostras com adição de PA85 no ligante asfáltico Replan, envelhecido no RTFOT.

Pode-se observar que para valores baixos de concentração de ácido 0,5\% e 1,0\%, o valor médio de $a_{\mathrm{f}}$ está em torno de $0,84 \mathrm{~mm}$, para ambas as amostras. Para amostras com 
adição de 1,5\% de PA85 nota-se um comprimento da trinca na ruptura por fadiga de $0,91 \mathrm{~mm}$, um pouco maior que os demais teores estudados.

Assim como as misturas com adição de PA85, para concentrações de 0,5 e 1,0\% de ácido PPA, os valores referentes ao af são próximos, neste caso o valor médio é de $0,83 \mathrm{~mm}$. No entanto, para esse tipo de modificador para concentração de $1,5 \%$ observa-se um valor próximo de $1,0 \mathrm{~mm}$, um pouco mais representativo ao se comparar a mesma concentração com adição do ácido PA85.

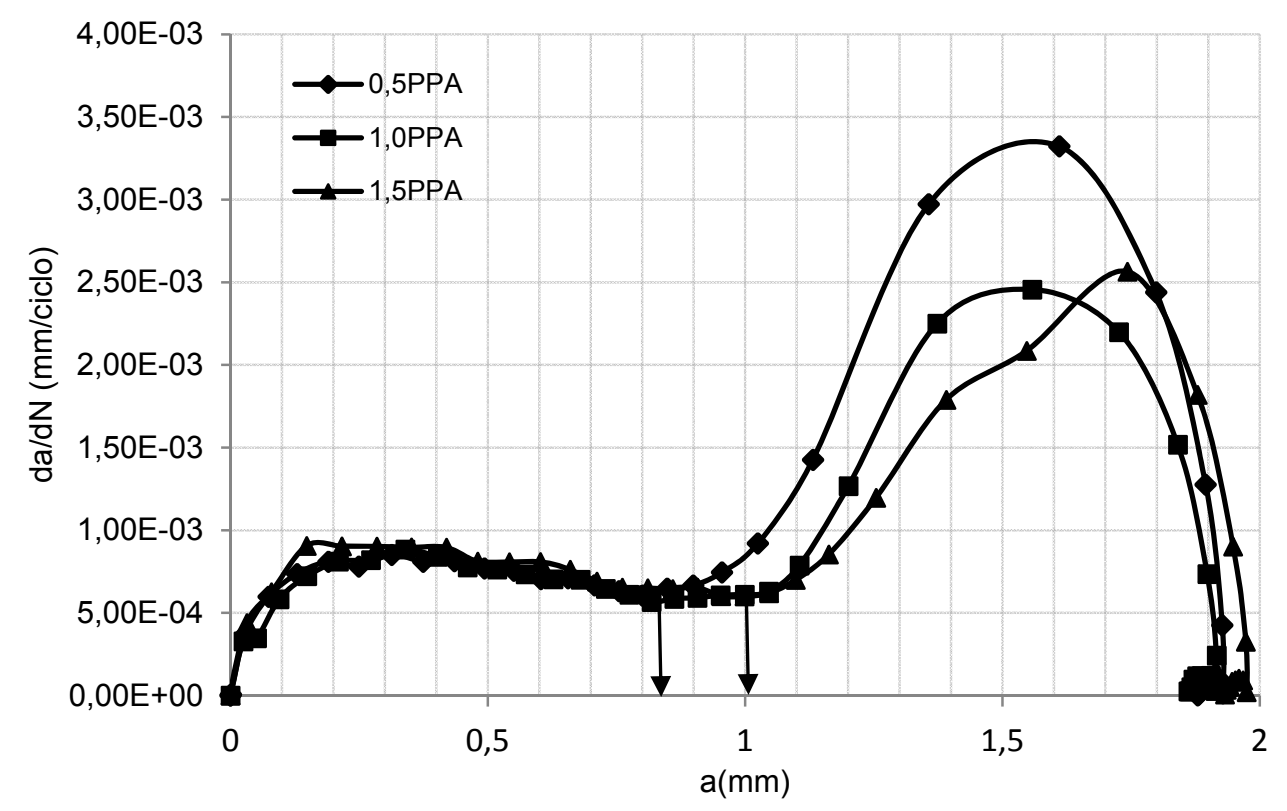

Figura 45 - Valores de af para amostras com adição de PPA no ligante asfáltico Replan, envelhecido no RTFOT.

Os valores de $a_{f}$ de todos os ligantes asfálticos da Replan e da Lubnor puro e modificados, na condição envelhecida em curto e em longo prazos, estão apresentados na Tabela 42. De maneira geral, os ligantes asfálticos da Replan modificados apresentam, com o aumento dos teores dos modificadores, valores de $a_{f}$ superiores aos do ligante asfáltico puro, independentemente do tipo de ácido adicionado e da condição de envelhecimento realizada. Pode-se observar que, nas amostras envelhecidas em curto prazo, no teor de $0,5 \%$ o valor de $a_{f}$ foi superior para a amostra modificada com o PA85 $(0,83 \mathrm{~mm})$ do que para a amostra com PPA $(0,78 \mathrm{~mm})$, porém este valor é bem próximo ao encontrado para o mesmo modificador no teor de 1,0\% (0,85mm). Nas amostras modificadas com 1,0\% dos dois ácidos foram encontrados valores iguais quanto à tolerância à fadiga; para o teor de 1,5\% nota-se um valor de $0,03 \mathrm{~mm}$ maior para as amostras modificadas com o PPA. 
Tabela 42 - Comprimento da fissura na ruptura af $(\mathrm{mm})$ para todos os ligantes asfálticos.

\begin{tabular}{ccccc}
\hline \multirow{2}{*}{ Teor } & \multicolumn{2}{c}{ Replan } & \multicolumn{2}{c}{ Lubnor } \\
\cline { 2 - 5 } & RTFOT & PAV & RTFOT & PAV \\
\hline Puro & 0,73 & 0,99 & 0,61 & 0,71 \\
0,5PA85 & 0,83 & 1,10 & 0,64 & 0,71 \\
1,0PA85 & 0,85 & 1,10 & 0,75 & 0,77 \\
1,5PA85 & 0,91 & 1,12 & 0,78 & 0,82 \\
0,5 PPA & 0,78 & 1,03 & 0,64 & 0,73 \\
1,0 PPA & 0,85 & 1,03 & 0,77 & 0,76 \\
1,5PPA & 0,94 & 1,19 & 0,80 & 0,84 \\
\hline
\end{tabular}

Em relação às respostas obtidas nas amostras condicionadas em longo prazo (PAV), observa-se que as amostras modificadas com 0,5\% e 1,0\% dos ácidos apresentam valores semelhantes de $a_{\mathrm{f}}$, e valores um pouco maiores para concentração de 1,5\%. Cabe destacar que, o comportamento em relação à tolerância à fadiga para as amostras com 0,5\% e 1,0\% dos ácidos são similares, independentemente do tipo de ácido. A maior diferença foi encontrada para os teores de $1,5 \%$, com valor de $a_{\mathrm{f}} 0,07 \mathrm{~mm}$ maior para a amostra modificada com PPA, quando comparada com a amostra modificada com PA85 para o mesmo teor. Ao comparar as amostras, na condição de envelhecimento RTFOT e PAV, observa-se que os valores de $a_{f}$ encontrados demostram que o envelhecimento foi benéfico ao material, pois os maiores comprimentos de fissuras na ruptura por fadiga foram encontrados para as amostras envelhecidas em longo prazo (PAV), com maiores incrementos para as amostras modificadas com $1,5 \%$ dos ácidos.

Quanto às amostras com o ligante asfáltico da Lubnor, envelhecidas em curto prazo, pode-se dizer que a adição de qualquer tipo de ácido proporciona um comportamento favorável à tolerância à fadiga, pois o comprimento da fissura na ruptura por fadiga aumenta à medida que se aumenta o teor dos modificadores. No entanto, para este ligante asfáltico de base não é possível observar diferença nos valores de $a_{f}$ quando se comparam os dois modificadores. E assim como no ligante asfáltico proveniente da Replan, o envelhecimento em longo prazo (PAV) proporcionou maiores valores de $a_{f}$ para os materiais.

Pode-se ainda destacar que, o efeito dos ácidos é maior nas amostras com o ligante asfáltico da Replan do que nas amostras com o ligante asfáltico da Lubnor, pois apresentam maiores valores de $\mathrm{a}_{\mathrm{f}}$, o que representa maior tolerância à fadiga. Quando comparado os dois tipos de modificadores (PA85 e PPA), pode-se perceber comportamento semelhante, com valores levemente superiores para o modificador PPA, mais significativo para concentração de $1,5 \%$ desse ácido. 


\subsubsection{Análise do dano contínuo viscoelástico (VECD)}

Nesta análise foram determinados os coeficientes do modelo de fadiga, à $25^{\circ} \mathrm{C}$, na condição de envelhecimento a curto e longo prazo. Foi obtido o modelo de fadiga para cada material, conforme a Figura 14, e com o modelo $N_{f}=A_{35} \times(\gamma)^{B}$, onde o $N_{f}$ é o número de ciclos para apresentar a falha, $\gamma$ a tensão cisalhante aplicada, os parâmetros $A_{35}$ e $B$ determinados experimentalmente. Cabe destacar que, o parâmetro $A_{35}$ corresponde ao critério de ruptura definido pela redução de $35 \%$ do valor do módulo inicial do material, proposto por Johnson (2010). Com auxílio do modelo pode-se estimar o valor de $\mathrm{N}_{\mathrm{f}}$ em níveis de deformações diferentes, sendo os baixos níveis de deformação comparados a uma estrutura espessa de pavimento, enquanto um nível alto de deformação corresponde a uma estrutura esbelta.

O parâmetro $A_{35}$ está relacionado à variação da integridade do material em função do dano acumulado, enquanto o parâmetro $B$ esta associado à sensibilidade ao nível de deformação. Neste contexto, seria favorável encontrar maiores valores de $A_{35}$, uma vez que, desta maneira os materiais estariam preservando sua integridade ao longo do número de ciclos. Quanto ao parâmetro B, altos valores desse parâmetro indicam que a vida de fadiga dos materiais diminui a uma taxa maior quando se aumenta a amplitude de deformação, e baixos valores de $\mathrm{B}$ apontam que a vida de fadiga dos materiais diminui a uma taxa menor.

$\mathrm{Na}$ Tabela 43 e Tabela 44 estão apresentados os valores dos parâmetros $A_{35}$ e $B$ do modelo de fadiga, obtidos a partir da análise VECD dos resultados do ensaio LAS modificado, para as amostras produzidas com o ligante asfáltico proveniente da Replan e Lubnor, respectivamente.

Tabela 43 - Parâmetro A e B para o ligante asfáltico proveniente da Replan puro e modificados.

\begin{tabular}{ccccc}
\hline \multirow{2}{*}{ Teores } & \multicolumn{2}{c}{ RTFOT } & \multicolumn{2}{c}{ PAV } \\
& $\mathrm{A}_{35}$ & $\mathrm{~B}$ & $\mathrm{~A}_{35}$ & $\mathrm{~B}$ \\
\hline 0,0 & $9,32 \mathrm{E}+04$ & $-2,76$ & $2,08 \mathrm{E}+05$ & $-3,29$ \\
0,5PA85 & $1,63 \mathrm{E}+05$ & $-2,90$ & $3,87 \mathrm{E}+05$ & $-3,45$ \\
0,5PPA & $1,87 \mathrm{E}+05$ & $-2,86$ & $9,04 \mathrm{E}+05$ & $-3,89$ \\
1,0PA85 & $2,61 \mathrm{E}+05$ & $-3,08$ & $5,96 \mathrm{E}+05$ & $-3,78$ \\
1,0PPA & $3,97 \mathrm{E}+05$ & $-3,25$ & $7,35 \mathrm{E}+05$ & $-3,95$ \\
1,5PA85 & $6,81 \mathrm{E}+05$ & $-3,50$ & $2,51 \mathrm{E}+06$ & $-4,13$ \\
1,5PPA & $8,59 \mathrm{E}+05$ & $-3,66$ & $3,06 \mathrm{E}+06$ & $-4,47$ \\
\hline
\end{tabular}

Estes valores são valores médios dos resultados de todos os ligantes asfálticos estudados. Pode-se observar que o parâmetro $A_{35}$ aumenta com a adição dos ácidos enquanto o parâmetro $B$ diminui. Isto mostra que ocorreu um descolamento das curvas de fadiga para cima (aumento de A) e uma diminuição da declividade da curva (diminuição de B). Quando comparadas as amostras produzidas com os dois ligantes asfálticos de base, 
pode-se perceber que os ligantes asfálticos da Replan apresentam maiores valores de $A_{35} \mathrm{e}$ menores de $\mathrm{B}$, e também são mais sensíveis à adição dos modificadores.

Tabela 44 - Parâmetro A e B para o ligante asfáltico proveniente da Lubnor puro e modificados.

\begin{tabular}{ccccc}
\hline \multirow{2}{*}{ Teores } & \multicolumn{2}{c}{ RTFOT } & \multicolumn{2}{c}{ PAV } \\
& A & B & A & B \\
\hline 0,0 & $4,75 E+04$ & $-2,25$ & $6,09 E+04$ & $-2,67$ \\
0,5PA85 & $6,08 E+04$ & $-2,42$ & $1,00 E+05$ & $-2,91$ \\
0,5PPA & $6,07 E+04$ & $-2,43$ & $1,42 E+05$ & $-2,96$ \\
1,0PA85 & $8,48 E+04$ & $-2,56$ & $1,58 E+05$ & $-3,13$ \\
1,0PPA & $8,29 E+04$ & $-2,61$ & $2,04 E+05$ & $-3,18$ \\
1,5PA85 & $1,24 E+05$ & $-2,75$ & $1,84 E+05$ & $-3,36$ \\
1,5PPA & $1,45 E+05$ & $-2,86$ & $3,17 E+05$ & $-3,46$ \\
\hline
\end{tabular}

Para melhor observar o efeito dos ácidos nos ligantes asfálticos de base estudados, nas figuras que seguem estão plotados os gráficos de vidas de fadiga $\left(N_{f}\right)$, em função da amplitude de deformação, obtidas a partir dos ensaios a $25^{\circ} \mathrm{C}$, envelhecidos em curto (RTFOT) e em longo prazo (PAV). O número de ciclos na falha por fadiga indica o volume de tráfego que o material suportaria, em função da deformação aplicada, enquanto a deformação está atrelada às condições em que os materiais poderiam ser submetidos em termos de estrutura do pavimento.

Na Figura 46 pode-se observar a variação do número de ciclos na ruptura em função da amplitude de deformação para os ligantes asfálticos da Replan envelhecidos no RTFOT modificados com PA85. A adição do PA85 é benéfica somente quando o pavimento estiver sujeito a pequenas deformações, observando-se os valores maiores de $\mathrm{N}_{\mathrm{f}}$. Cabe destacar que, para baixas deformações, os valores de $N_{f}$ para as amostras modificadas com $0,5 \%$ e $1,0 \%$ de PA85 são próximos. No entanto, a partir da amplitude de deformação de $10 \%$, podese observar outro comportamento, os ligantes asfálticos modificados passam a apresentar valores inferiores de $\mathrm{N}_{\mathrm{f}}$ quando comparados com o ligante asfáltico de base, exceto para as amostras modificadas com $0,5 \%$ de PA85 que apresentam valores similares aos do ligante asfáltico de base. 


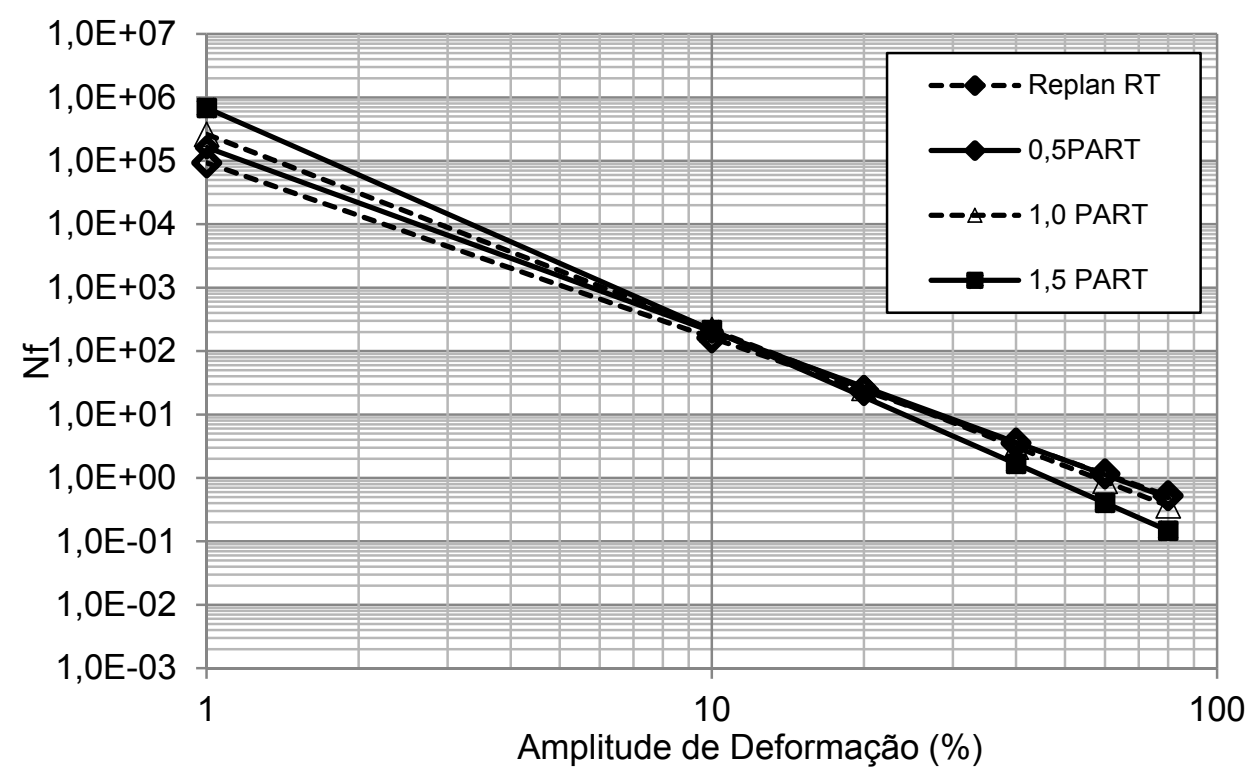

Figura 46 - Variação do número de ciclos na ruptura em função da amplitude de deformação para os ligantes asfálticos da Replan envelhecidos no RTFOT modificados com PA85.

Na Figura 47 pode-se observar a variação do número de ciclos na ruptura em função da amplitude de deformação para os ligantes asfálticos da Replan envelhecidos no PAV modificados com PA85.

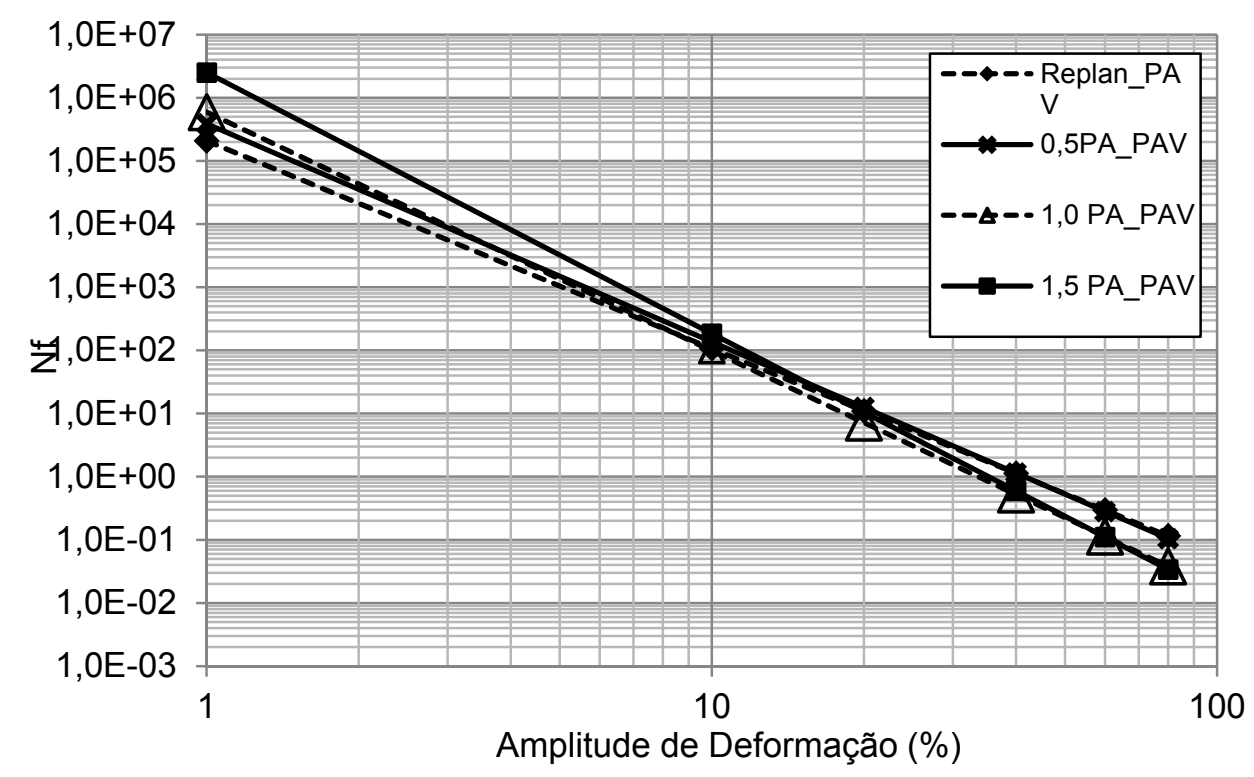

Figura 47 - Variação do número de ciclos na ruptura em função da amplitude de deformação para os ligantes asfálticos da Replan envelhecidos no PAV modificados com PA85.

Nota-se um comportamento semelhante às amostras envelhecidas em curto prazo. A adição do modificador é benéfica em deformações baixas, e somente a adição de $0,5 \%$ de PA85 apresentou comportamento próximo ao ligante asfáltico de base em deformações altas. 
Sendo assim, a adição deste modificador melhora o comportamento do material frente à resistência a fadiga em baixas deformações e não proporciona nenhum tipo de melhoria em altas deformações.

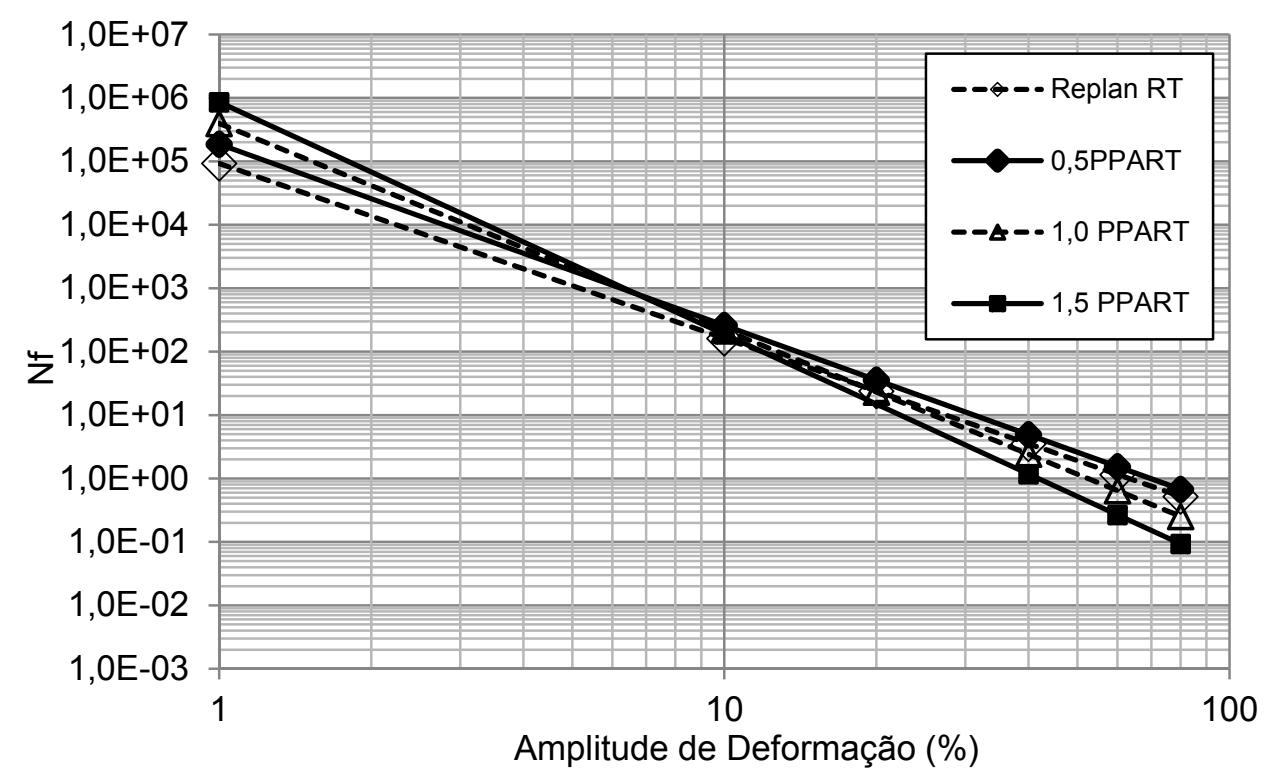

Figura 48 - Variação do número de ciclos na ruptura em função da amplitude de deformação para os ligantes asfálticos da Replan envelhecidos no RTFOT modificados com PPA.

Na Figura 48 pode-se observar a variação do número de ciclos na ruptura em função da amplitude de deformação para os ligantes asfálticos da Replan envelhecidos no RTFOT modificados com PPA. Nota-se comportamento semelhante ao encontrado para as amostras com adição de PA85. A adição do PPA também é benéfica somente quando o pavimento estiver sujeito a pequenas deformações, onde observam-se valores maiores de $\mathrm{N}_{f}$. No entanto, a partir da amplitude de deformação de 10\%, o comportamento é alterado, os ligantes asfálticos modificados passam a apresentar valores inferiores de $\mathrm{N}_{\mathrm{f}}$ quando comparados com o ligante asfáltico de base; apenas as amostras modificadas com 0,5\% de PPA apresentam valores similares aos do ligante asfáltico de base. 


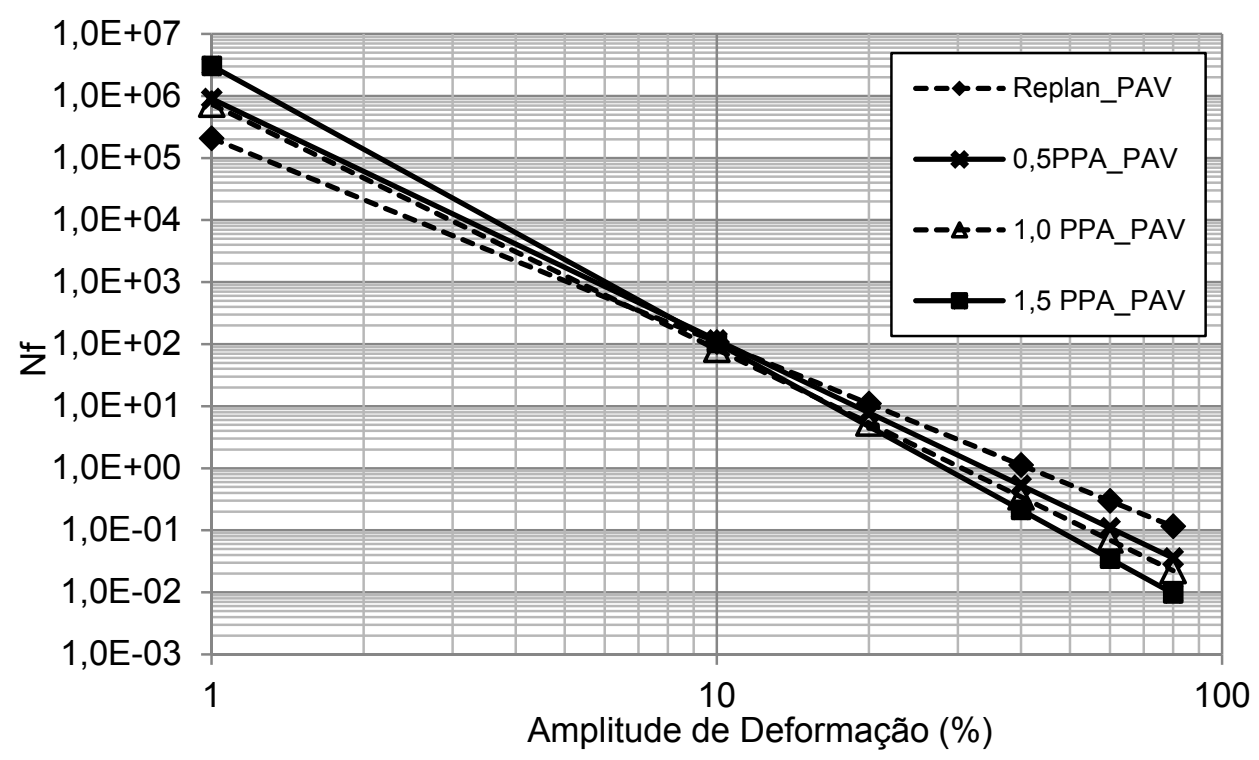

Figura 49 - Variação do número de ciclos na ruptura em função da amplitude de deformação para os ligantes asfálticos da Replan envelhecidos no PAV modificados com PPA.

A variação do número de ciclos na ruptura em função da amplitude de deformação para os ligantes asfálticos da Replan envelhecidos no PAV modificados com PPA, pode ser observada na Figura 49. De maneira geral, estas amostras apresentam comportamento semelhante às amostras envelhecidas em curto prazo. No entanto, pode-se observar que a baixas deformações as amostras com adição de $0,5 \%$ e $1,0 \%$ apresentam valores semelhantes de $\mathrm{N}_{\mathrm{f}}$. Mesmo assim, a adição do modificador é benéfica em deformações baixas; em altas deformações a adição do ácido não proporciona melhoras na resistência à fadiga, apresentando valores de $\mathrm{N}_{\mathrm{f}}$ inferiores ao ligante asfáltico de base. Nota-se ainda que nesta condição as amostras com adição de 0,5\% e 1,0\% também apresentam mesmo comportamento. Sendo assim, a adição deste modificador melhora o comportamento do material frente à resistência a fadiga em baixas deformações e não proporciona nenhum tipo de melhoria em altas deformações. Para este ligante asfáltico de base (Replan) nota-se comportamento semelhante, em relação à resistência à fadiga, de ambos os modificadores avaliados.

Na Figura 50 está apresentada a variação do número de ciclos na ruptura em função da amplitude de deformação para os ligantes asfálticos da Lubnor envelhecidos no RTFOT modificados com PA85. Nota-se que a adição do modificador proporciona maiores valores de $\mathrm{N}_{\mathrm{f}}$ em baixas deformações, porém em altas deformações apresenta valores de $\mathrm{N}_{\mathrm{f}}$ inferiores ao do ligante asfáltico de base. 


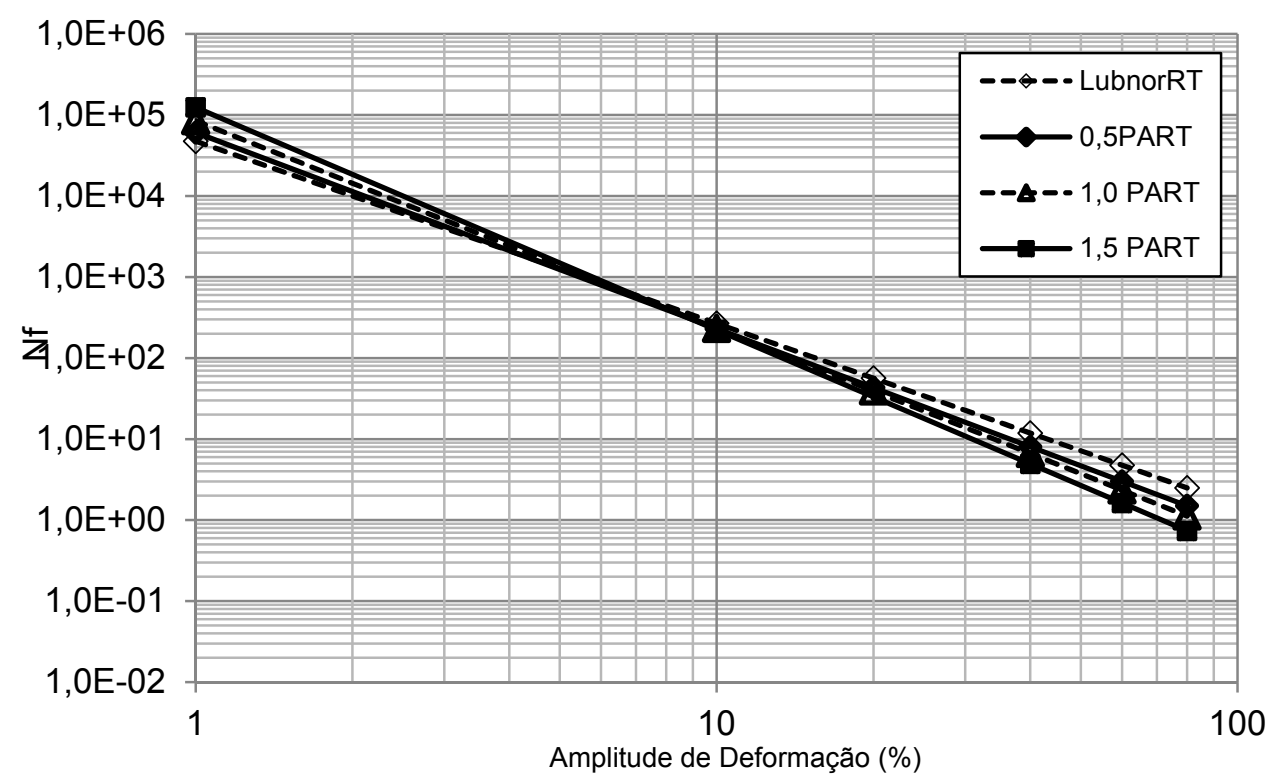

Figura 50 - Variação do número de ciclos na ruptura em função da amplitude de deformação para os ligantes asfálticos da Lubnor envelhecidos no RTFOT modificados com PA85.

A variação do número de ciclos na ruptura em função da amplitude de deformação para os ligantes asfálticos da Replan envelhecidos no PAV modificados com PA85, pode ser observada na Figura 51.

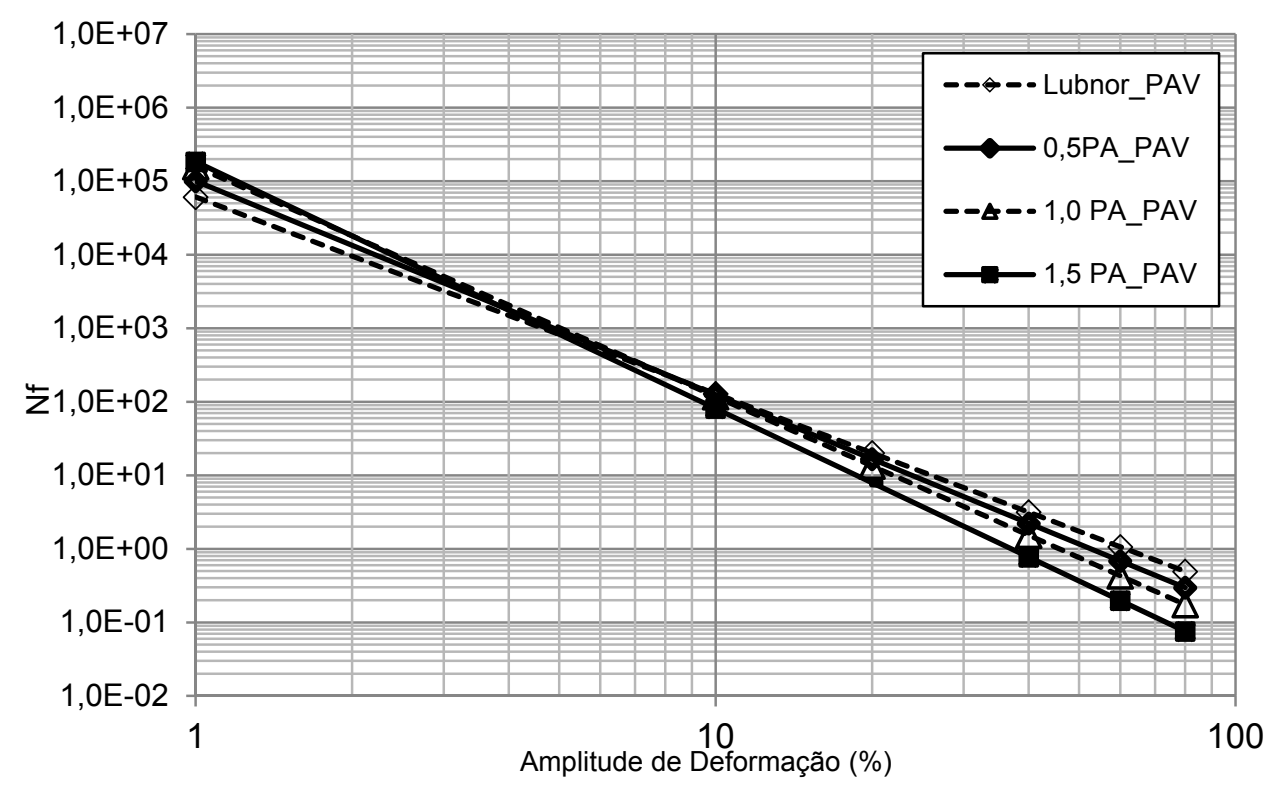

Figura 51 - Variação do número de ciclos na ruptura em função da amplitude de deformação para os ligantes asfálticos da Lubnor envelhecidos no PAV modificados com PA85.

Para esta condição, o comportamento é semelhante ao anterior, sendo importante salientar que a adição de 1,0\% e 1,5\% deste modificador proporcionam valores semelhantes 
de Nf a baixas deformações, apesar de serem benéficas à resistência à fadiga quando comparadas ao ligante asfáltico de base. No entanto, para altas deformações o aumento do teor deste modificador prejudica o comportamento dessas amostras frente a este parâmetro. Nota-se, neste caso, um comportamento pior destas amostras quando comparadas com as produzidas com o ligante asfáltico proveniente da Replan.

A variação do número de ciclos na ruptura em função da amplitude de deformação para os ligantes asfálticos da Lubnor, envelhecidos no RTFOT, modificados com PPA, pode ser observada na Figura 52. Para esta condição, o comportamento é semelhante ao comportamento das amostras modificadas com PA85, sendo importante salientar que a adição de 1,0\% deste modificador e do ligante asfáltico de base proporcionam valores semelhantes de $\mathrm{N}_{\mathrm{f}}$ a baixas deformações. No entanto, para altas deformações, o aumento do teor deste modificador prejudica o comportamento dessas amostras frente a este parâmetro.

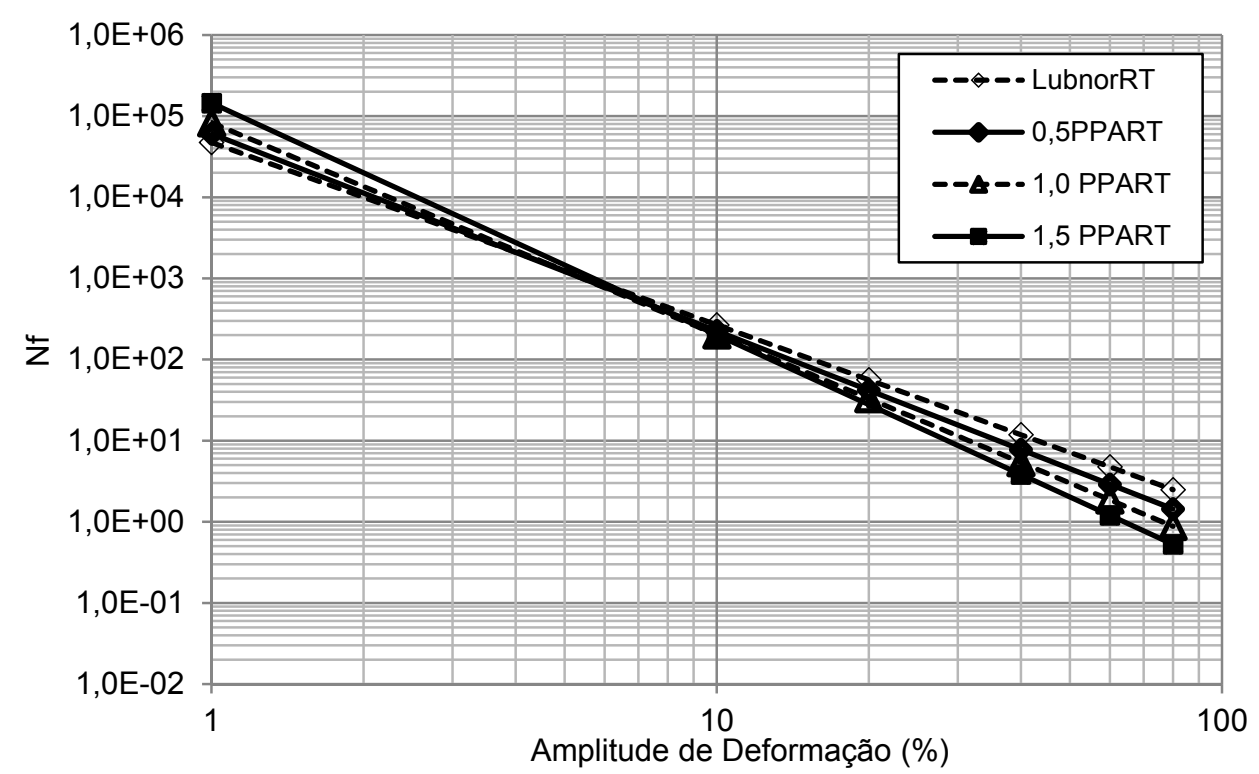

Figura 52 - Variação do número de ciclos na ruptura em função da amplitude de deformação para os ligantes asfálticos da Lubnor envelhecidos no RTFOT modificados com PPA

Na Figura 53 está apresentada a variação do número de ciclos na ruptura em função da amplitude de deformação para os ligantes asfálticos da Lubnor, envelhecidos no PAV, modificados com PPA. Nota-se um comportamento semelhantes à condição envelhecida em curto prazo. A adição do modificador benéfica em baixas deformações, e prejudicial em altas deformações.

Cabe destacar que, os valores encontrados de $\mathrm{N}_{\mathrm{f}}$ foram superiores no condicionamento em longo prazo (PAV), indicando que em baixas deformações a rigidez provocada pelo 
envelhecimento foi benéfica para esta propriedade, aumentando o número de solicitações até ocorrer a falha do material. No entanto, para deformações elevadas, o envelhecimento é prejudicial, pois proporciona valores de $\mathrm{N}_{\mathrm{f}}$ mais baixos até a falha do material. Os gráficos que mostram a comparação entre os dados das amostras envelhecidas em curto prazo e em longo prazo estão no Apêndice C e Apêndice D, para ligantes asfálticos da Replan e Lubnor, respectivamente.

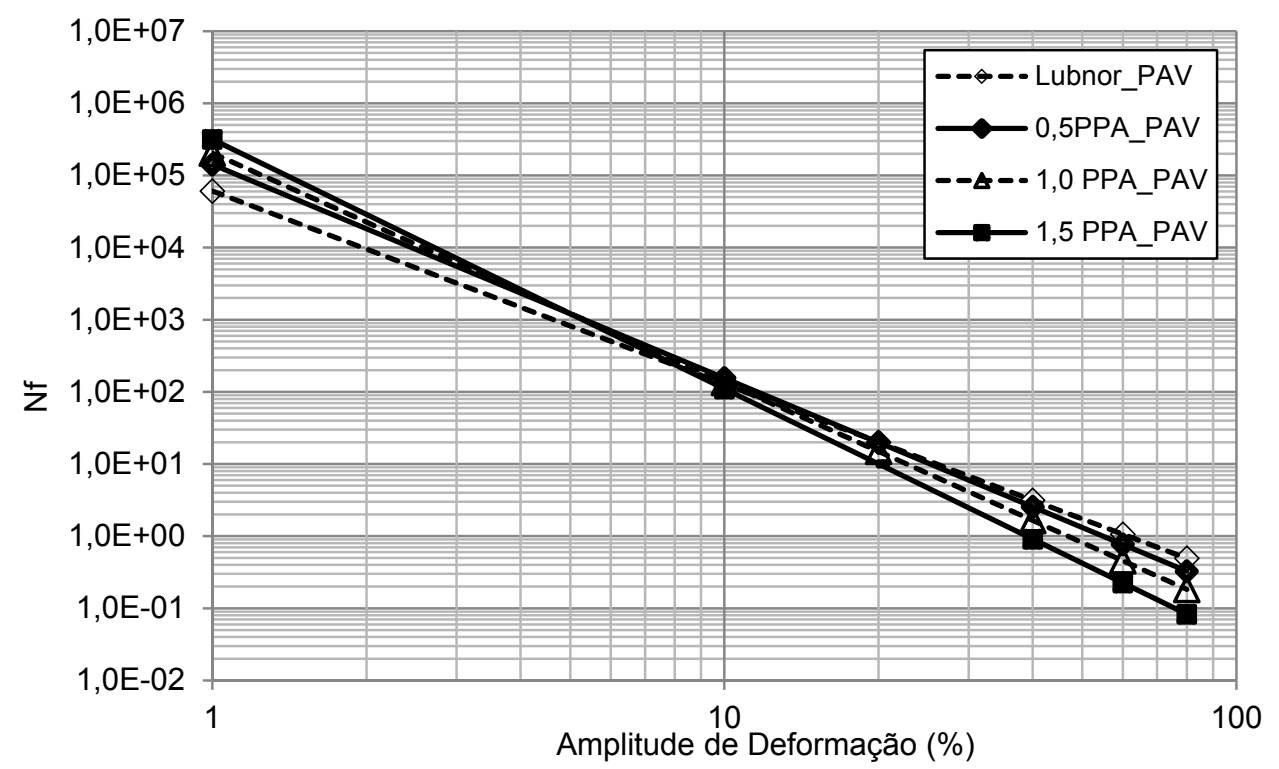

Figura 53 - Variação do número de ciclos na ruptura em função da amplitude de deformação para os ligantes asfálticos da Lubnor envelhecidos no PAV modificados com PPA.

Comparando estes resultados com os encontrados para o comprimento da fissura na ruptura $\left(\mathrm{a}_{\mathrm{f}}\right)$, onde também foi constatado que o envelhecimento em longo prazo é benéfico à resistência à fadiga, pode-se concluir com a ajuda dos modelos, que isto também deve ocorrer quando o material está em uma estrutura submetida a baixas deformações. 


\subsubsection{Resultados das Análises Estatísticas do Experimento Fatorial}

Foi executado, como explicado anteriormente, um experimento fatorial que considerou o efeito de quatro fatores, em diversos níveis, para os vários parâmetros analisados. Os fatores a serem considerados serão explicados para cada propriedade avaliada. Estão apresentados também a significância dos fatores e suas interações.

\subsubsection{Penetração}

Para esta propriedade foram avaliados quatro fatores, a saber: o tipo de ligante asfáltico em dois níveis (Replan e Lubnor), condicionamento em dois níveis (Virgem e RTFOT), tipo de ácido em dois níveis (PPA e PA85) e teor de ácido em quatro níveis $(0,0 ; 0,5$; 1,0; e 1,5\%). Na Tabela 45 está apresentada a análise da significância dos fatores e suas interações. Para a propriedade em questão pode-se verificar que todos os fatores e suas respectivas interações têm significância. Nota-se que o fator mais significativo para esta propriedade foi o condicionamento (maior valor de F), seguido pelo teor de ácido.

Tabela 45 - Análise da significância dos fatores e suas interações na penetração.

\begin{tabular}{|c|c|c|c|c|c|}
\hline Fatores & $\mathrm{GL}$ & $\begin{array}{l}\text { Soma dos } \\
\text { Quadrados }\end{array}$ & $\mathrm{F}$ & $\mathrm{P}$ & Significância \\
\hline Tipo de Ligante (A) & 1 & 270,40 & 131,7 & 0,000 & $\operatorname{sim}$ \\
\hline Condicionamento (B) & 1 & $12.924,00$ & 6293,52 & 0,000 & $\operatorname{sim}$ \\
\hline Tipo de Ácido (C) & 1 & 211,60 & 103,04 & 0,000 & $\operatorname{sim}$ \\
\hline Teor de Ácido (D) & 3 & $4.134,70$ & 671,14 & 0,000 & $\operatorname{sim}$ \\
\hline$(A) \times(B)$ & 1 & 837,20 & 407,7 & 0,000 & $\operatorname{sim}$ \\
\hline$(A) \times(C)$ & 1 & 44,10 & 21,48 & 0,000 & $\operatorname{sim}$ \\
\hline$(A) \times(D)$ & 3 & 485,10 & 78,75 & 0,000 & $\operatorname{sim}$ \\
\hline$(\mathrm{B}) \times(\mathrm{C})$ & 1 & 30,60 & 14,91 & 0,000 & $\operatorname{sim}$ \\
\hline (B) $\times(\mathrm{D})$ & 3 & $1.498,60$ & 243,26 & 0,000 & $\operatorname{sim}$ \\
\hline (C) $\times(D)$ & 3 & 73,10 & 11,87 & 0,000 & $\operatorname{sim}$ \\
\hline Erro & 141 & 289,60 & & & \\
\hline Total & 159 & $20.799,10$ & & & \\
\hline
\end{tabular}

$\mathrm{Na}$ Figura 54 podem ser vistas as influências dos fatores e suas interações nos valores da Penetração. Pode-se notar que o condicionamento é o fator com mais influência nesta propriedade, pois a condição RTFOT apresenta valores menores de penetração. Quanto aos ácidos, pode-se perceber comportamento semelhante, com valores um pouco maiores para o ácido PA85. Outro fator que provocou maiores alterações nos valores de penetração foram 
os teores de ácidos adicionados, sendo que os menores valores estão atribuídos a teores elevados de ácidos.

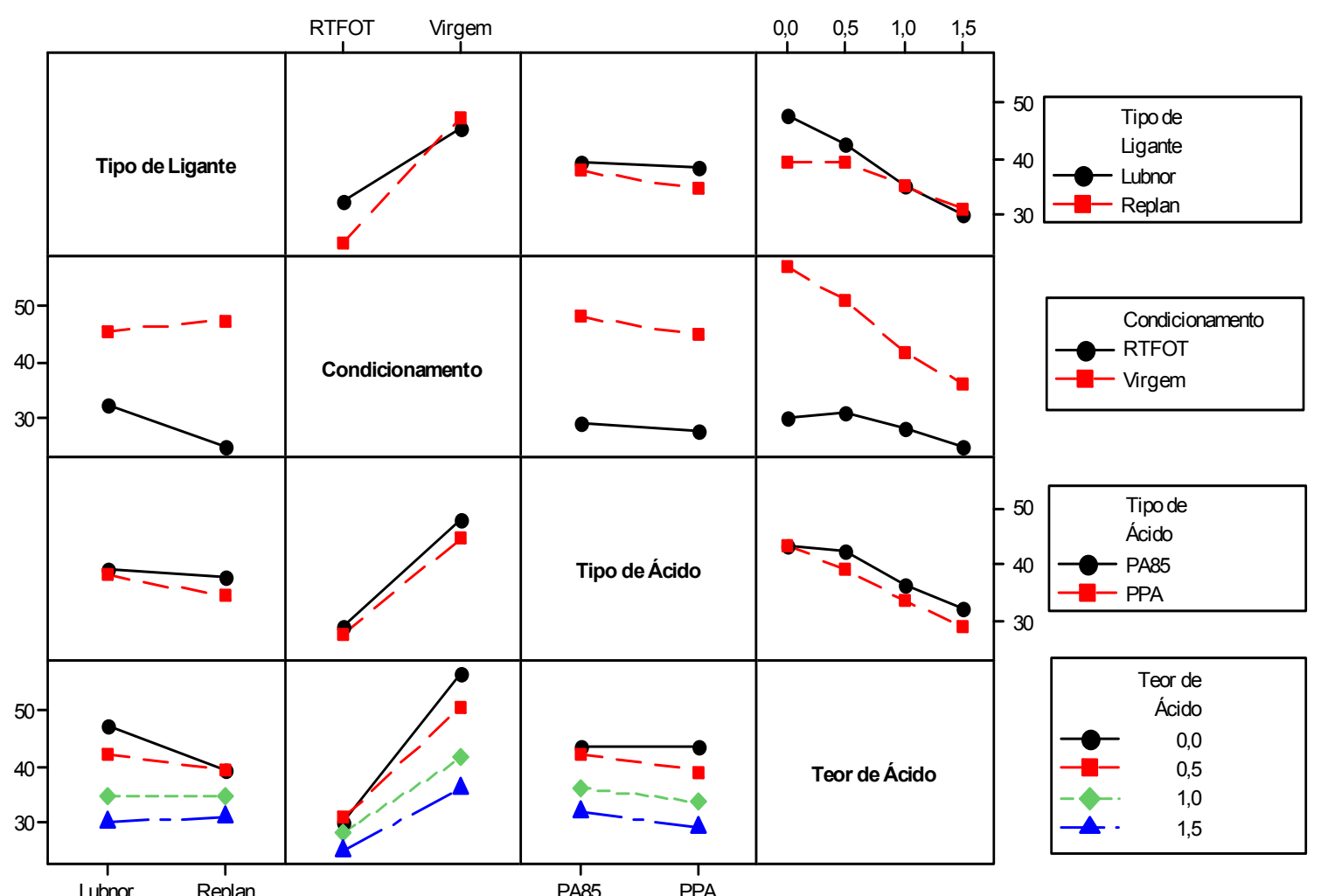

Figura 54 - Efeitos de interação entre fatores na penetração.

\subsubsection{Ponto de Amolecimento}

Para esta propriedade foram avaliados quatro fatores, a saber: o tipo de ligante asfáltico em dois níveis (Replan e Lubnor), Condicionamento em dois níveis (RTFOT e PAV), tipo de ácido em dois níveis (PPA e PA85) e teor de ácido em quatro níveis $(0,0 ; 0,5 ; 1,0 ;$ e 1,5\%). Na Tabela 46 está apresentada a análise da significância dos fatores e suas interações. Para a propriedade em questão apenas a interação $(B) \times(C)$ não foi significativa. Pode-se verificar que o fator mais significativo foi o condicionamento (maior valor de $F$ ), seguido pelo tipo de ligante asfáltico utilizado. 
Tabela 46 - Análise da significância dos fatores e suas interações no ponto de amolecimento.

\begin{tabular}{lccccc}
\hline Fatores & GL & $\begin{array}{c}\text { Soma dos } \\
\text { Quadrados }\end{array}$ & $F$ & $P$ & Significância \\
\hline Tipo de Ligante (A) & 1 & 726,28 & 1615,14 & 0,000 & Sim \\
Condicionamento (B) & 1 & $1.493,99$ & 3322,42 & 0,000 & Sim \\
Tipo de Ácido (C) & 1 & 56,84 & 126,41 & 0,000 & Sim \\
Teor de Ácido (D) & 3 & $2.003,69$ & 1485,3 & 0,000 & Sim \\
(A) $\times$ (B) & 1 & 33,72 & 74,99 & 0,000 & Sim \\
(A) $\times$ (C) & 1 & 4,54 & 10,09 & 0,002 & Sim \\
(A) $\times$ (D) & 3 & 143,15 & 106,12 & 0,000 & Sim \\
(B) $\times$ (C) & 1 & 0,37 & 0,83 & 0,365 & Não \\
(B) $\times$ (D) & 3 & 68,99 & 51,14 & 0,000 & Sim \\
(C) $\times$ (D) & 3 & 55,68 & 41,28 & 0,000 & Sim \\
Erro & 109 & 49,01 & & & \\
Total & 127 & $4.636,28$ & & & \\
\hline
\end{tabular}

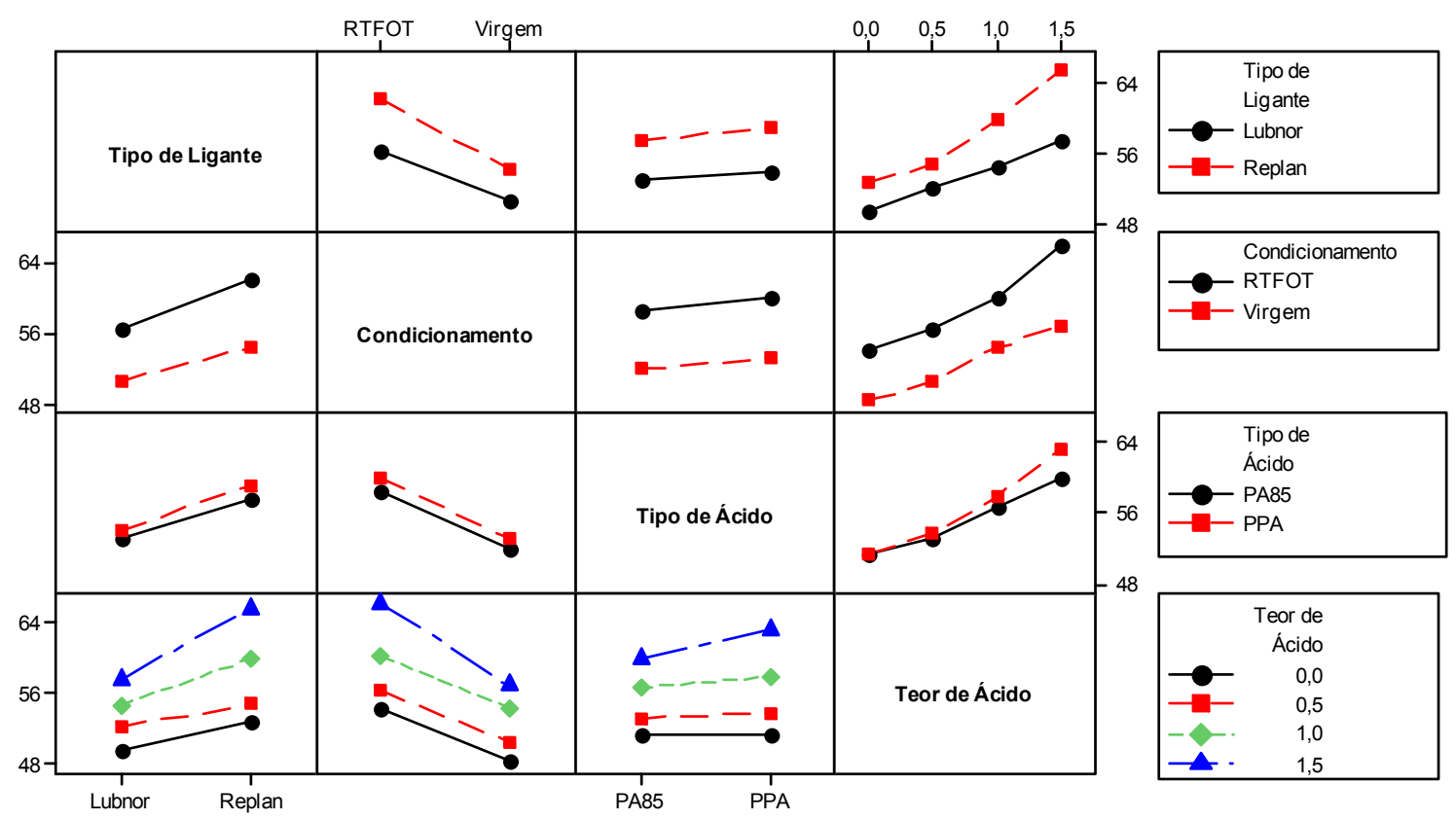

Figura 55 - Efeitos de interação entre fatores no ponto de amolecimento.

$\mathrm{Na}$ Figura 55 podem ser vistas as influências dos fatores e suas interações nos valores do ponto de amolecimento. Pode-se notar que o condicionamento é o fator com mais influência nesta propriedade. Quanto aos ácidos, pode-se perceber comportamento semelhante, com pequenas diferenças na adição de 1,5\% destes modificadores. Os teores de ácidos também se mostraram bastantes significativos nesta propriedade. Também pode ser observado que a adição dos ácidos proporciona maior efeito quando adicionado no ligante asfáltico de base da Replan. 


\subsubsection{Viscosidade Rotacional}

Para esta propriedade foram avaliados cinco fatores, a saber: o tipo de ligante asfáltico em dois níveis (Replan e Lubnor), condicionamento em dois níveis (Virgem e RTFOT), tipo de ácido em dois níveis (PPA e PA85), teor de ácido em quatro níveis $(0,0 ; 0,5 ; 1,0 ;$ e 1,5\%) e temperatura em cinco níveis $\left(135,143,150,163\right.$ e $\left.170^{\circ} \mathrm{C}\right)$. Na Tabela 47 está apresentada a análise da significância dos fatores e suas interações. Para a propriedade em questão três interações $(A) \times(C),(B) \times(C)$ e $(C) \times(E)$ não foram significativas. Pode-se verificar que o fator mais significativo para esta propriedade foi a temperatura, seguida pelo condicionamento das amostras.

Tabela 47 - Análise da significância dos fatores e suas interações na viscosidade rotacional.

\begin{tabular}{lccccc}
\hline Fatores & GL & Soma dos Quadrados & $F$ & $P$ & Significância \\
\hline Tipo de Ligante (A) & 1 & 1,26 & 125,11 & 0,000 & Sim \\
Condicionamento (B) & 1 & 4,73 & 468,41 & 0,000 & Sim \\
Tipo de Ácido (C) & 1 & 0,18 & 17,68 & 0,000 & Sim \\
Teor de Ácido (D) & 3 & 8,05 & 265,54 & 0,000 & Sim \\
Temperatura (E) & 4 & 25,89 & 640,97 & 0,000 & Sim \\
(A) $\times$ (B) & 1 & 0,53 & 52,6 & 0,000 & Sim \\
(A) $\times$ (C) & 1 & 0,04 & 3,64 & 0,057 & Não \\
(A) $\times$ (D) & 3 & 1,64 & 54,26 & 0,000 & Sim \\
(A) $\times$ (D) & 4 & 0,82 & 20,38 & 0,000 & Sim \\
(B) $\times$ (C) & 1 & 0,06 & 5,84 & 0,016 & Não \\
(B) $\times$ (D) & 3 & 1,80 & 59,38 & 0,000 & Sim \\
(B) $\times$ (E) & 4 & 2,52 & 62,38 & 0,000 & Sim \\
(C) $\times$ (D) & 3 & 0,21 & 7,01 & 0,000 & Sim \\
(C) $\times$ (E) & 4 & 0,12 & 2,98 & 0,019 & Não \\
(D) $\times$ (E) & 12 & 4,50 & 37,11 & 0,000 & Sim \\
Erro & 433 & 4,37 & & & \\
Total & 479 & 56,73 & & & \\
\hline
\end{tabular}

Na Figura 56 podem ser vistas as influências dos fatores e suas interações nos valores da viscosidade rotacional. Pode-se notar o comportamento dos ácidos é semelhante para esta propriedade. Nota-se que a altas temperaturas e em baixas concentrações de ácidos o comportamento para dois ligantes asfálticos de base é semelhante, e que a adição de ácido tem maior influência com teores de 1,0 e 1,5. 


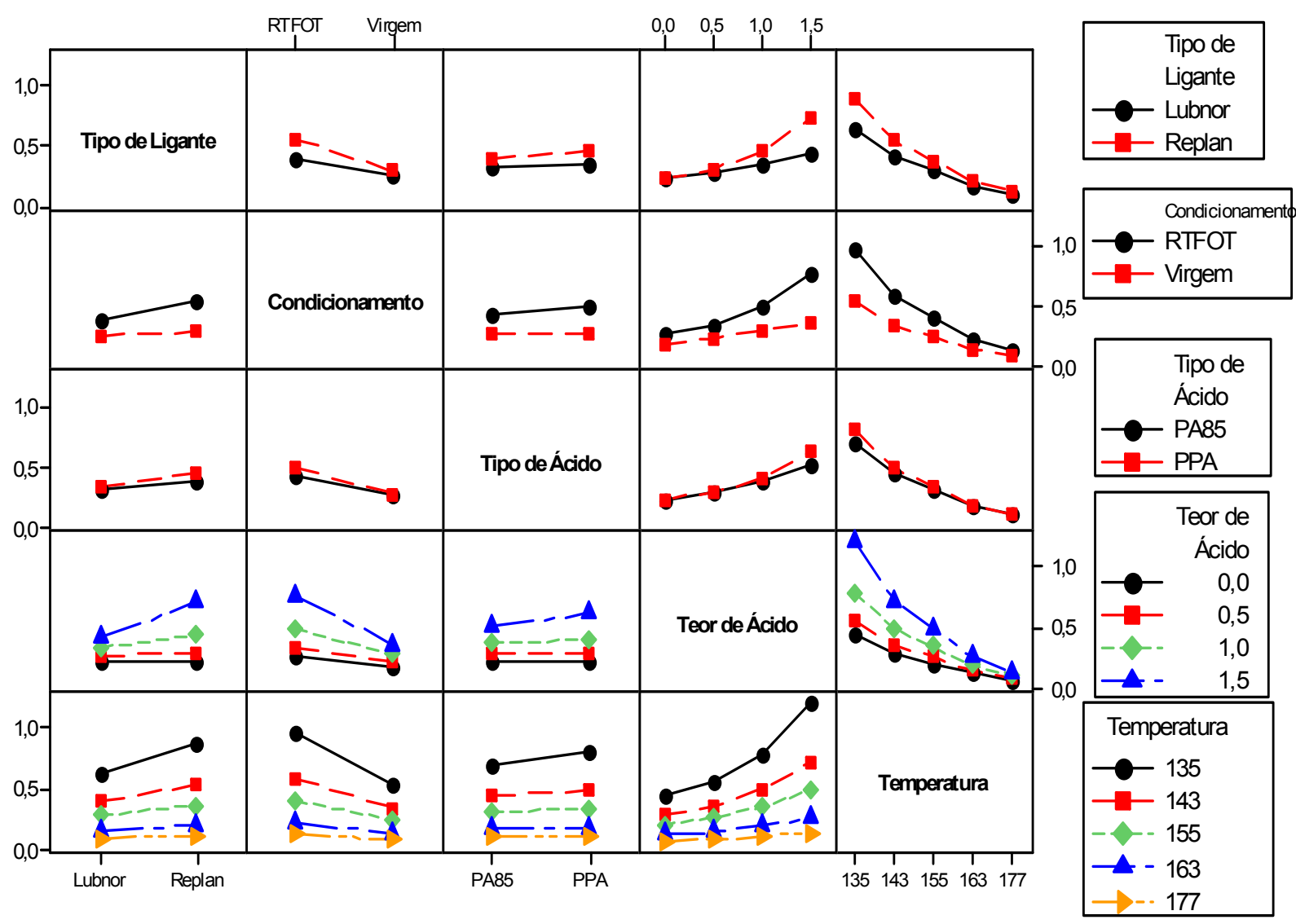

Figura 56 - Efeitos de interação entre fatores na viscosidade rotacional.

\subsubsection{Recuperação}

Para esta propriedade foram avaliados cinco fatores, a saber: o tipo de ligante asfáltico em dois níveis (Replan e Lubnor), tipo de ácido em dois níveis (PPA e PA85), teor de ácido em quatro níveis $(0,0 ; 0,5 ; 1,0$; e 1,5\%), tensão aplicada em dois níveis (100Pa e 3200Pa) e temperatura em cinco níveis $\left(52,58,64,70\right.$ e $\left.76^{\circ} \mathrm{C}\right)$. Na Tabela 48 está apresentada a análise da significância dos fatores e suas interações para a propriedade recuperação. Para essa propriedade duas interações $(B) \times(D)$ e $(B) \times(E)$ não foram significativas. Nota-se que o fator mais significativo para esta propriedade foi o tipo de ligante asfáltico de base, seguido pelo teor de ácido adicionado. 
Tabela 48 - Análise da significância dos fatores e suas interações na Recuperação.

\begin{tabular}{|c|c|c|c|c|c|}
\hline Fatores & $\mathrm{GL}$ & $\begin{array}{l}\text { Soma dos } \\
\text { Quadrados }\end{array}$ & $\mathrm{F}$ & $P$ & Significância \\
\hline Tipo de Ligante (A) & 1 & $31.120,70$ & 2852,25 & 0,000 & Sim \\
\hline Tipo de Ácido (B) & 1 & $1.069,60$ & 115,12 & 0,000 & Sim \\
\hline Teor de Ácido (C) & 1 & $63.992,40$ & 2169,05 & 0,000 & Sim \\
\hline Tensão (D) & 3 & $4.033,20$ & 404,34 & 0,000 & Sim \\
\hline Temperatura $(E)$ & 4 & $40.099,10$ & 959,19 & 0,000 & Sim \\
\hline$(A) \times(B)$ & 1 & 496,70 & 46,98 & 0,000 & Sim \\
\hline$(\mathrm{A}) \times(\mathrm{C})$ & 3 & $19.119,00$ & 569,26 & 0,000 & Sim \\
\hline$(A) \times(D)$ & 1 & 891,80 & 77,37 & 0,000 & Sim \\
\hline$(A) \times(D)$ & 4 & $4.120,60$ & 89,19 & 0,000 & Sim \\
\hline$(\mathrm{B}) \times(\mathrm{C})$ & 3 & $2.333,20$ & 69,43 & 0,000 & Sim \\
\hline$(B) \times(D)$ & 1 & 0,00 & 0,03 & 0,868 & Não \\
\hline$(B) \times(E)$ & 4 & 38,00 & 0,91 & 0,460 & Não \\
\hline$(C) \times(D)$ & 3 & $1.404,20$ & 41,85 & 0,000 & Sim \\
\hline$(C) \times(E)$ & 12 & $12.978,50$ & 96,71 & 0,000 & Sim \\
\hline (D) $\times(E)$ & 4 & 246,10 & 5,50 & 0,000 & Sim \\
\hline Erro & 502 & $5.613,70$ & & & \\
\hline Total & 548 & $188.556,80$ & & & \\
\hline
\end{tabular}

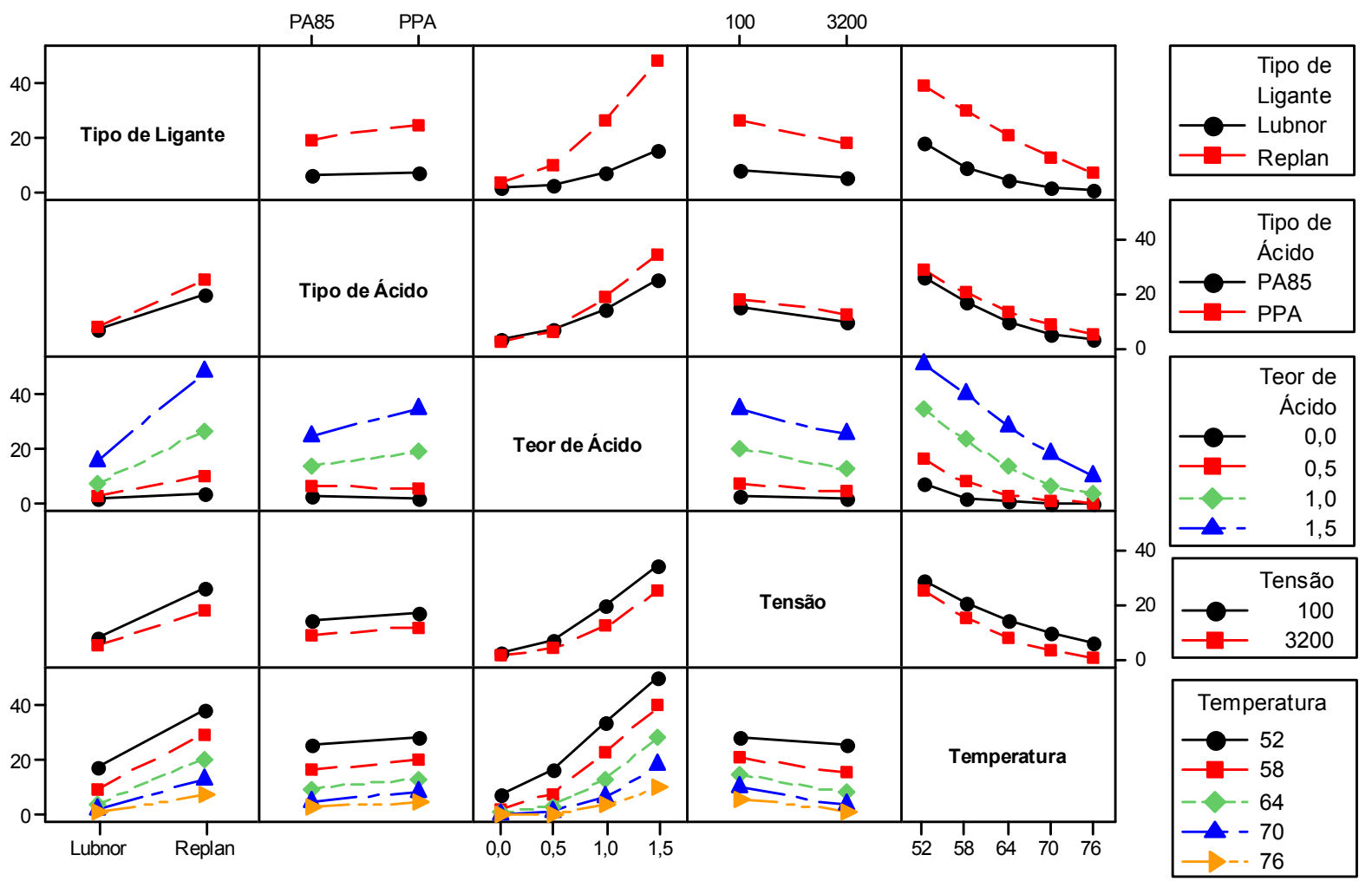

Figura 57 - Efeitos de interação entre fatores na Recuperação. 
$\mathrm{Na}$ Figura 57 podem ser vistas as influências dos fatores e suas interações nos valores da recuperação. Pode-se notar que com exceção do ligante asfáltico puro o ligante asfáltico da Replan apresentou maiores valores de recuperação, independente dos demais fatores, do que o ligante asfáltico da Lubnor. Novamente, nota-se que o comportamento dos ácidos é semelhante, apresentando valores um pouco maiores para o PPA. Pode-se observar também que para altas temperaturas não se tem grande influência para concentração baixas dos modificadores $(0,5 \%)$.

\subsubsection{Compliância não recuperável}

Para esta propriedade foram avaliados cinco fatores, a saber: o tipo de ligante asfáltico em dois níveis (Replan e Lubnor), tipo de ácido em dois níveis (PPA e PA85), teor de ácido em quatro níveis $(0,0 ; 0,5 ; 1,0 ;$ e 1,5\%), tensão aplicada em dois níveis (100Pa e 3200Pa) e temperatura em cinco níveis $\left(52,58,64,70\right.$ e $\left.76^{\circ} \mathrm{C}\right)$. Na Tabela 49 está apresentada a análise de significância dos fatores e suas interações para a compliância não recuperável. Para a propriedade em questão três interações $(A) \times(B),(A) \times(D)$ e $(B) \times(D)$ não foram significativas. Nota-se que o fator mais significativo para esta propriedade é a temperatura, seguido pelo teor de ácido adicionado.

Tabela 49- Análise da significância dos fatores e suas interações na compliância não recuperável.

\begin{tabular}{lccccc}
\hline Fatores & GL & $\begin{array}{c}\text { Soma dos } \\
\text { Quadrados }\end{array}$ & $F$ & $P$ & Significância \\
\hline Tipo de Ligante (A) & 1 & 382,28 & 5841,47 & 0,000 & Sim \\
Tipo de Ácido (B) & 1 & 3,00 & 72,22 & 0,000 & Sim \\
Teor de Ácido (C) & 1 & $1.720,22$ & 8993,03 & 0,000 & Sim \\
Tensão (D) & 3 & 28,83 & 451,45 & 0,000 & Sim \\
Temperatura (E) & 4 & $6.250,52$ & 22880,30 & 0,000 & Sim \\
(A) $\times(B)$ & 1 & 0,22 & 3,46 & 0,063 & Não \\
(A) $\times(C)$ & 3 & 3,66 & 19,14 & 0,000 & Sim \\
(A) $\times(D)$ & 1 & 0,01 & 0,23 & 0,632 & Não \\
(A) $\times(E)$ & 4 & 360,43 & 1378,47 & 0,000 & Sim \\
(B) $\times(C)$ & 3 & 5,29 & 28,28 & 0,000 & Sim \\
(B) $\times(D)$ & 1 & 0,10 & 1,56 & 0,212 & Não \\
(B) $\times($ (E) & 4 & 5,56 & 31,74 & 0,000 & Sim \\
(C) $\times(D)$ & 3 & 1,20 & 6,41 & 0,000 & Sim \\
(C) $\times($ (E) & 12 & $1.724,48$ & 2305,82 & 0,000 & Sim \\
(D) $\times($ E) & 4 & 34,57 & 138,68 & 0,000 & Sim \\
Erro & 503 & 31,35 & & & \\
Total & 549 & $10.551,70$ & & & \\
\hline
\end{tabular}


$\mathrm{Na}$ Figura 58 podem ser vistas as influências dos fatores e suas interações nos valores da compliância não recuperável. Pode-se notar um comportamento igual para os ácidos, e também nota-se que a adição dos modificadores não altera esta propriedade em temperatura mais baixa.

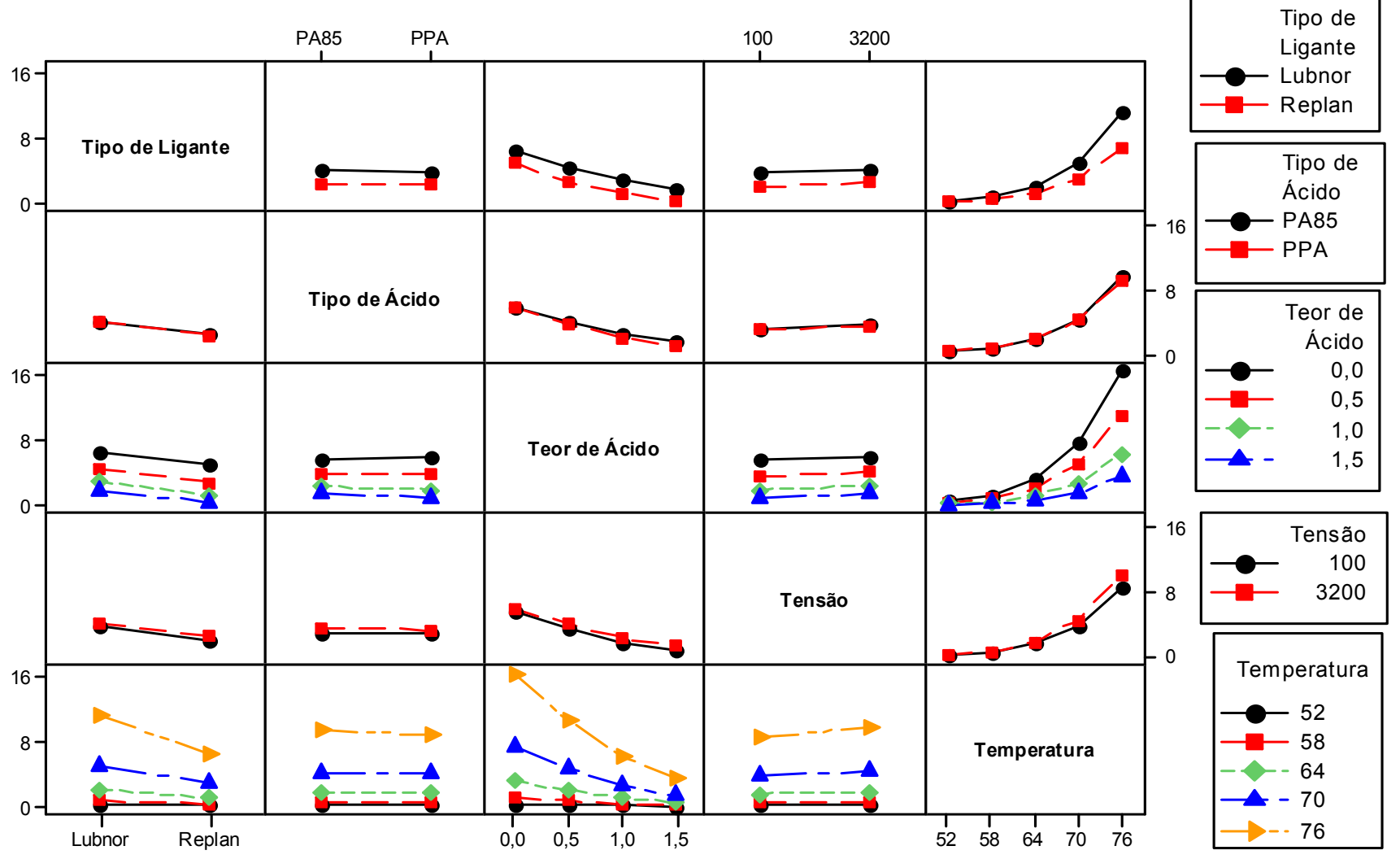

Figura 58- Efeitos de interação entre fatores na compliância não recuperável.

\subsubsection{LAS Modificado}

Para esta propriedade foram avaliados quatro fatores, a saber: o tipo de ligante asfáltico em dois níveis (Replan e Lubnor), condicionamento em dois níveis (RTFOT e PAV), tipo de ácido em dois níveis (PPA e PA85), e teor de ácido em quatro níveis $(0,0 ; 0,5 ; 1,0 ; \mathrm{e}$ 1,5\%). Na Tabela 50 está apresentada a análise da significância dos fatores e suas interações para a propriedade do LAS Modificado, representado aqui pelo parâmetro $a_{\text {f. }} \mathrm{O}$ fator tipo de ácido, juntamente com as interações $(A) \times(C),(A) \times(D),(B) \times(C)$ e (C) $\times(D)$ não foram significativas para a resistência à fadiga. Os fatores mais significativos foram o tipo de ligante asfáltico de base e o condicionamento das amostras. 
Tabela 50 - Análise da significância dos fatores e suas interações no LAS modificado (af).

\begin{tabular}{lccccc}
\hline Fatores & GL & $\begin{array}{c}\text { Soma dos } \\
\text { Quadrados }\end{array}$ & $F$ & $P$ & Significância \\
\hline Tipo de Ligante (A) & 1 & 1,80 & 200,25 & 0,000 & Sim \\
Condicionamento (B) & 1 & 0,81 & 90,52 & 0,000 & Sim \\
Tipo de Ácido (C) & 1 & 0,04 & 4,90 & 0,030 & Não \\
Teor de Ácido (D) & 3 & 0,55 & 20,34 & 0,000 & Sim \\
(A) $\times(B)$ & 1 & 0,12 & 12,92 & 0,001 & Sim \\
(A) $\times(C)$ & 1 & 0,01 & 1,67 & 0,200 & Não \\
(A) $\times($ D) & 3 & 0,10 & 3,83 & 0,013 & Não \\
(B) $\times(C)$ & 1 & 0,07 & 7,55 & 0,007 & Não \\
(B) $\times(D)$ & 3 & 0,22 & 8,16 & 0,000 & Sim \\
(C) $\times$ (D) & 3 & 0,10 & 3,83 & 0,013 & Não \\
Erro & 77 & 0,69 & & & \\
Total & 95 & 4,51 & & & \\
\hline
\end{tabular}

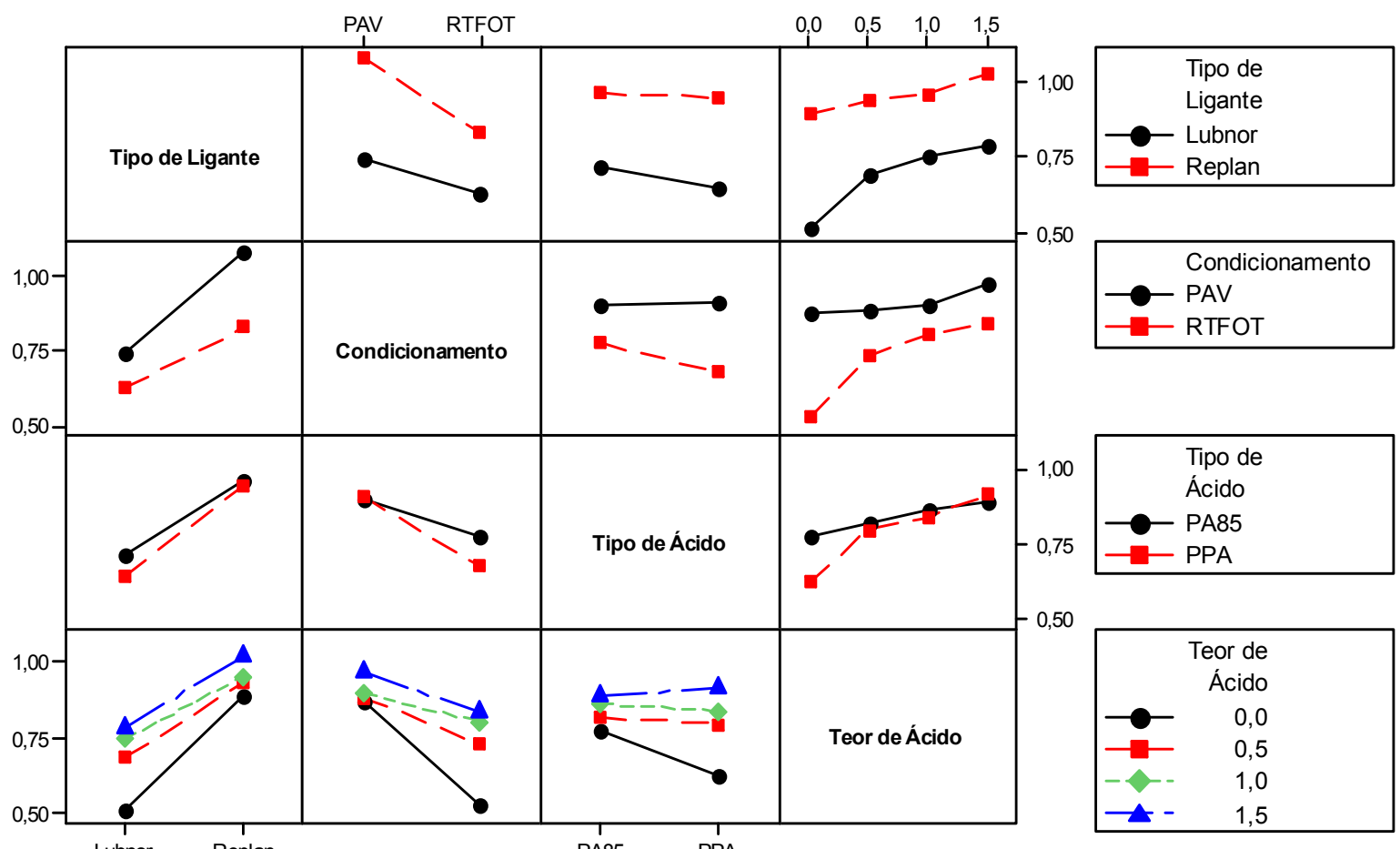

Figura 59 - Efeitos de interação entre fatores na resistência à fadiga.

$\mathrm{Na}$ Figura 59 podem ser vistas as influências dos fatores e suas interações nos valores da resistência à fadiga. Nota-se que o ligante asfáltico de base Replan sofre maior influência com a adição dos modificadores, apresentando valores maiores de $a_{\mathrm{f}}$. Além disso, pode-se perceber que o envelhecimento favorece esta propriedade, proporcionando um aumento no seu valor, e seu efeito é mais intenso para os ligantes asfálticos provenientes da Replan. 


\subsubsection{Considerações Finais}

Nesta primeira fase da pesquisa tentou-se avaliar o comportamento da adição de dois ácidos (PPA e PA85) em dois ligantes asfálticos de base diferentes. Diante do exposto nas análises acima, pode-se destacar que, para qualquer tipo de propriedade avaliada, o tipo de ligante asfáltico de base influenciou diretamente os resultados. De maneira geral, o ligante asfáltico proveniente da Replan apresentou um melhor comportamento frente às propriedades avaliadas, e foi mais influenciado pela adição dos modificadores. Quanto ao ligante asfáltico proveniente da Lubnor, pode-se dizer que não é recomendável a adição de pequenos teores de ácidos, pois não é perceptível melhora nas propriedades. Em relação aos modificadores, conclui-se que ambos produzem mesmo comportamento, porém em algumas propriedades nota-se um efeito mais intenso do ácido PPA, o que já era esperado pelo fato de ser mais concentrado. Percebe-se que para obter equivalência nas propriedades avaliadas, em relação aos dois modificadores, é necessária uma concentração um pouco maior para que as amostras modificadas com PA85 apresentem resultados similares às amostras modificadas com PPA. 


\subsection{Ligantes Asfálticos Modificados com Copolímero SBS e Ácidos}

Nesta subseção estão apresentadas as análises referentes aos ligantes asfálticos modificados com copolímero SBS e copolímero SBS + ácido (PPA e PA85). São apresentadas também as análises realizadas com o auxílio da estatística de experimento com misturas, por meio de gráficos de área de superfície e de efeito de componentes.

\subsubsection{Ensaio de Penetração}

Os resultados de penetração e penetração retida dos ligantes asfálticos modificados com o copolímero SBS sem ou com a presença dos ácidos estudados (PA85 e PPA) no ligante de base Replan, na condição virgem e envelhecida em curto prazo, estão apresentados na Tabela 51. De maneira geral, a adição desses modificadores proporciona uma redução dos valores de penetração, indicando uma maior rigidez desses materiais quando comparados com o ligante asfáltico base (Replan CAP 50/70) na temperatura de $25^{\circ} \mathrm{C}$. É observado também, como já esperado, valores inferiores para esta propriedade com o envelhecimento em curto prazo.

Tabela 51 - Resultados de Penetração (dmm) e Penetração Retida (\%) para os ligantes asfálticos modificados (Replan).

\begin{tabular}{|c|c|c|c|c|c|c|}
\hline \multirow{2}{*}{ Ligantes Asfálticos } & \multicolumn{2}{|c|}{ Virgem } & \multicolumn{2}{|c|}{ RTFOT } & \multicolumn{2}{|c|}{ Penetração retida (\%) } \\
\hline & PA85 & PPA & PA85 & PPA & PA85 & PPA \\
\hline Replan & 58 & 58 & 31 & 31 & 53 & 53 \\
\hline $2,5 \mathrm{SBS}$ & 47 & 47 & 36 & 36 & 75 & 75 \\
\hline 2,5SBS+0,75 Ácido a & 39 & 41 & 31 & 30 & 78 & 73 \\
\hline 2,5SBS+1,5 Ácido & 32 & 33 & 28 & 27 & 89 & 83 \\
\hline $5,0 \mathrm{SBS}^{\mathrm{a}}$ & 40 & 40 & 33 & 33 & 82 & 82 \\
\hline 5,0SBS + 0,75 Ácido & 35 & 33 & 30 & 28 & 82 & 84 \\
\hline 5,0SBS+1,5 Ácido & 33 & 28 & 27 & 24 & 82 & 84 \\
\hline
\end{tabular}

a: Apresentam os mesmos valores para propriedade de penetração.

O ligante asfáltico 5,0SBS+1,5 Ácido é o material que apresentou o menor valor de penetração. Nota-se que os valores de penetração da mistura com 2,5SBS+0,75 Ácido são próximos dos valores encontrados para o ligante asfáltico modificado com 5,0SBS, indicando que a adição do ácido pode diminuir o teor do polímero adicionado. Pode ser observado também que, com exceção do ligante asfáltico 5,0SBS+1,5 Ácido, os demais ligantes apresentaram valores de penetração próximos, considerando o limite estabelecido no ensaio de $2 \mathrm{dmm}$, independente do ácido utilizado. 
Segundo o Regulamento Técnico 03/2005 da ANP tem-se: (A) para ligantes asfálticos com penetração de 50 a 70 dmm o valor de penetração retida mínima de 55\%; e (B) para materiais com penetração de 30 a $45 \mathrm{dmm}$ o valor mínimo de penetração retida de $60 \%$. Na situação (A) encontra-se apenas o ligante asfáltico de base, as demais se enquadram na situação (B). Nota-se que o CAP 50/70 não se enquadra no limite especificado, uma vez que apresenta um valor de penetração retida inferior a 55\%. No entanto, os demais ligantes asfálticos modificados apresentam valores de penetração retida superiores a $60 \%$, atendendo ao limite especificado. Quanto à adição dos dois tipos de ácido, notam-se valores próximos de penetração retida, o que representa que os ligantes asfálticos modificados com ambos os ácidos apresentaram comportamentos semelhantes quanto à sensibilidade ao envelhecimento.

Na Tabela 52 estão apresentados os valores de penetração e penetração retida dos ligantes asfálticos modificados com o copolímero SBS e também com adição dos ácidos estudados (PA85 e PPA) no ligante de base Lubnor, na condição virgem e envelhecida em curto prazo. De maneira geral, notam-se valores de penetração inferiores para os ligantes modificados quando comparados ao ligante asfáltico de base, devido à maior consistência desses materiais. Os menores valores de penetração são encontrados para os ligantes asfálticos mais modificados. Como esperado, os valores dos materiais envelhecidos em curto prazo são inferiores quando comparados aos materiais na condição virgem.

Tabela 52 - Resultados de Penetração (dmm) e Penetração Retida (\%) para os ligantes asfálticos modificados (Lubnor).

\begin{tabular}{|c|c|c|c|c|c|c|}
\hline \multirow{2}{*}{ Ligantes Asfálticos } & \multicolumn{2}{|c|}{ Virgem } & \multicolumn{2}{|c|}{ RTFOT } & \multicolumn{2}{|c|}{ Penetração Retida (\%) } \\
\hline & PA85 & PPA & PA85 & PPA & PA85 & PPA \\
\hline Lubnor & 58 & 58 & 38 & 38 & 66 & 66 \\
\hline $2,5 \mathrm{SBS}$ & 42 & 42 & 34 & 34 & 80 & 80 \\
\hline 2,5SBS+0,75 Ácido & 40 & 40 & 29 & 30 & 72 & 76 \\
\hline 2,5SBS+1,5 Ácido & 33 & 33 & 26 & 25 & 77 & 75 \\
\hline 5,0 SBS & 37 & 37 & 31 & 31 & 84 & 84 \\
\hline 5,0SBS + 0,75 Ácido & 37 & 37 & 26 & 27 & 71 & 74 \\
\hline 5,0SBS+1,5 Ácido & 32 & 25 & 22 & 17 & 69 & 68 \\
\hline
\end{tabular}

Pode-se observar que os valores de penetração são similares, com exceção do ligante asfáltico 5,0SBS+1,5 Ácido, independente do ácido utilizado e do condicionamento. Pode também ser observado que os valores de penetração com adição de 5,0SBS então entre os valores encontrados para as misturas com 2,5SBS+0,75 Ácido e 2,5SBS+1,5 Ácido, independente do ácido utilizado. Quanto à penetração retida, considera-se que na situação (A) encontra-se apenas o ligante asfáltico de base, as demais se enquadram na situação (B). Para este ligante asfáltico de base todos os ligantes asfálticos atendem o limite estabelecido 
pelo Regulamento Técnico 03/2005 da ANP. Quanto à adição dos dois tipos de ácido, apesar de valores próximos de penetração retida, os ligantes asfálticos modificados com adição do ácido PPA para concentrações de $0,75 \%$ do ácido apresentam valores um pouco superiores, porém para concentrações mais elevadas de ácido $(1,5 \%)$ os ligantes modificados com adição do ácido PA85 são um pouco maiores. No entanto, como todos os ligantes modificados apresentam valores de penetração retida superiores ao valor do ligante asfáltico de base, a adição destes modificadores foi benéfica quanto ao comportamento destes materiais no que diz respeito à sensibilidade ao envelhecimento.

Quando comparado os dados de penetração para os dois ligantes asfálticos de base, nota-se que para os materiais modificados apenas com o copolímero SBS, o ligante asfáltico de base da Lubnor apresentou valores de penetração um pouco inferiores, o que indica que a adição deste tipo de modificador foi mais significativa para este ligante asfáltico de base. No entanto, para os demais materiais, adição de copolímero SBS e ácidos, o comportamento dos dois ligantes asfálticos de base é similar. Quanto à sensibilidade ao envelhecimento para os materiais modificados apenas com o copolímero SBS, o ligante asfáltico de base da Lubnor teve comportamento superiores, ou seja, maiores valores de penetração retirada. Para os demais ligantes modificados, nota-se maiores valores de penetração retira para os materiais modificados a partir do ligante asfáltico de base da Replan. Sendo assim, o maior efeito da adição somente do copolímero SBS é no ligante asfáltico de base Lubnor, enquanto adição conjunta do polímero e ácido apresentou melhores resultados para o ligante asfáltico de base Replan, à luz da propriedade de penetração.

\subsubsection{Ensaio de Ponto de Amolecimento}

$\mathrm{Na}$ Tabela 53 são apresentados os valores médios de ponto de amolecimento dos ligantes asfálticos provenientes da Replan, na condição virgem e envelhecida em curto prazo, assim como seus respectivos incrementos. De maneira geral, os materiais modificados aumentam o ponto de amolecimento nas duas condições testadas (virgem e envelhecida em curto prazo), indicando uma maior rigidez destes materiais em relação ao ligante asfáltico de base. Nota-se que para as misturas com combinação de 2,5SBS com os ácidos, os valores do ponto de amolecimento para ambos os ácidos são próximos, assim como o valor de incremento. Já para misturas de 5,0SBS em combinação com os ácidos, nota-se que o PPA teve efeito mais intenso, apresentando valores de ponto de amolecimento superiores do que com o ácido PA85. Outro item que pode ser observado é que os valores de ponto de amolecimento com adição de 5,0SBS então entre os valores encontrados para as misturas com 2,5SBS+0,75Ácido e 2,5SBS+1,5Ácido, independente do ácido utilizado. A adição de ambos os ácidos foi mais intensa juntamente com o teor de 5,0\% de SBS, apresentando 
valores com maiores diferenças para a mistura sem a presença destes modificadores (somente com adição de 5,0\% de SBS).

Tabela 53 - Resultados do Ponto de Amolecimento $\left({ }^{\circ} \mathrm{C}\right)$ e Incremento $\left({ }^{\circ} \mathrm{C}\right)$ para os ligantes asfálticos modificados (Replan).

\begin{tabular}{lcccccc}
\hline \multirow{2}{*}{ Ligantes Asfálticos } & \multicolumn{2}{c}{ Virgem } & \multicolumn{2}{c}{ RTFOT } & \multicolumn{2}{c}{ Incremento $\left({ }^{\circ} \mathrm{C}\right)$} \\
\cline { 2 - 7 } & PA85 & PPA & PA85 & PPA & PA85 & PPA \\
\hline Replan & 49 & 49 & 56 & 56 & 7 & 7 \\
2,5SBS & 52 & 52 & 57 & 57 & 5 & 5 \\
2,5SBS+0,75 Ácido & 56 & 57 & 65 & 68 & 9 & 10 \\
2,5SBS+1,5 Ácido & 63 & 64 & 74 & 79 & 11 & 15 \\
5,0SBS & 61 & 61 & 68 & 68 & 7 & 7 \\
5,0SBS + 0,75 Ácido & 75 & 80 & 79 & 86 & 4 & 6 \\
5,0SBS+1,5 Ácido & 81 & 87 & 88 & 92 & 7 & 5 \\
\hline
\end{tabular}

Analisando os dados, considerando a aplicação do valor máximo de $8^{\circ} \mathrm{C}$ para incremento do ponto de amolecimento (diferença entre os pontos de amolecimento do material envelhecido em curto prazo e o material na condição virgem), especificado pelo Regulamento Técnico 03/2005 da ANP, os ligantes asfálticos modificados com 2,5SBS+0,75 Ácido e 2,5SBS+1,5 Ácido não seriam adequados. Com exceção da mistura 2,5SBS+1,5 Ácido, as demais apresentaram valores próximos de incremento, apresentando o mesmo comportamento quanto à sensibilidade ao envelhecimento.

$\mathrm{Na}$ Tabela 54 são apresentados os valores médios de ponto de amolecimento dos ligantes asfálticos provenientes da Lubnor, na condição virgem e envelhecida em curto prazo, assim como seus respectivos incrementos. Os materiais modificados tiveram o ponto de amolecimento aumentado nas duas condições testadas. Nota-se que a adição do teor de $0,75 \%$ de ácido juntamente com o teor de 2,5\% de SBS apresentou valores próximos da mistura com mesma proporção do copolímero SBS sem adição dos ácidos, sendo que as misturas com adição dos ácidos apresentaram maior sensibilidade ao envelhecimento. $O$ mesmo pode ser observado para concentração de $5,0 \%$ de SBS. As maiores alterações/modificações podem ser observadas para as misturas com altas concentrações dos ácidos $(1,5 \%)$ quando comparadas com as misturas somente com a adição do copolímero SBS. Nota-se que para todas as misturas com adição de ácidos, os valores do ponto de amolecimento são próximos, independentemente do tipo de ácido utilizado. Para este ligante asfáltico de base, quanto maior a modificação, maiores são os valores de ponto de amolecimento. 
Tabela 54 - Resultados do Ponto de Amolecimento $\left({ }^{\circ} \mathrm{C}\right)$ e Incremento $\left({ }^{\circ} \mathrm{C}\right)$ para os ligantes asfálticos modificados (Lubnor).

\begin{tabular}{lcccccc}
\hline \multirow{2}{*}{ Ligantes Asfálticos } & \multicolumn{2}{c}{ Virgem } & \multicolumn{2}{c}{ RTFOT } & \multicolumn{2}{c}{ Incremento (\%) } \\
\cline { 2 - 7 } & PA85 & PPA & PA85 & PPA & PA85 & PPA \\
\hline Lubnor & 47 & 47 & 52 & 52 & 5 & 5 \\
$2,5 S B S$ & 53 & 53 & 56 & 56 & 3 & 3 \\
$2,5 S B S+0,75$ Ácido & 55 & 55 & 60 & 61 & 5 & 6 \\
2,5SBS+1,5 Ácido & 59 & 60 & 67 & 64 & 8 & 4 \\
$5,0 S B S$ & 62 & 62 & 64 & 64 & 2 & 2 \\
5,0SBS + 0,75 Ácido & 62 & 64 & 75 & 80 & 13 & 16 \\
5,0SBS+1,5 Ácido & 70 & 72 & 75 & 80 & 6 & 8 \\
\hline
\end{tabular}

Quanto ao incremento do ponto de amolecimento, considerando a aplicação do valor máximo de $8^{\circ} \mathrm{C}$, especificado pelo Regulamento Técnico 03/2005 da ANP, os ligantes asfálticos modificados com 5,0SBS+0,75 Ácido não seriam adequados. Com exceção da mistura 2,5SBS+1,5 Ácido, as demais apresentaram valores próximos de incremento, indicando mesma sensibilidade ao envelhecimento.

Quando comparados os dois tipos de ligante asfáltico de base, podem-se observar comportamentos semelhante, quanto ao ponto de amolecimento, para misturas com todas as combinações com $2,5 \%$ de SBS com ou sem a presença de ácido. Nota-se que o ligante asfáltico de base proveniente da Replan tem maiores modificações à luz dessa propriedade para as misturas mais modificados (5,0\% de SBS com ou sem a presença dos ácidos). Quanto à sensibilidade ao envelhecimento, de maneira geral, as misturas produzidas com o ligante asfáltico de base proveniente da Replan são mais sensíveis, com exceção da mistura 5,0SBS+0,75 Ácido.

\subsubsection{Viscosidade Rotacional}

Na Tabela 55 e na Tabela 56 são apresentados os valores da viscosidade rotacional para as amostras com adição do copolímero SBS e dos ácidos PA85 e PPA na condição virgem, respectivamente, produzidas com o ligante asfáltico de base Replan. Nota-se que o valor encontrado para o ligante asfáltico com 5,0\% de SBS está entre os valores encontrados para as misturas com 2,5SBS+0,75 Ácido e 2,5SBS+1,5 Ácido, independente do ácido utilizado, indicando que misturas com adição do ácido e redução do polímero podem apresentar mesmas características. 
Tabela 55 - Viscosidade (Pa.s) dos ligantes asfálticos modificados com SBS e PA85 na condição virgem (Replan).

\begin{tabular}{lccccc}
\hline \multirow{2}{*}{ Ligantes Asfálticos } & \multicolumn{5}{c}{ Temperaturas $\left({ }^{\circ} \mathrm{C}\right)$} \\
\cline { 2 - 6 } & $\mathbf{1 3 5}$ & 143 & 155 & 163 & 177 \\
\hline Replan & $\mathbf{0 , 3 4 3}$ & 0,232 & 0,170 & 0,102 & 0,063 \\
2,5SBS & $\mathbf{0 , 6 1 5}$ & 0,416 & 0,324 & 0,207 & 0,127 \\
2,5SBS+0,75 PA85 & $\mathbf{1 , 0 7 4}$ & 0,696 & 0,533 & 0,309 & 0,186 \\
2,5SBS+1,5 PA85 & $\mathbf{1 , 8 9 5}$ & 1,154 & 0,827 & 0,467 & 0,270 \\
5,0SBS & $\mathbf{1 , 5 4 4}$ & 0,847 & 0,628 & 0,395 & 0,235 \\
5,0SBS+0,75 PA85 & $\mathbf{2 , 2 6 5}$ & 1,545 & 1,159 & 0,663 & 0,411 \\
5,0SBS+1,5 PA85 & $\mathbf{3 , 8 4 6}$ & 2,505 & 1,695 & 0,950 & 0,563 \\
\hline
\end{tabular}

Nas tabelas pode-se observar que as misturas com adição de PPA apresentam valores mais elevados de viscosidade, independente da temperatura. Cabe destacar que, adotando como referência o limite sugerido pela especificação Superpave, que estabelece a viscosidade máxima de 3 Pa.s a $135^{\circ} \mathrm{C}$, para as misturas com adição de PA85, apenas a com alto teor do copolímero SBS juntamente com o ácido (5,0SBS+1,5 PA85) apresenta- valores acima do estabelecido. No entanto, as misturas com adição de PPA (Tabela 56) com 5,0\% de SBS não atendem o limite especificado pela norma.

Tabela 56 - Viscosidade (Pa.s) para os ligantes asfálticos modificados com SBS e PPA na condição virgem (Replan).

\begin{tabular}{lccccc}
\hline \multirow{2}{*}{ Ligantes Asfálticos } & \multicolumn{5}{c}{ Temperaturas $\left({ }^{\circ} \mathrm{C}\right)$} \\
\cline { 2 - 6 } & $\mathbf{1 3 5}$ & 143 & 155 & 163 & 177 \\
\hline Replan & $\mathbf{0 , 3 4 3}$ & 0,232 & 0,170 & 0,102 & 0,063 \\
2,5SBS & $\mathbf{0 , 6 1 5}$ & 0,416 & 0,324 & 0,207 & 0,127 \\
2,5SBS+0,75 PPA & $\mathbf{1 , 0 5 0}$ & 0,702 & 0,522 & 0,309 & 0,186 \\
2,5SBS+1,5PPA & $\mathbf{2 , 1 0 5}$ & 1,278 & 0,911 & 0,510 & 0,294 \\
5,0SBS & $\mathbf{1 , 5 4 4}$ & 0,847 & 0,628 & 0,395 & 0,235 \\
5,0SBS + 0,75PPA & $\mathbf{3 , 0 8 4}$ & 1,778 & 1,362 & 0,792 & 0,502 \\
5,0SBS+1,5 PPA & $\mathbf{5 , 8 0 9}$ & 3,495 & 2,380 & 1,357 & 0,799 \\
\hline
\end{tabular}

Na Tabela 57 e na Tabela 58 são apresentados os valores da viscosidade rotacional para as amostras com adição do copolímero SBS e dos ácidos PA85 e PPA na condição de envelhecimento em curto prazo (RTFOT), respectivamente, produzidas com o ligante asfáltico de base Replan. Neste condicionamento, nota-se que o valor encontrado para o ligante asfáltico com $5,0 \%$ de SBS está entre os valores encontrados para a mistura com 2,5SBS+0,75 Ácido e 2,5SBS+1,5 Ácido, independente do ácido utilizado. Os valores de viscosidade encontrados com a adição do PPA são superiores aos valores encontrados para as misturas com a incorporação de PA85. Quanto à sensibilidade ao envelhecimento, nas 
misturas com adição de 2,5 de SBS com os ácidos, o PPA apresentou mais sensibilidade ao envelhecimento, apresentando maiores diferenças percentuais em relação à viscosidade das mesmas misturas na condição virgem. Já para as misturas com adição de 5,0SBS com adição dos ácidos, os comportamentos em relação à sensibilidade ao envelhecimento são similares.

Tabela 57 - Viscosidade (Pa.s) para os ligantes asfálticos modificados com SBS e PA85 na condição RTFOT (Replan).

\begin{tabular}{lccccc}
\hline \multirow{2}{*}{ Ligantes Asfálticos } & \multicolumn{5}{c}{ Temperaturas $\left({ }^{\circ} \mathrm{C}\right)$} \\
\cline { 2 - 6 } & 135 & 143 & 155 & 163 & 177 \\
\hline Replan & 0,573 & 0,375 & 0,267 & 0,153 & 0,092 \\
2,5SBS & 0,944 & 0,621 & 0,452 & 0,270 & 0,161 \\
2,5SBS+0,75 PA85 & 2,130 & 1,239 & 0,863 & 0,484 & 0,277 \\
2,5SBS+1,5PA85 & 4,115 & 2,544 & 1,698 & 0,908 & 0,491 \\
5,0SBS & 1,974 & 1,276 & 0,912 & 0,536 & 0,307 \\
5,0SBS+ 0,75PA85 & 4,427 & 2,906 & 2,069 & 1,114 & 0,654 \\
5,0SBS+1,5PA85 & 9,763 & 5,659 & 3,542 & 2,023 & 1,127 \\
\hline
\end{tabular}

Tabela 58 - Viscosidade (Pa.s) para os ligantes asfálticos modificados com SBS e PPA na condição RTFOT (Replan).

\begin{tabular}{lccccc}
\hline \multirow{2}{*}{ Ligantes Asfálticos } & \multicolumn{5}{c}{ Temperaturas $\left({ }^{\circ} \mathrm{C}\right)$} \\
\cline { 2 - 6 } & 135 & 143 & 155 & 163 & 177 \\
\hline Replan & 0,573 & 0,375 & 0,267 & 0,153 & 0,092 \\
$2,5 S B S$ & 0,944 & 0,621 & 0,445 & 0,270 & 0,161 \\
$2,5 S B S+0,75$ PPA & 2,371 & 1,454 & 1,015 & 0,560 & 0,315 \\
$2,5 S B S+1,5 P P A$ & 5,277 & 3,029 & 1,984 & 1,069 & 0,578 \\
$5,0 S B S$ & 1,974 & 1,276 & 0,912 & 0,536 & 0,307 \\
5,0SBS+0,75PPA & 6,097 & 3,694 & 2,602 & 1,411 & 0,826 \\
5,0SBS+1,5 PPA & 14,671 & 7,998 & 4,887 & 2,634 & 1,389 \\
\hline
\end{tabular}

Na Tabela 59 e Tabela 60 são apresentados os valores da viscosidade rotacional para as amostras com adição do copolímero SBS e dos ácidos PA85 e PPA na condição virgem, respectivamente, produzidas com o ligante asfáltico de base Lubnor. Nota-se que ao aumentar a modificação do ligante asfáltico de base, os valores de viscosidade aumentaram, como já esperado. Assim como, tem-se a diminuição da viscosidade com o aumento da temperatura. Ao avaliar o limite adotado pela especificação Superpave, que limita a viscosidade ao máximo de $3 \mathrm{~Pa}$.s a $135^{\circ} \mathrm{C}$, apenas a mistura com alto teor do copolímero SBS juntamente com o ácidos (5,0SBS+1,5Ácido) apresentaram valores acima do estabelecido. Se analisarmos os dois tipos de ácido considerando este limite, ambos apresentam o mesmo comportamento. 
Tabela 59 - Viscosidade (Pa.s) para os ligantes asfálticos modificados com SBS e PA85 na condição virgem (Lubnor).

\begin{tabular}{lccccc}
\hline \multirow{2}{*}{ Ligantes Asfálticos } & \multicolumn{5}{c}{ Temperaturas $\left({ }^{\circ} \mathrm{C}\right)$} \\
\cline { 2 - 6 } & $\mathbf{1 3 5}$ & 143 & 155 & 163 & 177 \\
\hline Lubnor & $\mathbf{0 , 3 8 8}$ & 0,259 & 0,187 & 0,113 & 0,070 \\
2,5SBS & $\mathbf{0 , 7 2 0}$ & 0,470 & 0,366 & 0,240 & 0,146 \\
2,5SBS+0,75 PA85 & $\mathbf{0 , 8 8 7}$ & 0,578 & 0,442 & 0,284 & 0,175 \\
2,5SBS+1,5PA85 & $\mathbf{1 , 1 9 5}$ & 0,760 & 0,562 & 0,353 & 0,214 \\
5,0SBS & $\mathbf{1 , 5 9 9}$ & 0,841 & 0,580 & 0,378 & 0,234 \\
5,0SBS + 0,75PA855 & $\mathbf{2 , 1 9 7}$ & 1,144 & 0,809 & 0,518 & 0,310 \\
5,0SBS+1,5PA85 & $\mathbf{3 , 2 3 5}$ & 1,610 & 1,095 & 0,693 & 0,403 \\
\hline
\end{tabular}

Tabela 60 - Viscosidade (Pa.s) para os ligantes asfálticos modificados com SBS e PPA na condição virgem (Lubnor).

\begin{tabular}{lccccc}
\hline \multirow{2}{*}{ Ligantes Asfálticos } & \multicolumn{5}{c}{ Temperaturas $\left({ }^{\circ} \mathrm{C}\right)$} \\
\cline { 2 - 6 } & $\mathbf{1 3 5}$ & 143 & 155 & 163 & 177 \\
\hline Lubnor & $\mathbf{0 , 3 8 8}$ & 0,259 & 0,187 & 0,113 & 0,070 \\
2,5SBS & $\mathbf{0 , 7 2 0}$ & 0,470 & 0,366 & 0,240 & 0,146 \\
2,5SBS+0,75 PPA & $\mathbf{0 , 9 2 2}$ & 0,594 & 0,449 & 0,281 & 0,170 \\
2,5SBS+1,5PPA & $\mathbf{1 , 3 5 3}$ & 0,888 & 0,646 & 0,394 & 0,239 \\
5,0SBS & $\mathbf{1 , 5 9 9}$ & 0,841 & 0,580 & 0,378 & 0,234 \\
5,0SBS + 0,75PPA & $\mathbf{2 , 4 4 1}$ & 1,220 & 0,860 & 0,549 & 0,325 \\
5,0SBS+1,5 PPA & $\mathbf{4 , 3 7 7}$ & 2,074 & 1,439 & 0,888 & 0,509 \\
\hline
\end{tabular}

Na Tabela 61 e na Tabela 62 são apresentados os valores da viscosidade rotacional para as amostras com adição do copolímero SBS e dos ácidos PA85 e PPA na condição de envelhecimento em curto prazo (RTFOT), respectivamente, produzidas com o ligante asfáltico de base Lubnor. Nota-se que o valor encontrado para o ligante asfáltico com 5,0\% de SBS está entre os valores encontrados para a mistura com 2,5SBS+0,75 Ácido e 2,5SBS+1,5 Ácido. Os valores de viscosidade encontrados com a adição do PPA são maiores que os encontrados para as misturas com a incorporação de PA85. Quanto à sensibilidade ao envelhecimento, nas misturas com adição de 2,5 de SBS com os ácidos, os dados do PA85 mostraram que este modificador tem maior sensibilidade ao envelhecimento, pois apresentou maiores diferenças percentuais em relação à viscosidade das mesmas misturas na condição virgem. Já para as misturas com adição de 5,0SBS com adição dos ácidos, os comportamentos para ambas, em relação à sensibilidade ao envelhecimento, são similares. 
Tabela 61 - Viscosidade (Pa.s) para os ligantes asfálticos modificados com SBS e PA85 na condição RTFOT (Lubnor).

\begin{tabular}{lccccc}
\hline \multirow{2}{*}{ Ligantes Asfálticos } & \multicolumn{5}{c}{ Temperaturas $\left({ }^{\circ} \mathrm{C}\right)$} \\
\cline { 2 - 6 } & 135 & 143 & 155 & 163 & 177 \\
\hline Lubnor & 0,525 & 0,341 & 0,246 & 0,144 & 0,087 \\
2,5SBS & 0,866 & 0,561 & 0,405 & 0,239 & 0,144 \\
2,5SBS+0,75 PA85 & 1,446 & 0,924 & 0,665 & 0,391 & 0,233 \\
2,5SBS+1,5PA85 & 2,429 & 1,508 & 1,060 & 0,613 & 0,345 \\
5,0SBS & 1,563 & 0,989 & 0,723 & 0,439 & 0,265 \\
5,0SBS + 0,75PA85 & 2,579 & 1,665 & 1,256 & 0,777 & 0,436 \\
5,0SBS+1,5PA85 & 4,592 & 2,573 & 1,891 & 1,147 & 0,643 \\
\hline
\end{tabular}

Tabela 62 - Viscosidade (Pa.s) para os ligantes asfálticos modificados com SBS e PPA na condição RTFOT (Lubnor).

\begin{tabular}{lccccc}
\hline \multirow{2}{*}{ Ligantes Asfálticos } & \multicolumn{5}{c}{ Temperaturas $\left({ }^{\circ} \mathrm{C}\right)$} \\
\cline { 2 - 6 } & 135 & 143 & 155 & 163 & 177 \\
\hline Lubnor & 0,525 & 0,341 & 0,246 & 0,144 & 0,087 \\
$2,5 S B S$ & 0,866 & 0,561 & 0,405 & 0,239 & 0,144 \\
$2,5 S B S+0,75$ PPA & 1,410 & 0,915 & 0,665 & 0,394 & 0,235 \\
2,5SBS+1,5PPA & 2,704 & 1,667 & 1,160 & 0,648 & 0,366 \\
5,0SBS & 1,563 & 0,989 & 0,723 & 0,439 & 0,265 \\
5,0SBS + 0,75PPA & 2,647 & 1,631 & 1,213 & 0,727 & 0,428 \\
5,0SBS+1,5 PPA & 5,373 & 3,243 & 2,368 & 1,382 & 0,770 \\
\hline
\end{tabular}

Ao analisar os dois tipos de ligantes asfálticos de base utilizados, pode-se perceber que à luz da propriedade viscosidade, o efeito dos modificadores foi mais expressivo no ligante asfáltico proveniente da Replan, que também apresentou maior sensibilidade ao envelhecimento, com maiores diferenças percentuais entre os valores desta propriedade na condição virgem e na condição envelhecida em curto prazo. De posse dos valores de viscosidade na condição virgem, foram determinadas as temperaturas de usinagem e compactação das misturas estudadas, apresentadas no próximo item.

\subsubsection{Temperatura de Usinagem e Compactação}

Os cálculos das temperaturas de usinagem e de compactação (TUCs) dos ligantes asfálticos virgens foram realizados com base nos limites tradicionais de viscosidade rotacional, sendo eles: $0,17 \pm 0,02$ Pa.s para a usinagem e 0,28 $\pm 0,03$ Pa.s para a compactação. 
Os dados referentes às temperaturas de usinagem e compactação das amostras estudadas estão apresentadas na Tabela 63 e Tabela 64, para os ligantes asfálticos provenientes da Replan e Lubnor, respectivamente. As temperaturas de usinagem e compactação dos ligantes modificados estão acima dos valores encontrados para o ligante asfáltico de base, independente do modificador utilizado.

Nota-se, para amostras produzidas com o ligante asfáltico proveniente da Replan (Tabela 63), que para misturas com adição de 2,5SBS juntamente com os ácidos, os valores de temperatura de usinagem e compactação são similares independente do ácido adicionado. Para as misturas com altos teores de SBS (5,0\%), a adição do ácido PPA proporcionou temperatura de usinagem e compactação mais altas do que as misturas com adição de PA85. No entanto, as temperaturas encontradas para estas misturas estão acima das recomendadas pelas normas. Ao analisar os valores de temperatura e compactação considerando a especificação do DNIT 031/2006 referente à temperatura do ligante para concreto asfáltico, adota-se que a temperatura do ligante asfáltico não deve ser inferior a $107^{\circ} \mathrm{C}$ nem exceder a $177^{\circ} \mathrm{C}$, pode-se verificar que, para este ligante asfáltico de base, somente a mistura com adição de 2,5SBS poderia ser utilizado.

Tabela 63 - Temperatura $\left({ }^{\circ} \mathrm{C}\right)$ de Usinagem e Compactação dos Ligantes Modificados (Replan).

\begin{tabular}{lccccccc}
\hline Ligantes Asfálticos & \multicolumn{2}{c}{ Usinagem } & Média & \multicolumn{3}{c}{ Compactação } & Média \\
\hline Replan & 148 & -154 & $\mathbf{1 5 1}$ & 137 & - & 142 & $\mathbf{1 4 0}$ \\
\hline 2,5SBS & 167 & -173 & $\mathbf{1 7 0}$ & 155 & - & 160 & $\mathbf{1 5 8}$ \\
2,5SBS +0,75PA85 & 177 & -183 & $\mathbf{1 8 0}$ & 163 & - & 170 & $\mathbf{1 6 7}$ \\
2,5SBS +1,5PA85 & 185 & -191 & $\mathbf{1 8 8}$ & 175 & - & 180 & $\mathbf{1 7 8}$ \\
2,5SBS +0,75PPA & 177 & -183 & $\mathbf{1 8 0}$ & 164 & - & 170 & $\mathbf{1 6 7}$ \\
2,5SBS +1,5PPA & 186 & -194 & $\mathbf{1 9 0}$ & 176 & - & 181 & $\mathbf{1 7 9}$ \\
\hline 5,0SBS & 182 & -187 & $\mathbf{1 8 5}$ & 169 & - & 175 & $\mathbf{1 7 2}$ \\
5,0SBS +0,75PA85 & 200 & -205 & $\mathbf{2 0 3}$ & 185 & - & 192 & $\mathbf{1 8 9}$ \\
5,0SBS +1,5PA85 & 205 & -212 & $\mathbf{2 0 9}$ & 193 & - & 198 & $\mathbf{1 9 6}$ \\
5,0SBS +0,75PPA & 206 & -215 & $\mathbf{2 1 1}$ & 193 & - & 198 & $\mathbf{1 9 6}$ \\
5,0SBS +1,5PPA & 215 & -220 & $\mathbf{2 1 8}$ & 202 & - & 207 & $\mathbf{2 0 5}$ \\
\hline
\end{tabular}

Nas amostras produzidas com o ligante asfáltico proveniente da Lubnor (Tabela 64), as misturas com adição de 2,5SBS juntamente com os ácidos, os valores de temperatura de usinagem e compactação são similares independente do ácido adicionado. Para as misturas com altos teores de SBS $(5,0 \%)$ a adição do ácido PPA proporcionou temperatura de usinagem e compactação mais altas do que as misturas com adição de PA85. No que se refere à especificação do DNIT 031/2006 referente a temperatura do ligante para concreto asfáltico, pode-se verificar que, para este ligante asfáltico de base, somente misturas com 
adição de 2,5SBS sozinho ou juntamente com teores baixos dos ácidos poderiam ser utilizadas.

Tabela 64 - Temperatura $\left({ }^{\circ} \mathrm{C}\right)$ de Usinagem e Compactação dos Ligantes Modificados (Lubnor).

\begin{tabular}{lccccccc}
\hline Ligantes Asfálticos & Usinagem & Média & \multicolumn{3}{c}{ Compactação } & Média \\
\hline Lubnor & 150 & -155 & $\mathbf{1 5 3}$ & 138 & - & 144 & $\mathbf{1 4 1}$ \\
\hline 2,5SBS & 169 & -175 & $\mathbf{1 7 2}$ & 158 & - & 164 & $\mathbf{1 6 1}$ \\
2,5SBS +0,75PA85 & 175 & -180 & $\mathbf{1 7 7}$ & 162 & - & 167 & $\mathbf{1 6 5}$ \\
2,5SBS +1,5PA85 & 182 & -187 & $\mathbf{1 8 5}$ & 167 & - & 173 & $\mathbf{1 7 0}$ \\
2,5SBS +0,75PPA & 174 & -181 & $\mathbf{1 7 7}$ & 162 & - & 168 & $\mathbf{1 6 5}$ \\
2,5SBS +1,5PPA & 182 & -187 & $\mathbf{1 8 5}$ & 170 & - & 175 & $\mathbf{1 7 3}$ \\
\hline 5,0SBS & 182 & -187 & $\mathbf{1 8 5}$ & 169 & - & 175 & $\mathbf{1 7 2}$ \\
5,0SBS +0,75PA85 & 189 & -196 & $\mathbf{1 9 3}$ & 177 & - & 183 & $\mathbf{1 8 0}$ \\
5,0SBS +1,5PA85 & 196 & -203 & $\mathbf{2 0 0}$ & 184 & - & 189 & $\mathbf{1 8 7}$ \\
5,0SBS +0,75PPA & 192 & -197 & $\mathbf{1 9 5}$ & 177 & - & 184 & $\mathbf{1 8 1}$ \\
5,0SBS +1,5PPA & 203 & -208 & $\mathbf{2 0 6}$ & 189 & - & 195 & $\mathbf{1 9 2}$ \\
\hline
\end{tabular}

Ao analisarmos os ligantes asfálticos de base, independente dos valores encontrados atenderem os limites sugeridos pelas normas, nota-se que apesar do ligante asfáltico de base da Lubnor apresentar valores de viscosidade um pouco maiores que os encontrados para o ligante asfáltico da Replan, as temperaturas de usinagem e compactação para as misturas produzidas pelo último apresentaram valores maiores de temperaturas, indicando que o efeito dos modificadores foi mais expressivo neste ligante asfáltico de base.

\subsubsection{Balanço de Massa}

Os resultados da perda de massa para os ligantes modificados 2,5SBS e os ácidos (PA85 e PPA) produzidos com o ligante asfáltico de base Replan estão apresentados na Figura 60. Pode-se observar que, todos os ligantes asfálticos modificados apresentam maiores perdas de massa quando comparados aos ligantes asfálticos de base. Para todas as amostras observa-se uma maior perda com o aumento do teor dos modificadores. Para misturas com concentrações baixas de ácido $(0,75 \%)$, as misturas com adição de PA85 apresentaram perdas um pouco inferiores às misturas com adição de PPA. No entanto, para misturas com adição de altas concentrações dos ácidos $(1,5 \%)$ as misturas com adição de PA85 apresentaram perdas superiores. Contudo, considerando o limite de perda de massa 
de 0,50\% especificado pelo Regulamento Técnico 03/200519 da Agência Nacional de Petróleo, Gás Natural e Biocombustíveis (ANP) para CAPs modificados, todos os materiais estudados atendem a exigência estabelecida.

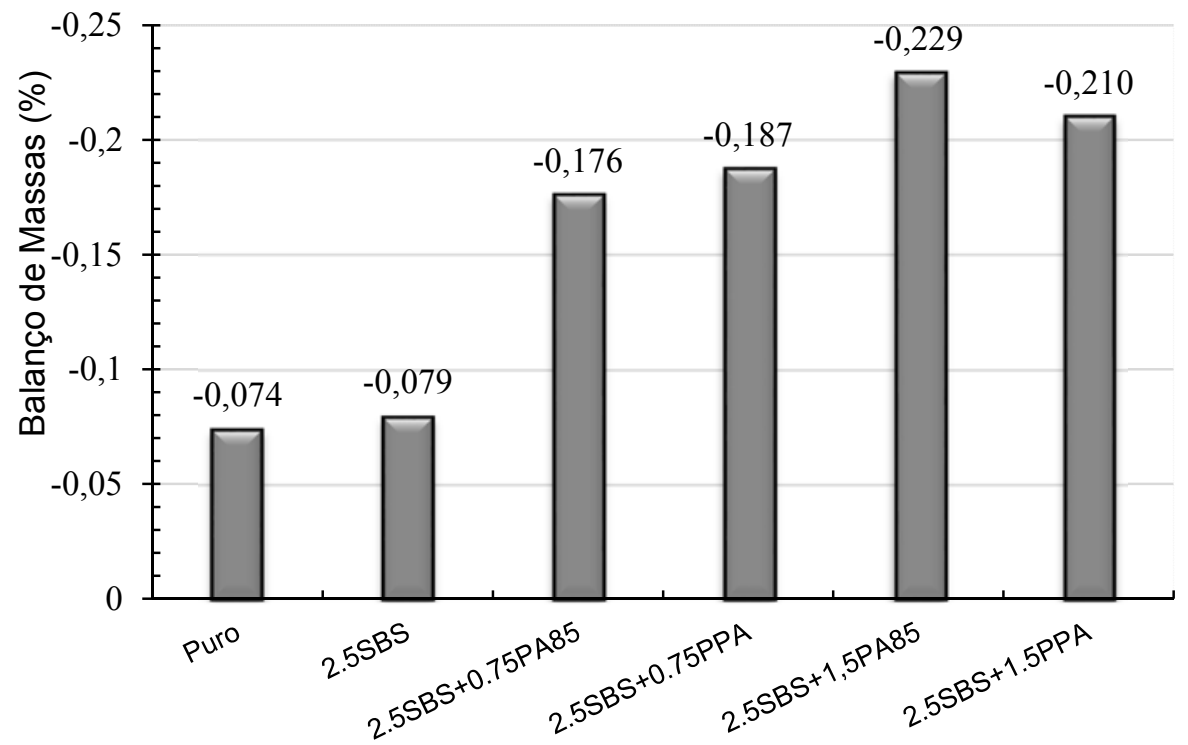

Figura 60 - Perda de massa para ligantes modificados com 2,5SBS e os ácidos (Replan).

Os resultados da perda de massa para os ligantes modificados 5,0 SBS e os ácidos (PA85 e PPA) produzidos com o ligante asfáltico de base Replan estão apresentados na Figura 60. Todos os ligantes asfálticos modificados apresentam maiores perdas de massa quando comparados aos ligantes asfálticos de base. Para todas as amostras observa-se uma maior perda com o aumento do teor dos modificadores, com exceção da mistura de 5,0SBS+0,75PA85 e 5,0SBS+1,5PA85 que apresentaram perdas semelhantes. Com a adição de altos teores do copolímero SBS, todas as misturas com adição de PA85 apresentaram perdas superiores quando comparadas com as misturas com adição de PPA. No entanto, considerando o limite de perda de massa de $0,50 \%$ para CAPs modificados, todos os materiais estudados atendem a exigência estabelecida.

\footnotetext{
${ }^{19}$ AGÊNCIA NACIONAL DO PETRÓLEO, GÁS NATURAL E BIOCOMBUSTíVEIS. (2005). Regulamento Técnico 03/2005: Cimento Asfáltico de Petróleo. Brasília, DF.
} 


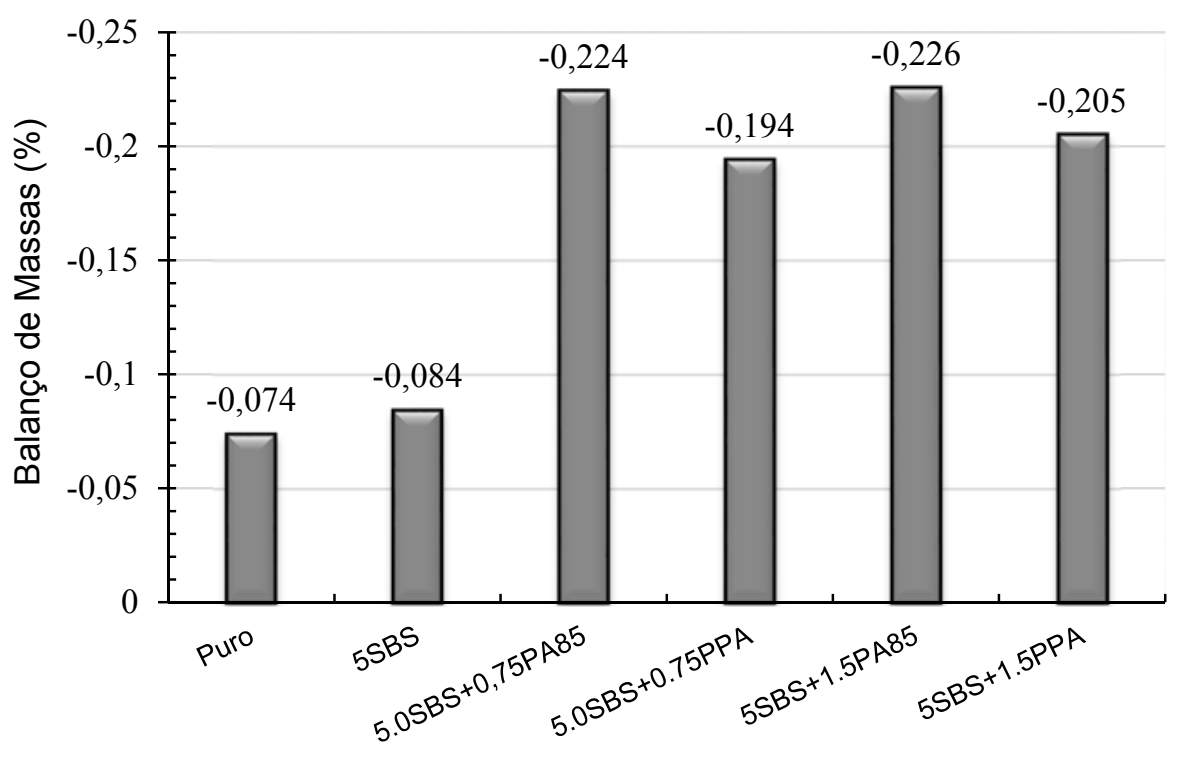

Figura 61 - Perda de massa para ligantes modificados com 5,0SBS e os ácidos (Replan).

O comportamento referente à perda de massa para o ligante asfáltico proveniente da Lubnor foi diferente do encontrado para o ligante asfáltico de base da Replan. Os resultados da perda de massa para os ligantes modificados 2,5 SBS e os ácidos (PA85 e PPA) produzidos com o ligante asfáltico de base Lubnor estão apresentados na Figura 62. Pode ser observado que a adição de $2,5 \%$ do copolímero SBS neste ligante asfáltico de base acarretou uma oxidação do material, fazendo com que o material tivesse um ganho de massa.

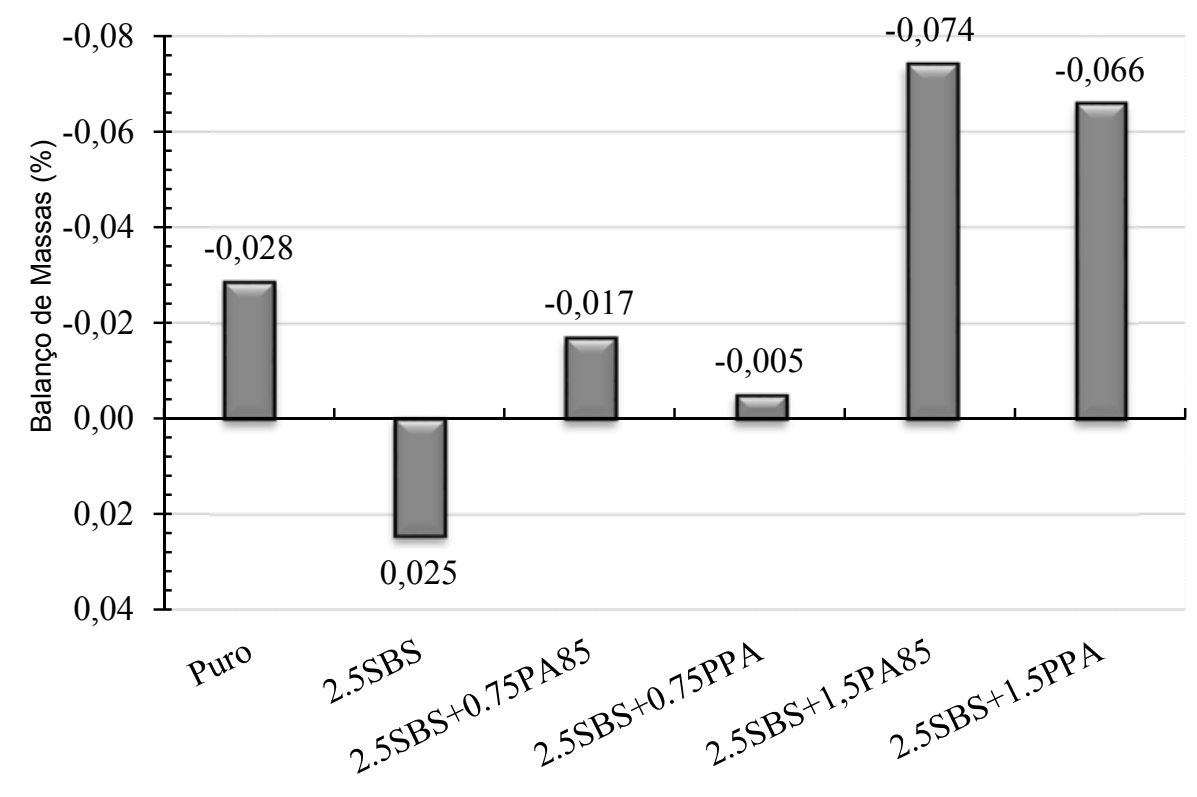

Figura 62 - Perda de massa para ligantes modificados com 2,5SBS e os ácidos (Lubnor). 
Além disso, as misturas com 2,5SBS e adição de baixos teores de ácido $(0,75 \%)$ apresentaram perdas inferiores ao ligante asfáltico de base. Apenas as misturas com adição de altos teores de ambos os ácidos apresentaram perdas superiores ao ligante asfáltico de baseNeste contexto, ainda cabe destacar que, as misturas com adição do PA85 apresentaram perdas de massa superiores às misturas com adição de PPA, porém, apesar disto, salientase que todas as misturas apresentam valores inferiores de perda quando verificado o limite estabelecido pela ANP.

O mesmo comportamento foi observado para as misturas com adição de 5,0\% de SBS sem ou com a presença dos ácidos, conforme pode ser verificado na Figura 63.

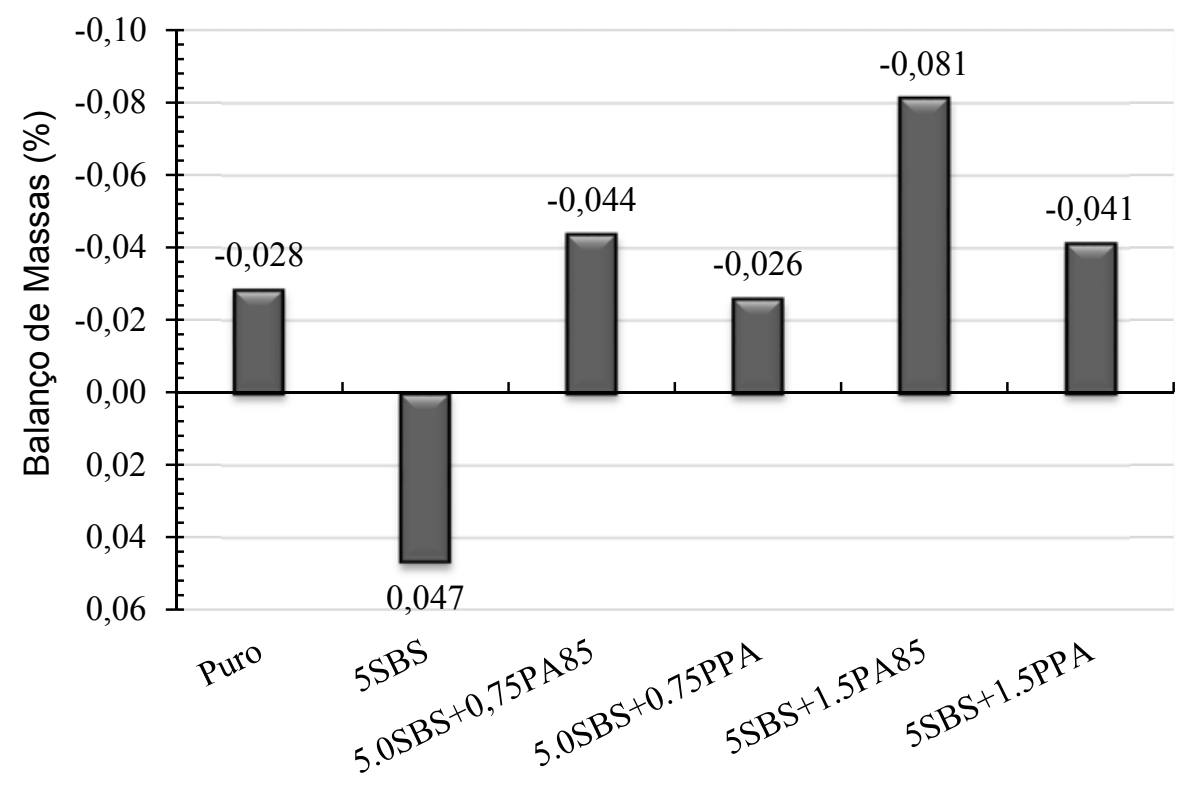

Figura 63 - Perda de massa para ligantes modificados com 5,0SBS e os ácidos (Lubnor).

A adição de 5,0\% do copolímero SBS acarretou ganho de massa ao material. Nota-se que a mistura com adição de 5,0SBS+0,75PPA apresentou valores de perdas de massa inferiores ao ligante asfáltico de base; o restante das misturas apresentaram maiores perdas. Assim como nas misturas com adição de 2,5SBS+ácidos, as misturas com adição de PA85 foram mais sensíveis ao envelhecimento, apresentando perdas maiores que as misturas com adição do PPA. No entanto, assim como as demais misturas produzidas com este ligante asfáltico de base, as perdas se encontram dentro do limite das especificações.

\subsubsection{Estabilidade à Estocagem}

A estabilidade à estocagem está atrelada à compatibilidade entre os agentes modificadores e o ligante asfáltico de base. Quando o polímero é solúvel no ligante asfáltico 
não existe separação de fase, o que não exige agitação na estocagem do material. Caso exista a separação de fases será necessário estocagem com agitação do material. Na Tabela 65 estão apresentados todos os valores referente à diferença do ponto de amolecimento no topo e no fundo das amostras estudadas. Nota-se que apenas a mistura produzida com o ligante asfáltico da Lubnor com adição de 2,5\% de copolímero SBS, apresentou valor abaixo de $5^{\circ} \mathrm{C}$ como recomenda a norma, para estocagem sem agitação. Nesta condição, a adição dos ácidos não foi benéfica, pois apresentaram maiores valores de diferença entre o ponto de amolecimento do topo e fundo.

Tabela 65- Diferença do Ponto de Amolecimento $\left({ }^{\circ} \mathrm{C}\right)$ entre topo e fundo das amostras de todos os ligantes asfálticos.

\begin{tabular}{lcc}
\hline Ligantes Asfálticos & Replan & Lubnor \\
\hline 2,5SBS & 15,05 & 0,60 \\
2,5SBS+0,75PA85 & 13,73 & 10,50 \\
2,5SBS+0,75PPA & 14,47 & 13,05 \\
2,5SBS+1,5PA85 & 9,48 & 9,50 \\
2,5SBS+1,5PPA & 13,58 & 12,60 \\
5SBS & 39,43 & 55,15 \\
5SBS+0,75PA85 & 29,73 & 49,75 \\
5SBS+0,75PPA & 21,73 & 47,80 \\
5SBS+1,5PA85 & 18,03 & 30,90 \\
5SBS+1,5PPA & 21,98 & 33,70 \\
\hline
\end{tabular}

Pode-se perceber que, para misturas com baixas concentrações do copolímero SBS (2,5SBS) e a adição dos ácidos, o ligante asfáltico de base proveniente da Lubnor apresentou maior estabilidade (menores valores na diferença de topo e fundo), apesar de não atenderem a especificação. A adição dos ácidos melhorou a estabilidade a estocagem das misturas, com exceção do Lubnor com $2,5 \%$ de SBS, e o PA85 apresentou valores um pouco inferior das diferenças do ponto de amolecimento entre o topo e fundo quando comparado com o PPA. No entanto, para as misturas com adição de altas concentrações do copolímero SBS (5,0SBS) os valores encontrados foram bem superiores aos indicados pela norma, e o ligante asfáltico de base da Replan apresentou um comportamento melhor quanto à estabilidade à estocagem se comparado com o ligante asfáltico de base da Lubnor. Nota-se também, que para estas misturas, independente do ligante asfáltico de base (com exceção do Lubnor com 2,5\% de SBS), a adição dos ácidos foi benéfica, sendo que a adição do PA85 apresentou valores um pouco inferiores do que os com a adição de PPA. 


\subsubsection{Ensaio de Fluência e Recuperação sob Tensão Múltipla (MSCR)}

Os resultados referentes aos ensaios MSCR serão avaliados em função das recuperações médias do ligante asfáltico e pelos valores médios da compliância nãorecuperável $\left(\mathrm{J}_{\mathrm{nr}}\right)$ nas tensões de 100Pa e 3200Pa. Por recomendações da Asphalt Institute (2010a), as análises devem ser realizadas na temperatura na qual o ligante asfáltico estará sendo solicitado durante sua vida útil. Assim como realizado para as misturas com adição somente dos ácidos, a temperatura adotada como a temperatura do pavimento é de $64^{\circ} \mathrm{C}$. Contudo, a título de análise, os dados aqui apresentados estão contemplando todas as cinco temperaturas de análise, $52^{\circ} \mathrm{C}, 58^{\circ} \mathrm{C}, 64^{\circ} \mathrm{C}, 70^{\circ} \mathrm{C}$ e $76^{\circ} \mathrm{C}$, e destacados os dados referentes à temperatura de $64^{\circ} \mathrm{C}$.

$\mathrm{Na}$ Tabela 66 estão apresentados os valores de recuperação dos ligantes asfálticos modificados produzidos com o ligante asfáltico da Replan, para as 5 (cinco) temperaturas ensaiadas.

Tabela 66 - Valores de Recuperação (\%) dos ligantes asfálticos modificados (Replan).

\begin{tabular}{lcccccccccc}
\hline \multirow{2}{*}{ Ligantes Asfálticos } & \multicolumn{3}{c}{$52^{\circ} \mathrm{C}$} & \multicolumn{2}{c}{$58^{\circ} \mathrm{C}$} & \multicolumn{2}{c}{$\mathbf{6 4}^{\circ} \mathbf{C}$} & \multicolumn{2}{c}{$70^{\circ} \mathrm{C}$} & \multicolumn{2}{c}{$76^{\circ} \mathrm{C}$} \\
\cline { 2 - 11 } & $100 \mathrm{~Pa}$ & $3200 \mathrm{~Pa}$ & $100 \mathrm{~Pa}$ & $3200 \mathrm{~Pa}$ & $\mathbf{1 0 0 P a}$ & $\mathbf{3 2 0 0 P a}$ & $100 \mathrm{~Pa}$ & $3200 \mathrm{~Pa}$ & $100 \mathrm{~Pa}$ & $3200 \mathrm{~Pa}$ \\
\hline Puro & 12,54 & 8,99 & 6,05 & 0,55 & $\mathbf{1 , 2 4}$ & $\mathbf{0 , 0 0}$ & 0,00 & 0,00 & 0,00 & 0,00 \\
2,5SBS & 22,77 & 19,66 & 14,68 & 8,24 & $\mathbf{8 , 0 1}$ & $\mathbf{0 , 3 3}$ & 2,26 & 0,00 & 0,00 & 0,00 \\
2,5SBS+0,75PA85 & 53,27 & 51,06 & 42,54 & 36,20 & $\mathbf{3 1 , 8 8}$ & $\mathbf{1 9 , 1 7}$ & 21,87 & 5,68 & 14,10 & 0,00 \\
2,5SBS+0,75PPA & 55,51 & 53,67 & 45,13 & 39,20 & $\mathbf{3 5 , 1 9}$ & $\mathbf{2 1 , 8 1}$ & 25,25 & 7,16 & 15,33 & 0,00 \\
2,5SBS+1.5PA85 & 72,67 & 72,16 & 65,90 & 62,62 & $\mathbf{5 6 , 8 2}$ & $\mathbf{4 7 , 8 8}$ & 46,87 & 28,14 & 35,82 & 10,42 \\
2,5SBS+1.5PPA & 78,44 & 78,71 & 73,92 & 71,75 & $\mathbf{6 6 , 1 9}$ & $\mathbf{6 0 , 2 8}$ & 57,10 & 42,98 & 46,96 & 22,35 \\
\hline 5SBS & 60,17 & 54,98 & 55,71 & 42,07 & $\mathbf{4 8 , 6 7}$ & $\mathbf{2 7 , 9 9}$ & 39,73 & 15,41 & 30,32 & 6,13 \\
5SBS+0,75PA85 & 67,58 & 67,34 & 61,19 & 55,55 & $\mathbf{5 1 , 6 5}$ & $\mathbf{4 0 , 4 5}$ & 42,02 & 24,54 & 32,22 & 11,73 \\
5SBS + 0,75PPA & 74,08 & 72,35 & 67,37 & 60,97 & $\mathbf{5 8 , 7 0}$ & $\mathbf{4 6 , 1 6}$ & 49,12 & 30,18 & 39,46 & 17,04 \\
5SBS+1,5 PA85 & 79,06 & 80,73 & 74,75 & 72,91 & $\mathbf{6 6 , 9 4}$ & $\mathbf{6 1 , 0 5}$ & 57,56 & 45,04 & 47,97 & 26,69 \\
5SBS+1,5 PPA & 87,67 & 86,11 & 84,88 & 81,13 & $\mathbf{7 8 , 5 8}$ & $\mathbf{7 2 , 7 5}$ & 70,88 & 60,39 & 61,93 & 44,24 \\
\hline
\end{tabular}

O ligante puro apresenta recuperação somente até a temperatura de $64^{\circ} \mathrm{C}$ na tensão de $100 \mathrm{~Pa}$, no restante das condicionantes ele apresenta valor de recuperação igual a zero. Nota-se que a adição dos modificadores, de forma geral, foi benéfica, pois os valores de recuperação aumentaram, e com o aumento nas concentrações desses modificadores temse um melhor comportamento dessa propriedade à medida que se aumenta a temperatura. Observa-se que as misturas com adição de 2,5SBS apresentam recuperação até a temperatura de $70^{\circ} \mathrm{C}$ na tensão de $100 \mathrm{~Pa}$, enquanto as misturas com adição de

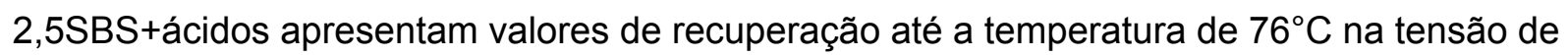
$100 \mathrm{~Pa}$, e as demais misturas apresentam alguma recuperação em quaisquer temperaturas e tensões aplicadas. 
Os aumentos da temperatura e da tensão tendem a reduzir o valor de recuperação dos materiais. Nota-se que os valores de recuperação das misturas com adição de PPA são superiores aos valores das misturas com adição de PA85. No entanto, pode-se verificar, que independente do ácido utilizado, os valores de recuperação da mistura com $5 \%$ do copolímero SBS está entre os valores encontrados para as misturas com 2,5SBS+0,75ácido e $2,5 \mathrm{SBS}+1,5$ ácido. Quanto à temperatura de interesse $\left(64^{\circ} \mathrm{C}\right)$, pode ser observado que todos os ligantes asfálticos modificados, independente da tensão aplicada, apresentaram valores de recuperação que indicam melhora do comportamento em relação ao ligante asfáltico de base.

$\mathrm{Na}$ Tabela 67 estão apresentados os dados de Compliância não recuperável dos ligantes asfálticos modificados produzidos com o ligante asfáltico da Replan, para as 5 (cinco) temperaturas ensaiadas.

Tabela 67 - Valores de Compliância não recuperável $\left(\mathrm{kPa}^{-1}\right)$ dos ligantes asfálticos modificados (Replan).

\begin{tabular}{llllllllllll}
\hline \multirow{2}{*}{ Ligantes Asfálticos } & \multicolumn{3}{c}{$52^{\circ} \mathrm{C}$} & \multicolumn{3}{c}{$58^{\circ} \mathrm{C}$} & \multicolumn{3}{c}{$\mathbf{6 4} \mathbf{}^{\circ} \mathbf{C}$} & \multicolumn{3}{c}{$70^{\circ} \mathrm{C}$} & \multicolumn{3}{c}{$76^{\circ} \mathrm{C}$} \\
\cline { 2 - 10 } & $100 \mathrm{~Pa}$ & $3200 \mathrm{~Pa}$ & $100 \mathrm{~Pa}$ & $3200 \mathrm{~Pa}$ & $\mathbf{1 0 0 P a}$ & $\mathbf{3 2 0 0 P a}$ & $100 \mathrm{~Pa}$ & $3200 \mathrm{~Pa}$ & $100 \mathrm{~Pa}$ & $3200 \mathrm{~Pa}$ \\
\hline Puro & 0,33 & 0,34 & 0,92 & 1,02 & $\mathbf{2 , 4 2}$ & $\mathbf{2 , 7 6}$ & 5,93 & 6,77 & 13,49 & 15,18 \\
2.5SBS & 0,21 & 0,22 & 0,55 & 0,62 & $\mathbf{1 , 4 1}$ & $\mathbf{1 , 6 7}$ & 3,46 & 4,14 & 8,22 & 9,64 \\
2.5SBS+0.75PA85 & 0,05 & 0,06 & 0,14 & 0,16 & $\mathbf{0 , 3 7}$ & $\mathbf{0 , 4 6}$ & 0,93 & 1,25 & 2,17 & 3,10 \\
2.5SBS+0.75PPA & 0,05 & 0,05 & 0,12 & 0,14 & $\mathbf{0 , 3 2}$ & $\mathbf{0 , 4 0}$ & 0,81 & 1,10 & 1,93 & 2,77 \\
2.5SBS+1.5PA85 & 0,02 & 0,02 & 0,04 & 0,04 & $\mathbf{0 , 1 0}$ & $\mathbf{0 , 1 3}$ & 0,26 & 0,37 & 0,62 & 1,02 \\
2.5SBS+1.5PPA & 0,01 & 0,01 & 0,02 & 0,02 & $\mathbf{0 , 0 6}$ & $\mathbf{0 , 0 7}$ & 0,14 & 0,20 & 0,35 & 0,58 \\
5SBS & 0,05 & 0,06 & 0,12 & 0,17 & $\mathbf{0 , 3 0}$ & $\mathbf{0 , 4 6}$ & 0,73 & 1,21 & 1,70 & 2,97 \\
5SBS + 0,75PA85 & 0,02 & 0,02 & 0,05 & 0,06 & $\mathbf{0 , 1 3}$ & $\mathbf{0 , 1 6}$ & 0,31 & 0,43 & 0,72 & 1,11 \\
5SBS + 0,75PPA & 0,02 & 0,02 & 0,04 & 0,05 & $\mathbf{0 , 0 9}$ & $\mathbf{0 , 1 3}$ & 0,24 & 0,34 & 0,55 & 0,88 \\
5SBS+1,5 PA85 & 0,01 & 0,01 & 0,02 & 0,02 & $\mathbf{0 , 0 4}$ & $\mathbf{0 , 0 5}$ & 0,11 & 0,15 & 0,26 & 0,41 \\
5SBS+1,5 PPA & 0,00 & 0,00 & 0,01 & 0,01 & $\mathbf{0 , 0 2}$ & $\mathbf{0 , 0 3}$ & 0,05 & 0,07 & 0,13 & 0,20 \\
\hline
\end{tabular}

A adição dos modificadores proporciona uma redução nos valores de compliância não recuperável, o que a torna positiva, visto que quanto menor o valor da compliância não recuperável, maior a tolerância do material frente à deformação permanente. No entanto, os aumentos da temperatura e do nível de tensão proporcionam um aumento nos valores de compliância não recuperável. Os valores de $J_{\mathrm{nr}}$ das misturas com adição de PPA são um pouco menores aos das misturas com adição de PA85.

$\mathrm{Na}$ Tabela 68 são apresentadas as diferenças percentuais entre as compliâncias $\left(\mathrm{J}_{\mathrm{nr}}, \mathrm{d}_{\mathrm{iff}}\right)$ para o ligante asfáltico de base proveniente da Replan e os ligantes asfálticos modificados com PPA e PA85, na condição envelhecida em curto prazo. O ligante asfáltico de base é o menos sensível à mudança da tensão. Pode ser observado também que para as temperaturas de $52^{\circ} \mathrm{C}$ e $58^{\circ} \mathrm{C}$, as adições dos ácidos diminuem a sensibilidade à mudança de 
tensão em relação aos ligantes asfálticos sem adição de ácido. Nas temperaturas de $70^{\circ} \mathrm{C} \mathrm{e}$ $76^{\circ} \mathrm{C}$ os ligantes asfálticos com baixos teores do copolímero SBS e altos teores de ácidos são os mais sensíveis à mudança de tensão. Já os ligantes asfálticos modificados com altos teores de copolímero SBS são os menos sensíveis à mudança de tensão, quando comparados com os ligantes asfálticos modificados somente com o copolímero SBS. É importante salientar que, os ligantes asfálticos avaliados não apresentam diferenças percentuais superiores ao valor de $75 \%$ estipulado pela norma AASHTO MP19.

Tabela 68 - Diferenças percentuais entre as compliâncias não-recuperáveis ( $\left.\mathrm{Jn}_{\mathrm{n}}, \mathrm{d}_{\mathrm{iff}}\right)$ dos ligantes asfálticos provenientes da Replan.

\begin{tabular}{lccccc}
\hline Ligantes Asfálticos & $52^{\circ} \mathrm{C}$ & $58^{\circ} \mathbf{C}$ & $\mathbf{6 4}{ }^{\circ} \mathbf{C}$ & $70^{\circ} \mathrm{C}$ & $76^{\circ} \mathbf{C}$ \\
\hline Puro & 4,93 & 11,43 & $\mathbf{1 4 , 3 4}$ & 14,08 & 12,54 \\
2.5SBS & 5,19 & 12,63 & $\mathbf{1 8 , 3 2}$ & 19,65 & 17,32 \\
$2.5 S B S+0.75 P A 85$ & 4,58 & 11,82 & $\mathbf{2 4 , 3 3}$ & 35,00 & 42,85 \\
2.5SBS+0.75 PPA & 4,18 & 11,29 & $\mathbf{2 5 , 2 3}$ & 36,80 & 43,67 \\
2.5SBS+1.5PA85 & 0,97 & 9,12 & $\mathbf{2 0 , 9 0}$ & 43,00 & 62,69 \\
2.5SBS+1.5PPA & 2,39 & 8,41 & $\mathbf{1 7 , 9 0}$ & 38,20 & 67,34 \\
5SBS & 14,71 & 35,89 & $\mathbf{5 2 , 6 8}$ & 65,83 & 74,82 \\
5SBS + 0,75PA85 & 5,33 & 15,80 & $\mathbf{2 6 , 3 7}$ & 40,72 & 56,96 \\
5SBS + 0,75PPA & 7,13 & 21,34 & $\mathbf{3 3 , 8 8}$ & 46,33 & 58,48 \\
5SBS+1,5 PA85 & 8,92 & 7,52 & $\mathbf{1 9 , 1 0}$ & 33,10 & 55,00 \\
5SBS+1,5 PPA & 13,40 & 13,19 & $\mathbf{2 9 , 7 9}$ & 40,91 & 56,80 \\
\hline
\end{tabular}

Os ligantes asfálticos mais sensíveis à mudança do nível de tensão foram os com adição de 5,0\% do copolímero SBS, que apresentam as maiores diferenças percentuais. Ao analisar o $\mathrm{J}_{\mathrm{nr}}, \mathrm{d}_{\mathrm{iff}}$ na temperatura do pavimento adotada no presente trabalho $\left(64^{\circ} \mathrm{C}\right)$, nota-se que a sensibilidade à tensão diminuiu com o aumento do teor dos ácidos, com exceção do ligante asfáltico 2,5SBS+0,75Ácido. Comparando-se os dois ácidos, pode-se observar que as amostras com adição de PPA, com exceção da mistura com 2,5SBS+1,5PPA, são mais sensíveis à tensão do que as amostras modificadas com PA85, pois apresentam diferenças percentuais maiores.

Com o auxílio dos valores de $\mathrm{J}_{\mathrm{nr}}$ na tensão de 3200Pa e na temperatura máxima do pavimento na condição de envelhecimento em curto prazo, os ligantes asfálticos foram classificados quanto ao critério de tráfego do FHWA, cujos resultados estão apresentados na Tabela 69, para os ligantes asfálticos modificados produzidos com o ligante asfáltico de base proveniente da Replan. 
Tabela 69 - Classificação dos ligantes asfálticos modificados (Replan) segundo critério de tráfego do FHWA.

\begin{tabular}{|c|c|c|c|c|c|}
\hline \multirow{2}{*}{ Ligantes Asfálticos } & $52^{\circ} \mathrm{C}$ & $58^{\circ} \mathrm{C}$ & $64^{\circ} \mathrm{C}$ & $70^{\circ} \mathrm{C}$ & $76^{\circ} \mathrm{C}$ \\
\hline & $3200 \mathrm{~Pa}$ & $3200 \mathrm{~Pa}$ & $3200 \mathrm{~Pa}$ & $3200 \mathrm{~Pa}$ & $3200 \mathrm{~Pa}$ \\
\hline Replan & $E$ & $\mathrm{H}$ & $\mathbf{S}$ & - & - \\
\hline $2,5 S B S$ & $E$ & V & $\mathbf{H}$ & - & - \\
\hline 2,5SBS+0,75 PA85 & $E$ & $E$ & $\mathbf{E}$ & V & $S$ \\
\hline 2,5SBS+0,75 PPA & $E$ & $E$ & $E$ & V & $\mathrm{S}$ \\
\hline 2,5SBS+1,5 PA85 & $E$ & $E$ & $E$ & $E$ & $\mathrm{H}$ \\
\hline 2,5SBS+1,5 PPA & $E$ & $E$ & $\mathbf{E}$ & $E$ & V \\
\hline 5SBS & $E$ & $E$ & $\mathbf{E}$ & $\mathrm{H}$ & S \\
\hline $5 S B S+0,75$ PA85 & $E$ & $E$ & $\mathbf{E}$ & $E$ & $\mathrm{H}$ \\
\hline $5 S B S+0,75$ PPA & $E$ & $E$ & $\mathbf{E}$ & $E$ & V \\
\hline 5SBS+1,5 PA85 & $E$ & $E$ & $E$ & $E$ & $E$ \\
\hline 5SBS+1,5 PPA & $E$ & $E$ & $E$ & $E$ & $E$ \\
\hline
\end{tabular}

O ligante asfáltico de base tem capacidade para atender um tráfego padrão (menos de 10 milhões de solicitações) na temperatura de serviço $\left(64^{\circ} \mathrm{C}\right)$. A modificação do ligante asfáltico de base aumenta a capacidade de suporte de tráfego desses materiais. Com adição dos ácidos todos os ligantes asfálticos apresentam capacidade de suporte de um tráfego extremamente pesado (mais de 100 milhões de solicitações). Com exceção da temperatura de $76^{\circ} \mathrm{C}$, a capacidade de suporte do tráfego, para qualquer tipo de ácido utilizado, é a mesmo.

$\mathrm{Na}$ Tabela 70 estão apresentados os valores de recuperação dos ligantes asfálticos modificados produzidos com o ligante asfáltico da Lubnor, para as 5 (cinco) temperaturas ensaiadas. $O$ ligante puro apresenta recuperação somente até a temperatura de $52^{\circ} \mathrm{C}$ na tensão de $3200 \mathrm{~Pa}$, nas outras condições ele apresenta valores de recuperação igual a zero. Nota-se que a adição dos modificadores, de forma geral, foi benéfica, pois aumentaram os valores de recuperação, e com o aumento na concentrações desses modificadores tem-se um melhor comportamento frente a essa propriedade, à medida que se aumenta a temperatura. Observa-se que as misturas com adição de 2,5SBS apresentam recuperação até a temperatura de $64^{\circ} \mathrm{C}$ na tensão de $100 \mathrm{~Pa}$, enquanto as misturas com adição de 2,5SBS+0,75 Ácidos apresentam valores de recuperação até a temperatura de $76^{\circ} \mathrm{C}$ na tensão de $100 \mathrm{~Pa}$, porém não apresentam recuperação a $70^{\circ} \mathrm{C}$ na tensão de $3200 \mathrm{~Pa}$. Este mesmo comportamento é observado para as misturas com adição de 5,0\% do copolímero SBS. Todas as misturas com adição de altos teores do copolímero SBS com adição dos ácidos apresentam recuperação independente da temperatura e da tensão.

Os aumentos da temperatura e da tensão tendem a reduzir o valor da recuperação dos materiais. Nota-se que os valores de recuperação das misturas com adição de PPA são um pouco superiores aos valores para as misturas com adição de PA85. No entanto, pode-se 
verificar que, independente do ácido utilizado, os valores de recuperação da mistura com 5\% de SBS está entre os valores encontrados para as misturas com 2,5SBS e $2,5 \mathrm{SBS}+0,75$ Ácido. Quanto à temperatura de interesse $\left(64^{\circ} \mathrm{C}\right)$, observa-se que todos os ligantes asfálticos modificados com ácidos, independente da tensão aplicada, apresentaram valores de recuperação, melhorando o comportamento do ligante asfáltico de base.

Tabela 70 - Valores de Recuperação (\%) dos ligantes asfálticos modificados (Lubnor).

\begin{tabular}{lcccccccccc}
\hline \multirow{2}{*}{ Ligantes Asfálticos } & \multicolumn{3}{c}{$52^{\circ} \mathrm{C}$} & \multicolumn{2}{c}{$58^{\circ} \mathrm{C}$} & \multicolumn{2}{c}{$\mathbf{6 4} \mathbf{C}^{\circ}$} & \multicolumn{2}{c}{$70^{\circ} \mathrm{C}$} & \multicolumn{3}{c}{$76^{\circ} \mathrm{C}$} \\
\cline { 2 - 11 } & $100 \mathrm{~Pa}$ & $3200 \mathrm{~Pa}$ & $100 \mathrm{~Pa}$ & $3200 \mathrm{~Pa}$ & $\mathbf{1 0 0 P a}$ & $\mathbf{3 2 0 0 P a}$ & $100 \mathrm{~Pa}$ & $3200 \mathrm{~Pa}$ & $100 \mathrm{~Pa}$ & $3200 \mathrm{~Pa}$ \\
\hline Puro & 1,79 & 0,56 & 0,00 & 0,00 & $\mathbf{0 , 0 0}$ & $\mathbf{0 , 0 0}$ & 0,00 & 0,00 & 0,00 & 0,00 \\
2.5SBS & 14,13 & 11,72 & 7,45 & 3,07 & $\mathbf{2 , 3 2}$ & $\mathbf{0 , 0 0}$ & 0,00 & 0,00 & 0,00 & 0,00 \\
2.5SBS+0.75PA85 & 33,65 & 30,04 & 22,46 & 15,97 & $\mathbf{1 3 , 1 0}$ & $\mathbf{4 , 4 2}$ & 5,69 & 0,00 & 0,77 & 0,00 \\
2.5SBS+0.75 PPA & 33,55 & 30,49 & 22,92 & 16,66 & $\mathbf{1 3 , 9 9}$ & $\mathbf{4 , 8 8}$ & 6,99 & 0,00 & 1,16 & 0,00 \\
2.5SBS+1.5PA85 & 55,52 & 54,04 & 43,97 & 39,49 & $\mathbf{3 2 , 5 4}$ & $\mathbf{2 2 , 3 6}$ & 21,97 & 7,54 & 13,02 & 0,00 \\
2.5SBS+1.5PPA & 59,38 & 57,92 & 48,28 & 43,82 & $\mathbf{3 6 , 6 7}$ & $\mathbf{2 6 , 3 1}$ & 25,05 & 9,88 & 14,49 & 0,56 \\
5SBS & 30,30 & 26,29 & 20,37 & 13,46 & $\mathbf{1 1 , 6 5}$ & $\mathbf{4 , 0 0}$ & 5,50 & 0,00 & 1,17 & 0,00 \\
5SBS+ 0,75PA85 & 48,04 & 47,47 & 39,06 & 32,94 & $\mathbf{2 9 , 9 2}$ & $\mathbf{1 8 , 5 7}$ & 21,19 & 8,57 & 12,87 & 4,10 \\
5SBS+ 0,75PPA & 49,71 & 48,19 & 43,25 & 34,68 & $\mathbf{3 5 , 4 2}$ & $\mathbf{2 1 , 7 2}$ & 27,34 & 11,39 & 19,29 & 4,47 \\
5SBS+1,5 PA85 & 60,84 & 65,13 & 58,58 & 53,02 & $\mathbf{5 2 , 9 3}$ & $\mathbf{3 9 , 5 3}$ & 46,22 & 26,87 & 38,77 & 17,32 \\
5SBS+1,5 PPA & 70,70 & 71,69 & 63,79 & 59,89 & $\mathbf{5 3 , 8 2}$ & $\mathbf{4 4 , 8 2}$ & 43,00 & 28,50 & 33,06 & 15,53 \\
\hline
\end{tabular}

Na Tabela 71 estão apresentados os dados de Compliância não recuperável dos ligantes asfálticos modificados produzidos com o ligante asfáltico da Lubnor, para as 5 (cinco) temperaturas ensaiadas.

Tabela 71 - Valores de Compliância não recuperável $\left(\mathrm{kPa}^{-1}\right)$ dos ligantes asfálticos modificados (Lubnor).

\begin{tabular}{|c|c|c|c|c|c|c|c|c|c|c|}
\hline \multirow{2}{*}{ Ligantes Asfálticos } & \multicolumn{2}{|c|}{$52^{\circ} \mathrm{C}$} & \multicolumn{2}{|c|}{$58^{\circ} \mathrm{C}$} & \multicolumn{2}{|c|}{$64^{\circ} \mathrm{C}$} & \multicolumn{2}{|c|}{$70^{\circ} \mathrm{C}$} & \multicolumn{2}{|c|}{$76^{\circ} \mathrm{C}$} \\
\hline & $100 \mathrm{~Pa}$ & $3200 \mathrm{~Pa}$ & $100 \mathrm{~Pa}$ & $3200 \mathrm{~Pa}$ & $100 \mathrm{~Pa}$ & $3200 \mathrm{~Pa}$ & $100 \mathrm{~Pa}$ & $3200 \mathrm{~Pa}$ & $100 \mathrm{~Pa}$ & $3200 \mathrm{~Pa}$ \\
\hline Puro & 0,55 & 0,57 & 1,48 & 1,53 & 3,61 & 3,82 & 8,33 & 8,83 & 17,77 & 18,88 \\
\hline $2.5 \mathrm{SBS}$ & 0,31 & 0,32 & 0,82 & 0,89 & 2,03 & 2,25 & 4,71 & 5,31 & 10,39 & 11,55 \\
\hline $2.5 \mathrm{SBS}+0.75 \mathrm{PA} 85$ & 0,13 & 0,14 & 0,36 & 0,40 & 0,94 & 1,10 & 2,28 & 2,76 & 5,11 & 6,27 \\
\hline 2.5SBS+0.75 PPA & 0,13 & 0,14 & 0,36 & 0,40 & 0,91 & 1,08 & 2,18 & 2,68 & 4,96 & 6,14 \\
\hline $2.5 \mathrm{SBS}+1.5 \mathrm{PA} 85$ & 0,04 & 0,05 & 0,12 & 0,13 & 0,32 & 0,38 & 0,80 & 1,05 & 1,88 & 2,59 \\
\hline 2.5SBS+1.5PPA & 0,04 & 0,04 & 0,10 & 0,11 & 0,26 & 0,31 & 0,67 & 0,89 & 1,60 & 2,24 \\
\hline $5 S B S$ & 0,18 & 0,19 & 0,47 & 0,53 & 1,17 & 1,37 & 2,69 & 3,24 & 5,84 & 7,16 \\
\hline $5 S B S+0,75 P A 85$ & 0,06 & 0,06 & 0,15 & 0,17 & 0,39 & 0,48 & 0,94 & 1,22 & 2,14 & 2,84 \\
\hline $5 \mathrm{SBS}+0,75 \mathrm{PPA}$ & 0,06 & 0,07 & 0,16 & 0,18 & 0,38 & 0,49 & 0,92 & 1,26 & 2,09 & 2,96 \\
\hline $5 S B S+1,5$ PA85 & 0,02 & 0,02 & 0,06 & 0,07 & 0,14 & 0,19 & 0,34 & 0,51 & 0,79 & 1,26 \\
\hline $5 \mathrm{SBS}+1,5 \mathrm{PPA}$ & 0,02 & 0,02 & 0,04 & 0,04 & 0,10 & 0,12 & 0,25 & 0,33 & 0,58 & 0,84 \\
\hline
\end{tabular}

A adição dos modificadores proporciona uma redução nos valores de compliância não recuperável, tornando a adição dos modificadores positiva, visto que quanto menor o valor da 
compliância não recuperável, maior a tolerância do material frente à deformação permanente. No entanto, os aumentos da temperatura e do nível de tensão proporcionam aumentos nos valores de compliância não recuperável. Os valores de $J_{\mathrm{nr}}$ das misturas com adição de PPA são um pouco menores aos das misturas com adição de PA85.

$\mathrm{Na}$ Tabela 72 são apresentadas as diferenças percentuais entre as compliâncias $\left(\mathrm{J}_{\mathrm{nr}}, \mathrm{d}_{\text {iff }}\right)$ para o ligante asfáltico de base proveniente da Lubnor e os ligantes asfálticos modificados com PPA e PA85, na condição envelhecida em curto prazo. O aumento da temperatura aumenta a sensibilidade à mudança da tensão. Nas temperaturas de $52^{\circ} \mathrm{C}$ e $58^{\circ} \mathrm{C}$, o aumento na modificação dos ligantes asfálticos proporciona redução na sensibilidade à mudança na tensão. Para temperatura de $64^{\circ} \mathrm{C}$ a $76^{\circ} \mathrm{C}$, a adição dos modificadores aumentou a sensibilidade à mudança de tensão. Contudo, todos os ligantes asfálticos avaliados não apresentam diferenças percentuais superiores ao valor de $75 \%$ estipulado pela norma AASHTO MP19.

Tabela 72 - Diferenças percentuais entre as compliâncias não-recuperáveis $\left(\mathrm{J}_{\mathrm{nr}}, \mathrm{d}_{\mathrm{iff}}\right)$ dos ligantes asfálticos provenientes da Lubnor.

\begin{tabular}{lccccc}
\hline Ligantes Asfálticos & $52^{\circ} \mathrm{C}$ & $58^{\circ} \mathrm{C}$ & $\mathbf{6 4} 4^{\circ} \mathbf{C}$ & $70^{\circ} \mathrm{C}$ & $76^{\circ} \mathrm{C}$ \\
\hline Puro & 2,38 & 3,74 & $\mathbf{5 , 7 7}$ & 6,04 & 6,23 \\
2.5SBS & 7,40 & 8,22 & $\mathbf{1 1 , 2 5}$ & 12,60 & 11,18 \\
2,5SBS+0,75 PA85 & 6,46 & 11,40 & $\mathbf{1 7 , 5 5}$ & 20,77 & 22,64 \\
2,5SBS+0,75 PPA & 5,47 & 11,28 & $\mathbf{1 8 , 5 3}$ & 23,19 & 23,80 \\
2,5SBS+1,5 PA85 & 3,55 & 8,96 & $\mathbf{1 9 , 8 1}$ & 30,77 & 37,69 \\
2,5SBS+1,5 PPA & 3,79 & 9,27 & $\mathbf{2 0 , 5 0}$ & 32,62 & 40,02 \\
5SBS & 8,07 & 13,40 & $\mathbf{1 7 , 4 2}$ & 20,31 & 22,73 \\
5SBS + 0,75 PA85 & 1,46 & 12,23 & $\mathbf{2 3 , 4 2}$ & 30,18 & 32,93 \\
5SBS + 0,75 PPA & 3,87 & 14,56 & $\mathbf{2 8 , 3 7}$ & 36,41 & 41,32 \\
5SBS+1,5 PA85 & 2,93 & 15,28 & $\mathbf{3 4 , 1 7}$ & 49,52 & 58,47 \\
5SBS+1,5 PPA & 3,62 & 12,05 & $\mathbf{2 2 , 6 8}$ & 33,70 & 44,67 \\
\hline
\end{tabular}

O ligante asfáltico mais sensível à mudança do nível de tensão, com exceção da temperatura de $52^{\circ} \mathrm{C}$, foi o com adição de 5,0SBS+1,5 PA85, que apresenta as maiores diferenças percentuais. Ao analisar o $\mathrm{J}_{\mathrm{nr}}, \mathrm{d}_{\mathrm{iff}}$ na temperatura do pavimento adotada no presente trabalho $\left(64^{\circ} \mathrm{C}\right)$, nota-se que a sensibilidade à tensão aumenta com o aumento do teor dos ácidos. Comparando os dois ácidos, pode-se observar que as amostras com adição de PPA, com exceção da com 5SBS+1,5PPA, são mais sensíveis à tensão do que as modificadas com PA85, pois apresentam diferenças percentuais maiores.

$\mathrm{Na}$ Tabela 73 estão apresentadas as classificações segundo critério de tráfego do FHWA dos ligantes asfálticos modificados produzidos com o ligante asfáltico de base da 
Lubnor. A classificação é realizada com base nos valores de $J_{n r}$ na tensão de 3200Pa e na temperatura máxima do pavimento na condição de envelhecimento em curto prazo.

Tabela 73 - Classificação segundo critério de tráfego do FHWA dos ligantes asfálticos modificados (Lubnor).

\begin{tabular}{|c|c|c|c|c|c|}
\hline \multirow{2}{*}{ Ligantes Asfálticos } & $52^{\circ} \mathrm{C}$ & $58^{\circ} \mathrm{C}$ & $64^{\circ} \mathrm{C}$ & $70^{\circ} \mathrm{C}$ & $76^{\circ} \mathrm{C}$ \\
\hline & $3200 \mathrm{~Pa}$ & $3200 \mathrm{~Pa}$ & $3200 \mathrm{~Pa}$ & $3200 \mathrm{~Pa}$ & $3200 \mathrm{~Pa}$ \\
\hline Lubnor & V & $\mathrm{H}$ & S & - & - \\
\hline $2,5 \mathrm{SBS}$ & $E$ & V & $\mathbf{S}$ & - & - \\
\hline $2,5 \mathrm{SBS}+0,75 \mathrm{PA} 85$ & $E$ & $E$ & H & $S$ & - \\
\hline $2,5 \mathrm{SBS}+0,75 \mathrm{PPA}$ & $E$ & $E$ & H & $S$ & - \\
\hline 2,5SBS+1,5PA85 & $E$ & $E$ & E & $S$ & $S$ \\
\hline $2,5 \mathrm{SBS}+1,5 \mathrm{PPA}$ & $E$ & $E$ & E & V & S \\
\hline 5 SBS & $E$ & V & H & $S$ & - \\
\hline $5 S B S+0,75 P A 85$ & $E$ & $E$ & E & $\mathrm{H}$ & $S$ \\
\hline $5 \mathrm{SBS}+0,75 \mathrm{PPA}$ & $E$ & $E$ & E & $\mathrm{H}$ & $S$ \\
\hline $5 S B S+1,5$ PA85 & $E$ & $E$ & E & V & $\mathrm{H}$ \\
\hline $5 \mathrm{SBS}+1,5 \mathrm{PPA}$ & $E$ & $E$ & E & $E$ & V \\
\hline
\end{tabular}

O aumento da temperatura, de maneira geral, diminui a capacidade de suporte ao tráfego. O ligante asfáltico de base tem capacidade para atender um tráfego padrão (menos de 10 milhões de solicitações) na temperatura de serviço $\left(64^{\circ} \mathrm{C}\right)$. A modificação do ligante asfáltico de base com adição dos ácidos aumenta a capacidade de suporte de tráfego desses materiais. Para temperatura de interesse, independente do ácido utilizado, a capacidade de suporte de tráfego suportada é a mesma. As misturas com 2,5SBS+0,75 Ácidos suportam um tráfego pesado, e as misturas com adição de 2,5SBS+1,5 Ácidos apresentam capacidade de suportarem um tráfego extremamente pesado. As misturas com adição de 5,0SBS+ Ácidos suportam tráfego extremamente pesado.

Quando comparadas as propriedades de recuperação, compliância não recuperável e sensibilidade ao nível de tensão para os dois tipos de ligantes asfálticos de base utilizados, pode-se constatar que as misturas provenientes do ligante asfáltico da Replan apresentaram maiores recuperações e menores valores de compliância não recuperáveis (menor sensibilidade à deformação permanente), porém foram mais sensíveis à mudança no nível de tensão, mas não ultrapassaram o limite da especificação de $75 \%$ entre as duas tensões aplicadas. Este mesmo ligante asfáltico de base apresentou maior suporte em relação ao tráfego. Sendo assim, percebe-se que o efeito dos modificadores para este ligante asfáltico de base foi mais expressivo. 


\subsubsection{Ensaio Tolerância ao Dano por Fadiga}

\subsubsection{Análise do índice de tolerância ao dano pelo parâmetro aff}

Os valores de $a_{f}$ de todos os ligantes asfálticos da Replan puro e modificados, na condição envelhecida em curto e em longo prazo, estão apresentados na Tabela 74. De maneira geral, os ligantes asfálticos modificados apresentam, com o aumento dos teores dos modificadores, valores de $a_{f}$ superiores aos do ligante asfáltico puro, independentemente do tipo de ácido adicionado e da condição de envelhecimento realizada. Pode-se observar que, independente do condicionamento das misturas, os valores de $a_{f}$ são superiores para as amostras com adição do PPA quando comparadas às com adição de PA85. Outro item que pode ser observado é que o envelhecimento é benéfico à luz da tolerância à fadiga, pois as misturas condicionadas ao envelhecimento em longo prazo apresentaram valores maiores de $a_{\mathrm{f}}$ quando comparadas com as envelhecidas em curto prazo.

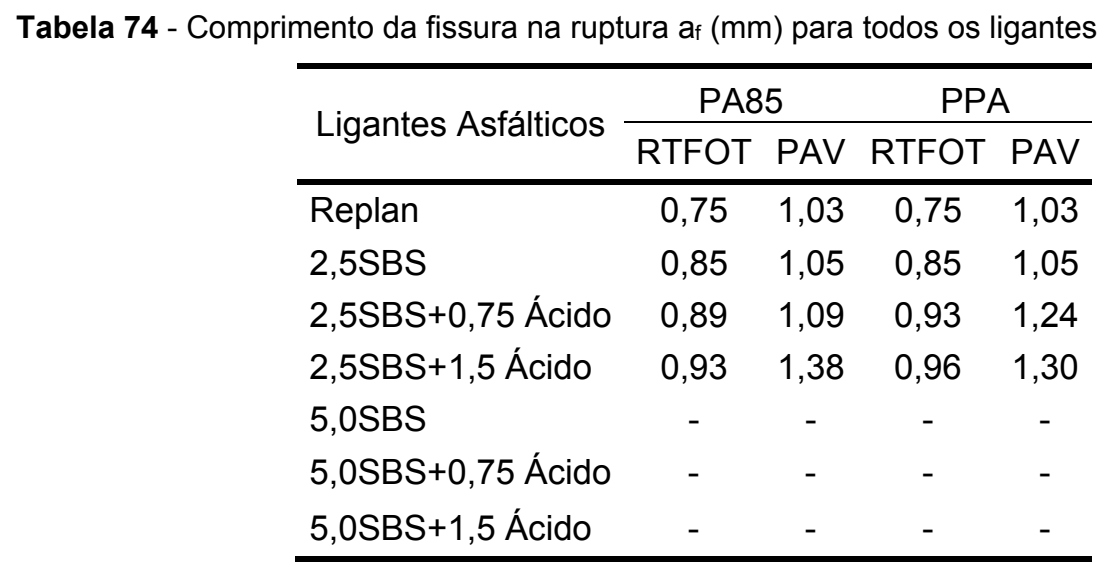

Cabe destacar que, como já explicado e apresentado para as misturas com adições somente de ácido, a análise do índice de tolerância à fadiga é realizada por meio do ponto mínimo da taxa de crescimento da fissura $\left(\mathrm{a}_{\mathrm{f}}\right)$, que corresponde ao ponto anterior ao rápido aumento na taxa de crescimento da fissura, por meio do gráfico da variação do crescimento da fissura em função do número de ciclos versus o comprimento da fissura. No entanto é observado na Tabela 74 que as misturas com adição de 5,0SBS sem ou com a presença de ácido não apresentam valores de $a_{\mathrm{f}}$, isto porque na realização do ensaio não se encontrou um ponto de mínimo, já que o rápido incremento na taxa de crescimento da fissura não é bem definido, conforme ilustra a Figura 64. Nestes materiais foi preciso aumentar a amplitude de deformação, pois não foi possível obter a curva completa quando se executou o ensaio de acordo com carregamento do protocolo da norma AASHTO TP 101-12-UL (máximo de 30\% em 300 segundos). A deformação no ensaio foi aumentada até $80 \%$ em 800 segundos, 
conservando a mesma taxa de incremento de deformação linear do protocolo da AASTHO, e mesmo assim não foi possível verificar um ponto de mínimo.

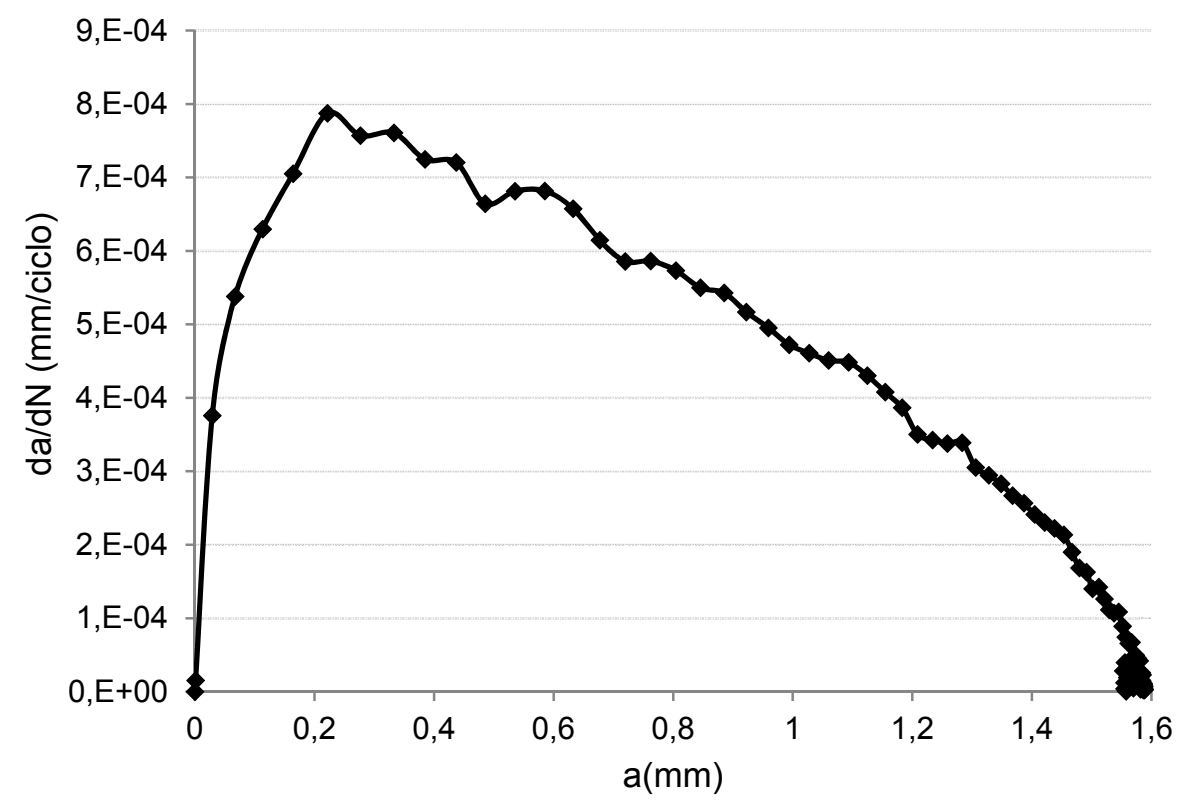

Figura 64 - Taxa de crescimento da fissura $(\mathrm{da} / \mathrm{dN})$ x a do ligante asfáltico 5,0SBS.

Para as misturas modificadas produzidas com o ligante asfáltico de base Lubnor, todos os pontos de mínimos foram determinados, conforme mostra a Tabela 75. Pode ser observado que a adição dos ácidos para misturas com 2,5\% do copolímero SBS não foi benéfica à luz desta propriedade, uma vez que apresentaram valores de $a_{f}$ inferiores.

Tabela 75 - Comprimento da fissura na ruptura af $(\mathrm{mm})$ para todos os ligantes asfálticos (Lubnor).

\begin{tabular}{lcccc}
\hline \multirow{2}{*}{ Ligantes Asfálticos } & \multicolumn{2}{c}{ PA85 } & \multicolumn{2}{c}{ PPA } \\
\cline { 2 - 5 } & RTFOT & PAV & RTFOT & PAV \\
\hline Lubnor & 0,61 & 0,71 & 0,61 & 0,71 \\
2,5SBS & 0,97 & 0,97 & 0,97 & 0,97 \\
2,5SBS+0,75 Ácido & 0,78 & 0,87 & 0,78 & 0,90 \\
2,5SBS+1,5 Ácido & 0,88 & 0,97 & 0,85 & 1,03 \\
5,0SBS & 0,83 & 0,96 & 0,83 & 0,96 \\
5,0SBS+0,75 Ácido & 0,88 & 0,99 & 0,92 & 1,02 \\
5,0SBS+1,5 Ácido & 0,94 & 1,15 & 0,91 & 1,36 \\
\hline
\end{tabular}

Cabe salientar ainda que, o comportamento destas misturas, independentemente do tipo de ácido e de envelhecimento, foi similar. Já para misturas com adição dos ácidos juntamente com 5,0\% do copolímero SBS, nota-se um efeito positivo dos ácidos, uma vez que aumentaram os valores de $a_{\mathrm{f}}$. Nota-se que para os ligantes asfálticos modificados com $2,5 \%$ do copolímero SBS o efeito do envelhecimento não foi significativo. Contudo é valido destacar 
que, todos os ligantes asfálticos modificados apresentaram maior tolerância à fadiga quando comparados com o ligante asfáltico de base. Nota-se que os valores de $a_{f}$ são superiores para as misturas produzidas com o ligante asfáltico da Replan, mostrando, como nas demais propriedades, que o efeito dos modificadores são mais expressivos para este ligante asfáltico de base. Quanto ao efeito dos ácidos, nota-se que as misturas com adição de PPA apresentaram valores um pouco superiores de $\mathrm{a}_{\mathrm{f}}$, independente do ligante asfáltico de base utilizado e do condicionamento de envelhecimento realizado.

\subsubsection{Análise do dano contínuo viscoelástico (VECD)}

$\mathrm{Na}$ Tabela 76 estão apresentados os valores dos parâmetros $A_{35}$ e $B$ do modelo de fadiga, obtidos a partir da análise VECD dos resultados do ensaio LAS modificado, para as amostras produzidas com o ligante asfáltico proveniente da Replan.

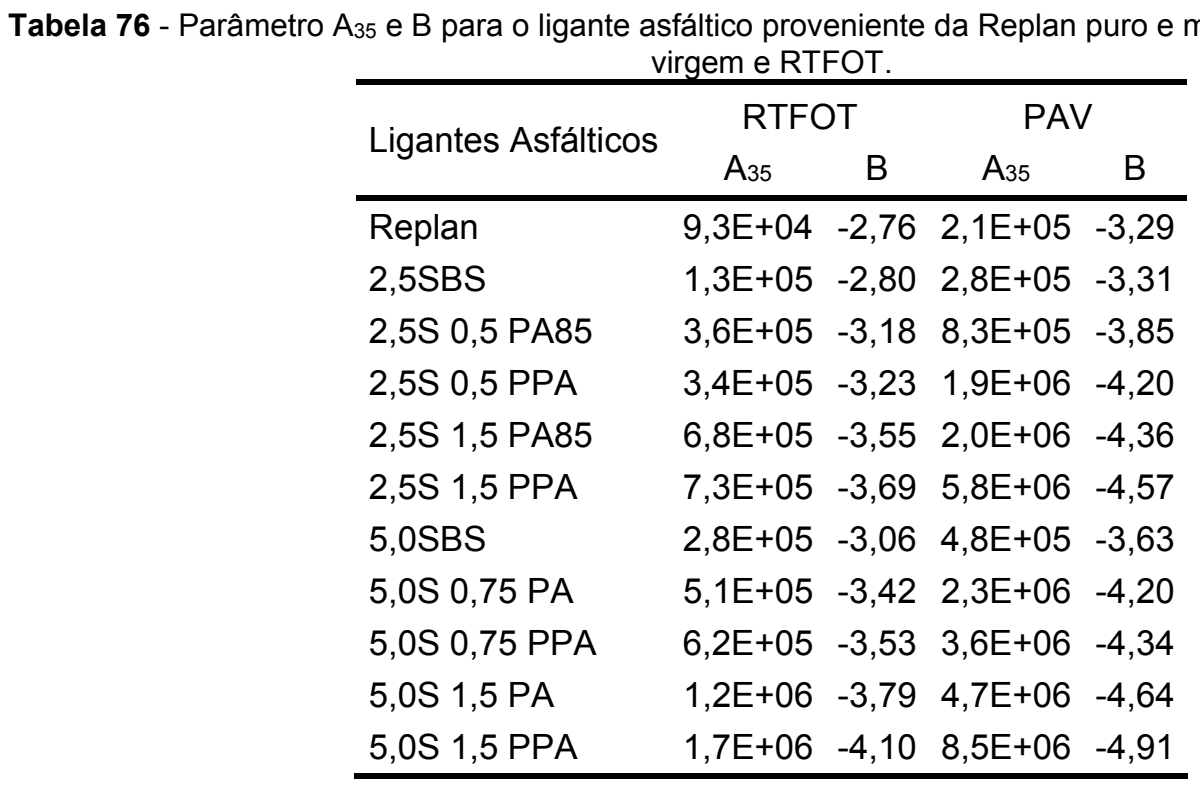

Pode-se observar que o parâmetro $A_{35}$ aumenta com a adição dos modificadores enquanto o parâmetro $B$ diminui. Isto mostra que ocorreu um descolamento das curvas de fadiga para cima (aumento de $\mathrm{A}_{35}$ ) e uma diminuição da declividade da curva (diminuição de B). Verifica-se também que os valores encontrados de $A_{35}$ e $B$ para as misturas com 5,0SBS estão entre estes valores encontrados para as misturas com 2,5\% do copolímero SBS e 2,5SBS+0,75 Ácido.

$\mathrm{Na}$ Tabela 77 e na Tabela 78 são apresentados os valores de Nf para os ligantes asfálticos provenientes da Replan na condição envelhecida em curto prazo e em longo prazo, 
respectivamente. Observa-se, nessas tabelas, que os valores de $N_{f}$ diminuem com o aumento da amplitude de deformação.

Tabela 77 - Valores de Nf para os ligantes modificados (Replan) em diversas amplitudes de deformação (\%), na condição envelhecida em curto prazo (RTFOT).

\begin{tabular}{ccccccc}
\hline \multirow{2}{*}{$\begin{array}{c}\text { Ligantes } \\
\text { Asfálticos }\end{array}$} & 1 & 10 & 20 & 40 & 60 & 80 \\
\hline Replan & $9,3 \mathrm{E}+04$ & $1,6 \mathrm{E}+02$ & $2,4 \mathrm{E}+01$ & $3,5 \mathrm{E}+00$ & $1,2 \mathrm{E}+00$ & $5,2 \mathrm{E}-01$ \\
$2,5 S B S$ & $1,3 \mathrm{E}+05$ & $2,1 \mathrm{E}+02$ & $2,9 \mathrm{E}+01$ & $4,2 \mathrm{E}+00$ & $1,4 \mathrm{E}+00$ & $6,1 \mathrm{E}-01$ \\
$2,5 \mathrm{~S} 0,75$ PA85 & $3,6 \mathrm{E}+05$ & $2,4 \mathrm{E}+02$ & $2,6 \mathrm{E}+01$ & $2,9 \mathrm{E}+00$ & $7,9 \mathrm{E}-01$ & $3,2 \mathrm{E}-01$ \\
$2,5 \mathrm{~S} 0,75$ PPA & $3,4 \mathrm{E}+05$ & $2,0 \mathrm{E}+02$ & $2,1 \mathrm{E}+01$ & $2,2 \mathrm{E}+00$ & $6,1 \mathrm{E}-01$ & $2,4 \mathrm{E}-01$ \\
$2,5 \mathrm{~S} 1,5$ PA85 & $6,8 \mathrm{E}+05$ & $1,9 \mathrm{E}+02$ & $1,6 \mathrm{E}+01$ & $1,4 \mathrm{E}+00$ & $3,3 \mathrm{E}-01$ & $1,2 \mathrm{E}-01$ \\
2,5S1,5 PPA & $7,3 \mathrm{E}+05$ & $1,5 \mathrm{E}+02$ & $1,2 \mathrm{E}+01$ & $8,9 \mathrm{E}-01$ & $2,0 \mathrm{E}-01$ & $6,9 \mathrm{E}-02$ \\
$5,0 S B S$ & $2,8 \mathrm{E}+05$ & $2,4 \mathrm{E}+02$ & $2,9 \mathrm{E}+01$ & $3,5 \mathrm{E}+00$ & $1,0 \mathrm{E}+00$ & $4,2 \mathrm{E}-01$ \\
$5,0 \mathrm{~S} 0,75$ PA & $5,1 \mathrm{E}+05$ & $2,0 \mathrm{E}+02$ & $1,8 \mathrm{E}+01$ & $1,7 \mathrm{E}+00$ & $4,3 \mathrm{E}-01$ & $1,6 \mathrm{E}-01$ \\
$5,0 \mathrm{~S} 0,75$ PPA & $6,2 \mathrm{E}+05$ & $1,8 \mathrm{E}+02$ & $1,6 \mathrm{E}+01$ & $1,4 \mathrm{E}+00$ & $3,3 \mathrm{E}-01$ & $1,2 \mathrm{E}-01$ \\
$5,0 \mathrm{~S} 1,5$ PA & $1,2 \mathrm{E}+06$ & $1,9 \mathrm{E}+02$ & $1,4 \mathrm{E}+01$ & $1,0 \mathrm{E}+00$ & $2,2 \mathrm{E}-01$ & $7,3 \mathrm{E}-02$ \\
$5,0 \mathrm{~S} 1,5$ PPA & $1,7 \mathrm{E}+06$ & $1,3 \mathrm{E}+02$ & $7,8 \mathrm{E}+00$ & $4,6 \mathrm{E}-01$ & $8,7 \mathrm{E}-02$ & $2,7 \mathrm{E}-02$ \\
\hline
\end{tabular}

Tabela 78 - Valores de Nf para os ligantes modificados (Replan) em diversas amplitudes de deformação (\%), na condição envelhecida em longo prazo (PAV).

\begin{tabular}{lcccccc}
\hline \multicolumn{1}{c}{ Ligantes } & \multicolumn{7}{c}{ Amplitude de deformação (\%) } \\
\multicolumn{1}{c}{ Asfálticos } & 1 & 10 & 20 & 40 & 60 & 80 \\
\hline Replan & $2,1 \mathrm{E}+05$ & $1,1 \mathrm{E}+02$ & $1,1 \mathrm{E}+01$ & $1,1 \mathrm{E}+00$ & $3,0 \mathrm{E}-01$ & $1,2 \mathrm{E}-01$ \\
2,5SBS & $2,8 \mathrm{E}+05$ & $1,4 \mathrm{E}+02$ & $1,4 \mathrm{E}+01$ & $1,4 \mathrm{E}+00$ & $3,6 \mathrm{E}-01$ & $1,4 \mathrm{E}-01$ \\
2,5S 0,5 PA85 & $8,3 \mathrm{E}+05$ & $1,2 \mathrm{E}+02$ & $8,0 \mathrm{E}+00$ & $5,6 \mathrm{E}-01$ & $1,2 \mathrm{E}-01$ & $3,8 \mathrm{E}-02$ \\
2,5S 0,5 PPA & $1,9 \mathrm{E}+06$ & $1,2 \mathrm{E}+02$ & $6,5 \mathrm{E}+00$ & $3,5 \mathrm{E}-01$ & $6,5 \mathrm{E}-02$ & $1,9 \mathrm{E}-02$ \\
2,5S 1,5 PA85 & $2,0 \mathrm{E}+06$ & $8,8 \mathrm{E}+01$ & $4,3 \mathrm{E}+00$ & $2,1 \mathrm{E}-01$ & $3,6 \mathrm{E}-02$ & $1,0 \mathrm{E}-02$ \\
2,5S 1,5 PPA & $5,8 \mathrm{E}+06$ & $1,5 \mathrm{E}+02$ & $6,5 \mathrm{E}+00$ & $2,7 \mathrm{E}-01$ & $4,3 \mathrm{E}-02$ & $1,1 \mathrm{E}-02$ \\
5,0SBS & $4,8 \mathrm{E}+05$ & $1,1 \mathrm{E}+02$ & $9,0 \mathrm{E}+00$ & $7,3 \mathrm{E}-01$ & $1,7 \mathrm{E}-01$ & $5,9 \mathrm{E}-02$ \\
5,0S ,75 PA85 & $2,3 \mathrm{E}+06$ & $1,5 \mathrm{E}+02$ & $8,1 \mathrm{E}+00$ & $4,4 \mathrm{E}-01$ & $8,0 \mathrm{E}-02$ & $2,4 \mathrm{E}-02$ \\
5,0S 0,75 PPA & $3,6 \mathrm{E}+06$ & $1,7 \mathrm{E}+02$ & $8,2 \mathrm{E}+00$ & $4,1 \mathrm{E}-01$ & $7,0 \mathrm{E}-02$ & $2,0 \mathrm{E}-02$ \\
5,0S 1,5 PA85 & $4,7 \mathrm{E}+06$ & $1,1 \mathrm{E}+02$ & $4,3 \mathrm{E}+00$ & $1,7 \mathrm{E}-01$ & $2,6 \mathrm{E}-02$ & $6,9 \mathrm{E}-03$ \\
5,0S 1,5 PPA & $8,5 \mathrm{E}+06$ & $1,1 \mathrm{E}+02$ & $3,5 \mathrm{E}+00$ & $1,2 \mathrm{E}-01$ & $1,6 \mathrm{E}-02$ & $3,9 \mathrm{E}-03$ \\
\hline
\end{tabular}

Pode-se destacar que, para deformações baixas, a adição dos modificadores é benéfica, uma vez que fornece maiores valores de $\mathrm{N}_{\mathrm{f}}$. No entanto, para amplitude de deformações maiores, o efeito dos modificadores não é positivo, tendo em vista que os maiores valores de $\mathrm{N}_{f}$ são apresentados pelo ligante asfáltico de base. Para a condição RTFOT é verificado que a partir de $10 \%$ de deformação, a adição dos modificadores não é benéfica, e para a condição PAV, as modificações com teores altos do copolímero SBS e intermediários de ácido $(0,75 \%)$ ainda seriam viáveis nessa amplitude de deformação. O efeito 
do envelhecimento, quando analisado $\circ \mathrm{N}_{\mathrm{f}}$, é vantajoso somente para amplitudes de deformações baixas, pois apresentam maiores valores de $\mathrm{N}_{\mathrm{f}}$, independente do ligante asfáltico de base utilizado. Ainda em relação ao $\mathrm{N}_{\mathrm{f}}$ na amplitude de deformação baixa, onde a adição dos modificadores seria benéfica, verifica-se que os valores encontrados para mistura de $5,0 \%$ de copolímero SBS estão entre os valores encontrados entre estes valores encontrados para as misturas com 2,5\% do copolímero SBS e 2,5SBS+0,75 Ácido.

$\mathrm{Na}$ Tabela 79 estão apresentados os valores dos parâmetros $A_{35}$ e $B$ do modelo de fadiga, obtidos a partir da análise VECD dos resultados do ensaio LAS modificado, para as amostras produzidas com o ligante asfáltico proveniente da Lubnor. Assim como para as misturas produzidas com o ligante asfáltico de base da Replan o parâmetro $A_{35}$ aumenta com a adição dos modificadores enquanto o parâmetro B diminui. Isto mostra que ocorreu um descolamento das curvas de fadiga para cima (aumento de A) e uma diminuição da declividade da curva (diminuição de B).

Tabela 79 - Parâmetro $A_{35}$ e B para o ligante asfáltico proveniente da Lubnor puro e modificados.

\begin{tabular}{lcccc}
\hline \multirow{2}{*}{ Ligantes Asfálticos } & \multicolumn{2}{c}{ RTFOT } & \multicolumn{2}{c}{ PAV } \\
& $\mathrm{A}_{35}$ & $\mathrm{~B}$ & $\mathrm{~A}_{35}$ & $\mathrm{~B}$ \\
\hline Lubnor & $4,8 \mathrm{E}+04$ & $-2,25$ & $6,1 \mathrm{E}+04$ & $-2,67$ \\
2,5SBS & $7,2 \mathrm{E}+04$ & $-2,43$ & $1,0 \mathrm{E}+05$ & $-2,91$ \\
2,5S 0,75 PA85 & $1,5 \mathrm{E}+05$ & $-2,78$ & $4,3 \mathrm{E}+05$ & $-3,33$ \\
2,5S 0,75 PPA & $1,5 \mathrm{E}+05$ & $-2,76$ & $3,4 \mathrm{E}+05$ & $-3,34$ \\
2,5S 1,5 PA85 & $2,3 \mathrm{E}+05$ & $-3,03$ & $7,0 \mathrm{E}+05$ & $-3,69$ \\
2,5S 1,5 PPA & $2,9 \mathrm{E}+05$ & $-3,13$ & $7,1 \mathrm{E}+05$ & $-3,84$ \\
5,0SBS & $1,0 \mathrm{E}+05$ & $-2,56$ & $2,1 \mathrm{E}+05$ & $-3,07$ \\
5,0S 0,75 PA85 & $2,4 \mathrm{E}+05$ & $-2,94$ & $6,3 \mathrm{E}+05$ & $-3,49$ \\
5,0S 0,75 PPA & $2,5 \mathrm{E}+05$ & $-2,93$ & $3,6 \mathrm{E}+05$ & $-3,54$ \\
5,0S 1,5 PA85 & $3,8 \mathrm{E}+05$ & $-3,16$ & $1,1 \mathrm{E}+06$ & $-3,83$ \\
5,0S 1,5PPA & $4,4 \mathrm{E}+05$ & $-3,32$ & $1,5 \mathrm{E}+06$ & $-4,03$ \\
\hline
\end{tabular}

Verifica-se também que os valores encontrados de $A_{35}$ e $B$ para as misturas com 5,0SBS estão entre estes valores encontrados para as misturas com $2,5 \%$ do copolímero SBS e 2,5SBS+0,75 Ácido. Quando comparado os dois tipos de ligantes asfálticos, nota-se um efeito mais intenso dos modificadores no ligante asfáltico da Replan, proporcionando maiores valores de $\mathrm{A}_{35}$ e menores de $\mathrm{B}$.

$\mathrm{Na}$ Tabela 80 e na Tabela 81 são apresentados os valores de Nf para os ligantes asfálticos provenientes da Lubnor na condição envelhecida em curto prazo e em longo prazo, respectivamente. Assim como para as misturas produzidas com o ligante asfáltico da Replan, os valores de $\mathrm{N}_{\mathrm{f}}$ diminuem com o aumento da amplitude de deformação. 
Tabela 80 - Valores de Nf para os ligantes modificados (Lubnor) em diversas amplitudes de deformação (\%), na condição envelhecida em curto prazo (RTFOT).

\begin{tabular}{lcccccc}
\hline \multirow{2}{*}{$\begin{array}{l}\text { Ligantes } \\
\text { Asfálticos }\end{array}$} & 1 & 10 & 20 & 40 & 60 & 80 \\
\hline Lubnor & $4,8 \mathrm{E}+04$ & $2,7 \mathrm{E}+02$ & $5,6 \mathrm{E}+01$ & $1,2 \mathrm{E}+01$ & $4,8 \mathrm{E}+00$ & $2,5 \mathrm{E}+00$ \\
2,5SBS & $7,2 \mathrm{E}+04$ & $2,7 \mathrm{E}+02$ & $5,0 \mathrm{E}+01$ & $9,3 \mathrm{E}+00$ & $3,5 \mathrm{E}+00$ & $1,7 \mathrm{E}+00$ \\
2,5S0,75PA85 & $1,5 \mathrm{E}+05$ & $2,5 \mathrm{E}+02$ & $3,6 \mathrm{E}+01$ & $5,2 \mathrm{E}+00$ & $1,7 \mathrm{E}+00$ & $7,6 \mathrm{E}-01$ \\
2,5S0,75PPA & $1,5 \mathrm{E}+05$ & $2,6 \mathrm{E}+02$ & $3,9 \mathrm{E}+01$ & $5,7 \mathrm{E}+00$ & $1,9 \mathrm{E}+00$ & $8,5 \mathrm{E}-01$ \\
2,5S1,5PA85 & $2,3 \mathrm{E}+05$ & $2,1 \mathrm{E}+02$ & $2,6 \mathrm{E}+01$ & $3,2 \mathrm{E}+00$ & $9,4 \mathrm{E}-01$ & $3,9 \mathrm{E}-01$ \\
2,5S1,5PPA & $2,9 \mathrm{E}+05$ & $2,2 \mathrm{E}+02$ & $2,5 \mathrm{E}+01$ & $2,8 \mathrm{E}+00$ & $7,9 \mathrm{E}-01$ & $3,2 \mathrm{E}-01$ \\
5,0SBS & $1,0 \mathrm{E}+05$ & $2,7 \mathrm{E}+02$ & $4,6 \mathrm{E}+01$ & $7,8 \mathrm{E}+00$ & $2,8 \mathrm{E}+00$ & $1,3 \mathrm{E}+00$ \\
5,0S0,75PA85 & $2,4 \mathrm{E}+05$ & $2,8 \mathrm{E}+02$ & $3,6 \mathrm{E}+01$ & $4,7 \mathrm{E}+00$ & $1,4 \mathrm{E}+00$ & $6,2 \mathrm{E}-01$ \\
5,0S0,75PPA & $2,5 \mathrm{E}+05$ & $3,0 \mathrm{E}+02$ & $3,9 \mathrm{E}+01$ & $5,2 \mathrm{E}+00$ & $1,6 \mathrm{E}+00$ & $6,8 \mathrm{E}-01$ \\
5,0S1,5PA85 & $3,8 \mathrm{E}+05$ & $2,6 \mathrm{E}+02$ & $3,0 \mathrm{E}+01$ & $3,3 \mathrm{E}+00$ & $9,2 \mathrm{E}-01$ & $3,7 \mathrm{E}-01$ \\
5,0S1,5PPA & $4,4 \mathrm{E}+05$ & $2,1 \mathrm{E}+02$ & $2,1 \mathrm{E}+01$ & $2,1 \mathrm{E}+00$ & $5,5 \mathrm{E}-01$ & $2,1 \mathrm{E}-01$ \\
\hline
\end{tabular}

Tabela 81 - Valores de Nf para os ligantes modificados (Lubnor) em diversas amplitudes de deformação (\%), na condição envelhecida em longo prazo (PAV).

\begin{tabular}{lcccccc}
\hline \multirow{2}{*}{ Ligantes Asfálticos } & \multicolumn{6}{c}{ Amplitude de deformação (\%) } \\
& 1 & 10 & 20 & 40 & 60 & 80 \\
\hline Lubnor & $6,1 \mathrm{E}+04$ & $1,3 \mathrm{E}+02$ & $2,0 \mathrm{E}+01$ & $3,2 \mathrm{E}+00$ & $1,1 \mathrm{E}+00$ & $4,9 \mathrm{E}-01$ \\
$2,5 S B S$ & $1,0 \mathrm{E}+05$ & $1,3 \mathrm{E}+02$ & $1,7 \mathrm{E}+01$ & $2,3 \mathrm{E}+00$ & $7,0 \mathrm{E}-01$ & $3,1 \mathrm{E}-01$ \\
2,5S 0,75PA85 & $4,3 \mathrm{E}+05$ & $2,0 \mathrm{E}+02$ & $2,0 \mathrm{E}+01$ & $2,0 \mathrm{E}+00$ & $5,2 \mathrm{E}-01$ & $2,0 \mathrm{E}-01$ \\
$2,5 \mathrm{~S}$ 0,75PPA & $3,4 \mathrm{E}+05$ & $1,5 \mathrm{E}+02$ & $1,5 \mathrm{E}+01$ & $1,5 \mathrm{E}+00$ & $3,9 \mathrm{E}-01$ & $1,5 \mathrm{E}-01$ \\
$2,5 \mathrm{~S}$ 1,5PA85 & $7,0 \mathrm{E}+05$ & $1,4 \mathrm{E}+02$ & $1,1 \mathrm{E}+01$ & $8,7 \mathrm{E}-01$ & $1,9 \mathrm{E}-01$ & $6,7 \mathrm{E}-02$ \\
2,5S 1,5PPA & $7,1 \mathrm{E}+05$ & $1,0 \mathrm{E}+02$ & $7,2 \mathrm{E}+00$ & $5,0 \mathrm{E}-01$ & $1,1 \mathrm{E}-01$ & $3,5 \mathrm{E}-02$ \\
5,0SBS & $2,1 \mathrm{E}+05$ & $1,8 \mathrm{E}+02$ & $2,1 \mathrm{E}+01$ & $2,5 \mathrm{E}+00$ & $7,2 \mathrm{E}-01$ & $3,0 \mathrm{E}-01$ \\
5,0S 0,75PA85 & $6,3 \mathrm{E}+05$ & $2,0 \mathrm{E}+02$ & $1,8 \mathrm{E}+01$ & $1,6 \mathrm{E}+00$ & $3,9 \mathrm{E}-01$ & $1,4 \mathrm{E}-01$ \\
5,0S 0,75PPA & $3,6 \mathrm{E}+05$ & $1,0 \mathrm{E}+02$ & $8,9 \mathrm{E}+00$ & $7,6 \mathrm{E}-01$ & $1,8 \mathrm{E}-01$ & $6,6 \mathrm{E}-02$ \\
5,0S 1,5PA85 & $1,1 \mathrm{E}+06$ & $1,6 \mathrm{E}+02$ & $1,1 \mathrm{E}+01$ & $7,9 \mathrm{E}-01$ & $1,7 \mathrm{E}-01$ & $5,6 \mathrm{E}-02$ \\
5,0S 1,5PPA & $1,5 \mathrm{E}+06$ & $1,4 \mathrm{E}+02$ & $8,6 \mathrm{E}+00$ & $5,3 \mathrm{E}-01$ & $1,0 \mathrm{E}-01$ & $3,2 \mathrm{E}-02$ \\
\hline
\end{tabular}

O comportamento encontrado para as misturas produzidas com o ligante asfáltico da Lubnor é semelhante, à luz do valor de $\mathrm{N}_{\mathrm{f}}$, ao das misturas com o ligante asfáltico da Replan. No entanto, os valores encontrados de $\mathrm{N}_{f}$ para as misturas com o ligante asfáltico de base da Replan são maiores que os valores encontrados para o ligante asfáltico de base da Lubnor. Cabe destacar que os gráficos referentes ao $N_{f} x$ amplitude de deformação referentes às tabelas anteriores estão no Apêndice $\mathrm{E}$. 


\subsubsection{Análise Estatística do Experimento com Misturas}

Esta seção tem por objetivo apresentar os procedimentos adotados na análise estatística dos resultados dos ensaios da segunda fase da pesquisa, com adição do copolímero SBS com ou sem a presença dos ácidos (PA85 e PPA). Foram realizados modelos estatísticos polinomiais lineares, com o auxílio do software Minitab versão 16.1. Com base nos modelos obtidos foram gerados gráficos de superfície de resposta e efeito dos componentes, que serão explicados posteriormente.

O modelo empregado na regressão, com o formato geral é indicado na equação 5.

$$
\eta=\sum_{\mathrm{i}=1}^{\mathrm{q}} \beta_{\mathrm{i}}^{0} \mathrm{x}_{\mathrm{i}}+\sum_{\mathrm{i}<\mathrm{j}} \sum_{\mathrm{ij}}^{\mathrm{q}} \beta_{\mathrm{i}}^{0} \mathrm{x}_{\mathrm{j}}+\beta_{\mathrm{ijk}}^{0} \mathrm{x}_{\mathrm{i}} \mathrm{x}_{\mathrm{j}} \mathrm{x}_{\mathrm{k}}
$$

com:

- $\mathrm{i}, \mathrm{j}, \mathrm{k}=1,2, \ldots \mathrm{q}$, sendo q o número de componentes da mistura,

- $\beta_{\mathrm{i}}, \beta_{\mathrm{ij}}$ e $\beta_{\mathrm{ijk}}$ as estimativas dos coeficientes dos termos $\mathrm{x}_{\mathrm{i}}, \mathrm{x}_{\mathrm{ij}}$ e $\mathrm{x}_{\mathrm{ijk}}$, respectivamente,

- $\mathrm{x}_{\mathrm{i}}, \mathrm{x}_{\mathrm{j}}$ e $\mathrm{x}_{\mathrm{k}}$ correspondentes aos teores de CAP, de copolímero SBS e de ácido, respectivamente.

A análise de regressão fornece os coeficientes dos termos dos modelos, com seus testes de significância, e seus valores de coeficiente de determinação $\left(R^{2}\right)$, assim como o gráfico de resíduos para análise. O teste de hipótese é realizado mediante avaliação da significância de cada termo do modelo gerado, sendo que um coeficiente zero indica que não é significativo dentro do nível de confiança estabelecido (95\%), e se for diferente de zero então entende-se como significativo, adotando o coeficiente encontrado. Apesar de, em alguns casos, o efeito da multicolinearidade estar presente, podendo prejudicar o significado físico do modelo, indicado pelos valores altos de inflação de variância (VIF) nos dados processados pelo software, o modelo foi considerado, pois podem ser utilizados para estimativas de novas ocorrências (Montgomery \& Peck, 1992). Neste caso, as análises são realizadas por meio de gráficos de superfície e efeito dos componentes, podendo suas previsões serem realizadas apenas dentro do limite da região experimental.

Na Figura 65 é apresentado um gráfico de superfície de resposta e de efeito dos componentes com o intuito de esclarecer como são realizadas suas análises. 


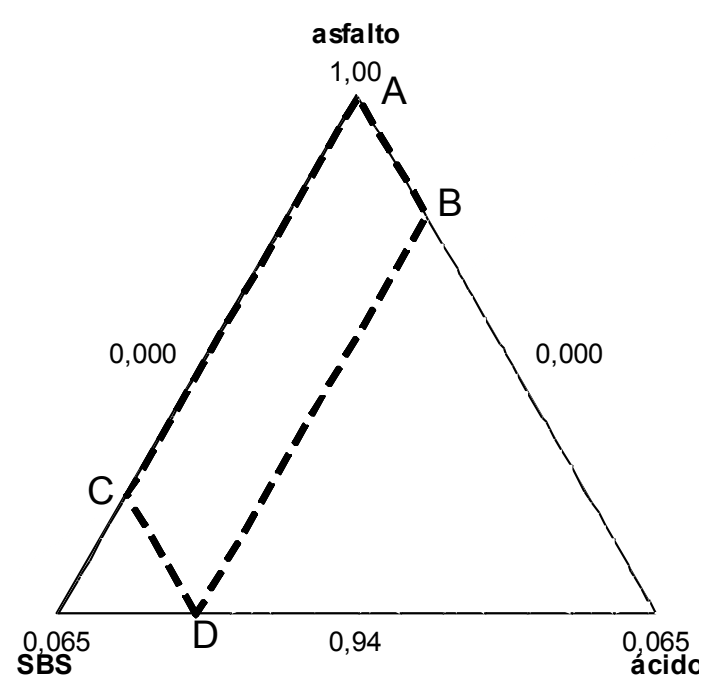

(a)

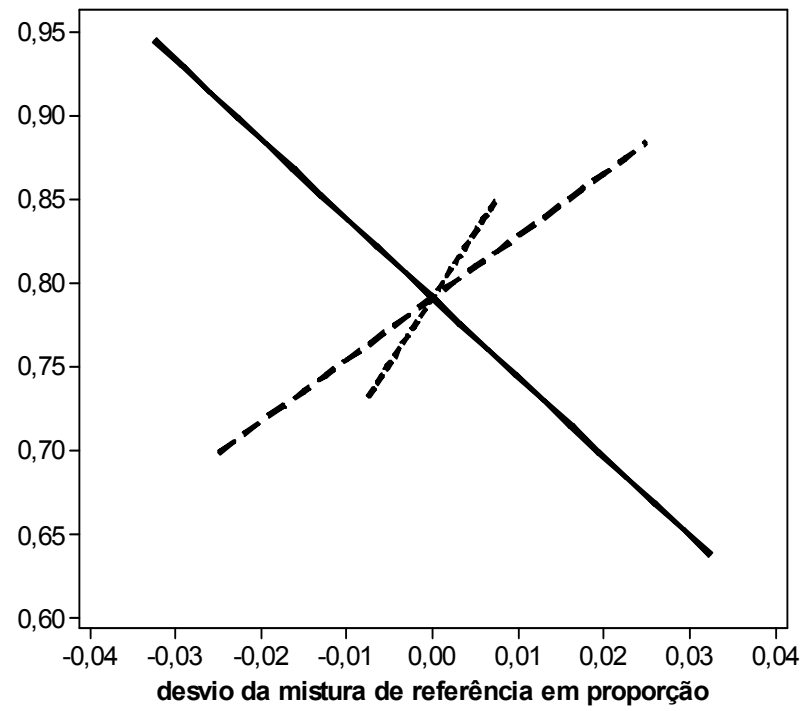

(b)

Figura 65 - Gráfico de Superfície de Resposta e efeito dos componentes.

Na Figura 65 (a) a região delimitada é a região experimental de interesse. Na linha A$B$ têm-se as misturas somente com adição de ácido, sendo que ao andar nessa linha no sentido do ponto A para o ponto B ocorre o aumento na concentração do ácido, de $0 \%$ a 1,5\%. $\mathrm{Na}$ linha A-C têm-se as misturas somente com adição do copolímero SBS, sendo que ao andar nessa linha do ponto $A$ para o ponto $C$ ocorre o aumento da concentração do copolímero SBS, de $0 \%$ a $5,0 \%$. Nas linhas B-D e C-D têm-se as misturas com adição dos dois modificadores. No entanto, ao andar na linha B-D encontram-se misturas com 1,5\% de ácido e o aumento na concentração do copolímero SBS até chegar ao ponto D. E ao andar na linha C-D estão às misturas com adição de 5,0 SBS e o aumento na concentração de ácido até chegar ao ponto $\mathrm{D}$, sendo que este ponto representa a mistura mais modificada do experimento (5,0SBS+1,5 Ácido). No interior da região de interesse encontram-se misturas com a combinação de diversas concentrações destes dois modificadores.

Na Figura 65 (b) é apresentado o gráfico de efeito dos componentes. Este gráfico mostra o efeito que cada componente tem isoladamente sobre a propriedade analisada. Cabe salientar que, a análise realizada por este tipo de gráfico é apenas uma dentre muitas possibilidades de análise (várias direções). Neste caso, a direção analisada corresponde à reta ligando o vértice ao lado oposto da região experimental, passando pela mistura do centróide da figura. Este efeito é indicado pela variação da proporção de um componente, mantendo constante a relação entre a proporção dos demais. O eixo horizontal indica a faixa de variação da proporção dos componentes partindo da mistura de referência $(0,0)$ para $+50 \%$ da faixa de variação e $-50 \%$ da faixa. O eixo vertical indica a intensidade do efeito da variação da proporção do componente sobre a propriedade avaliada. De maneira geral, os 
componentes que apresentam maior efeito sobre a propriedade avaliada são os que possuem curvas mais inclinadas. $O$ efeito do componente é calculado mediante a diferença entre o ponto da curva no limite superior e o ponto da curva no seu limite inferior divida pela concentração máxima desse componente considerado no simplex. Cabe destacar que os componentes não tem efeitos isolados, pois a medida que se altera um componente, tem-se a alteração de pelo menos mais um. No entanto, este tipo de gráfico auxilia na tentativa de entender a maneira como cada elemento atua nas propriedades monitoradas.

Os modelos gerados nesta pesquisa se aplicam aos dois tipos de ligantes asfálticos selecionados (Replan e Lubnor), assim como aos ácido (PA85 e PPA) e ao copolímero SBS utilizados, assim como as variáveis de processos considerados para obtenção das misturas estudadas. A seguir estão apresentadas as análises e os modelos gerados com o auxílio do experimento com misturas.

\subsubsection{Ensaio de Penetração}

Na Figura 66 estão apresentados os gráficos de superfície de resposta e de efeito dos componentes para a propriedade de penetração na condição virgem nos materiais modificados com adição do copolímero SBS e ácido PA85, ao ligante asfáltico de base da Replan.

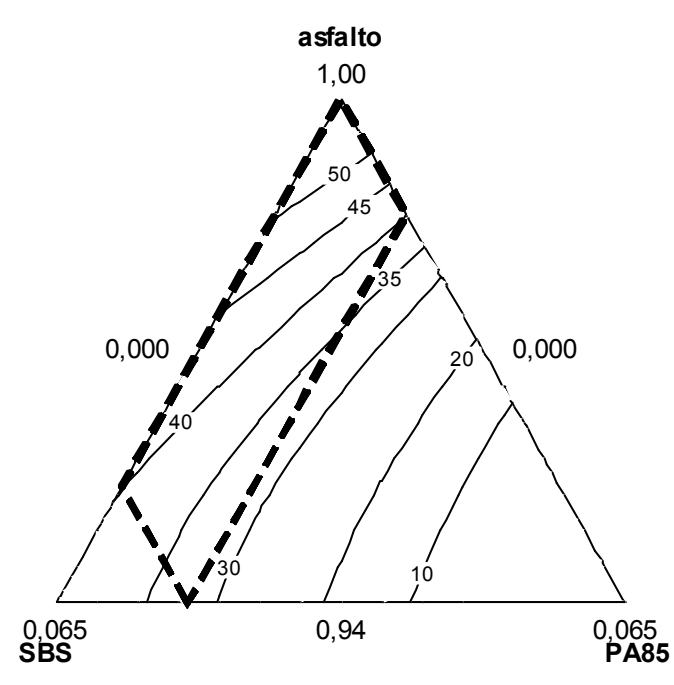

(a)

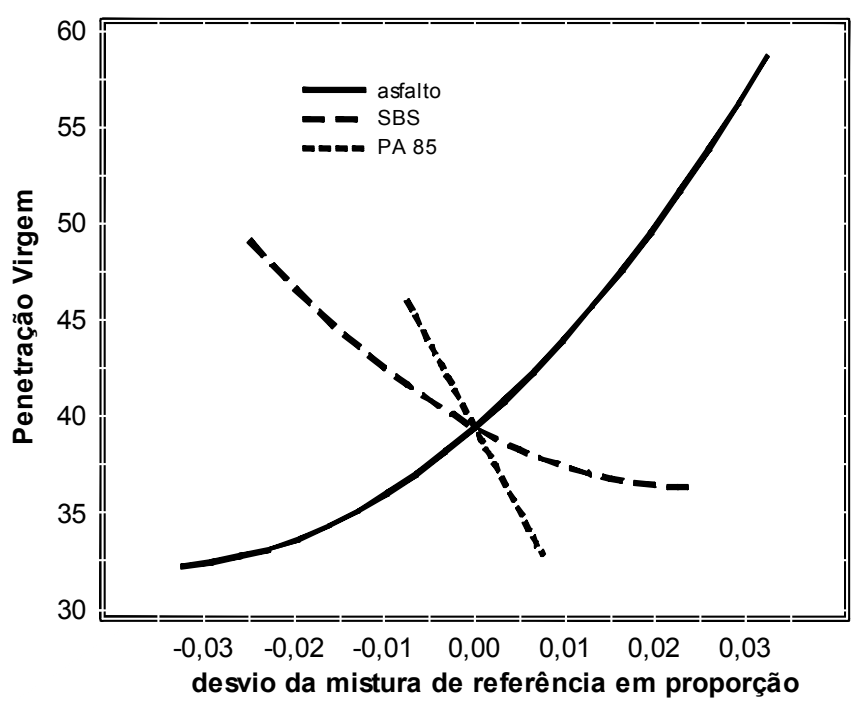

(b)

Figura 66 - Superfície de Resposta (a) e efeito de componentes (b) para penetração na condição virgem das misturas com PA85 (Replan). 
Na Figura 66 (a) nota-se que os maiores valores de penetração são encontrados na parte superior da figura (materiais menos modificados) e os menores valores de penetração estão na região inferior do gráfico (materiais mais modificados). Nota-se que o aumento do teor dos modificadores diminui os valores de penetração. O menor valor de penetração é encontrado para o ligante asfáltico 5SBS+1,5PA85 com o valor de $31 \mathrm{dmm}$. Na Figura 66 (b) está apresentado o gráfico de efeito dos componentes. Os dois modificadores proporcionam uma diminuição no valor de penetração. Pode-se observar que os componentes apresentam comportamentos próximos do linear e que, pela inclinação da reta, pode-se verificar que o ácido tem efeito mais expressivo nesta diminuição. O copolímero SBS diminui em 2,37 dmm a penetração para cada $1 \%$ de adição, enquanto o ácido proporciona uma redução de 8,89 dmm para cada $1 \%$ de adição.

Os gráficos de superfície de resposta e de efeito dos componentes para a propriedade de penetração na condição virgem nos materiais modificados com adição do copolímero SBS e ácido PPA, no ligante asfáltico de base da Replan, estão apresentados na Figura 67. Assim como para os ligantes asfáltico modificados com adição do ácido PA85, nota-se na Figura 67 (a) que os maiores valores de penetração são encontrados na parte superior da figura (materiais menos modificados) e os menores valores de penetração estão na região inferior do gráfico (materiais mais modificados). Nota-se também que o aumento do teor dos modificadores diminui os valores de penetração. O menor valor de penetração é encontrado para o ligante asfáltico 5SBS+1,5PPA com o valor de $28 \mathrm{dmm}$.

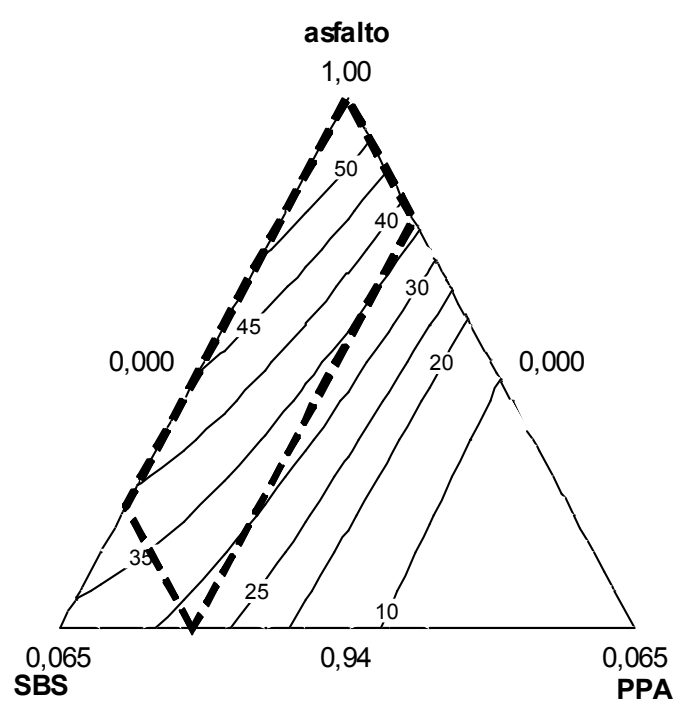

(a)

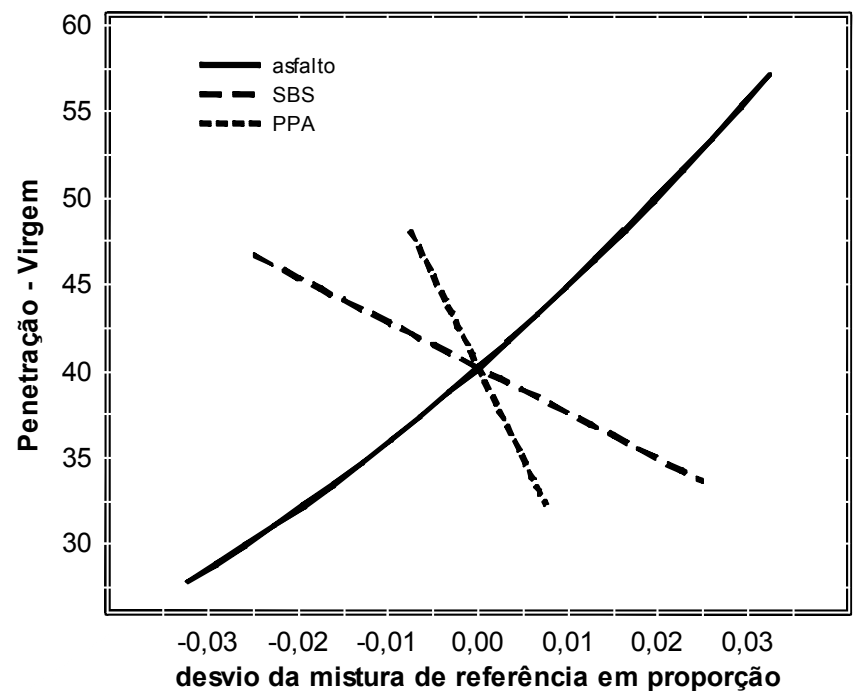

(b)

Figura 67 - Superfície de Resposta (a) e efeito de componentes (b) para penetração na condição virgem das misturas com PPA (Replan). 
$\mathrm{Na}$ Figura 67 (b) está apresentado o gráfico de efeito dos componentes. Os dois modificadores proporcionam diminuição no valor de penetração. Pode-se observar que os componentes apresentam comportamento próximo do linear e que, pela inclinação da reta, pode-se verificar que o ácido tem efeito mais expressivo nesta diminuição. O copolímero SBS diminui em 2,60 dmm a penetração para cada 1\% de adição, enquanto o ácido proporciona uma redução de 10,46 dmm para cada 1\% de adição. Quando comparados os dois tipos de ácidos utilizados, nota-se o mesmo comportamento, porém um efeito mais expressivo para os materiais modificados pelo ácido PPA, sendo que o valor máximo de penetração é de 1,13 vezes maior para os materiais modificados com o ácido PA85.

$\mathrm{Na}$ Figura 68 estão apresentados os gráficos de superfície de resposta e de efeito dos componentes para a propriedade de penetração na condição RTFOT nos materiais modificados com adição do copolímero SBS e ácido PA85, no ligante asfáltico de base da Replan. Na Figura 68 (a) nota-se pouca influência, nesta propriedade, com o aumento do teor do copolímero SBS nas misturas somente com este modificador. No entanto, os menores valores se encontram nas misturas com teores intermediários e altos do PA85. O menor valor de penetração é encontrado para o ligante asfáltico com 1,5PA85 com o valor de $25 \mathrm{dmm}$ (canto superior direito). Nota-se que o efeito do envelhecimento foi mais expressivo para as misturas com adição somente de ácido.

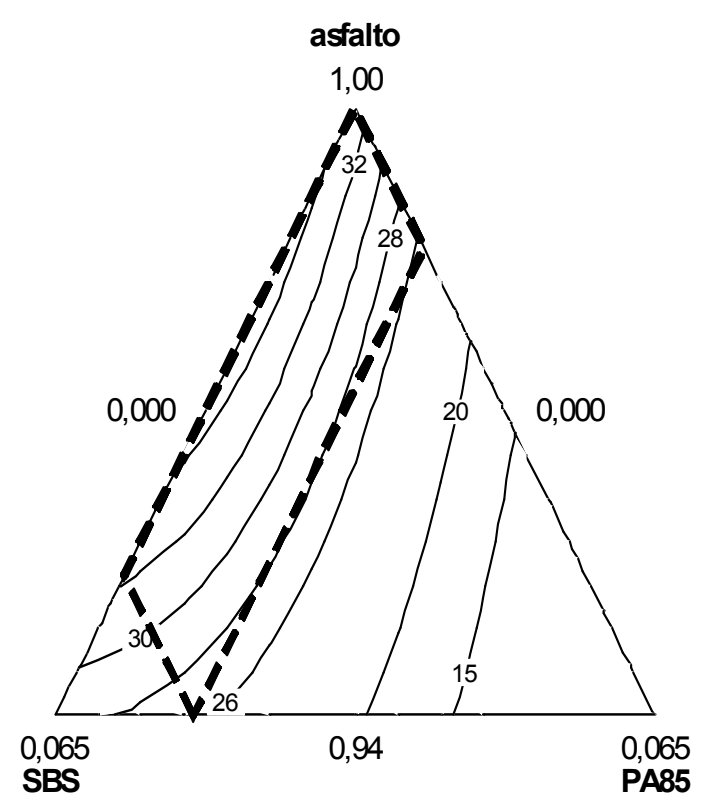

(a)

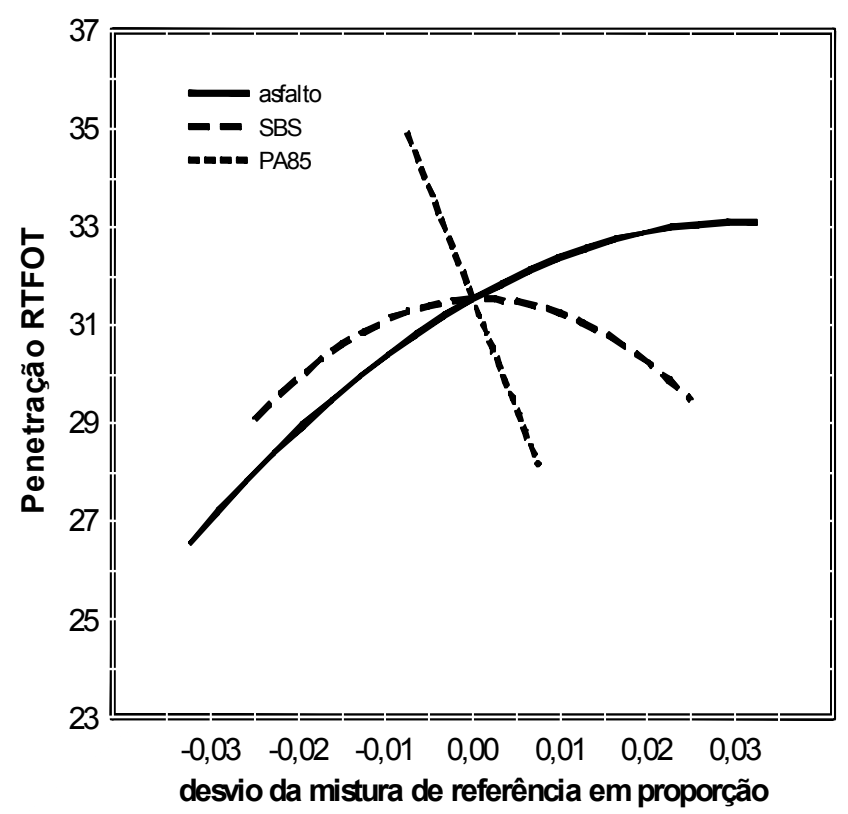

(b)

Figura 68 - Superfície de Resposta (a) e efeito de componentes (b) para penetração na condição RTFOT das misturas com PA85(Replan).

Na Figura 68 (b) está apresentado o gráfico de efeito dos componentes. Observam-se comportamentos diferentes para os dois modificadores. Pode-se observar que o ácido 
apresenta comportamento próximo do linear e que o copolímero SBS apresenta comportamento parabólico. O copolímero SBS aumenta o valor da penetração até a concentração de $2,5 \%$, diminuindo esta propriedade com teores acima deste valor, enquanto o PA85 proporciona uma redução de $4,48 \mathrm{dmm}$ para cada $1 \%$ adicionado.

Na Figura 69 estão apresentados os gráficos de superfície de resposta e de efeito dos componentes para a propriedade de penetração na condição RTFOT nos materiais modificados com adição do copolímero SBS e ácido PPA, no ligante asfáltico de base da Replan. Na Figura 69 (a) nota-se pouca influência, nesta propriedade, do aumento do teor do copolímero SBS para misturas somente com este modificador. No entanto, os menores valores se encontram nas misturas com teores intermediários e altos do PPA. O menor valor de penetração é encontrado para o ligante asfáltico com 1,5PPA com o valor de $22 \mathrm{dmm}$ (canto superior direito). Nota-se que o efeito do envelhecimento foi mais expressivo para as misturas com adição somente de ácido.

Na Figura 69 (b) está apresentado o gráfico de efeito dos componentes. Pode-se observar que o ácido apresenta comportamento próximo do linear e o copolímero SBS apresenta comportamento parabólico.

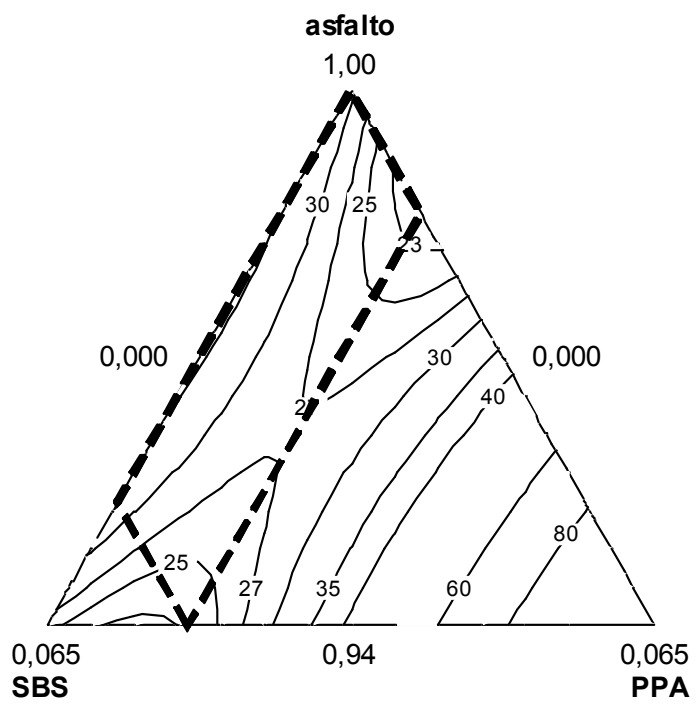

(a)

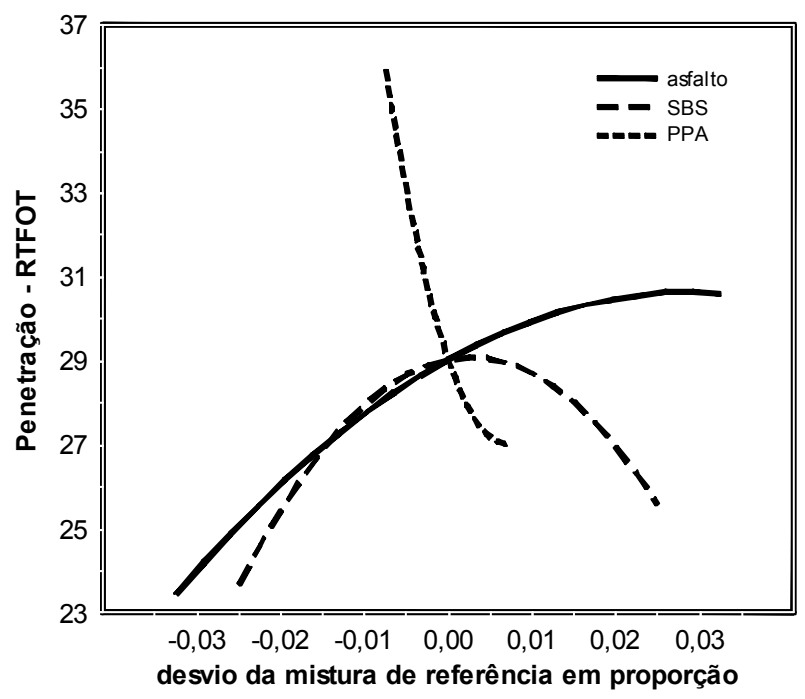

(b)

Figura 69 - Superfície de Resposta (a) e efeito de componentes (b) para penetração na condição RTFOT das misturas com PPA (Replan).

O copolímero SBS aumenta o valor da penetração até a concentração de 2,5\%, diminuindo esta propriedade com teores maiores, enquanto que o PPA proporciona uma redução de 5,91 dmm para cada 1\% adicionado. Comparando-se os efeitos dos dois tipos de ácidos na condição de envelhecido em curto prazo, observa-se um comportamento 
semelhante, sendo que as misturas com as concentrações intermediárias e altas dos ácidos apresentaram os menores valores de penetração.

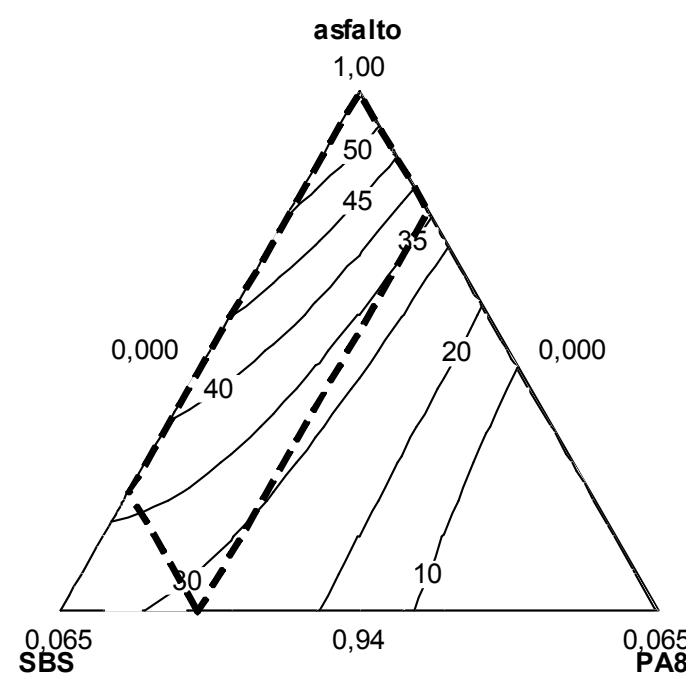

(a)

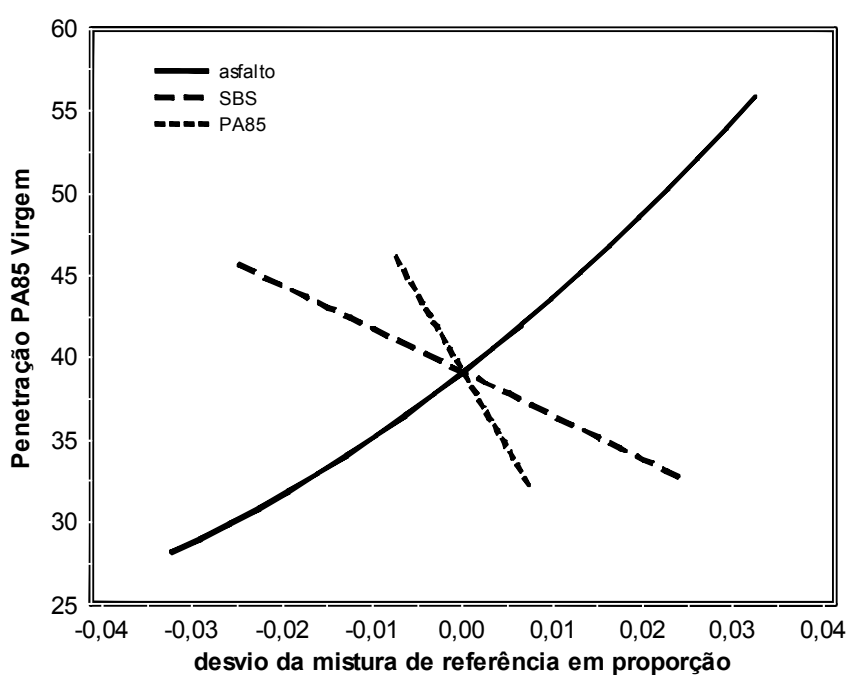

(b)

Figura 70 - Superfície de Resposta (a) e efeito de componentes (b) para a penetração na condição virgem das misturas com PA85 (Lubnor).

Na Figura 70 estão apresentados os gráficos de superfície de resposta e de efeito dos componentes para a propriedade de penetração na condição virgem nos materiais modificados com adição do copolímero SBS e ácido PA85, ao ligante asfáltico de base da Lubnor. Na Figura 70 (a) nota-se que a adição dos modificadores proporciona uma diminuição nesta propriedade. Os menores valores se encontram nas misturas com altos teores dos dois modificadores. O menor valor de penetração é encontrado para o ligante asfáltico com $5 S B S+1,5 P A 85$, com o valor de 28 dmm (canto inferior). Na Figura 70 (b) está apresentado o gráfico de efeito dos componentes. Os dois modificadores proporcionam uma diminuição no valor de penetração. Pode-se observar que os componentes apresentam comportamento próximo do linear e que, pela inclinação da reta, pode-se verificar que o ácido tem efeito mais expressivo nesta diminuição. O copolímero SBS diminui em 2,64 dmm a penetração para cada $1 \%$ adicionado, enquanto o ácido proporciona uma redução de $9,35 \mathrm{dmm}$ para cada $1 \%$ de PA85.

Na Figura 71 estão apresentados os gráficos de superfície de resposta e de efeito dos componentes para a propriedade de penetração na condição virgem nos materiais modificados com adição do copolímero SBS e ácido PPA, ao ligante asfáltico de base da Lubnor. Na Figura 71 (a) nota-se que a adição dos modificadores proporciona uma diminuição nesta propriedade. $O$ menor valor de penetração é encontrado para o ligante asfáltico com $5 \mathrm{SBS}+1,5 \mathrm{PA} 85 \mathrm{com}$ o valor de $33 \mathrm{dmm}$ (canto inferior). 


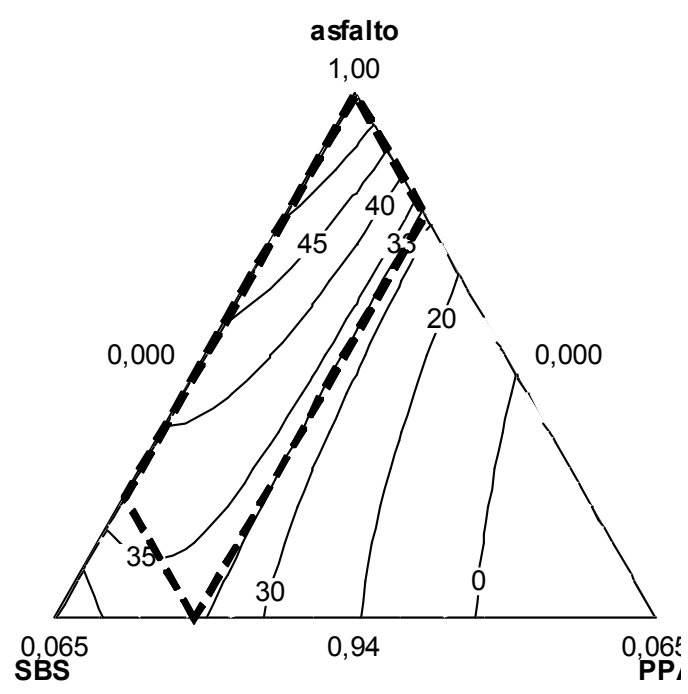

(a)

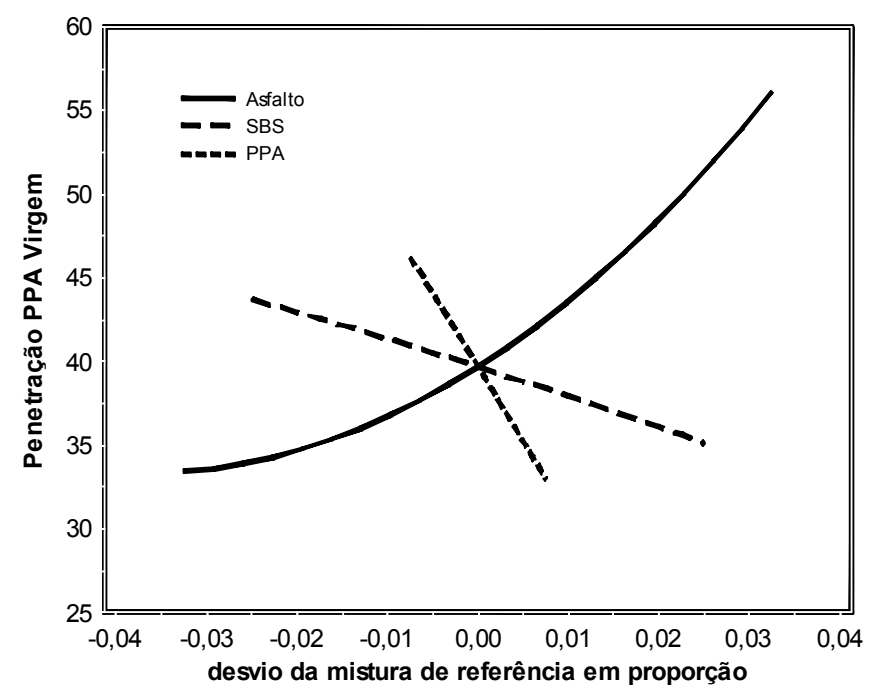

(b)

Figura 71 - Superfície de Resposta (a) e efeito de componentes (b) para a penetração na condição virgem das misturas com PPA (Lubnor).

Na Figura 71 (b) está apresentado o gráfico de efeito dos componentes. Os dois modificadores proporcionam uma diminuição no valor de penetração. Pode-se observar que os componentes apresentam comportamento próximo do linear e que o ácido tem efeito mais expressivo nesta diminuição. O copolímero SBS diminui em 1,67 dmm a penetração para cada $1 \%$ de adição, enquanto o ácido proporciona uma redução de $8,89 \mathrm{dmm}$ para cada $1 \%$ de PPA.

Na Figura 72 estão apresentados os gráficos de superfície de resposta e de efeito dos componentes para a propriedade de penetração na condição RTFOT nos materiais modificados com adição do copolímero SBS e ácido PA85, no ligante asfáltico de base da Lubnor. Na Figura 72 (a) nota-se que o aumento da concentração dos modificadores proporciona uma diminuição nos valores de penetração. O menor valor de penetração é encontrado para o ligante asfáltico com 5,0SBS+1,5PA85 com o valor de $19 \mathrm{dmm}$ (canto inferior). Na Figura 72 (b) está apresentado o gráfico de efeito dos componentes. Pode-se observar que ambos os modificadores apresentam comportamento próximo ao linear, sendo que o copolímero SBS diminui em 1,61 dmm a penetração para cada 1\% de adição, enquanto o ácido proporciona uma redução de 6,67 dmm para cada 1\% de PA85. 


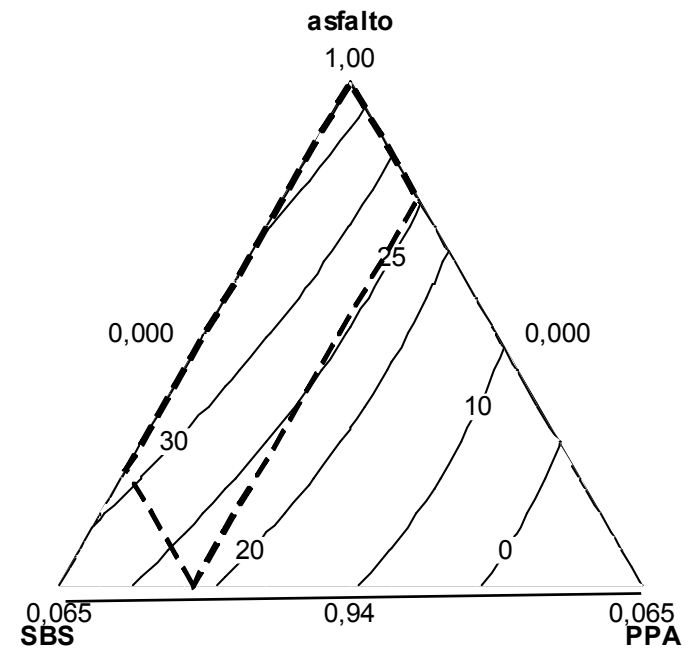

(a)

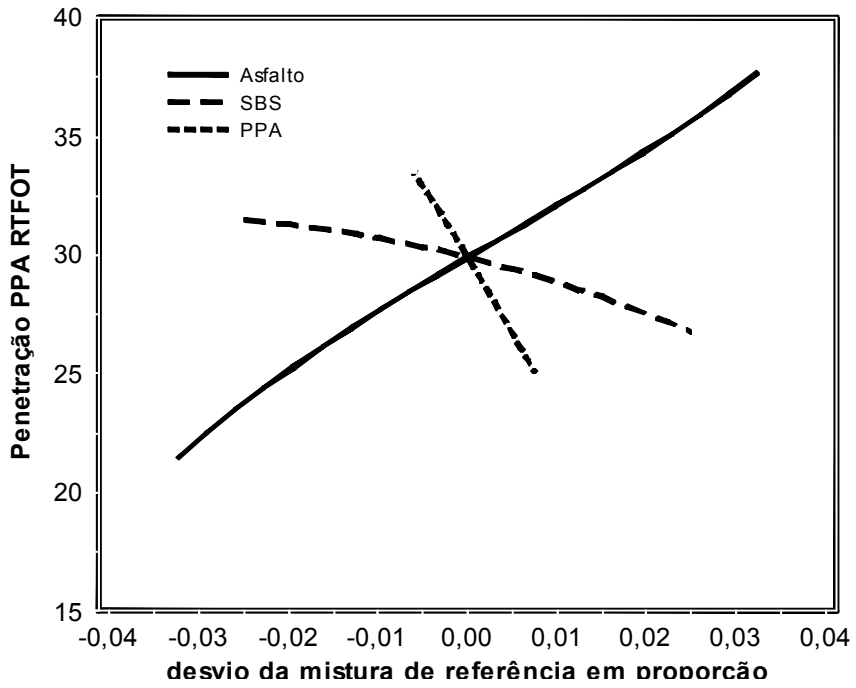

(b)

Figura 72 - Superfície de Resposta (a) e efeito de componentes (b) para a penetração na condição RTFOT das misturas com PA85 (Lubnor).

Na Figura 73 estão apresentados os gráficos de superfície de resposta e de efeito dos componentes para a propriedade de penetração na condição RTFOT nos materiais modificados com adição do copolímero SBS e ácido PPA, no ligante asfáltico de base da Lubnor. Na Figura 73 (a) nota-se que à medida que se adiciona maiores concentrações dos modificadores têm-se valores inferiores de penetração. O menor valor de penetração é encontrado para o ligante asfáltico com 5,0SBS+1,5PA85 com o valor de $22 \mathrm{dmm}$ (canto inferior).

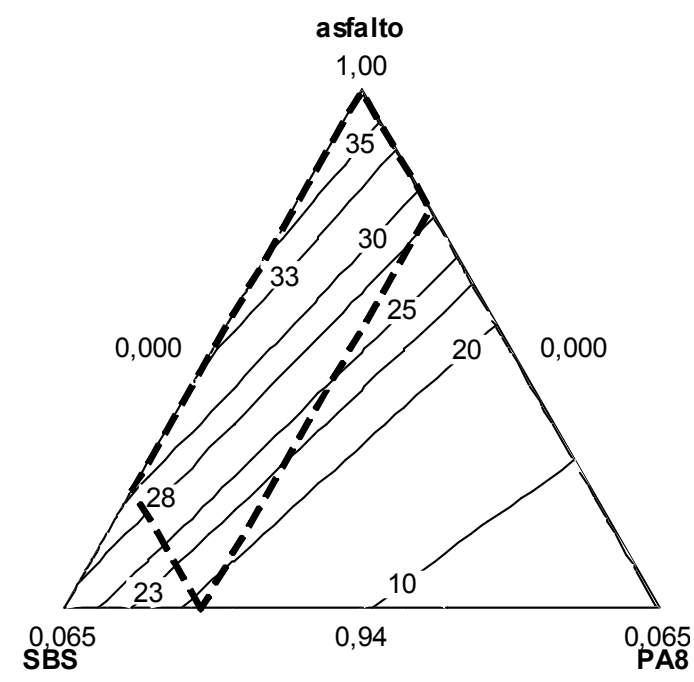

(a)

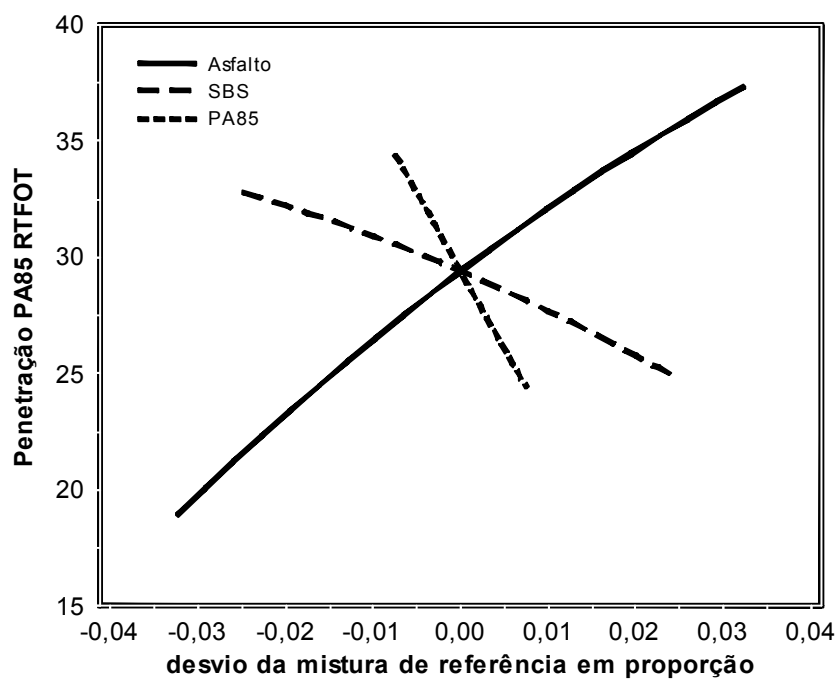

(b)

Figura 73 - Superfície de Resposta (a) e efeito de componentes (b) para a penetração na condição RTFOT das misturas com PPA (Lubnor). 
Na Figura 73 (b) está apresentado o gráfico de efeito dos componentes. Pode-se observar que ambos os modificadores apresentam comportamento próximo ao linear, sendo que o copolímero SBS diminui em $0,94 \mathrm{dmm}$ a penetração para cada $1 \%$ da adição, enquanto o ácido proporciona uma redução de 5,60 dmm para cada 1\% de PPA. Quando se comparam os efeitos dos dois tipos de ácidos, tanto para condição virgem quanto para a RTFOT, podese verificar um comportamento semelhante no gráfico de superfície, assim como para os efeitos dos componentes. Para este ligante asfáltico de base nota-se que o PA85 foi mais expressivo, apresentando valor máximo de penetração um pouco inferior ao encontrado nas misturas com PPA e, também maiores valores obtidos no gráfico de efeito dos componentes para adições de $1 \%$ de cada um desses materiais.

Quanto à penetração retida, tem-se na Figura 74 os gráficos de superfície de resposta e de efeito dos componentes para a penetração retida nos materiais modificados com adição do copolímero SBS e ácido PA85, no ligante asfáltico de base da Replan. Nota-se que à medida que se aumenta a concentração dos modificadores, aumenta-se o valor da penetração retida. O valor máximo de penetração retida é de $84,88 \%$ para a mistura com 5,0SBS+1,5PA85. Em relação aos efeitos dos componentes, pode-se observar na Figura 74 (b), um efeito linear para o ácido e parabólico para o copolímero SBS. O ácido proporciona um aumento de $6,43 \%$ na penetração para cada $1 \%$ da adição desse modificador, já o SBS aumenta o valor de penetração retida até a concentração de 4,0\%, aproximadamente, e após esse teor contribui para redução desta propriedade.

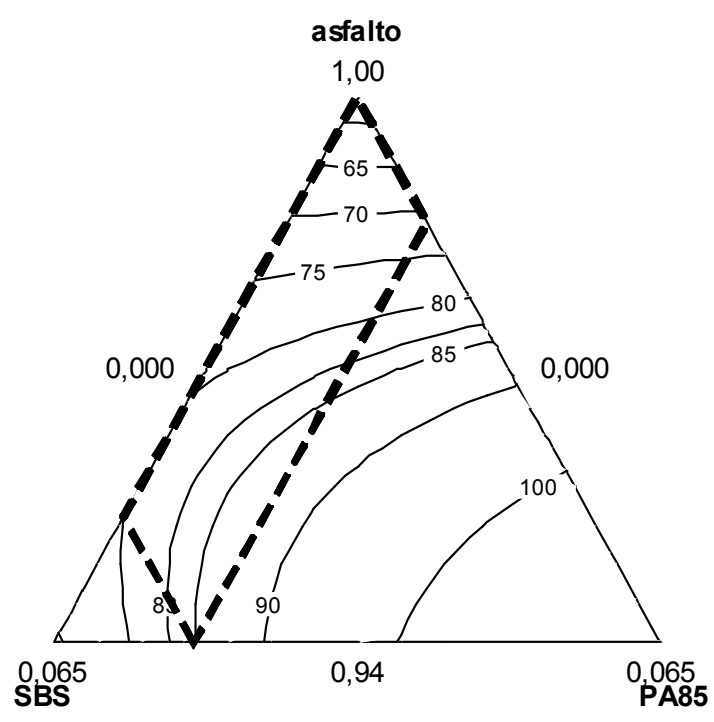

(a)

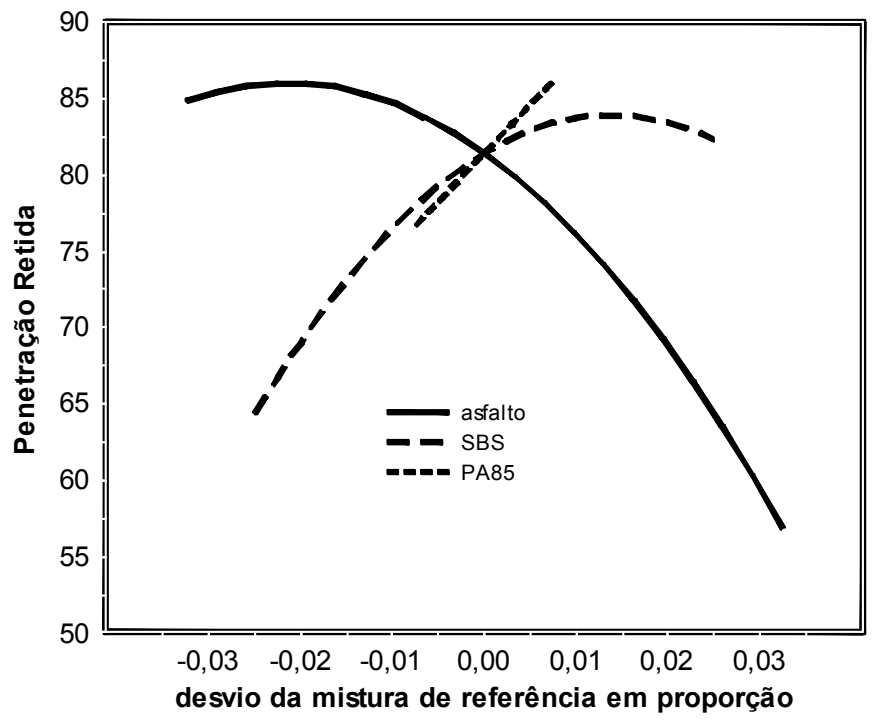

(b)

Figura 74 - Superfície de Resposta (a) e efeito de componentes (b) para penetração retida das misturas com PA85(Replan). 
Na Figura 75 estão apresentados os gráficos de superfície de resposta e de efeito dos componentes para a penetração retida nos materiais modificados com adição do copolímero SBS e ácido PPA, no ligante asfáltico de base da Replan. Nota-se na Figura 75 (a) que, à medida que se aumenta a concentração dos modificadores, aumenta-se o valor da penetração retida. O valor máximo de penetração retida é de $85,18 \%$ para a mistura com 5,0 SBS+1,5PA85.

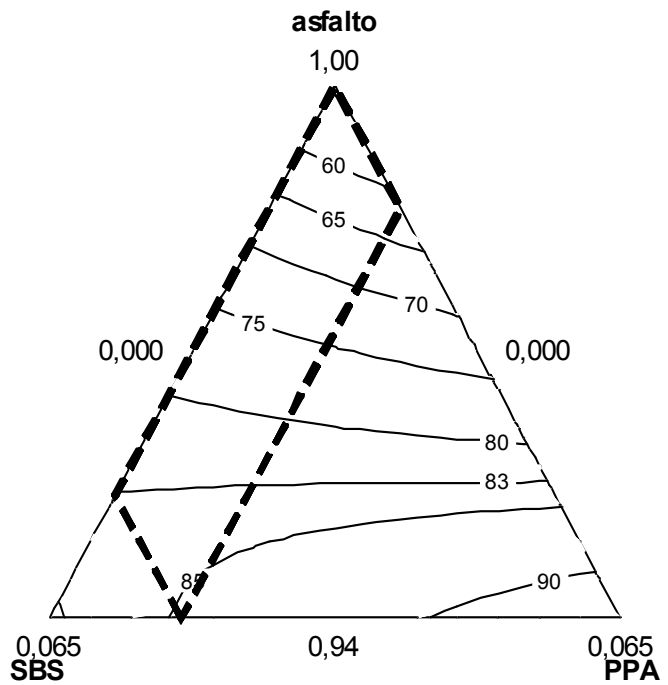

(a)

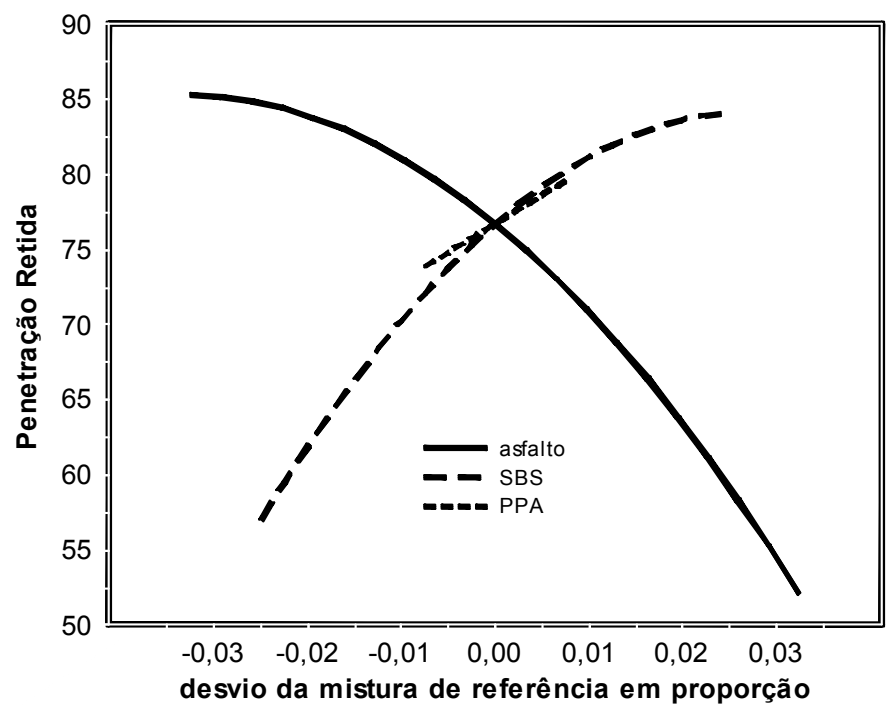

(b)

Figura 75 - Superfície de Resposta (a) e efeito de componentes (b) para penetração retida das misturas com PPA (Replan).

Em relação aos efeitos dos componentes, pode-se observar na Figura 75 (b), um efeito aproximadamente linear para ambos os modificadores. $O$ ácido proporciona um aumento de $3,63 \%$ na penetração para cada $1 \%$ da adição desse modificador, enquanto o SBS aumenta em $5,38 \%$ esta propriedade para cada $1 \%$ da adição do copolímero SBS.

Os efeitos, na penetração, da adição do PA85 ao ligante asfáltico de base Lubnor, estão apresentados na Figura 76. Na Figura 76 (a), que apresenta o gráfico de superfície de resposta, pode ser observado que os maiores valores de penetração retida estão na região com misturas somente com adição de copolímero SBS em altas concentrações (canto inferior esquerdo) e para as misturas com adição somente de PA85 com altos teores (canto superior direito). Para este tipo de ligante asfáltico de base, a adição desses modificadores juntos são menos expressivos do que dos modificadores adicionados isoladamente. Já na Figura 76 (b), que apresenta os efeitos dos componentes, percebe-se que para este ligante asfáltico de base, o PA85 reduz quase que inexpressivamente a penetração retida $(0,19 \% / 1 \%$ de ácido 
adicionado), enquanto o copolímero SBS proporciona um pequeno aumento, em $0,38 \%$ para cada $1 \%$ adicionado.

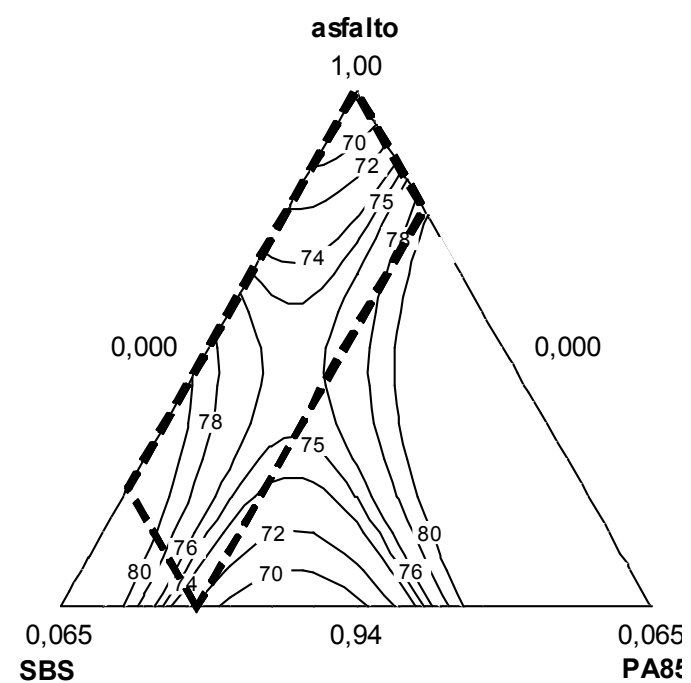

(a)

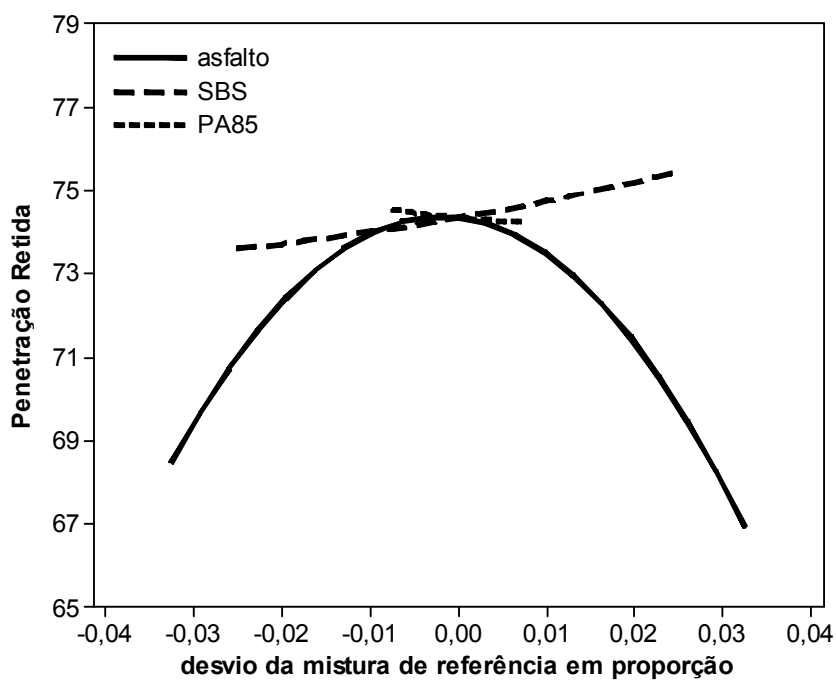

(b)

Figura 76 - Superfície de Resposta (a) e efeito de componentes (b) para a penetração retida das misturas com PA85 (Lubnor).

Na Figura 76 são observados os gráficos de superfície de resposta e efeito dos componentes para a penetração retida para o ligante asfáltico de base Lubnor com adição do PPA. Na Figura 76 (a), que apresenta o gráfico de superfície de resposta, pode ser observado, assim como para as misturas com a adição do PA85, que os maiores valores de penetração retida estão na região com misturas somente com adição de copolímero SBS em altas concentrações (canto inferior esquerdo) e para as misturas com adição somente de PPA com altos teores (canto superior direito).

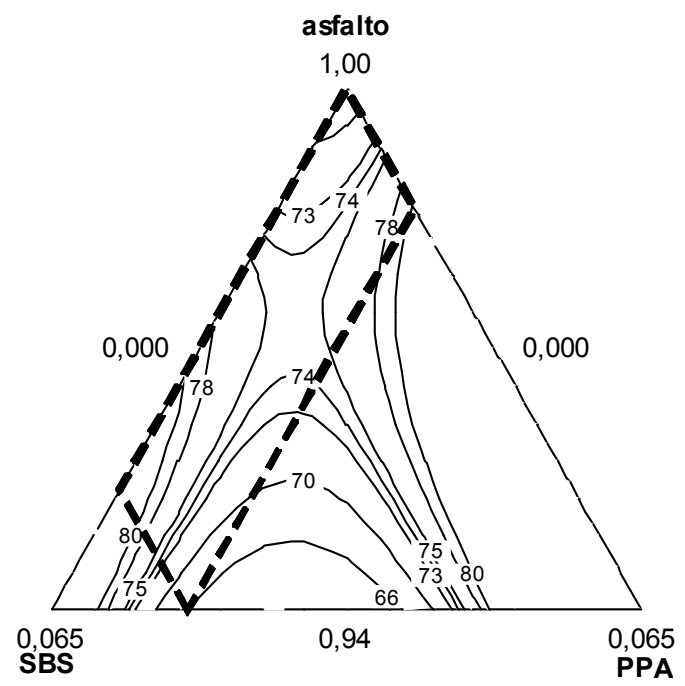

(a)

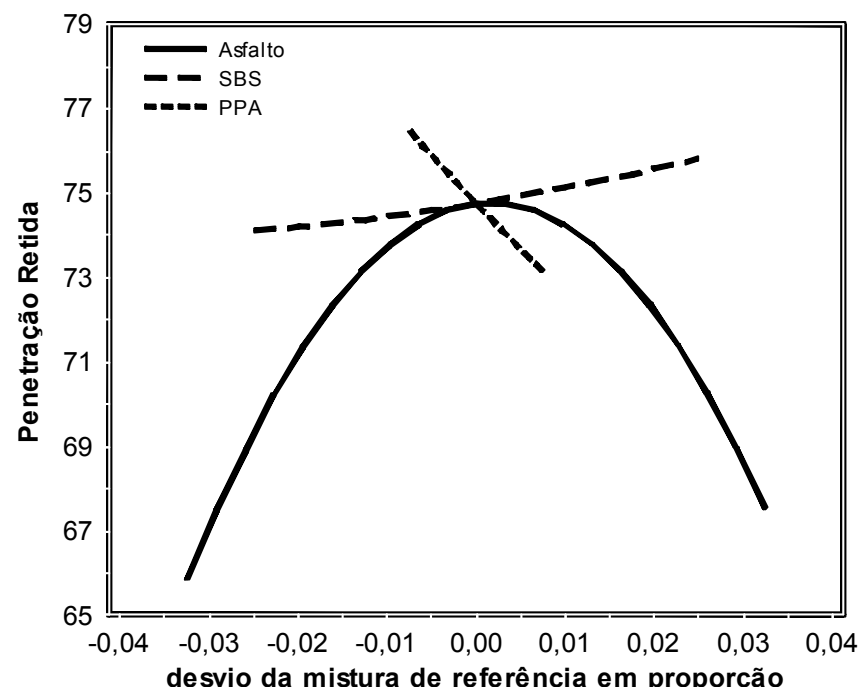

(b)

Figura 77 - Superfície de Resposta (a) e efeito de componentes (b) para a penetração retida das misturas com PPA (Lubnor). 
Já na Figura 76 (b), que apresenta os efeitos dos componentes, percebe-se que para este ligante asfáltico de base, o PPA reduz a penetração retida $(-2,22 \% / 1 \%$ de ácido adicionado), enquanto o copolímero SBS proporciona um pequeno aumento à propriedade, em $0,34 \%$ para cada $1 \%$ adicionado.

Após avaliar os dados de penetração na condição virgem e RTFOT e a penetração retida para os dois tipos de ligante de base e com os dois ácidos estudados, pode-se afirmar que a propriedade de penetração para os dois tipos de ligantes de base apresentam efeitos distintos na adição dos ácidos. Para o ligante asfáltico proveniente da Replan, o efeito da adição de PPA nas misturas, na condição virgem, foi um pouco mais expressivo do que a adição do PA85, apesar dos valores de penetração encontrados não apresentarem valores muito inferiores. Na condição de envelhecimento em curto prazo, os ligantes asfálticos modificados com teores intermediários e altos de ácidos, apresentam os menores valores de penetração. A adição do SBS até a concentração de 2,5\% proporciona um aumento nesta propriedade e somente valores acima deste teor fazem os valores de penetração diminuírem, apresentando desta maneira comportamento diferente do que foi observado para condição virgem.

No que diz respeito ao ligante asfáltico de base da Lubnor, o comportamento apresentado para as condições virgem e RTFOT foram similares. Em ambos a adição de maiores concentrações dos modificadores (SBS e ácidos) proporcionaram redução dos valores de penetração. Nota-se para este ligante asfáltico de base que a modificação do material com o ácido PA85 produziu menores valores de penetração do que com a adição de PPA. Sendo assim, o efeito do PA85 foi mais expressivo do que o do PPA.

Quanto à penetração retida, tem-se para o ligante asfáltico de base da Replan um aumento à medida que se aumenta a concentração dos modificadores. Tanto os ácidos quanto o copolímero SBS tendem a aumentar esta propriedade, sendo o ácido PA85 mais expressivo neste aumento quando comparado com o PPA. Já para o ligante asfáltico de base da Lubnor, observa-se um comportamento diferente. Para este ligante asfáltico de base os valores mais altos de penetração retida são encontrados em misturas com adição somente de ácido ou somente do copolímero SBS em altas concentrações. Nota-se que o efeito dos componentes é menos expressivo quando comparado com seus efeitos no ligante asfáltico de base da Replan. Observando-se esses resultados verificou-se que o ligante asfáltico de base influencia diretamente no resultado final do efeito desses modificadores.

$\mathrm{Na}$ Tabela 82 estão apresentados os modelos de regressão obtidos para cada ligante modificado (Replan e Lubnor) para as amostras com a adição de PA85 e PPA. 
Tabela 82 - Modelos de regressão referente à propriedade penetração.

\begin{tabular}{|c|c|c|c|c|}
\hline $\begin{array}{l}\text { Ligante } \\
\text { Asfáltico } \\
\text { de Base }\end{array}$ & Ácido & Propriedade & Modelo de Regressão & $\mathbf{R}^{2}(\%)$ \\
\hline \multirow{6}{*}{ Replan } & \multirow{3}{*}{ PA85 } & Pen. Virgem & $57 x_{1}-305 x_{2}+14162 x_{3}-15631 x_{1} x_{2}$ & 95,1 \\
\hline & & Pen. RTFOT & $33 x_{1}-3398 x_{2}-489 x_{3}+3594 x_{1} x_{2}+6412 x_{2} x_{3}$ & 73,5 \\
\hline & & Pen. Retida & $57 x_{1}-11828 x_{2}+1025 x_{3}+12998 x_{1} x_{2}$ & 81,4 \\
\hline & \multirow{3}{*}{ PPA } & Pen. Virgem & $57 x_{1}-304 x_{2}-1310 x_{3}+1222 x_{2} x_{3}$ & 98,6 \\
\hline & & Pen. RTFOT & $31 x_{1}+6649 x_{2}+42580 x_{3}+7069 x_{1} x_{3}-43789 x_{1} x_{3}-37016 x_{2} x_{3}$ & 98,5 \\
\hline & & Pen. Retida & $52 x_{1}-8716 x_{2}+692 x_{3}+9882 x_{1} x_{2}$ & 92,4 \\
\hline \multirow{6}{*}{ Lubnor } & \multirow{3}{*}{ PA85 } & Pen. Virgem & $56 x_{1}-332 x_{2}-1277 x_{3}+15467 x_{2} x_{3}$ & 93,0 \\
\hline & & Pen. RTFOT & $37 x_{1}-1066 x_{2}-552 x_{3}+1013 x_{1} x_{2}-2453 x_{2} x_{3}$ & 97,6 \\
\hline & & Pen. Retida & $66 x_{1}+448 x_{2}+937 x_{3}+35591 x_{2} x_{3}$ & 74,8 \\
\hline & \multirow{3}{*}{ PPA } & Pen. Virgem & $56 x_{1}-335 x_{2}-1557+30017 x_{1} x_{2} x_{3}$ & 95,7 \\
\hline & & Pen. RTFOT & $8 x_{1}-97 x_{2}-772 x_{3}-148055 x_{2} x_{3}+162055 x_{1} x_{2} x_{3}$ & 98,0 \\
\hline & & Pen. Retida & $68 x_{1}+423 x_{2}+923 x_{3}-430032 x_{2} x_{3}$ & 82,9 \\
\hline
\end{tabular}

$\mathrm{x}_{1}=$ asfalto; $\mathrm{x}_{2}$ : SBS e $\mathrm{x}_{3}$ : ácido em porcentagem.

\subsubsection{Ponto de Amolecimento}

Na Figura 78 estão apresentados os gráficos de superfície de resposta e de efeito dos componentes para a propriedade de ponto de amolecimento na condição virgem dos materiais modificados com adição do copolímero SBS e do ácido PA85, no ligante asfáltico de base da Replan.

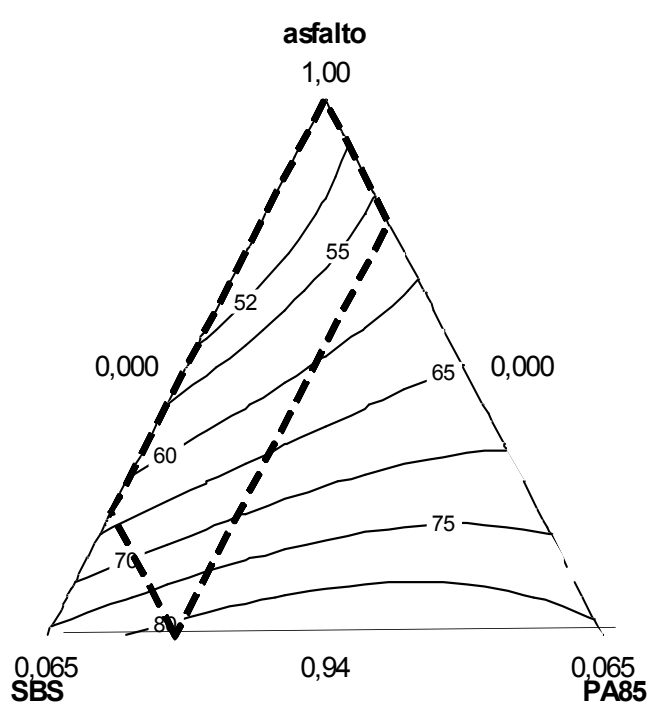

(a)

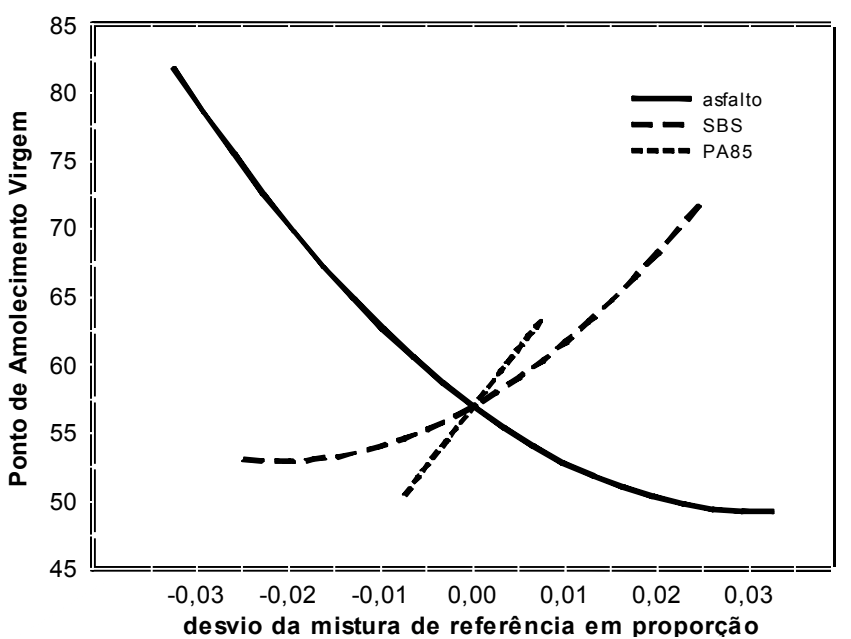

(b)

Figura 78 - Superfície de Resposta (a) e efeito de componentes (b) para ponto de amolecimento na condição virgem das misturas com PA85 (Replan). 
$\mathrm{Na}$ Figura 78 (a) nota-se que os maiores valores de ponto de amolecimento são encontrados na parte inferior da figura (materiais mais modificados) e os menores valores de penetração estão na região superior do gráfico (materiais menos modificados). Nota-se que o aumento do teor dos modificadores aumenta os valores de ponto de amolecimento. O maior valor desta propriedade é encontrado para o ligante asfáltico 5SBS+1,5PA85 com o valor de $81,92^{\circ} \mathrm{C}$. Na Figura 78 (b) está apresentado o gráfico de efeito dos componentes. Os dois modificadores proporcionam um aumento no valor do ponto de amolecimento. Pode-se observar que os componentes apresentam comportamento próximo do linear e, pela inclinação, pode-se verificar que o ácido tem efeito mais expressivo neste aumento. $O$ copolímero SBS aumenta em $3,84^{\circ} \mathrm{C}$ o ponto de amolecimento para cada $1 \%$ da adição desse modificador, enquanto o ácido proporciona um incremento de $8,72^{\circ} \mathrm{C}$ para cada $1 \%$ de PA85.

Pode se observar na Figura 79 os gráficos de superfície de resposta e de efeito dos componentes para a propriedade de ponto de amolecimento na condição virgem nos materiais modificados com adição do copolímero SBS e ácido PPA ao ligante asfáltico de base da Replan. Na Figura 79 (a) nota-se, assim como as misturas com adição de PA85, que os maiores valores de ponto de amolecimento são encontrados na parte inferior da figura (materiais mais modificados) e os menores valores de penetração estão na região superior do gráfico (materiais menos modificados). O maior valor desta propriedade é encontrado para o ligante asfáltico $5 \mathrm{SBS}+1,5 \mathrm{PPA}$ com o valor de $81,83^{\circ} \mathrm{C}$.

A Figura 79 (b) apresenta o gráfico de efeito dos componentes. Todos os modificadores proporcionam um incremento no valor do ponto de amolecimento.

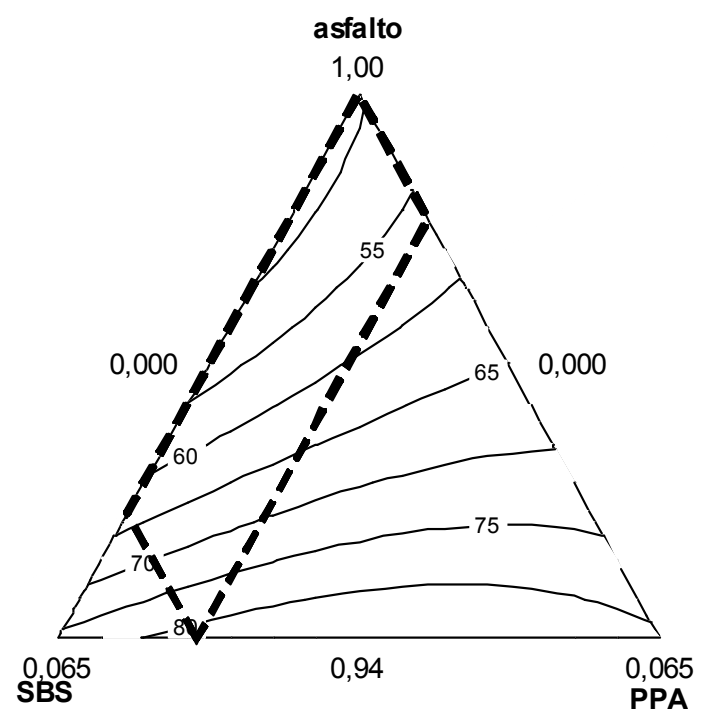

(a)

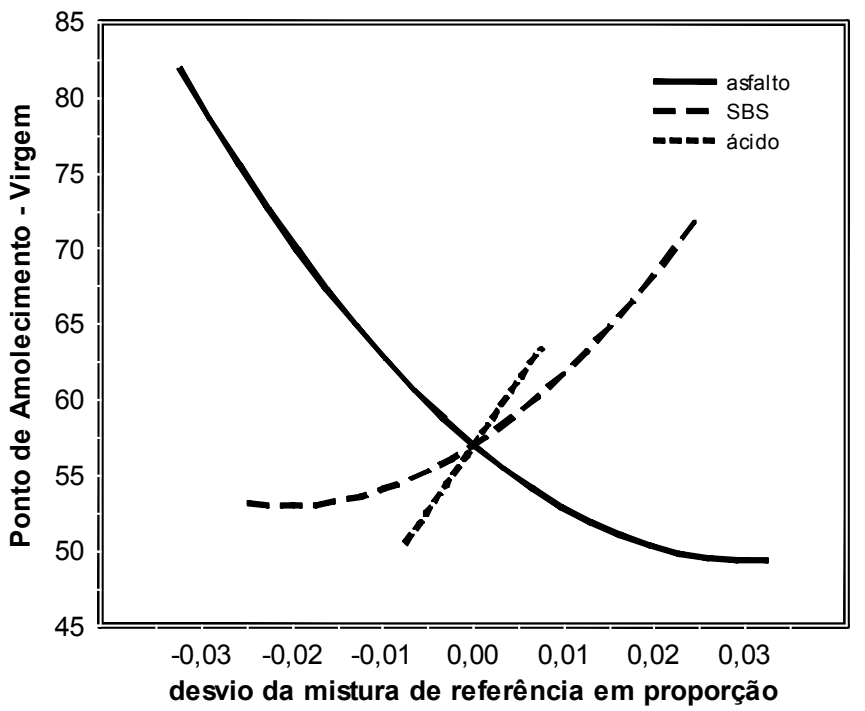

(b)

Figura 79 - Superfície de Resposta (a) e efeito de componentes (b) para ponto de amolecimento na condição virgem das misturas com PPA (Replan). 
Os componentes apresentam comportamento próximo do linear e, pelas inclinações, pode-se verificar que o ácido tem efeito mais expressivo. O copolímero SBS aumenta em $3,85^{\circ} \mathrm{C}$ o ponto de amolecimento para cada $1 \%$ da adição desse modificador, enquanto o ácido proporciona um incremento de $8,73^{\circ} \mathrm{C}$ para cada $1 \%$ de PPA. Para esta propriedade, 0 comportamento dos dois ácidos adicionados é similar.

Na Figura 80 estão apresentados os gráficos de superfície de resposta e de efeito dos componentes para a propriedade de ponto de amolecimento na condição RTFOT nos materiais modificados com adição do copolímero SBS e ácido PA85, no ligante asfáltico de base da Replan.

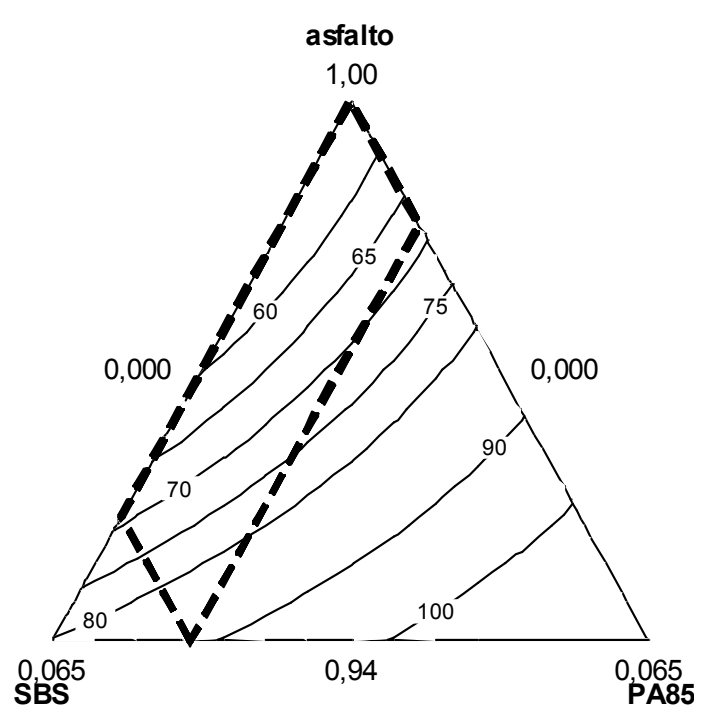

(a)

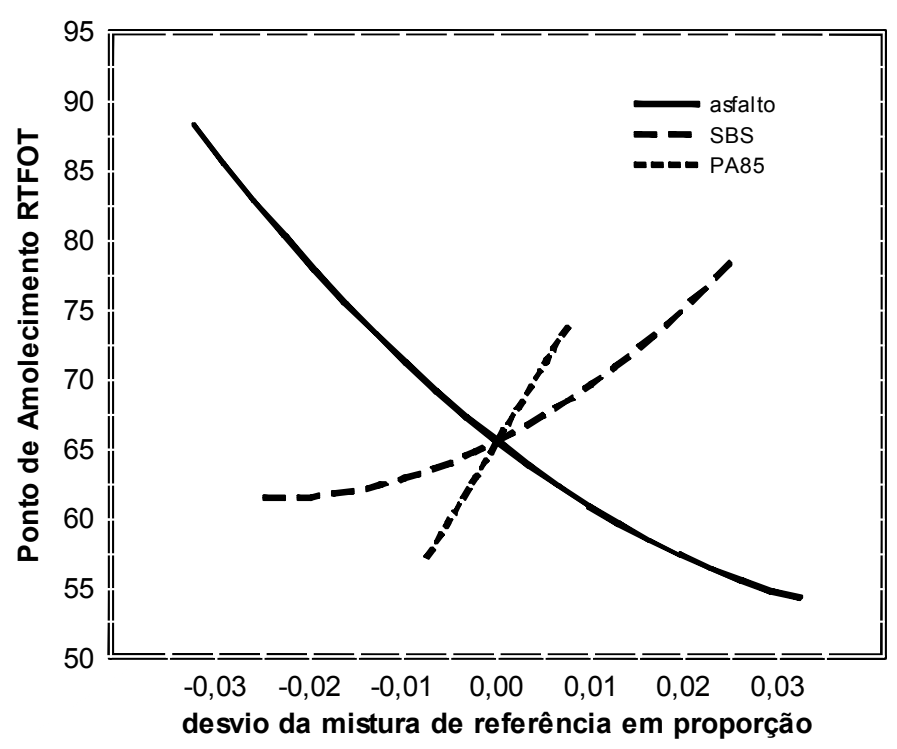

(b)

Figura 80 - Superfície de Resposta (a) e efeito de componentes (b) para ponto de amolecimento na condição RTFOT das misturas com PA85(Replan).

Na Figura 80 (a) nota-se, assim como na condição virgem, que os maiores valores de ponto de amolecimento são encontrados na parte inferior da figura (materiais mais modificados) e os menores valores de penetração estão na região superior do gráfico (materiais menos modificados). Como já esperado, os valores na condição RTFOT são superiores aos valores na condição virgem, sendo encontrado o maior valor desta propriedade, nesta condição, de $88,44^{\circ} \mathrm{C}$ para o ligante asfáltico $5 \mathrm{SBS}+1,5 \mathrm{PA} 85$. Na Figura 80 (b) está apresentado o gráfico de efeito dos componentes. Todos os modificadores proporcionam incremento no valor do ponto de amolecimento. Os componentes apresentam comportamento próximo do linear e, pelas inclinações, pode-se verificar que o ácido tem efeito mais expressivo. $\mathrm{O}$ copolímero SBS aumenta em $3,33^{\circ} \mathrm{C}$ o ponto de amolecimento para cada 
$1 \%$ da adição desse modificador, enquanto o ácido proporciona um incremento de $11,03^{\circ} \mathrm{C}$ para cada $1 \%$ de PA85.

A mesma propriedade avaliada para as misturas com adição de PPA, na condição RTFOT, do ligante asfáltico de base da Replan, pode ser observada na Figura 81 por meio dos gráficos de superfície de resposta e de efeito dos componentes. Na Figura 81 (a) notase, assim como para as misturas com adição de PPA na condição virgem, que os maiores valores do ponto de amolecimento são encontrados na parte inferior da figura (materiais mais modificados) e os menores valores de penetração estão na região superior do gráfico (materiais menos modificados), sendo o maior valor encontrado para o ligante asfáltico $5 S B S+1,5 P P A$, com valor de $94,00^{\circ} \mathrm{C}$.

O efeito dos componentes está apresentado na Figura 81 (b), na qual se pode verificar que todos os modificadores tendem a aumentar o valor do ponto de amolecimento. Os componentes apresentam comportamento próximo do linear e, pelas inclinações, verifica-se que o ácido tem efeito mais expressivo. O copolímero SBS aumenta em $4,89^{\circ} \mathrm{C}$ o ponto de amolecimento para cada $1 \%$ da adição, enquanto o ácido proporciona um incremento de $14,32^{\circ} \mathrm{C}$ para cada $1 \%$ de PPA. Nota-se que as misturas com adição de PPA apresentaram maiores valores do ponto de amolecimento quando comparadas com as misturas com adição de PA85.

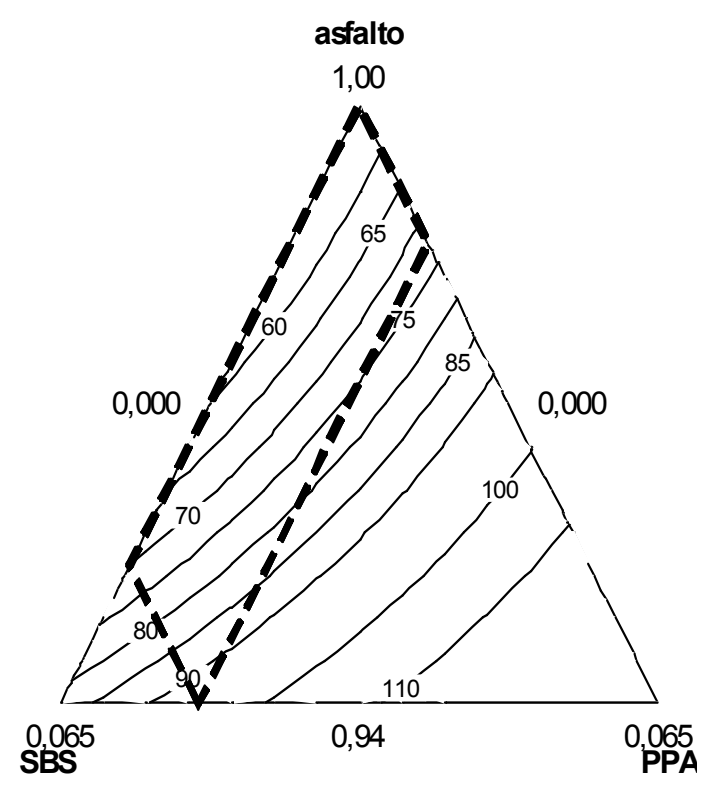

(a)

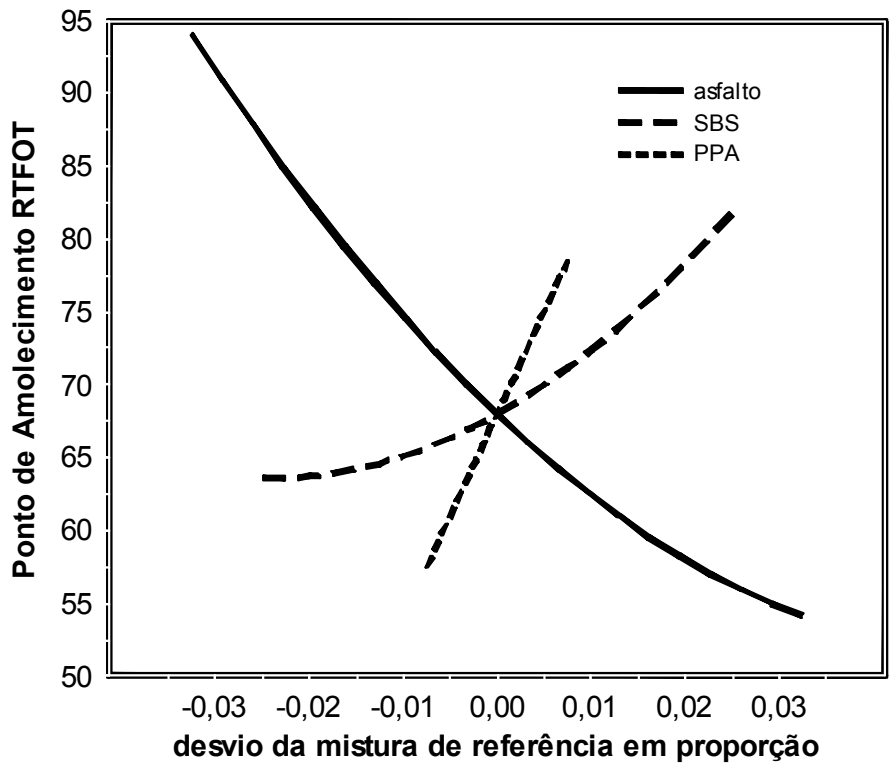

(b)

Figura 81 - Superfície de Resposta (a) e efeito de componentes (b) para ponto de amolecimento na condição RTFOT das misturas com PPA (Replan). 
Na Figura 82 estão apresentados os gráficos de superfície de resposta e de efeito dos componentes para incremento do ponto de amolecimento nos materiais modificados com adição do copolímero SBS e ácido PA85, ao ligante asfáltico de base da Replan. Na Figura 82 (a) pode-se verificar que os menores valores de incremento estão nas regiões com baixas concentrações de ácido e todos os teores do copolímero SBS. Imaginando-se que é válida a aplicação do limite máximo do incremento do ponto de amolecimento especificados pelo Regulamento Técnico 03/2005 da ANP a ligantes asfálticos modificados, pode-se observar que atenderiam este critério as misturas com teores baixos de ácidos e de copolímero SBS, assim como misturas com proporções intermediárias do copolímero SBS e quaisquer teores dos ácidos. Quanto ao comportamento dos componentes, mostrados na Figura 82 (b), notase que o PA85 apresenta um efeito linear, proporcionando um aumento de $3,16^{\circ} \mathrm{C}$ para cada $1 \%$ de ácido adicionado; enquanto o copolímero SBS apresenta um efeito parabólico, proporcionando um aumento no incremento do ponto de amolecimento até a concentração de $1,5 \%$ de SBS, e uma diminuição com adições superiores deste modificador.

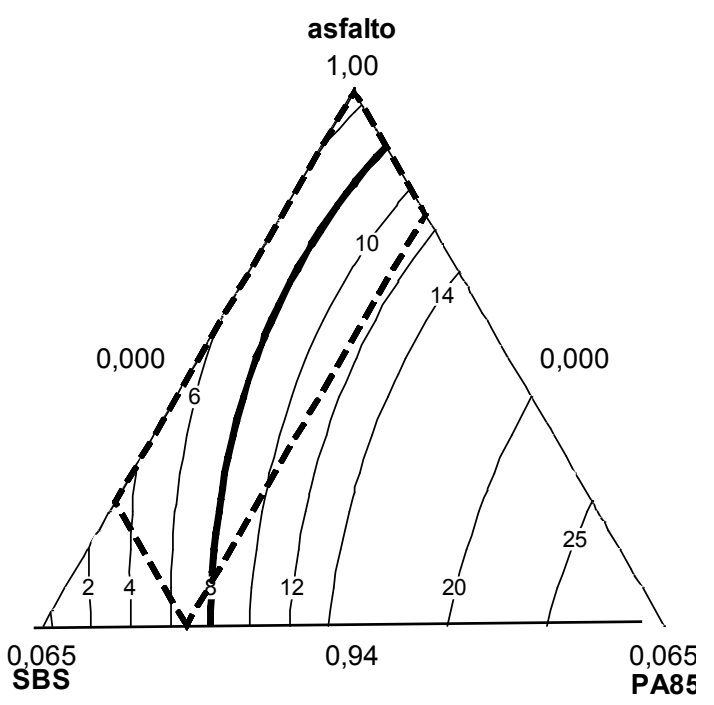

(a)

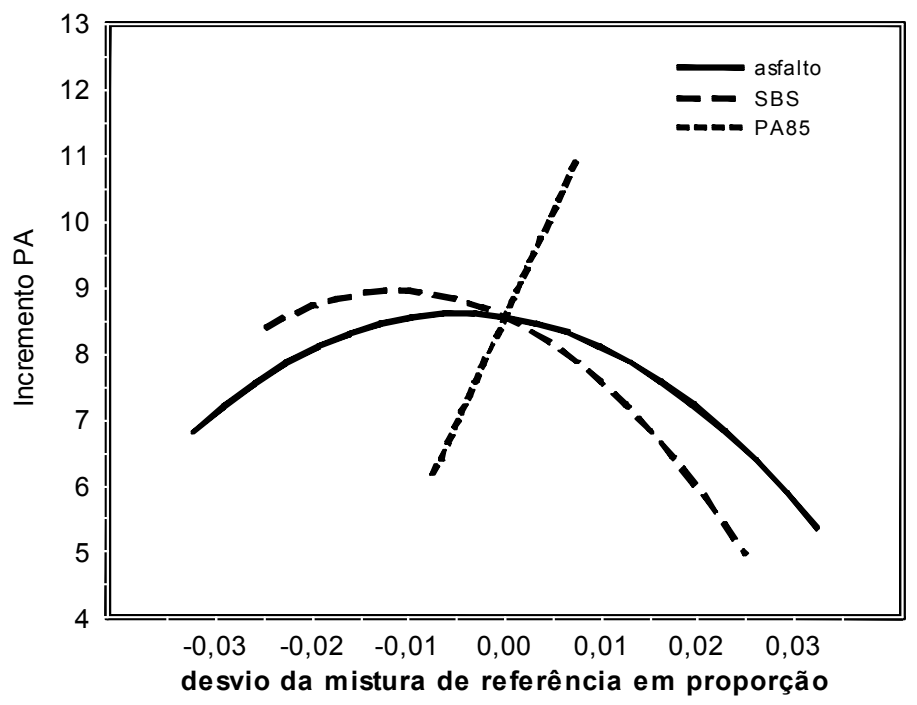

(b)

Figura 82 - Superfície de Resposta (a) e efeito de componentes (b) para o incremento do ponto de amolecimento das misturas com PA85(Replan).

Na Figura 83 estão apresentados os gráficos de superfície de resposta e de efeito dos componentes para o incremento do ponto de amolecimento nos materiais modificados com adição do copolímero SBS e ácido PPA, ao ligante asfáltico de base da Replan. Na Figura 83 (a) nota-se, que os menores valores de incremento estão nas regiões com baixas concentrações de ácido e do copolímero SBS, assim como para misturas com valores altos do copolímero SBS com quaisquer quantidades de ácido. Considerando válida a aplicação do 
limite máximo do incremento do ponto de amolecimento especificados pelo Regulamento Técnico 03/2005 da ANP a ligantes asfálticos modificados, pode-se observar que atenderiam este critério somente as misturas com adição de teores abaixo de 0,70\% de ácido e de 2,5\% de SBS, quando adicionados separadamente. No entanto, as misturas com adição dos dois modificadores que atenderiam este critério seriam as que apresentam teores baixos dos dois modificadores (parte superior esquerda da região de interesse) ou teores altos dos dois modificadores. Quanto ao comportamento dos componentes, mostrados na Figura 83 (b), nota-se que o PPA apresenta um efeito linear, proporcionando um aumento de $3,02^{\circ} \mathrm{C}$ para cada 1\% adicionado, enquanto o copolímero SBS apresenta um efeito parabólico, proporcionando um aumento no incremento do ponto de amolecimento até a concentração de $1,9 \%$ de SBS, e uma diminuição com adições maiores. Observa-se também comportamentos semelhantes para as misturas, independente dos tipos de ácido utilizados. Nota-se que, se considerado o limite de $8^{\circ} \mathrm{C}$, as misturas com adição do PA85 apresentam uma região com área maior que atende a este critério.

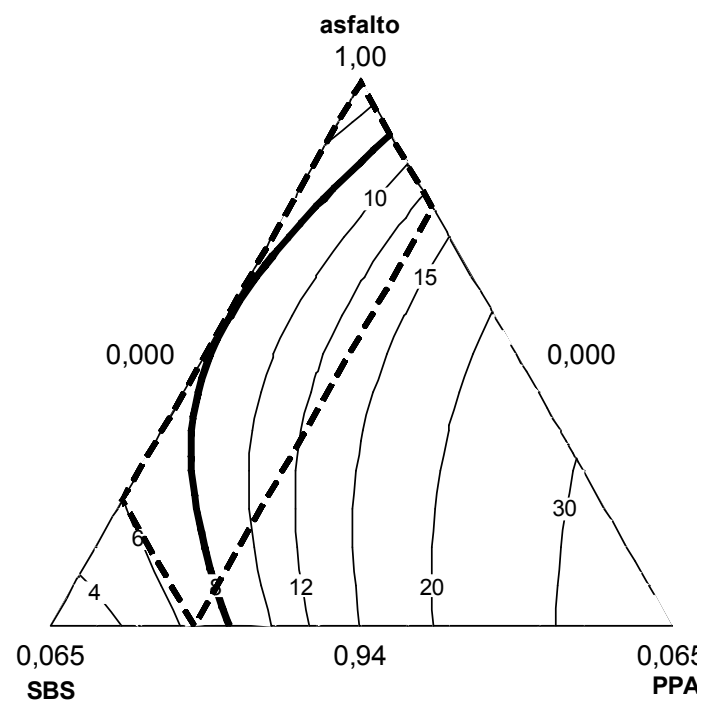

(a)

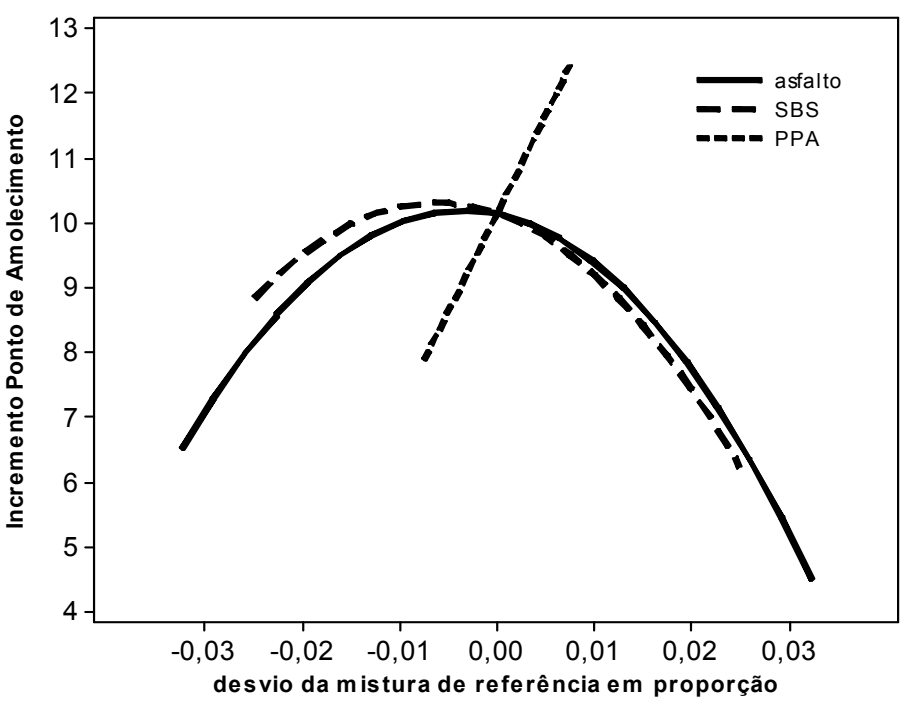

(b)

Figura 83 - Superfície de Resposta (a) e efeito de componentes (b) para o incremento do ponto de amolecimento das misturas com PPA (Replan).

Por fim, serão apresentados os gráficos de ponto de amolecimento para as misturas produzidas com o ligante asfáltico de base da Lubnor. Na Figura 84 estão apresentados os gráficos de superfície de resposta e de efeito dos componentes para a propriedade de ponto de amolecimento na condição virgem nos materiais modificados com adição do copolímero SBS e ácido PA85. Na Figura 84 (a) nota-se que os maiores valores de ponto de amolecimento são encontrados na parte inferior da figura (materiais mais modificados) e os 
menores valores estão na região superior do gráfico (materiais menos modificados). O maior valor desta propriedade, nesta condição, é de $68,28^{\circ} \mathrm{C}$ para o ligante asfáltico $5 \mathrm{SBS}+1,5 \mathrm{PA} 85$.

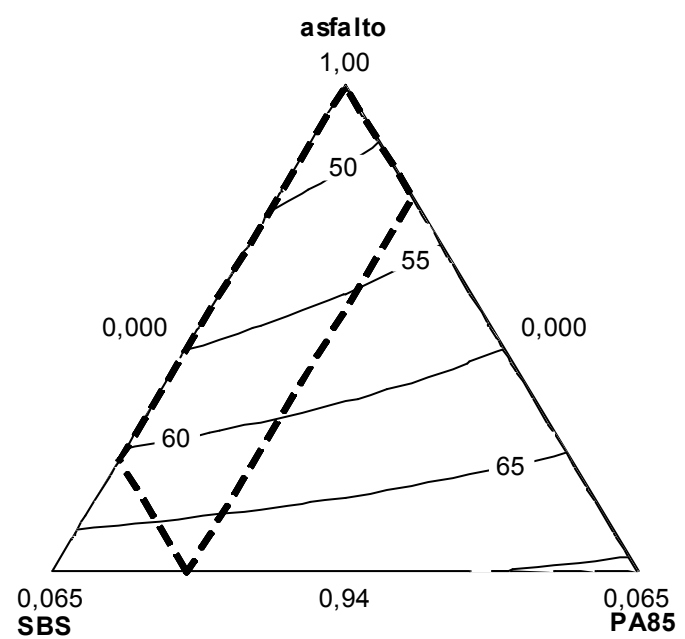

(a)

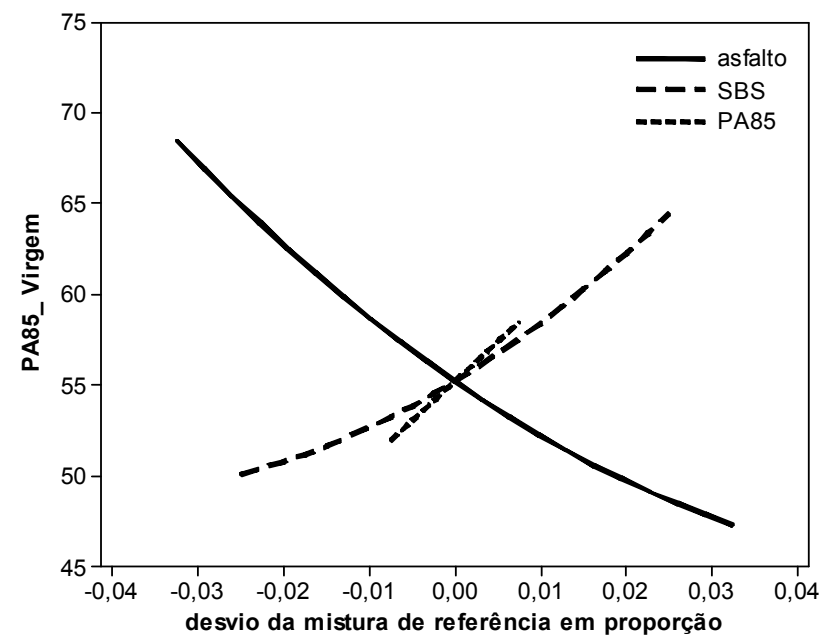

(b)

Figura 84 - Superfície de Resposta (a) e efeito de componentes (b) para o ponto de amolecimento na condição virgem das misturas com PA85 (Lubnor).

O efeito dos componentes está apresentado na Figura 84 (b), onde se pode verificar que todos os modificadores aumentam o valor do ponto de amolecimento. Os componentes apresentam comportamentos similares e próximos do linear, sendo que pelas inclinações das retas verifica-se que o ácido tem efeito mais expressivo. O copolímero SBS aumenta em $2,88^{\circ} \mathrm{C}$ o ponto de amolecimento para cada $1 \%$ adicionado, enquanto o ácido proporciona um incremento de $4,30^{\circ} \mathrm{C}$ para cada $1 \%$ de PA85.

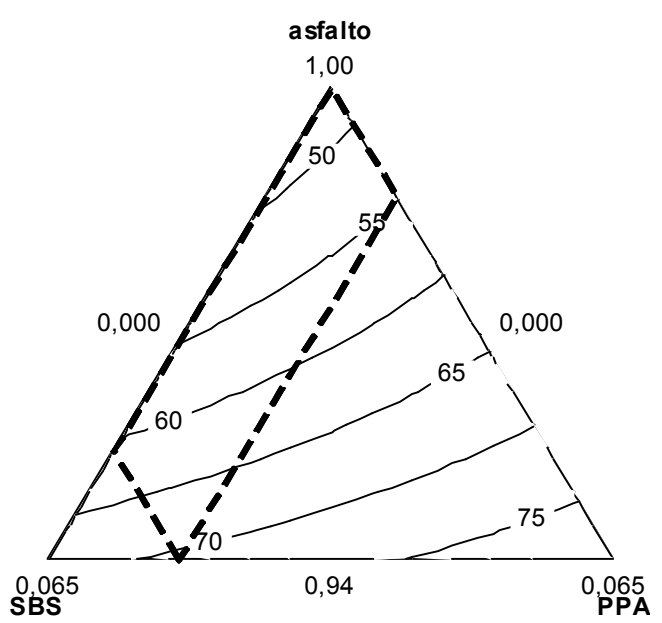

(a)

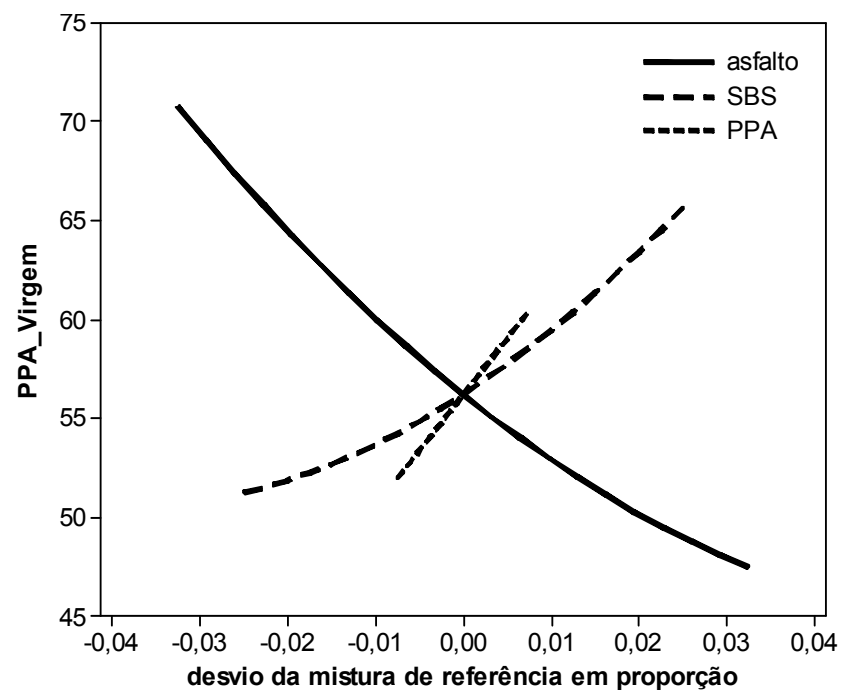

(b)

Figura 85 - Superfície de Resposta (a) e efeito de componentes (b) para o ponto de amolecimento na condição virgem das misturas com PPA (Lubnor).

Na Figura 85 estão apresentados os gráficos de superfície de resposta e de efeito dos componentes para a propriedade de ponto de amolecimento na condição virgem nos materiais 
modificados com adição do copolímero SBS e ácido PPA. A Figura 85 (a) indica, como já esperado, que os maiores valores do ponto de amolecimento são encontrados na parte inferior da figura (materiais mais modificados) e os menores valores estão na região superior do gráfico (materiais menos modificados). O maior valor desta propriedade, nesta condição, é de $70,68^{\circ} \mathrm{C}$ para o ligante asfáltico $5 \mathrm{SBS}+1,5 \mathrm{PPA}$. Quanto ao efeito dos modificadores, apresentado na Figura 85 (a), tem-se o mesmo efeito para os dois modificadores avaliados, ambos tendem a aumentar o ponto de amolecimento. $O$ ácido, que apresenta efeito mais expressivo, aumenta em $5,76^{\circ} \mathrm{C}$ para cada $1 \%$ adicionado, enquanto o copolímero SBS aumenta em $2,77^{\circ} \mathrm{C}$ esta propriedade para cada $1 \%$ deste modificador. Para este ligante asfáltico de base observa-se, considerando as misturas mais modificadas, valores semelhantes para esta propriedade, independente do ácido utilizado.

A seguir são apresentados os gráficos referentes a esta propriedade na condição envelhecida em curto prazo.

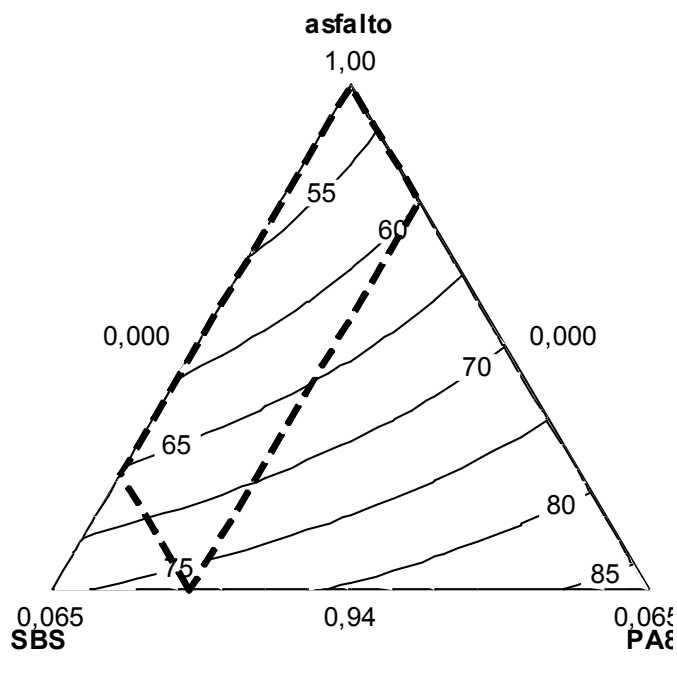

(a)

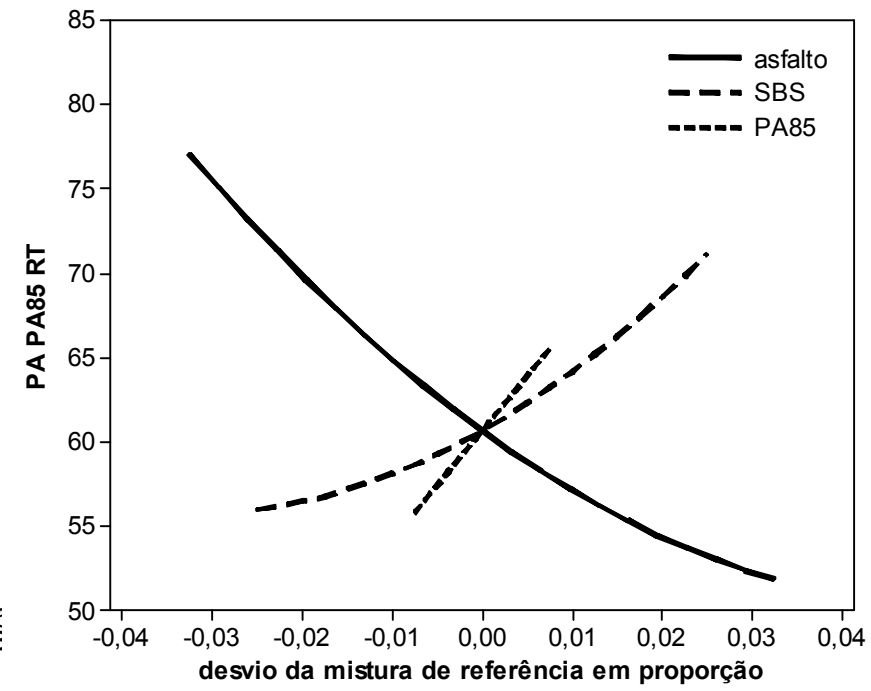

(b)

Figura 86 - Superfície de Resposta (a) e efeito de componentes (b) para o ponto de amolecimento na condição RTFOT das misturas com PA85 (Lubnor).

Na Figura 86, que apresenta os gráficos de superfície de resposta (a) e efeito dos componentes (b), pode-se perceber que os valores de ponto de amolecimento para a condição de envelhecimento em curto prazo estão entre $52^{\circ} \mathrm{C}$ para o ligante asfáltico de base e de $77,01^{\circ} \mathrm{C}$ para o ligante asfáltico mais modificado (5,0SBS+1,5PA85), e que à medida que aumenta a concentração dos modificares tem-se maiores valores do ponto de amolecimento. Ambos os modificadores tem a tendência de aumentar esta propriedade de forma aproximadamente linear, sendo que, o ácido aumenta a propriedade em $6,42^{\circ} \mathrm{C}$ para cada $1 \%$ adicionado, enquanto o copolímero SBS proporciona um aumento de $3,01^{\circ} \mathrm{C}$ para cada $1 \%$ de aumento da proporção deste modificador. 
$\mathrm{Na}$ Figura 87 os gráficos de superfície de respostas e efeito de componentes apresentados referem-se às misturas com adição de PPA, na condição de envelhecimento em curto prazo. Pode-se observar na Figura 87 (a) que a área de interesse apresenta valor mínimo de $52,70^{\circ} \mathrm{C}$ para o ligante asfáltico de base, e valor máximo para a mistura com maiores teores dos modificadores, igual a $82,13^{\circ} \mathrm{C}$. Quanto ao efeito dos componentes, ambos apresentam mesmo comportamento, com tendência de aumentar a propriedade, sendo que o copolímero SBS, com menor intensidade, $3,56^{\circ} \mathrm{C}$ para cada $1 \%$ adicionado, e o ácido aumenta em $7,65^{\circ} \mathrm{C}$ para cada $1 \%$ adicionado. Pode-se observar também que o valor de ponto de amolecimento máximo para as misturas com adição de PPA é 1,06 vezes maior que o das misturas com PA85.

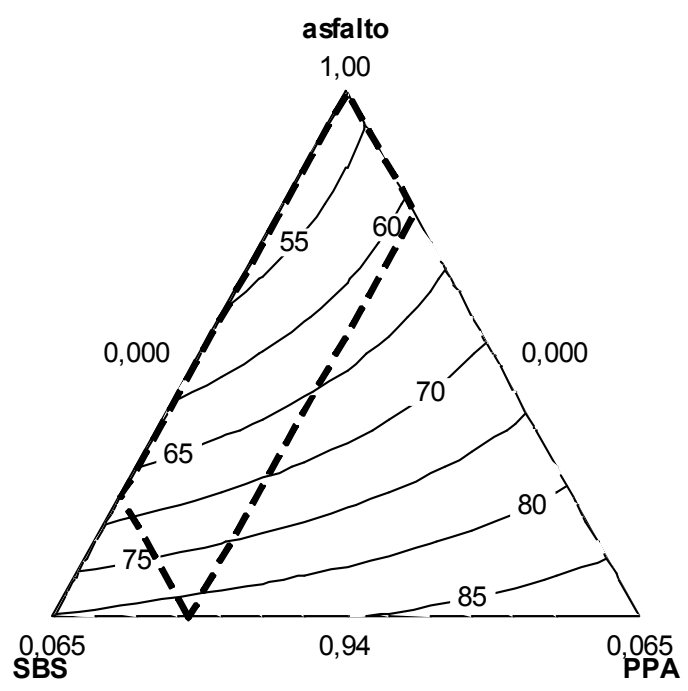

(a)

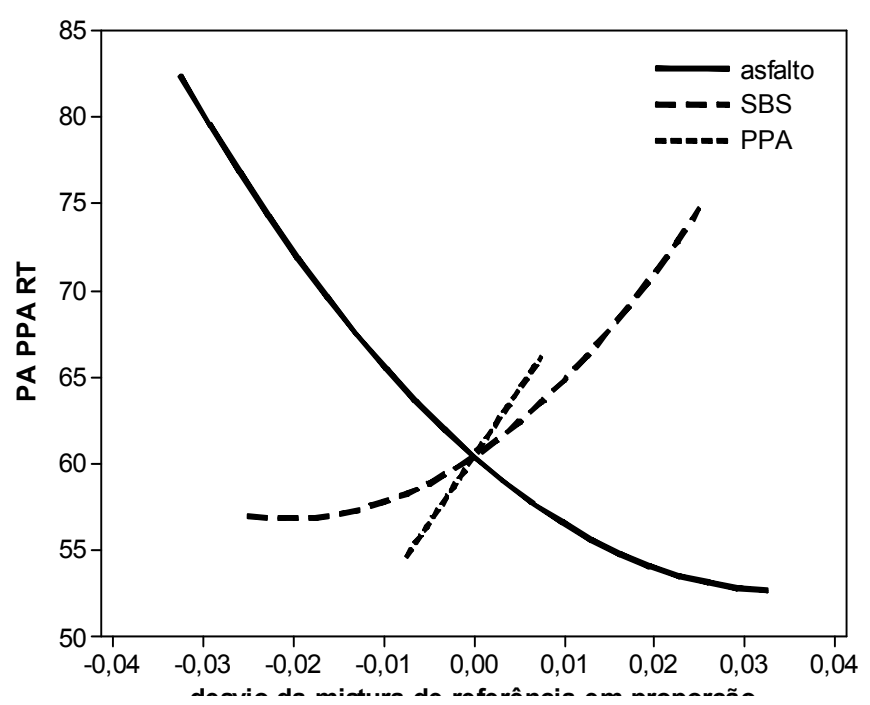

(b)

Figura 87 - Superfície de Resposta (a) e efeito de componentes (b) para o ponto de amolecimento na condição RTFOT das misturas com PPA (Lubnor).

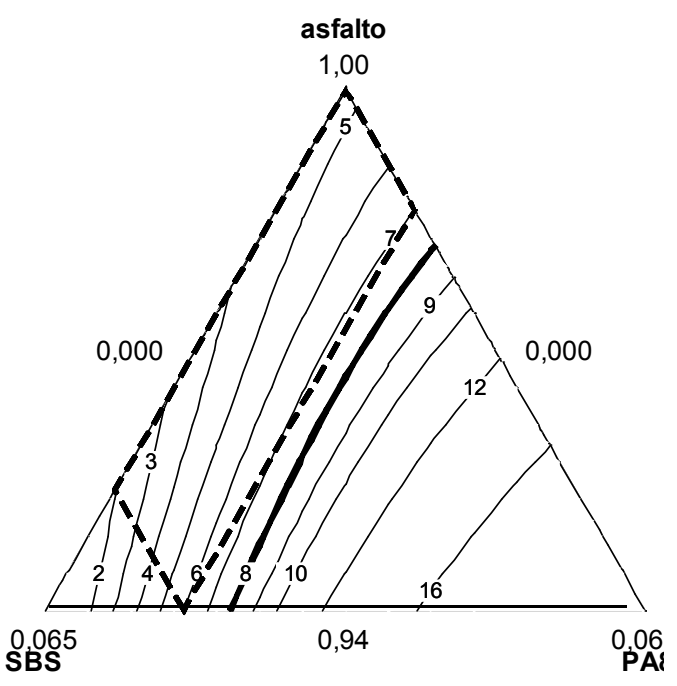

(a)

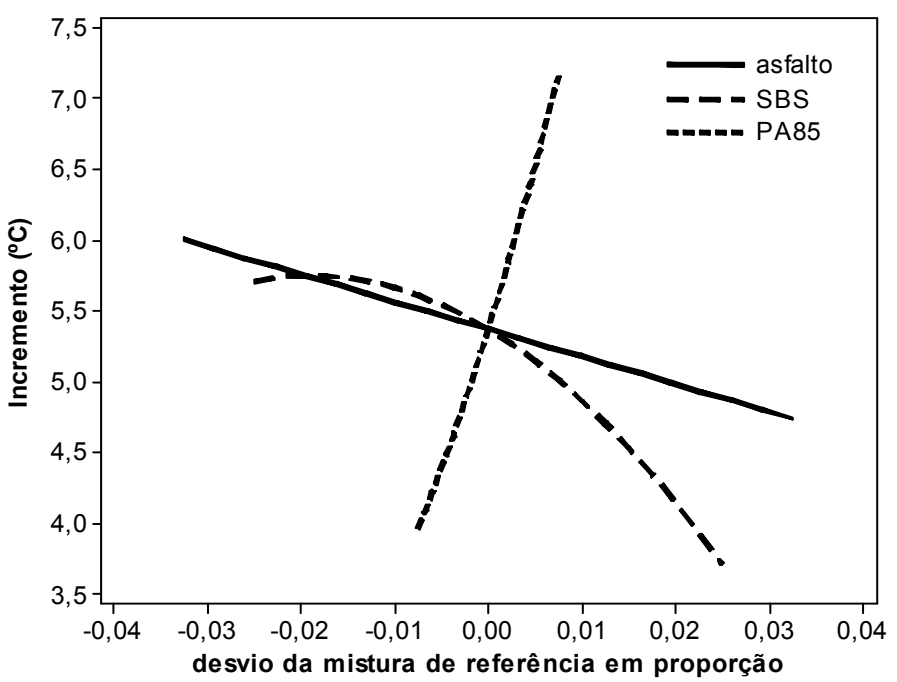

(b)

Figura 88 - Superfície de Resposta (a) e efeito de componentes (b) para incremento do ponto de amolecimento das misturas com PA85 (Lubnor). 
Na Figura 88 estão apresentados os gráficos de superfície de resposta e de efeito dos componentes para incremento do ponto de amolecimento nos materiais modificados com adição do copolímero SBS e do ácido PA85, ao ligante asfáltico de base da Lubnor. Na Figura 88 (a) nota-se que os menores valores de incremento estão nas regiões com baixas concentrações de modificadores. Considerando-se limite máximo do incremento do ponto de amolecimento especificado pelo Regulamento Técnico 03/2005 da ANP a ligantes asfálticos modificados, pode se observar que todas as misturas atenderiam a especificação, com limite no valor de $8^{\circ} \mathrm{C}$. Quanto ao comportamento dos componentes, mostrados na Figura 83 (b), nota-se que os modificadores apresentam efeitos antagônicos, enquanto o copolímero diminui em $0,41 \%$ para cada $1 \%$ de aumento na proporção deste modificador, o PA85, por sua vez, tende a aumentar esta propriedade em $2,11 \%$ para cada $1 \%$ adicionado. Nota-se, pelas inclinações das retas, que o efeito do ácido em aumentar o incremento do ponto de amolecimento é mais expressivo do que o do copolímero SBS em diminuir.

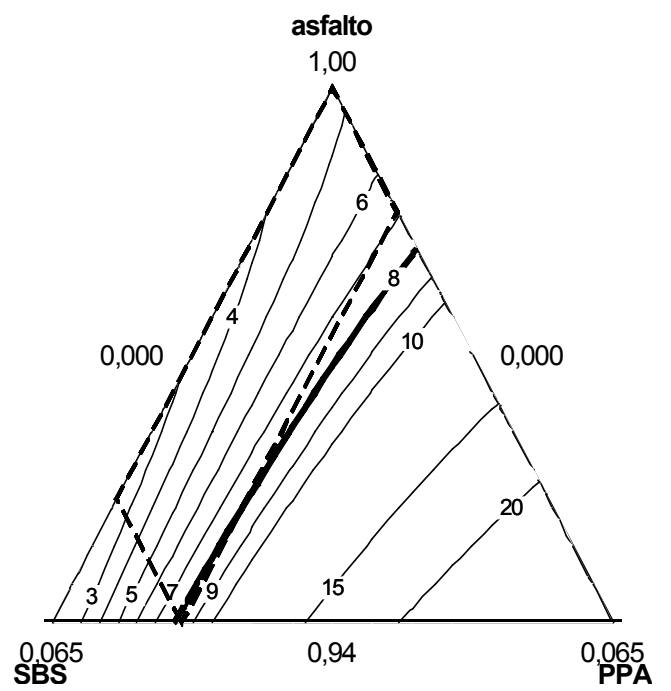

(a)

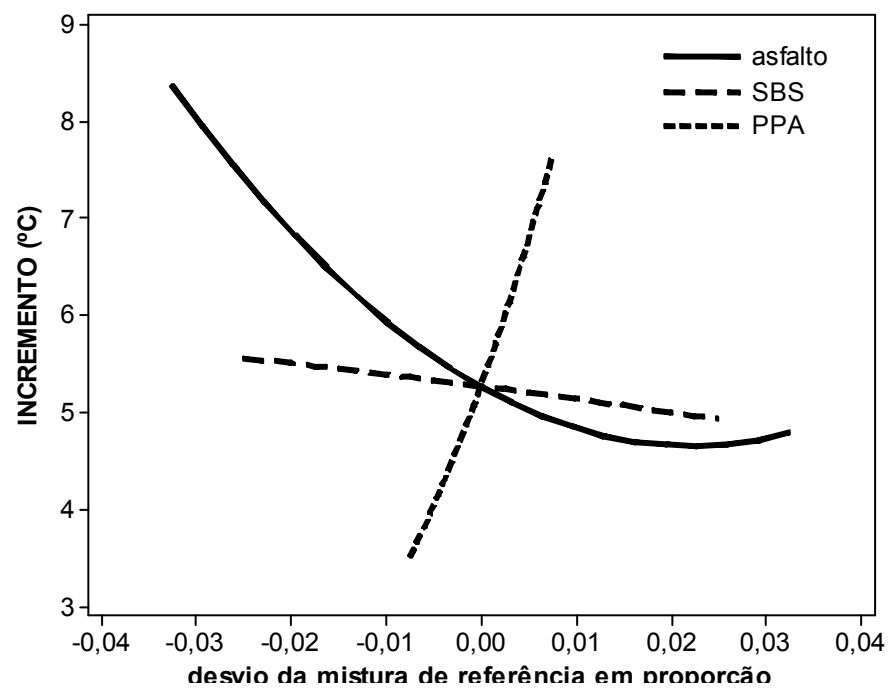

(b)

Figura 89 - Superfície de Resposta (a) e efeito de componentes (b) para incremento do ponto de amolecimento das misturas com PPA (Lubnor).

Na Figura 89 estão apresentados os gráficos de superfície de resposta e de efeito dos componentes para o incremento do ponto de amolecimento nos materiais modificados com adição do copolímero SBS e ácido PPA, no ligante asfáltico de base da Lubnor. Na Figura 89 (a) nota-se, que os menores valores de incremento estão nas regiões com baixas concentrações de modificadores, e apenas as misturas mais modificadas (5,0SBS+1,5PPA), região inferior da região de interesse, não atendem ao Regulamento Técnico 03/2005 da ANP especificados para ligantes asfálticos modificados. O efeito dos componentes, apresentado 
na Figura 89 (b), aponta que o copolímero SBS produz um efeito pouco expressivo que tende a diminuir esta propriedade, enquanto o PPA aumenta a propriedade em $2,74^{\circ} \mathrm{C}$ a cada $1 \%$ de aumento na proporção deste modificador. Comparando-se os dois ácidos, nota-se que ambos apresentam o mesmo efeito nesta propriedade, diminuí-la.

Ao analisar os dois tipos de ligantes asfálticos de base estudados, à luz dessa propriedade, constatou-se que os modificadores proporcionam um efeito mais intenso no ligante asfáltico de base da Replan, uma vez que estas misturas apresentam valores de ponto de amolecimento superiores em ambas as condições avaliadas (virgem e RTFOT). Quanto à sensibilidade ao envelhecimento, o ligante asfáltico da Lubnor se mostrou menos sensível, pois apresentou menores valores de incremento do ponto de amolecimento. No que ser refere aos ácidos, pode-se dizer que na condição virgem, independente do ligante asfáltico de base, as misturas com adição dos ácidos apresentaram comportamentos semelhantes. Para o condicionamento de envelhecimento em curto prazo o PPA apresentou efeito um pouco superior, sendo que as misturas com a adição deste ácido apresentaram valores de ponto de amolecimento maiores.

Na Tabela 83 estão apresentados os modelos de regressão obtidos para a propriedade do ponto de amolecimento para cada ligante modificado (Replan e Lubnor) para as amostras com a adição de PA85 e PPA.

Tabela 83 - Modelos de regressão referentes ao ponto de amolecimento.

\begin{tabular}{|c|c|c|c|c|}
\hline $\begin{array}{l}\text { Ligante } \\
\text { Asfáltico } \\
\text { de base }\end{array}$ & Ácido & Propriedade & Modelo de Regressão & $\mathbf{R}^{2}(\%)$ \\
\hline \multirow{6}{*}{ Replan } & & PA Virgem & $49 x_{1}+9051 x_{2}+537 x_{3}-9187 x_{1} x_{2}+6347 x_{2} x_{3}$ & $\overline{97,7}$ \\
\hline & PA85 & PA RTFOT & $54 x_{1}+7108 x_{2}+997 x_{3}-7115 x_{1} x_{2}$ & 98,7 \\
\hline & & Incremento PA & $5 x_{1}-2936 x_{2}+398 x_{3}+3051 x_{1} x_{2}$ & 80,7 \\
\hline & & PA Virgem & $49 x_{1}+8816 x_{2}+537 x_{3}-8645 x_{1} x_{2}+6588 x_{2} x_{3}$ & 97,7 \\
\hline & PPA & PA RTFOT & $54 x_{1}+7584 x_{2}+1280 x_{3}-7590 x_{1} x_{2}$ & 96,9 \\
\hline & & Incremento PA & $4 x_{1}-4001 x_{2}+571 x_{3}+4248 x_{1} x_{2}-6357 x_{2} x_{3}$ & 73,1 \\
\hline \multirow{6}{*}{ Lubnor } & & PA Virgem & $47 x_{1}+3463 x_{2}+407-3315 x_{1} x_{2}$ & 96,9 \\
\hline & PA85 & PA RTFOT & $52 x_{1}+4784 x_{2}+589 x_{3}-4694 x_{1} x_{2}$ & 96,7 \\
\hline & & Incremento PA & $5 x_{1}-1039 x_{2}+3565 x_{3}+1039 x_{1} x_{2}-3460 x_{1} x_{3}$ & 85,0 \\
\hline & & PA Virgem & $48 x_{1}+3758 x_{1}+530 x_{3}-3620 x_{1} x_{2}$ & 98,4 \\
\hline & PPA & PA RTFOT & $53 x_{1}+8726 x_{2}+612 x_{3}-8821 x_{1} x_{2} 5 x$ & 92,2 \\
\hline & & Incremento PA & $5 x_{1}-46 x_{2}+5454 x_{3}-5390 x_{1} x_{3}$ & 92,3 \\
\hline
\end{tabular}

$\mathrm{x}_{1}=$ asfalto; $\mathrm{x}_{2}$ : SBS e $\mathrm{x}_{3}$ : ácido em porcentagem.

\subsubsection{Viscosidade Rotacional}


Nesta subseção estão apresentados os dados referentes às viscosidades dos materiais estudados. Cabe ressaltar que os gráficos de superfície e de efeito dos componentes apresentados se referem à temperatura de $135^{\circ} \mathrm{C}$, uma vez que para esta temperatura há uma limitação especifica por norma, com valor máximo de 3,0Pa.s. Os dados referentes às demais temperaturas estão apresentados nas Tabela 84 e 85 , com os valores máximos de viscosidade, e nas Tabela 87 e 87 com os efeitos da adição de $1 \%$ de cada modificador nesta propriedade. Os gráficos de superfície de resposta e de efeito dos componentes, das demais temperaturas, estão apresentados no Apêndice $F$.

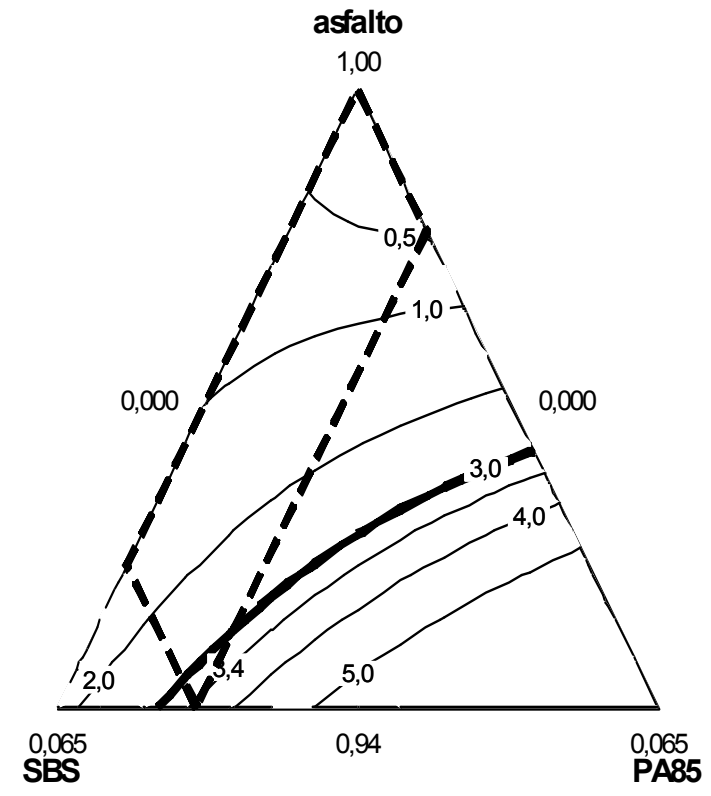

(a)

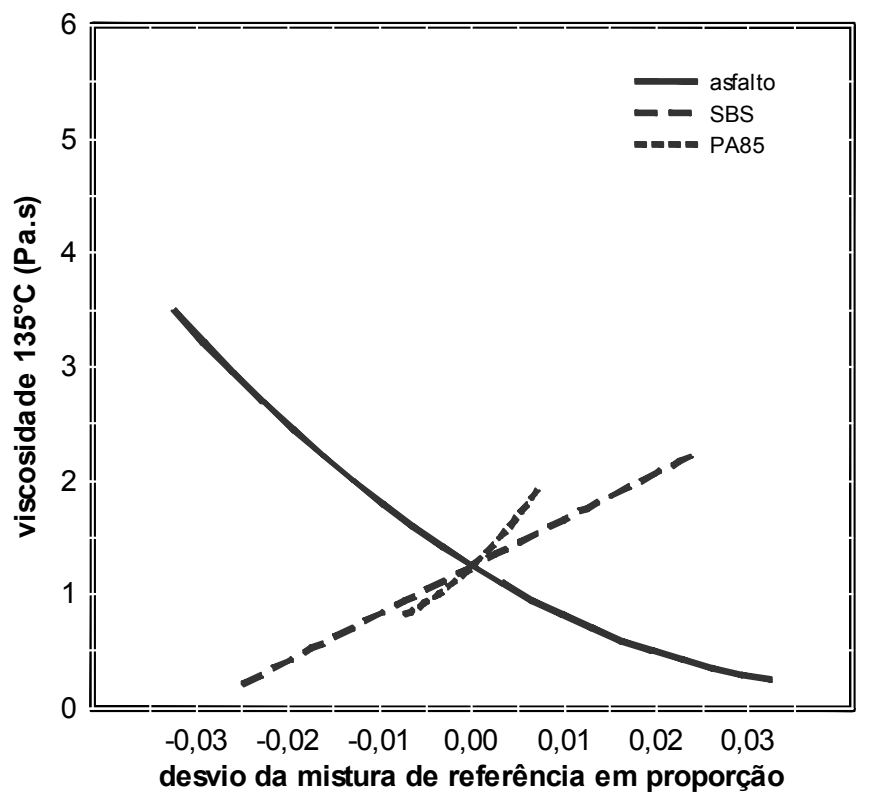

(b)

Figura 90 - Superfície de Resposta (a) e efeito de componentes (b) para Viscosidade à $135^{\circ} \mathrm{C}$ com amostras virgens das misturas com PA85 (Replan).

Na Figura 90 (a) tem-se o gráfico referente à superfície de resposta da viscosidade à $135^{\circ} \mathrm{C}$ na condição virgem para misturas com o ácido PA85. Observa-se que os menores valores das viscosidades se encontram na região com baixas concentrações do copolímero SBS e quaisquer teores de ácido (PA85). No entanto, os maiores valores de viscosidade então na região onde se encontram misturas com altos teores dos dois modificadores. Considerando o valor de 3,0 Pa.s, da norma, pode-se destacar que misturas com altos teores de copolímero SBS e concentrações de até $1,2 \%$ de ácido (PA85) e misturas com altos teores de ácido e concentrações máximas de copolímero SBS de 4,2\% atendem essa condição. Quanto ao efeito dos componentes, Figura 90 (b), observa-se que os dois modificadores apresentam comportamento próximo do linear, proporcionando um aumento da viscosidade. Nota-se pelas inclinações, que o ácido proporciona um efeito mais intenso na viscosidade do que o 
copolímero SBS. O copolímero SBS aumenta em 0,41 Pa.s a viscosidade para cada $1 \%$ adicionado, enquanto o ácido proporciona aumento de 0,73 Pa.s para cada $1 \%$ de PA85.

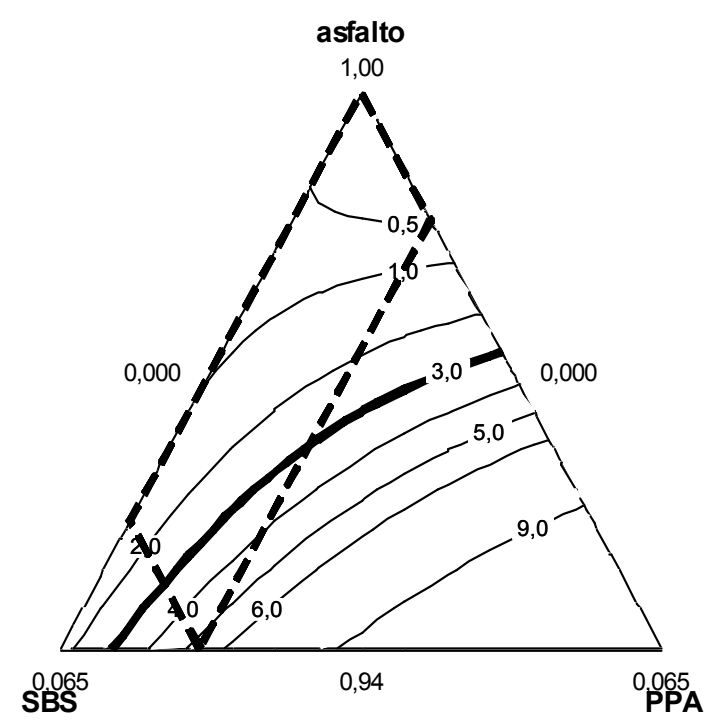

(a)

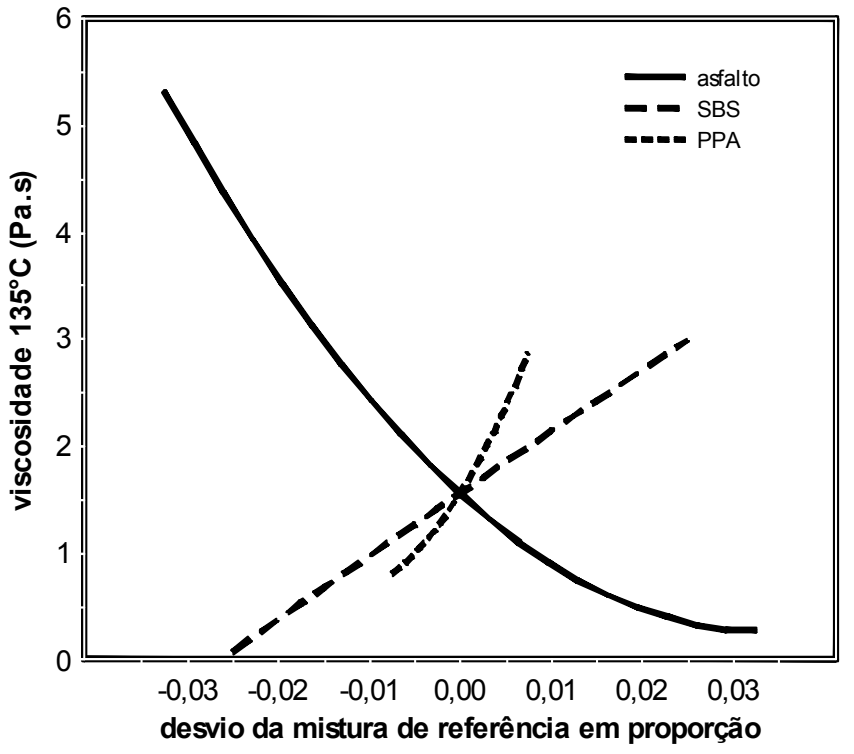

(b)

Figura 91 - Superfície de Resposta (a) e efeito de componentes (b) para Viscosidade à $135^{\circ} \mathrm{C}$ com amostras virgens das misturas com PPA (Replan).

Na Figura 91 (a) pode-se observar que os menores valores de viscosidade (<0,5 Pa.s) estão na região com baixas concentrações do modificador copolímero SBS e quaisquer concentrações de PPA. No entanto, os maiores valores de viscosidade (5,0 Pa.s) se encontram na região com altas concentrações tanto do copolímero SBS quanto do ácido (PPA). Nota-se que para temperatura em questão, $135^{\circ} \mathrm{C}$, mesmo na condição virgem, a viscosidade máxima encontrada está acima dos valores aceitáveis para bombeamento e compactação estabelecidos por norma (3,0 Pa.s). Para atender essa condição, deveriam ser consideradas misturas com concentrações intermediárias do copolímero SBS $(2,5 \%)$ juntamente com altos teores de ácido (1,5\%) ou misturas com altos teores do copolímero SBS e concentrações intermediárias de PPA (0,75\%).

Na Figura 91 (b) é apresentado o efeito dos componentes, onde nota-se que os dois modificadores proporcionam o aumento da propriedade em questão. O copolímero SBS apresenta comportamento linear enquanto o PPA tem efeito quase linear, porém próximo de parabólico. Pode-se observar também, pelas inclinações, que o efeito do ácido é mais intenso (maior inclinação) do que o efeito do copolímero SBS. Este último proporciona um aumento de 0,58 Pa.s para cada $1 \%$ do modificador copolímero SBS, enquanto o ácido aumenta em 0,94 Pa.s para cada $1 \%$ de PPA adicionado. 
Ao se comparar os gráficos da Figura 90 e Figura 91 nota-se um comportamento semelhante, principalmente no valor da viscosidade para teores baixos do copolímero SBS e quaisquer concentrações de ácido. Com o aumento das proporções dos modificadores observam-se maiores valores de viscosidade para as misturas com adição do PPA, sendo que o valor máximo de viscosidade apresentado para misturas com PA85 foi de 3,4 Pa.s, enquanto que para as misturas com PPA foi de 5,0 Pa.s(1,47 vezes superior). Quanto ao efeito dos componentes, os materiais também apresentam comportamentos semelhantes, com maiores intensidades tanto para o copolímero SBS quanto para o ácido nas misturas com adição de PPA.

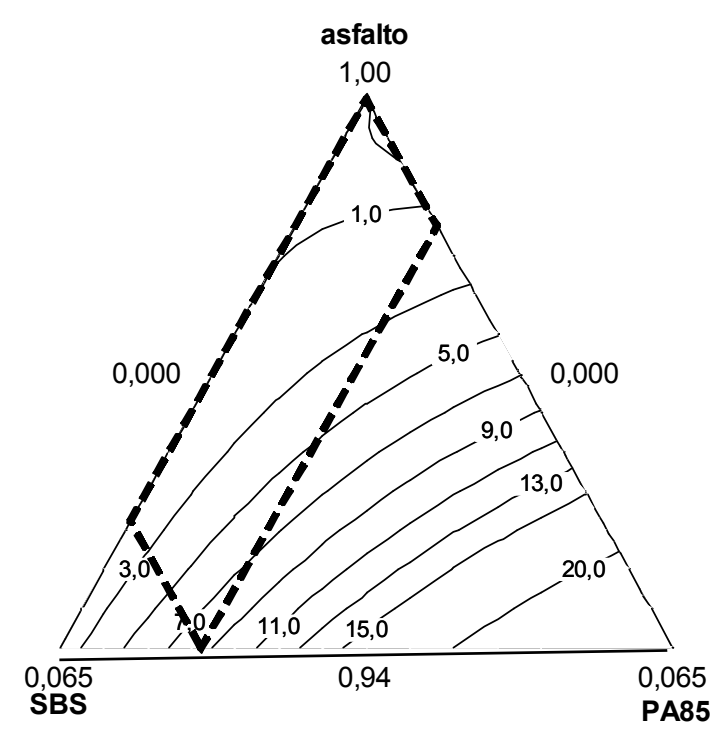

(a)

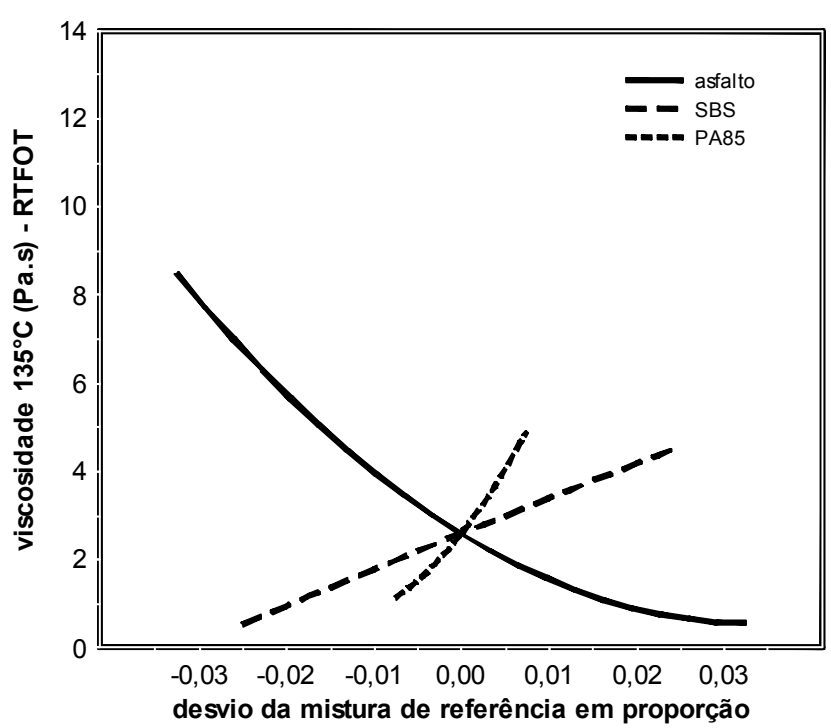

(b)

Figura 92 - Superfície de Resposta (a) e efeito de componentes (b) para Viscosidade à $135^{\circ} \mathrm{C}$ com amostras envelhecidas RTFOT das misturas com PA85(Replan).

No gráfico que representa a superfície de resposta referente à viscosidade na temperatura de $135^{\circ} \mathrm{C}$ em amostras envelhecidas em curto prazo, Figura 92 (a), pode-se observar que os menores valores estão na região de misturas com baixos teores do copolímero SBS e intermediários a altos teores de ácido (PA85). Na condição de envelhecimento em curto prazo tem-se o valor de 8,2 Pa.s como o máximo de viscosidade, na região com altas concentrações de modificadores. Quanto ao efeito dos componentes, observado na Figura 92 (b), os dois modificadores aumentam a viscosidade, apresentando comportamentos próximos do linear. O ácido proporciona um efeito mais intenso do que o copolímero SBS, com uma variação média da viscosidade próxima a 2,55 Pa.s para cada $1 \%$ desse modificador, enquanto o copolímero SBS aumenta em 0,82 Pa.s/1\%. 
Comparando os valores de viscosidade a $135^{\circ} \mathrm{C}$ das amostras virgens (Figura 90) com as amostras envelhecidas em curto prazo (Figura 92) observa-se que o valor máximo de viscosidade aumentou de 3,4 Pa.s (condição virgem) para 8,2 Pa.s (condição envelhecida), aumento de 2,41 vezes após envelhecimento em curto prazo. Quanto ao efeito dos modificadores, em relação à variação da viscosidade, o copolímero SBS proporcionou aumento de 2,0 vezes (0,41 Pa.s/1\% para 0,82 Pa.s/1\%) e o ácido PA85 de 3,49 vezes $(0,73$ Pa.s/1\% para 2,55 Pa.s/1\%).

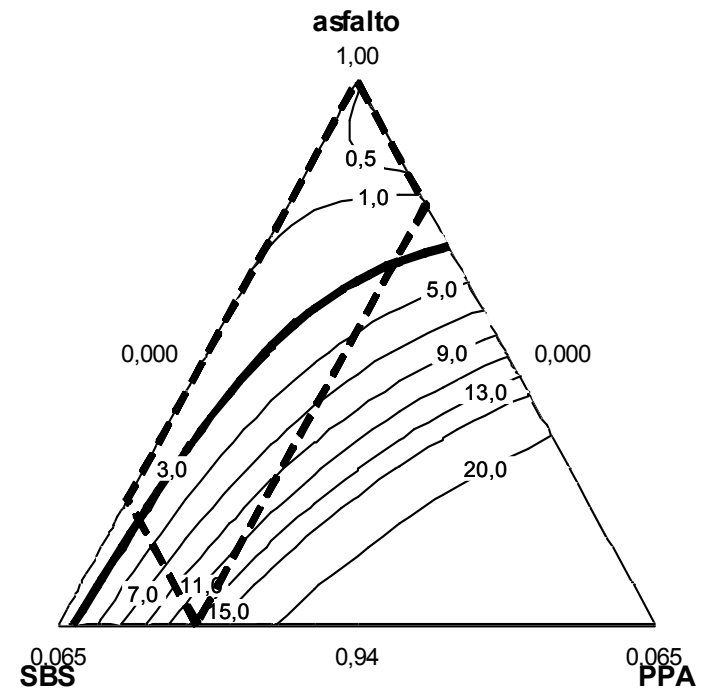

(a)

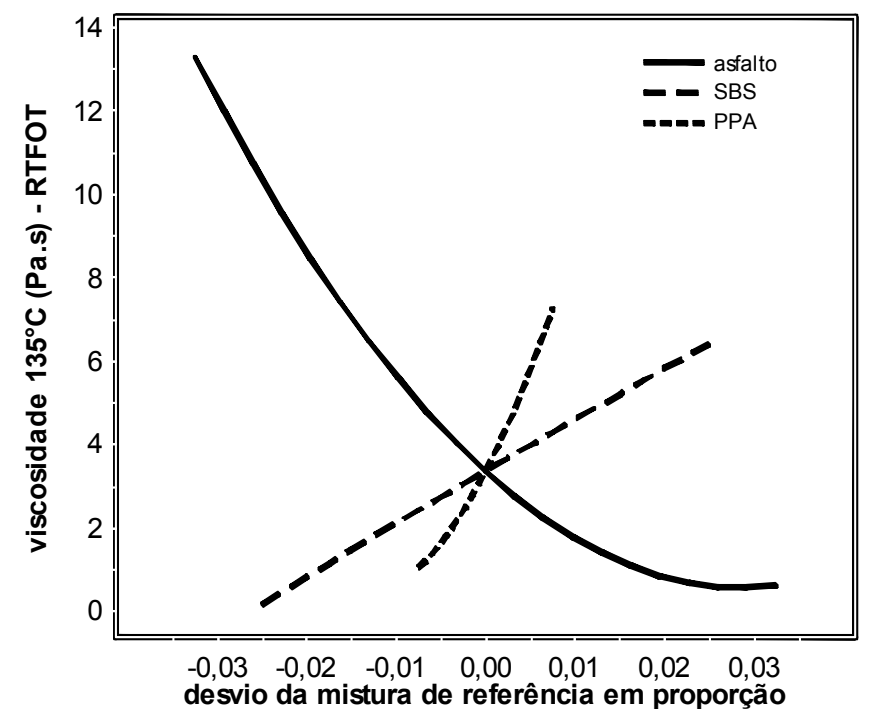

(b)

Figura 93 - Superfície de Resposta (a) e efeito de componentes (b) para Viscosidade à $135^{\circ} \mathrm{C}$ com amostras envelhecidas RTFOT das misturas com PPA.

O gráfico de superfície de resposta, conforme mostra Figura 93 (a), aponta que os maiores valores de viscosidade estão na região com baixos teores do copolímero SBS e concentrações intermediárias a altas de ácido (PPA). Na condição envelhecida em curto prazo para a região estudada foram encontrados valores máximos de viscosidade de 12,9 Pa.s. Em relação ao efeito dos componentes, apresentado na Figura 93 (b), observa-se que os aumentos dos dois modificadores aumentam a viscosidade, apresentando efeitos praticamente lineares. A variação média da viscosidade provocada pelo aumento de $1 \%$ na proporção de SBS é de 1,25 Pa.s, e para o ácido é próximo a 4,14 Pa.s para 1\%, o que indica que o efeito do PPA é mais intenso do que o copolímero SBS.

Comparando as viscosidades das amostras virgens (Figura 91) e das amostras envelhecidas em curto prazo (Figura 93) nota-se um aumento de 2,58 vezes (5 Pa.s - virgem para 12,9 Pa.s - envelhecido RTFOT). Em relação à variação média da propriedade devido ao aumento de $1 \%$ do modificador, o copolímero SBS causou aumento de 2,15 vezes $(0,58$ 
Pa.s/ 1\% (virgem) para 1,25 Pa.s/1\% (RTFOT)), enquanto o ácido de 4,40 vezes (de 0,94 Pa.s/1\% (virgem) para 4,14 Pa.s/1\% (RTFOT)).

Em relação à viscosidade na temperatura de $135^{\circ} \mathrm{C}$ nas condições virgem e envelhecida em curto prazo, comparando as misturas com adição de PA85 e PPA, observamse comportamentos semelhantes das misturas no gráfico de superfície de resposta, assim como para os modificadores quando avaliados no gráfico de efeito dos componentes. No entanto, nota-se para ambas as condições, virgem ou envelhecida em curto prazo, valores de viscosidade superiores para misturas com adição de PPA e também variações médias da viscosidade devidas ao aumento de $1 \%$ dos modificadores superiores tanto para o copolímero SBS quanto para o ácido PPA, em relação às misturas com adição de PA85. Após envelhecimento das amostras observou-se, tanto para os valores da viscosidade, quanto para as variações médias do aumento de $1 \%$ dos modificadores no efeito dessa propriedade, aumentos superiores para as misturas com PPA, o que aponta que essas misturas foram mais afetadas pelo efeito do envelhecimento em curto prazo.

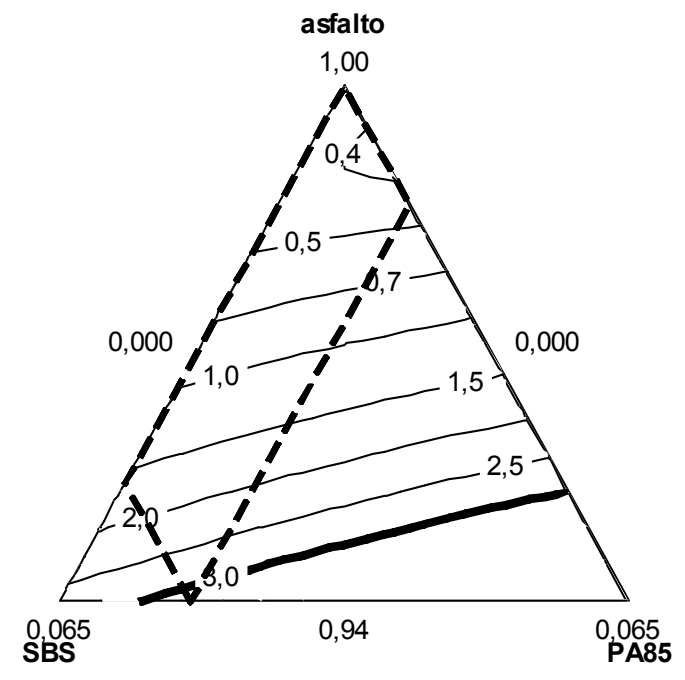

(a)

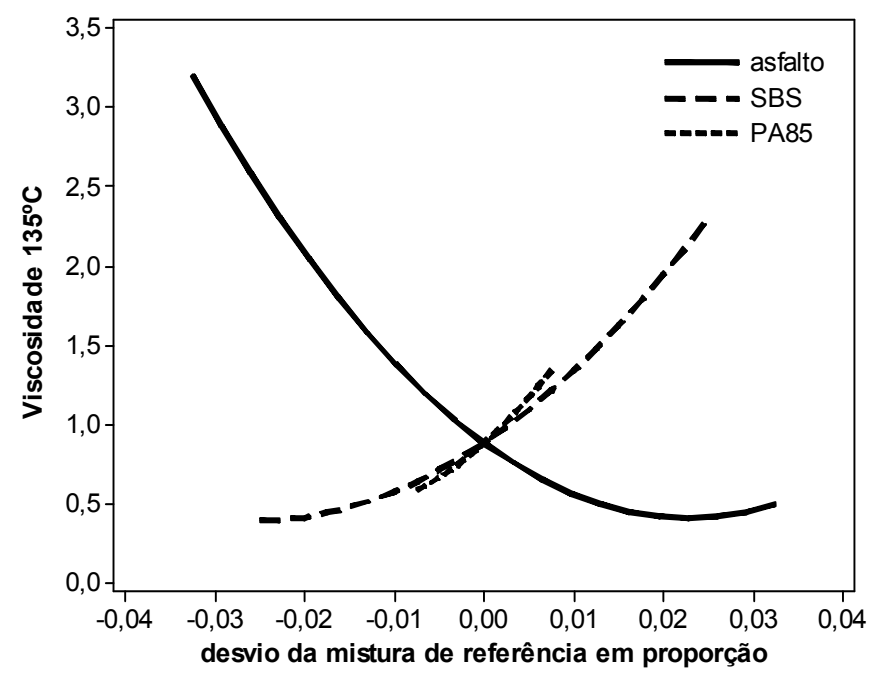

(b)

Figura 94 - Superfície de Resposta (a) e efeito de componentes (b) para a viscosidade à $135^{\circ} \mathrm{C}$ com amostras virgens das misturas com PA85 (Lubnor).

Na Figura 94 (a) tem-se o gráfico referente à superfície de resposta da viscosidade à $135^{\circ} \mathrm{C}$ na condição virgem para misturas com o ácido PA85, para o ligante asfáltico de base da Lubnor. Observa-se que os menores valores de viscosidade se encontram na região com baixas concentrações do copolímero SBS e quaisquer teores de ácido (PA85). No entanto, os maiores valores de viscosidade então na região onde se encontram misturas com altos teores dos dois modificadores. Considerando o valor de 3,0 Pa.s, da norma, como valor máximo de viscosidade para assegurar boa trabalhabilidade das misturas asfálticas, pode-se destacar que misturas com altos teores de copolímero SBS e concentrações de até 1,3\% de ácido 
(PA85) e misturas com alto teores de ácido e concentrações máximas de copolímero SBS de 4,7\% atendem essa condição. Em relação ao efeito dos componentes, Figura 94 (b), observase que os dois modificadores produzem comportamentos próximos do linear, proporcionando aumento da viscosidade. Nota-se pela inclinação da curva que o ácido proporciona um efeito um pouco mais intenso na viscosidade do que o copolímero SBS. O copolímero SBS aumenta em 0,38 Pa.s a viscosidade para cada $1 \%$ de sua adição, enquanto o ácido proporciona aumento de 0,50 Pa.s para cada $1 \%$ de PA85.

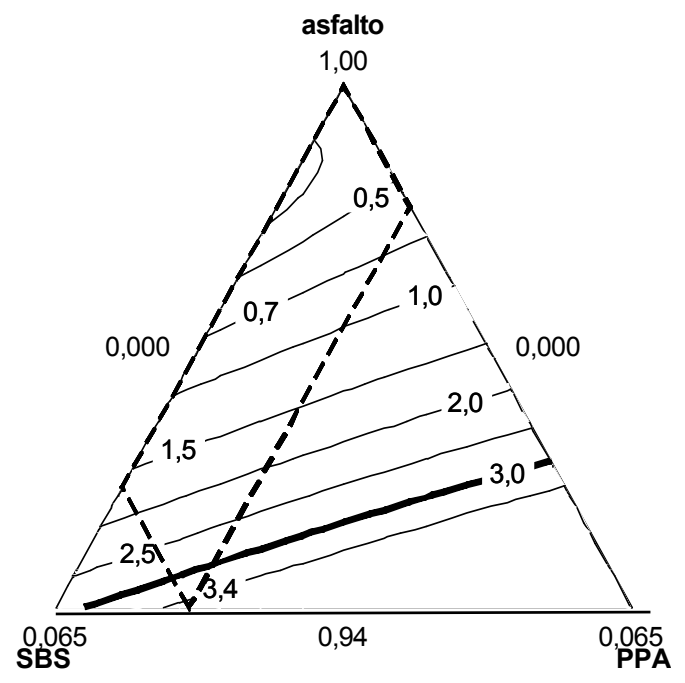

(a)

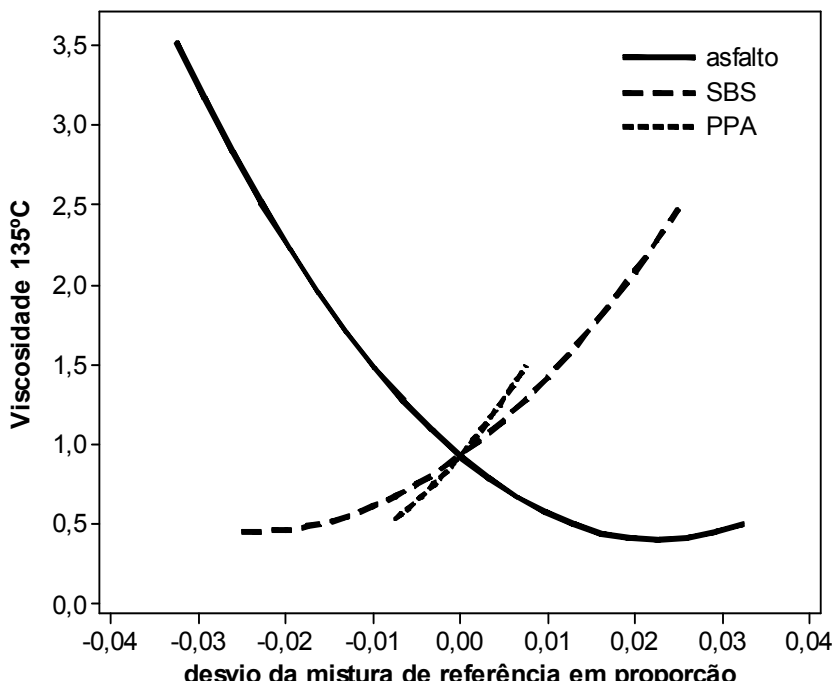

(b)

Figura 95 - Superfície de Resposta (a) e efeito de componentes (b) para a viscosidade à $135^{\circ} \mathrm{C}$ com amostras virgens das misturas com PPA (Lubnor).

Na Figura 95 (a) pode-se observar que os menores valores de viscosidade (<0,5 Pa.s) estão na região com baixas concentrações do modificador copolímero SBS e concentrações baixas e intermediárias de PPA. Já os maiores valores de viscosidade (3,50 Pa.s) se encontram na região com altas concentrações tanto do copolímero SBS quanto do ácido (PPA). Nota-se que para a temperatura em questão, $135^{\circ} \mathrm{C}$, na condição virgem, a viscosidade máxima encontrada está acima dos valores aceitáveis para bombeamento e compactação estabelecidos na norma (3,0 Pa.s). Para atender essa condição, deveriam ser consideradas misturas com concentrações máximas de $4,4 \%$ do copolímero SBS juntamente com quaisquer teores de ácido ou misturas com quaisquer teores do copolímero SBS e concentrações máximas de $1,10 \%$ de PPA.

Na Figura 95 (b) é apresentado o efeito dos componentes; nela nota-se que os dois modificadores proporcionam aumento da viscosidade, com efeito aproximadamente linear. Pode-se observar também, que o efeito do ácido é mais intenso (maior inclinação) do que o efeito do copolímero SBS. Este último proporciona um aumento de $0,40 \mathrm{~Pa}$.s para cada $1 \%$ 
do modificador copolímero SBS, enquanto o ácido aumenta em 0,66Pa.s para cada $1 \%$ de PPA adicionado.

Ao se comparar os gráficos da Figura 94 e Figura 95 notam-se comportamentos semelhantes nos valores da viscosidade para os dois ácidos utilizados. Com o aumento das proporções dos modificadores observam-se valores um pouco superiores de viscosidade para as misturas com adição do PPA, sendo que o valor máximo de viscosidade apresentado para misturas com PA85 foi de 3,16 Pa.s, enquanto para misturas com PPA foi de 3,50 Pa.s (1,10 vezes superior). Quanto ao efeito dos componentes, eles também produzem comportamentos semelhantes, aumentando a viscosidade com o aumento das suas concentrações, tanto do copolímero SBS quanto do ácido PPA.

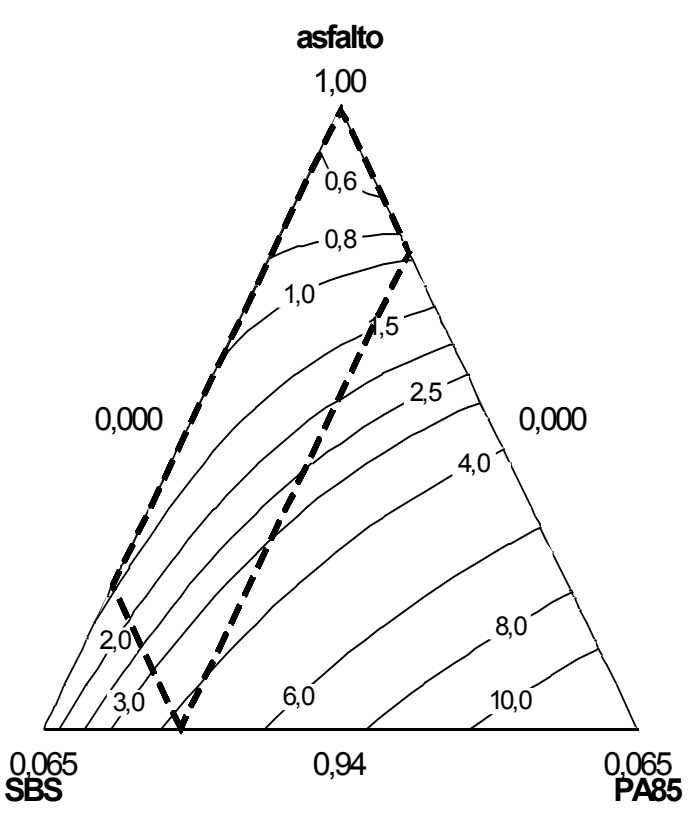

(a)

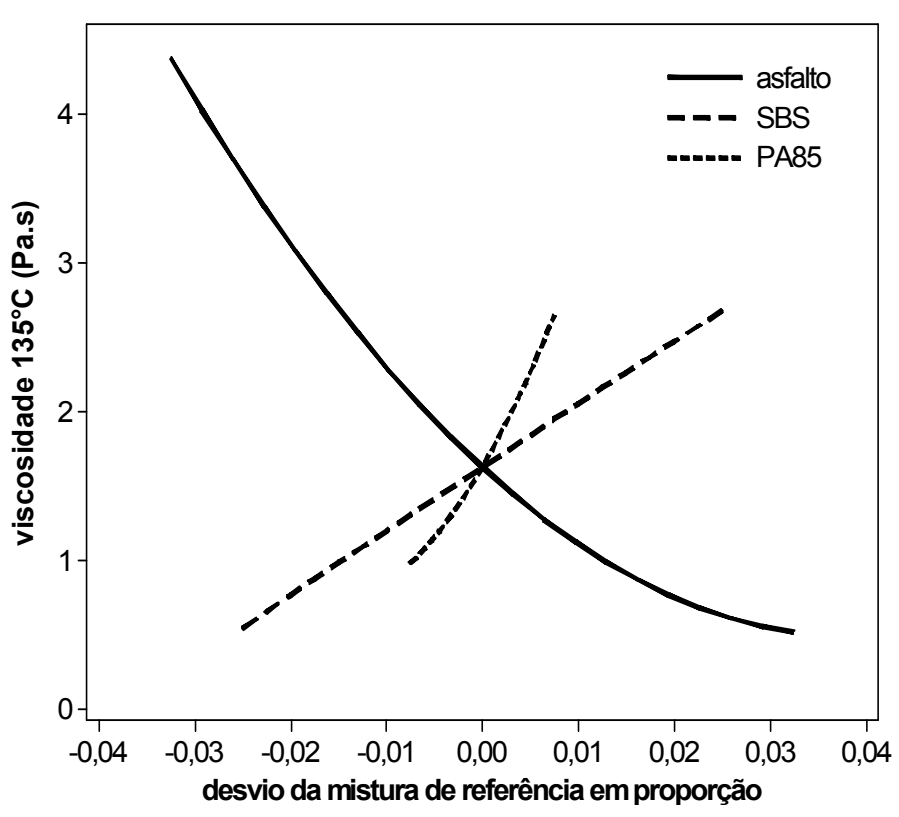

(b)

Figura 96 - Superfície de Resposta (a) e efeito de componentes (b) para a viscosidade à $135^{\circ} \mathrm{C}$ com amostras envelhecidas RTFOT das misturas com PA85(Lubnor).

No gráfico que apresenta a superfície de resposta referente à viscosidade na temperatura de $135^{\circ} \mathrm{C}$ em amostras envelhecidas em curto prazo, Figura 96 (a), pode-se observar que os menores valores estão na região de misturas com baixos teores do copolímero SBS e teores baixos a intermediários de ácido (PA85). Na condição de envelhecimento em curto prazo tem-se o valor de 4,3Pa.s como o valor máximo da viscosidade, na região com altas concentrações de modificadores. Quanto ao efeito dos componentes, observado na Figura 96 (b), os dois modificadores aumentam a viscosidade, apresentando comportamento linear. O ácido proporciona um efeito mais intenso do que o copolímero SBS, com uma variação média da viscosidade próxima a 1,12 Pa.s para cada 1\% desse modificador, enquanto o copolímero SBS aumenta em 0,43 Pa.s/1\%. 
Comparando os valores de viscosidade a $135^{\circ} \mathrm{C}$ das amostras virgens (Figura 94) com as das amostras envelhecidas em curto prazo (Figura 96), observa-se que o valor máximo de viscosidade aumentou de 3,16 Pa.s (condição virgem) para 4,3 Pa.s (condição envelhecida), aumento de 1,36 vezes do valor da propriedade após envelhecimento em curto prazo. Já para o efeito dos modificadores, em relação a variação da viscosidade, o copolímero SBS produziu aumento de 1,13 vezes (0,38 Pa.s/1\% para 0,43 Pa.s/1\%) e o ácido PA85 de 2,95 vezes $(0,38$ Pa.s/1\% para 1,12 Pa.s/1\%).

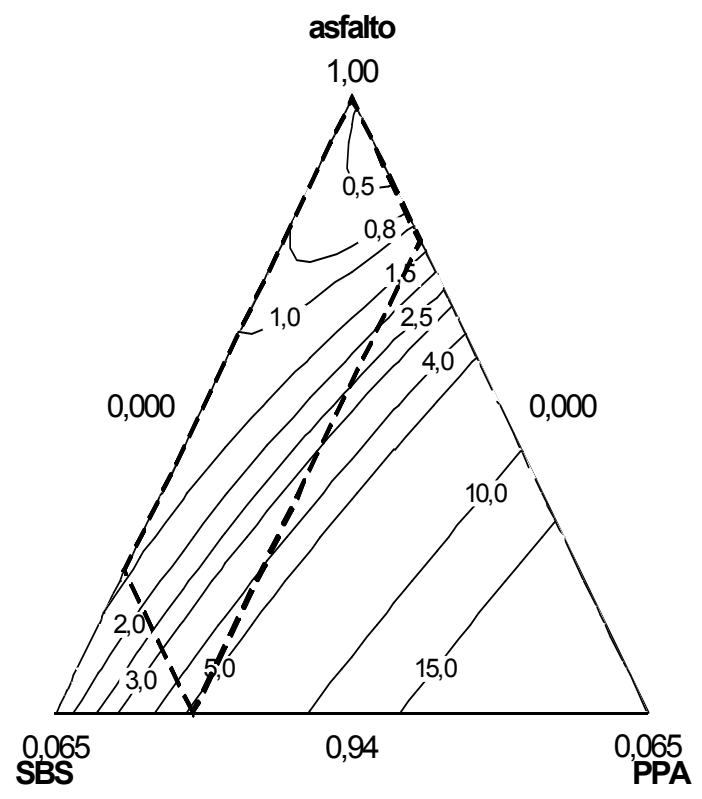

(a)

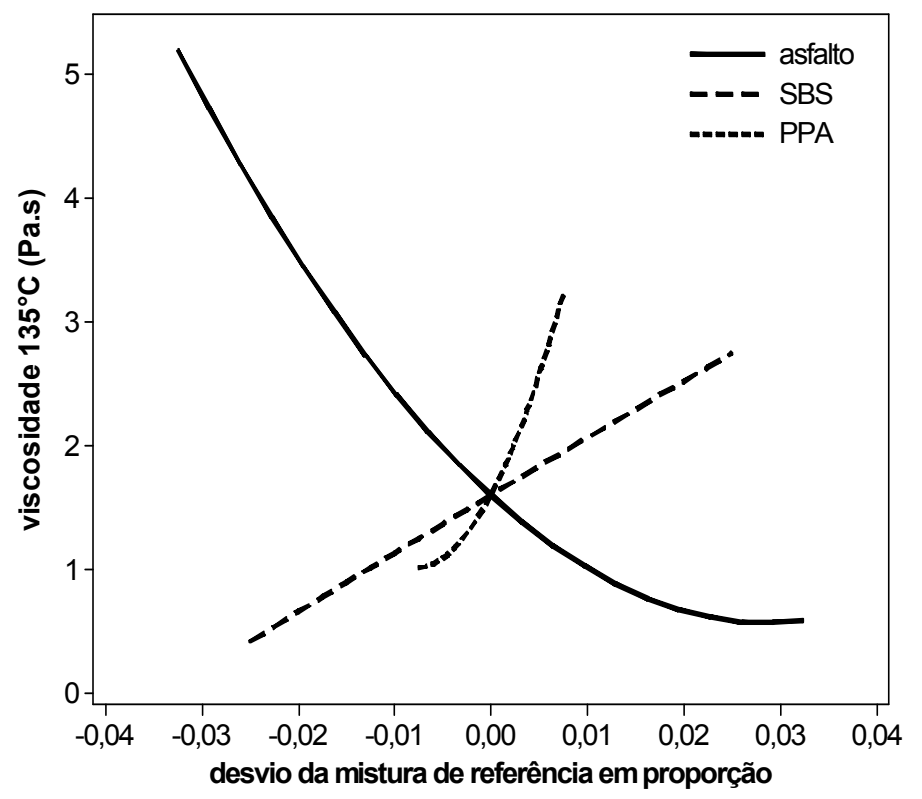

(b)

Figura 97 - Superfície de Resposta (a) e efeito de componentes (b) para a viscosidade à $135^{\circ} \mathrm{C}$ com amostras envelhecidas RTFOT das misturas com PPA (Lubnor).

Na Figura 97 (a) pode-se observar que os maiores valores de viscosidade estão na região com baixos teores do copolímero SBS e concentrações baixas a intermediárias de ácido (PPA). Na condição envelhecida em curto prazo para a região estudada foram encontrados valores máximos de viscosidade de 5,2 Pa.s. Em relação ao efeito dos componentes, apresentado na Figura 97 (b), observa-se que os dois modificadores causam aumento da viscosidade, apresentando efeito praticamente linear. A variação média da viscosidade provocada pelo aumento de $1 \%$ na proporção de SBS é de 0,47 Pa.s, e para o ácido é próxima a 1,47 Pa.s/1\%, o que indica que o efeito do PPA é mais intenso do que o copolímero SBS.

Comparando as viscosidades das amostras virgens (Figura 95) e das amostras envelhecidas em curto prazo (Figura 97) nota-se um aumento de 1,47 vezes (3,50 Pa.s virgem para 5,2 Pa.s - envelhecido RTFOT). Em relação à variação média da propriedade devida ao aumento de $1 \%$ do modificador, o copolímero SBS aumentou em 1,17 vezes $(0,40$ 
Pa.s/ 1\% (virgem) para 0,47 Pa.s/1\% (RTFOT)), enquanto o PPA produziu aumento de 2,23 vezes (de 0,66 Pa.s/1\% (virgem) para 1,47 Pa.s/1\% (RTFOT)).

Em relação à viscosidade na temperatura de $135^{\circ} \mathrm{C}$ nas condições virgem e envelhecida em curto prazo, comparando as misturas com adição de PA85 e PPA, observamse comportamentos semelhantes das misturas no gráfico de superfície de resposta, assim como para os modificadores quando avaliados no gráfico de efeito dos componentes. No entanto, notam-se para ambas as condições, virgem ou envelhecida em curto prazo, valores de viscosidade um pouco superiores para as misturas com adição de PPA e também variações médias da viscosidade devido aumento de $1 \%$ dos modificadores um pouco maiores tanto para o copolímero SBS, quanto para o ácido PPA, em relação às misturas com adição de PA85. Após envelhecimento das amostras observou-se, tanto para os valores da viscosidade, quanto para as variações médias do aumento de $1 \%$ dos modificadores no efeito dessa propriedade, aumentos maiores para as misturas com PPA, o que aponta que essas misturas foram mais afetadas pelo efeito do envelhecimento em curto prazo.

Comparando-se os dois tipos de ligante asfálticos de base, para esta temperatura $\left(135^{\circ} \mathrm{C}\right)$, observam-se comportamentos semelhantes, tanto para as amostras virgens quanto paras as envelhecidas, tanto nos valores de viscosidade quanto nos efeitos dos componentes. No entanto, pode-se verificar que o efeito dos modificadores é mais expressivo no ligante asfáltico de base da Replan, pois as misturas produzidas com este ligante asfáltico de base apresentaram maiores valores de viscosidade e efeitos de ambos os componentes.

$\mathrm{Na}$ Tabela 84 são apresentados os valores máximos de viscosidade, nas condições virgem e RTFOT, para as misturas produzidas com o ligante asfáltico de base da Replan, em todas as temperaturas estudadas. Nela pode-se observar, que independente do condicionamento e da temperatura, os valores encontrados para as misturas com adição do PPA são maiores que os valores encontrados para as misturas com adição de PA85.

Tabela 84 - Valores máximos de viscosidade (Pa.s) nas condições virgem e RTFOT (Replan).

\begin{tabular}{c|cc|cc}
\hline \multirow{2}{*}{ Temperatura } & \multicolumn{2}{|c|}{ Virgem } & \multicolumn{2}{c}{ RTFOT } \\
\cline { 2 - 5 } & PA85 & PPA & PA85 & PPA \\
\hline 135 & 3,43 & 5,32 & 8,35 & 13,08 \\
143 & 2,30 & 3,07 & 5,26 & 7,25 \\
155 & 1,57 & 2,10 & 3,35 & 4,78 \\
163 & 0,88 & 1,22 & 1,93 & 2,51 \\
177 & 0,53 & 0,71 & 1,07 & 1,38 \\
\hline
\end{tabular}

$\mathrm{Na}$ Tabela 85 são apresentados os valores máximos de viscosidade, nas condições virgem e RTFOT, para as misturas produzidas com o ligante asfáltico de base da Lubnor, em todas as temperaturas estudadas. 
Tabela 85 - Valores máximos de viscosidade (Pa.s) nas condições virgem e RTFOT (Lubnor).

\begin{tabular}{c|cc|cc}
\hline \multirow{2}{*}{ Temperatura } & \multicolumn{2}{|c|}{ Virgem } & \multicolumn{2}{c}{ RTFOT } \\
& PA85 & PPA & PA85 & PPA \\
\hline 135 & 3,16 & 3,50 & 4,27 & 5,16 \\
143 & 1,62 & 1,90 & 2,51 & 3,01 \\
155 & 1,12 & 1,35 & 1,83 & 2,18 \\
163 & 0,71 & 0,83 & 1,10 & 1,27 \\
177 & 0,41 & 0,48 & 0,63 & 0,71 \\
\hline
\end{tabular}

Assim como para o ligante asfáltico produzidos com o ligante asfáltico da Replan, independente do condicionamento e da temperatura, os valores encontrados para as misturas com o ligante asfáltico da Lubnor com adição do PPA são superiores aos valores encontrados para as misturas com adição de PA85, porém com valores mais próximos. As variações médias da viscosidade para adição e $1 \%$ de cada um dos modificadores, para os ligantes asfálticos de base da Replan e da Lubnor, estão apresentados nas Tabela 86 e Tabela 87, respectivamente.

Tabela 86 - Variação média de Viscosidade (Pa.s) para 1\% de aumento na proporção dos modificadores (Replan).

\begin{tabular}{c|c|cc|cc}
\hline Condição & Temperatura $\left({ }^{\circ} \mathbf{C}\right)$ & PA85 & SBS & PPA & SBS \\
\hline \multirow{5}{*}{ Virgem } & 135 & 0,73 & 0,41 & 0,94 & 0,58 \\
& 143 & 0,54 & 0,21 & 0,81 & 0,32 \\
& 155 & 0,35 & 0,18 & 0,52 & 0,23 \\
& 163 & 0,18 & 0,11 & 0,29 & 0,13 \\
& 177 & 0,11 & 0,06 & 0,16 & 0,08 \\
\hline \multirow{5}{*}{ RTFOT } & 135 & 2,55 & 0,82 & 4,14 & 1,25 \\
& 143 & 1,53 & 0,51 & 2,21 & 0,70 \\
& 155 & 0,95 & 0,34 & 1,51 & 0,45 \\
& 163 & 0,51 & 0,20 & 0,79 & 0,24 \\
& 177 & 0,28 & 0,11 & 0,39 & 0,13 \\
\hline
\end{tabular}

Pode ser observado que, independente do ligante asfáltico de base e dos modificadores utilizados, o efeito dos componentes foi aumentar o valor da viscosidade. Com o aumento da temperatura, assim como a viscosidade, o efeito de todos os componentes diminuiu. A mesma comparação pode ser feita para as variações médias para a viscosidade na condição RTFOT, ou seja, assim como os valores aumentam em relação à condição virgem, os efeitos corroboram com esse incremento, sendo superiores às variações médias apresentadas para a condição virgem. E por fim, assim como os valores de viscosidade, a variação média de viscosidade para cada $1 \%$ de aumento nas proporções dos modificadores foram maiores para as misturas produzidas com o ligante asfáltico de base da Replan. 
Tabela 87 - Variação média de Viscosidade (Pa.s) para 1\% de aumento na proporção dos modificadores (Lubnor).

\begin{tabular}{l|c|cc|cc}
\hline Condição & Temperatura & PA85 & SBS & PPA & SBS \\
\hline \multirow{5}{*}{ Virgem } & 135 & 0,50 & 0,38 & 0,66 & 0,40 \\
& 143 & 0,28 & 0,19 & 0,39 & 0,21 \\
& 155 & 0,19 & 0,13 & 0,28 & 0,15 \\
& 163 & 0,11 & 0,08 & 0,15 & 0,07 \\
& 177 & 0,06 & 0,05 & 0,09 & 0,06 \\
\hline \multirow{5}{*}{ RTFOT } & 135 & 1,11 & 0,43 & 1,47 & 0,47 \\
& 143 & 0,62 & 0,25 & 0,81 & 0,28 \\
& 155 & 0,45 & 0,18 & 0,57 & 0,21 \\
& 163 & 0,25 & 0,12 & 0,32 & 0,13 \\
& 177 & 0,14 & 0,07 & 0,17 & 0,02 \\
\hline
\end{tabular}

$\mathrm{Na}$ Tabela 88 estão apresentados os modelos de regressão da viscosidade obtidos para cada ligante modificado (Replan e Lubnor) para as amostras com a adição de PA85 e PPA.

Tabela 88 - Modelos de regressão referente à propriedade Viscosidade.

\begin{tabular}{|c|c|c|c|c|}
\hline $\begin{array}{c}\text { Ligante } \\
\text { Asfáltico } \\
\text { de base }\end{array}$ & Ácido & Propriedade & Modelo de Regressão & $\begin{array}{l}R^{2} \\
(\%)\end{array}$ \\
\hline \multirow[t]{20}{*}{ Replan } & \multirow[t]{10}{*}{ PA85 } & Viscosidade $135^{\circ} \mathrm{C}$ Virgem & $23 x_{2}+2541 x_{3}-2567 x_{1} x_{3}$ & 95,5 \\
\hline & & Viscosidade $135^{\circ} \mathrm{C}$ RTFOT & $1 x_{1}+24 x_{2}+7889 x_{3}-7951 x_{1} x_{3}$ & 95,4 \\
\hline & & Viscosidade $143^{\circ} \mathrm{C}$ Virgem & $12 x_{2}+1861 x_{3}-1883 x_{1} x_{3}$ & 94,1 \\
\hline & & Viscosidade $143^{\circ} \mathrm{C}$ RTFOT & $16 x_{2}+5048 x_{3}-5096 x_{1} x_{3}$ & 96,5 \\
\hline & & Viscosidade $155^{\circ} \mathrm{C}$ Virgem & $0,13 x_{1}+9,60 x_{2}+4,72 x_{3}-1223 x_{2} x_{3}$ & 95,4 \\
\hline & & Viscosidade $155^{\circ} \mathrm{C}$ RTFOT & $13 x_{2}+2947 x_{3}-2969 x_{1} x_{3}$ & 97,2 \\
\hline & & Viscosidade $163^{\circ} \mathrm{C}$ Virgem & $0,08 x_{1}+6,06 x_{2}+2,66 x_{3}+635 x_{2} x_{3}$ & 94,2 \\
\hline & & Viscosidade $163^{\circ} \mathrm{C}$ RTFOT & $7 x_{2}+1737 x_{3}-1755 x_{1} x_{3}$ & 96,8 \\
\hline & & Viscosidade $177^{\circ} \mathrm{C}$ Virgem & $0,05 x_{1}+3,65 x_{2}+1,29 x_{3}+381 x_{2} x_{3}$ & 92,5 \\
\hline & & Viscosidade $177^{\circ} \mathrm{C}$ RTFOT & $0,1 x_{1}+4,1 x_{2}+969 x_{3}-979 x_{1} x_{3}$ & 97,0 \\
\hline & \multirow[t]{10}{*}{ PPA } & Viscosidade $135^{\circ} \mathrm{C}$ Virgem & $22 x_{2}+5026 x_{3}-5090 x_{1} x_{3}$ & 92,6 \\
\hline & & Viscosidade $135^{\circ} \mathrm{C}$ RTFOT & $1 x_{1}+18 x_{2}+14596 x_{3}-14767 x_{1} x_{3}$ & 93,3 \\
\hline & & Viscosidade $143^{\circ} \mathrm{C}$ Virgem & $11 x_{2}+2898 x_{3}-2934 x_{1} x_{3}$ & 93,2 \\
\hline & & Viscosidade $143^{\circ} \mathrm{C}$ RTFOT & $14 x_{2+} 7704 x_{3}-7791 x_{1} x_{3}$ & 94,4 \\
\hline & & Viscosidade $155^{\circ} \mathrm{C}$ Virgem & $9 x_{2}+1913 x_{3}-1936 x_{1} x_{3}$ & 93,9 \\
\hline & & Viscosidade $155^{\circ} \mathrm{C}$ RTFOT & $12 x_{2}+4446 x_{3}-4472 x_{1} x_{3}$ & 97,8 \\
\hline & & Viscosidade $163^{\circ} \mathrm{C}$ Virgem & $6 x_{2}+1049 x_{3}-1062 x_{1} x_{3}$ & 93,2 \\
\hline & & Viscosidade $163^{\circ} \mathrm{C}$ RTFOT & $7 x_{2}+2398 x_{3}-2415 x_{1} x_{3}$ & 97,9 \\
\hline & & Viscosidade $177^{\circ} \mathrm{C}$ Virgem & $0,1 x_{1}+3,6 x_{2}+617 x_{3}-626 x_{1} x_{3}$ & 92,1 \\
\hline & & Viscosidade $177^{\circ} \mathrm{C}$ RTFOT & $4 x_{2}+1240 x_{3}-1249 x_{1} x_{3}$ & 97,9 \\
\hline \multirow[t]{8}{*}{ Lubnor } & \multirow[t]{8}{*}{ PA85 } & Viscosidade $135^{\circ} \mathrm{C}$ Virgem & $743 x_{2}+1426 x_{3}-758 x_{1} x_{2}-1451 x_{1} x_{3}$ & 97,6 \\
\hline & & Viscosidade $135^{\circ} \mathrm{C}$ RTFOT & $x_{1}+19 x_{2}+3342 x_{3}-3364 x_{1} x_{3}$ & 98,2 \\
\hline & & Viscosidade $143^{\circ} \mathrm{C}$ Virgem & $11 x_{2}+1039 x_{3}-1052 x_{1} x_{3}$ & 95,4 \\
\hline & & Viscosidade $143^{\circ} \mathrm{C}$ RTFOT & $13 x_{2}+1679 x_{3}-1683 x_{1} x_{3}$ & 99,1 \\
\hline & & Viscosidade $155^{\circ} \mathrm{C}$ Virgem & $0,2 x_{1}+7,7 x_{2}+686,1 x_{3}-694,3 x_{1} x_{3}$ & 97,2 \\
\hline & & Viscosidade $155^{\circ} \mathrm{C}$ RTFOT & $10 x_{2}+1059 x_{3}-1259 x_{1} x_{3}$ & 98,7 \\
\hline & & Viscosidade $163^{\circ} \mathrm{C}$ Virgem & $0,1 x_{1}+5,2 x_{2}+427,9 x_{3}-433,5 x_{1} x_{3}$ & 97,3 \\
\hline & & Viscosidade $163^{\circ} \mathrm{C}$ RTFOT & $\begin{aligned} 0,12 x_{1}+6,052 x_{2} & +6,316 x_{3} \\
& +802,317 x_{2} x_{3}\end{aligned}$ & 98,4 \\
\hline
\end{tabular}




\begin{tabular}{cccc}
\hline & Viscosidade $177^{\circ} \mathrm{C}$ Virgem & $0,1 x_{1}+3,3 x_{2}+229,3 x_{3}-231,9 x_{1} x_{3}$ & 97,9 \\
& Viscosidade $177^{\circ} \mathrm{C}$ RTFOT & $0,1 x_{1}+3,6 x_{2}+422 x_{3}-424,9 x_{1} x_{3}$ & 98,5 \\
\hline PPA & Viscosidade $135^{\circ} \mathrm{C}$ Virgem & $860 x_{2}+1507 x_{3}-881 x_{1} x_{2}-1525 x_{1} x_{3}$ & 97,3 \\
& Viscosidade $135^{\circ} \mathrm{C}$ RTFOT & $x_{1}+18 x_{2}+9191 x_{3}-9284 x_{1} x_{3}$ & 98,4 \\
& Viscosidade $143^{\circ} \mathrm{C}$ Virgem & $-5168 x_{2} x_{3}$ & 94,7 \\
& Viscosidade $143^{\circ} \mathrm{C}$ RTFOT & $11 x_{2}+4485 x_{3}-4531 x_{1} x_{3}-2096 x_{2} x_{3}$ & 97,7 \\
& Viscosidade $155^{\circ} \mathrm{C}$ Virgem & $7 x_{2}+1022 x_{3}-1035 x_{1} x_{3}$ & 96,5 \\
& Viscosidade $155^{\circ} \mathrm{C}$ RTFOT & $8 x_{2}+1844 x_{3}-1860 x_{1} x_{3}$ & 97,1 \\
& Viscosidade $163^{\circ} \mathrm{C}$ Virgem & $0,1 x_{1}+4,9 x_{2}+615,2 x_{3}-625 x_{1} x_{3}$ & 95,9 \\
& Viscosidade $163^{\circ} \mathrm{C}$ RTFOT & $5 x_{2}+1075 x_{3}-1086 x_{1} x_{3}$ & 96,8 \\
& Viscosidade $177^{\circ} \mathrm{C}$ Virgem & $0,1 x_{1}+3,0 x_{2}+331,4 x_{3}-336 x_{1} x_{3}$ & 96,7 \\
& Viscosidade $177^{\circ} \mathrm{C}$ RTFOT & $0,1 x_{1}+3,2 x_{2}+576,5 x_{3}-582,5 x_{1} x_{3}$ & 97,2 \\
\hline
\end{tabular}

$\mathrm{x}_{1}=$ asfalto; $\mathrm{x}_{2}$ : SBS e $\mathrm{x}_{3}$ : ácido em porcentagem.

\subsubsection{Balanço de Massa}

Uma vez que todas as misturas estudadas no presente trabalho atenderem a especificação que limita a perda de massa em $0,5 \%$, optou-se por apresentar e analisar nesta subseção a variação média da perda de massa para $1 \%$ de aumento nas proporções dos modificadores obtidas no gráfico de efeito dos componentes, apresentadas na Tabela 89. Os gráficos de superfície de respostas e efeitos dos componentes estão apresentados no Apêndice $F$.

$\mathrm{Na}$ Tabela 89 pode-se observar que os efeitos dos modificadores nesta propriedade são antagônicos, independente do ligante asfáltico de base utilizado. Os ácidos apresentam tendência de aumentar a perda de massa, enquanto o copolímero SBS tende a diminuí-la. Nota-se que para o ligante asfáltico proveniente da Lubnor, o efeito do copolímero SBS é mais intenso do que no ligante asfáltico da Replan. O efeito dos ácidos é um pouco mais expressivo para o ligante asfáltico de base da Replan.

Tabela 89 - Variação média da perda de massa para 1\% de aumento na proporção dos modificadores

\begin{tabular}{c|cc|cc}
\hline Ligante Asfáltico de Base & PA85 & SBS & PPA & SBS \\
\hline Replan & $+0,090$ & $-0,008$ & $+0,080$ & $-0,006$ \\
Lubnor & $+0,070$ & $-0,030$ & $+0,060$ & $-0,030$ \\
\hline
\end{tabular}

$\mathrm{Na}$ Tabela 90 estão apresentados os modelos de regressão da perda de massa obtidos para cada ligante modificado (Replan e Lubnor) para as amostras com a adição de PA85 e PPA. 
Tabela 90 - Modelos de regressão da Perda de Massa.

\begin{tabular}{lccc}
\hline Ligante Asfáltico de base & Ácidos & Modelo de Regressão & $\mathbf{R}^{\mathbf{2}}(\%)$ \\
\hline Replan & PA85 & $0,131 \mathrm{x}_{1}-0,899 \mathrm{x}_{2}+10,370 \mathrm{x}_{3}$ & 79,9 \\
& PPA & $0,118 \mathrm{x}_{1}-0,463 \mathrm{x}_{2}+8,793 \mathrm{x}_{3}$ & 78,9 \\
Lubnor & PA85 & $-0,026 \mathrm{x}_{1}+1,688 \mathrm{x}_{2}-8,873 \mathrm{x}_{3}$ & 83,3 \\
& PPA & $-0,007 \mathrm{x}_{1}+0,606 \mathrm{x}_{2}-6,572 \mathrm{x}_{3}$ & 78,9 \\
\hline
\end{tabular}

$\mathrm{X}_{1}=$ asfalto; $\mathrm{x}_{2}$ : SBS e $\mathrm{x}_{3}$ : ácido em porcentagem.

\subsubsection{Estabilidade à Estocagem}

O gráfico referente à superfície de resposta da estabilidade à estocagem para as misturas com o ácido PA85, para o ligante asfáltico da Replan, está apresentado na Figura 98 (a). Pode-se observar que os menores valores estão na região superior do simplex, onde se encontram as misturas com baixos teores do copolímero SBS e quaisquer teores de PA85. Considerando o limite máximo de $5^{\circ} \mathrm{C}$ para a diferença entre os pontos de amolecimento do topo e fundo das misturas, pode ser observado que misturas com adição somente com SBS atendem esse critério para teores de até $0,8 \%$ do copolímero SBS, enquanto para as misturas com adição dos dois modificadores, o critério é atendido para misturas até 2,5\% SBS com altos teores de ácido.
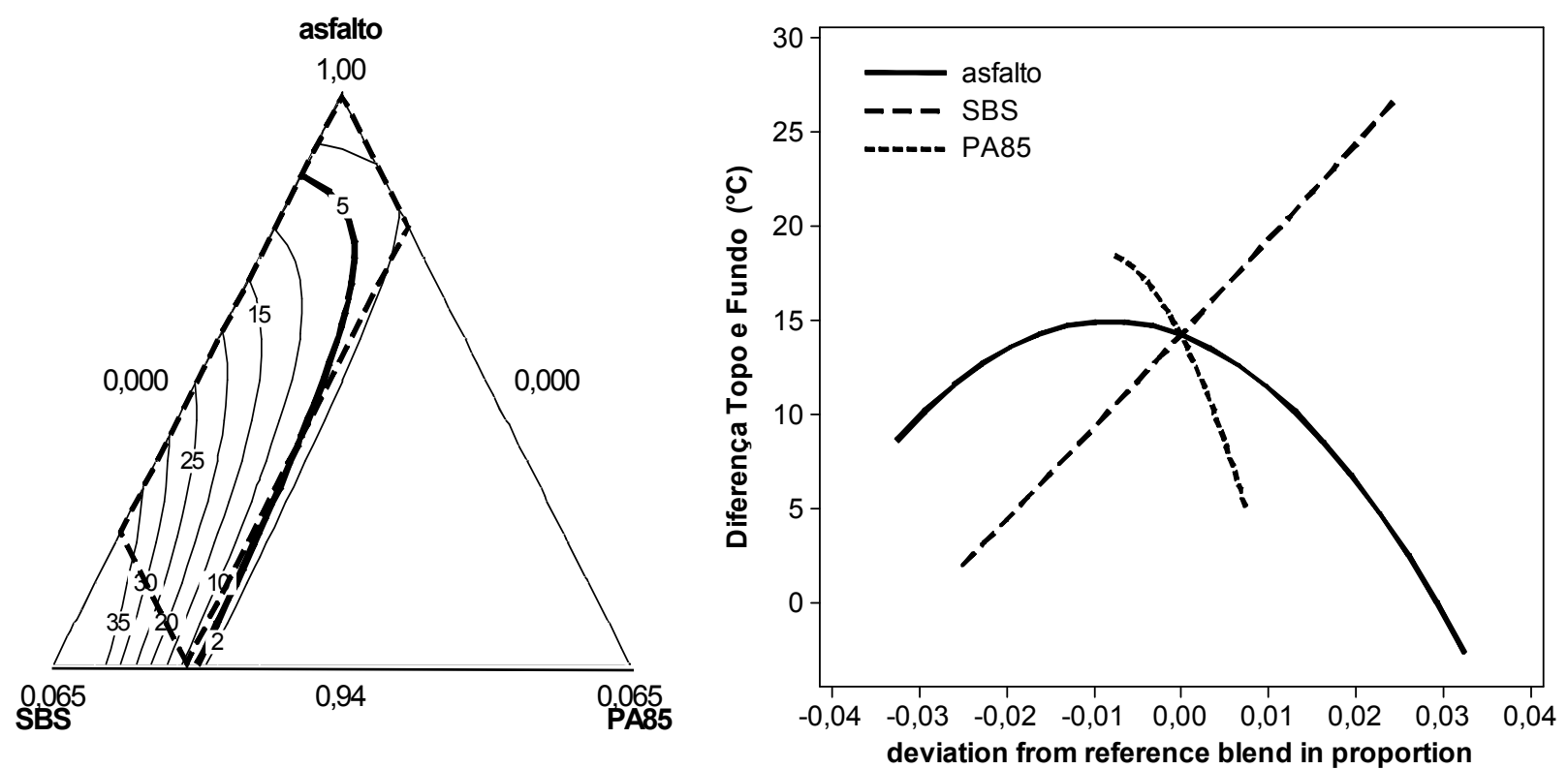
(a)

(b)

Figura 98 - Superfície de Resposta (a) e efeito de componentes (b) da diferença dos pontos de amolecimento entre topo e fundo das misturas com PA85 (Replan).

Em relação ao efeito dos componentes, apresentado na Figura 98 (b), observa-se que os efeitos dos componentes são antagônicos, sendo que o copolímero SBS aumenta a diferença entre os pontos de amolecimento do topo e fundo, prejudicando a estabilidade à estocagem, enquanto o PA85 diminui essa diferença e contribui para melhorar a estabilidade à estocagem. A variação média da diferença dos pontos de amolecimento entre topo e fundo provocada pelo aumento de $1 \%$ na proporção do copolímero SBS é de $4,98{ }^{\circ} \mathrm{C}$ e para o ácido é próxima a $8,93{ }^{\circ} \mathrm{C} / 1 \%$, o que indica que o efeito do PA85 é mais intenso do que o do copolímero SBS, na tendência de reduzir a diferença dos pontos de amolecimento entre topo e fundo, favorecendo a estabilidade à estocagem.

O gráfico referente à superfície de resposta da estabilidade à estocagem para misturas com o ácido PPA, para o ligante asfáltico da Replan, está apresentado na Figura 99 (a). Assim como para as misturas com PA85, os menores valores estão na região superior do simplex, onde se encontram as misturas com baixos teores do copolímero SBS e quaisquer teores de PPA.

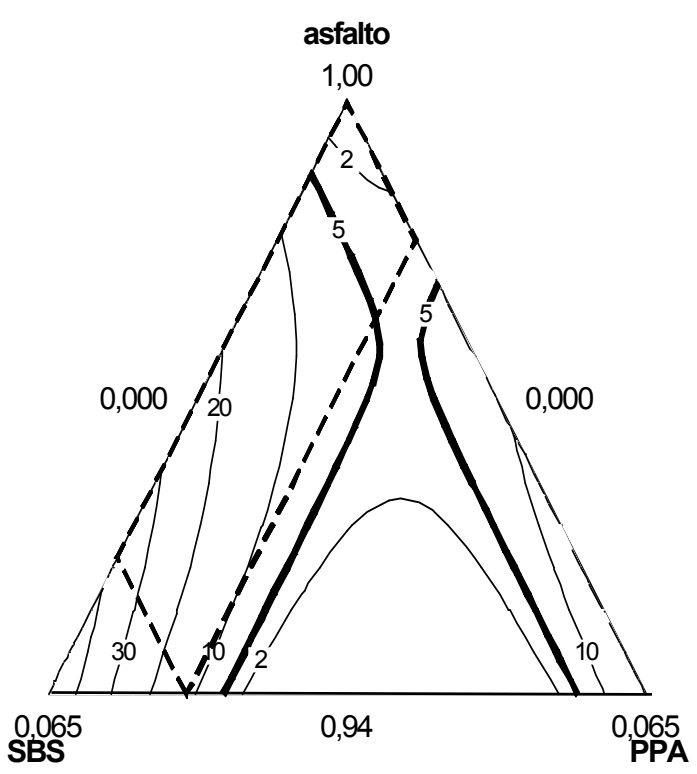

(a)

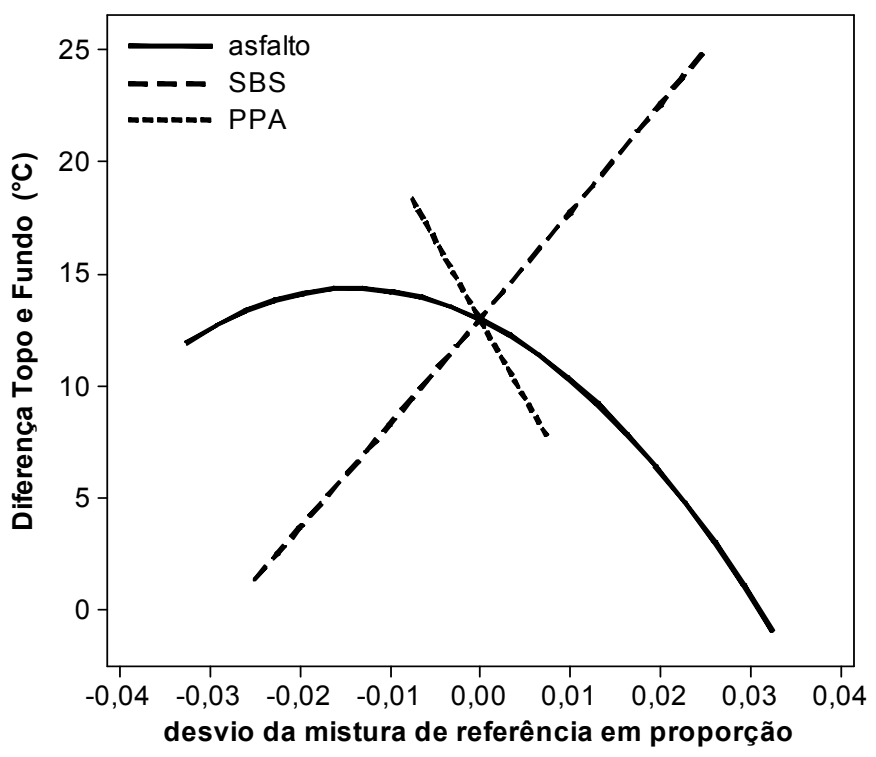

(b)

Figura 99 - Superfície de Resposta (a) e efeito de componentes (b) da diferença dos pontos de amolecimento entre topo e fundo das misturas com PPA (Replan).

Os maiores valores estão na região esquerda inferior, onde estão as misturas com altos teores de SBS, o que indica que a adição do ácido proporciona uma melhora na estabilidade à estocagem das misturas. Considerando-se o limite máximo de $5^{\circ} \mathrm{C}$ para a 
diferença entre os pontos de amolecimento do topo e fundo das misturas, pode ser observado que misturas com adição somente com SBS atendem esse critério para teores de até $0,8 \%$ do copolímero SBS, enquanto para as misturas com adição dos dois modificadores, o critério é atendido para misturas até $0,8 \%$ SBS com altos teores de ácido.

Quanto ao efeito dos componentes, apresentado na Figura 99 (b), tem-se que os efeitos são antagônicos, sendo que o copolímero SBS aumenta a diferença entre os pontos de amolecimento do topo e fundo, prejudicando a estabilidade à estocagem, enquanto o PA85 diminui essa diferença e melhorando a estabilidade à estocagem. A variação média da diferença dos pontos de amolecimento entre topo e fundo provocada pelo aumento de $1 \%$ na proporção do copolímero SBS é de $4,12{ }^{\circ} \mathrm{C}$; já para o ácido é próxima a $7,08{ }^{\circ} \mathrm{C} / 1 \%$, o que expressa que o efeito do PA85 é mais intenso do que o do copolímero SBS na tendência de reduzir a diferença dos pontos de amolecimento entre topo e fundo, favorecendo a estabilidade à estocagem. Ao se comparar os gráficos da Figura 98 e da Figura 99 nota-se que o ácido PA85 é mais efetivo para melhorar a estabilidade à estocagem das misturas com o copolímero SBS estudadas quando comparado com o efeito do ácido PPA.

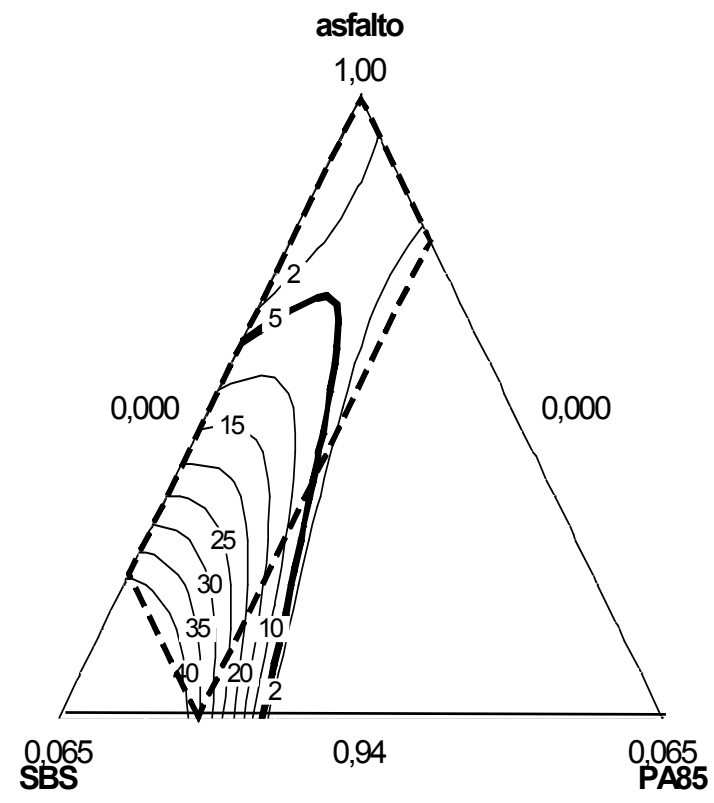

(a)

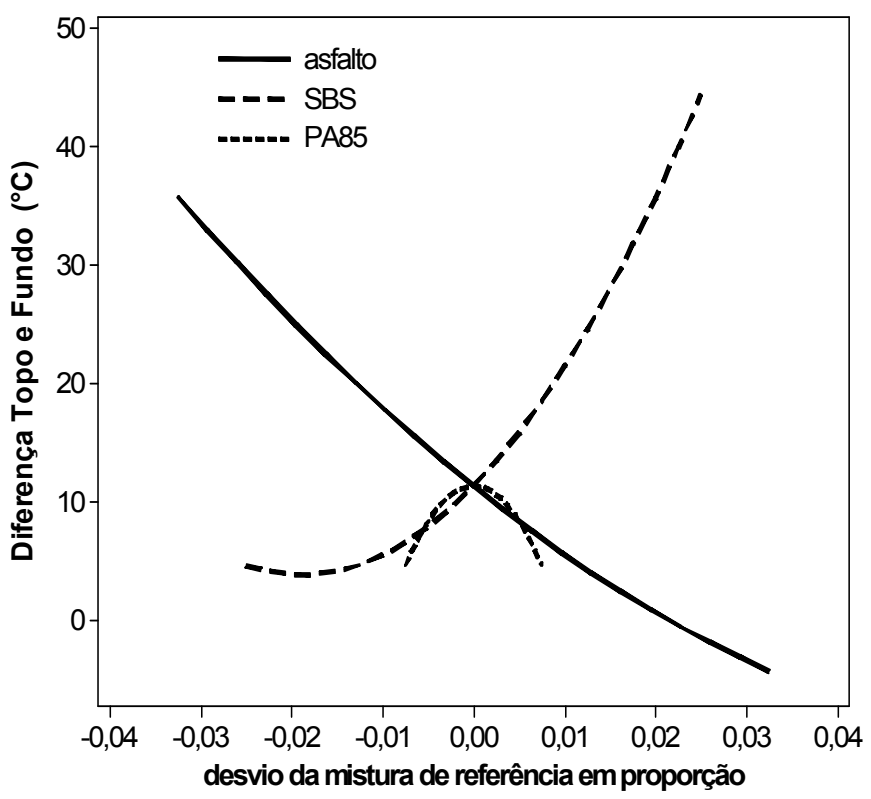

(b)

Figura 100 - Superfície de Resposta (a) e efeito de componentes (b) da diferença dos pontos de amolecimento entre topo e fundo das misturas com PA85 (Lubnor).

Na Figura 100 (a) tem-se o gráfico referente à superfície de resposta da estabilidade à estocagem para misturas com o ácido PA85, para o ligante asfáltico da Lubnor. Nela pode ser observado que os menores valores estão na região superior do simplex, onde encontramse as misturas com baixos teores do copolímero SBS e quaisquer teores de ácido. Os maiores valores estão na região esquerda inferior, onde estão as misturas com altos teores de SBS e 
ácido. Considerando o limite máximo de $5^{\circ} \mathrm{C}$ para a diferença entre os pontos de amolecimento do topo e fundo das misturas, pode ser observado que as misturas com adição somente com SBS atendem esse critério para teores de até 2,5\% do copolímero SBS, enquanto que para as misturas com adição dos dois modificadores, o critério é atendido para misturas até $2,6 \%$ SBS com altos teores de ácido.

O efeito dos componentes, apresentado na Figura 100 (b), aponta que o PA85 tem efeito parabólico com ponto de máximo em $0,75 \%$, ou seja, aumenta a diferença entre os pontos de amolecimento do topo e fundo até a proporção intermediaria $(0,75 \%)$ e a diminui a partir de teores maiores. O copolímero SBS apresenta um efeito próximo do linear, sendo que a variação média da diferença dos pontos de amolecimento entre topo e fundo provocada pelo aumento de $1 \%$ na proporção deste modificador é de $8,08^{\circ} \mathrm{C}$.

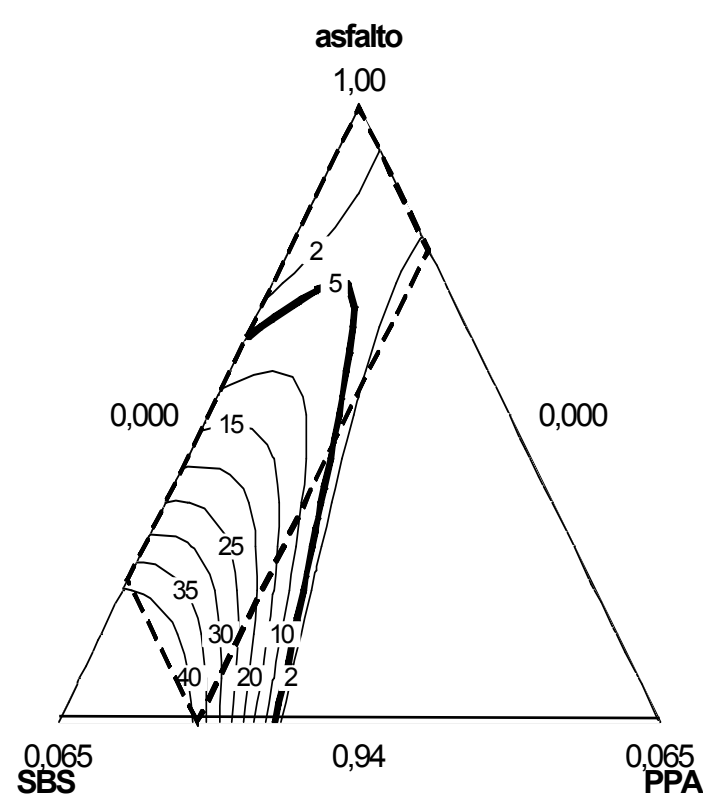

(a)

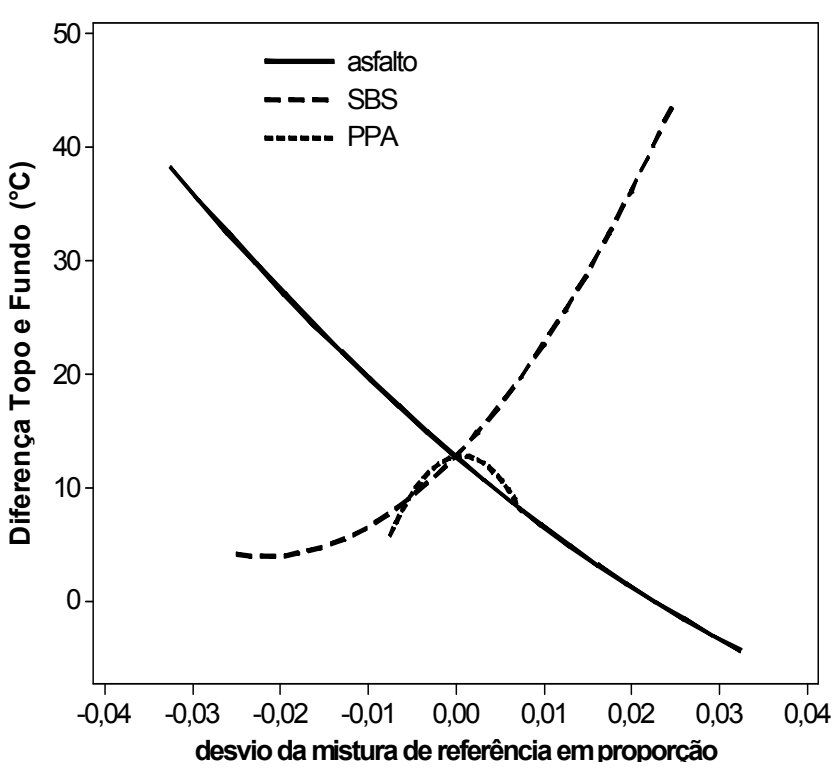

(b)

Figura 101 - Superfície de Resposta (a) e efeito de componentes (b) da diferença dos pontos de amolecimento entre topo e fundo das misturas com PPA (Lubnor).

O gráfico referente à superfície de resposta da estabilidade à estocagem para misturas com o ácido PPA, para o ligante asfáltico da Replan, está apresentado na Figura 101(a). Assim como para as misturas com PA85, os menores valores estão na região superior do simplex, onde se encontram as misturas com baixos teores do copolímero SBS e quaisquer teores de PPA. Os maiores valores estão na região inferior, onde estão as misturas com altos teores de SBS e PPA. Considerando o limite máximo de $5^{\circ} \mathrm{C}$ para a diferença entre os pontos de amolecimento do topo e fundo das misturas, pode-se observar que misturas com adição somente de SBS atendem esse critério para teores de até $2,4 \%$, enquanto que para as 
misturas com adição dos dois modificadores, o critério é atendido para misturas com até 2,0\% SBS e altos teores de ácido.

Em relação ao efeito dos componentes, apresentado na Figura 101 (b), o PA85 tem efeito parabólico com ponto de máximo em $0,76 \%$, ou seja, aumenta a diferença entre os pontos de amolecimento do topo e fundo até a proporção intermediaria $(0,76 \%)$ e a diminui a partir de teores maiores. O copolímero SBS apresenta um efeito próximo do linear, sendo que a variação média da diferença dos pontos de amolecimento entre topo e fundo provocada pelo aumento de $1 \%$ na proporção deste modificador é de $7,98^{\circ} \mathrm{C}$. Ao comparar os gráficos Figura 100 e Figura 101 pode-se verificar comportamentos semelhantes para os ácidos estudados. O ligante asfáltico de base da Lubnor apresenta melhor comportamento à luz da estabilidade à estocagem.

Na Tabela 91 estão apresentados os modelos de regressão da estabilidade à estocagem obtidos para cada ligante modificado (Replan e Lubnor) para as amostras com a adição de PA85 e PPA.

Tabela 91 - Modelos de regressão da Estabilidade à estocagem.

\begin{tabular}{lccc}
\hline $\begin{array}{l}\text { Ligante } \\
\text { Asfáltico } \\
\text { de base }\end{array}$ & Ácidos & Modelo de Regressão & $\begin{array}{c}\mathbf{R}^{2} \\
(\%)\end{array}$ \\
\hline Replan & PA85 & $-3 x_{1}+836 x_{2}+45222 x_{3}+46179 x_{2} x_{3}$ & 94,1 \\
& PPA & $-1 x_{1}+768 x_{2}+300 x_{3}+40067 x_{2} x_{3}$ & 92,1 \\
Lubnor & PA85 & $-4 x_{1}+20740 x_{2}-117773 \times 3-20913 x_{1} x_{3}+119852 x_{1} x_{3}+88372 x_{2} x_{3}$ & 92,1 \\
& PPA & $-4 x_{1}+18199 x_{2}-103429 \times 3-18260 x_{1} x_{3}+1105333 x_{1} x_{3}+80307 x_{2} x_{3}$ & 92,1 \\
\hline
\end{tabular}

$\mathrm{x}_{1}=$ asfalto; $\mathrm{x}_{2}$ : SBS e $\mathrm{x}_{3}$ : ácido em porcentagem.

\subsubsection{Ensaio de Fluência e Recuperação sob Tensão Múltipla (MSCR)}

Nesta subseção estão apresentados os gráficos de superfície de resposta e do efeito dos componentes na Recuperação e na Compliância não recuperável para a temperatura de $64^{\circ} \mathrm{C}$, adotada como a temperatura de serviço dos pavimentos no Brasil. Os demais gráficos referentes às outras temperaturas avaliadas estão no Apêndice F. Quanto ao comportamento encontrado nos gráficos de superfície, tem-se que os menores valores de recuperação estão na região onde se encontram as misturas menos modificadas e os maiores valores de recuperação estão na região inferior do simplex, onde estão as misturas com maiores modificações. Quanto ao efeito dos componentes, ambos os modificadores tendem a aumentar o valor da recuperação dos materiais. 
Na Figura 102 (a) tem-se o gráfico referente à superfície de resposta da recuperação à $64^{\circ} \mathrm{C}$ na tensão de $100 \mathrm{~Pa}$ para misturas com o ácido PA85, para o ligante asfáltico da Replan. Pode ser observado que os menores valores estão na região superior do simplex, onde se encontram as misturas com baixos teores do copolímero SBS e de ácido, sendo o valor máximo de $66,30 \%$. Os maiores teores estão na região inferior, onde estão as misturas com altos teores dos modificadores, o que indica que a adição dos modificadores proporciona um aumento nos valores de recuperação destes materiais.

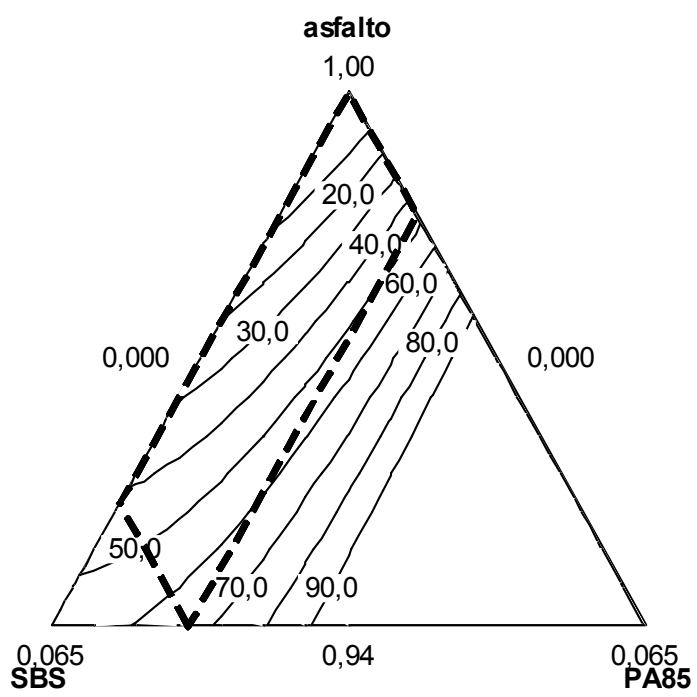

(a)

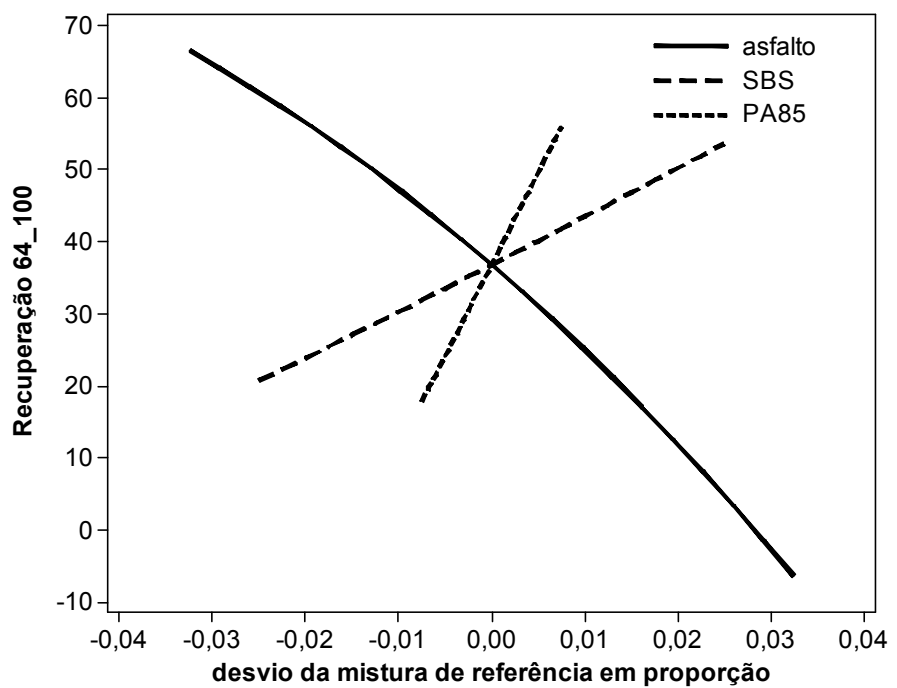

(b)

Figura 102 - Superfície de Resposta (a) e efeito de componentes (b) para a Recuperação (\%) à $64^{\circ} \mathrm{C}$ na tensão de 100Pa das misturas com PA85 (Replan).

Em relação ao efeito dos componentes, apresentado na Figura 102 (b), o copolímero SBS tem efeito linear, com tendência a aumentar o valor de recuperação. O copolímero SBS apresenta variação média da recuperação provocada pelo aumento de $1 \%$ na sua proporção de 6,54\%, enquanto o ácido apresenta um aumento de $25,55 \%$ com a adição de $1 \%$ na proporção de PA85, indicando que o efeito do ácido é mais expressivo no aumento dessa propriedade. 


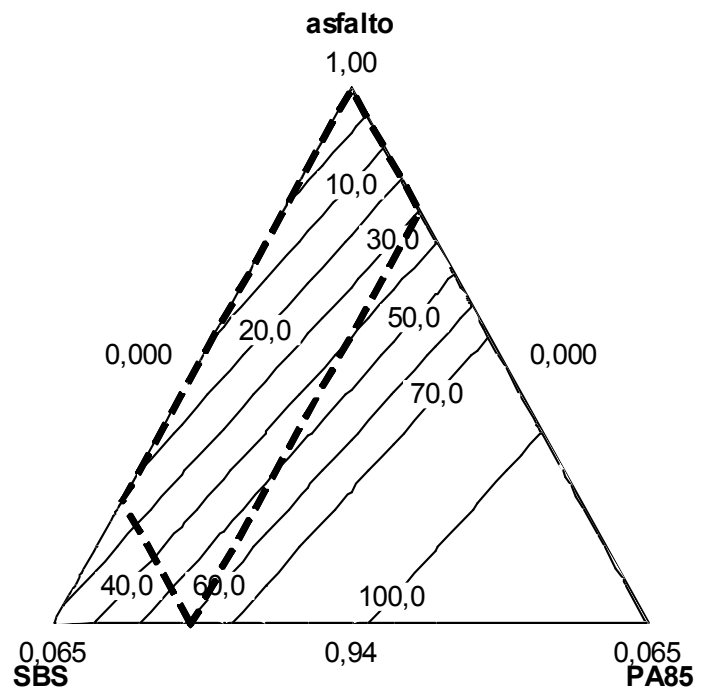

(a)

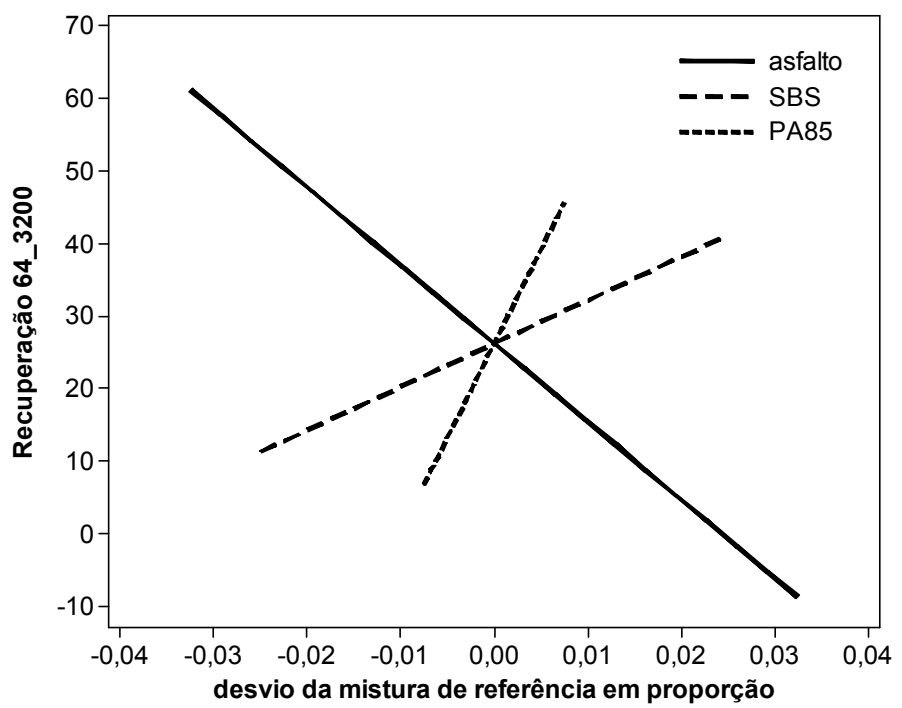

(b)

Figura 103 - Superfície de Resposta (a) e efeito de componentes (b) para a Recuperação (\%) à $64^{\circ} \mathrm{C}$ na tensão de 3200Pa das misturas com PA85 (Replan).

Na Figura 103 (a) tem-se o gráfico referente à superfície de resposta da recuperação à $64^{\circ} \mathrm{C}$ na tensão de $3200 \mathrm{~Pa}$ para misturas com o ácido PA85, para o ligante asfáltico da Replan. Pode ser observado o mesmo comportamento da recuperação a 100Pa, com valores um pouco menores, sendo o valor máximo igual a $61,37 \%$. Os maiores valores estão na região inferior, onde estão as misturas com altos teores dos modificadores, o que indica a adição dos modificadores proporciona um aumento nos valores de recuperação destes materiais. Em relação ao efeito dos componentes, apresentado na Figura 103 (b), o copolímero SBS tem efeito linear, com tendência a aumentar o valor da recuperação, com variação média da recuperação provocada pelo aumento de $1 \%$ na proporção deste modificador de 5,89\%, enquanto que o ácido produz aumento de $25,89 \%$ com a adição de $1 \%$ na sua proporção, indicando que o efeito do ácido é mais expressivo no aumento dessa propriedade. Ao considerar a recuperação máxima encontrada, os valores na tensão de $100 \mathrm{~Pa}$ foram 1,08 vezes superior ao valor encontrado na tensão de 3200Pa. 


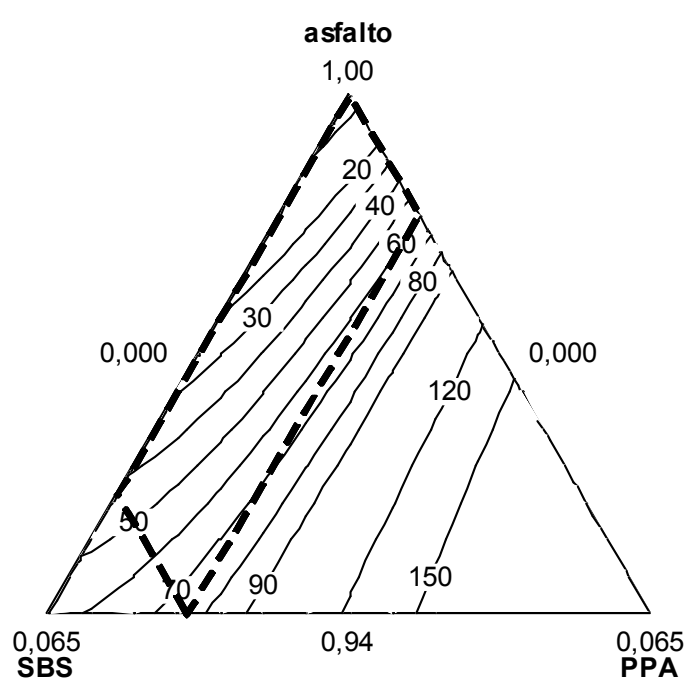

(a)

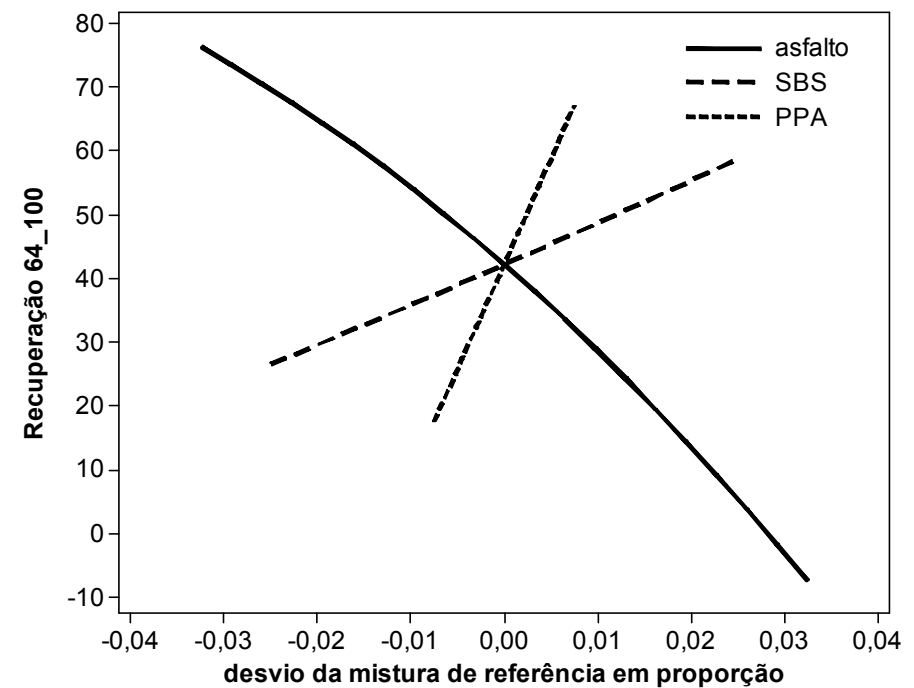

(b)

Figura 104 - Superfície de Resposta (a) e efeito de componentes (b) para a Recuperação (\%) à $64^{\circ} \mathrm{C}$ na tensão de 100Pa das misturas com PPA (Replan).

Na Figura 104 (a) tem-se o gráfico referente à superfície de resposta da recuperação à $64^{\circ} \mathrm{C}$ na tensão de $100 \mathrm{~Pa}$ para misturas com o ácido PPA, para o ligante asfáltico da Replan. Pode ser observado o mesmo comportamento da recuperação encontrado para as misturas com PA85, sendo o valor máximo de $75,84 \%$. Os maiores valores estão na região inferior, onde estão as misturas com altos teores dos modificadores, sendo esses valores maiores que os encontrados para as misturas com PA85. Em relação ao efeito dos componentes, apresentado na Figura 104 (b), o copolímero SBS tem efeito linear, com tendência a aumentar o valor da recuperação. O copolímero SBS produz variação média da recuperação provocada pelo aumento de $1 \%$ na sua proporção de $6,45 \%$, enquanto o ácido provoca um aumento de $33,14 \%$ para a adição de $1 \%$ na proporção do PPA, indicando que o efeito do PPA é mais expressivo no aumento dessa propriedade. 


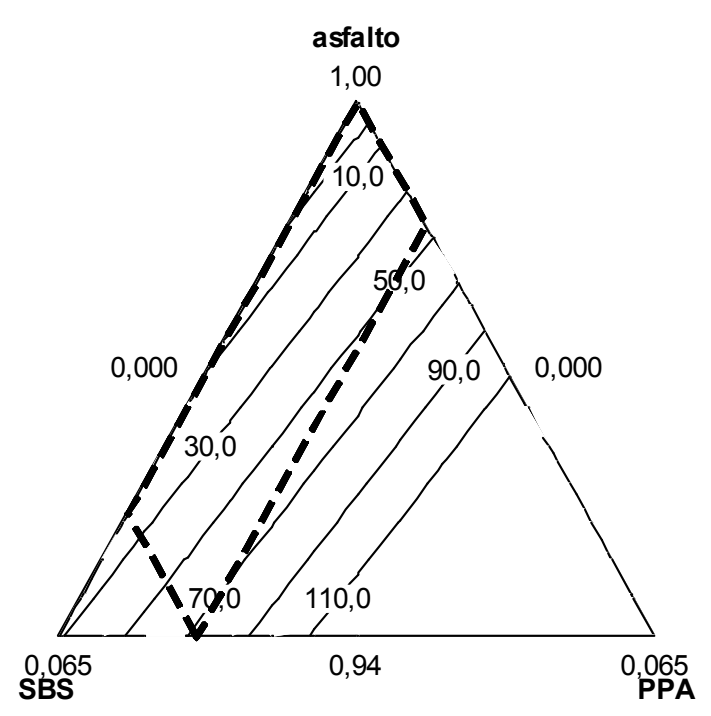

(a)

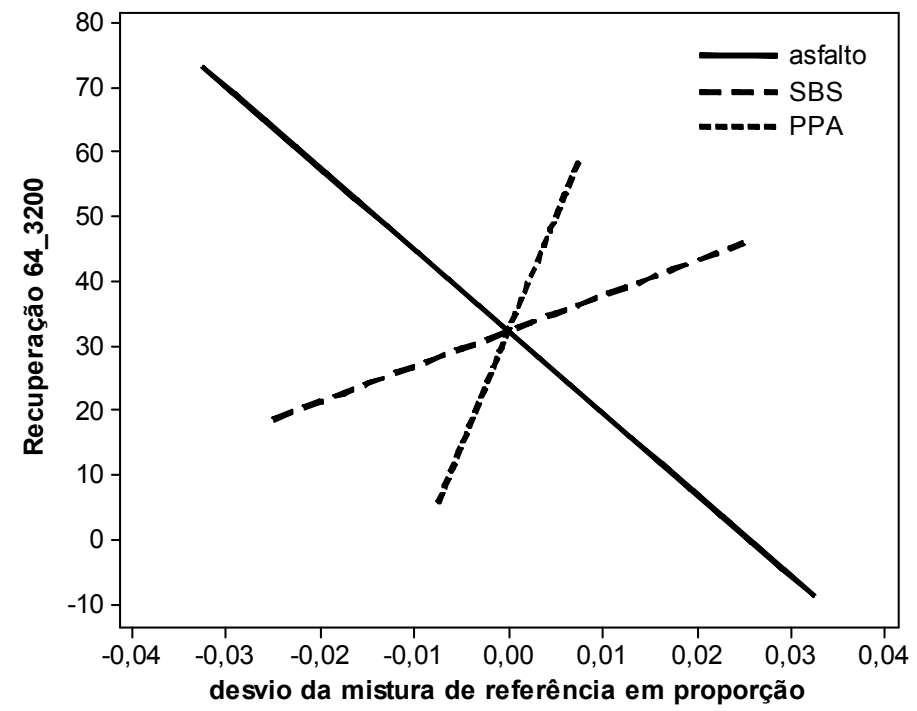

(b)

Figura 105 - Superfície de Resposta (a) e efeito de componentes (b) para a Recuperação (\%) à $64^{\circ} \mathrm{C}$ na tensão de 3200Pa das misturas com PPA (Replan).

Na Figura 105 (a) tem-se o gráfico referente à superfície de resposta da recuperação à $64^{\circ} \mathrm{C}$ na tensão de $3200 \mathrm{~Pa}$ para misturas com o PPA, para o ligante asfáltico da Replan. Pode ser observado o mesmo comportamento da recuperação a $100 \mathrm{~Pa}$, com valores um pouco inferiores, sendo o valor máximo de $73,00 \%$. Em relação ao efeito dos componentes, apresentado na Figura 105 (b), ambos têm efeito linear, com tendência a aumentar o valor de recuperação. O copolímero SBS produz variação média da recuperação provocada pelo aumento de $1 \%$ na sua proporção de $5,45 \%$, enquanto o ácido apresenta um aumento de $35,58 \%$ com a adição de $1 \%$ na proporção do PPA, indicando que o efeito do ácido é mais expressivo. Ao considerar a recuperação máxima encontrada, os valores encontrados na tensão de 100Pa foram 1,04 vezes superior aos valores encontrados para esta propriedade na tensão de 3200Pa.

Na Figura 106 (a) tem-se o gráfico referente à superfície de resposta da compliância não recuperável à $64^{\circ} \mathrm{C}$ na tensão de $100 \mathrm{~Pa}$ para misturas com o PA85, para o ligante asfáltico da Replan. Pode ser observado comportamento contrário ao da recuperação a $100 \mathrm{~Pa}$, com valores menores para as misturas com grandes concentrações dos modificadores, indicando que a adição destes é favorável para uma maior tolerância à deformação permanente. Em relação ao efeito dos componentes, apresentado na Figura 106 (b), ambos têm efeito linear, proporcionando a diminuição desta propriedade. O copolímero SBS apresenta variação média da recuperação provocada pelo aumento de $1 \%$ na proporção deste modificador de $0,21 \mathrm{kPa}^{-1}$, enquanto o ácido apresenta um aumento de 0,85 $\mathrm{kPa}^{-1} \mathrm{com}$ a adição de $1 \%$ na proporção do PA85, indicando que o efeito do ácido é mais expressivo. 


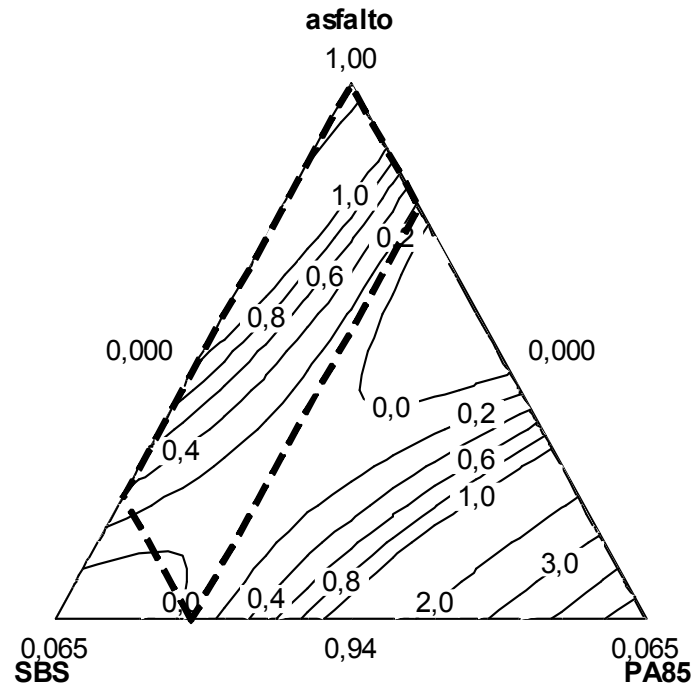

(a)

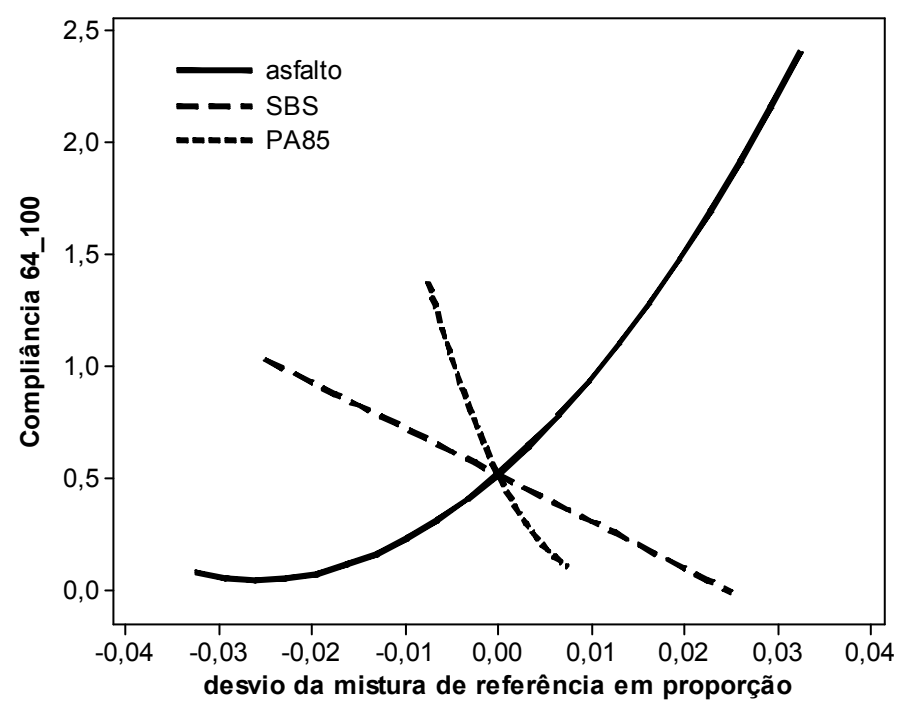

(b)

Figura 106 - Superfície de Resposta (a) e efeito de componentes (b) para a Compliância não recuperável $\left(\mathrm{kPa}^{-1}\right)$ à $64^{\circ} \mathrm{C}$ na tensão de $100 \mathrm{~Pa}$ das misturas com PA85 (Replan).

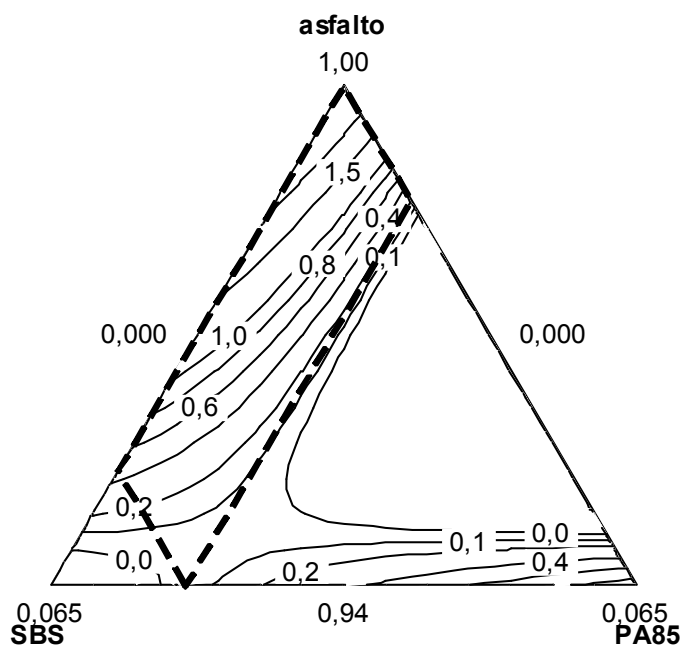

(a)

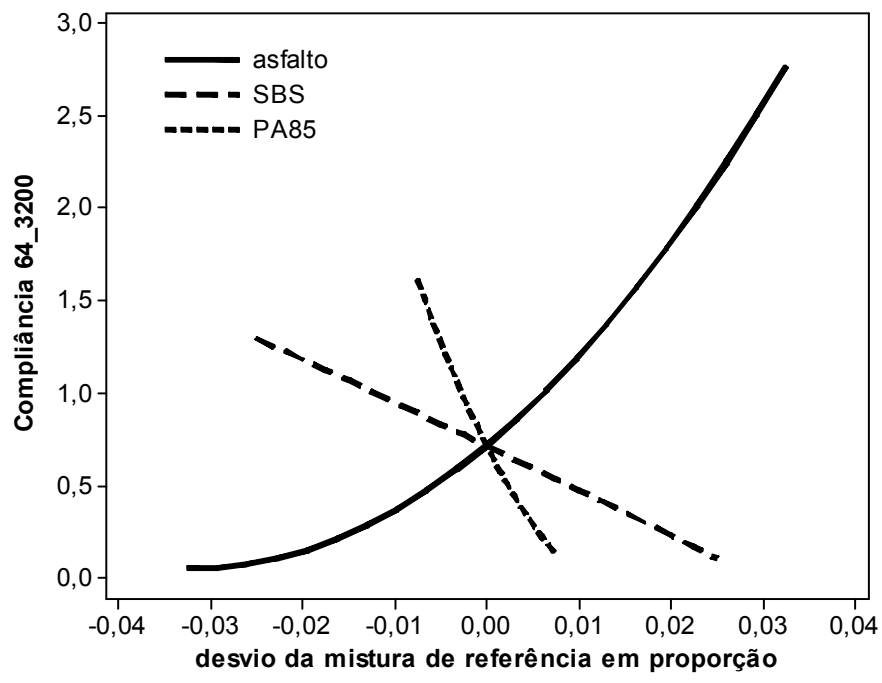

(b)

Figura 107 - Superfície de Resposta (a) e efeito de componentes (b) para a Compliância não recuperável $\left(\mathrm{kPa}^{-1}\right)$ à $64^{\circ} \mathrm{C}$ na tensão de $3200 \mathrm{~Pa}$ das misturas com PA85 (Replan).

Na Figura 107 (a) tem-se o gráfico referente à superfície de resposta da compliância não recuperável à $64^{\circ} \mathrm{C}$ na tensão de $3200 \mathrm{~Pa}$ para misturas com o PA85, para o ligante asfáltico da Replan. Nela observa-se comportamento semelhante ao encontrado na tensão de $100 \mathrm{~Pa}$, com valores menores para as misturas com grandes concentrações dos modificadores, porém com valores um pouco menores que os na tensão de $100 \mathrm{~Pa}$, indicando 
que o aumento da tensão diminui a tolerância dos materiais a deformação permanente. Em relação ao efeito dos componentes, apresentado na Figura 107 (b), ambos têm efeito linear, com tendência de diminuir o valor da compliância não recuperável. O copolímero SBS apresenta variação média da recuperação provocada pelo aumento de $1 \%$ na sua proporção de $0,24 \mathrm{kPa}^{-1}$, enquanto o ácido apresenta um aumento de $0,99 \mathrm{kPa}^{-1} \mathrm{com}$ a adição de $1 \% \mathrm{na}$ proporção do PA85, indicando que o efeito do ácido é mais expressivo no aumento dessa propriedade.

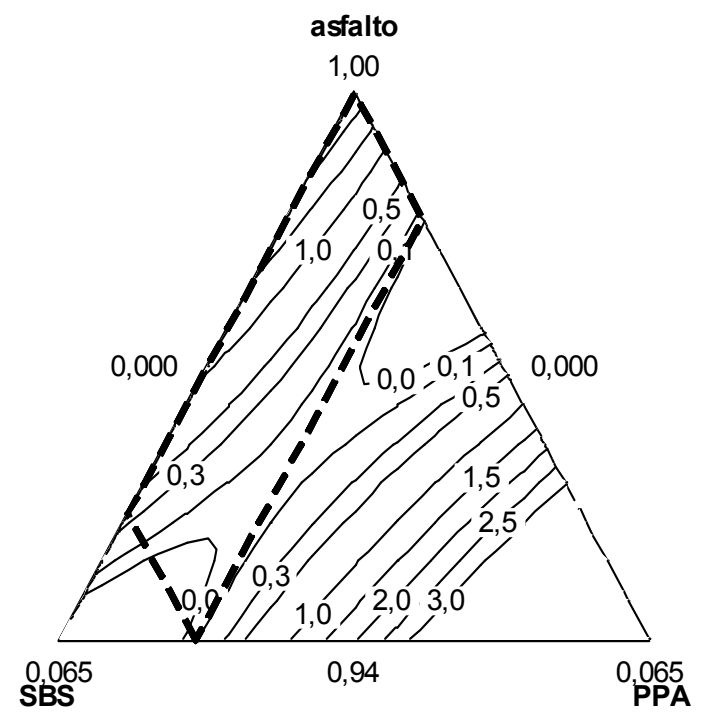

(a)

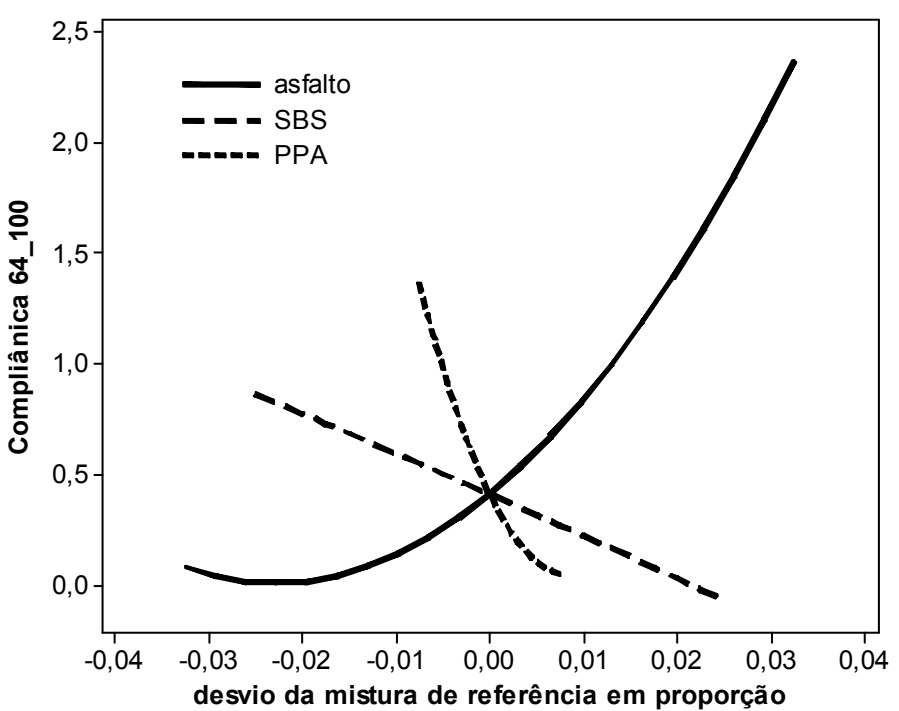

(b)

Figura 108 - Superfície de Resposta (a) e efeito de componentes (b) para a Compliância não recuperável $\left(\mathrm{kPa}^{-1}\right)$ à $64^{\circ} \mathrm{C}$ na tensão de $100 \mathrm{~Pa}$ das misturas com PPA (Replan).

O gráfico referente à superfície de resposta da compliância não recuperável à $64^{\circ} \mathrm{C}$ na tensão de $100 \mathrm{~Pa}$ para misturas com o PPA, para o ligante asfáltico da Replan, está apresentado na Figura 108(a). Nele pode ser observado comportamento semelhante ao encontrado nas misturas com adição de PA85, com valores menores para as misturas com altas concentrações dos modificadores. Em relação ao efeito dos componentes, apresentado na Figura 108 (b), ambos têm efeito linear, com tendência de diminuir o valor da compliância não recuperável. O copolímero SBS produz variação média da recuperação provocada pelo aumento de $1 \%$ na sua proporção de $0,19 \mathrm{kPa}^{-1}$, enquanto o ácido produz um aumento de $0,87 \mathrm{kPa}^{-1}$ com a adição de $1 \%$ na proporção do PPA, indicando que o efeito do ácido é mais expressivo no aumento dessa propriedade. 


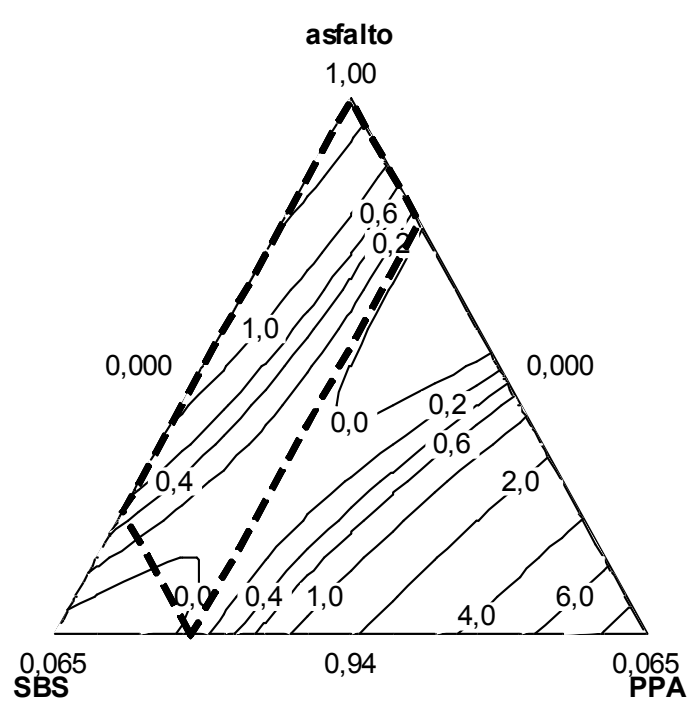

(a)

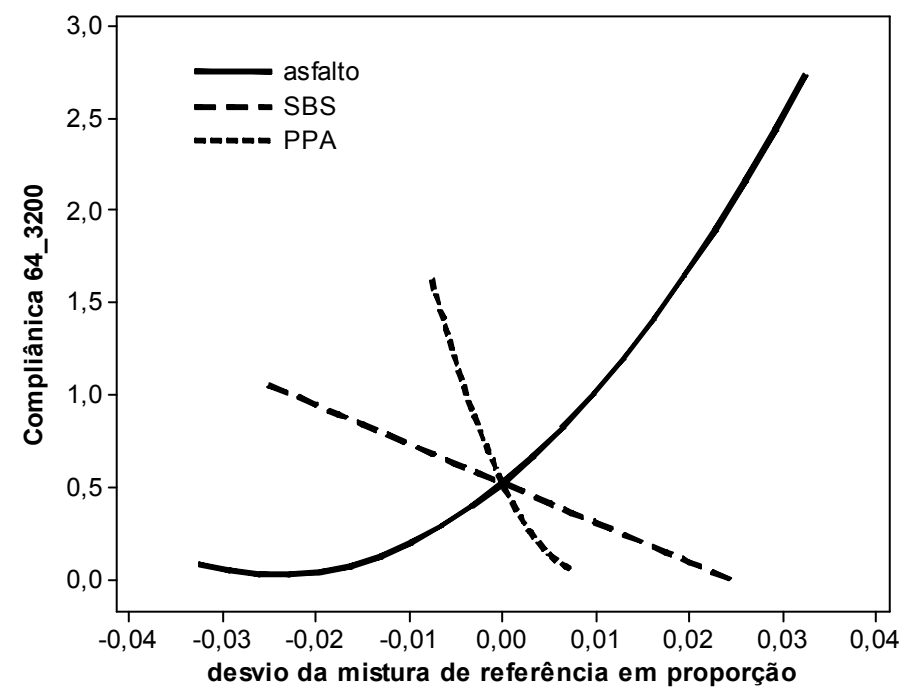

(b)

Figura 109 - Superfície de Resposta (a) e efeito de componentes (b) para a Compliância não recuperável $\left(\mathrm{kPa}^{-1}\right)$ à $64^{\circ} \mathrm{C}$ na tensão de $3200 \mathrm{~Pa}$ das misturas com PPA (Replan).

O gráfico referente à superfície de resposta da compliância não recuperável à $64^{\circ} \mathrm{C}$ na tensão de 3200Pa para misturas com o PPA, para o ligante asfáltico da Replan, é apresentado na Figura 109 (a). Nele pode ser observado comportamento semelhante ao encontrado na tensão de $100 \mathrm{~Pa}$, com valores menores para as misturas com grandes concentrações dos modificadores, porém com valores um pouco superior do que os da tensão de $100 \mathrm{~Pa}$, indicando que o aumento da tensão diminui a tolerância dos materiais a deformação permanente. Em relação ao efeito dos componentes, apresentado na Figura 109 (b), ambos têm efeito linear, com tendência de diminuir o valor da compliância não recuperável. $O$ copolímero SBS produz variação média da recuperação provocada pelo aumento de $1 \%$ na sua proporção de $0,21 \mathrm{kPa}^{-1}$, enquanto o ácido apresenta um aumento de $1,05 \mathrm{kPa}^{-1} \mathrm{com}$ a adição de $1 \%$ na proporção do PPA, indicando que o efeito do ácido é mais expressivo na redução dessa propriedade.

Na Figura 110 (a) tem-se o gráfico referente à superfície de resposta da recuperação à $64^{\circ} \mathrm{C}$ na tensão de $100 \mathrm{~Pa}$ para misturas com o ácido PA85, para o ligante asfáltico da Lubnor. Nela observa-se que os menores valores estão na região superior do simplex, onde se encontram as misturas com baixos teores do copolímero SBS e ácido, sendo o valor máximo de 49,39\%. Nota-se que, nesta temperatura, o ligante asfáltico de base não apresenta valores de recuperação. Os maiores valores estão na região inferior, onde estão as misturas com altos teores dos modificadores, o que indica a adição dos modificadores proporciona um aumento nos valores da recuperação destes materiais. Em relação ao efeito dos componentes, apresentado na Figura 110 (b), o copolímero SBS tem efeito linear, com tendência de aumentar o valor de recuperação. O copolímero SBS provoca variação média 
da recuperação devido ao aumento de $1 \%$ na sua proporção de $5,16 \%$, enquanto o ácido apresenta um aumento de 16,10\% com a adição de 1\% na proporção do PA85, indicando que o efeito do ácido é mais expressivo no aumento dessa propriedade.

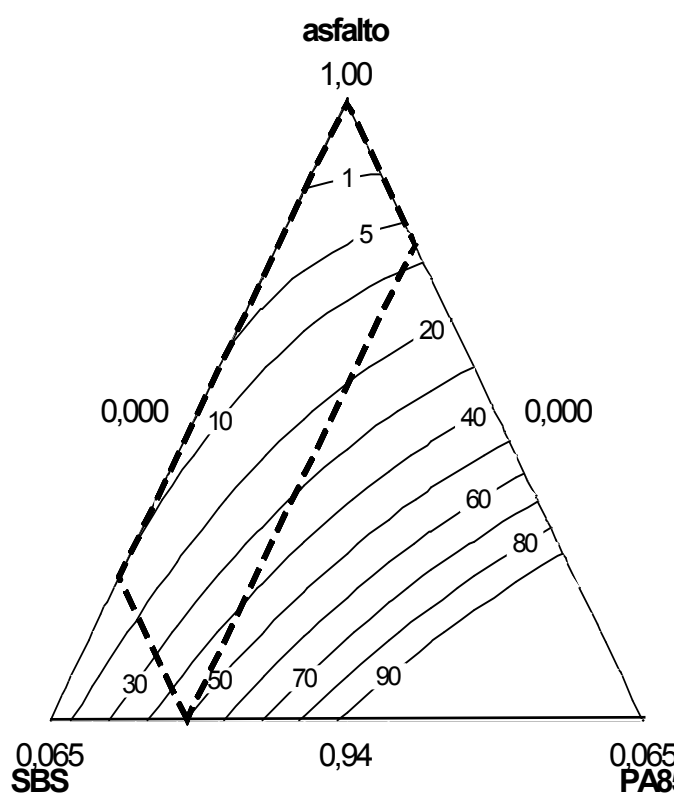

(a)

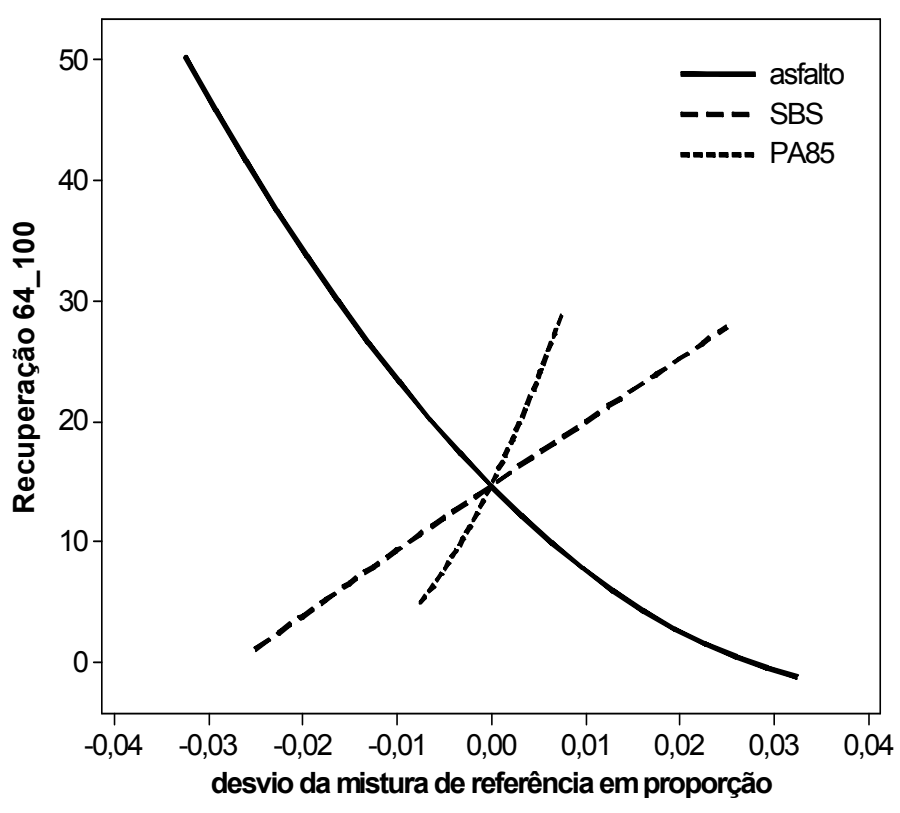

(b)

Figura 110 - Superfície de Resposta (a) e efeito de componentes (b) para a Recuperação $(\%)$ à $64^{\circ} \mathrm{C}$ na tensão de 100Pa das misturas com PA85 (Lubnor).

Na Figura 111 (a) tem-se o gráfico referente à superfície de resposta da recuperação à $64^{\circ} \mathrm{C}$ na tensão de $3200 \mathrm{~Pa}$ para misturas com o ácido PA85, para o ligante asfáltico da Replan. Observa-se nela o mesmo comportamento da recuperação a 100Pa, com valores menores, sendo o valor máximo igual a $36,49 \%$. Em relação ao efeito dos componentes, apresentado na Figura 111 (b), os modificadores tem efeito linear, com tendência de aumentar o valor de recuperação. O copolímero SBS provoca variação média da recuperação devido ao aumento de $1 \%$ na sua proporção de $3,76 \%$, enquanto o ácido, um aumento de $11,95 \%$ para a adição de $1 \%$ na proporção do PA85, indicando que o efeito do ácido é mais expressivo no aumento dessa propriedade. Ao considerar a recuperação máxima encontrada, os valores encontrados para a tensão de $100 \mathrm{~Pa}$ foram 1,35 vezes superior do que os valores encontrados na tensão de 3200Pa. 


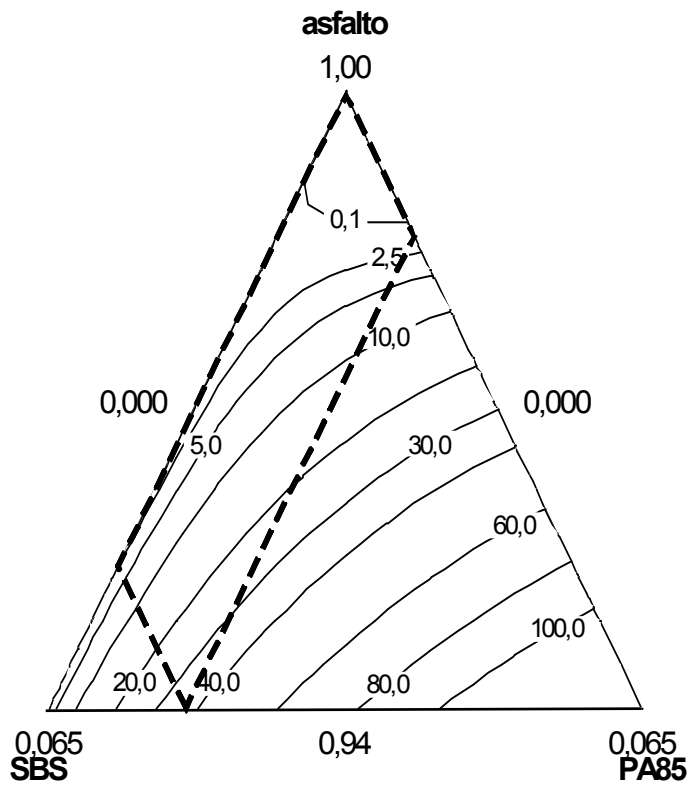

(a)

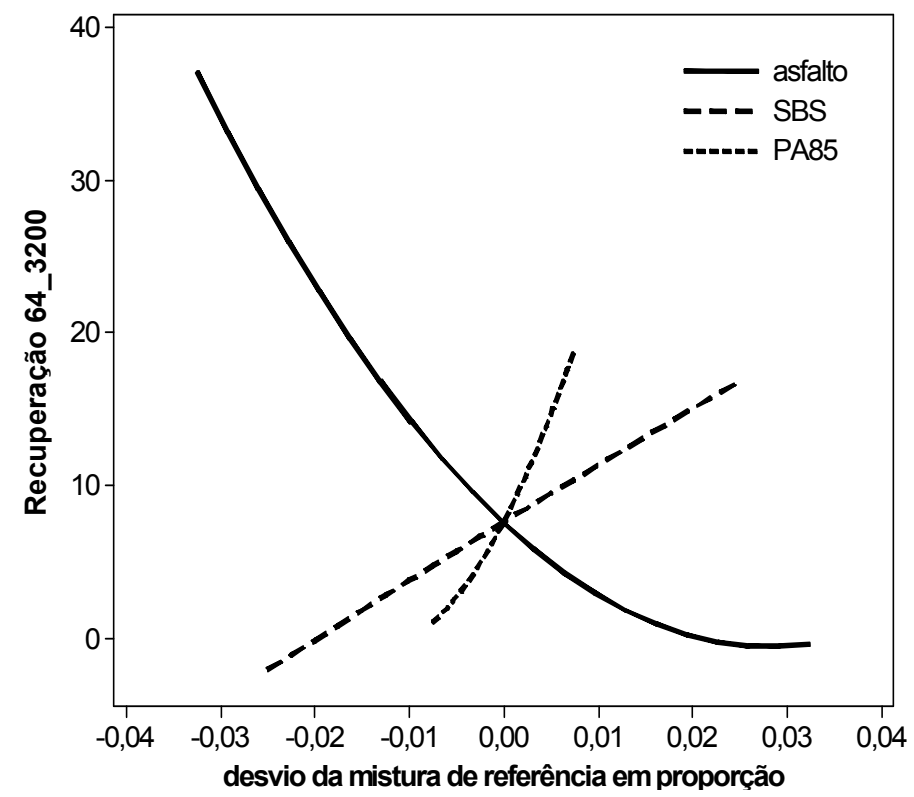

(b)

Figura 111 - Superfície de Resposta (a) e efeito de componentes (b) para a Recuperação (\%) à $64^{\circ} \mathrm{C}$ na tensão de 3200Pa das misturas com PA85(Lubnor).

Na Figura 112 (a) tem-se o gráfico da superfície de resposta da recuperação à $64^{\circ} \mathrm{C}$ na tensão de 100Pa para misturas com o ácido PPA, para o ligante asfáltico da Lubnor.

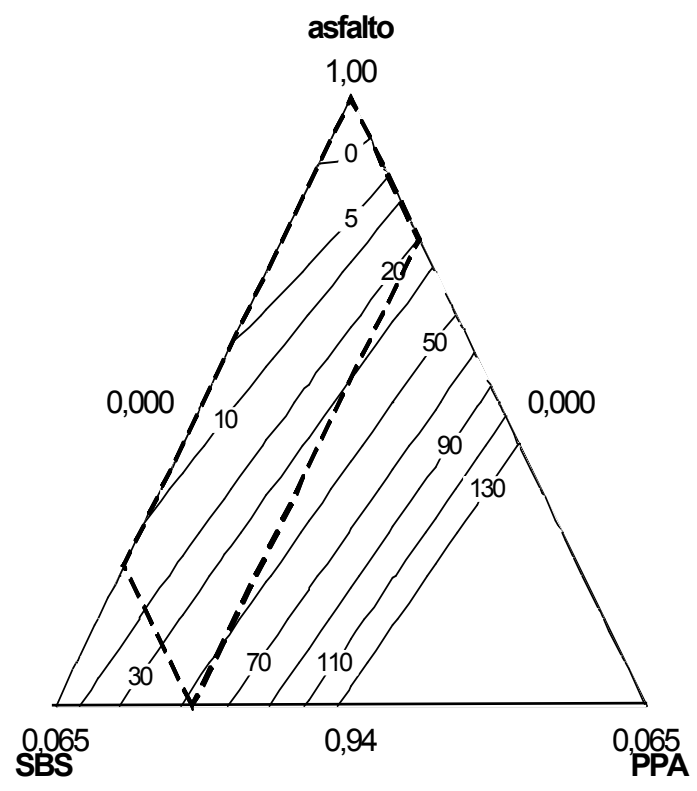

(a)

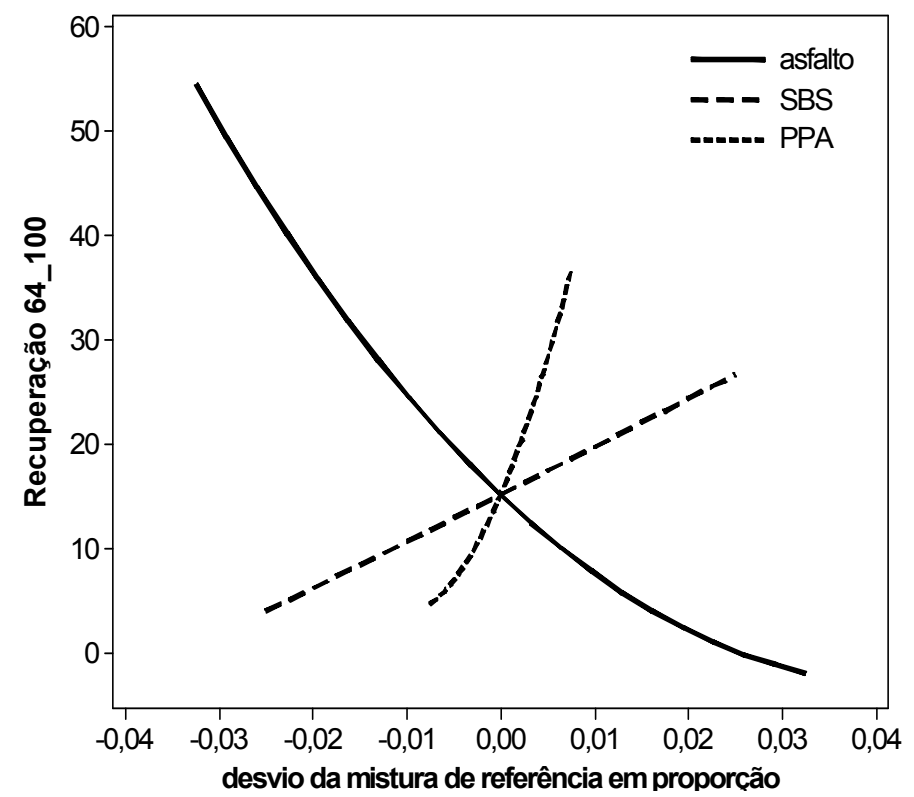

(b)

Figura 112 - Superfície de Resposta (a) e efeito de componentes (b) para a Recuperação (\%) à $64^{\circ} \mathrm{C}$ na tensão de 100Pa das misturas com PPA(Lubnor).

Na Figura 112 (a) pode ser observado o mesmo comportamento da recuperação obtido para as misturas com PA85, sendo o valor máximo de $53,78 \%$. Em relação ao efeito dos 
componentes, apresentado na Figura 112 (b), ambos os modificadores têm efeito linear, com tendência de aumentar o valor de recuperação. O copolímero SBS produz variação média da recuperação provocada devido ao aumento de $1 \%$ na sua proporção de $4,53 \%$, enquanto o ácido apresenta um aumento de $21,04 \%$ com a adição de $1 \%$ na proporção do PA85, indicando que o efeito do ácido é mais expressivo no aumento dessa propriedade.

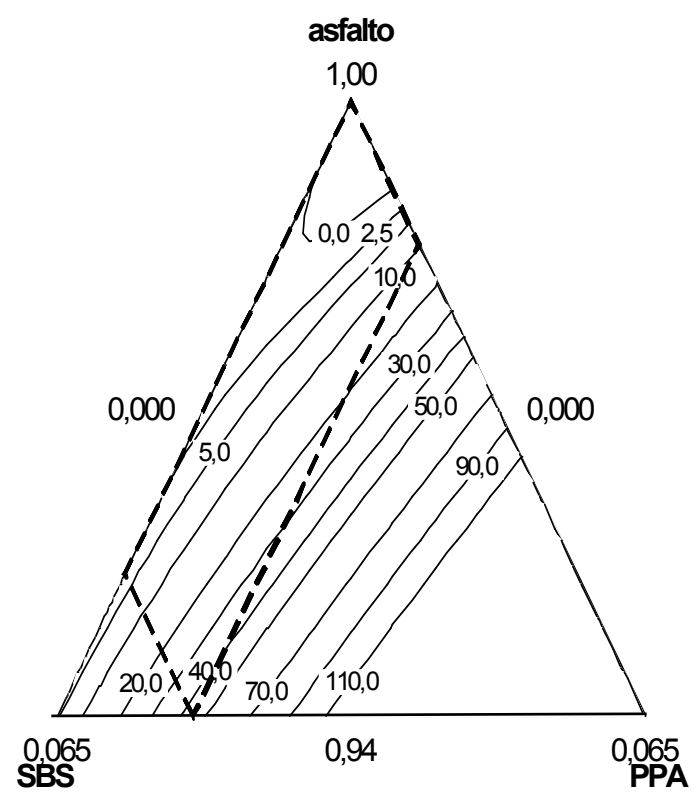

(a)

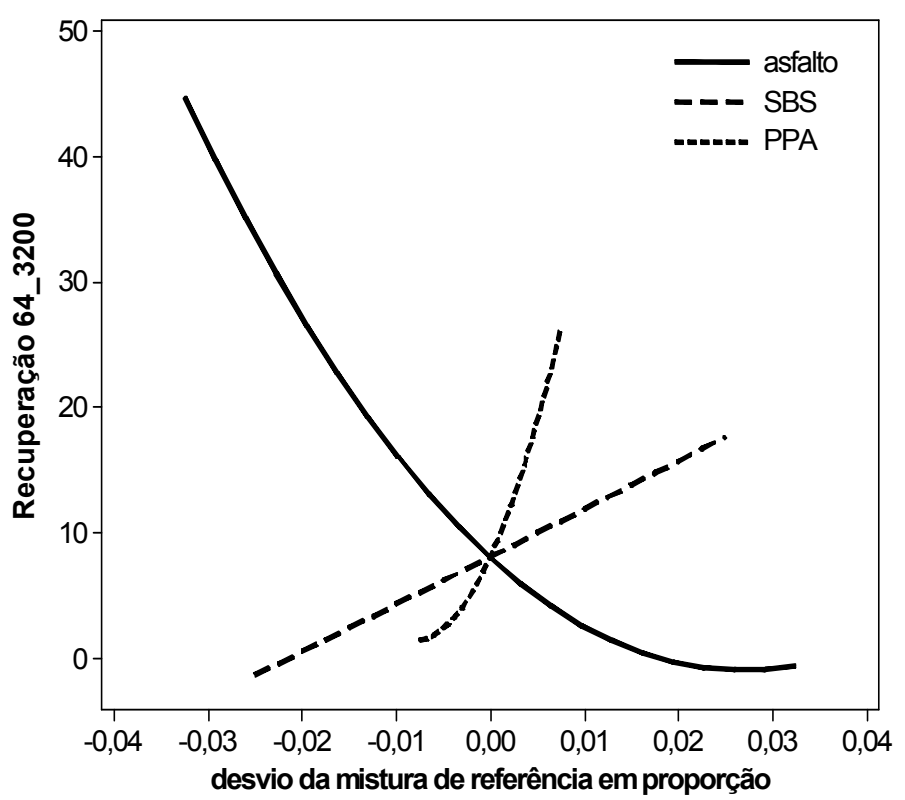

(b)

Figura 113 - Superfície de Resposta (a) e efeito de componentes (b) para a Recuperação (\%) à $64^{\circ} \mathrm{C}$ na tensão de 3200Pa das misturas com PPA(Lubnor).

Na Figura 113 (a) tem-se o gráfico referente à superfície de resposta da recuperação à $64^{\circ} \mathrm{C}$ na tensão de $3200 \mathrm{~Pa}$ para misturas com o ácido PPA, para o ligante asfáltico da Lubnor. Pode ser observado o mesmo comportamento da recuperação a 100Pa, com valores inferiores, sendo o valor máximo de $43,37 \%$. Em relação ao efeito dos componentes, a Figura 113 (b) aponta que ambos os modificadores têm efeito linear, aumentando o valor de recuperação. O copolímero SBS causa variação média da recuperação provocada pelo aumento de $1 \%$ na sua proporção de $3,30 \%$, enquanto o ácido produz um aumento de $16,50 \%$ com a adição de $1 \%$ na proporção do PPA, indicando que o efeito do ácido é mais expressivo no aumento dessa propriedade. Ao considerar a recuperação máxima encontrada, os valores encontrados para a tensão de 100Pa foram 1,24 vezes superior aos valores encontrados na tensão de 3200Pa. 


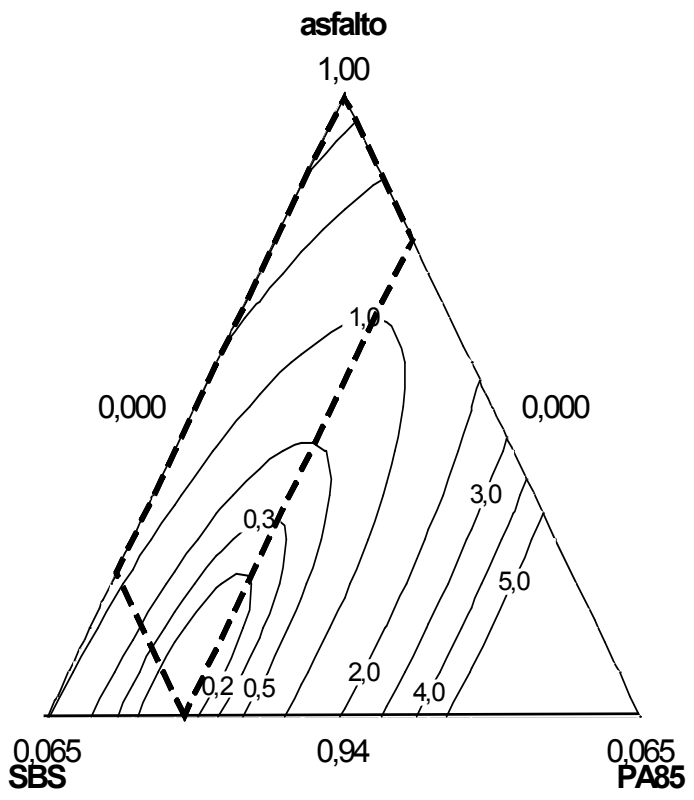

(a)

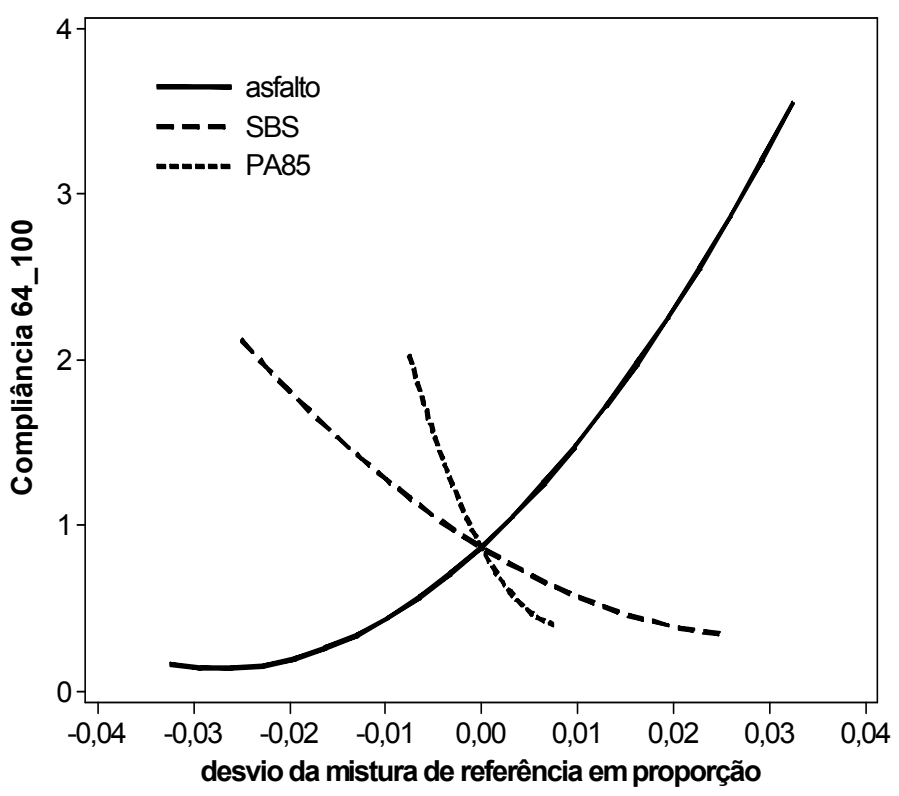

(b)

Figura 114 - Superfície de Resposta (a) e efeito de componentes (b) para a Compliância não recuperável $\left(\mathrm{kPa}^{-1}\right)$ à $64^{\circ} \mathrm{C}$ na tensão de 100Pa das misturas com PA85 (Lubnor).

O gráfico referente à superfície de resposta da compliância não recuperável à $64^{\circ} \mathrm{C}$ na tensão de 100Pa para misturas com o PPA, para o ligante asfáltico da Lubnor, estão apresentados na Figura 114 (a). Nela pode ser observado comportamento semelhante ao encontrado nas misturas com adição de PA85, com valores menores para as misturas com altas concentrações dos modificadores. Em relação ao efeito dos componentes, apresentado na Figura 114 (b), ambos têm efeito aproximadamente linear, com tendência de diminuir o valor da compliância não recuperável. O copolímero SBS causa variação média da recuperação provocada pelo aumento de $1 \%$ na sua proporção de $0,36 \mathrm{kPa}^{-1}$, enquanto o ácido, um aumento de $1,08 \mathrm{kPa}^{-1}$ com a adição de $1 \%$ na proporção do PA85, indicando que o efeito do ácido é mais expressivo no redução dessa propriedade.

Pode ser observado no gráfico de superfície de resposta da compliância não recuperável à $64^{\circ} \mathrm{C}$ na tensão de 3200Pa para misturas com o PA85, para o ligante asfáltico da Lubnor, apresentado na Figura 115 (a) que estas misturas apresentam comportamento semelhante ao encontrado na tensão de 100Pa, porém valores um pouco maiores, indicando que o aumento da tensão diminui a tolerância dos materiais à deformação permanente. Em relação ao efeito dos componentes, apresentado na Figura 115 (b), esta aponta que ambos têm efeito linear, com tendência de diminuir o valor da compliância não recuperável. $O$ copolímero SBS produz variação média da recuperação provocada pelo aumento de $1 \%$ na sua proporção de $0,38 \mathrm{kPa}^{-1}$, enquanto o ácido provoca um aumento de $1,13 \mathrm{kPa}^{-1} \mathrm{com}$ a adição de $1 \%$ na proporção do PA85, indicando que o efeito do ácido é mais expressivo na redução dessa propriedade. 


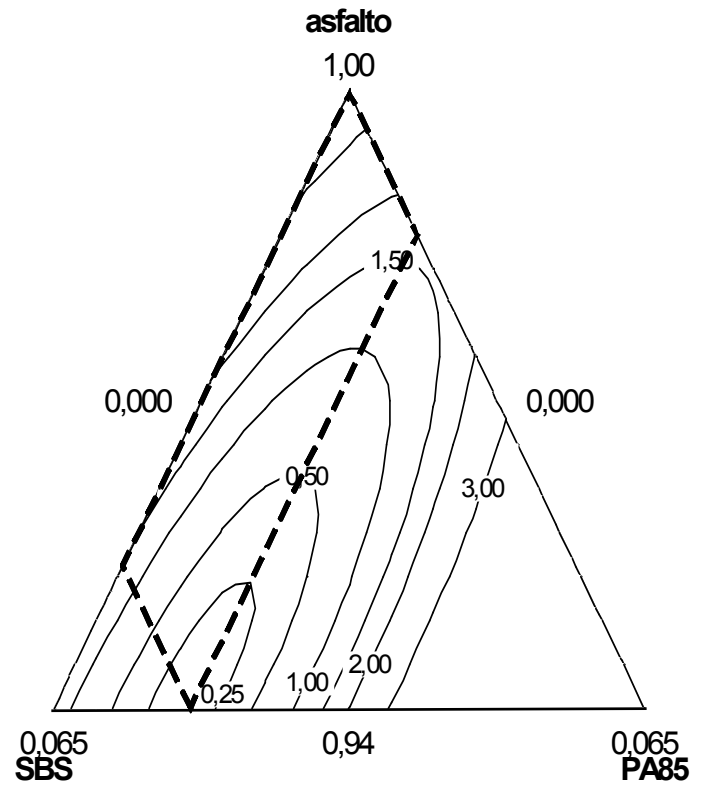

(a)

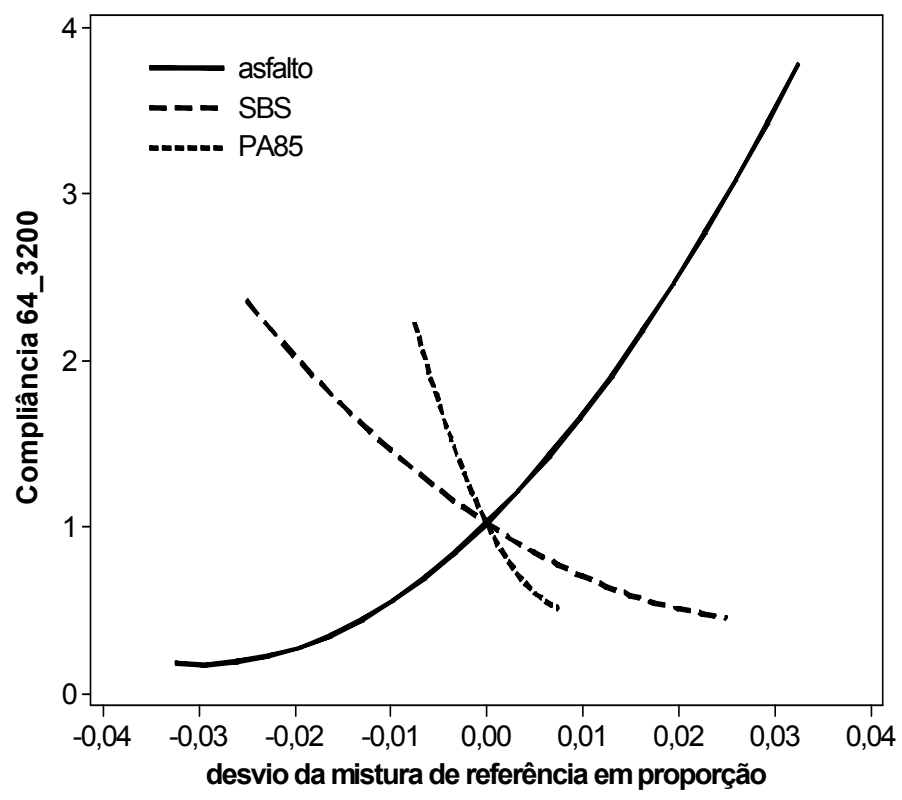

(b)

Figura 115 - Superfície de Resposta (a) e efeito de componentes (b) para a Compliância não recuperável $\left(\mathrm{kPa}^{-1}\right)$ à $64^{\circ} \mathrm{C}$ na tensão de 3200Pa das misturas com PA85(Lubnor).

Na Figura 116 (a) tem-se o gráfico referente à superfície de resposta da compliância não recuperável à $64^{\circ} \mathrm{C}$ na tensão de $100 \mathrm{~Pa}$ para misturas com o PPA, para o ligante asfáltico da Lubnor.

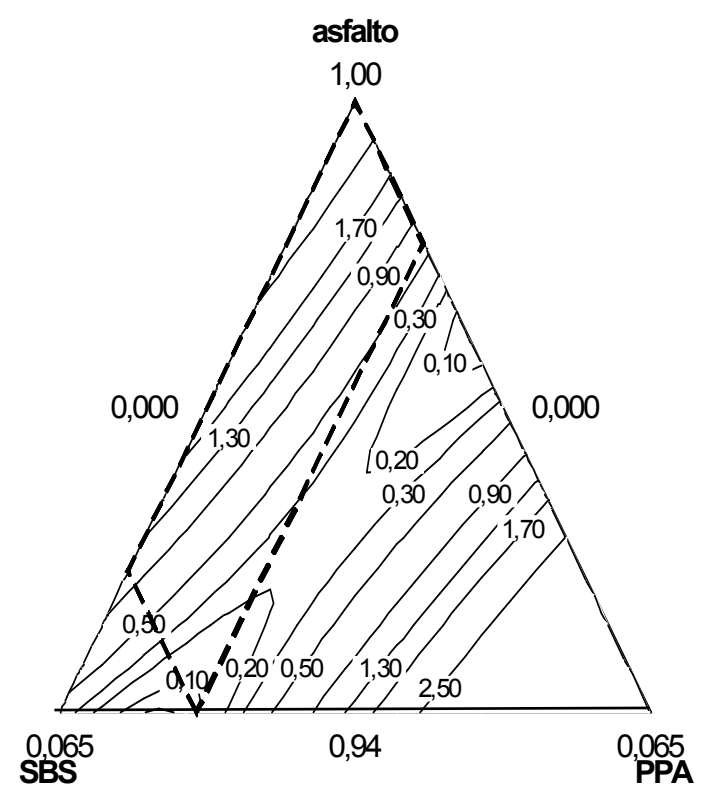

(a)

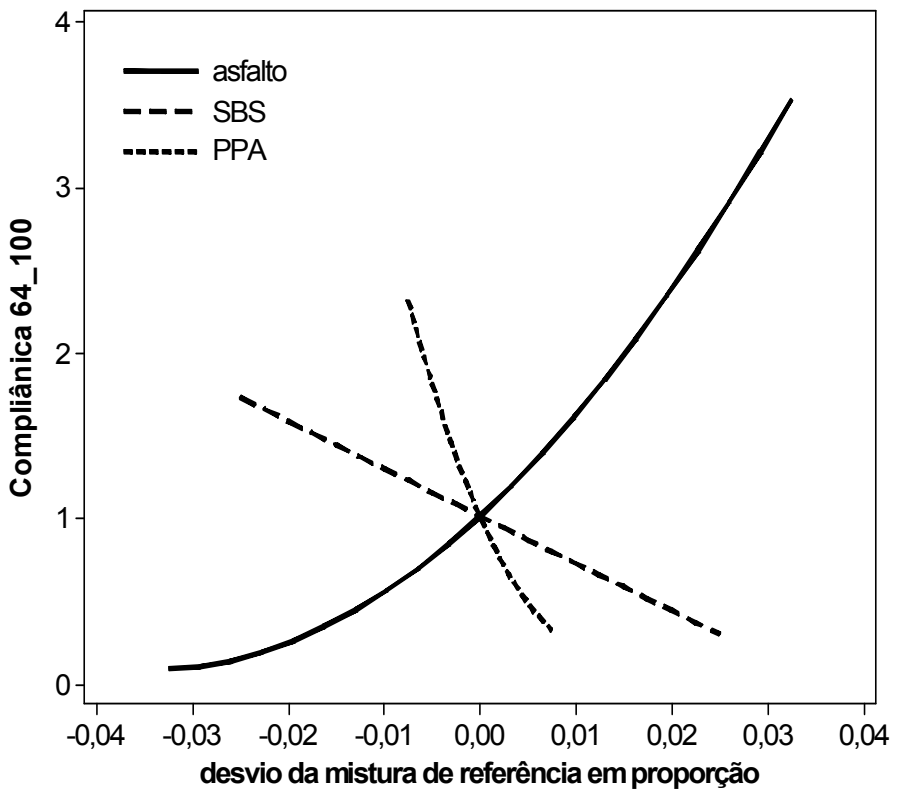

(b)

Figura 116 - Superfície de Resposta (a) e efeito de componentes (b) para a Compliância não recuperável $\left(\mathrm{kPa}^{-1}\right)$ à $64^{\circ} \mathrm{C}$ na tensão de $100 \mathrm{~Pa}$ das misturas com PPA(Lubnor). 
O comportamento destas misturas frente a essa propriedade é semelhante ao encontrado nas misturas com adição de PA85, apresentando valores inferiores para as misturas com altas concentrações dos modificadores. Em relação ao efeito dos componentes, apresentado na Figura 116 (b), ambos têm efeito linear, com tendência em diminuir o valor da compliância não recuperável. O copolímero SBS produz variação média da recuperação provocada pelo aumento de $1 \%$ na sua proporção de $0,28 \mathrm{kPa}^{-1}$, enquanto o ácido apresenta um aumento de $1,33 \mathrm{kPa}^{-1}$ com a adição de $1 \%$ na proporção do PPA, indicando que o efeito do ácido é mais expressivo no aumento dessa propriedade.

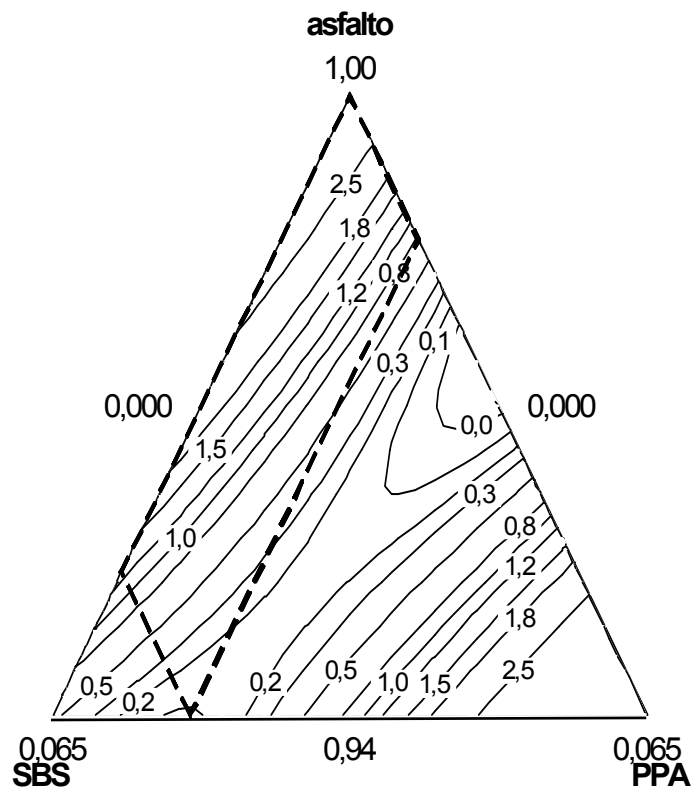

(a)

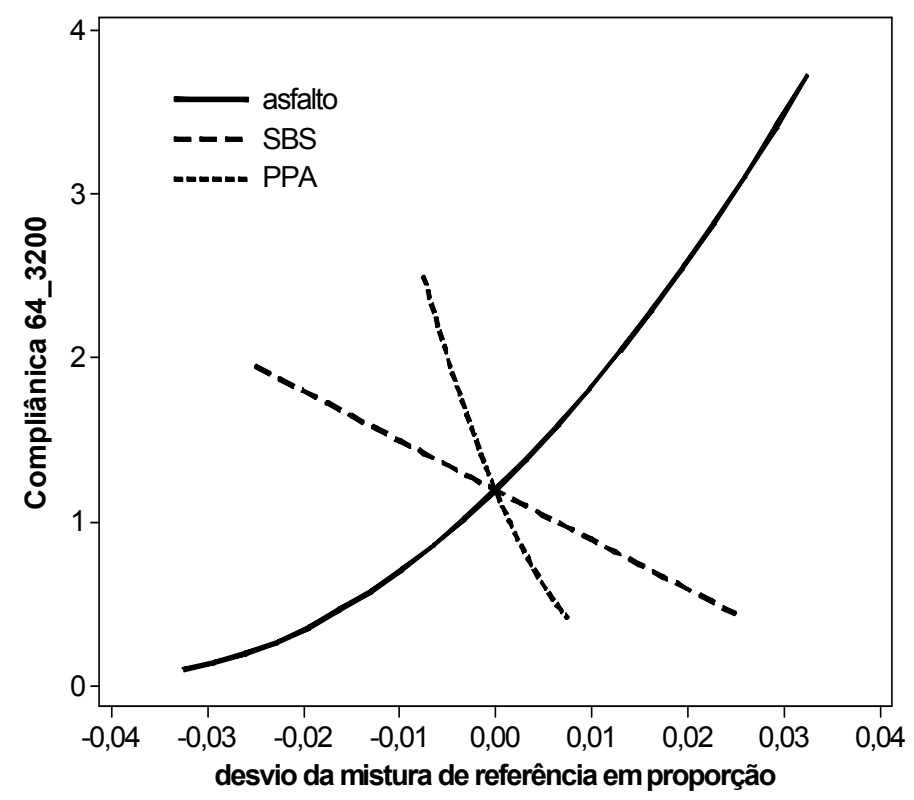

(b)

Figura 117 - Superfície de Resposta (a) e efeito de componentes (b) para a Compliância não recuperável $\left(\mathrm{kPa}^{-1}\right)$ à $64^{\circ} \mathrm{C}$ na tensão de $3200 \mathrm{~Pa}$ das misturas com PPA(Lubnor).

A Figura 117 (a) apresenta a superfície de resposta da compliância não recuperável à $64^{\circ} \mathrm{C}$ na tensão de 3200Pa para misturas com o PPA, para o ligante asfáltico da Replan. Nela observa-se comportamento semelhante ao encontrado na tensão de $100 \mathrm{~Pa}$, porém, de maneira geral, com valores um pouco superiores aos da tensão de $100 \mathrm{~Pa}$. Em relação ao efeito dos componentes, apresentado na Figura 117 (b), ambos têm efeito linear, com tendência de diminuir o valor da compliância não recuperável. O copolímero SBS produz variação média da recuperação provocada pelo aumento de $1 \%$ na sua proporção de 0,29 $\mathrm{kPa}^{-1}$, enquanto o ácido provoca um aumento de $1,39 \mathrm{kPa}^{-1}$ com a adição de $1 \%$ na proporção do PA85, indicando que o efeito do ácido é mais expressivo na redução dessa propriedade.

Para este ligante asfáltico de base é verificado que as misturas com adição de PPA apresentam maiores valores de recuperação e menores de compliância não recuperável, do que as misturas com adição de PA85, apesar de mesmo comportamento. As misturas com 
ambos os ácidos apresentam melhora frente essas duas propriedades quando comparada com o ligante asfáltico de base.

Observando-se a Tabela 92 e a Tabela 93 verifica-se que os modificadores tendem a a aumentar a recuperação dos materiais com a diminuição da temperatura e com o aumento da tensão, com exceção da temperatura de $76^{\circ} \mathrm{C}$ no ligante asfáltico de base da Lubnor, onde o PA85 e SBS apresentaram efeito parabólico, com mínimos em 0,5\% e 0,2\%, respectivamente.

Tabela 92 - Variação média da recuperação e compliância não recuperável para 1\% de aumento na proporção dos modificadores, para os ligantes asfálticos de base Replan.

\begin{tabular}{cccc|cc|cc|cc}
\hline \multirow{2}{*}{ Propriedades } & \multirow{2}{*}{ Temperatura } & \multicolumn{4}{c|}{$\mathbf{1 0 0 P a}$} & \multicolumn{4}{c}{$\mathbf{3 2 0 0 P a}$} \\
\cline { 2 - 10 } & & PA85 & SBS & PPA & SBS & PA85 & SBS & PPA & SBS \\
\hline \multirow{4}{*}{$\mathrm{R}(\%)$} & 52 & 26,73 & 6,02 & 32,01 & 6,04 & 29,57 & 6,54 & 31,26 & 6,00 \\
& 58 & 26,63 & 6,61 & 33,43 & 6,46 & 30,26 & 6,66 & 37,48 & 5,98 \\
& $\mathbf{6 4}$ & $\mathbf{2 5 , 5 5}$ & $\mathbf{6 , 5 4}$ & $\mathbf{3 3 , 1 4}$ & $\mathbf{6 , 4 5}$ & $\mathbf{2 5 , 8 9}$ & $\mathbf{5 , 8 9}$ & $\mathbf{3 5 , 5 8}$ & $\mathbf{5 , 4 5}$ \\
& 70 & 22,08 & 5,79 & 30,65 & 5,95 & 16,98 & $\mathbf{4 , 6 0}$ & 27,38 & 4,34 \\
& 76 & 18,01 & 5,11 & 26,53 & 5,33 & $\mathbf{7 , 2 9}$ & 2,73 & 16,64 & 3,34 \\
\hline \multirow{3}{*}{$\mathrm{Jn}_{\mathrm{nr}}\left(\mathrm{kPa}^{-1}\right)$} & 52 & $-0,12$ & $-0,02$ & $-0,12$ & $-0,02$ & $-0,13$ & $-0,02$ & $-0,13$ & $-0,02$ \\
& 58 & $-0,32$ & $-0,08$ & $-0,33$ & $-0,09$ & $-0,37$ & $-0,09$ & $-0,39$ & $-0,08$ \\
& $\mathbf{6 4}$ & $-\mathbf{0 , 8 5}$ & $\mathbf{- 0 , 2 1}$ & $\mathbf{- 0 , 8 7}$ & $\mathbf{- 0 , 1 9}$ & $\mathbf{- 0 , 9 9}$ & $\mathbf{- 0 , 2 4}$ & $\mathbf{- 1 , 0 5}$ & $\mathbf{- 0 , 2 1}$ \\
& 70 & $-2,11$ & $-0,51$ & $-2,15$ & $-0,51$ & $-2,38$ & $-0,58$ & $-2,56$ & $-0,53$ \\
& 76 & $-4,71$ & $-1,16$ & $-4,98$ & $-1,06$ & $-5,3$ & $-1,35$ & $-5,84$ & $-1,21$ \\
\hline
\end{tabular}

Tabela 93 - Variação média da recuperação e compliância não recuperável para 1\% de aumento na proporção dos modificadores, para os ligantes asfálticos de base Lubnor.

\begin{tabular}{|c|c|c|c|c|c|c|c|c|c|}
\hline \multirow{2}{*}{ Propriedades } & \multirow{2}{*}{ Temperatura } & \multicolumn{4}{|c|}{$100 \mathrm{~Pa}$} & \multicolumn{4}{|c|}{$3200 \mathrm{~Pa}$} \\
\hline & & PA85 & SBS & PPA & SBS & PA85 & SBS & PPA & SBS \\
\hline \multirow{5}{*}{$\mathrm{R}(\%)$} & 52 & 18,43 & 6,43 & 27,40 & 5,85 & 19,16 & 7,13 & 28,41 & 5,88 \\
\hline & 58 & 19,00 & 6,18 & 25,56 & 17,38 & 17,84 & 5,91 & 24,23 & 4,88 \\
\hline & 64 & 16,10 & 5,16 & 21,04 & 4,53 & 11,95 & 3,76 & 16,50 & 3,30 \\
\hline & 70 & 13,86 & 3,73 & 16,45 & 3,6 & 6,64 & 0,69 & 8,63 & 2,42 \\
\hline & 76 & $\begin{array}{c}\text { Efeito } \\
\text { parabólico } \\
\text { mínimo } \\
0,5 \%\end{array}$ & 2,84 & 11,00 & 2,81 & $\begin{array}{c}\text { Efeito } \\
\text { parabólico } \\
\text { mínimo } \\
0,5 \%\end{array}$ & 1,14 & $\begin{array}{c}\text { Efeito } \\
\text { parabólico } \\
\text { mínimo } \\
\text { até } 0,2 \%\end{array}$ & 1,30 \\
\hline \multirow{5}{*}{$J_{\mathrm{nr}}\left(\mathrm{kPa}^{-1}\right)$} & 52 & $-0,17$ & $-0,05$ & $-0,20$ & $-0,04$ & $-0,18$ & $-0,05$ & $-0,21$ & $-0,04$ \\
\hline & 58 & $-0,44$ & $-0,14$ & $-0,53$ & $-0,12$ & $-0,47$ & $-0,07$ & $-0,56$ & $-0,12$ \\
\hline & 64 & $-1,08$ & $-0,36$ & $-1,33$ & $-0,28$ & $-1,13$ & $-0,38$ & $-1,39$ & $-0,29$ \\
\hline & 70 & $-2,69$ & $-0,73$ & $-2,91$ & $-0,68$ & $-2,85$ & $-0,79$ & $-3,06$ & $-0,71$ \\
\hline & 76 & $-5,77$ & $-1,62$ & $-6,20$ & $-2,21$ & $-5,93$ & $-1,69$ & $-10,28$ & $-0,48$ \\
\hline
\end{tabular}

Nota-se que o efeito do ácido PPA é maior que o efeito do PA85 em aumentar a recuperação. Em relação à compliância não recuperável, o efeito dos componentes é de reduzí-la, tornando esses materiais mais tolerantes à deformação permanente. Verifica-se um efeito contrário ao encontrado para a recuperação, pois para esta propriedade o efeito dos 
componentes aumenta com os aumentos da temperatura e da tensão. Para esta propriedade, de maneira geral, têm-se efeitos similares para os ácidos estudados. Em relação aos ligantes asfálticos de base, é observado que o efeito dos modificadores são maiores para o ligante asfáltico da Replan.

Nas Tabela 94 e Tabela 95 estão apresentados os modelos de regressão obtidos para cada ligante modificado (Replan e Lubnor) para as amostras com a adição de PA85 e PPA, para as propriedades recuperação e compliância não recuperável. 
Tabela 94 - Modelos de regressão da Recuperação e Compliância não recuperável dos ligantes modificados (Replan).

\begin{tabular}{|c|c|c|c|c|c|}
\hline \multirow{3}{*}{ Ácido } & \multirow{3}{*}{ Temp. } & \multicolumn{4}{|c|}{ Recuperação } \\
\hline & & \multicolumn{2}{|l|}{$100 \mathrm{~Pa}$} & \multicolumn{2}{|l|}{$3200 \mathrm{~Pa}$} \\
\hline & & Equação & $R^{2}$ & Equação & $R^{2}$ \\
\hline \multirow[t]{11}{*}{ PA85 } & 52 & $8 x_{1}+984 x_{2}+3792-47497 x_{2} x_{3}$ & 97,30 & $3 x_{1}+970 x_{3}+3952 x_{3}-3911 x_{2} x_{3}$ & 97,60 \\
\hline & 58 & $-1 x_{1}+1012 x_{2}+3835 x_{3}-46976 x_{1} x_{2} x_{3}$ & 96,03 & $-7 x_{1}+894 x_{2}+3785 x_{3}-30375 x_{1} x_{2} x_{3}$ & 96,47 \\
\hline & 64 & $-6 x_{1}+954 x_{2}+3509 x_{3}-39880 x_{1} x_{2} x_{3}$ & 94,44 & $-8,75 x_{1}+907,9 x_{2}+2595,18 x_{3}$ & 92,90 \\
\hline & 70 & $-7 x_{1}+764 x_{2}+2768 x_{3}-22879 x_{1} x_{2} x_{3}$ & 91,70 & $-x_{1}+804 x_{2}+131071 x_{3}-8546 x_{1} x_{2}-131927 x_{1} x_{3}-122953 x_{1} x_{2} x_{3}$ & 99,42 \\
\hline & 76 & $-4 x_{1}+12279 x_{2}+2066 x_{3}-12300 x_{1} x_{2}-22122 x_{2} x_{3}$ & 93,20 & $100 x_{2}+70614 x_{3}-71544 x_{1} x_{2}-506512 x_{1} x_{2} x_{3}$ & 92,40 \\
\hline & \multicolumn{5}{|c|}{ Compliância Não Recuperável } \\
\hline & 52 & $0,3 x_{1}-5,1 x_{2}+530,2 x_{3}-558,6 x_{1} x_{3}-234,3 x_{1} x_{2} x_{3}$ & 99,00 & $0,3 x_{1}-5,3 x_{2}+541,4 x_{3}-571,0 x_{1} x_{3}-238,1 x_{1} x_{2} x_{3}$ & 99,01 \\
\hline & 58 & $1 x_{1}-14 x_{2}+1456 x_{3}-1535 x_{1} x_{3}-599 x_{1} x_{2} x_{3}$ & 99,09 & $1 x_{1}-16 x_{2}+1570 x_{3}-1657 x_{1} x_{3}-652 x_{1} x_{2} x_{3}$ & 99,08 \\
\hline & 64 & $2 x_{1}-38 x_{2}+3818 x_{3}-4026 x_{1} x_{3}-1522 x_{1} x_{2} x_{3}$ & 99,09 & $3 x_{1}-43 x_{2}+2634 x_{3}-2844 x_{1} x_{3}$ & 99,25 \\
\hline & 70 & $6 x_{1}-96 x_{2}+10113 x_{3}-10631 x_{1} x_{3}-4539 x_{1} x_{2} x_{3}$ & 99,26 & $7 x_{1}-104 x_{2}+4395 x_{3}-4872 x_{1} x_{3}+1761 x_{2} x_{3}$ & 99,91 \\
\hline & 76 & $14 x_{1}-215 x_{2}+21317 x_{3}-22471 x_{1} x_{3}-8690 x_{1} x_{2} x_{3}$ & 99,05 & $15 x_{1}-230 x_{2}+8328 x_{3}-9346 x_{1} x_{3}-4779 x_{2} x_{3}$ & 99,84 \\
\hline \multicolumn{6}{|c|}{ Recuperação } \\
\hline \multirow[t]{11}{*}{ PPA } & 52 & $9 x_{1}+9657 x_{2}+4440 x_{3}-9121 x_{1} x_{2}-59916 x_{1} x_{2} x_{3}$ & 98,68 & $6 x_{1}+986 x_{2}+4392 x_{3}-49567 x_{1} x_{2} x_{3}$ & 99,17 \\
\hline & 58 & $-2 x_{1}+1033 x_{2}+4606 x_{3}-51055 x_{1} x_{2} x_{3}$ & 96,22 & $-8 x_{1}+917 x_{2}+4724 x_{3}-40505 x_{1} x_{2} x_{3}$ & 96,40 \\
\hline & 64 & $-8 x_{1}+986 x_{2}+4416 x_{3}-46147 x_{1} x_{2} x_{3}$ & 94,76 & $-8,76 x_{1}+564,40 x_{2}+3548,65 x_{3}$ & 90,77 \\
\hline & 70 & $-10 x_{1}+844 x_{2}+3864 x_{3}-32659 x_{1} x_{2} x_{3}$ & 92,03 & $-7 x_{1}+11060 x_{2}+2458 x_{3}-112244 x_{1} x_{2}$ & 89,47 \\
\hline & 76 & $-7 x_{1}+14814 x_{2}+3076 x_{3}-14899 x_{1} x_{2}-30112 x_{2} x_{3}$ & 92,80 & $-x_{1}+120 x_{2}+161007 x_{3}-162550 x_{1} x_{3}-140079 x_{2} x_{3}$ & 93,20 \\
\hline & \multicolumn{5}{|c|}{ Compliância Não Recuperável } \\
\hline & 52 & $0,3 x_{1}-4,9 x_{2}+734,7 x_{3}-767,2 x_{1} x_{3}-414,1 x_{2} x_{3}$ & 98,98 & $0,3 x_{1}-5,1 x_{2}+758,5 x_{3}-792,3 x_{1} x_{3}-457,4 x_{1} x_{2} x_{3}$ & 99,11 \\
\hline & 58 & $x_{1}-14 x_{2}+1981 x_{3}-20,71 x_{1} x_{3}-1051 x_{2} x_{3}$ & 98,93 & $x_{1}-15 x_{2}+2178 x_{3}-2277 x_{1} x_{3}-1260 x_{1} x_{2} x_{3}$ & 99,14 \\
\hline & 64 & $2 x_{1}-37 x_{2}+5174 x_{3}-5409 x_{1} x_{3}-2676 x_{2} x_{3}$ & 98,87 & $3 x_{1}-41 x_{2}+5387 x_{3}-5648 x_{1} x_{3}-2867 x_{1} x_{2} x_{3}$ & 99,29 \\
\hline & 70 & $6 x_{1}-208 x_{2}+17170 x_{3}-116 x_{1} x_{2}-17015 x_{1} x_{2}-10978 x_{2} x_{3}$ & 99,94 & $7 x_{1}-101 x_{2}+11908 x_{3}-12522 x_{1} x_{3}-5806 x_{1} x_{2} x_{3}$ & 99,44 \\
\hline & 76 & $13 x_{1}-210 x_{2}+27037 x_{3}-28323 x_{1} x_{3}-14053 x_{1} x_{2} x_{3}$ & 98,96 & $15 x_{1}-224 x_{2}+24859 x_{3}-26196 x_{1} x_{3}-11659 x_{1} x_{2} x_{3}$ & 99,50 \\
\hline
\end{tabular}


Tabela 95 - Modelos de regressão da Recuperação e Compliância não recuperável dos ligantes modificados (Lubnor).

\begin{tabular}{|c|c|c|c|c|c|}
\hline \multirow{3}{*}{ Ácido } & \multirow{3}{*}{ Temp. } & \multicolumn{4}{|c|}{ Recuperação } \\
\hline & & \multicolumn{2}{|l|}{$100 \mathrm{~Pa}$} & \multicolumn{2}{|l|}{$3200 \mathrm{~Pa}$} \\
\hline & & Equação & $R^{2}$ & Equação & $R^{2}$ \\
\hline \multirow[t]{11}{*}{ PA85 } & 52 & $2,4 x_{1}+563,5 x_{2}+1525,5 x_{3}+14587,6 x_{1} x_{2} x_{3}$ & 97,17 & $0,9 x_{1}+509 x_{2}+1207,2 x_{3}+30989,9 x_{1} x_{2} x_{3}$ & 99,32 \\
\hline & 58 & $-0,8 x_{1}+392,8 x_{2}+1101,6 x_{3}+35231,5 x_{1} x_{2} x_{3}$ & 97,30 & $-x_{1}+275 x_{2}+43869 x_{3}-43827 x_{1} x_{3}$ & 97,04 \\
\hline & 64 & $-x_{1}+240 x_{2}+40788 x_{3}-40806 x_{1} x_{3}$ & 97,37 & $56 x_{2}+43818 x_{3}-44387 x_{1} x_{3}$ & 97,31 \\
\hline & 70 & $-x_{1}+107 x_{2}+81376 x_{3}-82112 x_{1} x_{3}-48236 x_{1} x_{2} x_{3}$ & 98,02 & $x_{1}-21 x_{2}+58069 x_{3}-59009 x_{1} x_{3}-31235 x_{1} x_{2} x_{3}$ & 93,91 \\
\hline & 76 & $x_{1}-8 x_{2}+84175 x_{3}-85450 x_{1} x_{3}-48681 x_{1} x_{2} x_{3}$ & 94,62 & $-13 x_{2}+37175 x_{3}-37739 x_{1} x_{3}-21358 x_{1} x_{2} x_{3}$ & 92,07 \\
\hline & \multicolumn{5}{|c|}{ Compliância Não Recuperável } \\
\hline & 52 & $x_{1}+79 x_{2}+1049 x_{3}-90 x_{1} x_{2}-1088 x_{1} x_{3}-922 x_{2} x_{3}$ & 99,07 & $x_{1}+75 x_{2}+1012 x_{3}-86 x_{1} x_{2}-1050 x_{1} x_{3}-969 x_{1} x_{2} x_{3}$ & 99,30 \\
\hline & 58 & $x_{1}+210 x_{2}+2631_{x 3}-240 x_{1} x_{2}-2731 x_{1} x_{3}-2316 x_{2} x_{3}$ & 99,25 & $2 x_{1}+206 x_{2}-236 x_{3}-2683 x_{1} x_{3}-2524 x_{1} x_{2} x_{3}$ & 99,41 \\
\hline & 64 & $4 x_{1}+480 x_{2}+5861 x_{3}-551 x_{1} x_{2}-6091 x_{1} x_{3}-5864 x_{1} x_{2} x_{3}$ & 99,39 & $4 x_{1}+510 x_{2}+5854 x_{3}-583 x_{1} x_{2}-6083 x_{1} x_{3}-5864 x_{1} x_{2} x_{3}$ & 99,45 \\
\hline & 70 & $8 x_{1}-104 x_{2}+10147 x_{3}-10691 x_{1} x_{3}-6223 x_{1} x_{2} x_{3}$ & 98,44 & $9 x_{1}-104 x_{2}+9774 x_{3}-10310 x_{1} x_{3}-6473 x_{1} x_{2} x_{3}$ & 98,50 \\
\hline & 76 & $17 x_{1}-220 x_{2}+21138 x_{3}-22264 x_{1} x_{3}-13464 x_{1} x_{2} x_{3}$ & 98,60 & $18 x_{1}-217 x_{2}+19924 x_{3}-21015 x_{1} x_{3}-13761 x_{1} x_{2} x_{3}$ & 98,52 \\
\hline \multicolumn{6}{|c|}{ Recuperação } \\
\hline \multirow[t]{11}{*}{ PPA } & 52 & $-0,65 x_{1}+600,27 x_{2}+2787,73 x_{3}$ & 98,43 & $-x_{1}+550 x_{2}+67830 x_{3}-66184 x_{1} x_{3}-56737 x_{2} x_{3}$ & 99,49 \\
\hline & 58 & $-x_{1}+427 x_{2}+92803 x_{3}+92016 x_{1} x_{3}-76034 x_{2} x_{3}$ & 99,38 & $-2 x_{1}+287 x_{2}+121821 x_{3}-121938 x_{1} x_{3}-91992 x_{2} x_{3}$ & 99,41 \\
\hline & 64 & $-2 x_{1}+259 x_{2}+95540 x_{3}-95507 x_{1} x_{3}-71724 x_{1} x_{2} x_{3}$ & 98,73 & $-x_{1}+78 x_{2}+100649 x_{3}-101532 x_{1} x_{3}-63172 x_{1} x_{2} x_{3}$ & 98,77 \\
\hline & 70 & $-x_{1}+127 x_{2}+94370 x_{3}-94933 x_{1} x_{3}-66065 x_{1} x_{2} x_{3}$ & 98,17 & $x_{1}-38 x_{2}+37863 x_{3}-38531 x_{1} x_{3}$ & 94,67 \\
\hline & 76 & $x_{1}+5039 x_{2}+66256 x_{3}-5285 x_{1} x_{2}-67060 x_{1} x_{3}-37667 x_{1} x_{2} x_{3}$ & 97,57 & $x_{1}-21 x_{2}+41829 x_{3}-42470 x_{1} x_{3}-23173 x_{1} x_{2} x_{3}$ & 91,71 \\
\hline & \multicolumn{5}{|c|}{ Compliância Não Recuperável } \\
\hline & 52 & $0,5 x_{1}-6,8 x_{2}+802,3 x_{3}-844,5 x_{1} x_{3}-467,9 x_{1} x_{2} x_{3}$ & 98,46 & $0,5 x_{1}-6,8 x_{2}+802,6 x_{3}-845,3 x_{1} x_{3}-479 x_{1} x_{2} x_{3}$ & 98,62 \\
\hline & 58 & $x_{1}-18 x_{2}+2083 x_{3}-2194 x_{1} x_{3}-1205 x_{1} x_{2} x_{3}$ & 98,58 & $x_{1}-18 x_{1}+2044 x_{3}-2156 x_{1} x_{3}-1212 x_{1} x_{2} x_{3}$ & 98,79 \\
\hline & 64 & $4 x_{1}-45 x_{2}+5217 x_{3}-5490 x_{1} x_{3}-3194 x_{1} x_{2} x_{3}$ & 99,24 & $4 x_{1}-45 x_{2}+4392 x_{3}-4655 x_{1} x_{3}-2464 x_{1} x_{2} x_{3}$ & 99,05 \\
\hline & 70 & $8 x_{1}-104 x_{2}+9858 x_{3}-10437 x_{1} x_{3}-5149 x_{1} x_{2} x_{3}$ & 98,75 & $9 x_{1}-103 x_{2}+8375 x_{3}-8934 x_{1} x_{3}-4202 x_{1} x_{2} x_{3}$ & 98,92 \\
\hline & 76 & $17 x_{1}-221 x_{2}+19408 x_{3}-20598 x_{1} x_{3}-9862 x_{1} x_{2} x_{3}$ & 98,96 & $18 x_{1}-217 x_{2}+15971 x_{3}-17099 x_{1} x_{3}-7868 x_{1} x_{2} x_{3}$ & 98,93 \\
\hline
\end{tabular}




\subsubsection{Análise do índice de tolerância ao dano pelo parâmetro af}

Cabe destacar que nesta subseção estão apresentados os gráficos de superfície e efeito dos componentes referentes às misturas produzidas com o ligante asfáltico de base da Lubnor, uma vez que não foi realizada a análise estatística do experimento com misturas para os dados do ligante asfáltico de base Replan, pois não foi possível determinar todos os valores de $a_{\mathrm{f}}$ como já explicado no item 4.2.8.1 deste trabalho.

Na Figura 118 (a) está apresentado o gráfico referente à superfície de resposta da recuperação à $25^{\circ} \mathrm{C}$, na condição de envelhecimento em curto prazo (RTFOT), dos valores de $a_{f}$ para as misturas com PA85, para o ligante asfáltico da Lubnor. Pode ser observado que a modificação do ligante asfáltico de base foi benéfica, tendo em vista que as misturas modificadas apresentaram valores maiores de $a_{\mathfrak{f}}$ quando comparadas com o ligante asfáltico de base, apresentando valor máximo de 0,94mm. Sendo assim, a área superior do simplex apresenta os menores valores de $\mathrm{a}_{\mathrm{f}} \mathrm{e}$ a área inferior do simplex, misturas mais modificadas, os maiores valores de $a_{f}$. Em relação ao efeito dos componentes, apresentado na Figura 118 (b), ambos os modificadores tem efeito linear, aumentando o valor de af. O copolímero SBS produz variação média da recuperação provocada pelo aumento de $1 \%$ na sua proporção de $0,04 \mathrm{~mm}$, enquanto o ácido, um aumento de $0,08 \mathrm{~mm}$ com a adição de $1 \%$ na proporção do PA85, indicando que o efeito do ácido é mais expressivo no aumento dessa propriedade.

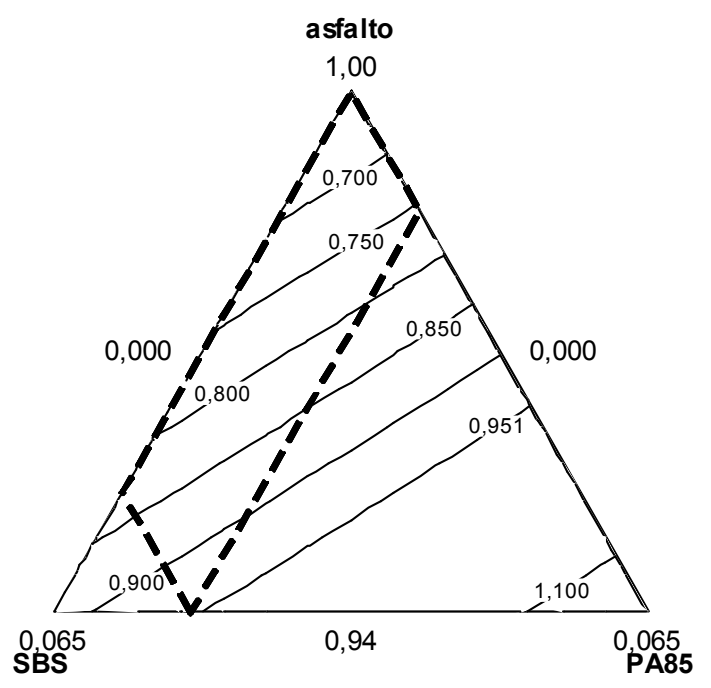

(a)

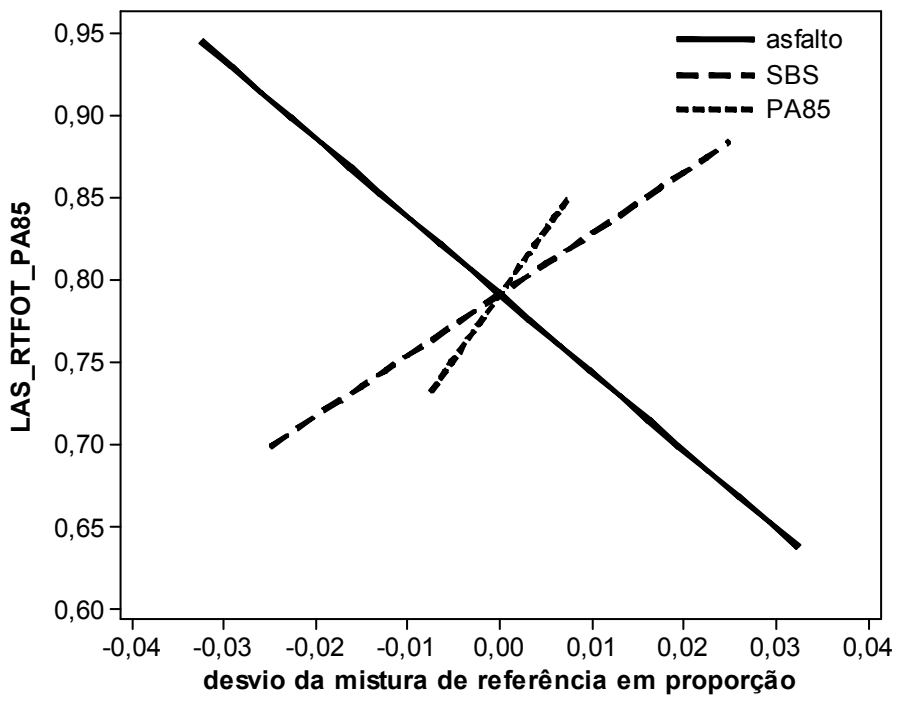

(b)

Figura 118 - Superfície de Resposta (a) e efeito de componentes (b) para o LAS modificado (af) à $25^{\circ} \mathrm{C}$ na condição de RTFOT das misturas com PA85, para o ligante asfáltico da Lubnor. 
Com base na Figura 119 (a), que apresenta o gráfico referente à superfície de resposta da recuperação à $25^{\circ} \mathrm{C}$, na condição de envelhecimento em curto prazo (RTFOT), dos valores de $a_{f}$ para misturas com PPA, para o ligante asfáltico da Lubnor, verifica-se que o comportamento destas misturas é similar ao apresentado pelas misturas com adição de PA85, apresentando valor máximo de 0,93mm. Em relação ao efeito dos componentes, apresentado na Figura 119 (b), os modificadores têm efeito linear, aumentando o valor de $a_{\text {f. }}$ O copolímero SBS produz variação média da recuperação provocada pelo aumento de $1 \%$ na proporção deste modificador de $0,04 \mathrm{~mm}$, enquanto o ácido provoca um aumento de $0,07 \mathrm{~mm}$ com a adição de $1 \%$ na proporção do PA85, indicando que o efeito do ácido é mais expressivo no aumento dessa propriedade. Comparando a Figura 118 e Figura 119, o efeito dos ácidos testados é o mesmo, à luz da tolerância à fadiga.

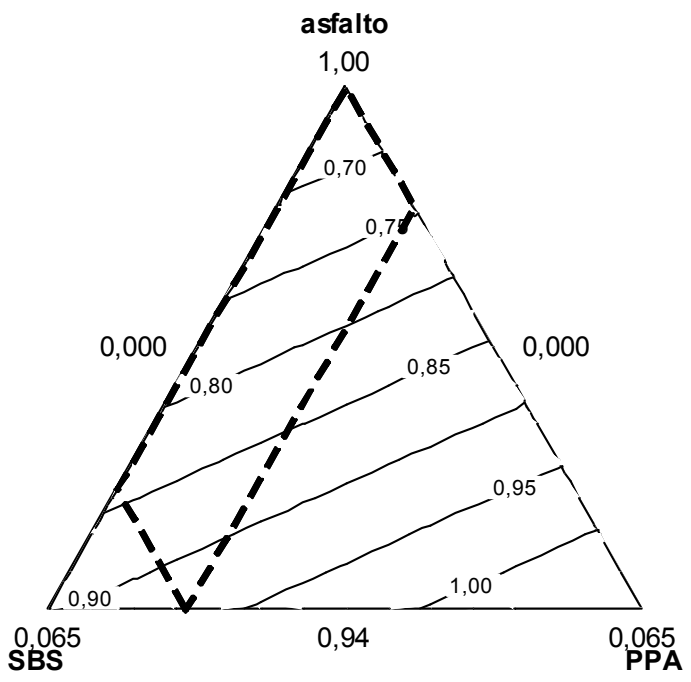

(a)

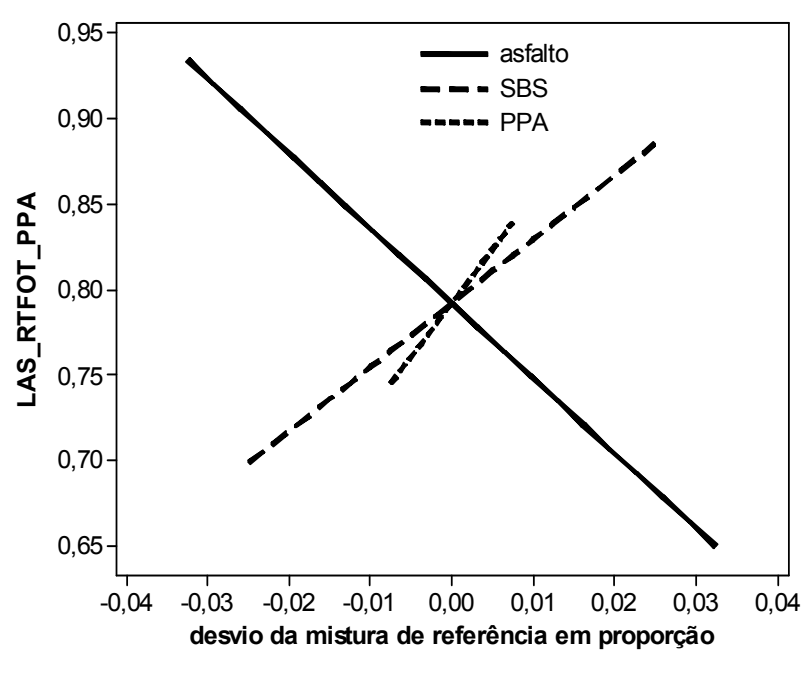

(b)

Figura 119 - Superfície de Resposta (a) e efeito de componentes (b) para o LAS modificado (af) à $25^{\circ} \mathrm{C}$ na condição de RTFOT das misturas com PPA, para o ligante asfáltico da Lubnor.

A Figura 120 (a) apresenta o gráfico referente à superfície de resposta da recuperação à $25^{\circ} \mathrm{C}$, na condição de envelhecimento em longo prazo (PAV), dos valores de $a_{\mathrm{f}}$ para misturas com PA85, para o ligante asfáltico da Lubnor. Nota-se um comportamento semelhante ao encontrado para as misturas na condição RTFOT, porém com valores de $a_{f}$ maiores, com valor máximo de $1,21 \mathrm{~mm}$, indicando que o efeito do envelhecimento é benéfico para a tolerância à fagida. Em relação ao efeito dos componentes, apresentado na Figura 118 (b), os modificadores têm efeito linear, aumentando o valor de $a_{\mathrm{f}}$. O copolímero SBS produz variação média da recuperação provocada pelo aumento de $1 \%$ na sua proporção de $0,07 \mathrm{~mm}$, enquanto o ácido provoca um aumento de $0,05 \mathrm{~mm}$ com a adição de $1 \%$ na proporção do 
PA85, indicando que o efeito do copolímero SBS é um pouco maior no aumento dessa propriedade.

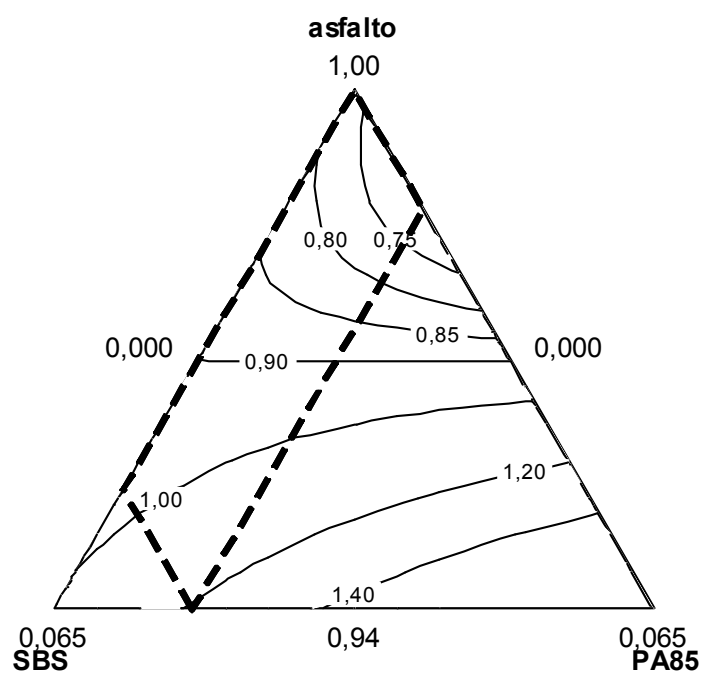

(a)

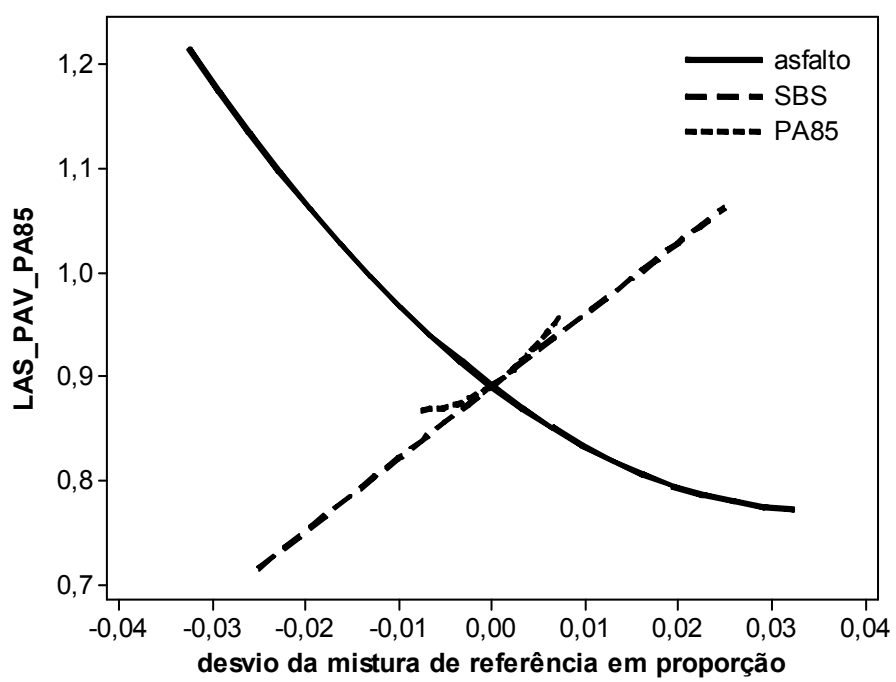

(b)

Figura 120 - Superfície de Resposta (a) e efeito de componentes (b) para o LAS modificado (af) à $25^{\circ} \mathrm{C}$ na condição de PAV das misturas com PA85, para o ligante asfáltico da Lubnor.

A Figura 121 (a) apresenta o gráfico referente à superfície de resposta da recuperação à $25^{\circ} \mathrm{C}$, na condição de envelhecimento em longo prazo (PAV), dos valores de $a_{f}$ para misturas com PPA, para o ligante asfáltico da Lubnor.

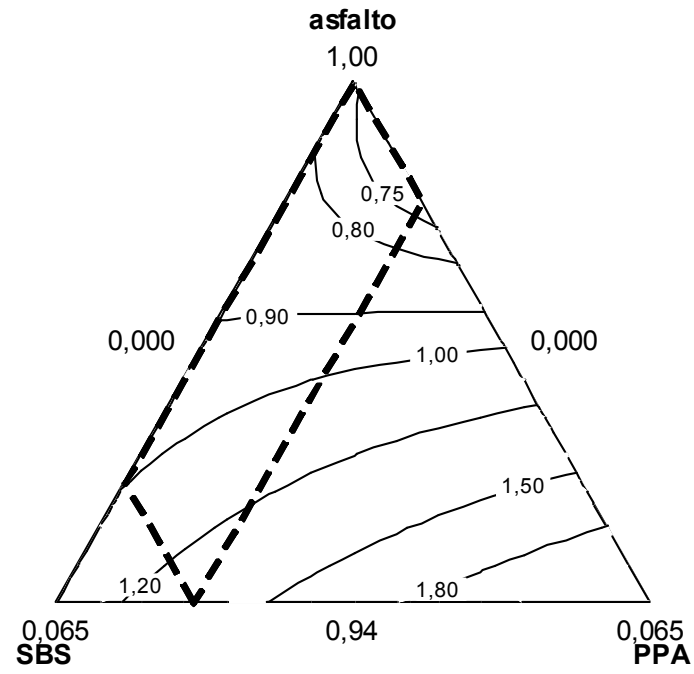

(a)

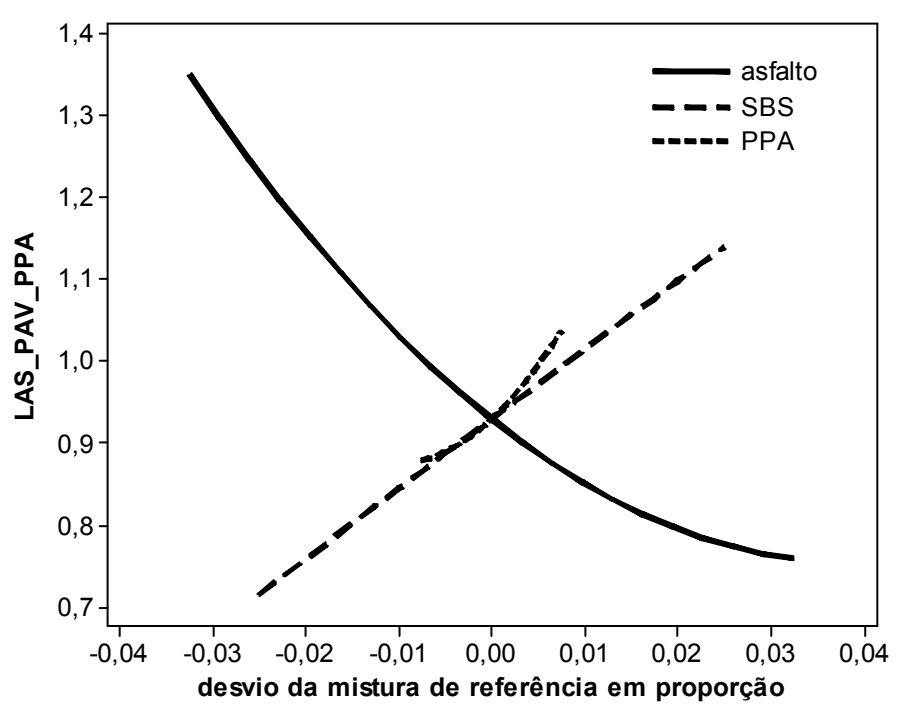

(b)

Figura 121 - Superfície de Resposta (a) e efeito de componentes (b) para o LAS modificado (af) à $25^{\circ} \mathrm{C}$ na condição de PAV das misturas com PPA, para o ligante asfáltico da Lubnor. 
Nota-se um comportamento semelhante ao encontrado para as misturas na condição RTFOT, porém com valores de $a_{f}$ maiores, com valor máximo de $1,34 \mathrm{~mm}$. Em relação ao efeito dos componentes, apresentado na Figura 121 (b), ambos os modificadores têm efeito linear, aumentando o valor de $a_{f}$. O copolímero SBS apresenta variação média da recuperação provocada pelo aumento de $1 \%$ na proporção deste modificador de $0,10 \mathrm{~mm}$, enquanto o ácido apresenta um aumento de $0,08 \mathrm{~mm}$ com a adição de $1 \%$ na proporção do PPA, indicando que o efeito do copolímero SBS é um pouco maior no aumento dessa propriedade. Quando os dois ácidos utilizados, verificou-se que o PPA apresentou valores superiores para $a_{f}$, na proporção de 1,10 vezes superiores na condição PAV, porém na condição RTFOT os ácidos apresentaram valores similares.

$\mathrm{Na}$ Tabela 96 estão apresentados os modelos de regressão obtidos para cada ligante modificado (para o ligante asfáltico de base da Lubnor) para as amostras com a adição de PA85 e PPA, para tolerância à fadiga $\left(\mathrm{a}_{\mathrm{f}}\right)$.

Tabela 96 - Modelos de regressão da tolerância à fadiga (af).

\begin{tabular}{ccc}
\hline Propriedade & Modelo de Regressão & $\mathbf{R}^{\mathbf{2}} \mathbf{( \% )}$ \\
\hline PA85 RTFOT & $0,631 x_{1}+4,404 x_{2}+8,607 x_{3}$ & 88,59 \\
PPA RTFOT & $0,649 x_{1}+4,426 x_{2}+7,011 x_{3}$ & 81,05 \\
PA85 PAV & $0,8 x_{1}+4,6 x_{2}+414,1 x_{3}-424 x_{1} x_{3}$ & 85,50 \\
PPA PAV & $0,8 x_{1}+5,5 x_{2}+505,4 x_{3}-514,5 x_{1} x_{3}$ & 91,34 \\
\hline
\end{tabular}

X1= asfalto; $x_{2}$ : SBS e $x_{3}$ : ácido em porcentagem.

No intuito de resumir os efeitos de cada componente, dos ligantes asfálticos modificados somente com adição de ácidos e com adição do copolímero SBS juntamente com os ácidos, é apresentada a Tabela 97 e Tabela 98, para o ligante asfáltico de base da Replan e da Lubnor, respectivamente. Nestas tabelas pode-se verificar os efeitos dos componentes nos ligantes asfálticos modificados, para as propriedades monitoradas no presente trabalho. O sinal (+) indica um aumento na propriedade, enquanto o sinal (-) demonstra sua redução. Quando o efeito não é monotônico, é indicado em até qual ou a partir de qual concentração a propriedade aumenta ou diminui. 
Tabela 97 - Efeitos dos componentes nas propriedades monitoradas para os ligantes asfálticos modificados (Replan).

\begin{tabular}{|c|c|c|c|c|c|c|}
\hline \multirow{3}{*}{ Propriedade } & \multicolumn{6}{|c|}{ Tipo de Modificador } \\
\hline & \multirow{2}{*}{ PPA } & \multirow{2}{*}{ PA85 } & \multicolumn{2}{|c|}{ SBS +PPA } & \multicolumn{2}{|c|}{ SBS +PA85 } \\
\hline & & & SBS & PPA & SBS & PA85 \\
\hline Penetração Virgem & - & - & - & - & - & - \\
\hline Penetração RTFOT & - & - & - & Aumenta até $2,5 \%$ & - & Aumenta até $2,5 \%$ \\
\hline Penetração Retida & + & + & + & + & + & + \\
\hline Ponto de Amolecimento Virgem & + & + & + & + & + & + \\
\hline Ponto de Amolecimento RTFOT & + & + & + & + & + & + \\
\hline Incremento do Ponto de Am. & + & + & Aumenta até 1,9\% & + & Aumenta até $1,5 \%$ & + \\
\hline Viscosidade Virgem & + & + & + & + & + & + \\
\hline Viscosidade RTFOT & + & + & + & + & + & + \\
\hline Perda de Massa & + & + & - & + & - & + \\
\hline Estabilidade à estocagem & Não se aplica & Não se aplica & + & - & + & - \\
\hline Recuperação & + & + & + & + & + & + \\
\hline Compliância Não Recuperável & - & - & - & - & - & - \\
\hline Tolerância à fadiga (af) & + & + & + & + & + & + \\
\hline Capacidade de Suporte de Tráfego & + & + & + & + & + & + \\
\hline
\end{tabular}


Tabela 98 - Efeitos dos componentes nas propriedades monitoradas para os ligantes asfálticos modificados (Lubnor).

\begin{tabular}{|c|c|c|c|c|c|c|}
\hline & \multicolumn{6}{|c|}{ Tipo de Modificador } \\
\hline & \multirow{2}{*}{ PPA } & \multirow{2}{*}{ PA85 } & \multicolumn{2}{|l|}{ SBS +PPA } & \multicolumn{2}{|l|}{ SBS +PA85 } \\
\hline & & & SBS & PPA & SBS & PA85 \\
\hline Penetração Virgem & - & - & - & - & - & - \\
\hline Penetração RTFOT & - & - & - & - & - & - \\
\hline Penetração Retida & + & + & - & + & - & + \\
\hline Ponto de Amolecimento Virgem & + & + & + & + & + & + \\
\hline Ponto de Amolecimento RTFOT & + & + & + & + & + & + \\
\hline Incremento do Ponto de Am. & + & + & - & + & - & + \\
\hline Viscosidade Virgem & + & + & + & + & + & + \\
\hline Viscosidade RTFOT & + & + & + & + & + & + \\
\hline Perda de Massa & + & + & - & + & - & + \\
\hline Estabilidade à estocagem & Não se aplica & Não se aplica & Aumenta até $2,5 \%$ & - & Aumenta até $2,5 \%$ & - \\
\hline Recuperação & + & + & + & + & + & + \\
\hline Compliância Não Recuperável & - & - & - & - & - & - \\
\hline Tolerância à fadiga (af) & + & + & + & + & + & + \\
\hline Capacidade de Suporte de Tráfego & $\begin{array}{c}\text { Aumenta para } \\
\text { teores acima de } \\
1,0 \%\end{array}$ & $\begin{array}{c}\text { Aumenta para } \\
\text { teores acima de } \\
1,0 \%\end{array}$ & $\begin{array}{l}\text { Aumenta com adição } \\
\text { acima de } 2,5 \%\end{array}$ & + & $\begin{array}{l}\text { Aumenta com adição } \\
\text { acima de } 2,5 \%\end{array}$ & + \\
\hline
\end{tabular}




\subsubsection{Considerações Finais}

De maneira geral, as adições dos modificadores nos ligantes asfálticos de base estudadas diminuem o valor da penetração, aumentam o ponto de amolecimento e a viscosidade, e reduzem a sensibilidade ao envelhecimento. Pode-se constatar que, na condição virgem, a adição dos ácidos não alterou as propriedades de penetração e ponto de amolecimento, quando comparadas às dos ligantes asfálticos modificados somente com o copolímero SBS. Para altos teores dos modificadores nota-se um aumento na consistência dos materiais modificados, e consequentemente, alterações nestas propriedades, assim como na condição e envelhecimento em curto prazo.

Foi possível verificar que o comportamento do ligante asfáltico modificado é dependente do ligante asfáltico de base, visto que nota-se comportamentos diferentes à luz das propriedades avaliadas para os dois tipos de ligante asfálticos utilizados, independente do modificador adicionado. A adição dos modificadores foi mais expressiva para o ligante asfáltico de base da Replan, pois as misturas modificadas produzidas com este ligante asfáltico de base apresentaram maiores alterações nos valores das propriedades quando comparadas com as do ligante asfáltico não modificado. No entanto, o ligante asfáltico de base da Lubnor se mostrou menos sensível ao envelhecimento e apresentou melhor comportamento em relação à estabilidade à estocagem.

Apesar do ligante asfáltico de base da Lubnor apresentar valores maiores de viscosidade quando comparado ao ligante asfáltico proveniente da Replan, a adição dos modificadores proporcionaram temperaturas de usinagem e compactação maiores para o ligante asfáltica da Replan, de acordo com as demais propriedades que apontam que a adição destes modificadores foi mais expressiva para este ligante asfáltico de base. Quanto à perda de massa, foi constatado maior sensibilidade ao envelhecimento para os ligantes asfálticos com adição de PA85 do que com PPA. Notou-se comportamento diferente na perda de massa nos ligantes asfálticos com adição somente do copolímero SBS, apesar de todas as misturas atenderem os requisitos estabelecidos pela norma, pois para o ligante asfáltico de base a perda das misturas com esse modificador apresentaram perdas muito semelhantes à do ligante asfáltico de base, porém para o ligante asfáltico da Replan as misturas sofreram processo de oxidação e tiveram o valor da massa final aumentado.

Os modificadores não apresentaram boa compatibilidade com os ligantes asfálticos de base, apresentando valores acima do especificado para a estabilidade à estocagem, com exceção das misturas com baixos teores do copolímero SBS para o ligante asfáltico de base da Lubnor, cuja adição dos ácidos melhorou a estabilidade à estocagem dos materiais.

As adições dos modificadores melhoraram o comportamento dos materiais em relação à recuperação, e todos os ligantes asfálticos modificados atenderam o requisito da norma 
referente à mudança no nível de tensão aplicada. As modificações permitiram que os materiais apresentassem maior capacidade de suporte de tráfego, independente do ácido utilizado, na temperatura de serviço considerada de $64^{\circ} \mathrm{C}$. Apesar de apresentarem mesmo comportamento à luz da classificação da capacidade de suporte de tráfego, o ligante asfáltico da Replan, que sofre maior influência da adição dos modificadores, apresenta maior capacidade de suporte de tráfego do que os ligantes asfálticos modificados produzidos com o Lubnor. Ao considerar essa classificação, constatou-se que a adição de altos teores dos modificadores não é interessante devido ao fato de se produzirem ligantes asfálticos modificados com mesma classificação que os menos modificados. Para o ligante asfáltico da Replan a adição de baixos teores do copolímero SBS e ácidos seria suficiente, enquanto para o ligante asfáltico proveniente da Lubnor modificados com baixos teores do copolímero SBS e altos de ácidos atenderiam à mesma capacidade, sendo que para este ligante asfáltico de base a adição somente de baixos teores do copolímero SBS não melhora a capacidade de tráfego do ligante asfáltico sem modificação.

Cabe destacar ainda que, a adição de altos teores do copolímero SBS, aqui representado pelo ligante asfáltico com 5,0\% SBS, apresentaram valores das propriedades avaliadas no intervalo entre as misturas de 2,5SBS+0,75Ácido e 2,5SBS+1,5Ácido, independentemente do tipo de ácido e ligante asfáltico de base utilizado, indicando que a adição dos ácidos permite a redução do copolímero SBS.

Dentro deste contexto, a adição dos modificadores, melhora o comportamento dos ligantes asfálticos, tendo em vista que os tornam mais consistentes, melhoram a recuperação, ficam menos sensíveis à deformação permanente (menores valores de $\mathrm{J}_{\mathrm{nr}}$ ) e os tornam mais tolerantes à fadiga (maiores valores de $\mathrm{a}_{\mathrm{f}}$ ). No entanto, a adição destes modificadores só é benéfica em pavimentos com estrutura com pequenas deformações, visto que nesta situação apresentam valores de número de ciclos na ruptura $\left(\mathrm{N}_{\mathrm{f}}\right)$ superiores ao ligantes asfáltico de base sem modificação. Para situações com estruturas com grandes deformações, a adição destes modificadores diminui o número de ciclos na ruptura (menores valores de $\mathrm{N}_{\mathrm{f}}$ ) não sendo recomendável sua utilização. 


\section{Considerações Finais e Conclusões}

Este trabalho teve como objetivo analisar o efeito da adição de agentes fosfóricos (ácidos fosfórico e polifosfórico) no comportamento reológico de diferentes ligantes asfálticos puros e modificados com o copolímero SBS. Para isso a pesquisa foi dividida em duas fases: (a) incorporação somente dos ácidos em dois ligantes asfálticos de base diferentes (Replan e Lubnor); (b) incorporação do copolímero SBS com e sem a presença dos ácidos nos mesmos ligantes asfálticos de base. Para avaliação das amostras foram realizados ensaios empíricos e reológicos nos ligantes asfálticos. A seguir estão apresentadas as principais conclusões acerca dos materiais estudados.

\subsection{Apontamentos sobre os ligantes asfálticos modificados somente com ácidos}

Nesta primeira fase foram produzidas 7 (sete) amostras diferentes para cada tipo de ligante asfáltico de base. No total foram avaliadas 14 misturas diferentes. Os teores produzidos foram de 0,5\%, 1,0\% e 1,5\% para cada tipo de ácido (PPA e PA85) em cada um dos ligantes asfálticos de base. As propriedades avaliadas foram: o grau de desempenho, ensaio de penetração, ensaio de ponto de amolecimento, viscosidade rotacional, temperatura de usinagem e de compactação, ensaio de fluência e recuperação sob tensão múltipla (MSCR), ensaio de tolerância ao dano por fadiga. A seguir estão apresentadas as principais conclusões acerca dessas propriedades.

Grau de desempenho: A adição dos dois ácidos proporcionou o mesmo comportamento no que se refere ao grau de desempenho dos ligantes asfálticos. No entanto, o comportamento foi dependente do tipo de ligante asfáltico de base. Para o ligante asfáltico de base da Replan, o aumento nos teores dos ácidos proporciona o aumento do grau de desempenho. No entanto, para o ligante asfáltico de base da Lubnor, a adição de teores intermediários e altos produziram o mesmo grau de desempenho. Sendo assim, o ligante asfáltico proveniente da Replan é mais sensível à adição dos ácidos, tornando-o mais adequado para modificação com ácidos, pois exige menos consumo dos modificadores para obter graus de desempenho mais elevados. 
Ensaio de Penetração: A adição dos ácidos proporcionaram misturas mais consistentes que, por sua vez, apresentam valores menores de penetração. Para o ligante asfáltico da Replan, a adição de baixos teores de PA85 não é benéfica, uma vez que estas amostras apresentaram valores de penetração similares ao do ligante asfáltico de base, tanto na condição virgem quanto na envelhecida em curto prazo. As amostras com adição de PA85 se mostraram mais sensíveis ao envelhecimento. Para este ligante asfáltico de base, à luz da penetração, para utilizar o PA85 como modificador almejando os mesmos resultados da adição do PPA seria necessário um adicional de $0,5 \%$ de PA85. No entanto, no ligante asfáltico de base do Lubnor, os ácidos também proporcionam valores inferiores de penetração, porém os valores desta propriedade, independentemente do modificador e do teor, foram similares.

Ensaio de Ponto de Amolecimento: A adição dos ácidos proporcionou um aumento no valor do ponto de amolecimento dos materiais. Para o ligante asfáltico de base da Replan a adição de teores baixos e intermediários $(0,5 \%$ e $1,0 \%)$ os valores de ponto de amolecimento foram similares para ambos os ácidos, porém para concentrações mais altas $(1,5 \%)$ o efeito da adição do PPA é um pouco mais expressivo. A adição destes modificadores no ligante asfáltico de base da Lubnor apresentou, independentemente do modificador e do teor, valores próximos. Para esta propriedade as amostras produzidas com o ligante asfáltico de base da Replan foram mais sensíveis ao efeito do envelhecimento quando comparadas com as amostras produzidas com o ligante asfáltico de base proveniente da Lubnor.

Viscosidade Rotacional: De maneira geral, independente do modificador e do ligante asfáltico de base, foi observado que à medida que se aumenta o teor dos modificadores tem-se um aumento no valor da viscosidade dos materiais. Para as amostras produzidas com o ligante asfáltico de base da Replan esta propriedade teve comportamento similar ao do ponto de amolecimento, ou seja, as adições de teores baixos e intermediários $(0,5 \%$ e 1,0\%) proporcionaram valores de viscosidade próximos, porém para concentrações mais altas $(1,5 \%)$, o efeito da adição do PPA é um pouco mais expressivo. Para o ligante asfáltico de base da Lubnor, para todos os teores, foi constatado que o efeito do PPA foi mais intenso do que o do PA85. Apesar do aumento da viscosidade, todas as amostras, independente do ligante asfáltico de base, do tipo de modificador e do teor, se enquadram nas especificações Superpave que indica o valor máximo de $3 \mathrm{~Pa} . \mathrm{s}$ na temperatura de $135^{\circ} \mathrm{C}$ para a viscosidade. As amostras modificadas com PA85 foram mais susceptíveis ao efeito do envelhecimento, para ambos os ligantes asfálticos de base, porém mesmo assim, apresentam valores inferiores de viscosidade quando comparados com as das amostras modificadas com PPA. 
Temperatura de usinagem e compactação: As temperaturas de usinagem e compactação encontradas para as ligantes asfálticos modificados, independente do ligante asfáltico de base, do modificador e do teor, foram superiores às temperaturas de usinagem e compactação dos ligantes asfálticos de base. Para o ligante asfáltico de base da Replan com teores baixos de modificadores, as temperaturas de usinagem e compactação, para ambos, modificadores são próximas, e para teores intermediários a altos tem-se temperaturas mais elevadas para as amostras modificadas com o PPA. No entanto, para as amostras produzidas com o ligante asfáltico de base da Lubnor, as temperaturas de usinagem e compactação ficaram praticamente iguais para teores baixos a intermediários dos ácidos, porém para altos teores foram encontradas temperaturas mais elevadas para amostras modificadas com PPA. Apesar do aumento nas temperaturas de usinagem e compactação para ambos os ligantes asfálticos de base, nenhuma temperatura ultrapassou a $177^{\circ} \mathrm{C}$.

Balanço de Massa: Para todas as amostras testadas observou-se maior perda de massa com o aumento do teor dos modificadores. Para ambos os ligantes asfálticos de base, as amostras modificadas com PA85 apresentaram maiores perdas de massa quando comparadas com as amostras modificadas com PPA. Em relação aos ligantes asfálticos de base, o ligante asfáltico proveniente da Replan apresentou perdas superiores às do ligante asfáltico da Lubnor. Apesar das considerações anteriores, todas as amostras se enquadraram no limite de $0,5 \%$ especificado pelo Regulamento Técnico 03/2005.

Ensaio de Fluência e Recuperação (MSCR): Neste ensaio é avaliada a recuperação dos materiais e a compliância não recuperável que está atrelada à tolerância do material à deformação permanente. De maneira geral, os valores de recuperação aumentam com o teor de modificadores, mas diminuem com o aumento da temperatura e da tensão. Quanto á compliância não recuperável, independente da tensão aplicada, ela aumenta com o aumento da temperatura e diminui com a adição dos modificadores.

Para o ligante asfáltico de base da Replan a adição de PPA foi mais benéfica para a recuperação dos materiais, apresentando valores maiores para esta propriedade. Para este modificador, as amostras com adição dos ácidos apresentaram mais sensibilidade à mudança do nível de tensão. A adição do PA85 também aumentou os valores da recuperação quando comparados com o do ligante asfáltico de base, mas com intensidade menor que as amostras com adição de PPA. Quanto à sensibilidade à mudança do nível de tensão, as amostras com adição de PA85 apresentaram mesmo comportamento que as amostras modificadas com o PPA. Ao analisar esta propriedade na temperatura de interesse $\left(64^{\circ} \mathrm{C}\right)$, pode-se observar que, na tensão de $100 \mathrm{~Pa}$, todos os teores adicionados dos modificadores são viáveis. Para a 
tensão de 3200Pa todos os teores adicionados de PPA são benéficos, e para o PA85, teores acima de $1,0 \%$.

Foi observado o mesmo comportamento para o ligante asfáltico da Lubnor. No entanto, os valores da recuperação para as amostras produzidas com este ligante asfáltico de base foram menores que as do ligante asfáltico da Replan. Ao considerar a temperatura de interesse analisada no presente trabalho $\left(64^{\circ} \mathrm{C}\right)$, apenas a adição de teores acima de $1,0 \%$, na tensão de 100Pa seria benéfica para este tipo de ligante asfáltico de base, enquanto para tensão de $3200 \mathrm{~Pa}$, somente adição de 1,5\% dos modificadores seria interessante.

Em relação às diferenças percentuais entre as compliâncias não recuperáveis, todas as amostras atendem o limite estipulado da norma AASHTO MP19 de não ultrapassarem $75 \%$.

Quanto à capacidade de suporte de tráfego, considerando os dados referentes à temperatura de $64^{\circ} \mathrm{C}$, as amostras produzidas com ligante asfáltico da Replan apresentaram, em todos os teores de modificadores, melhora na capacidade de tráfego. Já para o ligante asfáltico de base da Lubnor, somente adições de concentração acima de 1,0\% apontam melhoria para a capacidade de tráfego.

Ensaio de Tolerância à fadiga: As amostras foram avaliadas mediante ensaio do LAS modificado e pela análise do dano contínuo viscoelástico (VECD). Os ligantes asfálticos da Replan apresentaram, com o aumento dos teores dos modificadores, comprimento da fissura na ruptura $\left(\mathrm{a}_{\mathrm{f}}\right)$ maiores que os do ligante asfáltico de base.

O efeito dos ácidos é similar para teores baixos e intermediários, independente do ligante asfáltico de base utilizado, sendo um pouco mais expressivo no teor de 1,5\% para amostras modificadas com PPA. Este ensaio aponta um efeito benéfico do envelhecimento a longo prazo, uma vez que, para esta condição, os valores de $a_{f}$ encontrados foram superiores.

No que se refere ao número de ciclo na falha por fadiga $\left(\mathrm{N}_{\mathrm{f}}\right)$, a adição dos modificadores é benéfica para pavimentos sujeitos a deformações pequenas (maiores valores de $\mathrm{N}_{\mathrm{f}}$ ), porém não apresenta benefícios em pavimentos sujeitos a grandes deformações (menores valores de $\mathrm{N}_{f}$ ). Os valores encontrados de $\mathrm{N}_{\mathrm{f}}$ foram maiores no condicionamento a longo prazo (PAV), indicando que em baixas deformações a rigidez provocada pelo envelhecimento é benéfica para esta propriedade, pois aumenta o número de solicitações até ocorrer falha.

O comportamento desta propriedade para as amostras produzidas com os dois ligantes asfálticos de base são semelhantes, no entanto, o ligante asfáltico proveniente da Replan apresentou maiores valores de $a_{f}$ e $N_{f}$, sendo mais sensível ao efeito da adição dos modificadores. 


\subsection{Apontamentos sobre os ligantes asfálticos modificados com o copolímero SBS com ou sem a presença dos ácidos.}

Nesta segunda fase foram produzidas 16 (dezesseis) amostras diferentes para cada tipo de ligante asfáltico de base. No total foram avaliadas 34 misturas diferentes, considerando os ligantes asfálticos puros. O número de amostras produzidas foi determinado pelo experimento de misturas com ligantes asfálticos modicados somente com SBS, e com adição dos ácidos. Para isto foram definidos os limites máximos de cada modificador, sendo $5 \%$ o máximo para o copolímero SBS e 1,5\% para os ácidos. As propriedades avaliadas foram: ensaio de penetração, ensaio de ponto de amolecimento, viscosidade rotacional, temperatura de usinagem e de compactação, ensaio de fluência e recuperação sob tensão múltipla (MSCR), ensaio de tolerância ao dano por fadiga. As principais conclusões verificadas para esta fase do trabalho estão apresentadas a seguir.

Ensaio de Penetração: Todos os ligantes asfálticos modificados apresentaram valores inferiores de penetração quando comparados com as dos ligantes asfálticos de base, visto que aumentam a rigidez destes materiais. A adição somente do copolímero SBS foi mais expressiva para o ligante asfáltico da Lubnor, porém os ligantes asfálticos modificados com os dois modificadores (copolímero SBS e ácidos) apresentaram mesmo comportamento à luz desta propriedade para os dois ligantes asfálticos de base. A adição do ácido PPA foi um pouco mais expressiva do que a adição do PA85, independente do ligante asfáltico de base. No que diz respeito ao efeito dos componentes, na condição virgem, para os dois ligante asfálticos de base, os componentes tendem a reduzir o valor da penetração. No entanto, na condição envelhecida em curto prazo, observou-se comportamento diferente para os dois ligantes asfálticos de base, enquanto para o ligante asfáltico proveniente da Lubnor os ácidos e copolímero SBS tendem reduzir a penetração, para o ligante asfáltico da Replan, o copolímero SBS aumenta o valor de penetração até a concentração de $2,5 \%$ e os ácidos reduzem esta propriedade em qualquer proporção.

Quanto à penetração retida, a adição dos modificadores torna os ligantes asfálticos menos sensíveis ao envelhecimento, apresentando maiores valores de penetração retida. Para o ligante asfáltico da Replan, as misturas que apresentaram menor sensibilidade ao envelhecimento foram as mais modificadas. Neste ligante asfáltico de base, ambos os ácidos e o copolímero SBS tendem a aumentar o valor da penetração retira, ajudando a reduzir a sensibilidade ao envelhecimento a curto prazo. No entanto, para o ligante asfáltico da Lubnor, os ligantes asfálticos menos sensíveis ao envelhecimento foram os modificados com altos teores do copolímero SBS e altos teores dos ácidos. Diferentemente do efeito encontrado para o ligante asfáltico da Replan, para este ligante asfáltico de base, o copolímero SBS 
apresenta uma leve tendência de aumentar a penetração retida, enquanto os ácidos reduzem esta propriedade. O efeito do PA85 é mais expressivo no aumento da penetração retida no ligante asfáltico da Replan, enquanto o PPA é mais expressivo na diminuição do valor da penetração retida no ligante asfáltico do Lubnor; sendo assim, pode-se dizer que, para esta propriedade, a adição de PA85 é menos sensível ao envelhecimento.

Ponto de Amolecimento: $\mathrm{O}$ valor do ponto de amolecimento aumenta com a adição dos modificadores quando comparado ao do ligante asfáltico puro. Para os dois tipos de ligantes asfáltico de base, nota-se que a adição de qualquer proporção dos ácidos e do copolímero SBS proporcionou efeito quando comparado com os ligantes somente com o copolímero SBS. Em relação ao efeito dos componentes, independe do ligante asfáltico de base e do tipo de ácido utilizado, na condição virgem, o copolímero SBS e os ácidos tendem aumentar o ponto de amolecimento, sendo o efeito do ácido mais expressivo. Para a mesma propriedade avaliada na condição de envelhecimento a curto prazo, o efeito dos componentes também é de aumentar o valor do ponto de amolecimento, porém o ácido PPA tem efeito mais expressivo do que o PA85.

Quanto ao incremento do ponto de amolecimento, para o ligante asfáltico de base da Replan, o efeito dos componentes foi parabólico para o copolímero SBS, com ponto de máximo de 1,5\% nas misturas PA85 e 1,9\% para misturas com PPA; enquanto os ácidos proporcionam um aumento do incremento do ponto de amolecimento, sendo seus valores similares. Cabe ressaltar que, ao considerar o valor de $8^{\circ} \mathrm{C}$ como limite máximo para este incremento, pela análise dos gráficos de superfície de resposta, nota-se maiores possibilidades de misturas com adição de PA85 do que de PPA, indicando que as misturas com adição de PPA foram mais sensíveis ao envelhecimento.

No tocante a essa propriedade para o ligante asfáltico da Lubnor, o efeito dos componentes são antagônicos, os ácidos tendem a aumentar o incremento do ponto de amolecimento e o copolímero SBS a diminuir, sendo que para misturas com o PPA, o copolímero SBS tem efeito inexpressivo. Para este ligante asfáltico de base, todas as misturas com adição de PA85 atenderam o limite de $8^{\circ} \mathrm{C}$, enquanto para as misturas modificadas com o PPA, somente a mistura mais modificada (5SBS+1,5PPA), não atendeu este limite.

Viscosidade Rotacional: De maneira geral, a adição dos modificadores aumenta o valor da viscosidade destes materiais, devido ao aumento de rigidez. Os componentes tendem a aumentar o valor dessa propriedade, sendo o efeito do PPA maior que o do PA85, independente do ligante asfáltico de base e da temperatura. O efeito dos componentes diminui com o aumento da temperatura, assim como os valores de viscosidade. 
No que diz respeito ao limite de 3 Pa.s para a viscosidade na temperatura de $135^{\circ} \mathrm{C}$, para o ligante asfáltico da Replan nota-se que um maior número de misturas com adição de PA85 atendem a esse critério do que com adição de PPA, independente do ligante asfáltico de base. Para o ligante asfáltico da Replan com adição do PA85, a composição das misturas que atendem este limite é de 4,2SBS+1,5PA85 e 5SBS+1,2PA85, enquanto para as misturas com adição de PPA, o limite é 2,5SBS+1,5PPA e 5SBS+0,75PPA, praticamente metade dos teores dos modificadores do outro ácido. Já para o ligante asfáltico da Lubnor, a quantidade de misturas que atendem este critério é maior, devido ao fato do efeito dos modificadores ser menor, sendo que para o ácido do PA85 as misturas limites são 4,7SBS+1,5PA85 e 5SBS+1,3PA85, enquanto para as misturas com PPA são 4,4SBS+1,5PA85 e $5 S B S+1,1 P A 85$, indicando que, para este ligante asfáltico de base, o efeito do PPA foi mais próximo do efeito causado pela adição do PA85. Dentro deste contexto, verifica-se que o ligante asfáltico da Replan é mais influenciado pela adição dos modificadores, e que apesar de comportamentos semelhantes, a ação do PPA é mais expressiva do que a do PA85.

Balanço de Massa: Foram verificados comportamentos diferentes para os ligantes asfálticos de base, visto que para o ligante asfáltico da Replan, a adição de qualquer tipo de modificador proporciona perda de voláteis dos materiais, fazendo com que os ligantes modificados apresentem perda de massa maior que o ligante asfáltico de base. No entanto, os ligantes asfálticos com a adição somente do copolímero SBS, independente do teor, para o ligante asfáltico de base da Lubnor, apresentaram ganho de massa, o que indica que ocorreu a oxidação do material no processo de envelhecimento. Para este ligante asfáltico de base, os ligantes asfálticos modificados com baixos teores do copolímero SBS e ácidos, apresentaram perdas de massa inferior ao do ligante asfáltico de base. Apesar de todas as misturas se enquadrarem nos limites de norma $(0,5 \%)$, de maneira geral, as misturas com adição de PA85 apresentaram maiores perdas que as misturas com PPA. Nota-se também maior sensibilidade ao envelhecimento do ligante asfáltico da Replan. Quanto ao efeito dos componentes, verificou-se efeitos antagônicos, sendo que os ácidos tendem a aumentar a perda de massa, enquanto do copolímero SBS a diminuí-la, sendo o efeito do copolímero SBS mais intenso para o ligante asfáltico da Lubnor.

Estabilidade à estocagem: Pode-se constatar que a adição dos ácidos melhorou o comportamento de todas as misturas frente à estocagem, para o ligante asfáltico da Replan, enquanto que para o ligante asfáltico da Lubnor a adição só foi benéfica para misturas com altos teores do copolímero SBS. Quanto ao limite estabelecido de $5^{\circ} \mathrm{C}$, tem-se um maior número de misturas adequadas para os ligantes asfálticos modificados com PA85, independente do ligante asfáltico de base utilizado. Quanto ao efeito dos componentes, para 
o ligante asfáltico da Replan, os ácidos tendem a melhorar a estabilidade à estocagem, diminuindo a diferença entre os pontos de amolecimento do topo e fundo dos materiais, enquanto o copolímero SBS apresenta a tendência de prejudicar a estabilidade à estocagem. No entanto, para o ligante asfáltico da Lubnor, o copolímero SBS apresentou efeito parabólico, com ponto de máximo em $2,5 \%$, enquanto o ácido tende diminuir a diferença entre o ponto de amolecimento do topo e fundo, melhorando o comportamento do material no que diz respeito a estabilidade à estocagem. Sendo assim, percebe-se um melhor comportamento para o ligante asfáltico da Lubnor quando analisado essa propriedade.

Ensaio de Fluência e Recuperação sob Tensões Múltiplas: A adição dos modificadores aumenta os valores de recuperação e diminui os valores de compliância não recuperável quando comparados com o ligante asfáltico puro. Sendo assim, melhora o comportamento de recuperação e a sensibilidade destes materiais à deformação permanente, independente do ligante asfáltico de base utilizado. Os aumentos da temperatura e da tensão proporcionam uma diminuição dos valores de recuperação e aumento da compliância não recuperável, independente do ligante asfáltico de base. A adição dos modificadores apresentou maior efeito para o ligante asfáltico da Replan, apresentando maiores valores de recuperação e menores de compliância não recuperável do que os do ligante asfáltico da Lubnor. De maneira geral, o efeito dos componentes são similares para os dois tipos de ácidos e ligantes asfálticos de base, aumentando o valor da recuperação e diminuindo os valores de compliância não recuperável.

Quanto à capacidade de suporte de tráfego, para o ligante asfáltico de base da Replan, qualquer concentração dos modificadores melhora seu comportamento em relação ao do ligante asfáltico de base. No entanto, a adição de baixos teores do copolímero SBS com baixos teores de ácido seriam suficientes para suportar um tráfego extremamente pesado. Para o ligante asfáltico da Lubnor, a adição somente de baixa concentração de SBS não é suficiente para melhorar a capacidade de suporte de tráfego do ligante asfáltico de base; a adição de baixas concentrações do copolímero SBS e dos ácidos permite que este ligantes asfálticos suportem um tráfego pesado, porém somente as misturas com baixas concentrações do copolímero SBS e com altas concentrações dos ácidos são capazes de suportar um tráfego extremamente pesado. Cabe destacar que, para esta classificação, os ácidos apresentaram comportamento semelhante.

Tolerância ao dano por fadiga: Na análise do parâmetro $\mathrm{a}_{\mathrm{f}}$, notou-se que a adição dos modificadores tornou as misturas menos sensíveis ao dano por fadiga, apresentando valores de $a_{f}$ maiores que os encontrados para os ligantes asfálticos de base. $O$ efeito dos modificadores, assim como nas demais propriedades, foi mais intenso para o ligante asfáltico 
da Replan. O envelhecimento foi benéfico para esta propriedade, pois amostras envelhecidas a longo prazo (PAV) apresentaram valores de $a_{f}$ maiores que as amostras envelhecidas a curto prazo. Para esta propriedade o efeito dos componentes são semelhantes, tendem a aumentar o $\mathrm{a}_{\mathrm{f}}$, porém nesta propriedade o efeito do copolímero SBS foi mais expressivo do que o dos ácidos.

Quanto à análise do dano viscoelástico através dos parâmetros $A_{35}$ e $B$, e dos valores dos números de ciclos na falha por fadiga $\left(\mathrm{N}_{\mathrm{f}}\right)$, independente do ligante asfáltico de base utilizado, constatou-se um aumento nos valores de $A_{35}$ e diminuição dos valores de $B$, sendo que maiores valores de $A_{35}$ seriam favoráveis, pois os materiais estariam preservando sua integridade ao longo do número de ciclos. Sendo assim, independente do ligante asfáltico de base e do tipo de modificador adicionado, foi verificado que para pavimentos submetidos a pequenas deformações (comportamento deflectométrico mais próximo do rígido), a adição de modificadores é benéfica, apresentando maiores valores de $N_{f}$, porém para pavimentos submetidos a grandes deformações, a adição dos modificações não se mostrou favorável, pois se verificou redução da vida de fadiga com a modificação dos ligantes asfálticos de base. $\mathrm{O}$ envelhecimento a longo prazo (PAV) é benéfico para estruturas com pequenas deformações e prejudicial para grandes deformações.

\subsection{Considerações Finais}

A adição do ácido PA85 foi satisfatória, tendo em vista que proporcionou comportamento semelhante ao do PPA. Quando avaliados os ligantes asfálticos somente com adição dos ácidos, contatou-se que para a propriedade referente à deformação permanente seria necessário a adição de $20 \%$ a mais de PA85 para se obter o mesmo comportamento dos ligantes modificados com PPA. Para as misturas com adição conjunta com o copolímero SBS foi possível constatar efeito semelhante dos ácidos, porém efeito mais expressivo para as misturas com adição do PPA.

O comportamento dos ligantes asfálticos modificados são dependentes do tipo de ligante asfáltico de base, independente do tipo de modificador utilizado, sendo que esta modificação foi mais expressiva no ligante asfáltico da Replan do que no ligante asfáltico proveniente da Lubnor.

De maneira geral, a adição dos modificadores melhora o comportamento dos ligantes asfálticos de base. Analisando os materiais, testados pela presente pesquisa, em relação às propriedades que avaliam os ligantes asfálticos no que se refere à tolerância destes aos principais defeitos do pavimento, deformação permanente e fadiga, tem-se que a adição dos modificadores proporcionaram um aumento no valor da recuperação e uma diminuição dos 
valores de compliância não recuperável, o que torna estes materiais menos sensíveis à deformação permanente. Quanto à vida de fadiga, a adição dos modificadores se mostrou favorável para pavimentos sujeitos a pequenas deformações (comportamento deflectométrico mais próximo do rígido), porém foi verificada uma redução da vida de fadiga em pavimentos sujeito a grandes deformações.

Ao considerar a classificação de suporte de tráfego, para misturas somente com adição dos ácidos, o aumento da concentração desses modificadores é favorável devido ao fato de aumentarem sua capacidade de suporte de tráfego. No entanto, para misturas com adição do copolímero SBS e ácidos constatou-se que a adição de altos teores dos modificadores não é interessante devido ao fato de produzirem ligantes asfálticos modificados capazes de suportar o mesmo tráfego que os menos modificados. Sendo assim, para o ligante asfáltico da Replan a adição de baixos teores do copolímero SBS e ácidos seria suficiente (2,5SBS+0,75Ácido) para suportar um tráfego extremamente pesado, enquanto para o ligante asfáltico proveniente da Lubnor seria necessário adição de baixos teores do copolímero SBS e altos de ácidos (2,5SBS+1,5Ácido), independente do tipo de ácido adicionado.

Foi verificado que a adição de ambos os ácidos permite a redução do copolímero SBS, sendo que, de maneira geral, os ligantes asfálticos modificados com adição de $5,0 \%$ do copolímero SBS apresentaram valores das propriedades monitoras entre os valores encontrados para as misturas de 2,5SBS+0,75Ácido e 2,5SBS+1,5Ácido.

E por fim, foi constatado pela adição do ácido uma melhora na estabilidade à estocagem para todos os ligantes asfálticos modificados produzidos com o Replan, e para ligantes asfálticos produzidos com o Lubnor com altas concentrações dos modificadores. 


\section{Referências Bibliográficas}

Airey, G. (2003). Rheological properties of styrene butadiene styrene polymer modified road bitumens. Fuel, 82(14), pp. 1709-1719.

Anderson, A., Hir, L., Marasteanu, O., Planche, P., Martin, D., \& Gauther, G. (2001). Evaluation of fatigue criteria for asphalt binders. Transportation Research Record, 48-56.

Anderson, M., D'Angelo, J., \& Walker, D. (2010). MSCR: A better tool for characterizing high temperature performance properties. Asphalt - The magazineof the Asphalt Institute, pp. 15-16, 18, 21-23.

Arnold, T. (2008). Phosphoric Acid as an Asphalt Modifier Guidelines for Use: Acid Type. FHWA.

Arnold, T., Youtcheff, J., \& Needham, P. (2009). Use of Phosphoric Acid as Modifier for HotMix Asphalt. Polyphosphoric Acid Modification of Asphalt Binders (pp. 40-51). Minneapolis- Minnesota: Transportation Research Board.

Asphalt Institute. (2010a). Implementation of the multiple stress creep recovery test and specification. Asphast Institute Technical Advisory Committee in cooperation with Federal Highway Administration.

Bahia, H. (1993). Bibliographies for physical properties of asphalt cement. Strategic Highway Research Program, SHRP-A-626(National Academy of Sciences).

Bahia, H. U., Hanson, D. I., Zeng, K., Zhai, H., Khatri, M. A., \& Anderson, R. M. (2001). NCHRP Report 459: Characterization of modified asphalt binders . Naciona Cooperative Highway Research Program. Washington.

Bahia, H., \& Anderson, D. (1995). Strategic Highway Research Program Binder Rheological Parameters: Background and comparison with conventional properties. Transportation Research Record(n. 1488), p.32-39. 
Bahia, H., Hanson, D., Zeng, M., Zhai, H., Khatri, M., \& Anderson, R. (2001). Characterization of Modified Asphalt Binders in Superpave Mix Design. WASHINGTON: NCHRP Report 459.

Bahia, H., Onnetti, H., \& Kose, K. (1999). Non-Linear viscoelastic and Fatigue Properties of Asphalt Binders. Journal of the Association of Asphalt Technologist, 1-34.

Barnes, H., Hutton, J., \& Walters, K. (1993). An Introdution of Rheology. Elsevier.

Baumgardnet, G. L., Masson, J. F., \& Hardee, J. R. (2005). Polyphosphoric acid modified asphalt: proposed mechanisms. Journal of the Association of Asphalt Paving Tecnologists., 283-205.

Bernnet, T., \& Martin, J. (2012). Polyphosphoric Acid in Combination with Styrene-ButadieneStyrene Block Copolymer. Transportation Research Board Circular E-C 160, pp. 7085

Bernucci, L., Motta, L., Ceratti, J., \& Soares, J. (2006). Pavimentação asfáltica: Formação para engenheiros. Rio de Janeiro: Petrobras.

Cao, W.-d., Liu, S.-t., \& Mao, H.-I. (2010). Experimental Study on Polyphosphoric Acid (PPA) Modified Asphalt Binders. New Materials and Advanced Materials, pp. 288-294.

CNT. (2012). Boletim de Pesquisa CNT de Rodovias.

Corbertt, L. (abril de 1969). Composition of asphalt based on generic fractionation, using solvent deasphaltening, elution-adsorption chromatography, and densimetric characterization. Analytical Chemistry, pp. 580-583.

Cornell, J. (2002). Experiments with mixtures: design, models and the analysis of mixture data. New York: John Wiley.

D'Angelo, A. (Abril de 2009). Effect of Polyphosphoric Acid on Asphalt Binder Properties. Polyphosphoric Acid Modification of Asphalt Binders, pp. 27-39. 
D'Angelo, J. (2010). The multiple stress creep recovery (MSCR) procedure. . Technical Brief prepared by the United States Department of Transportation, Federal Highway Administration.

D'Angelo, J., \& Dongré, R. (2009). Practical Use of Multiple Stress Creep and Recovery Test: Characterization of Styrene-Butadiene-Styrene Dispersion and Other Additives in Polymer-Modified Asphalt Binders. Transportation Research Record., pp. 73-82.

Delgadillo, R., Cho, D., \& Bahia, H. (2006). Nonlinearity of Repeated Creep and Recovery Binder test and Relationship with Mixture Permanent Deformation. Transportation Research Record, 3-11.

DNER. (1997). Glossário de Termos Técnicos Rodoviários. Rio de Janeiro.

DNIT. (2003.). DNIT 005/2003 - TER Defeitos nos pavimentos flexíveis e semi-rígidos Terminologia . Rio de Janeiro.

Domingos, M., \& Faxina, A. (2013). Avaliação do comportamento fluência-recuperação de ligantes asfálticos modificados com SBS e PPA. Revista Transporte, pp. 51-58.

Edwards, Y., Tasdemir, Y., \& Isacsson, U. (2006). Rheological effects of commercial waxes and polyphosphoric acid in bitumen 160/220 - low temperature performance. Fuel, pp. 989-997.

Faxina, A. (2010). Peculiaridades do comportamento reológico de ligantes asfálticos modificados de mesmo grau de desempenho. 40 RAPV - Reunião Anual de Pavimentação.

Faxina, A., Fabbri, G., \& Soares, J. (2009). Efeito da adição de ácido polifosfórico sobre o comportamento reológico de um cap 50/70. IV Simpósio Internacional de Avaliação de Pavimentos e Projetos de Reforço.

Faxina, L. (2006). Estudo da viabilidade técnica do uso do óleo de xisto como óleo extensor em ligantes asfalto-borracha. Universidade de São Paulo, São Carlos.

Fee, D., Maldonado, R., Reinke, G., \& Romagosa, H. (2010). Polyphosphoric acid modification of asphalt. Annual Meeting of TRB , (p. 18). 
Fernandes, R., Fortes, M., \& Leite, F. (2008). Reologia de asfaltos modificados com SBS. Instituto Brasileiro de Petróleo, Gás e Biocombustíveis - IBP.

FHWA. (Março de 2012). The Use Performance of Asphalt Binder Modified with Polyphosphoric Acid (PPA).

Filippis, D., Giavarini, C., \& Scarsella, M. (1995). Improving the ageing resistance of straightrun bitumens by addition of phosphoric compounds. Fuel, 836-840.

Fillipis, P., Giavarini, C., \& Santarelli, M. L. (1992). Reaction of phosphoric acid with thermal residues and bitumens. Fuel science and technology, 1671-1690.

Giavarini, C., Filippis,, P., Santarelli, , L. M., \& Scars, M. (1996). Production of stable polyphopylene-modified. Fuel, pp. 495-502.

Giavarini, C., Mastrofini, D., Scarsella, M., Barre, L., \& Espinat, D. (2000). Macrostructure and rheological properties of chemically modified residues and bitumens. Energy and Fuels., pp. 495-502.

Grande, D. R., Furlan, P. A., Gigante, C. A., Klinsky, G. M., \& Fabbri, P. T. (2009). Efeitos da cal hidratada e do ácido polifosfórico na suscetibilidade térmica de misturas asfálticas densas. ANPET.

Grande, W. (2011). Efeito da cal hidratada e do ácido polifosfórico nas propriedades mecânicas e suscetibilidade à umidade de misturas asfálticas densas. Dissertação de Mestrado. EESC/USP.

Herrington, P. R., Wu, Y., \& Forbes, M. C. (1999). Rheological Modification of Bitumen with Maleic Anhydride and Dicarboxylic Acids. Fuel, 78.

Hintz, C. (2012). Understanding Mechanisms Leading to Asphalt Binder Fatigue. University of Wisconsin - Madison, Phd.

IPEA. (2010). Rodovias Brasileiras: Gargalos, investimentos, concessões e preoucupações com o futuro. 
Johnson, C. (2010). Estimating asphalt binder fatigue resistance using an accerated test method. University of Wisconsin - Madison: Phd.

Joliet, Y., \& Mallot, M. (2000). Precautions when interpreting rutting results from the LCPC traffic simulater. $2^{\circ}$ Eurasphalt \& Eurobitume Congress Barcelona.

Kanabar, N. (December de 2010). Comparasion of ethylene terpolymer, styrene butadiene, and polyphosphoric acid type modifiers for asphalt cement. Canada: Queen's University (Thesis).

Kim, S., Sholar, G., Byron, T., \& Kim, J. (2009). Performance of polymer-modified asphalt mixture with reclaimed asphalt pavement. Transportation Research Record., pp. 109114.

Kodrat, I., Sohn, D., \& Hesp, S. A. (2007). Asphalt Binders with straight and polumer-modified materials. Transportation Research Record, 47-55.

Leite. (1999). Estudos de preparo e caracterização de asfaltos modificados por polímeros. Rio de Janeiro, Universidade Federal do Rio: Tese.

Leite, M. F., Bittencourt, B. C., \& Nascimento, H. A. (2004). Efeito do ácido polifosfórico no desempenho dos ligantes rodoviários. ANPET.

Lesueur, D. (2009). The colloidal structure of bitumen: Consequence on the rheology and on the mechanisms of bitumen modification. Advances in Colloid and Interface Science, pp. 42-82.

Loeber, L., Muller, J., Morel, J., \& Sutton, O. (1998). Bitumen in colloid science: a chemical, structural and rheological approach. Fuel, 1443-1450.

Lu, X., \& Isacsson, U. (maio de 1997). Influence of styrene-butadiene-styrene polymer modification on bitumen viscosity. Elsevier, pp. 1353-1359.

Lu, X., \& Isacsson, U. (1997b). Influence of syrene-butadiene-styrene polymer modification on bitumen viscosity. Fuel, pp. 1353-1359. 
Lucena, M., Soares, J., Soares, S., \& Leite, L. (2004). Reologia e asfaltos brasileiros puros e modificados com SBS. ANPET.

Maldonado, R., Shulga, O., Romagosa, H., Dongre, R., \& D'Angelo, J. (2012). The effect of processing conditions on the performance of hybrid (SBS+PPA) modified binders. 5th Eurasphalt \& Eurobitumen Congress.

Malkin, A. Y. (1994). Rheology Fundamentals. ChemTec Publishing.

Mano, E. B., \& Mendes, L. C. (1999). Introdução a Polímeros. São Paulo: Blucher.

Martin, J. V., \& Baumgardner, G. (2006). A new to produce polymer modifier asphalt with crumb rubber and poluphosphoric acid: combining recycling and performance. Asphalt Rubber, pp. 903-930.

Masson, J. F., Price, T., \& Collins, P. (2001). Dynamics of bitumen fractions by thin-layer chromatography/flame ionization detection. Energy and Fuel, 955-960.

Masson, J.-F. (2008). Brief Review of the Chemistry of Polyphosphoric Acid (PPA) and Bitumen. Energy and Fuels, pp. 2637-2640.

Montgomery, D. C., \& Peck, E. A. (1992). Introduction to linear regression analysis. 2ed. New York: John Wiley.

Morilha, J. (2004). Estudo sobre ação de modificadores no envelhecimento dos ligantes asfálticos e nas propriedades mecânicas e de fadiga das misturas asfálticas. Florianópolis, Universidade Federal de Santa Catarina: Dissertação (mestrado).

Mortazavi, M., \& Moulthrop, J. (1993). Materials Reference Library. Washington D. C.: National Research Council: SHRP report A-646.

Motta, L., Tonial, I., Leite, L., \& Constantino, R. (1996). Príncipios do projeto e análise superpave de misturas asfálticas. Rio de Janeiro: Instituto Brasileiro de Petróleo.

Moura, E. (2010). Estudo da deformação permanente em trilha de roda misturas asfálticas em pista em laboratório. São Paulo: Tese. 
Navarro, R. (1997). Fundamentos de reologia de polímeros. Caxias do Sul: EDUCS.

Nuñez, J. (2013). Caracterização à fadiga de ligantes asfálticos modificados envelhecidos a curto e a longo prazo. Dissertação de Mestrado. EESC/USP.

Nuñez, J., Faxina, A., Gigante, A., Domingos, M., \& Suarez, D. (2012). Propriedades mecânicas de misturas asfálticas preparadas com ligantes asfálticos modificados de mesmo grau de desempenho. Associação Nacional de Pesquisa e Ensino em Transportes - ANPET.

Orange, G., Dupuis, D., Martin, J. V., Farcas, F., Such, c., \& Marcant, B. (2004). Chemical modification of bitumen trhough polyphosphoric acid: properties - microstruture relationship. $3^{a}$ Eurasphalt \& Eurobitumen Congress, (p. 13). Vienna.

Pamplona, T. (2013). Efeito da adição de ácido polifosfórico em ligantes asfálticos de diferentes fontes. Dissertação de Mestrado. Universidade de São Paulo. EESCDepartamento de Transportes.

Pfeiffer, J. P., \& Saal, R. N. (1939). Asphaltic Bitumenas Colloid System. Sixteenth Colloid Symposium (pp. 139-149). California: Stanford University.

Pinheiro, J. (2004). Incorporação de Borracha de Pneu em Misturas Asfálticas de DiferentesGranulometrias (Processos Úmido e Seco). Dissertação.

Pulzic, O., \& Williamson, K. E. (2002). US Patente No 6414056B1.

Robinson, H. (2004). Polymers in Asphalt. Rapra Review Reports ISSN 0889-3144, 1-33.

Shell. (2003). The Shell bitumen handbook (Fifth edition ed.).

Shulga, O., Maldonado, R., Lewandowski, L., \& Romagosa, H. (2012). Aplication of Polyphosphoric Acid for HMA Modification. US and European Experience. 5th Eurasphalt \& Eurobitume Congress, Istanbul,.

Silva. (2005). Contribuição ao estudo do envelhecimento de ligantes asfálticos. Influência da adição de polímeros e comportamento frente a radiação UV. Porto Alegre, Universidade Federal do Rio Grande do Sul: Tese. 
Silva, L. S., Forte, M. M., Specht, L. P., \& Ceratti, J. A. (2002). Polímeros como Modificadores Asfálticos. 10(01).

Soenen, H., \& Eckmann, B. (2004). Fatigue testing of bitumens binders with a dynamic shear rheometer. Eurasphalt \& Eurobitumen Congress, (p. 827). Barcelona.

Thomas, P., \& Turner, F. (2008). Polyphosphoric acid modification of asphalt binders: impact on rheological and thermal properties. Road Materials and Pavement Design, 181-205.

Tonial, I. (2001). Influência do envelhecimento do revestimento asfáltico na vida de fadiga dos pavimentos. Universidade Federal do Rio: Dissertação (mestrado).

Trakarnpruk, W., \& Chanathup, R. (2005). Physical and Rheological Properties of Asphalt Modified with Polyethylene-co-methylacrylate and Acids. Journals of Metals, Materials and Minerals, pp. 79-87.

Wen, G., Zhang, Y., Zhang, Y., Sun, K., \& Fan, Y. (2002). Rheological characterization of storage-stable SBS-modified asphalts. Polymer Testing, pp. 295-302.

Wu, S., Pang, L., Mo, L., Chen, Y., \& Zhu, G. (2008). Influence of aging on the evolution of structure, morphology and rheology of base and SBS modified bitumen. Construction and Building Materials, pp. 1005-1010. 


\section{Apêndice A - Viscosidade (Replan)}

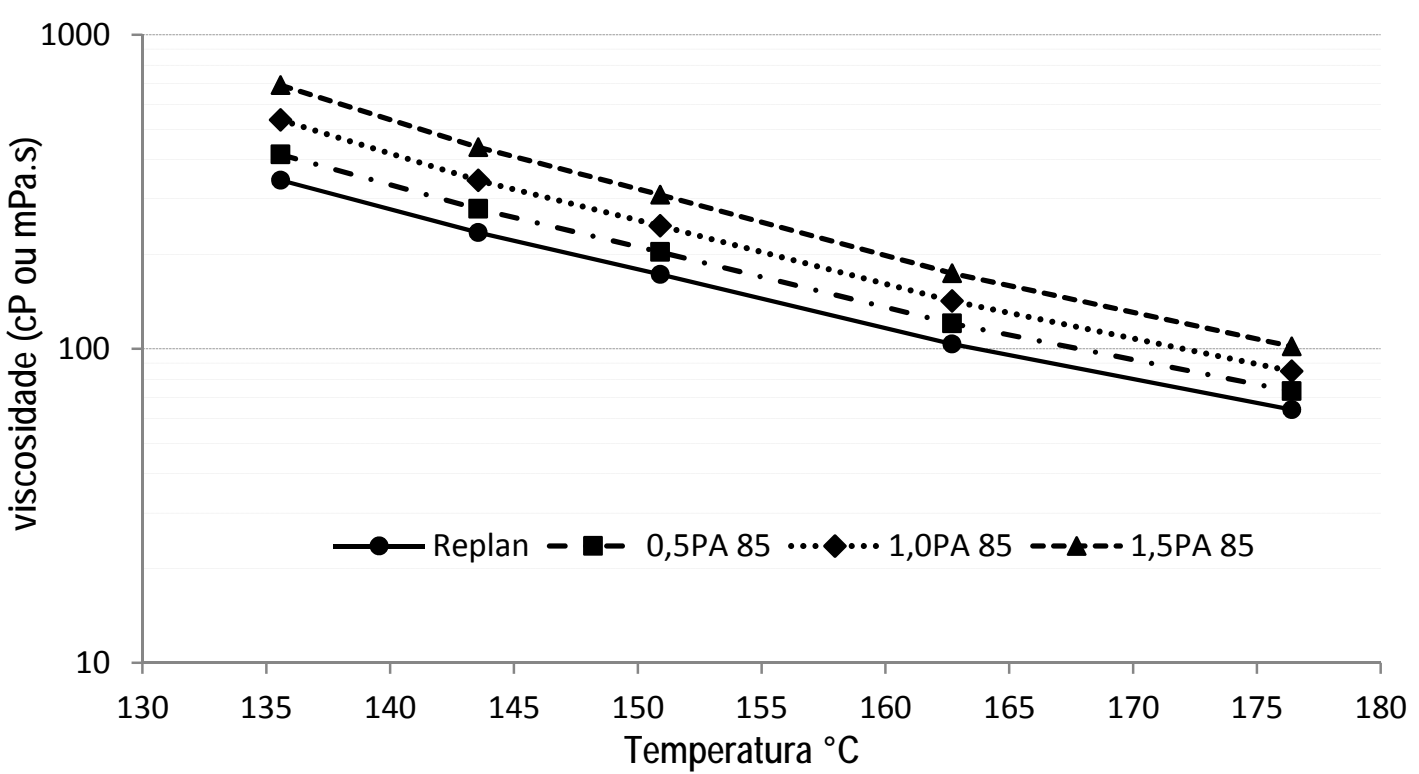

Figura 122 - Viscosidade Ligante Replan na condição Virgem com adição do ácido PA85.

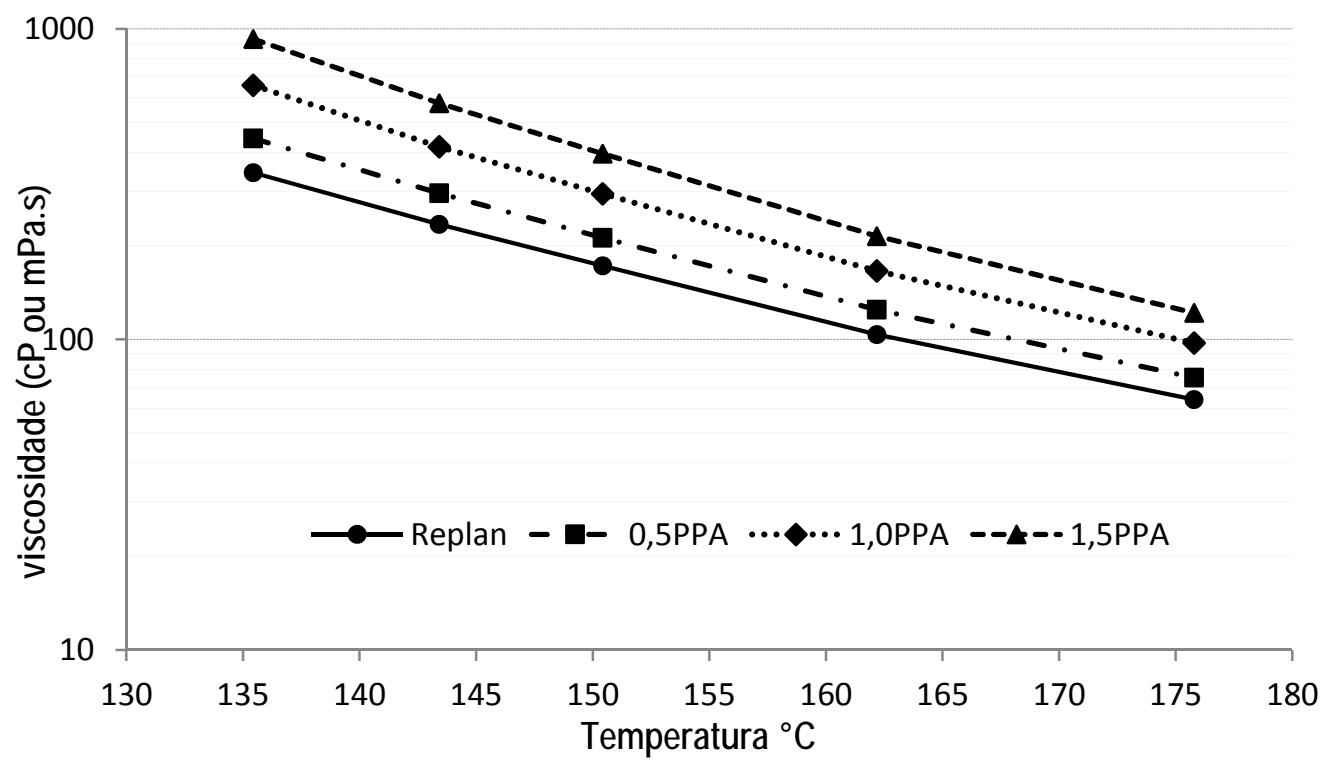

Figura 123 - Viscosidade Ligante Replan na condição Virgem com adição do ácido PPA. 


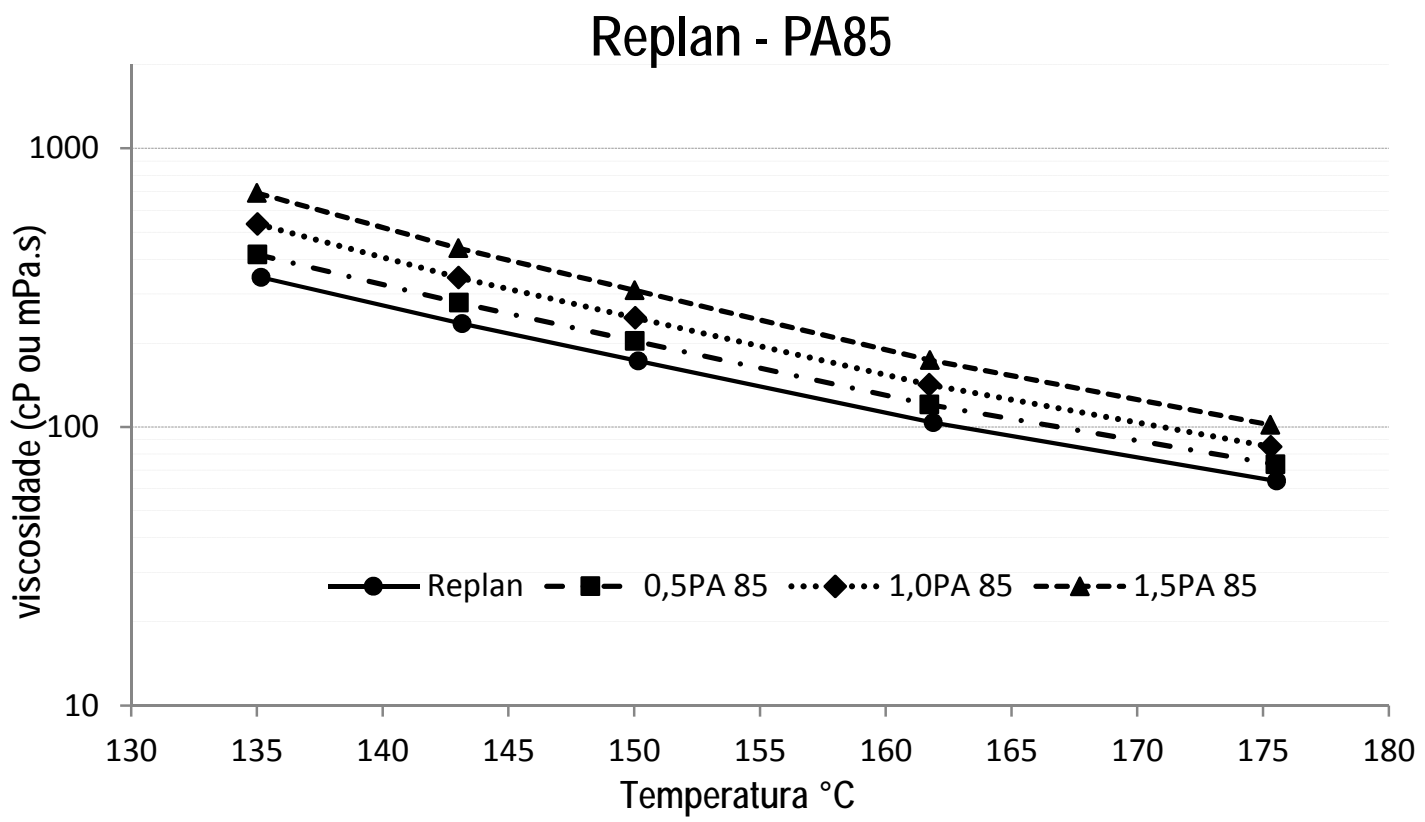

Figura 124 - Viscosidade Ligante Replan na condição RTFOT com adição do ácido PA85.

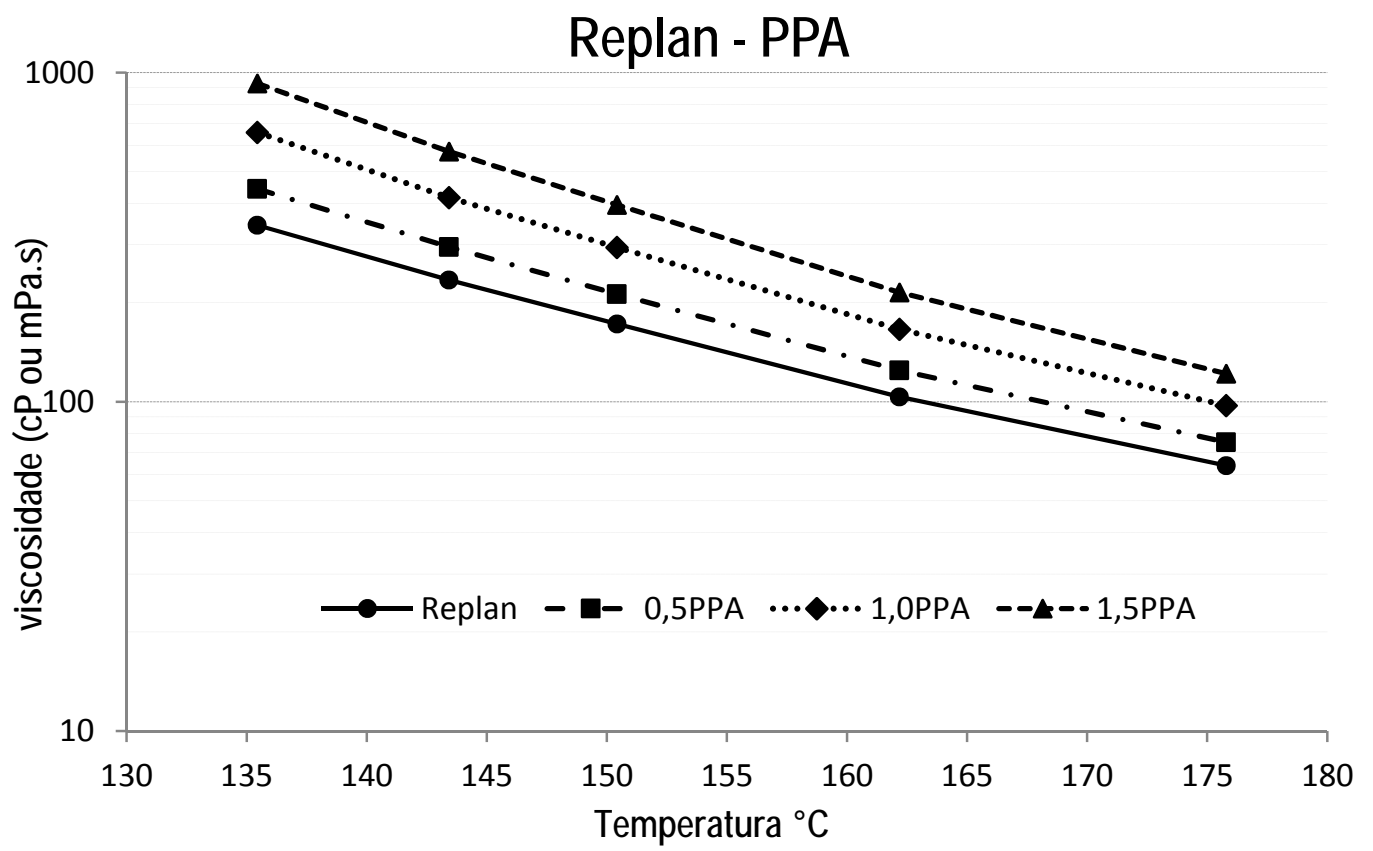

Figura 125 - Viscosidade Ligante Replan na condição RTFOT com adição do ácido PPA. 


\section{Apêndice B - Viscosidade (Lubnor)}

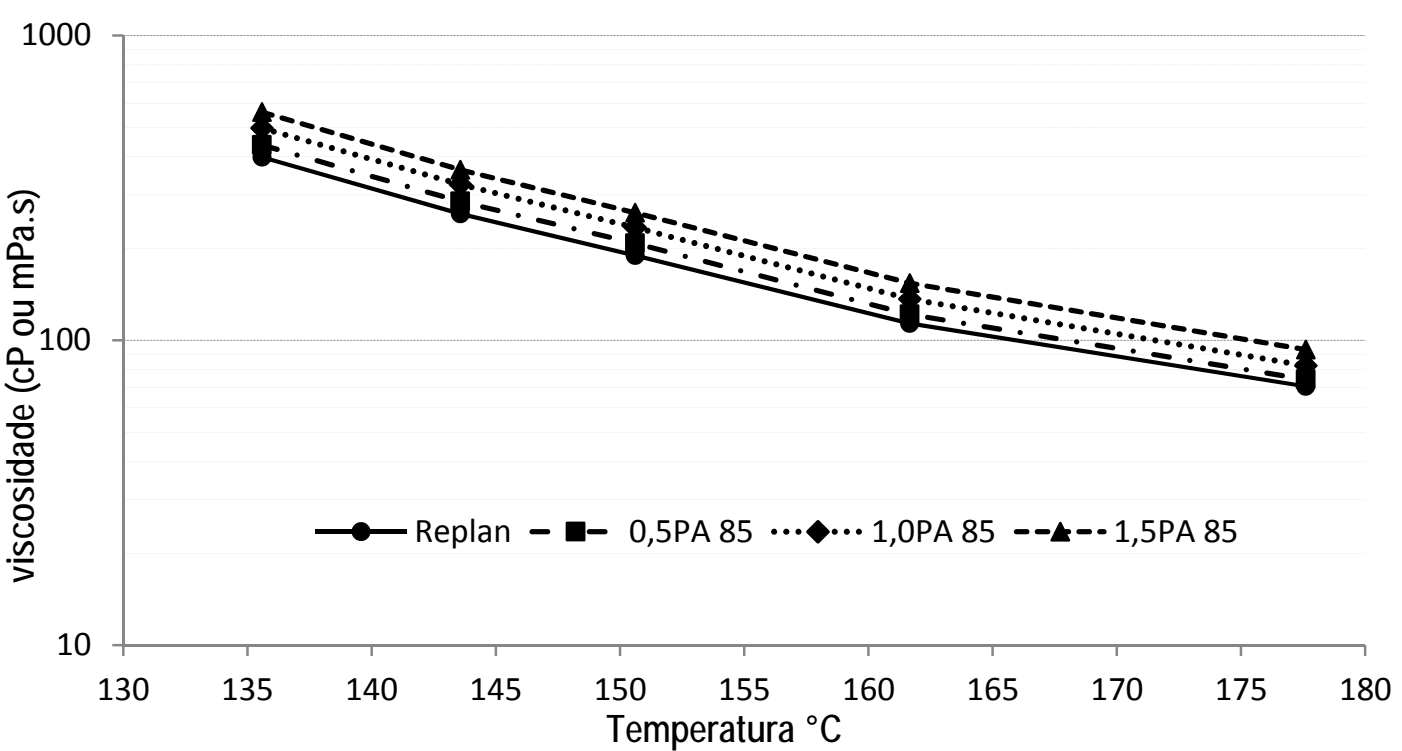

Figura 126 - Viscosidade Ligante Lubnor na condição Virgem com adição do ácido PA85.

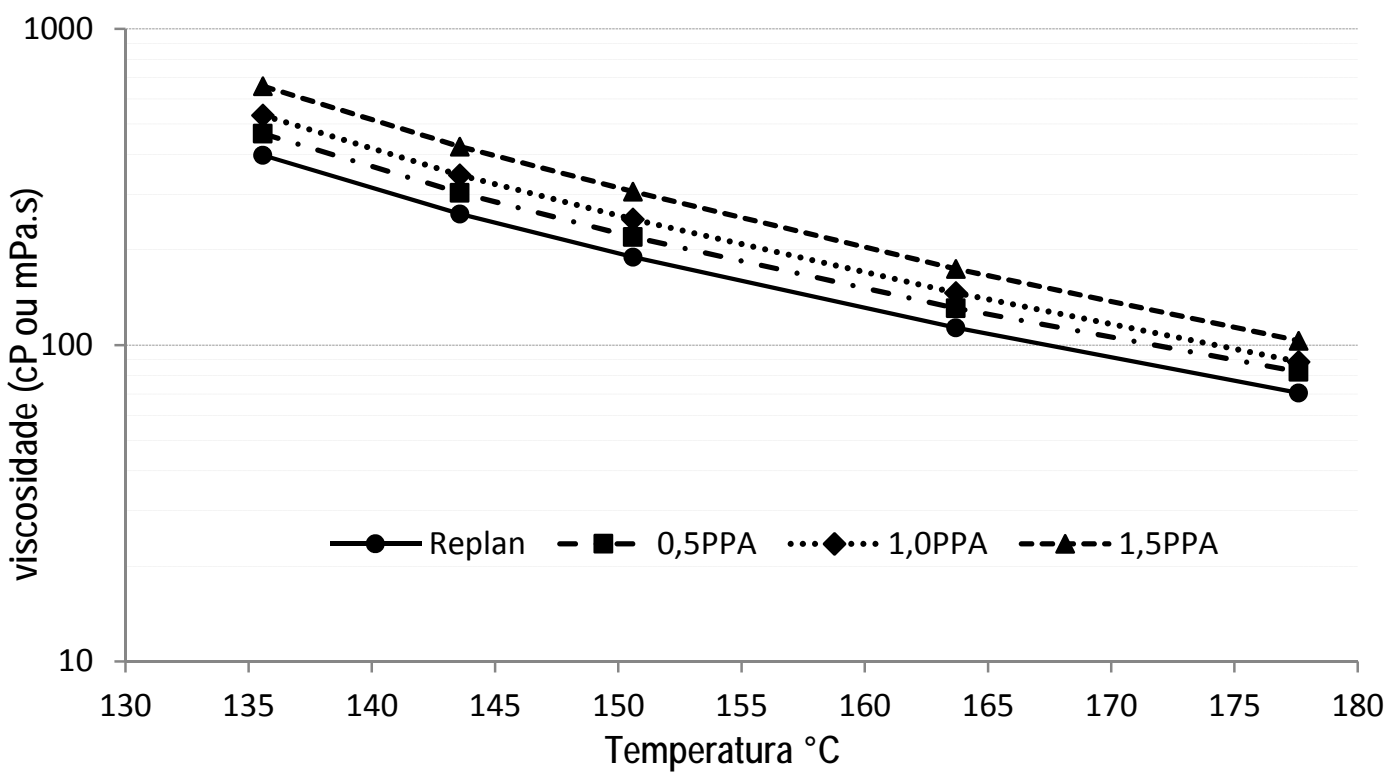

Figura 127 - Viscosidade Ligante Lubnor na condição Virgem com adição do ácido PPA. 


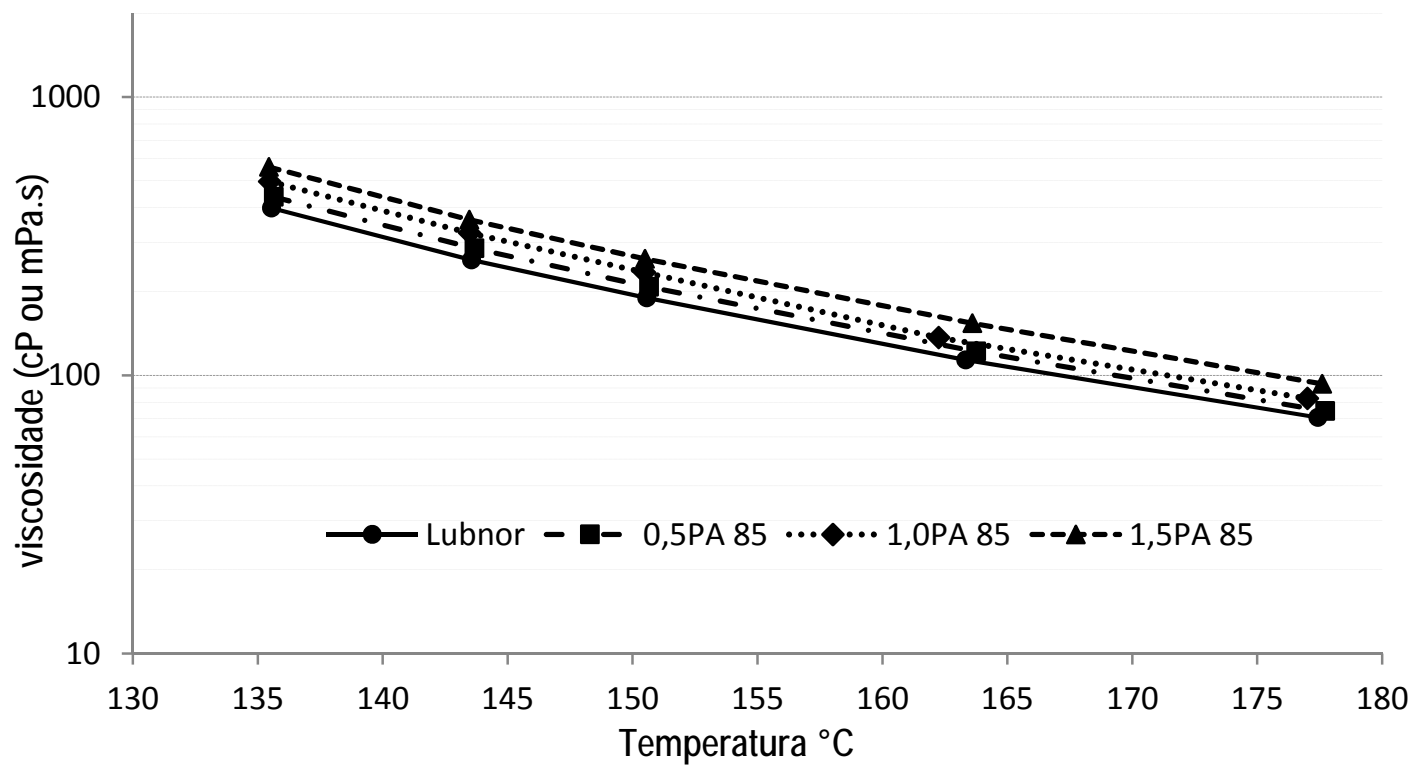

Figura 128 - Viscosidade Ligante Lubnor na condição RTFOT com adição do ácido PA85.

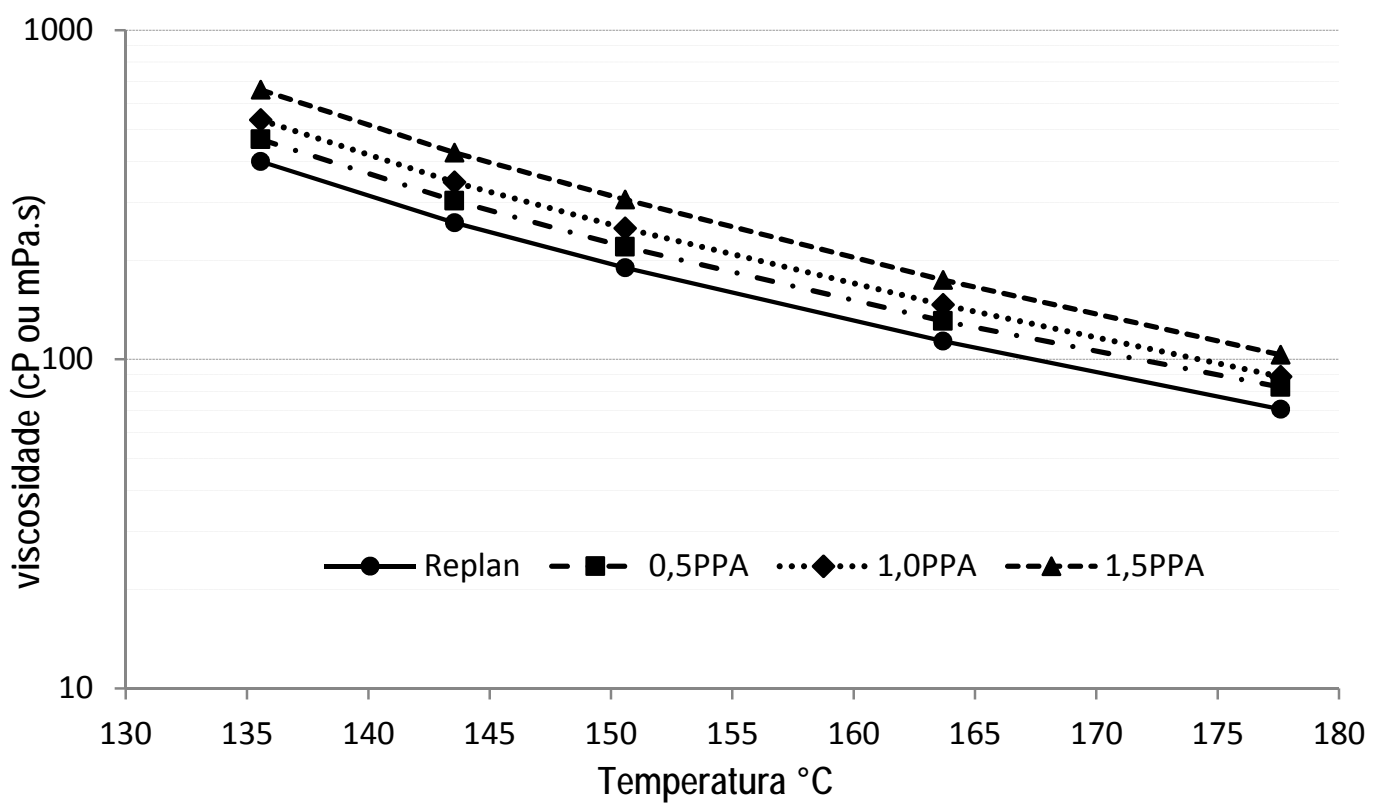

Figura 129 - Viscosidade Ligante Lubnor na condição RTFOT com adição do ácido PPA. 


\section{Apêndice C-Dados de Recuperação e Compliância não recuperável para ligantes asfálticos puros e modificados (Replan e Lubnor).}

Ligantes Asfáltico Lubnor:

\begin{tabular}{|c|c|c|c|}
\hline \multicolumn{4}{|c|}{$52^{\circ} \mathrm{C}$} \\
\hline \multicolumn{2}{|c|}{$100 \mathrm{PA}$} & \multicolumn{2}{|c|}{$3200 \mathrm{PA}$} \\
\hline $\mathbf{R}$ & C & $\mathbf{R}$ & C \\
\hline Média & Média & Média & Média \\
\hline 2,65 & 0,56 & 0,58 & 0,58 \\
\hline 2,08 & 0,55 & 0,53 & 0,57 \\
\hline 0,67 & 0,55 & 0,57 & 0,55 \\
\hline 1,74 & 0,55 & 0,55 & 0,56 \\
\hline
\end{tabular}

\begin{tabular}{|c|c|c|c|}
\hline \multicolumn{4}{|c|}{$58^{\circ} \mathrm{C}$} \\
\hline \multicolumn{2}{|c|}{$100 \mathrm{PA}$} & \multicolumn{2}{|c|}{$3200 \mathrm{PA}$} \\
\hline $\mathbf{R}$ & C & $\mathbf{R}$ & C \\
\hline Média & Média & Média & Média \\
\hline 0,00 & 1,52 & 0,00 & 1,56 \\
\hline 0,00 & 1,49 & 0,00 & 1,54 \\
\hline 0,00 & 1,45 & 0,00 & 1,51 \\
\hline 0,00 & 1,47 & 0,00 & 1,53 \\
\hline
\end{tabular}

\begin{tabular}{|c|c|c|c|}
\hline \multicolumn{4}{|c|}{$64^{\circ} \mathrm{C}$} \\
\hline \multicolumn{2}{|c|}{$100 \mathrm{PA}$} & \multicolumn{2}{|c|}{3200 PA } \\
\hline $\mathbf{R}$ & C & $\mathbf{R}$ & C \\
\hline Média & Média & Média & Média \\
\hline 0,00 & 3,60 & 0,00 & 3,89 \\
\hline 0,00 & 3,62 & 0,00 & 3,82 \\
\hline 0,00 & 3,64 & 0,00 & 3,79 \\
\hline 0,00 & 3,58 & 0,00 & 3,78 \\
\hline
\end{tabular}

\begin{tabular}{|l|l|}
\hline \multicolumn{2}{|c|}{} \\
\hline $100 \mathrm{PA}$ \\
\hline $\mathbf{R}$ & $\mathbf{C}$ \\
\hline Média & Média \\
\hline 0,00 & 8,31 \\
\hline 0,00 & 8,40 \\
\hline 0,00 & 8,27 \\
\hline 0,00 & 8,33 \\
\hline
\end{tabular}

\begin{tabular}{|c|c|}
\hline $70^{\circ} \mathrm{C}$ & \\
\hline $3200 \mathrm{~F}$ & \\
\hline $\mathbf{R}$ & C \\
\hline Média & Média \\
\hline 0,00 & 9,00 \\
\hline 0,00 & 8,85 \\
\hline 0,00 & 8,69 \\
\hline 0,00 & 8,79 \\
\hline
\end{tabular}

\begin{tabular}{|c|c|c|c|}
\hline \multicolumn{4}{|c|}{$76^{\circ} \mathrm{C}$} \\
\hline \multicolumn{2}{|c|}{$100 \mathrm{PA}$} & \multicolumn{2}{|c|}{3200 PA } \\
\hline $\mathbf{R}$ & C & $\mathbf{R}$ & C \\
\hline Média & Média & Média & Média \\
\hline 0,00 & 17,95 & 0,00 & 19,27 \\
\hline 0,00 & 17,97 & 0,00 & 18,94 \\
\hline 0,00 & 17,45 & 0,00 & 18,45 \\
\hline 0,00 & 17,71 & 0,00 & 18,85 \\
\hline
\end{tabular}

0,5PPA

\begin{tabular}{|c|c|c|c|}
\hline \multicolumn{4}{|c|}{$52^{\circ} \mathrm{C}$} \\
\hline \multicolumn{2}{|c|}{$100 \mathrm{PA}$} & \multicolumn{2}{|c|}{$3200 \mathrm{PA}$} \\
\hline $\mathbf{R}$ & C & $\mathbf{R}$ & C \\
\hline Média & Média & Média & Média \\
\hline 10,10 & 0,35 & 7,56 & 0,37 \\
\hline 10,88 & 0,35 & 7,93 & 0,36 \\
\hline 12,91 & 0,34 & 7,77 & 0,37 \\
\hline 9,80 & 0,36 & 7,20 & 0,37 \\
\hline
\end{tabular}

\begin{tabular}{|l|l|}
\hline \multicolumn{2}{|c|}{$58^{\circ}$} \\
\hline \multicolumn{2}{|c|}{100 PA } \\
\hline $\mathbf{R}$ & \multicolumn{1}{|c|}{$\mathbf{C}$} \\
\hline Média & Média \\
\hline 3,40 & 0,97 \\
\hline 4,58 & 0,94 \\
\hline 4,18 & 0,96 \\
\hline 4,45 & 0,96 \\
\hline
\end{tabular}

$58^{\circ} \mathrm{C}$

\begin{tabular}{|l|l|}
\hline \multicolumn{2}{|c|}{$3200 \mathrm{PA}$} \\
\hline $\mathbf{R}$ & \multicolumn{1}{c|}{$\mathbf{C}$} \\
\hline Média & Média \\
\hline 0,03 & 1,03 \\
\hline 0,05 & 1,02 \\
\hline 0,10 & 1,03 \\
\hline 0,21 & 1,04 \\
\hline
\end{tabular}

\begin{tabular}{|c|c|c|c|}
\hline \multicolumn{4}{|c|}{$64^{\circ} \mathrm{C}$} \\
\hline \multicolumn{2}{|c|}{$100 \mathrm{PA}$} & \multicolumn{2}{|c|}{3200 PA } \\
\hline $\mathbf{R}$ & C & $\mathbf{R}$ & C \\
\hline Média & Média & Média & Média \\
\hline 0,00 & 2,40 & 0,00 & 2,65 \\
\hline 0,00 & 2,36 & 0,00 & 2,61 \\
\hline 0,01 & 2,37 & 0,00 & 2,62 \\
\hline 0,00 & 2,39 & 0,00 & 2,65 \\
\hline
\end{tabular}

\begin{tabular}{|c|c|}
\hline \multicolumn{2}{|c|}{$70^{\circ}$} \\
\hline 100 & PA \\
\hline $\mathbf{R}$ & $\mathbf{C}$ \\
\hline Média & Média \\
\hline 0,00 & 5,60 \\
\hline 0,00 & 5,48 \\
\hline 0,00 & 5,52 \\
\hline 0,00 & 5,51 \\
\hline
\end{tabular}

$70^{\circ} \mathrm{C}$

\begin{tabular}{|c|l|}
\hline \multicolumn{2}{|c|}{3200 PA } \\
\hline $\mathbf{R}$ & \multicolumn{1}{c|}{$\mathbf{C}$} \\
\hline Média & Média \\
\hline 0,00 & 6,23 \\
\hline 0,00 & 6,14 \\
\hline 0,00 & 6,16 \\
\hline 0,00 & 6,23 \\
\hline
\end{tabular}

\begin{tabular}{|c|c|c|c|}
\hline \multicolumn{4}{|c|}{$76^{\circ} \mathrm{C}$} \\
\hline \multicolumn{2}{|c|}{$100 \mathrm{PA}$} & \multicolumn{2}{|c|}{$3200 \mathrm{PA}$} \\
\hline $\mathbf{R}$ & C & $\mathbf{R}$ & C \\
\hline Média & Média & Média & Média \\
\hline 0,00 & 12,29 & 0,00 & 13,55 \\
\hline 0,00 & 12,09 & 0,00 & 13,43 \\
\hline 0,00 & 12,18 & 0,00 & 13,59 \\
\hline 0,00 & 11,76 & 0,00 & 13,60 \\
\hline
\end{tabular}


0,5PA85

\begin{tabular}{|l|l|}
\hline \multicolumn{2}{|c|}{$52^{\circ}$} \\
\hline \multicolumn{2}{|c|}{100} \\
\hline $\mathbf{R}$ & $\mathbf{P A}$ \\
\hline Média & Média \\
\hline 11,03 & 0,38 \\
\hline 9,56 & 0,38 \\
\hline 10,56 & 0,34 \\
\hline 9,93 & 0,37 \\
\hline
\end{tabular}

\section{$52^{\circ} \mathrm{C}$}

\begin{tabular}{|c|l|}
\hline \multicolumn{2}{|c|}{3200 PA } \\
\hline $\mathbf{R}$ & \multicolumn{1}{|c|}{$\mathbf{C}$} \\
\hline Média & Média \\
\hline 6,31 & 0,41 \\
\hline 6,40 & 0,40 \\
\hline 7,93 & 0,36 \\
\hline 6,84 & 0,38 \\
\hline
\end{tabular}

\section{0,75PPA}

\begin{tabular}{|c|c|c|c|}
\hline & \multicolumn{3}{|c|}{$52^{\circ} \mathrm{C}$} \\
\hline \multicolumn{2}{|c|}{$100 \mathrm{PA}$} & \multicolumn{2}{|c|}{$3200 \mathrm{PA}$} \\
\hline $\mathbf{R}$ & C & $\mathbf{R}$ & C \\
\hline Média & Média & Média & Média \\
\hline 17,56 & 0,26 & 13,25 & 0,28 \\
\hline 16,24 & 0,26 & 13,65 & 0,27 \\
\hline 18,36 & 0,24 & 14,64 & 0,25 \\
\hline 17,65 & 0,24 & 14,76 & 0,25 \\
\hline 15,96 & 0,27 & 12,67 & 0,28 \\
\hline
\end{tabular}

\begin{tabular}{|c|c|}
\hline \multicolumn{2}{|c|}{$64^{\circ}$} \\
\hline \multicolumn{2}{|c|}{$100 \mathrm{PA}$} \\
\hline $\mathbf{R}$ & $\mathbf{C}$ \\
\hline Média & Média \\
\hline 0,90 & 2,65 \\
\hline 0,53 & 2,49 \\
\hline 0,97 & 2,29 \\
\hline 1,21 & 2,50 \\
\hline
\end{tabular}

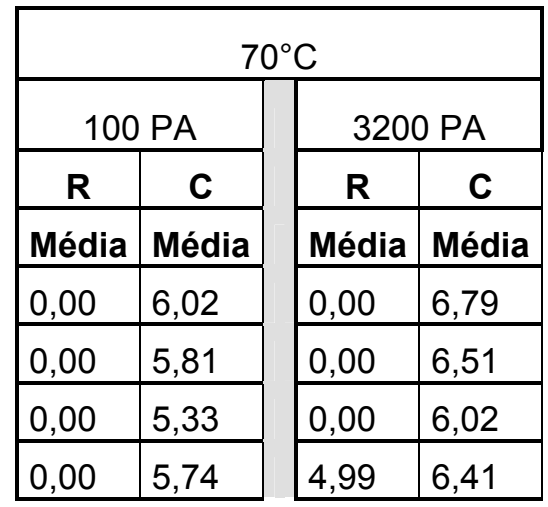

\begin{tabular}{|l|l|}
\hline 0,00 & 5,74 \\
\hline
\end{tabular}

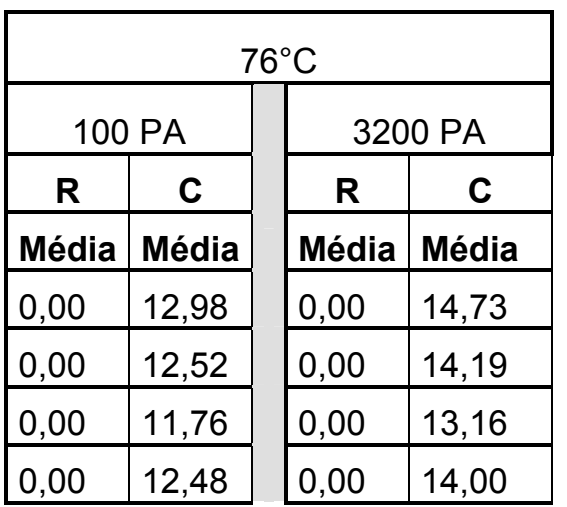

\begin{tabular}{|c|c|c|c|}
\hline \multicolumn{4}{|c|}{$70^{\circ} \mathrm{C}$} \\
\hline \multicolumn{2}{|c|}{$100 \mathrm{PA}$} & \multicolumn{2}{|c|}{3200 PA } \\
\hline $\mathbf{R}$ & C & $\mathbf{R}$ & C \\
\hline Média & Média & Média & Média \\
\hline 0,00 & 4,44 & 0,00 & 5,11 \\
\hline 0,00 & 4,34 & 0,00 & 5,00 \\
\hline 0,00 & 4,22 & 0,00 & 4,86 \\
\hline 0,00 & 4,12 & 0,00 & 4,75 \\
\hline 0,00 & 4,55 & 0,00 & 5,21 \\
\hline
\end{tabular}

\begin{tabular}{|c|c|c|c|}
\hline \multicolumn{4}{|c|}{$76^{\circ} \mathrm{C}$} \\
\hline \multicolumn{2}{|c|}{$100 \mathrm{PA}$} & \multicolumn{2}{|r|}{$3200 \mathrm{PA}$} \\
\hline $\mathbf{R}$ & C & $\mathbf{R}$ & C \\
\hline Média & Média & Média & Média \\
\hline 0,00 & 9,77 & 0,00 & 11,37 \\
\hline 0,00 & 9,66 & 0,00 & 11,16 \\
\hline 0,00 & 9,45 & 0,00 & 10,83 \\
\hline 0,00 & 9,20 & 0,00 & 10,60 \\
\hline 0,00 & 10,14 & 0,00 & 11,54 \\
\hline
\end{tabular}

\begin{tabular}{|c|c|c|c|}
\hline \multicolumn{4}{|c|}{$64^{\circ} \mathrm{C}$} \\
\hline \multicolumn{2}{|c|}{$100 \mathrm{PA}$} & \multicolumn{2}{|c|}{3200 PA } \\
\hline $\mathbf{R}$ & C & $\mathbf{R}$ & C \\
\hline Média & Média & Média & Média \\
\hline 3,61 & 1,84 & 0,00 & 2,11 \\
\hline 3,77 & 1,79 & 0,00 & 2,04 \\
\hline 2,89 & 1,75 & 0,00 & 1,98 \\
\hline 3,14 & 1,70 & 0,00 & 1,93 \\
\hline 2,35 & 1,90 & 0,00 & 2,15 \\
\hline
\end{tabular}

\begin{tabular}{|c|c|}
\hline \multicolumn{2}{|c|}{3200 PA } \\
\hline $\mathbf{R}$ & $\mathbf{C}$ \\
\hline
\end{tabular}

Média Média

\begin{tabular}{|l|l|}
\hline 3,37 & 0,80 \\
\hline 3,64 & 0,78 \\
\hline
\end{tabular}

\begin{tabular}{|l|l|}
\hline 3,64 & 0,78 \\
\hline
\end{tabular}

\begin{tabular}{|l|l|}
\hline 4,13 & 0,74 \\
\hline
\end{tabular}

\begin{tabular}{|l|l|}
\hline 4,34 & 0,72 \\
\hline 2,97 & 0,81 \\
\hline
\end{tabular}

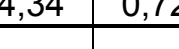

\begin{tabular}{|l|l||l|l|l|}
\hline 8,695 & 0,73 & 2,97 & 0,81 \\
\hline 8
\end{tabular}

\begin{tabular}{|l|l|}
\hline 0,00 & 10,14 \\
\hline
\end{tabular} 


\begin{tabular}{|c|c|c|c|c|c|c|c|c|c|c|c|c|c|c|c|c|c|c|c|}
\hline \multicolumn{4}{|c|}{$52^{\circ} \mathrm{C}$} & \multicolumn{4}{|c|}{$58^{\circ} \mathrm{C}$} & \multicolumn{4}{|c|}{$64^{\circ} \mathrm{C}$} & \multicolumn{4}{|c|}{$70^{\circ} \mathrm{C}$} & \multicolumn{4}{|c|}{$76^{\circ} \mathrm{C}$} \\
\hline \multicolumn{2}{|c|}{$100 \mathrm{PA}$} & \multicolumn{2}{|c|}{3200 PA } & \multicolumn{2}{|c|}{$100 \mathrm{PA}$} & \multicolumn{2}{|c|}{$3200 \mathrm{PA}$} & \multicolumn{2}{|c|}{$100 \mathrm{PA}$} & \multicolumn{2}{|c|}{3200 PA } & \multicolumn{2}{|c|}{$100 \mathrm{PA}$} & \multicolumn{2}{|c|}{3200 PA } & \multicolumn{2}{|c|}{$100 \mathrm{PA}$} & \multicolumn{2}{|c|}{$3200 \mathrm{PA}$} \\
\hline $\mathbf{R}$ & C & $\mathbf{R}$ & C & $\mathbf{R}$ & C & $\mathbf{R}$ & C & $\mathbf{R}$ & C & $\mathbf{R}$ & C & $\mathbf{R}$ & C & $\mathbf{R}$ & C & $\mathbf{R}$ & C & $\mathbf{R}$ & C \\
\hline Média & Média & Média & Média & Média & Média & Média & Média & Média & Média & Média & Média & Média & Média & Média & Média & Média & Média & Média & Média \\
\hline 15,68 & 0,29 & 11,75 & 0,31 & 7,11 & 0,81 & 2,31 & 0,88 & 2,25 & 2,01 & 0,00 & 2,28 & 0,00 & 4,83 & 0,00 & 5,50 & 0,00 & 10,68 & 0,00 & 12,06 \\
\hline 16,92 & 0,27 & 12,01 & 0,30 & 9,85 & 0,76 & 2,52 & 0,86 & 2,62 & 1,98 & 0,00 & 2,26 & 0,00 & 4,79 & 0,00 & 5,51 & 0,00 & 10,52 & 0,00 & 12,19 \\
\hline 15,55 & 0,27 & 12,63 & 0,28 & 8,19 & 0,75 & 2,79 & 0,82 & 2,35 & 1,93 & 0,00 & 2,18 & 0,00 & 4,63 & 0,00 & 5,30 & 0,00 & 10,16 & 0,00 & 11,68 \\
\hline \multicolumn{20}{|c|}{ 1,0PPA } \\
\hline \multicolumn{4}{|c|}{$52^{\circ} \mathrm{C}$} & \multicolumn{4}{|c|}{$58^{\circ} \mathrm{C}$} & \multicolumn{4}{|c|}{$64^{\circ} \mathrm{C}$} & \multicolumn{4}{|c|}{$70^{\circ} \mathrm{C}$} & \multicolumn{4}{|c|}{$76^{\circ} \mathrm{C}$} \\
\hline \multicolumn{2}{|c|}{$100 \mathrm{PA}$} & \multicolumn{2}{|c|}{3200 PA } & \multicolumn{2}{|c|}{$100 \mathrm{PA}$} & \multicolumn{2}{|c|}{3200 PA } & \multicolumn{2}{|c|}{$100 \mathrm{PA}$} & \multicolumn{2}{|c|}{$3200 \mathrm{PA}$} & 100 & $\mathrm{PA}$ & 3200 & $0 \mathrm{PA}$ & 100 & PA & 320 & $0 \mathrm{PA}$ \\
\hline $\mathbf{R}$ & C & $\mathbf{R}$ & C & $\mathbf{R}$ & C & $\mathbf{R}$ & C & $\mathbf{R}$ & C & $\mathbf{R}$ & $C$ & $\mathbf{R}$ & C & $\mathbf{R}$ & C & $\mathbf{R}$ & $C$ & $\mathbf{R}$ & $C$ \\
\hline Média & Média & Média & Média & Média & Média & Média & Média & Média & Média & Média & Média & Média & Média & Média & Média & Média & Média & Média & Média \\
\hline 23,52 & 0,19 & 19,92 & 0,21 & 13,92 & 0,54 & 7,85 & 0,60 & 6,91 & 1,39 & 0,00 & 1,61 & 1,11 & 3,35 & 0,00 & 3,95 & 0,00 & 7,50 & 0,00 & 9,02 \\
\hline 23,38 & 0,20 & 20,16 & 0,21 & 14,08 & 0,54 & 7,99 & 0,61 & 7,43 & 1,39 & 0,00 & 1,67 & 1,12 & 3,29 & 0,00 & 4,13 & 0,00 & 7,49 & 0,00 & 9,06 \\
\hline 23,51 & 0,19 & 20,16 & 0,20 & 14,39 & 0,53 & 8,13 & 0,59 & 7,94 & 1,35 & 0,00 & 1,59 & 1,15 & 3,30 & 0,00 & 3,91 & 0,00 & 7,42 & 0,00 & 8,94 \\
\hline $1,0 \mathrm{PA} 8$ & & & & & & & & & & & & & & & & & & & \\
\hline & 52 & & & & & & & & & & & & 70 & & & & & ${ }^{\circ} \mathrm{C}$ & \\
\hline 100 & $\mathrm{PA}$ & 3200 & $0 \mathrm{PA}$ & 100 & $\mathrm{PA}$ & 3200 & PA & 100 & PA & 3200 & $0 \mathrm{PA}$ & 100 & $\mathrm{PA}$ & 3200 & $0 \mathrm{PA}$ & 100 & PA & 320 & $0 \mathrm{PA}$ \\
\hline $\mathbf{R}$ & C & $\mathbf{R}$ & C & $\mathbf{R}$ & C & $\mathbf{R}$ & C & $\mathbf{R}$ & C & $\mathbf{R}$ & C & $\mathbf{R}$ & C & $\mathbf{R}$ & C & $\mathbf{R}$ & C & $\mathbf{R}$ & C \\
\hline Média & Média & Média & Média & Média & Média & Média & Média & Média & Média & Média & Média & Média & Média & Média & Média & Média & Média & Média & Média \\
\hline 21,86 & 0,21 & 18,16 & 0,22 & 13,57 & 0,57 & 6,56 & 0,64 & 6,77 & 1,47 & 0,00 & 1,75 & 2,78 & 3,56 & 0,00 & 4,33 & 0,00 & 8,09 & 0,00 & 10,01 \\
\hline 21,31 & 0,22 & 17,47 & 0,23 & 12,45 & 0,60 & 6,14 & 0,66 & 5,70 & 1,53 & 0,00 & 1,77 & 1,19 & 3,62 & 0,00 & 4,29 & 0,00 & 8,19 & 0,00 & 9,59 \\
\hline 24,07 & 0,21 & 17,40 & 0,23 & 16,97 & 0,55 & 6,23 & 0,65 & 6,12 & 1,50 & 0,00 & 1,74 & 1,32 & 3,58 & 0,00 & 4,23 & 0,00 & 8,09 & 0,00 & 9,67 \\
\hline 22,22 & 0,21 & 17,96 & 0,23 & 11,73 & 0,60 & 6,42 & 0,66 & 6,19 & 1,51 & 0,00 & 1,75 & 1,23 & 3,64 & 0,00 & 4,27 & 0,00 & 8,16 & 0,00 & 9,71 \\
\hline
\end{tabular}


1,5PPA

\begin{tabular}{|c|c|c|c|c|c|c|c|}
\hline \multicolumn{4}{|c|}{$52^{\circ} \mathrm{C}$} & \multicolumn{4}{|c|}{$58^{\circ} \mathrm{C}$} \\
\hline \multicolumn{2}{|c|}{$100 \mathrm{PA}$} & \multicolumn{2}{|c|}{$3200 \mathrm{PA}$} & \multicolumn{2}{|c|}{$100 \mathrm{PA}$} & \multicolumn{2}{|c|}{3200 PA } \\
\hline $\mathbf{R}$ & $\mathrm{C}$ & $\mathbf{R}$ & $\mathrm{C}$ & $\mathbf{R}$ & $\mathrm{C}$ & $\mathbf{R}$ & C \\
\hline Média & Média & Média & Média & Média & Média & Média & Média \\
\hline 42,17 & 0,09 & 37,91 & 0,10 & 31,10 & 0,25 & 22,96 & 0,29 \\
\hline 40,59 & 0,09 & 38,52 & 0,09 & 29,80 & 0,25 & 23,51 & 0,28 \\
\hline 44,25 & 0,08 & 38,63 & 0,09 & 31,88 & 0,24 & 23,73 & 0,27 \\
\hline 42,63 & 0,08 & 40,46 & 0,08 & 31,56 & 0,25 & 24,45 & 0,28 \\
\hline
\end{tabular}

\begin{tabular}{|c|c|c|c|}
\hline \multicolumn{4}{|c|}{$64^{\circ} \mathrm{C}$} \\
\hline \multicolumn{2}{|c|}{$100 \mathrm{PA}$} & \multicolumn{2}{|c|}{$3200 \mathrm{PA}$} \\
\hline $\mathbf{R}$ & C & $\mathbf{R}$ & C \\
\hline Média & Média & Média & Média \\
\hline 20,61 & 0,67 & 8,17 & 0,82 \\
\hline 19,87 & 0,66 & 8,57 & 0,80 \\
\hline 20,10 & 0,65 & 8,77 & 0,78 \\
\hline 20,84 & 0,68 & 9,30 & 0,82 \\
\hline
\end{tabular}

\section{1,5PA85}

\begin{tabular}{|c|c|c|c|c|c|}
\hline \multicolumn{4}{|c|}{$52^{\circ} \mathrm{C}$} & \multicolumn{2}{|c|}{$58^{\circ}$} \\
\hline \multicolumn{2}{|c|}{$100 \mathrm{PA}$} & \multicolumn{2}{|c|}{3200 PA } & \multicolumn{2}{|c|}{$100 \mathrm{PA}$} \\
\hline $\mathbf{R}$ & C & $\mathbf{R}$ & C & $\mathbf{R}$ & C \\
\hline Média & Média & Média & Média & Média & Média \\
\hline 32,87 & 0,13 & 29,79 & 0,14 & 22,67 & 0,37 \\
\hline 33,80 & 0,12 & 30,74 & 0,13 & 24,31 & 0,34 \\
\hline 32,87 & 0,13 & 30,22 & 0,13 & 23,26 & 0,35 \\
\hline 33,27 & 0,14 & 30,66 & 0,14 & 23,50 & 0,37 \\
\hline
\end{tabular}

\begin{tabular}{|c|c|}
\hline 3200 & $\mathrm{PA}$ \\
\hline $\mathbf{R}$ & $\mathbf{C}$ \\
\hline Média & Média \\
\hline 15,53 & 0,41 \\
\hline 16,21 & 0,39 \\
\hline 15,97 & 0,39 \\
\hline 16,40 & 0,42 \\
\hline
\end{tabular}

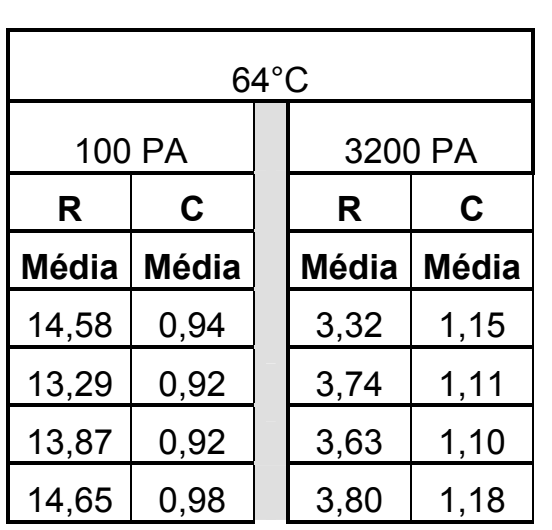

\begin{tabular}{|c|c|c|c|}
\hline \multicolumn{4}{|c|}{$70^{\circ} \mathrm{C}$} \\
\hline \multicolumn{2}{|c|}{$100 \mathrm{PA}$} & \multicolumn{2}{|c|}{3200 PA } \\
\hline $\mathbf{R}$ & C & $\mathbf{R}$ & C \\
\hline Média & Média & Média & Média \\
\hline 11,24 & 1,69 & 0,00 & 2,19 \\
\hline 12,23 & 1,63 & 0,00 & 2,13 \\
\hline 12,95 & 1,68 & 0,00 & 2,19 \\
\hline 12,95 & 1,68 & 0,00 & 2,19 \\
\hline
\end{tabular}

\begin{tabular}{|c|c|}
\hline \multicolumn{2}{|c|}{76} \\
\hline 100 PA \\
\hline $\mathbf{R}$ & $\mathbf{C}$ \\
\hline Média & Média \\
\hline 3,81 & 4,01 \\
\hline 2,20 & 4,01 \\
\hline 3,16 & 3,99 \\
\hline 5,16 & 3,99 \\
\hline
\end{tabular}

\begin{tabular}{|c|c|c|c|}
\hline \multicolumn{4}{|c|}{$70^{\circ} \mathrm{C}$} \\
\hline \multicolumn{2}{|c|}{$100 \mathrm{PA}$} & \multicolumn{2}{|c|}{3200 PA } \\
\hline $\mathbf{R}$ & C & $\mathbf{R}$ & C \\
\hline Média & Média & Média & Média \\
\hline 7,78 & 2,29 & 0,00 & 2,92 \\
\hline 7,51 & 2,23 & 0,00 & 2,83 \\
\hline 5,32 & 2,30 & 0,00 & 2,82 \\
\hline 6,43 & 2,41 & 0,00 & 3,00 \\
\hline
\end{tabular}

\begin{tabular}{|c|c|}
\hline \multicolumn{3}{|c|}{${ }^{70}$ PA } \\
\hline $\mathbf{R}$ & $\mathbf{C}$ \\
\hline Média & Média \\
\hline 0,50 & 5,41 \\
\hline 0,83 & 5,25 \\
\hline 0,90 & 5,39 \\
\hline 0,87 & 5,64 \\
\hline
\end{tabular}

\begin{tabular}{|c|c|}
\hline \multicolumn{2}{|c|}{3200 PA } \\
\hline $\mathbf{R}$ & $\mathbf{C}$ \\
\hline Média & Média \\
\hline 0,00 & 5,28 \\
\hline 0,00 & 5,16 \\
\hline 0,00 & 5,31 \\
\hline 0,00 & 5,31 \\
\hline
\end{tabular}

\begin{tabular}{|c|c|}
\hline \multicolumn{2}{|c|}{3200 PA } \\
\hline $\mathbf{R}$ & C \\
\hline Média & Média \\
\hline 0,00 & 6,80 \\
\hline 0,00 & 6,70 \\
\hline 0,00 & 6,64 \\
\hline 0,00 & 7,09 \\
\hline
\end{tabular}


Adição do Copolímero SBS + Ácido:

\section{SBS+1,5PPA}

\begin{tabular}{|c|c|c|c|}
\hline \multicolumn{4}{|c|}{$52^{\circ} \mathrm{C}$} \\
\hline \multicolumn{2}{|c|}{ 100PA } & \multicolumn{2}{|c|}{3200 PA } \\
\hline $\mathbf{R}$ & C & $\mathbf{R}$ & C \\
\hline Média & Média & Média & Média \\
\hline 70,88 & 0,02 & 72,69 & 0,01 \\
\hline 69,65 & 0,02 & 71,79 & 0,01 \\
\hline 67,11 & 0,02 & 70,89 & 0,02 \\
\hline 75,16 & 0,01 & 71,41 & 0,02 \\
\hline
\end{tabular}

\begin{tabular}{|c|c|c|c|}
\hline \multicolumn{4}{|c|}{$58^{\circ} \mathrm{C}$} \\
\hline \multicolumn{2}{|c|}{$100 \mathrm{PA}$} & \multicolumn{2}{|c|}{3200 PA } \\
\hline $\mathbf{R}$ & C & $\mathbf{R}$ & C \\
\hline Média & Média & Média & Média \\
\hline 65,04 & 0,04 & 61,39 & 0,04 \\
\hline 61,69 & 0,04 & 59,90 & 0,04 \\
\hline 61,88 & 0,04 & 58,90 & 0,05 \\
\hline 66,53 & 0,04 & 59,40 & 0,04 \\
\hline
\end{tabular}

\begin{tabular}{|c|c|c|c|}
\hline \multicolumn{4}{|c|}{$64^{\circ} \mathrm{C}$} \\
\hline \multicolumn{2}{|c|}{$100 \mathrm{PA}$} & \multicolumn{2}{|c|}{$3200 \mathrm{PA}$} \\
\hline $\mathbf{R}$ & C & $\mathbf{R}$ & C \\
\hline Média & Média & Média & Média \\
\hline 56,30 & 0,09 & 46,69 & 0,11 \\
\hline 50,96 & 0,10 & 44,55 & 0,12 \\
\hline 52,13 & 0,11 & 43,69 & 0,13 \\
\hline 55,90 & 0,10 & 44,36 & 0,13 \\
\hline
\end{tabular}

\begin{tabular}{|c|c|c|c|}
\hline \multicolumn{4}{|c|}{$76^{\circ} \mathrm{C}$} \\
\hline \multicolumn{2}{|c|}{$100 \mathrm{PA}$} & \multicolumn{2}{|c|}{3200 PA } \\
\hline $\mathbf{R}$ & C & $\mathbf{R}$ & C \\
\hline Média & Média & Média & Média \\
\hline 34,02 & 0,56 & 17,40 & 0,79 \\
\hline 28,55 & 0,60 & 12,33 & 0,84 \\
\hline 32,94 & 0,60 & 15,34 & 0,87 \\
\hline 36,75 & 0,58 & 17,06 & 0,87 \\
\hline
\end{tabular}

\section{SBS+1,5PA85}

\begin{tabular}{|c|c|c|c|}
\hline \multicolumn{4}{|c|}{$52^{\circ} \mathrm{C}$} \\
\hline \multicolumn{2}{|c|}{$100 \mathrm{PA}$} & \multicolumn{2}{|c|}{3200 PA } \\
\hline $\mathbf{R}$ & C & $\mathbf{R}$ & C \\
\hline Média & Média & Média & Média \\
\hline 62,88 & 0,03 & 67,82 & 0,02 \\
\hline 58,20 & 0,03 & 65,01 & 0,02 \\
\hline 59,88 & 0,03 & 64,22 & 0,02 \\
\hline 62,42 & 0,03 & 63,47 & 0,03 \\
\hline
\end{tabular}

\begin{tabular}{|c|c|c|c|}
\hline \multicolumn{4}{|c|}{$64^{\circ} \mathrm{C}$} \\
\hline \multicolumn{2}{|c|}{100 PA } & \multicolumn{2}{|c|}{3200 PA } \\
\hline $\mathbf{R}$ & C & $\mathbf{R}$ & C \\
\hline Média & Média & Média & Média \\
\hline 67,03 & 0,10 & 48,30 & 0,17 \\
\hline 47,81 & 0,15 & 37,30 & 0,19 \\
\hline 48,36 & 0,16 & 37,00 & 0,20 \\
\hline 48,54 & 0,16 & 35,51 & 0,21 \\
\hline
\end{tabular}

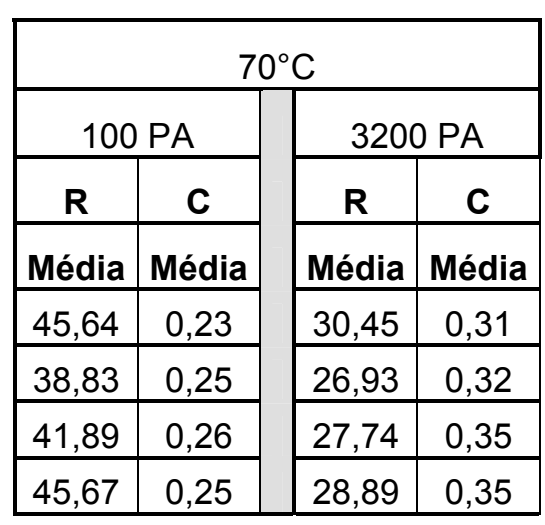

\begin{tabular}{|c|c|c|c|}
\hline \multicolumn{4}{|c|}{$70^{\circ} \mathrm{C}$} \\
\hline \multicolumn{2}{|c|}{$100 \mathrm{PA}$} & \multicolumn{2}{|c|}{3200 PA } \\
\hline $\mathbf{R}$ & C & $\mathbf{R}$ & C \\
\hline Média & Média & Média & Média \\
\hline 64,26 & 0,24 & 38,48 & 0,46 \\
\hline 39,73 & 0,37 & 23,76 & 0,50 \\
\hline 41,85 & 0,38 & 23,55 & 0,54 \\
\hline 39,04 & 0,39 & 21,72 & 0,56 \\
\hline
\end{tabular}

\begin{tabular}{|c|c|c|c|}
\hline \multicolumn{4}{|c|}{$76^{\circ} \mathrm{C}$} \\
\hline \multicolumn{2}{|c|}{$100 \mathrm{PA}$} & \multicolumn{2}{|c|}{3200 PA } \\
\hline $\mathbf{R}$ & C & $\mathbf{R}$ & C \\
\hline Média & Média & Média & Média \\
\hline 58,05 & 0,57 & 28,86 & 1,14 \\
\hline 32,42 & 0,83 & 14,41 & 1,22 \\
\hline 34,99 & 0,85 & 14,50 & 1,30 \\
\hline 29,63 & 0,93 & 11,51 & 1,38 \\
\hline
\end{tabular}


5SBS+0,75PPA

\begin{tabular}{|c|c|c|c|c|c|c|c|}
\hline \multicolumn{4}{|c|}{$52^{\circ} \mathrm{C}$} & \multicolumn{4}{|c|}{$58^{\circ} \mathrm{C}$} \\
\hline \multicolumn{2}{|c|}{$100 \mathrm{PA}$} & \multicolumn{2}{|c|}{$3200 \mathrm{PA}$} & \multicolumn{2}{|c|}{$100 \mathrm{PA}$} & \multicolumn{2}{|c|}{3200 PA } \\
\hline $\mathbf{R}$ & C & $\mathbf{R}$ & C & $\mathbf{R}$ & C & $\mathbf{R}$ & C \\
\hline Média & Média & Média & Média & Média & Média & Média & Média \\
\hline 52,56 & 0,06 & 50,06 & 0,06 & 45,80 & 0,15 & 36,79 & 0,18 \\
\hline 53,17 & 0,06 & 49,84 & 0,06 & 47,90 & 0,14 & 37,19 & 0,18 \\
\hline 45,45 & 0,07 & 47,00 & 0,07 & 41,22 & 0,16 & 33,31 & 0,19 \\
\hline 47,65 & 0,06 & 45,84 & 0,07 & 38,06 & 0,17 & 31,43 & 0,19 \\
\hline
\end{tabular}

\begin{tabular}{|c|c|c|c|}
\hline \multicolumn{4}{|c|}{$64^{\circ} \mathrm{C}$} \\
\hline \multicolumn{2}{|c|}{$100 \mathrm{PA}$} & \multicolumn{2}{|c|}{3200 PA } \\
\hline $\mathbf{R}$ & C & $\mathbf{R}$ & C \\
\hline Média & Média & Média & Média \\
\hline 37,41 & 0,37 & 22,03 & 0,49 \\
\hline 41,69 & 0,35 & 25,95 & 0,47 \\
\hline 33,86 & 0,39 & 20,82 & 0,50 \\
\hline 28,72 & 0,43 & 18,10 & 0,52 \\
\hline
\end{tabular}

\begin{tabular}{|c|c|c|c|}
\hline \multicolumn{4}{|c|}{$76^{\circ} \mathrm{C}$} \\
\hline \multicolumn{2}{|c|}{100 PA } & \multicolumn{2}{|c|}{3200 PA } \\
\hline $\mathbf{R}$ & C & $\mathbf{R}$ & C \\
\hline Média & Média & Média & Média \\
\hline 22,55 & 1,88 & 2,31 & 2,94 \\
\hline 26,31 & 1,89 & 9,15 & 2,77 \\
\hline 16,18 & 2,23 & 4,30 & 3,01 \\
\hline 12,13 & 2,38 & 2,12 & 3,12 \\
\hline
\end{tabular}

\section{SBS $+0,75$ PA85}

\begin{tabular}{|c|c|c|c|c|c|c|c|}
\hline \multicolumn{4}{|c|}{$52^{\circ} \mathrm{C}$} & \multicolumn{4}{|c|}{$58^{\circ} \mathrm{C}$} \\
\hline \multicolumn{2}{|c|}{$100 \mathrm{PA}$} & \multicolumn{2}{|c|}{3200 PA } & \multicolumn{2}{|c|}{$100 \mathrm{PA}$} & \multicolumn{2}{|c|}{3200 PA } \\
\hline $\mathbf{R}$ & C & $\mathbf{R}$ & C & $\mathbf{R}$ & C & $\mathbf{R}$ & C \\
\hline Média & Média & Média & Média & Média & Média & Média & Média \\
\hline 46,60 & 0,06 & 50,19 & 0,06 & 42,56 & 0,14 & 36,97 & 0,16 \\
\hline 49,00 & 0,06 & 47,38 & 0,06 & 38,40 & 0,16 & 32,34 & 0,17 \\
\hline 47,61 & 0,06 & 45,07 & 0,07 & 35,53 & 0,17 & 29,96 & 0,19 \\
\hline 48,96 & 0,06 & 47,26 & 0,06 & \begin{tabular}{|l|}
39,74 \\
\end{tabular} & 0,15 & 32,49 & 0,17 \\
\hline
\end{tabular}

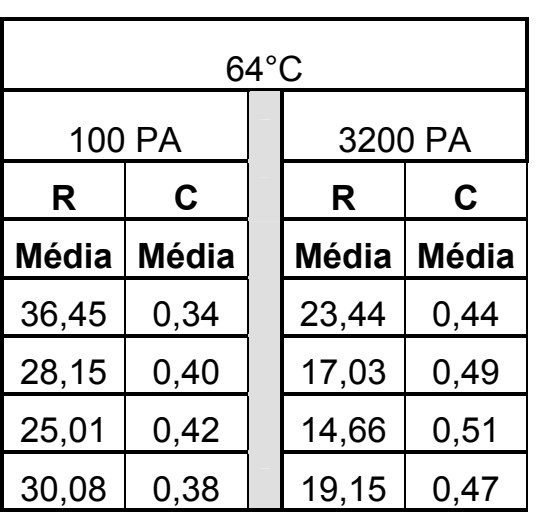

\begin{tabular}{|c|c|c|c|}
\hline \multicolumn{4}{|c|}{$70^{\circ} \mathrm{C}$} \\
\hline \multicolumn{2}{|c|}{$100 \mathrm{PA}$} & \multicolumn{2}{|c|}{$3200 \mathrm{PA}$} \\
\hline $\mathbf{R}$ & C & $\mathbf{R}$ & C \\
\hline Média & Média & Média & Média \\
\hline 29,59 & 0,85 & 9,70 & 1,25 \\
\hline 35,13 & 0,82 & 16,93 & 1,17 \\
\hline 24,50 & 0,98 & 10,87 & 1,28 \\
\hline 20,15 & 1,04 & 8,06 & 1,33 \\
\hline
\end{tabular}

\begin{tabular}{|l|l|}
\hline 12,13 & 2,38 \\
\hline
\end{tabular}

\begin{tabular}{|c|c|c|c|}
\hline \multicolumn{4}{|c|}{$70^{\circ} \mathrm{C}$} \\
\hline \multicolumn{2}{|c|}{$100 \mathrm{PA}$} & \multicolumn{2}{|c|}{3200 PA } \\
\hline $\mathbf{R}$ & C & $\mathbf{R}$ & C \\
\hline Média & Média & Média & Média \\
\hline 28,78 & 0,82 & 13,72 & 1,12 \\
\hline 17,81 & 0,98 & 6,71 & 1,25 \\
\hline 15,15 & 1,04 & 4,20 & 1,31 \\
\hline 23,04 & 0,92 & 9,65 & 1,21 \\
\hline
\end{tabular}

\begin{tabular}{|c|c|c|c|}
\hline \multicolumn{4}{|c|}{$76^{\circ} \mathrm{C}$} \\
\hline \multicolumn{2}{|c|}{$100 \mathrm{PA}$} & \multicolumn{2}{|c|}{3200 PA } \\
\hline $\mathbf{R}$ & C & $\mathbf{R}$ & C \\
\hline Média & Média & Média & Média \\
\hline 21,88 & 1,81 & 3,46 & 2,60 \\
\hline 17,13 & 2,30 & 3,26 & 2,92 \\
\hline 17,07 & 2,34 & 3,77 & 3,03 \\
\hline 15,42 & 2,10 & 3,58 & 2,81 \\
\hline
\end{tabular}




\begin{tabular}{|c|c|c|c|c|c|c|c|}
\hline \multicolumn{4}{|c|}{$52^{\circ} \mathrm{C}$} & \multicolumn{4}{|c|}{$58^{\circ} \mathrm{C}$} \\
\hline \multicolumn{2}{|c|}{$100 \mathrm{PA}$} & \multicolumn{2}{|c|}{3200 PA } & \multicolumn{2}{|c|}{$100 \mathrm{PA}$} & \multicolumn{2}{|c|}{3200 PA } \\
\hline $\mathbf{R}$ & C & $\mathbf{R}$ & C & $\mathbf{R}$ & C & $\mathbf{R}$ & C \\
\hline Média & Média & Média & Média & Média & Média & Média & Média \\
\hline 34,30 & 0,16 & 26,54 & 0,18 & 20,88 & 0,44 & 13,76 & 0,50 \\
\hline 29,19 & 0,18 & 25,87 & 0,19 & 19,53 & 0,47 & 12,98 & 0,53 \\
\hline 29,16 & 0,18 & 26,22 & 0,19 & 20,68 & 0,47 & 13,36 & 0,54 \\
\hline 28,55 & 0,19 & 26,53 & 0,20 & 20,37 & 0,49 & 13,75 & 0,55 \\
\hline
\end{tabular}

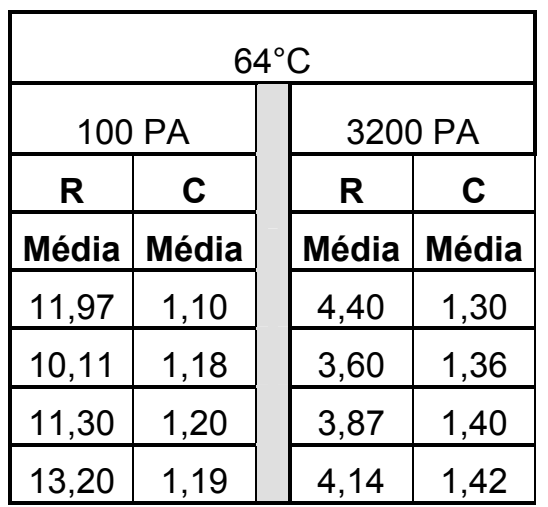

2,5SBS+1,5PPA

\begin{tabular}{|c|c|c|c|}
\hline \multicolumn{4}{|c|}{$52^{\circ} \mathrm{C}$} \\
\hline \multicolumn{2}{|c|}{$100 \mathrm{PA}$} & \multicolumn{2}{|c|}{3200 PA } \\
\hline $\mathbf{R}$ & C & $\mathbf{R}$ & C \\
\hline Média & Média & Média & Média \\
\hline 58,50 & 0,04 & 57,02 & 0,04 \\
\hline 59,46 & 0,04 & 57,94 & 0,04 \\
\hline 60,18 & 0,03 & 58,81 & 0,04 \\
\hline
\end{tabular}

\begin{tabular}{|c|c|c|c|}
\hline \multicolumn{4}{|c|}{$58^{\circ} \mathrm{C}$} \\
\hline \multicolumn{2}{|c|}{$100 \mathrm{PA}$} & \multicolumn{2}{|c|}{$3200 \mathrm{PA}$} \\
\hline $\mathbf{R}$ & C & $\mathbf{R}$ & C \\
\hline Média & Média & Média & Média \\
\hline 47,75 & 0,10 & 42,86 & 0,11 \\
\hline 47,81 & 0,10 & 43,82 & 0,11 \\
\hline 49,28 & 0,09 & 44,77 & 0,10 \\
\hline
\end{tabular}

2,5SBS+1,5PA85

\begin{tabular}{|c|c|}
\hline \multicolumn{2}{|c|}{$100 \mathrm{PA}$} \\
\hline $\mathbf{R}$ & C \\
\hline Média & Média \\
\hline 55,53 & 0,04 \\
\hline 56,38 & 0,04 \\
\hline 54,64 & 0,04 \\
\hline
\end{tabular}

\section{$2^{\circ} \mathrm{C}$}

3200 PA

R C

Média Média

54,16 0,05

\begin{tabular}{|l|l|}
54,16 & 0,05 \\
\hline
\end{tabular}

\begin{tabular}{|l|l|}
\hline 53,81 & 0,05 \\
\hline
\end{tabular}

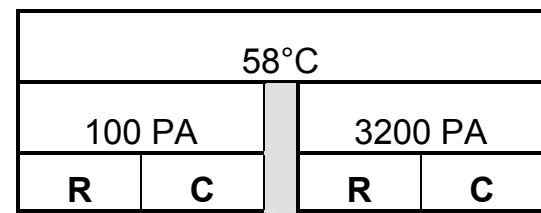

Média Média

$39,610,13$

$39,55 \quad 0,13$

\begin{tabular}{|l|l|}
\hline 39,31 & 0,13 \\
\hline
\end{tabular}

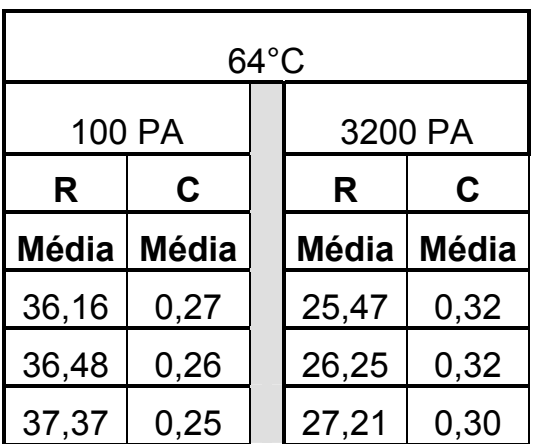

\begin{tabular}{|l|l|}
\hline 37,37 & 0,25 \\
\hline
\end{tabular}

\begin{tabular}{|c|c|}
\hline \multicolumn{2}{|c|}{$64^{\circ}$} \\
\hline 100 PA \\
\hline $\mathbf{R}$ & $\mathbf{C}$ \\
\hline Média & Média \\
\hline 32,64 & 0,31 \\
\hline 32,70 & 0,32 \\
\hline 32,27 & 0,32 \\
\hline
\end{tabular}

$64^{\circ} \mathrm{C}$

\begin{tabular}{|c|c|}
\hline \multicolumn{2}{|c|}{3200 PA } \\
\hline $\mathbf{R}$ & $\mathbf{C}$ \\
\hline Média & Média \\
\hline 22,45 & 0,38 \\
\hline 22,35 & 0,39 \\
\hline 22,28 & 0,38 \\
\hline
\end{tabular}

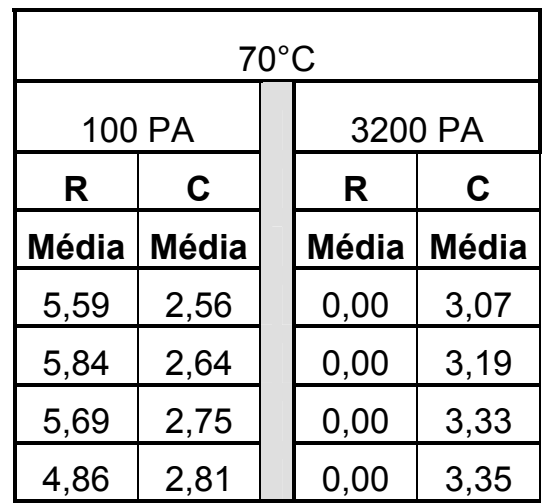

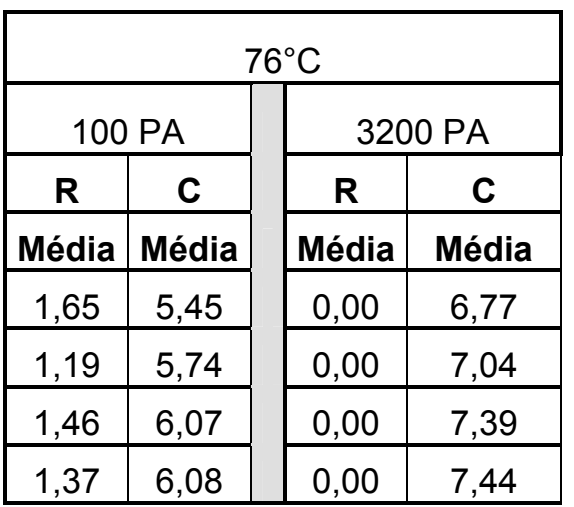

\begin{tabular}{|c|c|c|c|}
\hline \multicolumn{4}{|c|}{$70^{\circ} \mathrm{C}$} \\
\hline \multicolumn{2}{|c|}{$100 \mathrm{PA}$} & \multicolumn{2}{|c|}{3200 PA } \\
\hline $\mathbf{R}$ & C & $\mathbf{R}$ & C \\
\hline Média & Média & Média & Média \\
\hline 24,78 & 0,68 & 9,28 & 0,91 \\
\hline 24,88 & 0,68 & 9,81 & 0,89 \\
\hline 25,49 & 0,65 & 10,56 & 0,86 \\
\hline
\end{tabular}

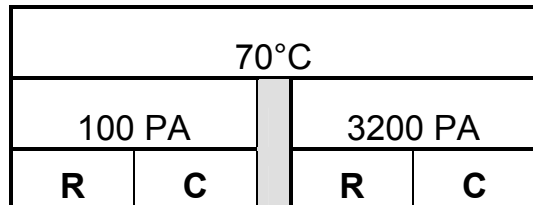

Média Média

Média Média

\begin{tabular}{|l|l|}
\hline 22,51 & 0,78 \\
\hline
\end{tabular}

\begin{tabular}{|l|l|}
\hline 21,58 & 0,81 \\
\hline
\end{tabular}

\begin{tabular}{|l|l|}
\hline 21,81 & 0,81 \\
\hline
\end{tabular} \begin{tabular}{|l|l|}
\hline 7,61 & 1,03 \\
\hline
\end{tabular}

\begin{tabular}{l|l}
7,52 & 1,06 \\
\hline
\end{tabular}

\begin{tabular}{|l|l|}
\hline 7,48 & 1,05 \\
\hline
\end{tabular}

\begin{tabular}{|c|c|c|c|}
\hline \multicolumn{4}{|c|}{$76^{\circ} \mathrm{C}$} \\
\hline \multicolumn{2}{|c|}{$100 \mathrm{PA}$} & \multicolumn{2}{|c|}{3200 PA } \\
\hline $\mathbf{R}$ & C & $\mathbf{R}$ & C \\
\hline Média & Média & Média & Média \\
\hline 13,51 & 1,63 & 0,32 & 2,28 \\
\hline 13,85 & 1,64 & 0,51 & 2,27 \\
\hline 16,12 & 1,54 & 0,86 & 2,18 \\
\hline
\end{tabular}

\begin{tabular}{|c|c|}
\hline \multicolumn{2}{|c|}{76} \\
\hline 100 PA \\
\hline $\mathbf{R}$ & $\mathbf{C}$ \\
\hline Média & Média \\
\hline 13,50 & 1,84 \\
\hline 13,19 & 1,90 \\
\hline 12,36 & 1,91 \\
\hline
\end{tabular}

$76^{\circ} \mathrm{C}$

\begin{tabular}{|c|c|}
\hline \multicolumn{2}{|c|}{$3200 \mathrm{PA}$} \\
\hline $\mathbf{R}$ & $\mathbf{C}$ \\
\hline Média & Média \\
\hline 0,00 & 2,55 \\
\hline 0,00 & 2,61 \\
\hline 0,00 & 2,61 \\
\hline
\end{tabular}


2,5SBS+0,75PPA

\begin{tabular}{|c|c|c|c|}
\hline \multicolumn{4}{|c|}{$52^{\circ} \mathrm{C}$} \\
\hline \multicolumn{2}{|c|}{$100 \mathrm{PA}$} & \multicolumn{2}{|c|}{3200 PA } \\
\hline $\mathbf{R}$ & C & $\mathbf{R}$ & C \\
\hline Média & Média & Média & Média \\
\hline 32,67 & 0,14 & 29,70 & 0,14 \\
\hline 33,19 & 0,13 & 30,60 & 0,14 \\
\hline 34,56 & 0,13 & 30,95 & 0,14 \\
\hline 33,77 & 0,12 & 30,70 & 0,13 \\
\hline
\end{tabular}

\begin{tabular}{|c|c|c|c|}
\hline \multicolumn{4}{|c|}{$58^{\circ} \mathrm{C}$} \\
\hline \multicolumn{2}{|c|}{$100 \mathrm{PA}$} & \multicolumn{2}{|c|}{3200 PA } \\
\hline $\mathbf{R}$ & C & $\mathbf{R}$ & C \\
\hline Média & Média & Média & Média \\
\hline 21,64 & 0,38 & 16,08 & 0,41 \\
\hline 22,52 & 0,36 & 16,77 & 0,40 \\
\hline 24,59 & 0,35 & 17,05 & 0,40 \\
\hline 22,92 & 0,33 & 16,75 & 0,37 \\
\hline
\end{tabular}

2,5SBS+0,75PA85

\begin{tabular}{|c|c|}
\hline \multicolumn{2}{|c|}{$52^{\circ} \mathrm{C}$} \\
\hline $\mathbf{2} 100 \mathrm{PA}$ \\
\hline $\mathbf{R}$ & $\mathbf{C}$ \\
\hline Média & Média \\
\hline 33,16 & 0,14 \\
\hline 33,83 & 0,14 \\
\hline 35,25 & 0,13 \\
\hline 32,36 & 0,12 \\
\hline
\end{tabular}

\section{$2^{\circ} \mathrm{C}$}

3200 PA

\begin{tabular}{|l|l|}
\hline $\mathbf{R}$ & $\mathbf{C}$ \\
\hline
\end{tabular}

\begin{tabular}{|l|}
\hline Média Média \\
\hline
\end{tabular} \begin{tabular}{|l|l|}
\hline 30,50 & 0,14 \\
\hline 30,32 & 0,14 \\
\hline
\end{tabular} \begin{tabular}{|l|l|}
\hline 30,32 & 0,14 \\
\hline
\end{tabular} \begin{tabular}{|l|l|}
\hline 29,94 & 0,14 \\
\hline 29,40 & 0,13 \\
\hline
\end{tabular} \begin{tabular}{|l|l|}
29,40 & 0,13 \\
\hline
\end{tabular}

\begin{tabular}{|c|c|c|c|}
\hline \multicolumn{4}{|c|}{$58^{\circ} \mathrm{C}$} \\
\hline \multicolumn{2}{|c|}{$100 \mathrm{PA}$} & \multicolumn{2}{|c|}{$3200 \mathrm{PA}$} \\
\hline $\mathbf{R}$ & C & $\mathbf{R}$ & C \\
\hline Média & Média & Média & Média \\
\hline 23,22 & 0,37 & \begin{tabular}{|l|}
16,27 \\
\end{tabular} & 0,41 \\
\hline 23,54 & 0,37 & 16,13 & 0,42 \\
\hline 22,04 & 0,37 & 16,00 & 0,41 \\
\hline 21,04 & 0,34 & 15,49 & 0,38 \\
\hline
\end{tabular}

\begin{tabular}{|c|c|c|c|}
\hline \multicolumn{4}{|c|}{$64^{\circ} \mathrm{C}$} \\
\hline \multicolumn{2}{|c|}{$100 \mathrm{PA}$} & \multicolumn{2}{|c|}{3200 PA } \\
\hline $\mathbf{R}$ & C & $\mathbf{R}$ & C \\
\hline Média & Média & Média & Média \\
\hline 14,17 & 0,94 & 4,51 & 1,12 \\
\hline 13,84 & 0,93 & 4,96 & 1,10 \\
\hline 14,67 & 0,91 & 5,17 & 1,08 \\
\hline 13,29 & 0,85 & 4,89 & 1,02 \\
\hline
\end{tabular}

\begin{tabular}{|c|c|c|c|}
\hline \multicolumn{4}{|c|}{$70^{\circ} \mathrm{C}$} \\
\hline \multicolumn{2}{|c|}{$100 \mathrm{PA}$} & \multicolumn{2}{|c|}{$3200 \mathrm{PA}$} \\
\hline $\mathbf{R}$ & C & $\mathbf{R}$ & C \\
\hline Média & Média & Média & Média \\
\hline 6,44 & 2,27 & 0,00 & 2,77 \\
\hline 7,27 & 2,23 & 0,00 & 2,74 \\
\hline 5,96 & 2,22 & 0,00 & 2,69 \\
\hline 8,29 & 1,99 & 0,00 & 2,53 \\
\hline
\end{tabular}

\begin{tabular}{|c|c|c|c|}
\hline \multicolumn{4}{|c|}{$64^{\circ} \mathrm{C}$} \\
\hline \multicolumn{2}{|c|}{$100 \mathrm{PA}$} & \multicolumn{2}{|c|}{3200 PA } \\
\hline $\mathbf{R}$ & C & $\mathbf{R}$ & C \\
\hline Média & Média & Média & Média \\
\hline 12,75 & 0,96 & 4,57 & 1,12 \\
\hline 13,74 & 0,96 & 4,55 & 1,13 \\
\hline 13,07 & 0,96 & 4,48 & 1,12 \\
\hline 12,83 & 0,88 & 4,08 & 1,03 \\
\hline
\end{tabular}

\begin{tabular}{|c|c|c|c|}
\hline \multicolumn{4}{|c|}{$70^{\circ} \mathrm{C}$} \\
\hline \multicolumn{2}{|c|}{$100 \mathrm{PA}$} & \multicolumn{2}{|c|}{$3200 \mathrm{PA}$} \\
\hline $\mathbf{R}$ & C & $\mathbf{R}$ & C \\
\hline Média & Média & Média & Média \\
\hline 4,92 & 2,35 & 0,00 & 2,80 \\
\hline 5,80 & 2,34 & 0,00 & 2,84 \\
\hline 6,38 & 2,31 & 0,00 & 2,80 \\
\hline 5,66 & 2,13 & 0,00 & 2,58 \\
\hline
\end{tabular}
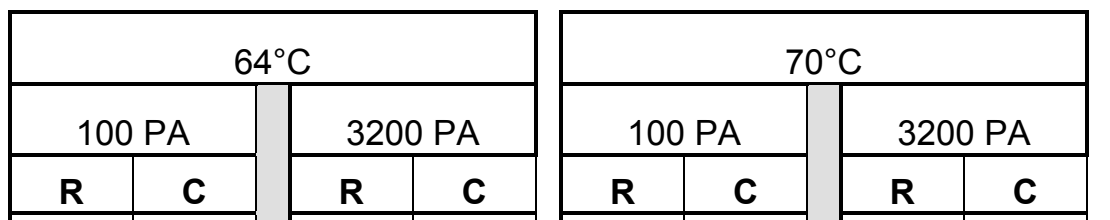

\begin{tabular}{|l|c|}
\hline R & C \\
\hline
\end{tabular}

\begin{tabular}{l|l}
\hline $\mathbf{R}$ & $\mathbf{C}$ \\
\hline
\end{tabular}

Média Média

\begin{tabular}{|l|l|}
\hline 12,38 & 0,31 \\
\hline
\end{tabular}

\begin{tabular}{|l|l|}
\hline 16,35 & 0,29 \\
\hline 13,89 & 0,30 \\
\hline
\end{tabular}

\begin{tabular}{|l|l|}
\hline 13,89 & 0,30 \\
\hline
\end{tabular}

\begin{tabular}{|l|l|}
\hline 13,90 & 0,33 \\
\hline
\end{tabular}

Média Média

\begin{tabular}{|l|l|}
\hline 11,07 & 0,32 \\
\hline 11,57 & 0,32 \\
\hline
\end{tabular}

\begin{tabular}{|l|l|}
11,57 & 0,32 \\
\hline 11,80 & 0,31 \\
\hline
\end{tabular}

\begin{tabular}{|l|l|}
\hline 11,80 & 0,31 \\
\hline 12,45 & 0,34 \\
\hline
\end{tabular}

\begin{tabular}{|l|l|}
12,45 & 0,34 \\
\hline
\end{tabular} $58^{\circ} \mathrm{C}$

$3200 \mathrm{PA}$

\begin{tabular}{l|l}
$\mathbf{R}$ & $\mathbf{C}$ \\
\hline
\end{tabular}

Média Média

\begin{tabular}{|l|l|}
\hline 2,45 & 0,89 \\
\hline 3,01 & 0,87 \\
\hline
\end{tabular}

\begin{tabular}{|l|l|}
\hline 3,01 & 0,87 \\
\hline 3,15 & 0,86 \\
\hline
\end{tabular}

\begin{tabular}{|l|l|}
3,15 & 0,86 \\
\hline 3,66 & 0,93 \\
\hline
\end{tabular}

\begin{tabular}{|l|l|}
\hline 3,66 & 0,93 \\
\hline
\end{tabular}
Média Média

\begin{tabular}{|l|l|l|}
\hline 0,56 & 208 \\
\cline { 2 - 3 } & 0,00 & 2,27 \\
\hline
\end{tabular}

\begin{tabular}{|l|l|}
\hline 2,91 & 1,97 \\
\hline
\end{tabular}

\begin{tabular}{|l|l|}
\hline 2,77 & 1,96 \\
\hline 3,04 & 2,10 \\
\hline
\end{tabular}

\begin{tabular}{|l|l|}
\hline 3,04 & 2,10 \\
\hline
\end{tabular} \begin{tabular}{|l|l|}
\hline 0,00 & 2,27 \\
\hline 0,00 & 2,22 \\
\hline 0,00 & 2,9 \\
\hline
\end{tabular}

\begin{tabular}{|l|l|}
\hline 0,00 & 2,19 \\
\hline
\end{tabular}

\begin{tabular}{|l|l|}
\hline 0,00 & 2,33 \\
\hline
\end{tabular}

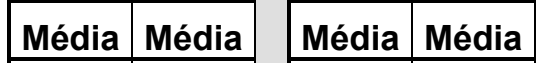

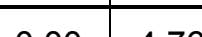

\begin{tabular}{|l|l|}
\hline 0,00 & 4,64 \\
\hline 0,00 & 4,60 \\
\hline
\end{tabular}

\begin{tabular}{|l|l|}
\hline 0,00 & 4,60 \\
\hline 0,00 & 4,85 \\
\hline
\end{tabular}

\begin{tabular}{|l|l|}
\hline 0,00 & 4,85 \\
\hline
\end{tabular}

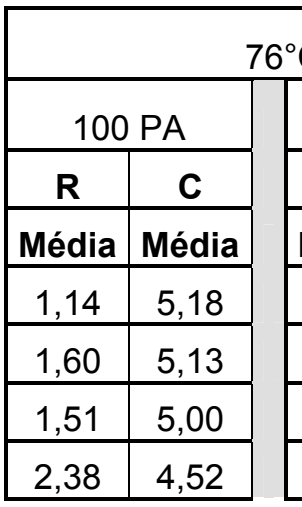

$76^{\circ} \mathrm{C}$

\begin{tabular}{|c|c|}
\hline \multicolumn{2}{|c|}{$3200 \mathrm{PA}$} \\
\hline $\mathbf{R}$ & $\mathbf{C}$ \\
\hline Média & Média \\
\hline 0,00 & 6,32 \\
\hline 0,00 & 6,30 \\
\hline 0,00 & 6,22 \\
\hline 0,00 & 5,72 \\
\hline
\end{tabular}

\begin{tabular}{|c|c|c|c|}
\hline \multicolumn{4}{|c|}{$76^{\circ} \mathrm{C}$} \\
\hline \multicolumn{2}{|c|}{$100 \mathrm{PA}$} & \multicolumn{2}{|c|}{$3200 \mathrm{PA}$} \\
\hline $\mathbf{R}$ & C & $\mathbf{R}$ & C \\
\hline Média & Média & Média & Média \\
\hline 0,95 & 5,23 & 0,00 & 6,38 \\
\hline 1,55 & 5,18 & 0,00 & 6,51 \\
\hline 0,19 & 5,25 & 0,00 & 6,35 \\
\hline 0,38 & 4,78 & 0,00 & 5,84 \\
\hline
\end{tabular}

\begin{tabular}{|c|c|c|c|}
\hline \multicolumn{4}{|c|}{76} \\
\hline \multicolumn{2}{|c|}{$100 \mathrm{PA}$} & \multicolumn{2}{|c|}{$3200 \mathrm{PA}$} \\
\hline $\mathbf{R}$ & C & $\mathbf{R}$ & c \\
\hline Média & Média & Média & Média \\
\hline 0,00 & 10,39 & 0,00 & 11,39 \\
\hline 0,00 & 10,18 & 0,00 & 11,43 \\
\hline 0,00 & \begin{tabular}{|l|l|} 
& 10,14
\end{tabular} & 0,00 & 11,30 \\
\hline 0,00 & \begin{tabular}{|l|l}
10,84 \\
\end{tabular} & 0,00 & 12,08 \\
\hline
\end{tabular}


Misturas realizadas com o Ligante Replan:

Ligantes Asfáltico Replan:

\begin{tabular}{|c|c|c|c|}
\hline \multicolumn{4}{|c|}{$52^{\circ} \mathrm{C}$} \\
\hline \multicolumn{2}{|c|}{$100 \mathrm{PA}$} & \multicolumn{2}{|c|}{$3200 \mathrm{PA}$} \\
\hline $\mathbf{R}$ & C & $\mathbf{R}$ & C \\
\hline Média & Média & Média & Média \\
\hline 12,14 & 0,33 & 8,71 & 0,35 \\
\hline 12,87 & 0,32 & 9,25 & 0,34 \\
\hline 12,60 & 0,33 & 9,01 & 0,35 \\
\hline
\end{tabular}

\begin{tabular}{|c|c|c|c|}
\hline \multicolumn{4}{|c|}{$58^{\circ} \mathrm{C}$} \\
\hline \multicolumn{2}{|c|}{$100 \mathrm{PA}$} & \multicolumn{2}{|c|}{$3200 \mathrm{PA}$} \\
\hline $\mathbf{R}$ & C & $\mathbf{R}$ & C \\
\hline Média & Média & Média & Média \\
\hline 5,64 & 0,92 & 0,37 & 1,02 \\
\hline 6,56 & 0,91 & 0,67 & 1,01 \\
\hline 5,94 & 0,92 & 0,62 & 1,02 \\
\hline
\end{tabular}

\begin{tabular}{|c|c|c|c|}
\hline \multicolumn{4}{|c|}{$64^{\circ} \mathrm{C}$} \\
\hline \multicolumn{2}{|c|}{$100 \mathrm{PA}$} & \multicolumn{2}{|c|}{3200 PA } \\
\hline $\mathbf{R}$ & C & $\mathbf{R}$ & C \\
\hline Média & Média & Média & Média \\
\hline 1,01 & 2,44 & 0,00 & 2,78 \\
\hline 1,63 & 2,39 & 0,00 & 2,74 \\
\hline 1,08 & 2,43 & 0,00 & 2,77 \\
\hline
\end{tabular}

\begin{tabular}{|c|c|c|c|}
\hline \multicolumn{4}{|c|}{$70^{\circ} \mathrm{C}$} \\
\hline \multicolumn{2}{|c|}{$100 \mathrm{PA}$} & \multicolumn{2}{|c|}{$3200 \mathrm{PA}$} \\
\hline $\mathbf{R}$ & C & $\mathbf{R}$ & C \\
\hline Média & Média & Média & Média \\
\hline 0,00 & 5,99 & 0,00 & 6,84 \\
\hline 0,00 & 5,88 & 0,00 & 6,72 \\
\hline 0,00 & 5,92 & 0,00 & 6,74 \\
\hline
\end{tabular}

\begin{tabular}{|c|c|c|c|}
\hline \multicolumn{4}{|c|}{$76^{\circ} \mathrm{C}$} \\
\hline \multicolumn{2}{|c|}{$100 \mathrm{PA}$} & \multicolumn{2}{|c|}{$3200 \mathrm{PA}$} \\
\hline $\mathbf{R}$ & C & $\mathbf{R}$ & C \\
\hline Média & Média & Média & Média \\
\hline 0,00 & 13,61 & 0,00 & 15,40 \\
\hline 0,00 & 13,41 & 0,00 & 15,08 \\
\hline 0,00 & 13,44 & 0,00 & 15,06 \\
\hline
\end{tabular}

Somente com adição de Ácido:

\section{0,5PPA}

\begin{tabular}{|c|c|c|c|}
\hline \multicolumn{4}{|c|}{$52^{\circ} \mathrm{C}$} \\
\hline \multicolumn{2}{|c|}{$100 \mathrm{PA}$} & \multicolumn{2}{|c|}{3200 PA } \\
\hline $\mathbf{R}$ & C & $\mathbf{R}$ & C \\
\hline Média & Média & Média & Média \\
\hline 28,42 & 0,16 & 24,06 & 0,17 \\
\hline 28,15 & 0,18 & 22,90 & 0,19 \\
\hline 28,00 & 0,17 & 23,67 & 0,18 \\
\hline
\end{tabular}

\begin{tabular}{|c|c|c|c|}
\hline \multicolumn{4}{|c|}{$58^{\circ} \mathrm{C}$} \\
\hline \multicolumn{2}{|c|}{$100 \mathrm{PA}$} & \multicolumn{2}{|c|}{3200 PA } \\
\hline $\mathbf{R}$ & C & $\mathbf{R}$ & C \\
\hline Média & Média & Média & Média \\
\hline 19,00 & 0,45 & 10,70 & 0,51 \\
\hline 17,58 & 0,49 & 10,06 & 0,55 \\
\hline 19,39 & 0,47 & 10,34 & 0,54 \\
\hline
\end{tabular}

\begin{tabular}{|c|c|c|c|}
\hline \multicolumn{4}{|c|}{$64^{\circ} \mathrm{C}$} \\
\hline \multicolumn{2}{|c|}{$100 \mathrm{PA}$} & \multicolumn{2}{|c|}{3200 PA } \\
\hline $\mathbf{R}$ & $\mathrm{C}$ & $\mathbf{R}$ & C \\
\hline Média & Média & Média & Média \\
\hline 9,56 & 1,55 & 0,00 & 1,88 \\
\hline 10,05 & 1,56 & 0,00 & 1,93 \\
\hline 10,33 & 1,22 & 0,00 & 1,45 \\
\hline
\end{tabular}

\begin{tabular}{|c|c|c|c|}
\hline \multicolumn{4}{|c|}{$70^{\circ} \mathrm{C}$} \\
\hline \multicolumn{2}{|c|}{$100 \mathrm{PA}$} & \multicolumn{2}{|c|}{$3200 \mathrm{PA}$} \\
\hline $\mathbf{R}$ & C & $\mathbf{R}$ & C \\
\hline Média & Média & Média & Média \\
\hline 4,20 & 3,67 & 0,00 & 4,56 \\
\hline 4,79 & 3,74 & 0,00 & 4,75 \\
\hline 4,51 & 3,00 & 0,00 & 3,69 \\
\hline
\end{tabular}

\begin{tabular}{|c|c|c|c|}
\hline \multicolumn{4}{|c|}{$76^{\circ} \mathrm{C}$} \\
\hline \multicolumn{2}{|c|}{$100 \mathrm{PA}$} & \multicolumn{2}{|c|}{3200 PA } \\
\hline $\mathbf{R}$ & C & $\mathbf{R}$ & C \\
\hline Média & Média & Média & Média \\
\hline 0,00 & 7,00 & 0,00 & 8,67 \\
\hline 0,00 & 7,40 & 0,00 & 9,22 \\
\hline 0,00 & 6,83 & 0,00 & 8,66 \\
\hline
\end{tabular}




\begin{tabular}{|c|c|c|c|}
\hline \multicolumn{4}{|c|}{$52^{\circ} \mathrm{C}$} \\
\hline \multicolumn{2}{|c|}{$100 \mathrm{PA}$} & \multicolumn{2}{|c|}{$3200 \mathrm{PA}$} \\
\hline $\mathbf{R}$ & $\mathrm{C}$ & $\mathbf{R}$ & $\mathrm{C}$ \\
\hline Média & Média & Média & Média \\
\hline 27,64 & 0,18 & 23,06 & 0,19 \\
\hline 29,70 & 0,16 & 25,24 & 0,17 \\
\hline 28,85 & 0,15 & 24,84 & 0,16 \\
\hline
\end{tabular}

\begin{tabular}{|c|c|c|c|c|c|c|c|}
\hline \multicolumn{4}{|c|}{$58^{\circ} \mathrm{C}$} & \multicolumn{4}{|c|}{$64^{\circ} \mathrm{C}$} \\
\hline \multicolumn{2}{|c|}{$100 \mathrm{PA}$} & \multicolumn{2}{|c|}{$3200 \mathrm{PA}$} & \multicolumn{2}{|c|}{$100 \mathrm{PA}$} & \multicolumn{2}{|c|}{3200 PA } \\
\hline $\mathbf{R}$ & C & $\mathbf{R}$ & C & $\mathbf{R}$ & C & $\mathbf{R}$ & C \\
\hline Média & Média & Média & Média & Média & Média & Média & Média \\
\hline 18,88 & 0,51 & 9,45 & 0,59 & 11,24 & 1,35 & 1,00 & 1,65 \\
\hline 21,08 & 0,43 & 11,86 & 0,49 & 17,47 & 1,07 & 1,11 & 1,39 \\
\hline 20,00 & 0,43 & 11,43 & 0,49 & 12,19 & 1,12 & 1,00 & 1,37 \\
\hline
\end{tabular}

\begin{tabular}{|c|c|c|c|}
\hline \multicolumn{4}{|c|}{$70^{\circ} \mathrm{C}$} \\
\hline \multicolumn{2}{|c|}{$100 \mathrm{PA}$} & \multicolumn{2}{|c|}{3200 PA } \\
\hline $\mathbf{R}$ & C & $\mathbf{R}$ & C \\
\hline Média & Média & Média & Média \\
\hline 4,58 & 3,68 & 0,00 & 4,60 \\
\hline 5,23 & 2,87 & 0,00 & 3,58 \\
\hline 6,24 & 2,76 & 0,00 & 3,48 \\
\hline
\end{tabular}

\begin{tabular}{|c|c|c|c|}
\hline \multicolumn{4}{|c|}{$76^{\circ} \mathrm{C}$} \\
\hline \multicolumn{2}{|c|}{$100 \mathrm{PA}$} & \multicolumn{2}{|c|}{3200 PA } \\
\hline $\mathbf{R}$ & C & $\mathbf{R}$ & C \\
\hline Média & Média & Média & Média \\
\hline 0,61 & 8,44 & 0,00 & 10,63 \\
\hline 1,01 & 6,72 & 0,00 & 8,49 \\
\hline 0,40 & 6,53 & 0,00 & 8,18 \\
\hline
\end{tabular}

\begin{tabular}{|c|c|c|c|}
\hline \multicolumn{4}{|c|}{$52^{\circ} \mathrm{C}$} \\
\hline \multicolumn{2}{|c|}{$100 \mathrm{PA}$} & \multicolumn{2}{|c|}{3200 PA } \\
\hline $\mathbf{R}$ & C & $\mathbf{R}$ & C \\
\hline Média & Média & Média & Média \\
\hline 39,53 & 0,12 & 34,86 & 0,12 \\
\hline 40,11 & 0,11 & 35,69 & 0,12 \\
\hline 39,16 & 0,12 & 34,35 & 0,13 \\
\hline
\end{tabular}

\begin{tabular}{|c|c|}
\hline \multicolumn{2}{|c|}{$58^{\circ}$} \\
\hline 100 & $\mathrm{PA}$ \\
\hline $\mathbf{R}$ & $\mathbf{C}$ \\
\hline Média & Média \\
\hline 29,28 & 0,32 \\
\hline 30,56 & 0,30 \\
\hline 29,66 & 0,33 \\
\hline
\end{tabular}

\begin{tabular}{|c|c|c|c|}
\hline \multicolumn{4}{|c|}{$64^{\circ} \mathrm{C}$} \\
\hline \multicolumn{2}{|c|}{$100 \mathrm{PA}$} & \multicolumn{2}{|c|}{3200 PA } \\
\hline $\mathbf{R}$ & C & $\mathbf{R}$ & C \\
\hline Média & Média & Média & Média \\
\hline 20,86 & 0,83 & 5,33 & 1,07 \\
\hline 21,36 & 0,80 & 6,01 & 1,02 \\
\hline 21,12 & 0,83 & 5,31 & 1,07 \\
\hline
\end{tabular}

\begin{tabular}{|c|c|c|c|}
\hline \multicolumn{4}{|c|}{$70^{\circ} \mathrm{C}$} \\
\hline \multicolumn{2}{|c|}{$100 \mathrm{PA}$} & \multicolumn{2}{|c|}{3200 PA } \\
\hline $\mathbf{R}$ & C & $\mathbf{R}$ & C \\
\hline Média & Média & Média & Média \\
\hline 11,96 & 2,10 & 0,00 & 2,82 \\
\hline 12,97 & 2,01 & 0,00 & 2,74 \\
\hline 12,16 & 2,07 & 0,00 & 2,76 \\
\hline
\end{tabular}

\begin{tabular}{|c|c|}
\hline \multicolumn{2}{|c|}{$76^{\circ}$} \\
\hline 100 & PA \\
\hline $\mathbf{R}$ & $\mathbf{C}$ \\
\hline Média & Média \\
\hline 5,21 & 5,00 \\
\hline 6,15 & 4,83 \\
\hline 5,80 & 4,79 \\
\hline
\end{tabular}

$76^{\circ} \mathrm{C}$

\begin{tabular}{|c|c|}
\hline \multicolumn{2}{|c|}{3200 PA } \\
\hline R & C \\
\hline Média & Média \\
\hline 19,46 & 0,37 \\
\hline 20,38 & 0,35 \\
\hline 19,12 & 0,38 \\
\hline
\end{tabular}

\begin{tabular}{|c|c|}
\hline \multicolumn{2}{|c|}{$58^{\circ}$} \\
\hline \multicolumn{2}{|c|}{$100 \mathrm{PA}$} \\
\hline $\mathbf{R}$ & $\mathbf{C}$ \\
\hline Média & Média \\
\hline 24,85 & 0,42 \\
\hline 25,37 & 0,41 \\
\hline 25,44 & 0,40 \\
\hline
\end{tabular}

$58^{\circ} \mathrm{C}$

\begin{tabular}{|c|c|c|c|}
\hline \multicolumn{4}{|c|}{$52^{\circ} \mathrm{C}$} \\
\hline \multicolumn{2}{|c|}{$100 \mathrm{PA}$} & \multicolumn{2}{|c|}{3200 PA } \\
\hline $\mathbf{R}$ & C & $\mathbf{R}$ & C \\
\hline Média & Média & Média & Média \\
\hline 34,05 & 0,15 & 28,71 & 0,17 \\
\hline 34,32 & 0,15 & 28,88 & 0,17 \\
\hline 34,72 & 0,15 & 29,45 & 0,16 \\
\hline
\end{tabular}

\begin{tabular}{|l|l|}
\hline 25,44 & 0,40 \\
\hline
\end{tabular}

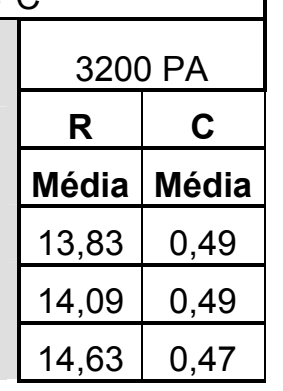

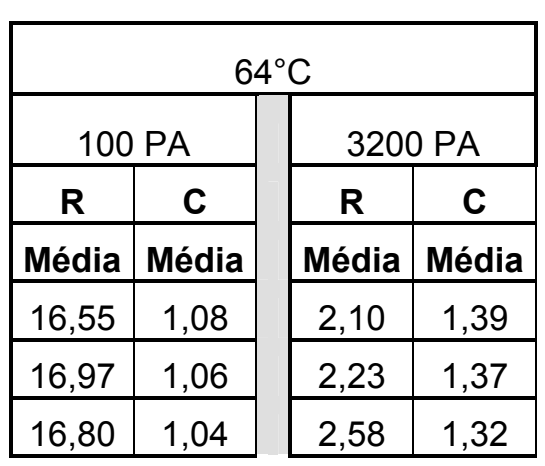

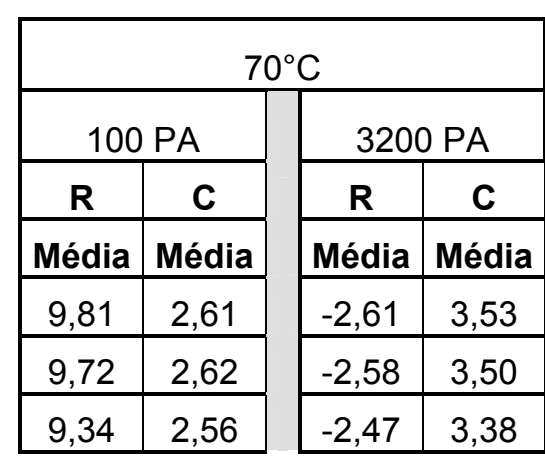

\begin{tabular}{|c|c|c|c|}
\hline \multicolumn{4}{|c|}{$76^{\circ} \mathrm{C}$} \\
\hline \multicolumn{2}{|c|}{$100 \mathrm{PA}$} & \multicolumn{2}{|c|}{3200 PA } \\
\hline $\mathbf{R}$ & C & $\mathbf{R}$ & C \\
\hline Média & Média & Média & Média \\
\hline 4,25 & 6,14 & 0,00 & 8,42 \\
\hline 4,04 & 6,11 & 0,00 & 8,35 \\
\hline 3,44 & 6,00 & 0,00 & 8,04 \\
\hline
\end{tabular}


1,0PPA

\begin{tabular}{|c|c|c|c|}
\hline \multicolumn{4}{|c|}{$52^{\circ} \mathrm{C}$} \\
\hline \multicolumn{2}{|c|}{$100 \mathrm{PA}$} & \multicolumn{2}{|c|}{3200 PA } \\
\hline $\mathbf{R}$ & C & $\mathbf{R}$ & C \\
\hline Média & Média & Média & Média \\
\hline 55,01 & 0,06 & 51,77 & 0,06 \\
\hline 54,38 & 0,06 & 51,24 & 0,07 \\
\hline 56,83 & 0,05 & 54,45 & 0,05 \\
\hline
\end{tabular}

\begin{tabular}{|c|c|}
\hline \multicolumn{3}{|c|}{$58^{\circ} \mathrm{C}$} \\
\hline 100 & PA \\
\hline $\mathbf{R}$ & $\mathbf{C}$ \\
\hline Média & Média \\
\hline 46,35 & 0,16 \\
\hline 46,04 & 0,16 \\
\hline 47,91 & 0,13 \\
\hline
\end{tabular}

\section{$58^{\circ} \mathrm{C}$}

\begin{tabular}{|c|c|}
\hline \multicolumn{2}{|c|}{3200 PA } \\
\hline $\mathbf{R}$ & $\mathbf{C}$ \\
\hline Média & Média \\
\hline 37,02 & 0,19 \\
\hline 36,54 & 0,19 \\
\hline 40,62 & 0,14 \\
\hline
\end{tabular}

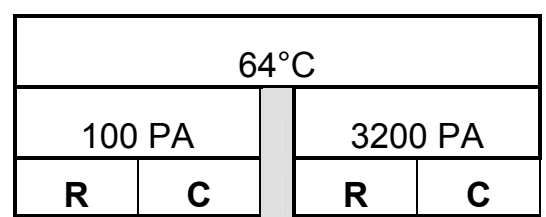

\begin{tabular}{|c|c|c|c|}
\hline \multicolumn{4}{|c|}{$70^{\circ} \mathrm{C}$} \\
\hline \multicolumn{2}{|c|}{$100 \mathrm{PA}$} & \multicolumn{2}{|c|}{$3200 \mathrm{PA}$} \\
\hline $\mathbf{R}$ & C & $\mathbf{R}$ & C \\
\hline Média & Média & Média & Média \\
\hline 26,77 & 1,02 & 4,29 & 1,50 \\
\hline 26,63 & 1,03 & 4,06 & 1,53 \\
\hline 27,06 & 0,86 & 6,09 & 1,25 \\
\hline
\end{tabular}

\section{Média Média}

\begin{tabular}{|l|l|}
\hline 36,62 & 0,41 \\
\hline 36,33 & 0,41 \\
\hline
\end{tabular}

\begin{tabular}{|l|l|}
\hline 36,33 & 0,41 \\
\hline 37,81 & 0,33 \\
\hline
\end{tabular}

\begin{tabular}{|l|l|}
\hline 37,81 & 0,33 \\
\hline
\end{tabular}

\begin{tabular}{l|l}
18,82 & 0,54 \\
\hline
\end{tabular} \begin{tabular}{|l|l|}
18,38 & 0,55 \\
\hline
\end{tabular}

\begin{tabular}{|l|l|}
\hline 22,28 & 0,43 \\
\hline
\end{tabular}

\section{1,0PA85}

\begin{tabular}{|c|c|c|c|}
\hline \multicolumn{4}{|c|}{$52^{\circ} \mathrm{C}$} \\
\hline \multicolumn{2}{|c|}{$100 \mathrm{PA}$} & \multicolumn{2}{|c|}{$3200 \mathrm{PA}$} \\
\hline $\mathbf{R}$ & C & $\mathbf{R}$ & C \\
\hline Média & Média & Média & Média \\
\hline 47,30 & 0,08 & 43,75 & 0,08 \\
\hline 47,84 & 0,08 & 44,09 & 0,08 \\
\hline 48,37 & 0,07 & 44,99 & 0,08 \\
\hline
\end{tabular}

\begin{tabular}{|c|c|}
\hline \multicolumn{2}{|c|}{$58^{\circ}$} \\
\hline $100 \mathrm{PA}$ \\
\hline $\mathbf{R}$ & $\mathbf{C}$ \\
\hline Média & Média \\
\hline 38,25 & 0,21 \\
\hline 38,23 & 0,20 \\
\hline 38,73 & 0,20 \\
\hline
\end{tabular}

$58^{\circ} \mathrm{C}$

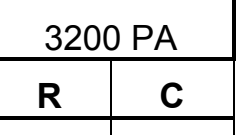

Média Média

\begin{tabular}{|l|l|}
\hline 28,32 & 0,25 \\
\hline 28,87 & 0,24 \\
\hline
\end{tabular}

\begin{tabular}{|l|l|}
\hline 28,87 & 0,24 \\
\hline
\end{tabular}

\begin{tabular}{|l|l|}
\hline 29,55 & 0,23 \\
\hline
\end{tabular}

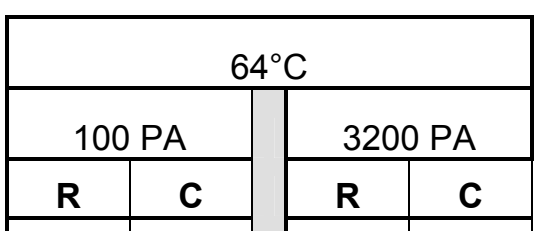

\begin{tabular}{|lll|l|} 
Média & Média & Média & Média \\
&
\end{tabular} \begin{tabular}{|l|l||l|l|}
\hline 28,37 & 0,56 & 11,67 & 0,73 \\
\hline
\end{tabular} \begin{tabular}{|l|l||l|l|}
\hline 28,43 & 0,54 \\
\hline
\end{tabular} \mid \begin{tabular}{ll}
11,27 & 0,70 \\
\hline
\end{tabular} \begin{tabular}{|l|l|}
\hline 28,72 & 0,53 \\
\hline 12,50 & 0,69 \\
\hline
\end{tabular}

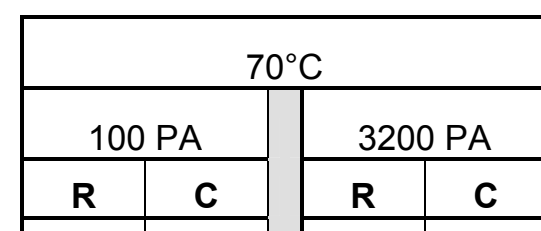

Média Média

\begin{tabular}{l|l}
\hline 19,35 & 1,40 \\
\hline 18,90 & 1,36
\end{tabular}

\begin{tabular}{|l|l|}
\hline 18,90 & 1,36 \\
\hline
\end{tabular}

\begin{tabular}{|l|l|}
\hline 18,90 & 1,36 \\
\hline 19,47 & 1,36 \\
\hline
\end{tabular}

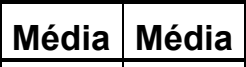

\begin{tabular}{|l|l|}
\hline 0,84 & 1,98 \\
\hline
\end{tabular}

\begin{tabular}{|l|l|}
\hline 1,15 & 1,89 \\
\hline 1,10 & 1,90 \\
\hline
\end{tabular}

\begin{tabular}{|l|l|}
\hline 1,15 & 1,89 \\
\hline 1,10 & 1,90 \\
\hline
\end{tabular}
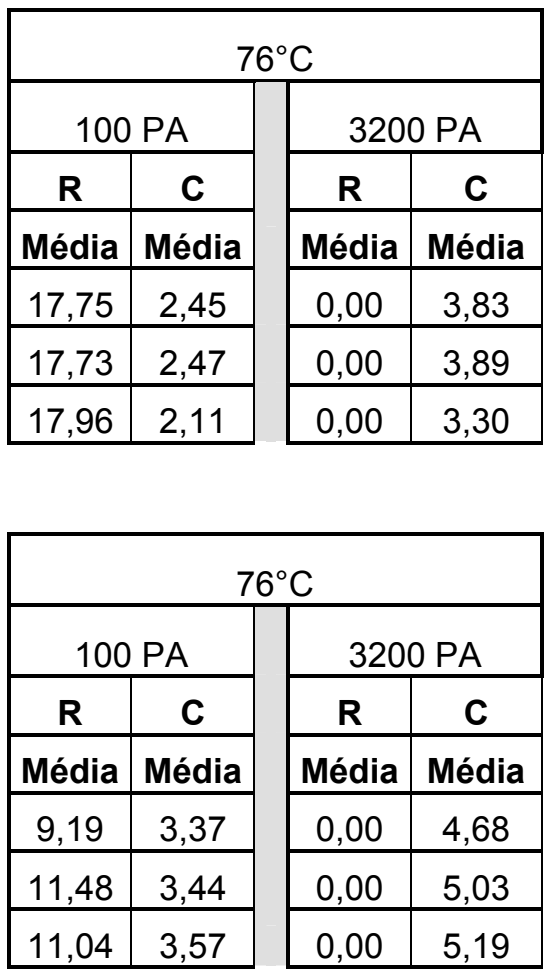

\section{1,5PPA}

\begin{tabular}{|c|c|c|c|}
\hline \multicolumn{4}{|c|}{$52^{\circ} \mathrm{C}$} \\
\hline \multicolumn{2}{|c|}{$100 \mathrm{PA}$} & \multicolumn{2}{|c|}{3200 PA } \\
\hline $\mathbf{R}$ & C & $\mathbf{R}$ & C \\
\hline Média & Média & Média & Média \\
\hline 75,02 & 0,02 & 74,46 & 0,02 \\
\hline 76,16 & 0,01 & 75,27 & 0,02 \\
\hline 75,15 & 0,01 & 74,83 & 0,01 \\
\hline
\end{tabular}

$58^{\circ} \mathrm{C}$

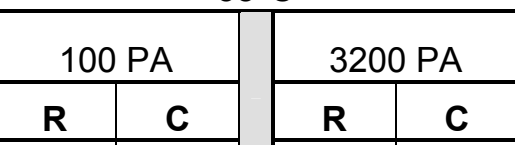

Média Média

\begin{tabular}{|l|l|}
\hline 70,44 & 0,04 \\
\hline
\end{tabular}

\begin{tabular}{|l|l|}
\hline 71,69 & 0,03 \\
\hline
\end{tabular}

\begin{tabular}{|l|l|}
\hline 71,69 & 0,03 \\
\hline 70,32 & 0,03 \\
\hline
\end{tabular}

Média Média

\begin{tabular}{|l|l|}
\hline 67,18 & 0,04 \\
\hline 68,57 & 0,04 \\
\hline
\end{tabular}

\begin{tabular}{|l|l|}
\hline 68,57 & 0,04 \\
\hline
\end{tabular}

\begin{tabular}{|c|c|c|c|}
\hline \multicolumn{4}{|c|}{$64^{\circ} \mathrm{C}$} \\
\hline \multicolumn{2}{|c|}{$100 \mathrm{PA}$} & \multicolumn{2}{|c|}{3200 PA } \\
\hline $\mathbf{R}$ & C & $\mathbf{R}$ & C \\
\hline Média & Média & Média & Média \\
\hline 62,84 & 0,09 & 54,15 & 0,11 \\
\hline 64,46 & 0,08 & 56,22 & 0,10 \\
\hline 62,34 & 0,08 & 55,75 & 0.09 \\
\hline
\end{tabular}

\begin{tabular}{|c|c|}
\hline \multicolumn{2}{|c|}{$70^{\circ}$} \\
\hline \multicolumn{2}{|c|}{$100 \mathrm{PA}$} \\
\hline $\mathbf{R}$ & $\mathbf{C}$ \\
\hline Média & Média \\
\hline 53,43 & 0,23 \\
\hline 55,28 & 0,21 \\
\hline 52,38 & 0,20 \\
\hline
\end{tabular}

$70^{\circ} \mathrm{C}$

\begin{tabular}{|l|l|}
\hline 67,98 & 0,03 \\
\hline
\end{tabular}

\begin{tabular}{|l|l|}
\hline 52,38 & 0,20 \\
\hline
\end{tabular}

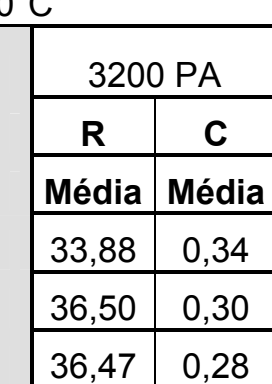


1,5PA85

\begin{tabular}{|c|c|c|c|}
\hline \multicolumn{4}{|c|}{$52^{\circ} \mathrm{C}$} \\
\hline \multicolumn{2}{|c|}{$100 \mathrm{PA}$} & \multicolumn{2}{|c|}{$3200 \mathrm{PA}$} \\
\hline $\mathbf{R}$ & C & $\mathbf{R}$ & C \\
\hline Média & Média & Média & Média \\
\hline 65,75 & 0,03 & 64,21 & 0,03 \\
\hline 64,79 & 0,03 & 63,60 & 0,03 \\
\hline 65,77 & 0,03 & 64,98 & 0,03 \\
\hline
\end{tabular}

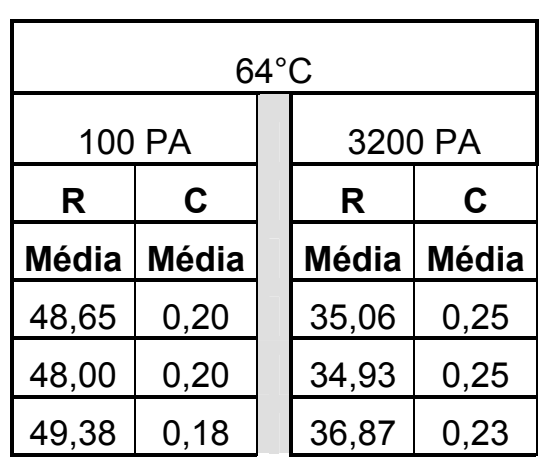

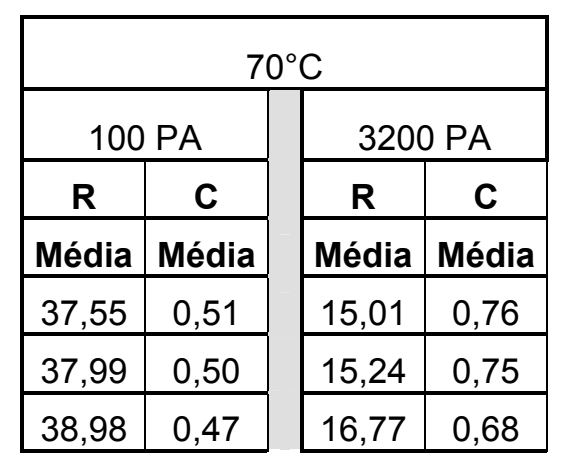

\begin{tabular}{|c|c|c|c|}
\hline \multicolumn{4}{|c|}{$76^{\circ} \mathrm{C}$} \\
\hline \multicolumn{2}{|c|}{$100 \mathrm{PA}$} & \multicolumn{2}{|c|}{3200 PA } \\
\hline $\mathbf{R}$ & C & $\mathbf{R}$ & C \\
\hline Média & Média & Média & Média \\
\hline 28,05 & 1,26 & 1,98 & 2,12 \\
\hline 27,96 & 1,25 & 2,11 & 2,08 \\
\hline 28,82 & 1,16 & 2,78 & 1,92 \\
\hline
\end{tabular}

Adição do Copolímero SBS + Ácido:

\section{SBS + 1,5PPA}

\begin{tabular}{|c|c|c|c|}
\hline \multicolumn{4}{|c|}{$52^{\circ} \mathrm{C}$} \\
\hline \multicolumn{2}{|c|}{$100 \mathrm{PA}$} & \multicolumn{2}{|c|}{$3200 \mathrm{PA}$} \\
\hline $\mathbf{R}$ & C & $\mathbf{R}$ & C \\
\hline Média & Média & Média & Média \\
\hline 87,60 & 0,00 & 86,29 & 0,00 \\
\hline 87,71 & 0,00 & 86,20 & 0,00 \\
\hline \begin{tabular}{|l|} 
\\
\end{tabular} & 0,00 & 85,84 & 0,00 \\
\hline
\end{tabular}

\begin{tabular}{|c|c|c|c|}
\hline \multicolumn{4}{|c|}{$64^{\circ} \mathrm{C}$} \\
\hline \multicolumn{2}{|c|}{$100 \mathrm{PA}$} & \multicolumn{2}{|c|}{$3200 \mathrm{PA}$} \\
\hline $\mathbf{R}$ & C & $\mathbf{R}$ & C \\
\hline Média & Média & Média & Média \\
\hline 78,30 & 0,02 & 73,36 & 0,03 \\
\hline 80,40 & 0,02 & 73,10 & 0,02 \\
\hline 77,03 & 0,02 & 71,79 & 0,03 \\
\hline
\end{tabular}

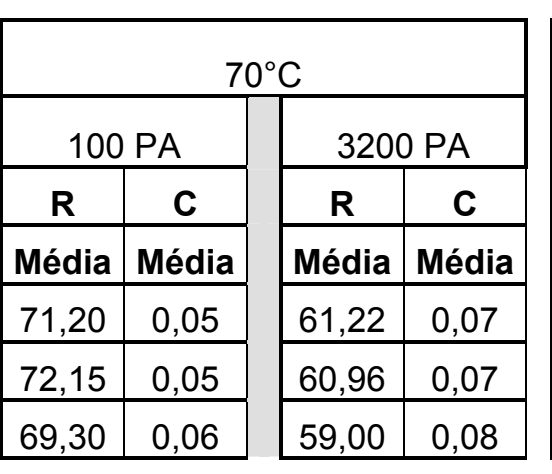

\begin{tabular}{|c|c|c|c|}
\hline \multicolumn{4}{|c|}{$76^{\circ} \mathrm{C}$} \\
\hline \multicolumn{2}{|c|}{$100 \mathrm{PA}$} & \multicolumn{2}{|c|}{$3200 \mathrm{PA}$} \\
\hline $\mathbf{R}$ & C & $\mathbf{R}$ & C \\
\hline Média & Média & Média & Média \\
\hline 63,09 & 0,12 & 45,20 & 0,20 \\
\hline 62,49 & 0,12 & 45,07 & 0,19 \\
\hline 60,23 & 0,13 & 42,45 & 0,21 \\
\hline
\end{tabular}


5 SBS + 1,5PA85

\begin{tabular}{|c|c|c|c|}
\hline \multicolumn{4}{|c|}{$52^{\circ} \mathrm{C}$} \\
\hline \multicolumn{2}{|c|}{$100 \mathrm{PA}$} & \multicolumn{2}{|c|}{3200 PA } \\
\hline $\mathbf{R}$ & C & $\mathbf{R}$ & C \\
\hline Média & Média & Média & Média \\
\hline 79,45 & 0,01 & 80,54 & 0,01 \\
\hline 78,85 & 0,01 & 80,13 & 0,01 \\
\hline 78,90 & 0,01 & 81,51 & 0,01 \\
\hline 73,34 & 0,01 & 82,16 & 0,01 \\
\hline
\end{tabular}

\begin{tabular}{|c|c|c|c|}
\hline \multicolumn{4}{|c|}{$58^{\circ} \mathrm{C}$} \\
\hline \multicolumn{2}{|c|}{$100 \mathrm{PA}$} & \multicolumn{2}{|c|}{$3200 \mathrm{PA}$} \\
\hline $\mathbf{R}$ & C & $\mathbf{R}$ & C \\
\hline Média & Média & Média & Média \\
\hline 74,43 & 0,02 & 72,40 & 0,02 \\
\hline 73,82 & 0,02 & 72,14 & 0,02 \\
\hline 76,00 & 0,02 & 74,20 & 0,02 \\
\hline 75,26 & 0,02 & 75,04 & 0,02 \\
\hline
\end{tabular}

\begin{tabular}{|c|c|c|c|}
\hline \multicolumn{4}{|c|}{$64^{\circ} \mathrm{C}$} \\
\hline \multicolumn{2}{|c|}{$100 \mathrm{PA}$} & \multicolumn{2}{|c|}{$3200 \mathrm{PA}$} \\
\hline $\mathbf{R}$ & C & $\mathbf{R}$ & C \\
\hline Média & Média & Média & Média \\
\hline 65,92 & 0,05 & 60,35 & 0,05 \\
\hline 65,12 & 0,05 & 60,08 & 0,06 \\
\hline 69,77 & 0,04 & 62,72 & 0,05 \\
\hline 70,46 & 0,04 & 63,97 & 0,05 \\
\hline
\end{tabular}

\begin{tabular}{|c|c|}
\hline \multicolumn{2}{|c|}{70} \\
\hline \multicolumn{2}{|c|}{$100 \mathrm{PA}$} \\
\hline $\mathbf{R}$ & $\mathbf{C}$ \\
\hline Média & Média \\
\hline 55,80 & 0,12 \\
\hline 55,06 & 0,12 \\
\hline 61,82 & 0,10 \\
\hline 64,02 & 0,09 \\
\hline
\end{tabular}

$70^{\circ} \mathrm{C}$

\begin{tabular}{|c|c|}
\hline \multicolumn{2}{|c|}{$3200 \mathrm{PA}$} \\
\hline $\mathbf{R}$ & $\mathbf{C}$ \\
\hline Média & Média \\
\hline 44,12 & 0,15 \\
\hline 43,70 & 0,15 \\
\hline 47,30 & 0,14 \\
\hline 48,96 & 0,13 \\
\hline
\end{tabular}

\section{SBS + 0,75PPA}

\begin{tabular}{|c|c|c|c|}
\hline \multicolumn{4}{|c|}{$52^{\circ} \mathrm{C}$} \\
\hline \multicolumn{2}{|c|}{$100 \mathrm{PA}$} & \multicolumn{2}{|c|}{$3200 \mathrm{PA}$} \\
\hline $\mathbf{R}$ & C & $\mathbf{R}$ & C \\
\hline Média & Média & Média & Média \\
\hline 74,79 & 0,02 & 72,54 & 0,02 \\
\hline 73,71 & 0,02 & 72,62 & 0,02 \\
\hline 73,74 & 0,01 & 71,87 & 0,02 \\
\hline
\end{tabular}

\section{SBS + 0,75PA85}

$52^{\circ} \mathrm{C}$

\begin{tabular}{|c|c|}
\hline \multicolumn{2}{|c|}{100 PA } \\
\hline $\mathbf{R}$ & $\mathbf{C}$ \\
\hline
\end{tabular}

3200 PA

Média Média

\begin{tabular}{ll|l}
69,70 & 0,02 \\
\hline
\end{tabular}

\begin{tabular}{l|l|}
66,09 & 0,02 \\
\hline
\end{tabular}

\begin{tabular}{|l|l|}
\hline 66,94 & 0,02 \\
\hline
\end{tabular}

\begin{tabular}{|c|c|c|c|}
\hline \multicolumn{4}{|c|}{$58^{\circ} \mathrm{C}$} \\
\hline \multicolumn{2}{|c|}{$100 \mathrm{PA}$} & \multicolumn{2}{|c|}{3200 PA } \\
\hline $\mathbf{R}$ & C & $\mathbf{R}$ & C \\
\hline Média & Média & Média & Média \\
\hline 67,66 & 0,04 & 61,10 & 0,05 \\
\hline 67,35 & 0,04 & 61,50 & 0,05 \\
\hline 67,11 & 0,04 & 60,32 & 0,04 \\
\hline
\end{tabular}

\begin{tabular}{|c|c|}
\hline \multicolumn{2}{|c|}{$58^{\circ}$} \\
\hline \multicolumn{2}{|c|}{$100 \mathrm{PA}$} \\
\hline $\mathbf{R}$ & $\mathbf{C}$ \\
\hline Média & Média \\
\hline 61,55 & 0,05 \\
\hline 61,67 & 0,05 \\
\hline 60,33 & 0,05 \\
\hline
\end{tabular}

$58^{\circ} \mathrm{C}$

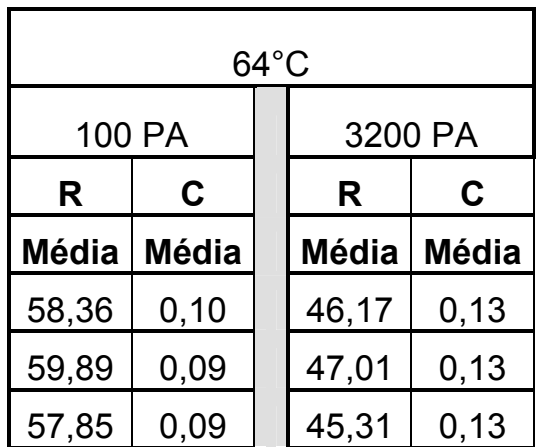

3200 PA

\begin{tabular}{l|l|}
$\mathbf{R}$ & $\mathbf{C}$ \\
\hline
\end{tabular}

\begin{tabular}{|l|l|}
\hline Média & Média \\
\hline 56,53 & 0,06 \\
\hline
\end{tabular}

\begin{tabular}{|l|l|l|}
\hline 51,38 & 0,13 \\
\hline 53,06 & 0,12 \\
\hline
\end{tabular}

\begin{tabular}{|l|l|}
55,53 & 0,06 \\
\hline 54,57 & 0,06 \\
\hline
\end{tabular}

\begin{tabular}{|l|l|}
\hline 40,63 & 0,16 \\
\hline
\end{tabular}

\begin{tabular}{|l|l|l|}
54,57 & 0,06 \\
\hline 50,51 & 0,13 \\
\hline
\end{tabular} \begin{tabular}{|l|l|l|}
\hline 39,39 & 0,17 \\
\hline
\end{tabular}

\begin{tabular}{|c|c|c|c|}
\hline \multicolumn{4}{|c|}{$64^{\circ} \mathrm{C}$} \\
\hline \multicolumn{2}{|c|}{$100 \mathrm{PA}$} & \multicolumn{2}{|c|}{3200 PA } \\
\hline $\mathbf{R}$ & C & $\mathbf{R}$ & C \\
\hline Média & Média & Média & Média \\
\hline 51,38 & 0,13 & 41,33 & 0,16 \\
\hline 53,06 & 0,12 & 40,63 & 0,16 \\
\hline 50,51 & 0,13 & 39,39 & 0,17 \\
\hline
\end{tabular}

\section{$70^{\circ} \mathrm{C}$}

\begin{tabular}{|c|c||c|c|}
\hline \multicolumn{2}{|c|}{100 PA } & & \multicolumn{2}{|c|}{3200 PA } \\
\cline { 1 - 1 } \cline { 5 - 6 } $\mathbf{R}$ & $\mathbf{C}$ & $\mathbf{R}$ & $\mathbf{C}$ \\
\hline
\end{tabular}

Média Média Média Média

\begin{tabular}{|l|l|l|l|}
\hline 48,07 & 0,24 & 29,56 & 0,35 \\
\hline
\end{tabular}

\begin{tabular}{|l|l|}
\hline 48,25 & 0,24 \\
\hline
\end{tabular}

\begin{tabular}{|l|l|}
\hline 29,08 & 0,35 \\
\hline
\end{tabular} \begin{tabular}{|l|l|l|l|l|}
\hline 51,04 & 0,23 \\
\hline 48,25 & 0,24 & 31,90 & 0,34 \\
\hline
\end{tabular}

\begin{tabular}{|c|c|}
\hline \multicolumn{2}{|c|}{$70^{\circ}$} \\
\hline \multicolumn{2}{|c|}{100 PA } \\
\hline $\mathbf{R}$ & $\mathbf{C}$ \\
\hline Média & Média \\
\hline 41,36 & 0,30 \\
\hline 43,84 & 0,30 \\
\hline 40,86 & 0,32 \\
\hline
\end{tabular}

$70^{\circ} \mathrm{C}$

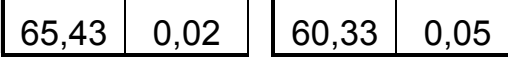

\begin{tabular}{|c|c|}
\hline \multicolumn{2}{|c|}{$3200 \mathrm{PA}$} \\
\hline $\mathbf{R}$ & $\mathbf{C}$ \\
\hline Média & Média \\
\hline 24,31 & 0,42 \\
\hline 25,69 & 0,43 \\
\hline 23,62 & 0,44 \\
\hline
\end{tabular}

\begin{tabular}{|c|c|c|c|}
\hline \multicolumn{4}{|c|}{$76^{\circ} \mathrm{C}$} \\
\hline \multicolumn{2}{|c|}{$100 \mathrm{PA}$} & \multicolumn{2}{|c|}{$3200 \mathrm{PA}$} \\
\hline $\mathbf{R}$ & C & $\mathbf{R}$ & C \\
\hline Média & Média & Média & Média \\
\hline 38,13 & 0,56 & 15,80 & 0,88 \\
\hline 42,06 & 0,53 & 19,47 & 0,86 \\
\hline 38,19 & 0,57 & 15,86 & 0,90 \\
\hline
\end{tabular}

\begin{tabular}{|c|c|c|c|}
\hline \multicolumn{4}{|c|}{$76^{\circ} \mathrm{C}$} \\
\hline \multicolumn{2}{|c|}{$100 \mathrm{PA}$} & \multicolumn{2}{|c|}{3200 PA } \\
\hline $\mathbf{R}$ & $\mathrm{C}$ & $\mathbf{R}$ & $\mathrm{C}$ \\
\hline Média & Média & Média & Média \\
\hline 31,20 & 0,72 & 10,38 & 1,10 \\
\hline 34,33 & 0,71 & 13,52 & 1,09 \\
\hline 31,12 & 0,74 & 11,29 & 1,12 \\
\hline
\end{tabular}




\begin{tabular}{|c|c|c|c|c|c|c|c|c|c|c|c|}
\hline \multicolumn{4}{|c|}{$52^{\circ} \mathrm{C}$} & \multicolumn{4}{|c|}{$58^{\circ} \mathrm{C}$} & \multicolumn{4}{|c|}{$64^{\circ} \mathrm{C}$} \\
\hline \multicolumn{2}{|c|}{$100 \mathrm{PA}$} & \multicolumn{2}{|c|}{3200 PA } & \multicolumn{2}{|c|}{$100 \mathrm{PA}$} & \multicolumn{2}{|c|}{$3200 \mathrm{PA}$} & \multicolumn{2}{|c|}{$100 \mathrm{PA}$} & \multicolumn{2}{|c|}{3200 PA } \\
\hline $\mathbf{R}$ & C & $\mathbf{R}$ & $\mathrm{C}$ & $\mathbf{R}$ & C & $\mathbf{R}$ & C & $\mathbf{R}$ & C & $\mathbf{R}$ & C \\
\hline Média & Média & Média & Média & Média & Média & Média & Média & Média & Média & Média & Média \\
\hline 60,16 & 0,05 & 54,74 & 0,06 & 54,63 & 0,13 & 42,25 & 0,17 & 47,05 & 0,32 & 27,84 & 0,47 \\
\hline 59,72 & 0,05 & 54,82 & 0,06 & 54,64 & 0,13 & 41,87 & 0,17 & 47,35 & 0,31 & 27,08 & 0,47 \\
\hline 60,62 & 0,05 & 55,37 & 0,06 & 57,85 & 0,12 & 42,08 & 0,17 & 51,62 & 0,28 & 29,04 & 0,45 \\
\hline
\end{tabular}

\begin{tabular}{|c|c|c|c|}
\hline \multicolumn{4}{|c|}{$70^{\circ} \mathrm{C}$} \\
\hline \multicolumn{2}{|c|}{$100 \mathrm{PA}$} & \multicolumn{2}{|c|}{$3200 \mathrm{PA}$} \\
\hline $\mathbf{R}$ & C & $\mathbf{R}$ & C \\
\hline Média & Média & Média & Média \\
\hline 39,25 & 0,74 & 14,66 & 1,22 \\
\hline 39,06 & 0,73 & 14,06 & 1,22 \\
\hline 40,87 & 0,71 & 17,52 & 1,18 \\
\hline
\end{tabular}

\begin{tabular}{|c|c|c|c|}
\hline \multicolumn{4}{|c|}{$76^{\circ} \mathrm{C}$} \\
\hline \multicolumn{2}{|c|}{100 PA } & \multicolumn{2}{|c|}{3200 PA } \\
\hline $\mathbf{R}$ & C & $\mathbf{R}$ & C \\
\hline Média & Média & Média & Média \\
\hline 30,23 & 1,72 & 5,21 & 2,99 \\
\hline \begin{tabular}{|l}
28,69 \\
\end{tabular} & 1,72 & 5,03 & 2,99 \\
\hline 32,05 & 1,66 & 8,15 & 2,93 \\
\hline
\end{tabular}

\section{2,5 SBS + 1,5PPA}

\begin{tabular}{|c|c|c|c|}
\hline \multicolumn{4}{|c|}{$52^{\circ} \mathrm{C}$} \\
\hline \multicolumn{2}{|c|}{$100 \mathrm{PA}$} & \multicolumn{2}{|c|}{3200 PA } \\
\hline $\mathbf{R}$ & C & $\mathbf{R}$ & C \\
\hline Média & Média & Média & Média \\
\hline 79,16 & 0,01 & 80,39 & 0,01 \\
\hline 77,97 & 0,01 & 77,67 & 0,01 \\
\hline 78,19 & 0,01 & 78,07 & 0,01 \\
\hline
\end{tabular}

\begin{tabular}{|c|c|}
\hline \multicolumn{2}{|c|}{58} \\
\hline 100 PA \\
\hline R & C \\
\hline Média & Média \\
\hline 76,33 & 0,02 \\
\hline 72,42 & 0,02 \\
\hline 73,02 & 0,02 \\
\hline
\end{tabular}

$58^{\circ} \mathrm{C}$

\begin{tabular}{|c|c|}
\hline 3200 & PA \\
\hline R & C \\
\hline Média & Média \\
\hline 74,37 & 0,02 \\
\hline 70,18 & 0,03 \\
\hline 70,71 & 0,03 \\
\hline
\end{tabular}

\section{2,5 SBS + 1,5PA85}

\begin{tabular}{|c|c|c|c|}
\hline \multicolumn{4}{|c|}{$52^{\circ} \mathrm{C}$} \\
\hline \multicolumn{2}{|c|}{$100 \mathrm{PA}$} & \multicolumn{2}{|c|}{3200 PA } \\
\hline $\mathbf{R}$ & C & $\mathbf{R}$ & C \\
\hline Média & Média & Média & Média \\
\hline 72,96 & 0,02 & 72,20 & 0,02 \\
\hline 72,32 & 0,02 & 71,69 & 0,02 \\
\hline 72,73 & 0,02 & 72,60 & 0,02 \\
\hline
\end{tabular}

\begin{tabular}{|c|c|}
\hline \multicolumn{2}{|c|}{$58^{\circ}$} \\
\hline 100 & PA \\
\hline $\mathbf{R}$ & $\mathbf{C}$ \\
\hline Média & Média \\
\hline 66,21 & 0,04 \\
\hline 65,35 & 0,04 \\
\hline 66,14 & 0,04 \\
\hline
\end{tabular}

$58^{\circ} \mathrm{C}$

3200 PA

\begin{tabular}{l|c|} 
R & $\mathbf{C}$ \\
\hline
\end{tabular}

Média Média

Média Média Média Média

\begin{tabular}{|l|l|}
\hline 62,83 & 0,04 \\
\hline 61,95 & 0,05 \\
\hline
\end{tabular}

\begin{tabular}{|l|l|}
\hline 61,95 & 0,05 \\
\hline 63,09 & 0,04 \\
\hline
\end{tabular}

\begin{tabular}{|c|c|c|c|}
\hline \multicolumn{4}{|c|}{$64^{\circ} \mathrm{C}$} \\
\hline \multicolumn{2}{|c|}{$100 \mathrm{PA}$} & \multicolumn{2}{|c|}{3200 PA } \\
\hline $\mathbf{R}$ & C & $\mathbf{R}$ & C \\
\hline Média & Média & Média & Média \\
\hline 69,80 & 0,05 & 63,99 & 0,06 \\
\hline 64,12 & 0,06 & 58,11 & 0,07 \\
\hline 64,64 & 0,06 & 58,73 & 0,07 \\
\hline
\end{tabular}

\begin{tabular}{|c|c|}
\hline \multicolumn{2}{|c|}{70} \\
\hline 100 & PA \\
\hline $\mathbf{R}$ & $\mathbf{C}$ \\
\hline Média & Média \\
\hline 61,70 & 0,12 \\
\hline 54,45 & 0,16 \\
\hline 55,15 & 0,16 \\
\hline
\end{tabular}

$70^{\circ} \mathrm{C}$

\begin{tabular}{|c|c|}
\hline \multicolumn{2}{|c|}{3200 PA } \\
\hline R & C \\
\hline Média & Média \\
\hline 48,16 & 0,17 \\
\hline 40,12 & 0,21 \\
\hline 40,65 & 0,21 \\
\hline
\end{tabular}

\begin{tabular}{|c|c|c|c|}
\hline \multicolumn{4}{|c|}{$64^{\circ} \mathrm{C}$} \\
\hline \multicolumn{2}{|c|}{$100 \mathrm{PA}$} & \multicolumn{2}{|c|}{3200 PA } \\
\hline $\mathbf{R}$ & C & $\mathbf{R}$ & C \\
\hline Média & Média & Média & Média \\
\hline 56,93 & 0,10 & 48,22 & 0,12 \\
\hline 56,50 & 0,11 & 46,92 & 0,13 \\
\hline 57,04 & 0,10 & 48,51 & 0,12 \\
\hline
\end{tabular}

$70^{\circ} \mathrm{C}$

Média Média Média Média

\begin{tabular}{|l|l|l|l|l|}
\hline 46,97 & 0,25 & 28,57 & 0,36 \\
\cline { 2 - 4 } & &
\end{tabular} \begin{tabular}{|l|l|l|l|l|}
46,76 & 0,27 & 26,97 & 0,39 \\
\hline
\end{tabular} \begin{tabular}{|l|l|}
\hline 46,90 & 0,25 \\
\hline
\end{tabular} \begin{tabular}{|l|l|l|}
$26,8,88$ & 0,36 \\
\hline
\end{tabular}

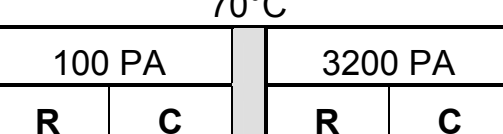

\begin{tabular}{|c|c|c|c|}
\hline \multicolumn{4}{|c|}{$76^{\circ} \mathrm{C}$} \\
\hline \multicolumn{2}{|c|}{$100 \mathrm{PA}$} & \multicolumn{2}{|c|}{3200 PA } \\
\hline $\mathbf{R}$ & C & $\mathbf{R}$ & C \\
\hline Média & Média & Média & Média \\
\hline 52,38 & 0,29 & 27,94 & 0,50 \\
\hline 43,73 & 0,38 & 19,53 & 0,62 \\
\hline 44,77 & 0,38 & 19,60 & 0,63 \\
\hline
\end{tabular}

\begin{tabular}{|c|c|c|c|}
\hline \multicolumn{4}{|c|}{$76^{\circ} \mathrm{C}$} \\
\hline \multicolumn{2}{|c|}{$100 \mathrm{PA}$} & \multicolumn{2}{|c|}{3200 PA } \\
\hline $\mathbf{R}$ & C & $\mathbf{R}$ & C \\
\hline Média & Média & Média & Média \\
\hline 35,81 & 0,62 & 10,47 & 1,00 \\
\hline 35,65 & 0,65 & 9,73 & 1,06 \\
\hline 36,00 & 0,61 & 11,05 & 0,98 \\
\hline
\end{tabular}


2,5 SBS + 0,75PPA

\begin{tabular}{|c|c|c|c|}
\hline \multicolumn{4}{|c|}{$52^{\circ} \mathrm{C}$} \\
\hline \multicolumn{2}{|c|}{$100 \mathrm{PA}$} & \multicolumn{2}{|c|}{$3200 \mathrm{PA}$} \\
\hline $\mathbf{R}$ & C & $\mathbf{R}$ & C \\
\hline Média & Média & Média & Média \\
\hline 55,17 & 0,05 & 53,19 & 0,05 \\
\hline 55,60 & 0,05 & 53,66 & 0,05 \\
\hline 55,76 & 0,04 & 54,16 & 0,05 \\
\hline
\end{tabular}

\begin{tabular}{|c|c|}
\hline \multicolumn{2}{|c|}{$58^{\circ}$} \\
\hline \multicolumn{2}{|c|}{$100 \mathrm{PA}$} \\
\hline $\mathbf{R}$ & $\mathbf{C}$ \\
\hline Média & Média \\
\hline 45,16 & 0,13 \\
\hline 45,46 & 0,12 \\
\hline 44,77 & 0,12 \\
\hline
\end{tabular}

\section{$58^{\circ} \mathrm{C}$}

3200 PA

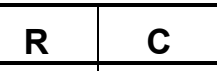

Média Média

\begin{tabular}{|l|l|l|l|l|}
\cline { 1 - 2 } 38,70 & 0,14 & 34,90 & 0,33 \\
\hline
\end{tabular}

\begin{tabular}{|l|l|}
\hline 39,25 & 0,14 \\
\hline
\end{tabular}

\begin{tabular}{|l|l|}
39,66 & 0,13 \\
\hline
\end{tabular} \begin{tabular}{|l|l|}
\hline 35,37 & 0,32 \\
\hline
\end{tabular}

\begin{tabular}{|c|c|}
\hline \multicolumn{3}{|c|}{$64^{\circ}$} \\
\hline 100 PA \\
\hline $\mathbf{R}$ & $\mathbf{C}$ \\
\hline Média & Média \\
\hline 34,90 & 0,33 \\
\hline 35,37 & 0,32 \\
\hline 35,31 & 0,32 \\
\hline
\end{tabular}

$64^{\circ} \mathrm{C}$

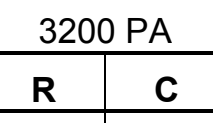

Média Média

\begin{tabular}{|l|l|}
\hline 21,41 & 0,41 \\
\hline
\end{tabular}

\begin{tabular}{|l|l|}
\hline 21,89 & 0,40 \\
\hline
\end{tabular}

\begin{tabular}{|l|l|}
\hline 22,14 & 0,40 \\
\hline
\end{tabular}

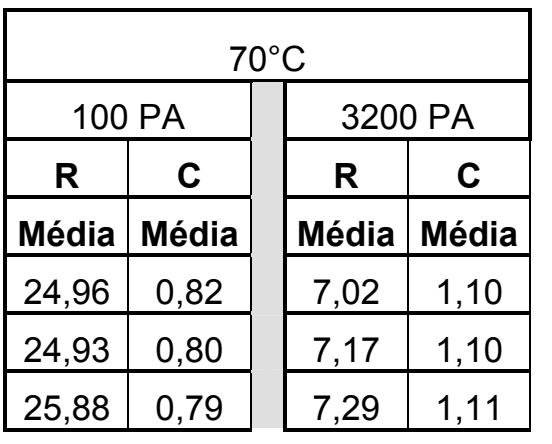

\begin{tabular}{|c|c|c|c|}
\hline \multicolumn{4}{|c|}{$76^{\circ} \mathrm{C}$} \\
\hline \multicolumn{2}{|c|}{$100 \mathrm{PA}$} & \multicolumn{2}{|c|}{3200 PA } \\
\hline $\mathbf{R}$ & C & $\mathbf{R}$ & C \\
\hline Média & Média & Média & Média \\
\hline 15,80 & 1,90 & 0,00 & 2,73 \\
\hline 14,80 & 1,93 & 0,00 & 2,77 \\
\hline 15,39 & 1,95 & 0,00 & 2,81 \\
\hline
\end{tabular}

\section{2,5 SBS + 0,75PA85}

\begin{tabular}{|c|c|c|c|}
\hline \multicolumn{4}{|c|}{$52^{\circ} \mathrm{C}$} \\
\hline \multicolumn{2}{|c|}{$100 \mathrm{PA}$} & \multicolumn{2}{|c|}{3200 PA } \\
\hline $\mathbf{R}$ & C & $\mathbf{R}$ & C \\
\hline Média & Média & Média & Média \\
\hline 53,27 & 0,05 & 51,22 & 0,05 \\
\hline 53,80 & 0,05 & 51,48 & 0,06 \\
\hline 52,73 & 0,05 & 50,48 & 0,06 \\
\hline
\end{tabular}

\begin{tabular}{|c|c|}
\hline \multicolumn{2}{|c|}{$58^{\circ}$} \\
\hline 100 PA \\
\hline R & C \\
\hline Média & Média \\
\hline 42,32 & 0,14 \\
\hline 43,30 & 0,14 \\
\hline 42,02 & 0,15 \\
\hline
\end{tabular}

$58^{\circ} \mathrm{C}$

\begin{tabular}{|c|c|}
\hline \multicolumn{2}{|c|}{$3200 \mathrm{PA}$} \\
\hline $\mathbf{R}$ & $\mathbf{C}$ \\
\hline Média & Média \\
\hline 36,37 & 0,16 \\
\hline 36,59 & 0,16 \\
\hline 35,62 & 0,16 \\
\hline
\end{tabular}

\begin{tabular}{|c|c|c|c|}
\hline \multicolumn{4}{|c|}{$64^{\circ} \mathrm{C}$} \\
\hline \multicolumn{2}{|c|}{$100 \mathrm{PA}$} & \multicolumn{2}{|c|}{$3200 \mathrm{PA}$} \\
\hline $\mathbf{R}$ & C & $\mathbf{R}$ & C \\
\hline Média & Média & Média & Média \\
\hline 31,56 & 0,37 & 19,35 & 0,46 \\
\hline 32,77 & 0,37 & 19,47 & 0,46 \\
\hline 31,29 & 0,38 & 18,68 & 0,47 \\
\hline
\end{tabular}

\section{2,5 SBS}

\begin{tabular}{|c|c|c|c|}
\hline \multicolumn{4}{|c|}{$52^{\circ} \mathrm{C}$} \\
\hline \multicolumn{2}{|c|}{$100 \mathrm{PA}$} & \multicolumn{2}{|c|}{3200 PA } \\
\hline $\mathbf{R}$ & C & $\mathbf{R}$ & C \\
\hline Média & Média & Média & Média \\
\hline 22,92 & 0,20 & 19,99 & 0,21 \\
\hline 22,48 & 0,21 & 19,06 & 0,22 \\
\hline 22,92 & 0,20 & 19,94 & 0,21 \\
\hline
\end{tabular}

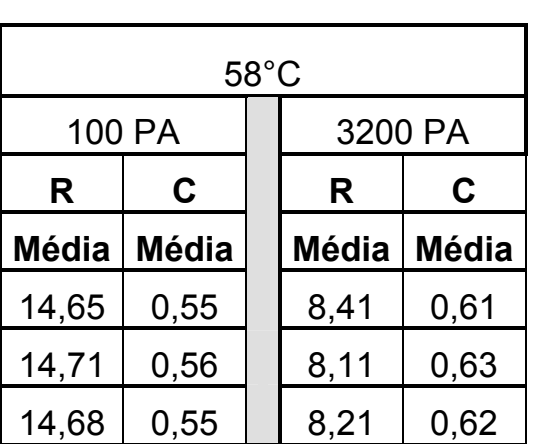

\begin{tabular}{|c|c|c|c|}
\hline \multicolumn{4}{|c|}{$70^{\circ} \mathrm{C}$} \\
\hline \multicolumn{2}{|c|}{$100 \mathrm{PA}$} & \multicolumn{2}{|c|}{3200 PA } \\
\hline $\mathbf{R}$ & C & $\mathbf{R}$ & C \\
\hline Média & Média & Média & Média \\
\hline 22,51 & 0,92 & 5,83 & 1,24 \\
\hline 20,74 & 0,93 & 5,94 & 1,24 \\
\hline 22,35 & 0,93 & 5,28 & 1,28 \\
\hline
\end{tabular}

\begin{tabular}{|c|c|c|c|}
\hline \multicolumn{4}{|c|}{$76^{\circ} \mathrm{C}$} \\
\hline \multicolumn{2}{|c|}{$100 \mathrm{PA}$} & \multicolumn{2}{|c|}{3200 PA } \\
\hline $\mathbf{R}$ & C & $\mathbf{R}$ & C \\
\hline Média & Média & Média & Média \\
\hline 13,99 & 2,18 & 0,00 & 3,08 \\
\hline 14,89 & 2,12 & 0,00 & 3,04 \\
\hline 13,41 & 2,21 & 0,00 & 3,17 \\
\hline
\end{tabular}

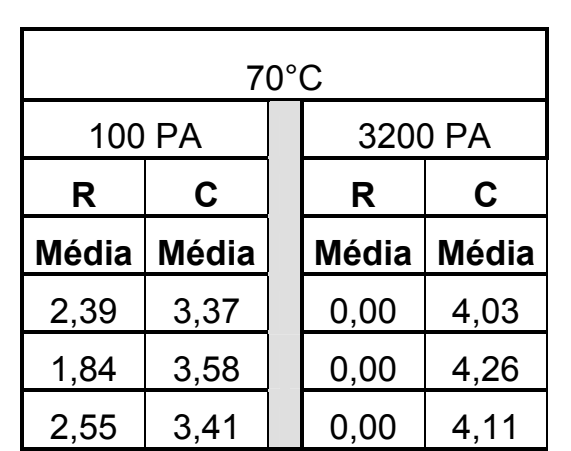

\begin{tabular}{|c|c|c|c|}
\hline \multicolumn{4}{|c|}{$76^{\circ} \mathrm{C}$} \\
\hline \multicolumn{2}{|c|}{$100 \mathrm{PA}$} & \multicolumn{2}{|c|}{3200 PA } \\
\hline $\mathbf{R}$ & C & $\mathbf{R}$ & C \\
\hline Média & Média & Média & Média \\
\hline 0,00 & 8,07 & 0,00 & 9,46 \\
\hline 0,00 & 8,26 & 0,00 & 9,75 \\
\hline 0,00 & 8,32 & 0,00 & 9,70 \\
\hline
\end{tabular}




\section{Apêndice $\mathscr{D}$ - Efeito do envelhecimento na $\mathcal{N}_{f}$ em função da amplitude de deformação (Replan)}

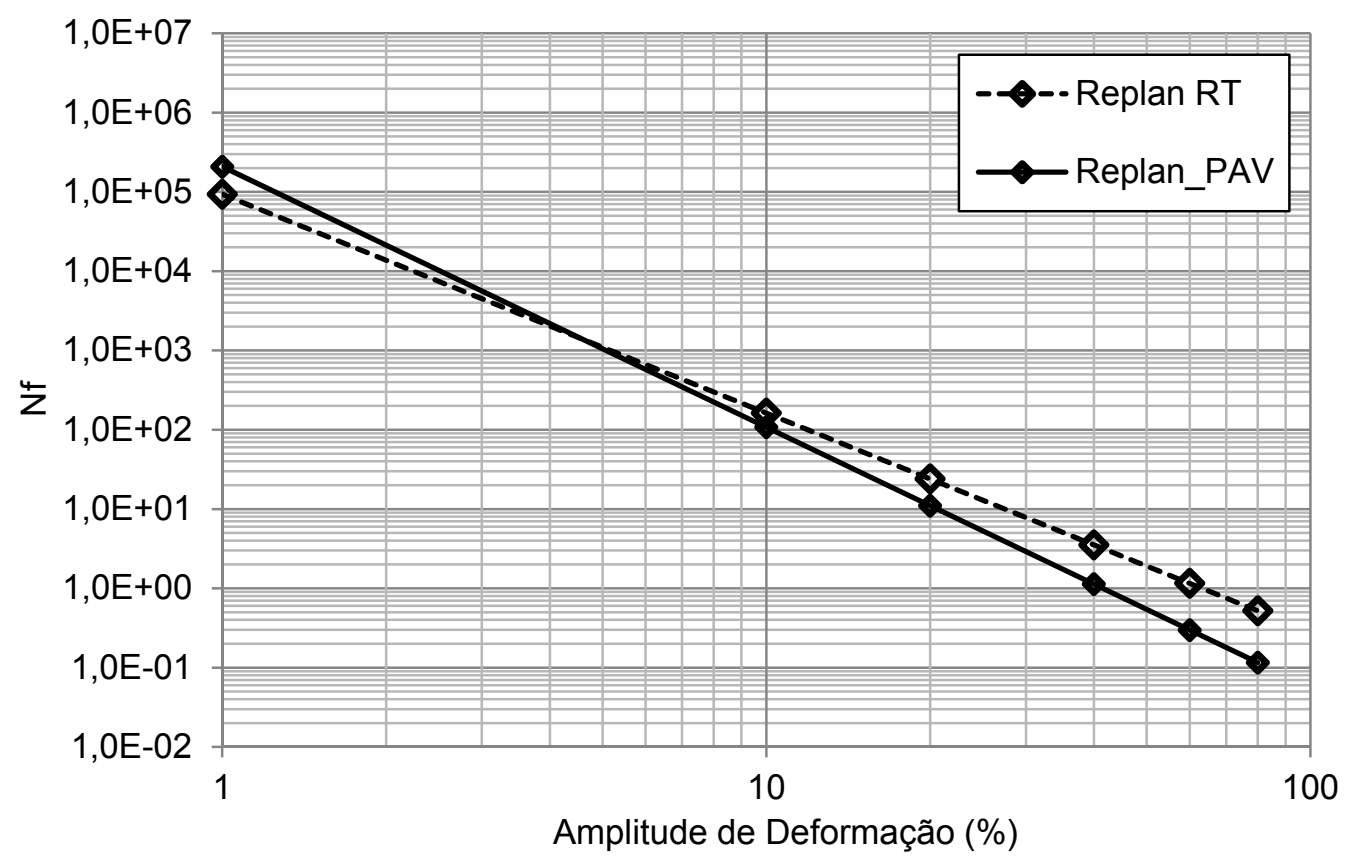

Figura 130 - Efeito do envelhecimento na variação do número de ciclos na ruptura em função da amplitude de deformação para o REPLAN puro.

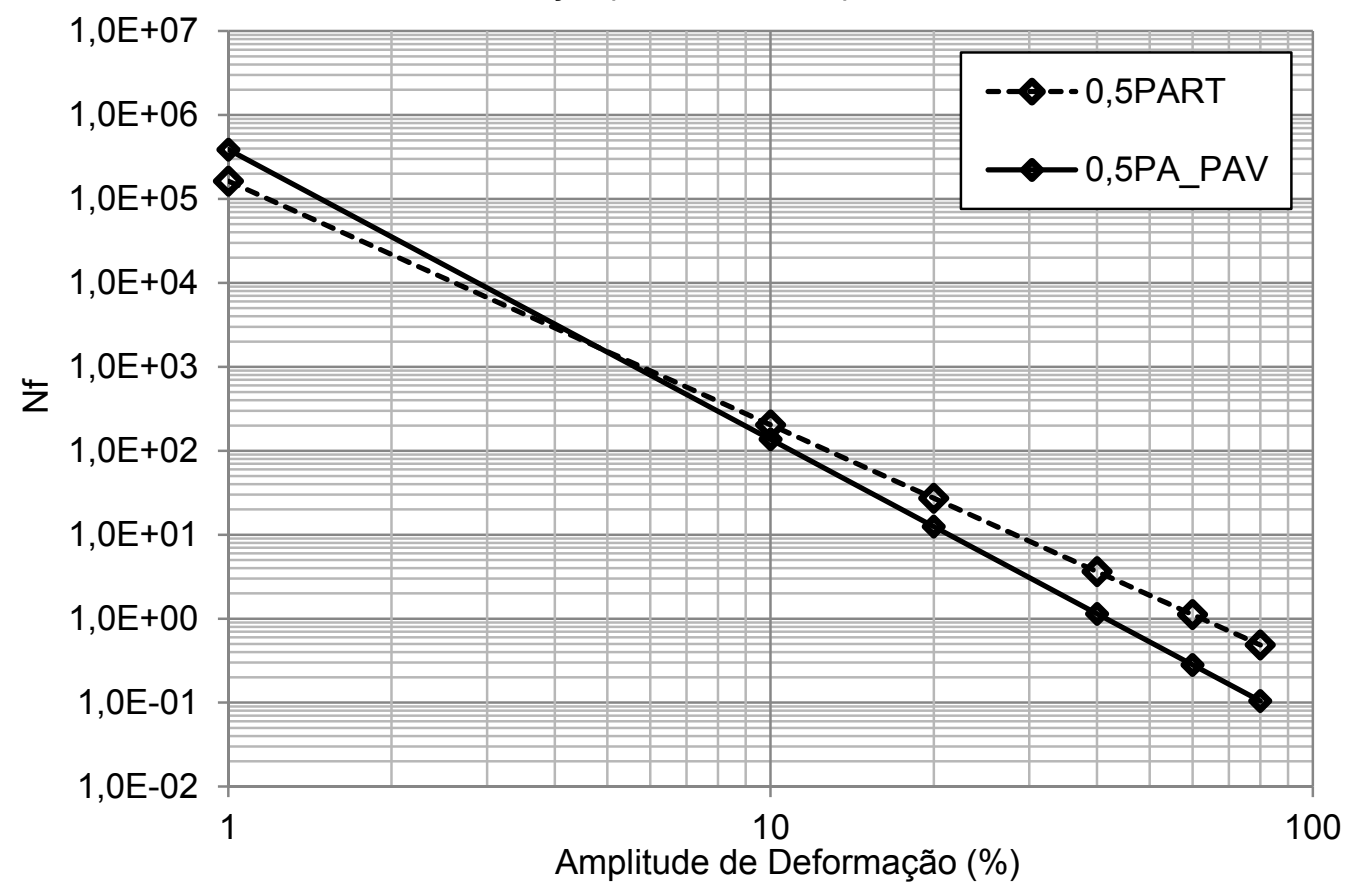

Figura 131 - Efeito do envelhecimento na variação do número de ciclos na ruptura em função da amplitude de deformação para o REPLAN + 0,5\%PA85. 


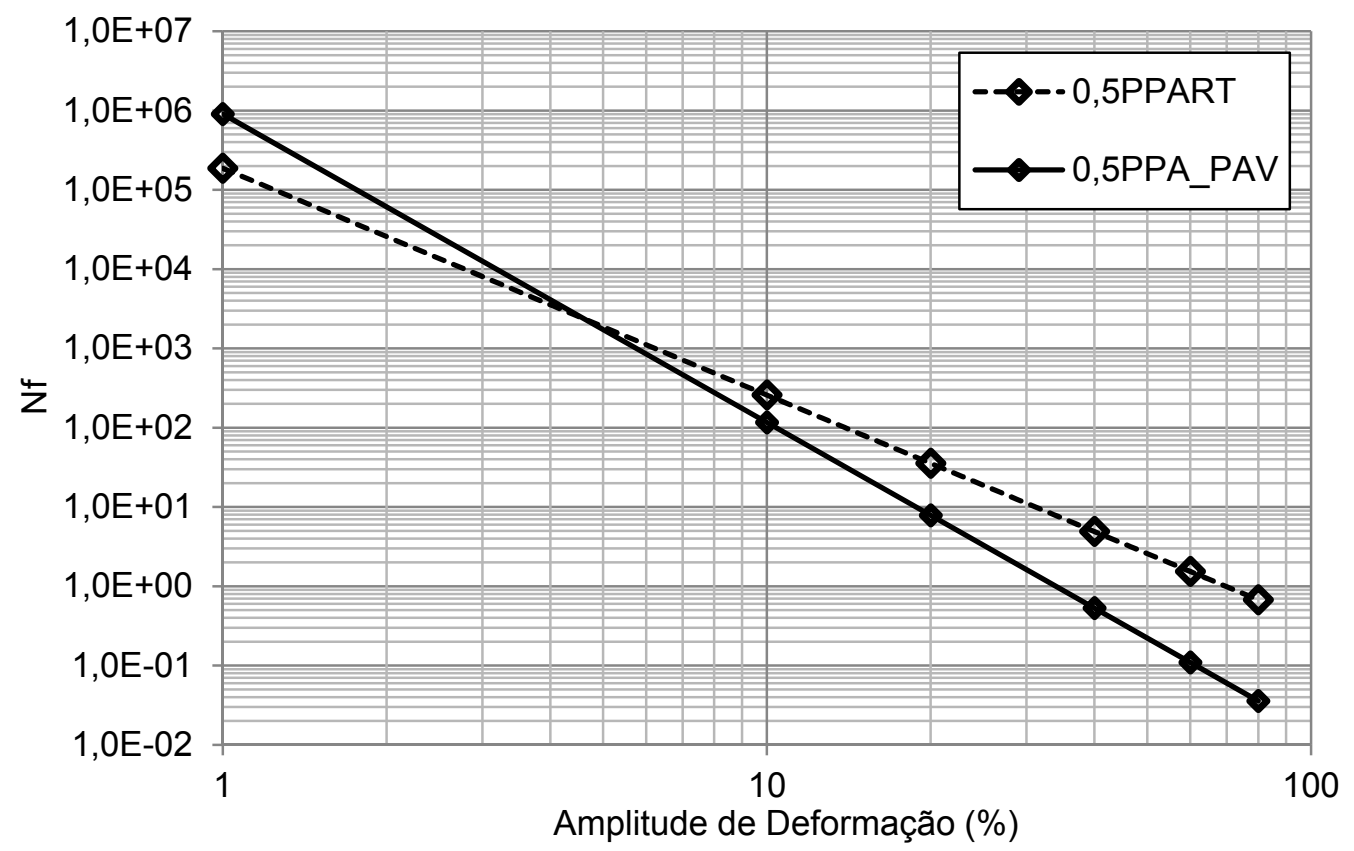

Figura 132 - Efeito do envelhecimento na variação do número de ciclos na ruptura em função da amplitude de deformação para o REPLAN + 0,5\%PPA.

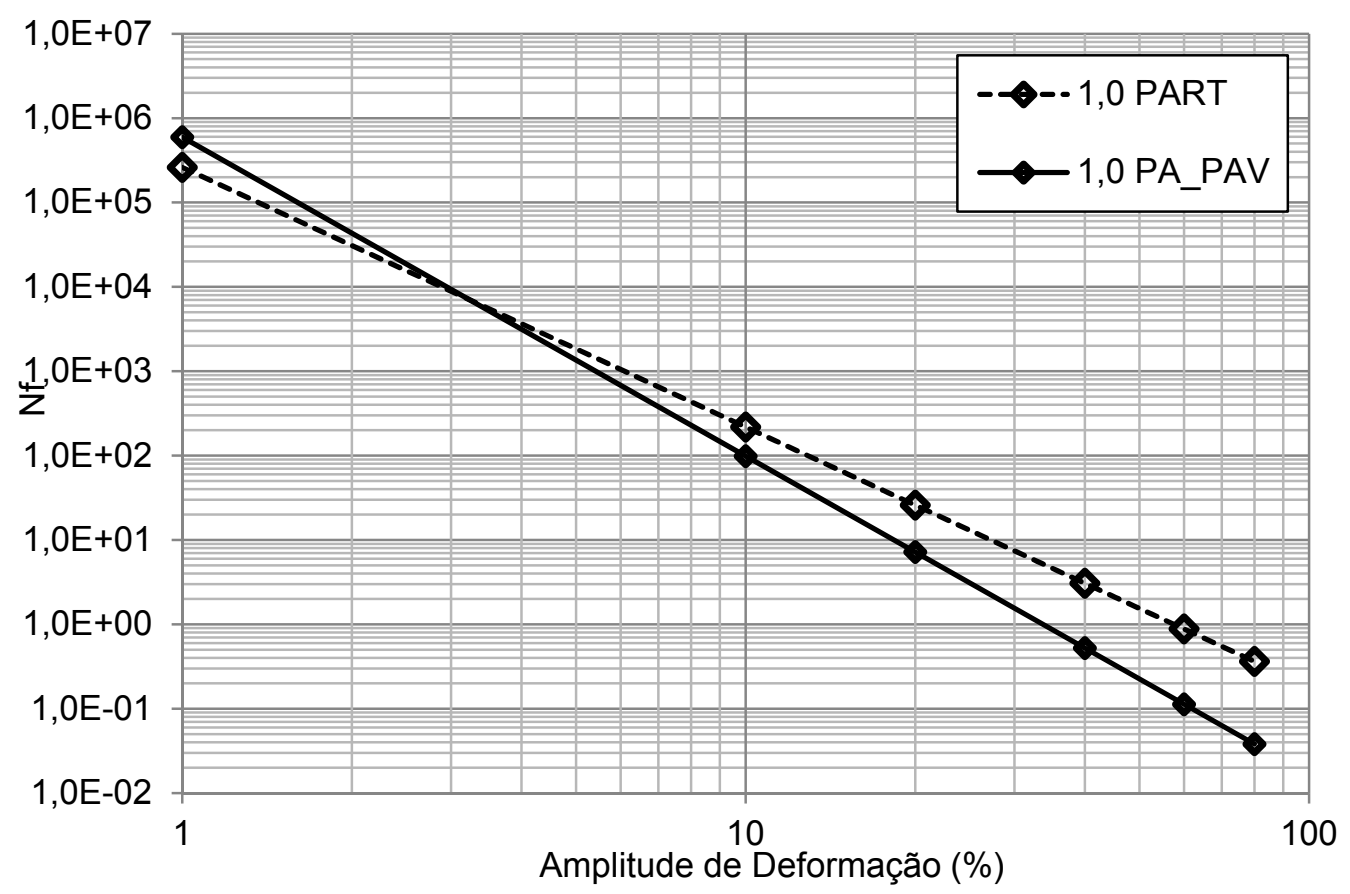

Figura 133 - Efeito do envelhecimento na variação do número de ciclos na ruptura em função da amplitude de deformação para o REPLAN +1,0\%PA85. 


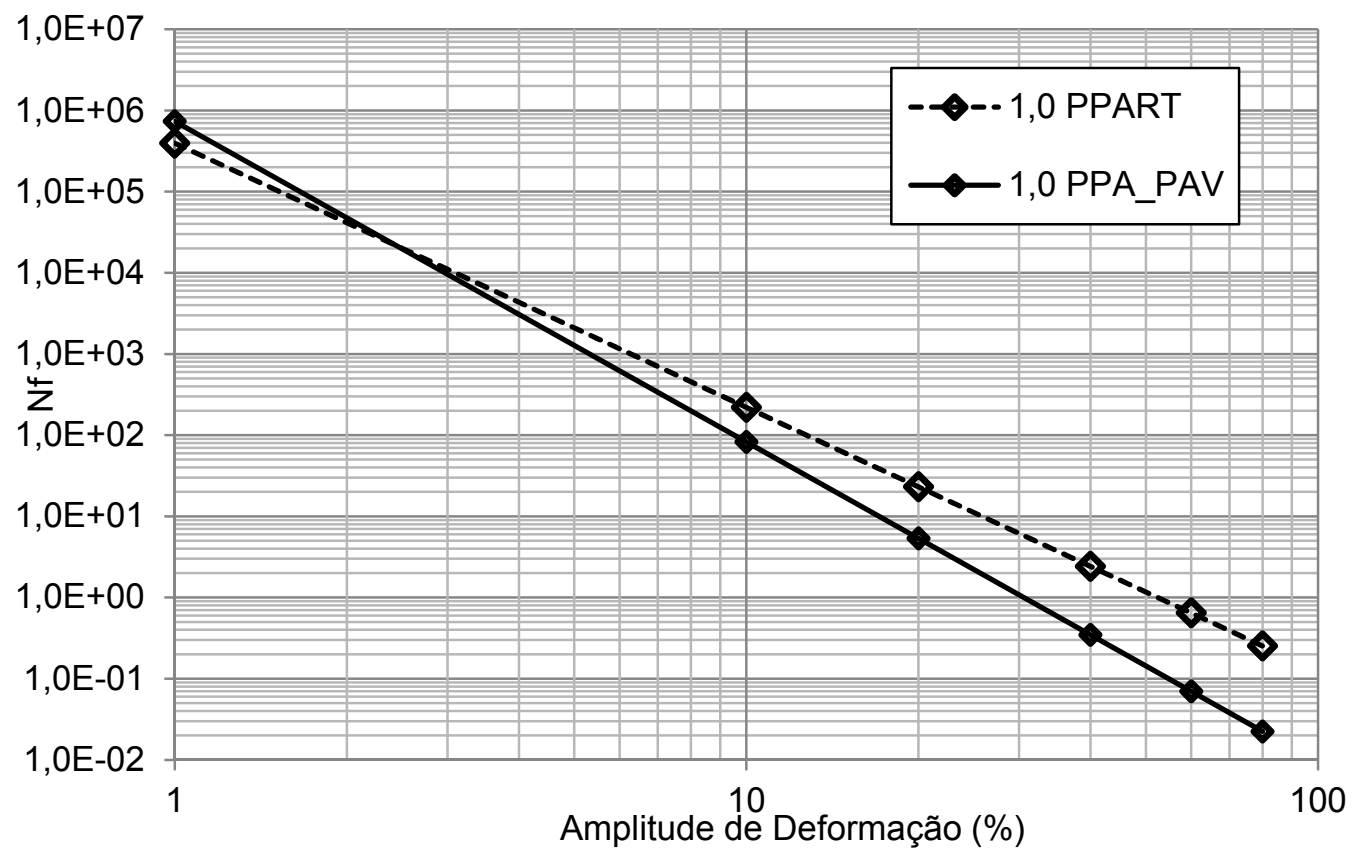

Figura 134 - Efeito do envelhecimento na variação do número de ciclos na ruptura em função da amplitude de deformação para o REPLAN +1,0\%PPA.

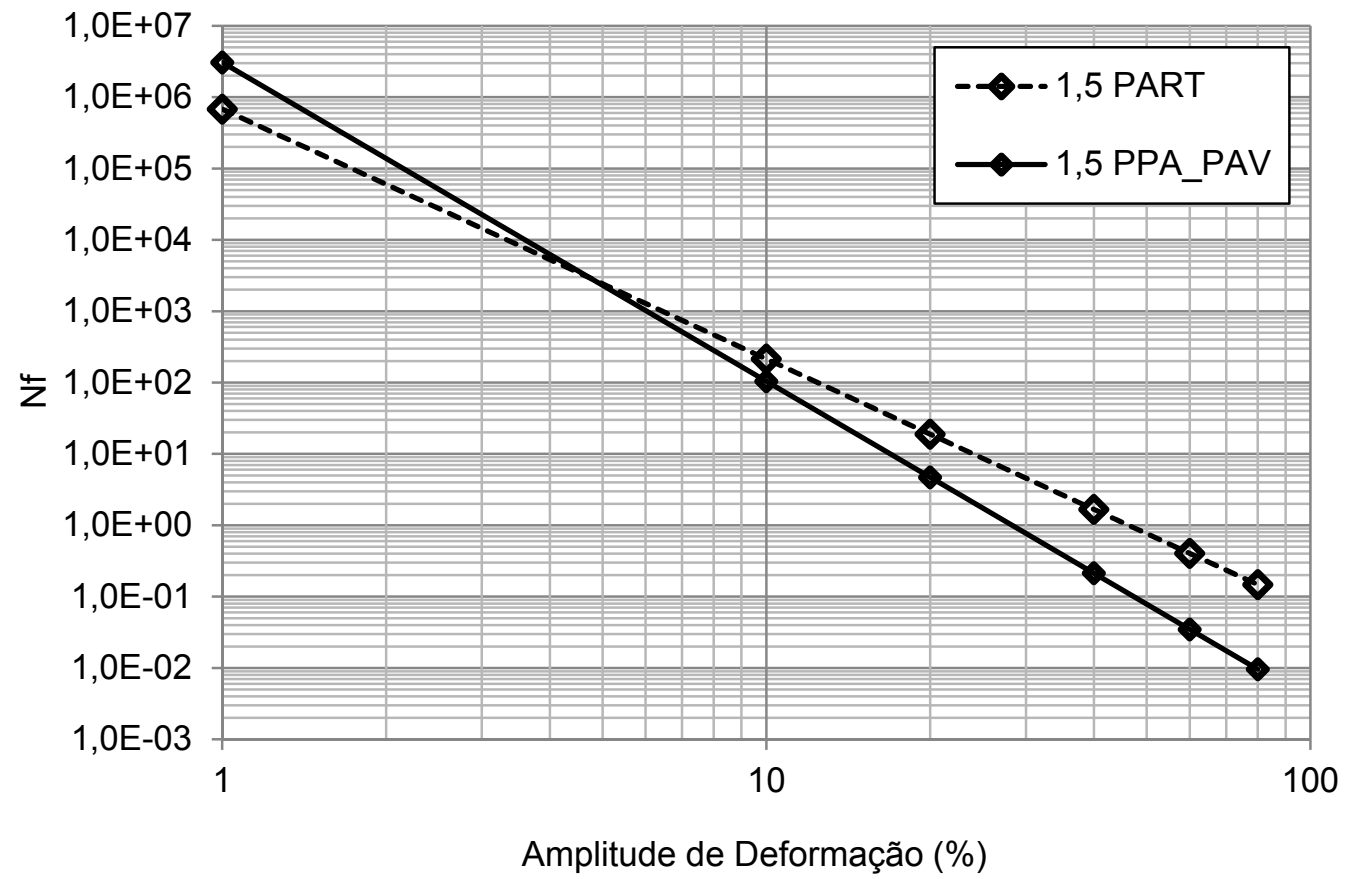

Figura 135 - Efeito do envelhecimento na variação do número de ciclos na ruptura em função da amplitude de deformação para o REPLAN +1,5\%PA85. 


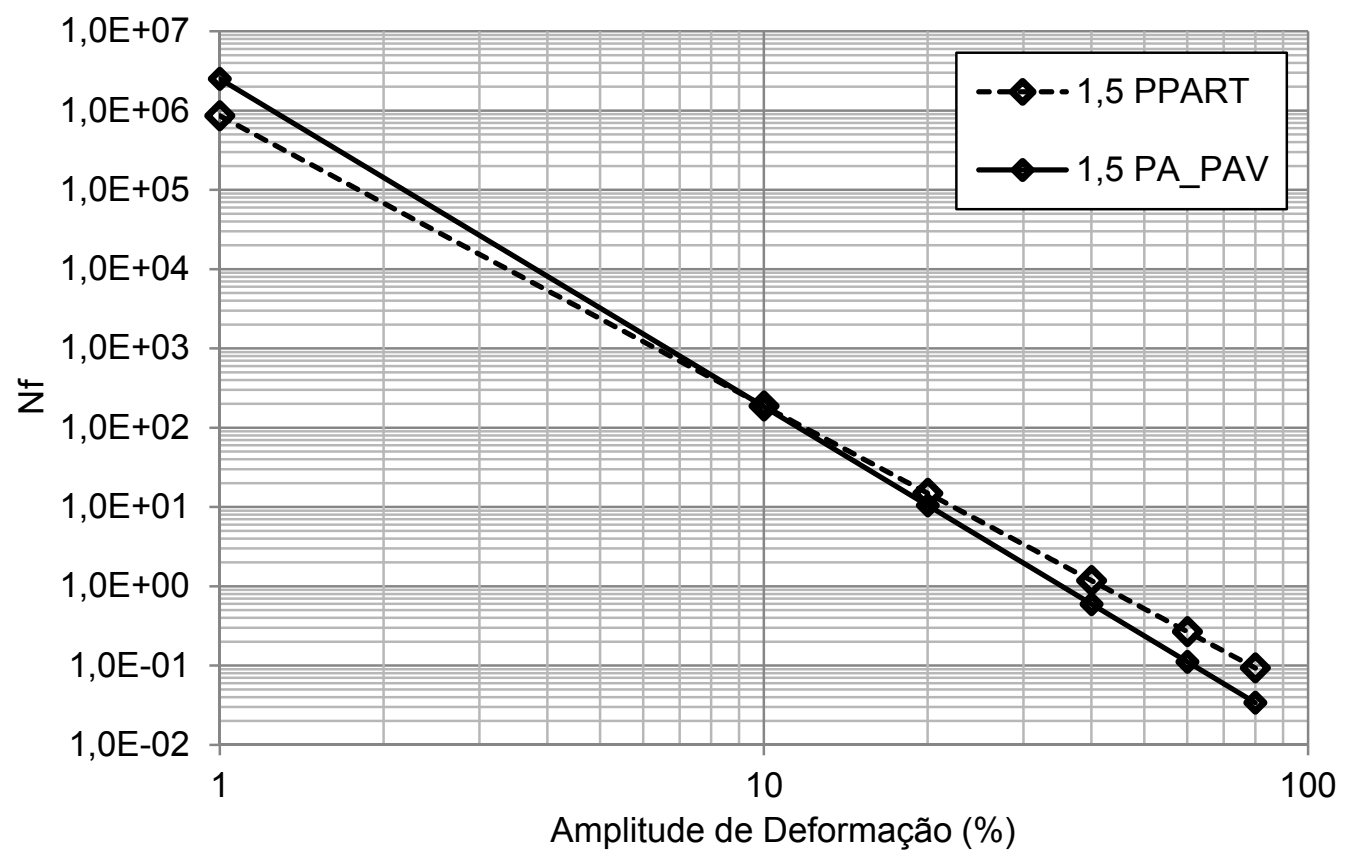

Figura 136 - Efeito do envelhecimento na variação do número de ciclos na ruptura em função da amplitude de deformação para o REPLAN +1,5\%PPA. 


\section{Apêndice $\mathcal{E}-$ Variação do $\mathcal{N}_{f}$ em função da amplitude de deformação (Replan e Lubnor)}

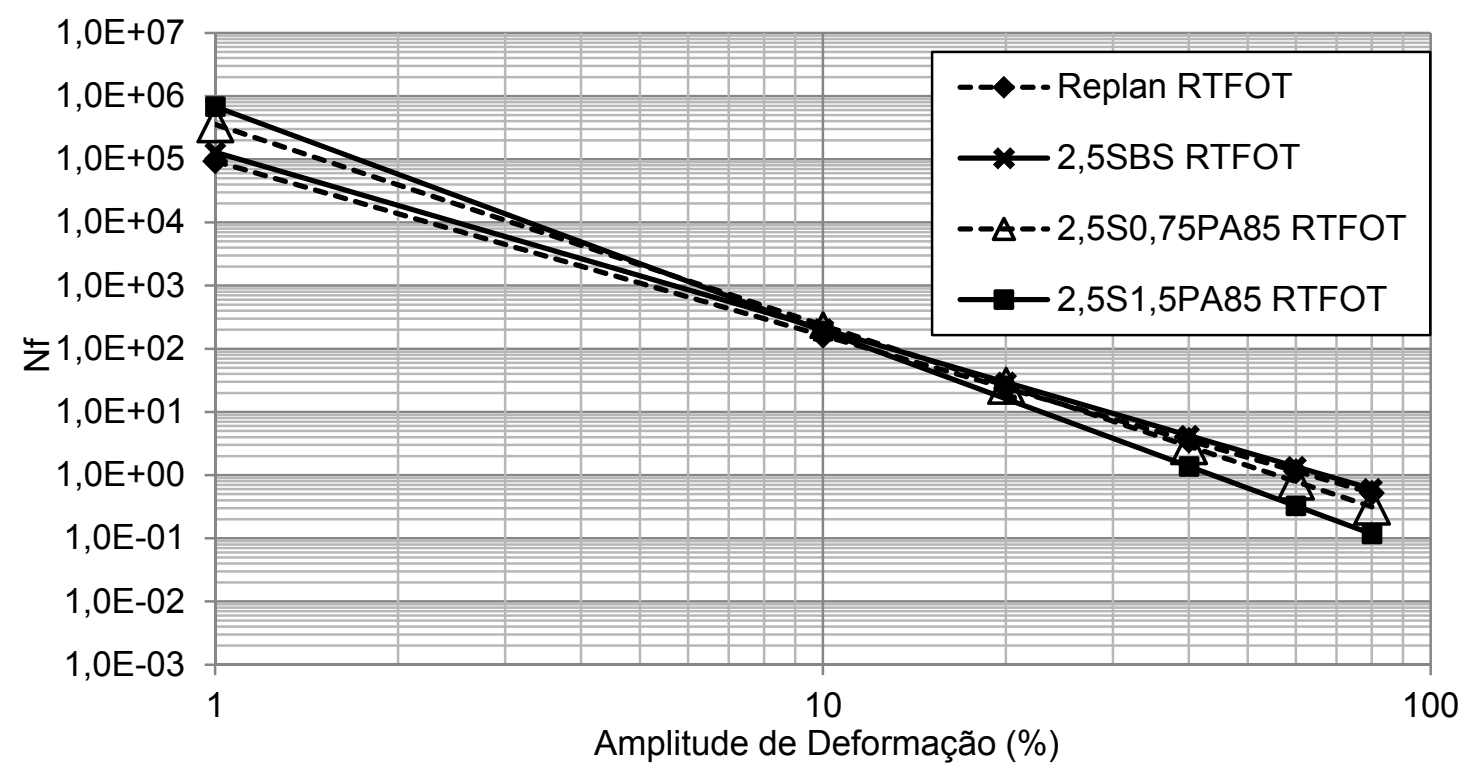

Figura 137- Variação do número de ciclos na ruptura em função da amplitude de deformação para os ligantes asfálticos da Replan envelhecidos no RTFOT modificados 2,5 SBS e PA85.

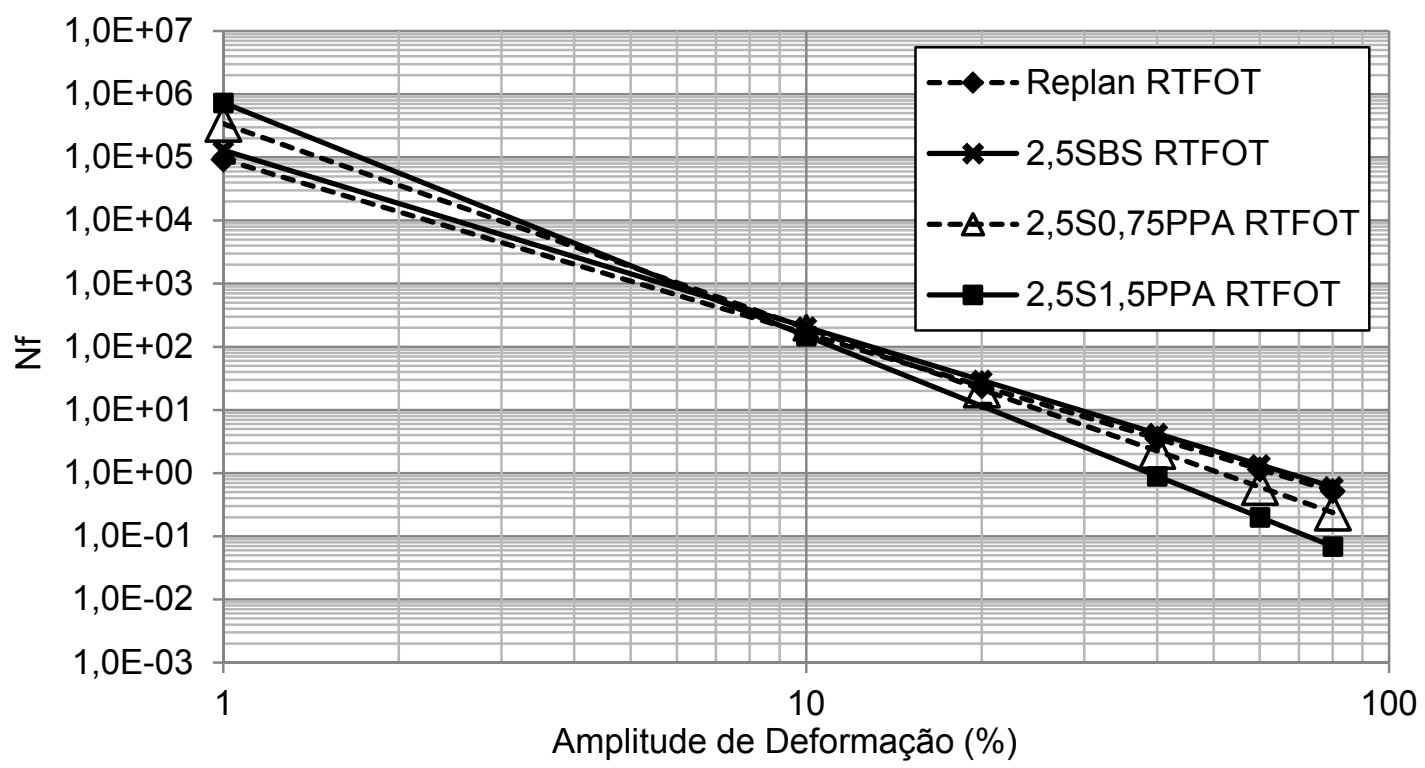

Figura 138 - Variação do número de ciclos na ruptura em função da amplitude de deformação para os ligantes asfálticos da Replan envelhecidos no RTFOT modificados 2,5 SBS e PPA. 


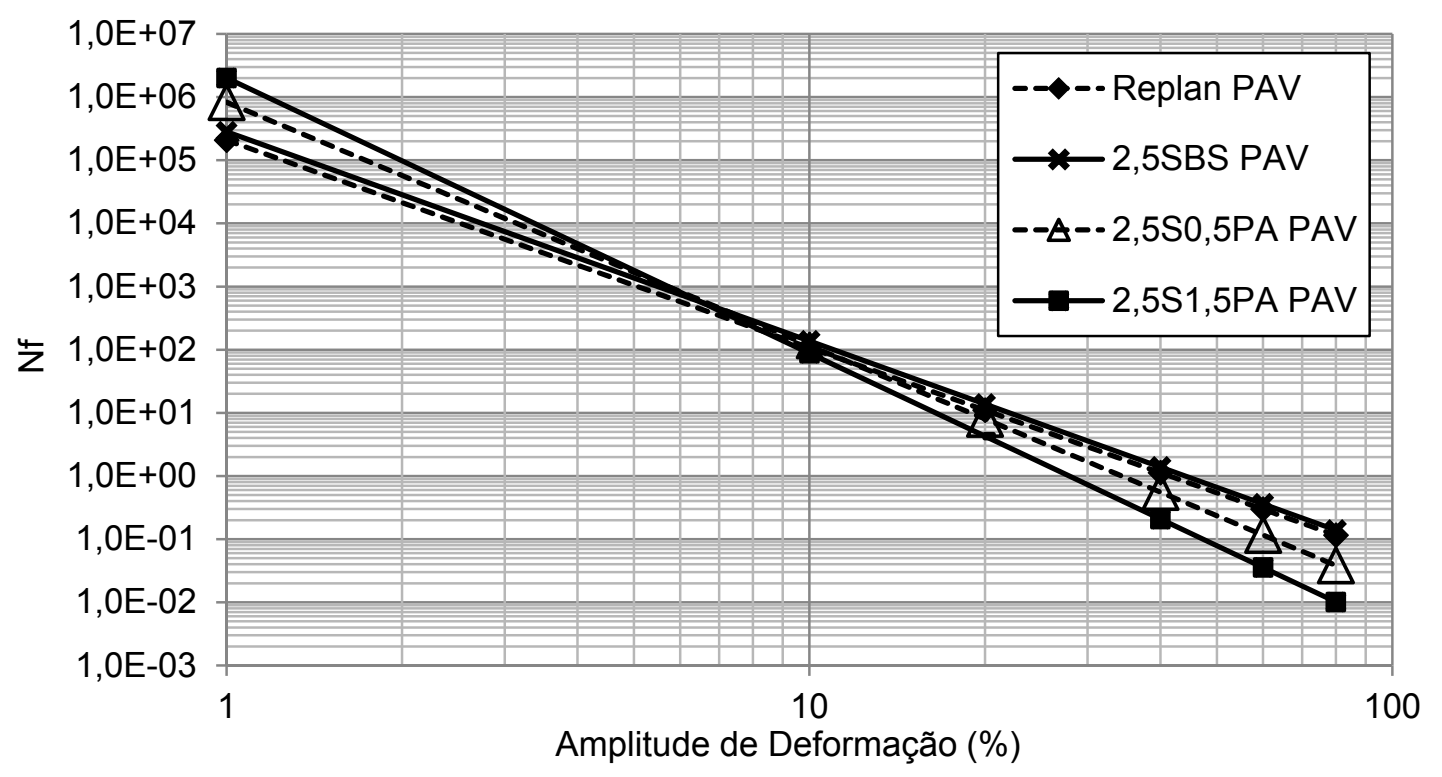

Figura 139 - Variação do número de ciclos na ruptura em função da amplitude de deformação para os ligantes asfálticos da Replan envelhecidos no PAV modificados 2,5 SBS e PA85.

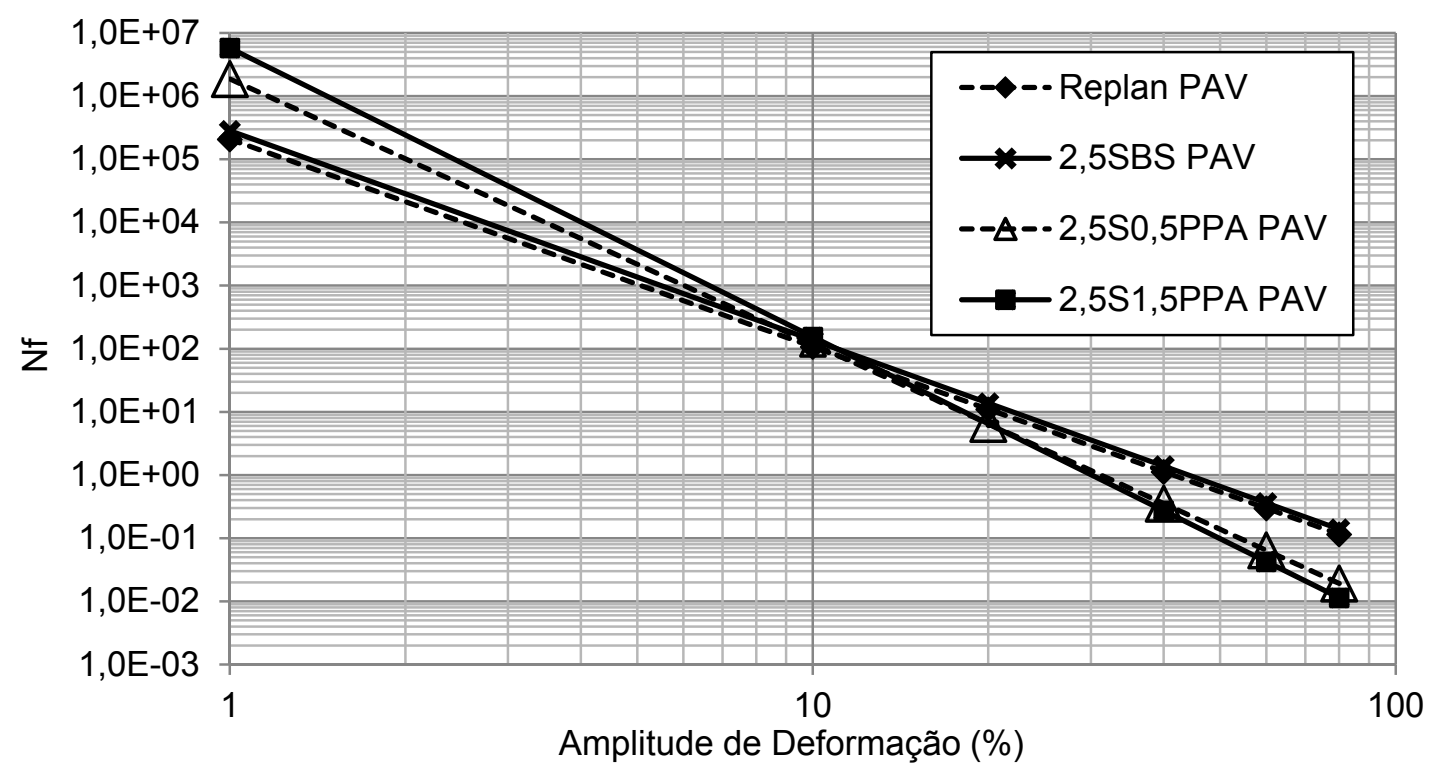

Figura 140 - Variação do número de ciclos na ruptura em função da amplitude de deformação para os ligantes asfálticos da Replan envelhecidos no PAV modificados 2,5 SBS e PPA. 


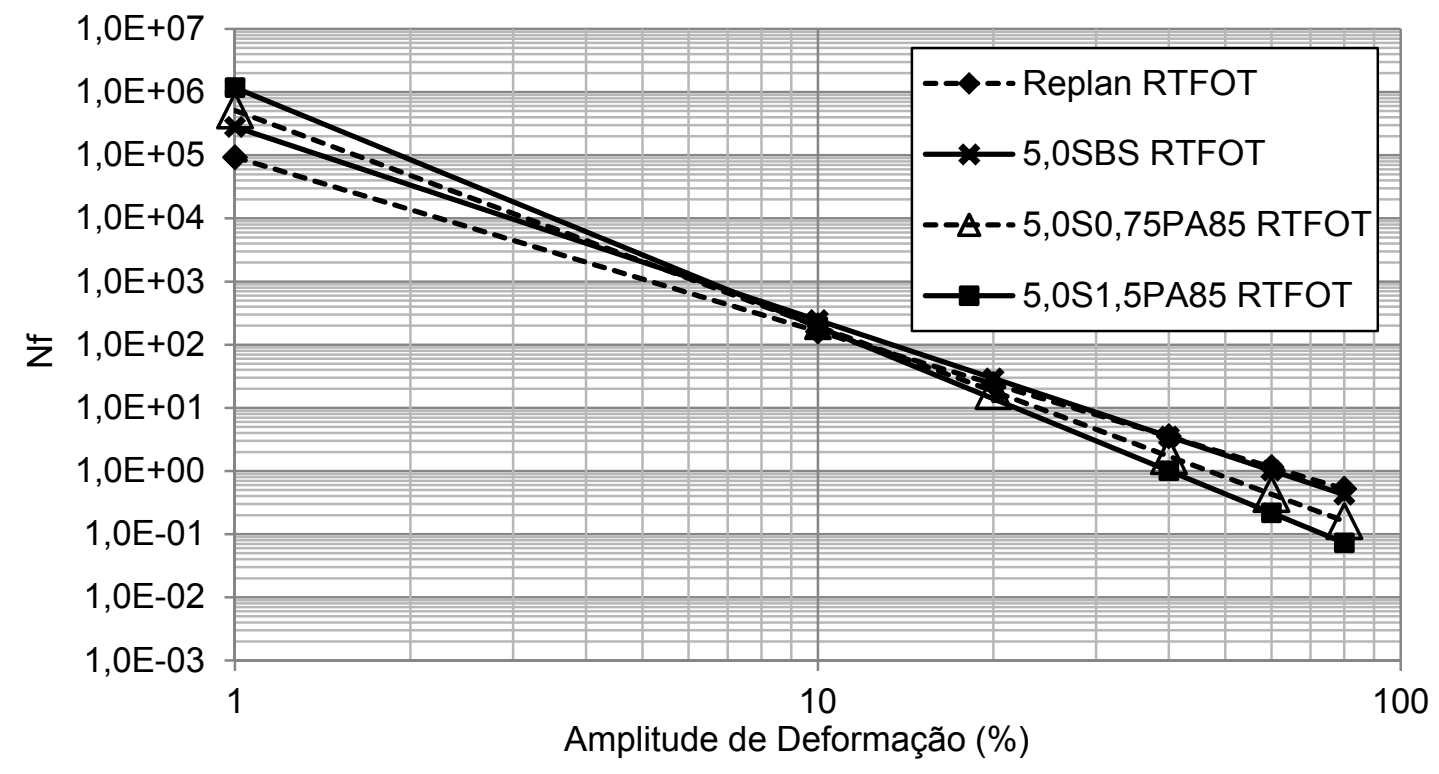

Figura 141 - Variação do número de ciclos na ruptura em função da amplitude de deformação para os ligantes asfálticos da Replan envelhecidos no RTFOT modificados 5,0 SBS e PA85.

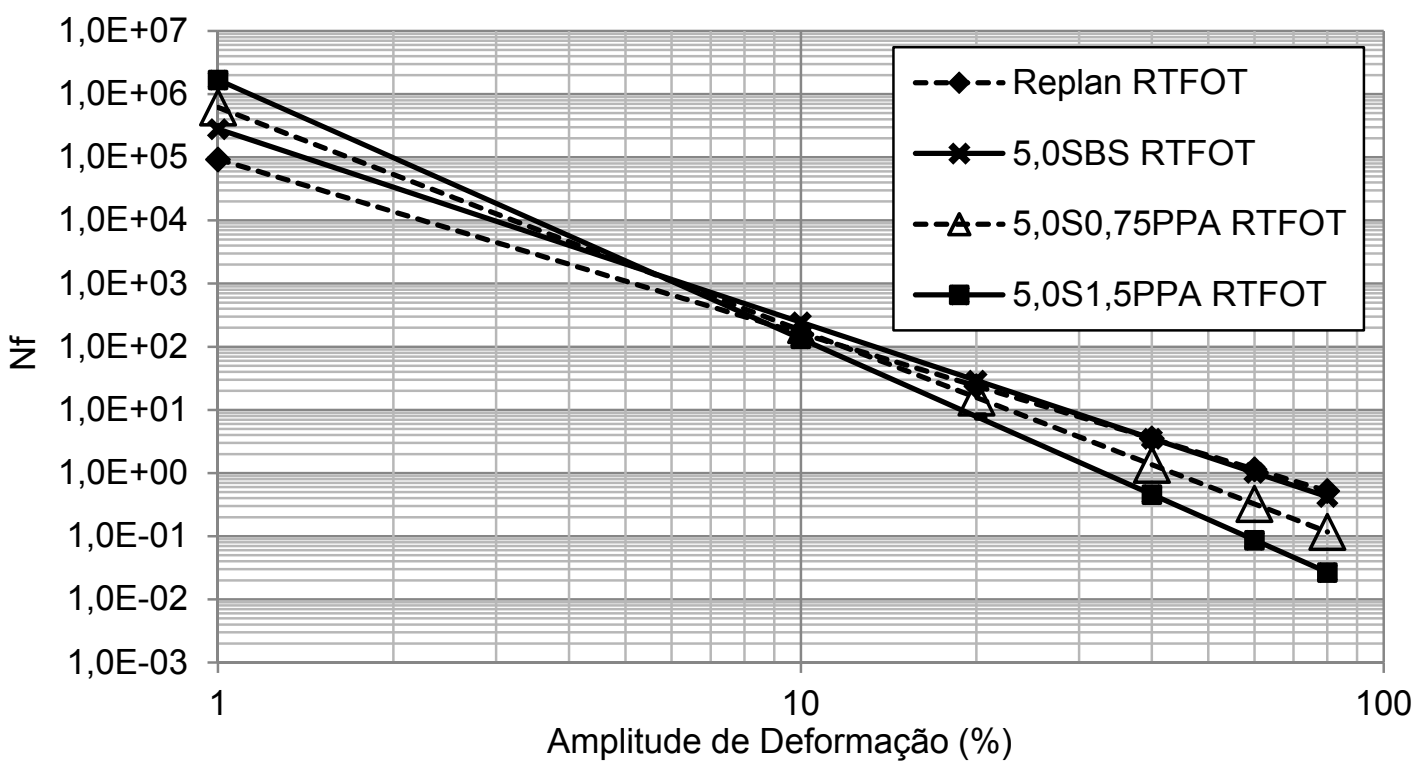

Figura 142 - Variação do número de ciclos na ruptura em função da amplitude de deformação para os ligantes asfálticos da Replan envelhecidos no RTFOT modificados 5,0 SBS e PPA. 


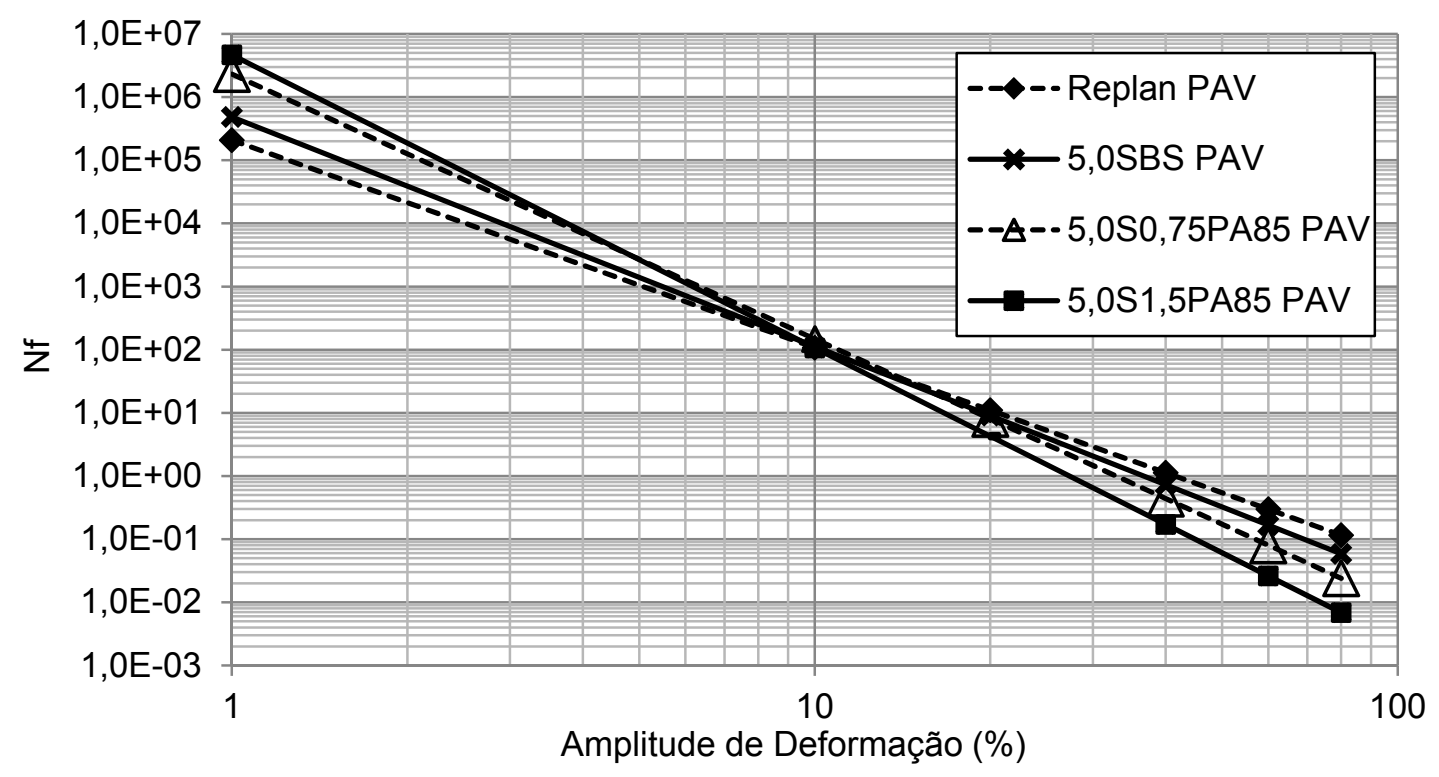

Figura 143 - Variação do número de ciclos na ruptura em função da amplitude de deformação para os ligantes asfálticos da Replan envelhecidos no PAV modificados 5,0 SBS e PA85.

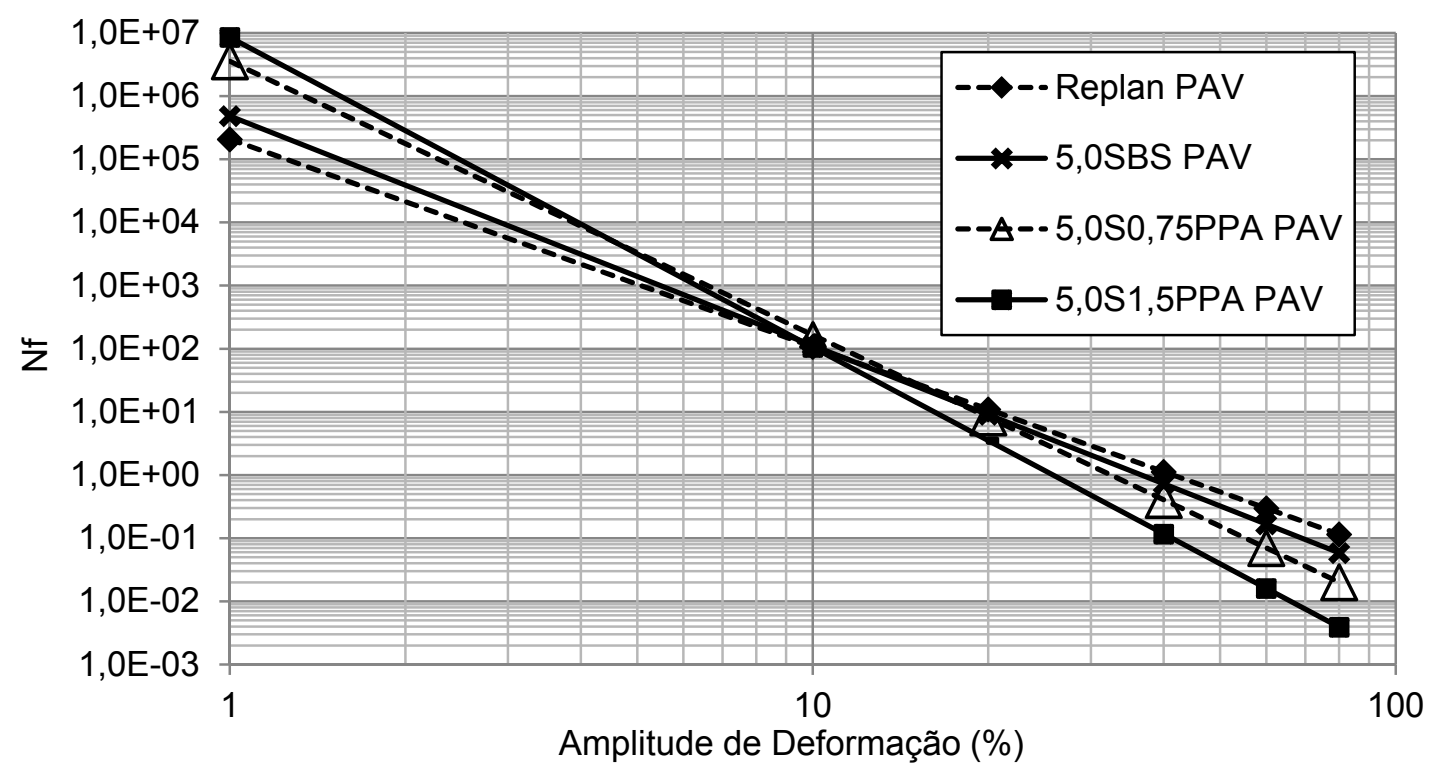

Figura 144 - Variação do número de ciclos na ruptura em função da amplitude de deformação para os ligantes asfálticos da Replan envelhecidos no PAV modificados 5,0 SBS e PPA. 


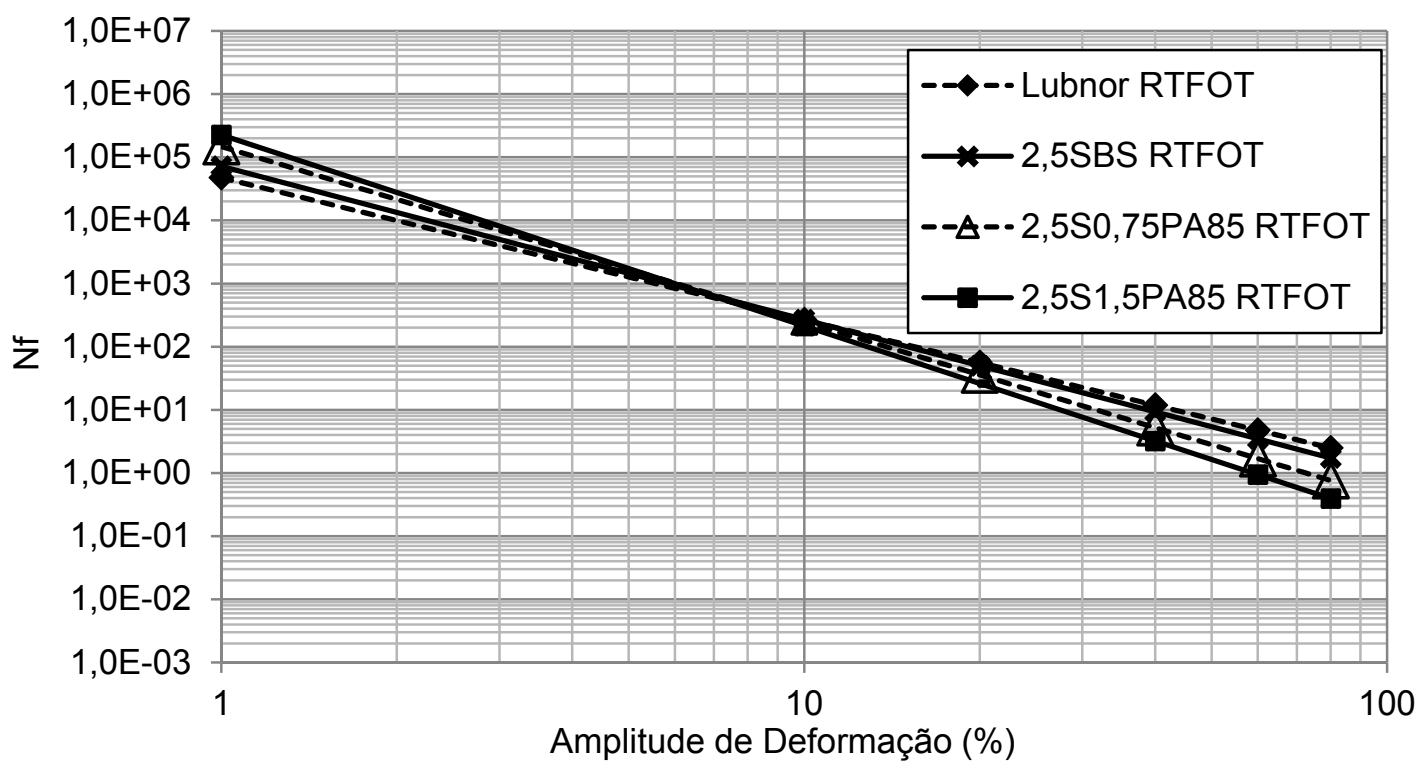

Figura 145 - Variação do número de ciclos na ruptura em função da amplitude de deformação para os ligantes asfálticos da Lubnor envelhecidos no RTFOT modificados 2,5 SBS e PA85.

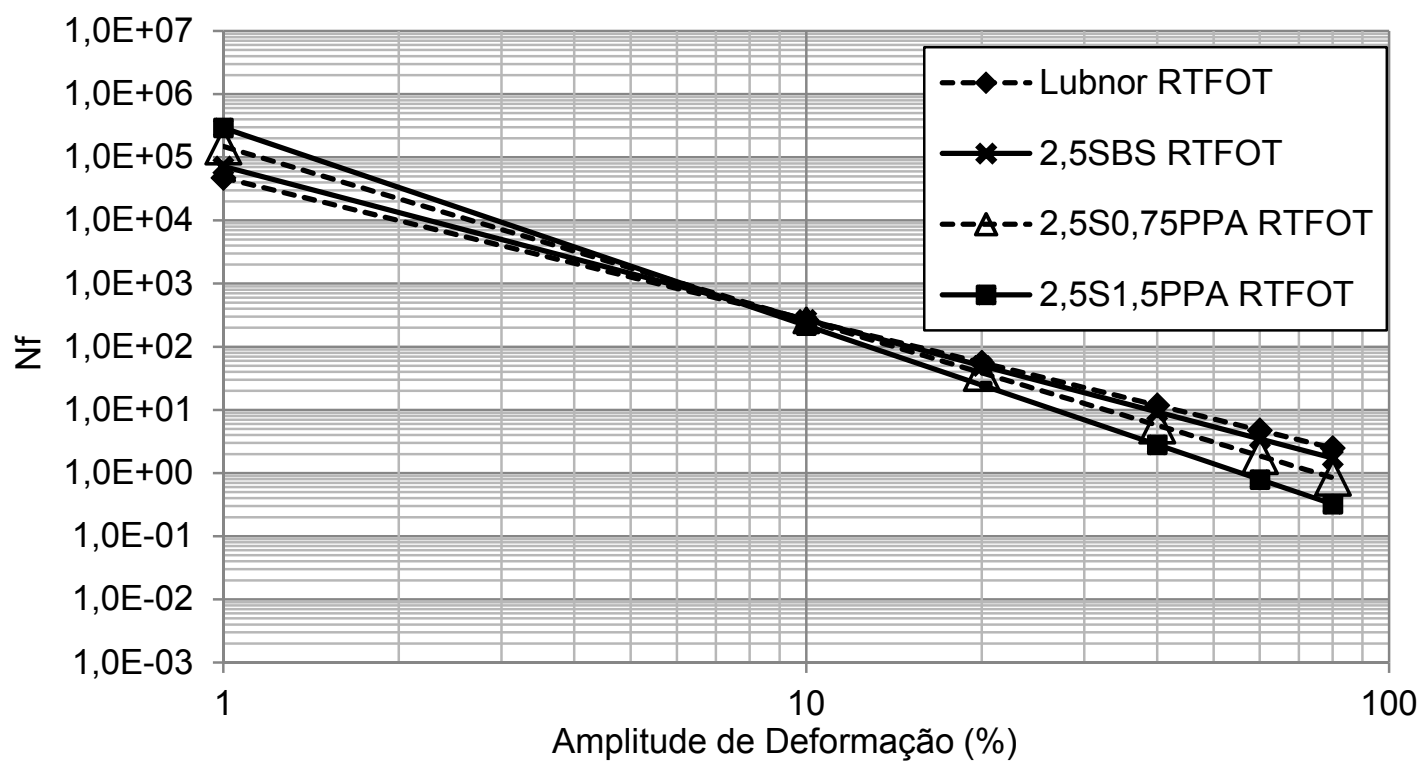

Figura 146 - Variação do número de ciclos na ruptura em função da amplitude de deformação para os ligantes asfálticos da Lubnor envelhecidos no RTFOT modificados 2,5 SBS e PPA. 


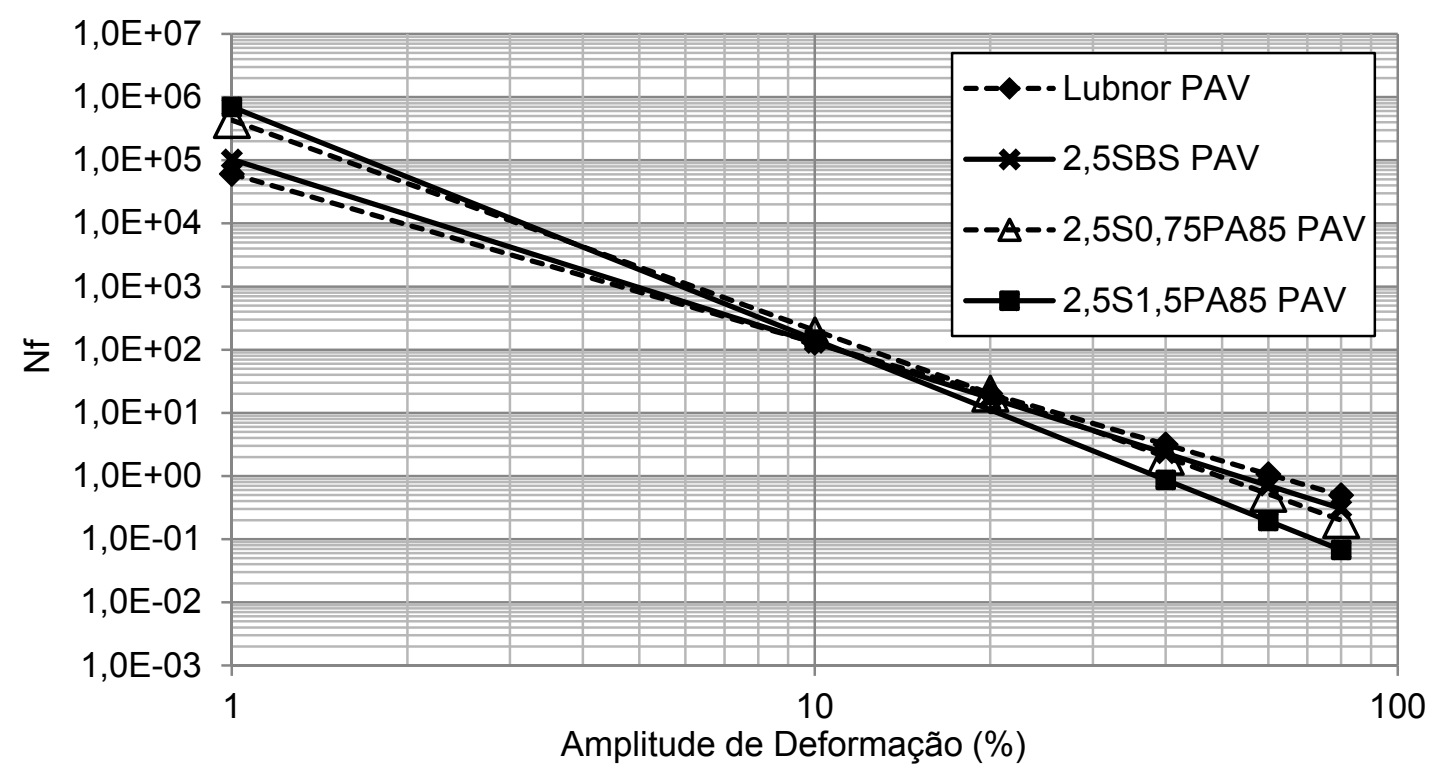

Figura 147 - Variação do número de ciclos na ruptura em função da amplitude de deformação para os ligantes asfálticos da Lubnor envelhecidos no PAV modificados 2,5 SBS e PA85.

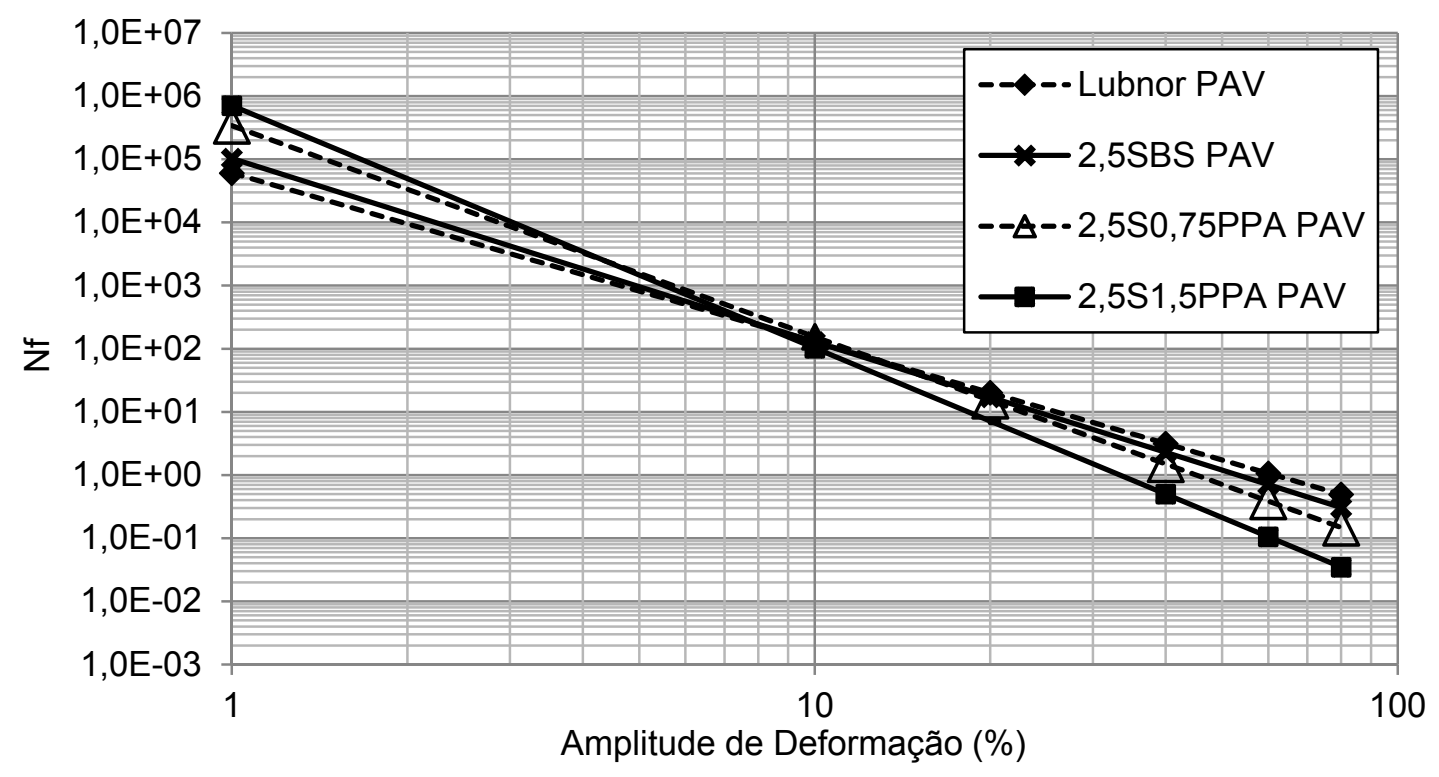

Figura 148 - Variação do número de ciclos na ruptura em função da amplitude de deformação para os ligantes asfálticos da Lubnor envelhecidos no PAV modificados 2,5 SBS e PPA. 


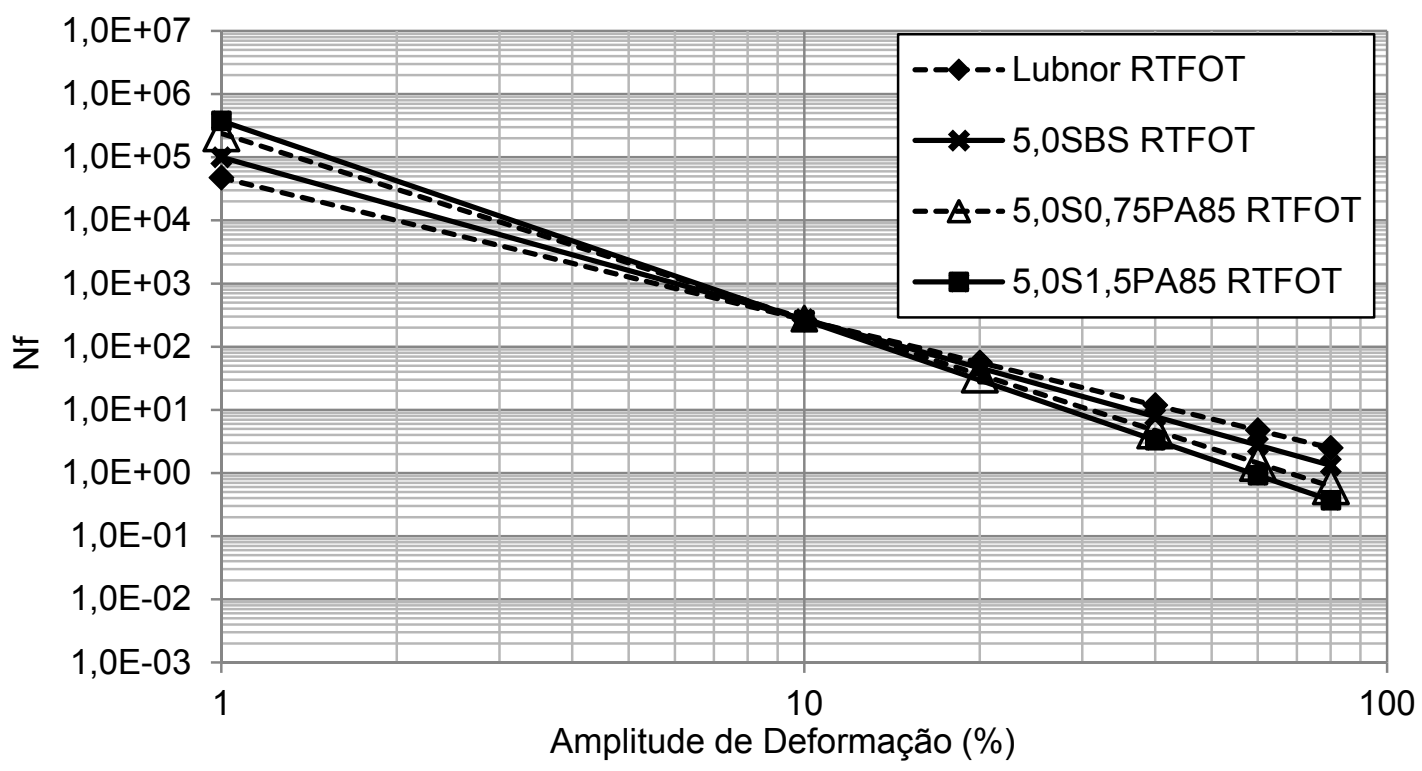

Figura 149 - Variação do número de ciclos na ruptura em função da amplitude de deformação para os ligantes asfálticos da Lubnor envelhecidos no RTFOT modificados 5,0 SBS e PA85.

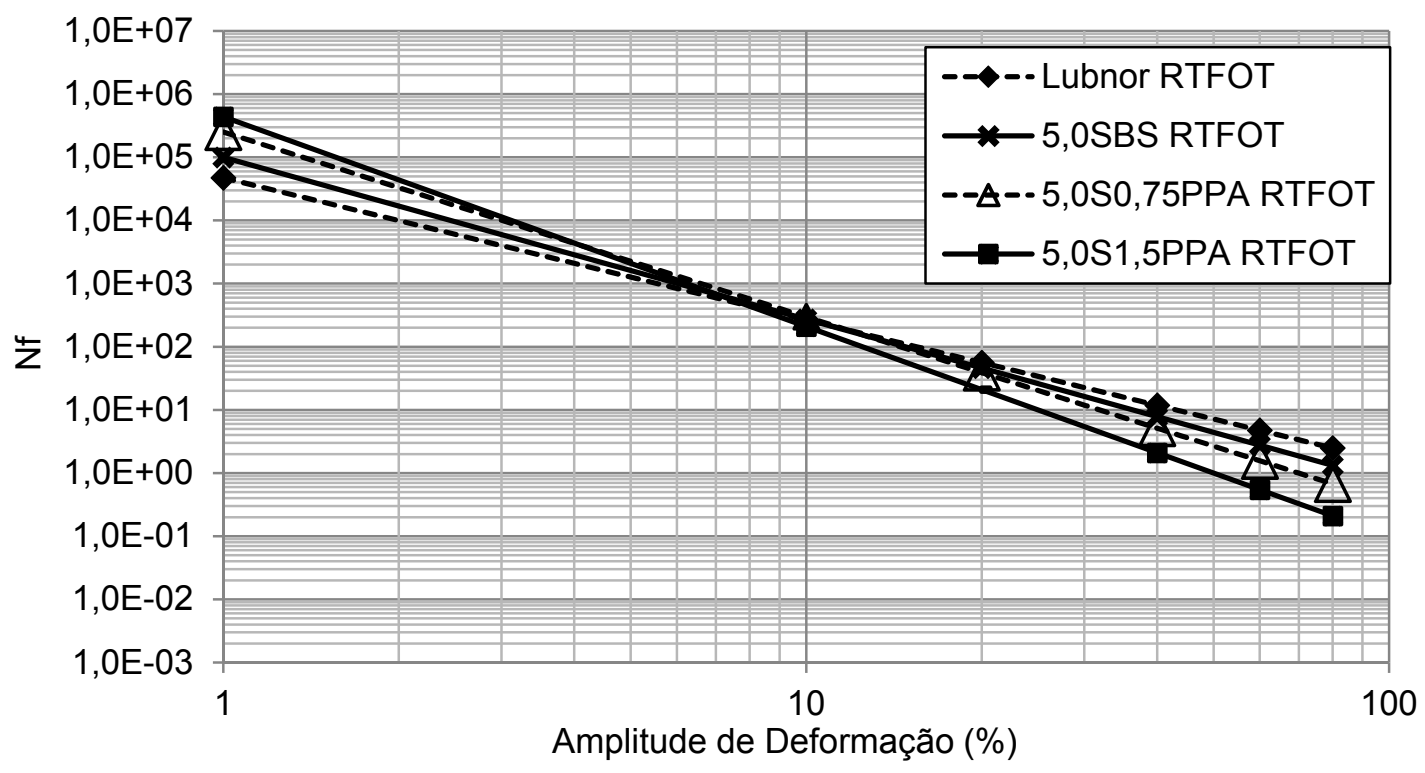

Figura 150 - Variação do número de ciclos na ruptura em função da amplitude de deformação para os ligantes asfálticos da Lubnor envelhecidos no RTFOT modificados 5,0 SBS e PPA. 


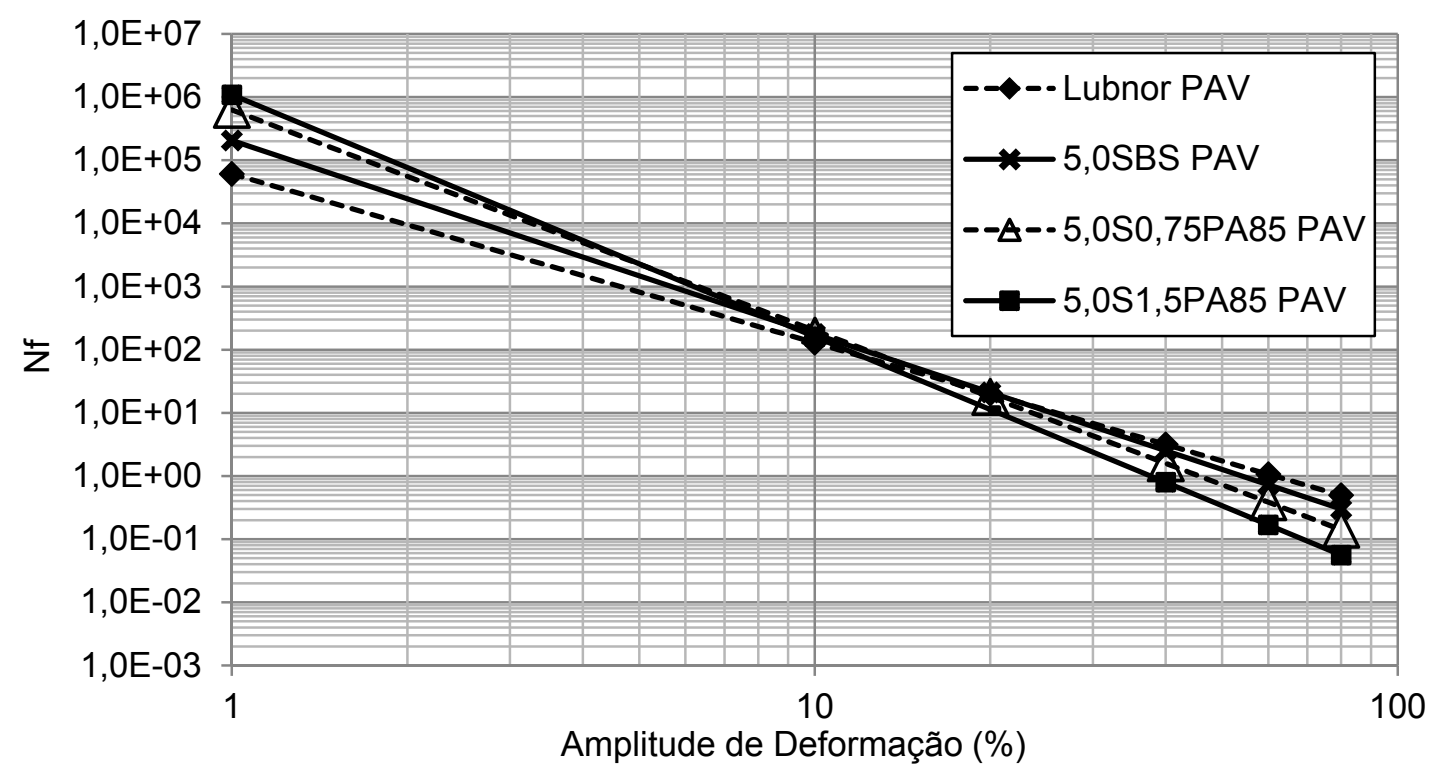

Figura 151 - Variação do número de ciclos na ruptura em função da amplitude de deformação para os ligantes asfálticos da Lubnor envelhecidos no PAV modificados 5,0 SBS e PA85.

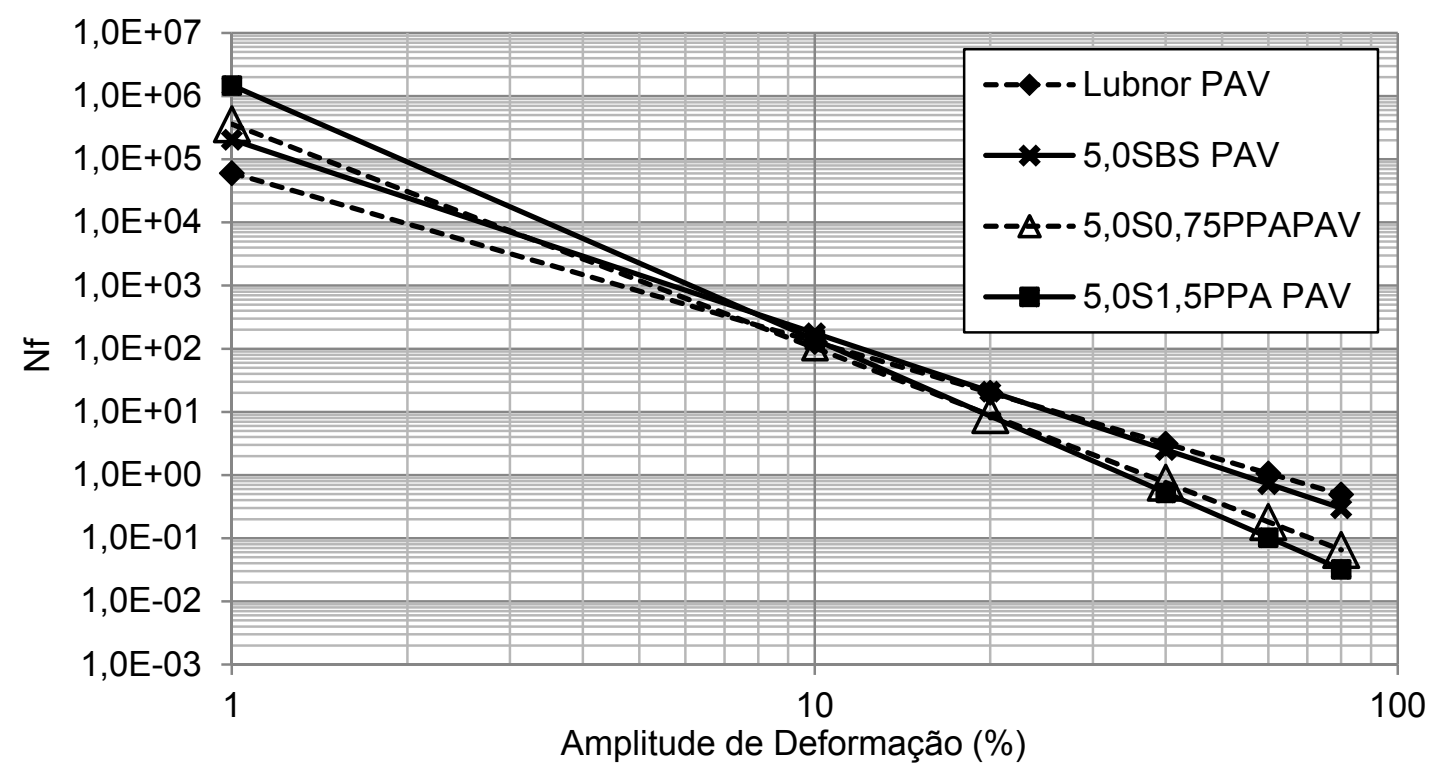

Figura 152 - Variação do número de ciclos na ruptura em função da amplitude de deformação para os ligantes asfálticos da Lubnor envelhecidos no PAV modificados 5,0 SBS e PPA. 


\section{Apêndice G - Efeito do envelhecimento $\mathcal{N}_{f}$ na ruptura em função da amplitude de deformação (Lubnor).}

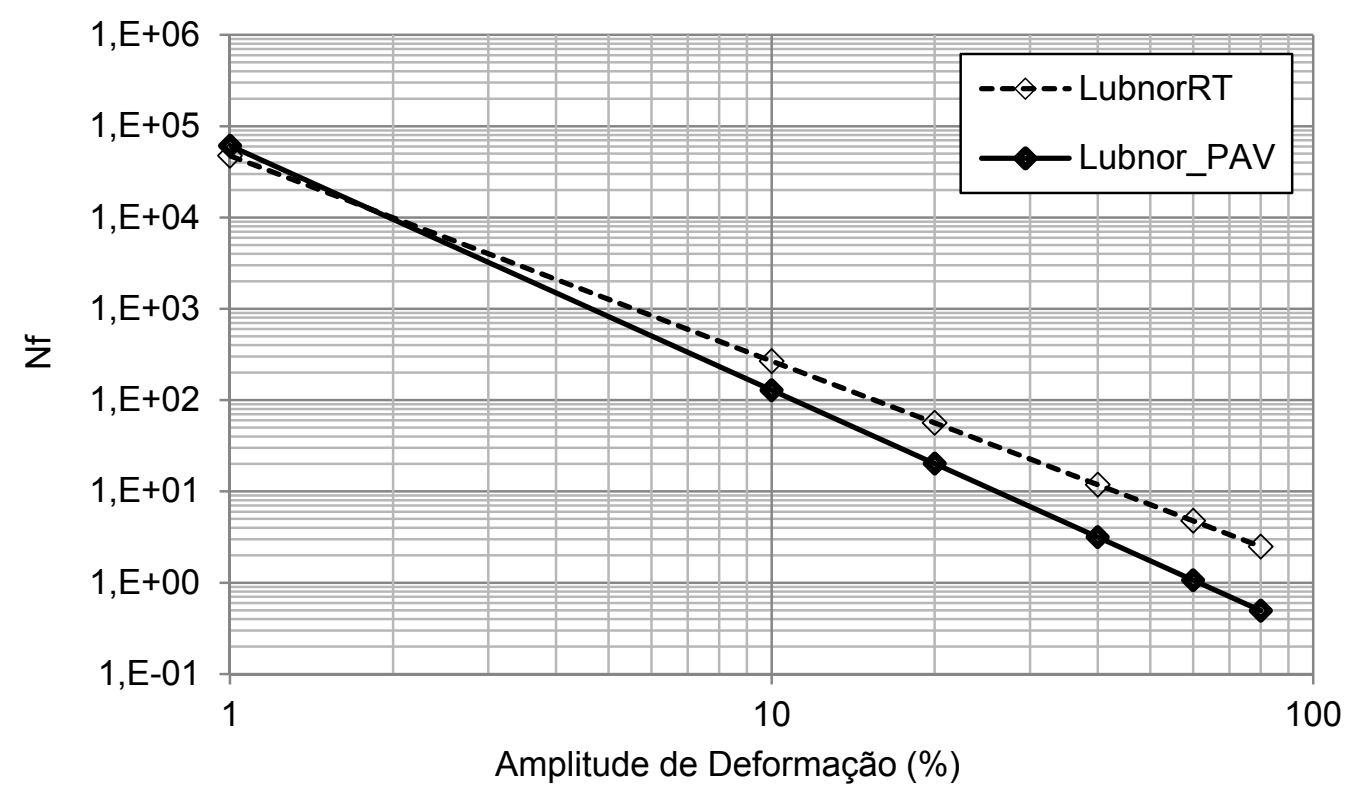

Figura 153 - Efeito do envelhecimento na variação do número de ciclos na ruptura em função da amplitude de deformação para o LUBNOR puro.

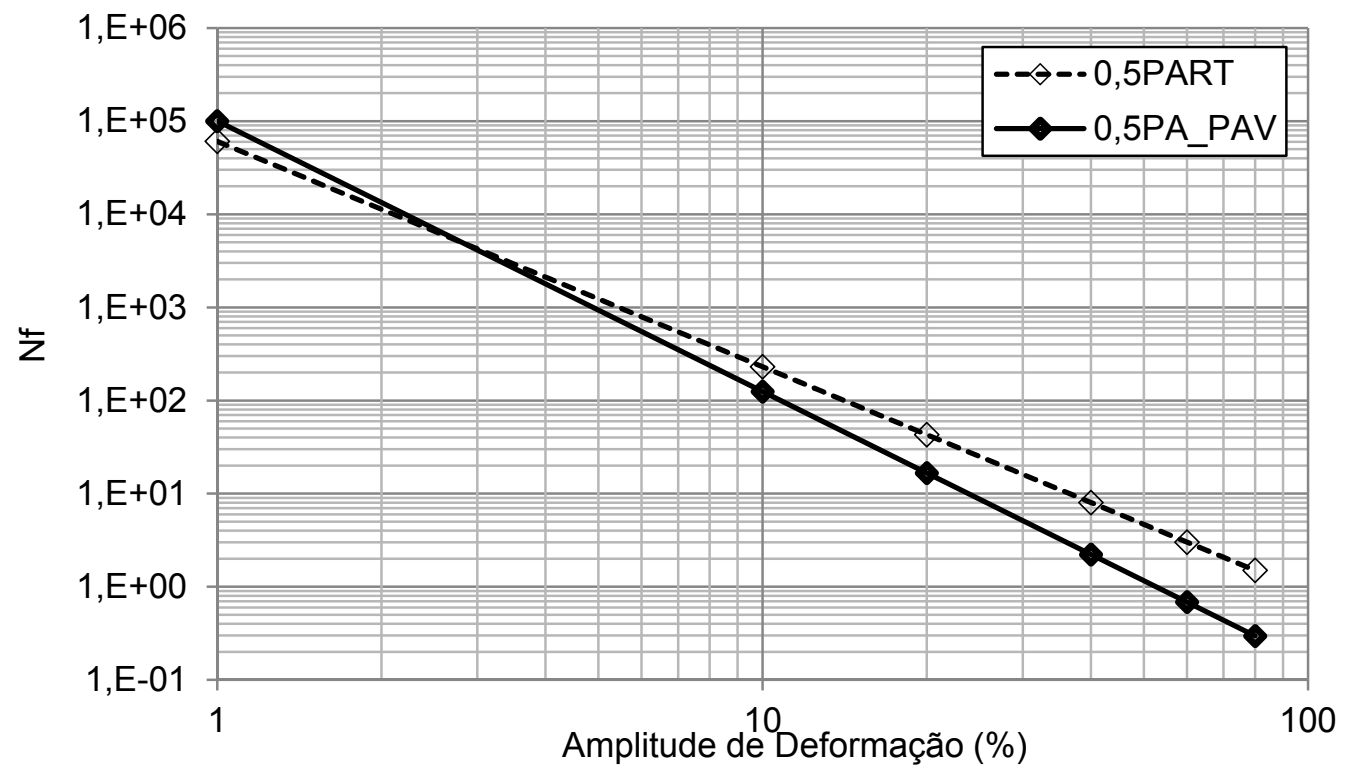

Figura 154 - Efeito do envelhecimento na variação do número de ciclos na ruptura em função da amplitude de deformação para o LUBNOR + 0,5\%PA85. 


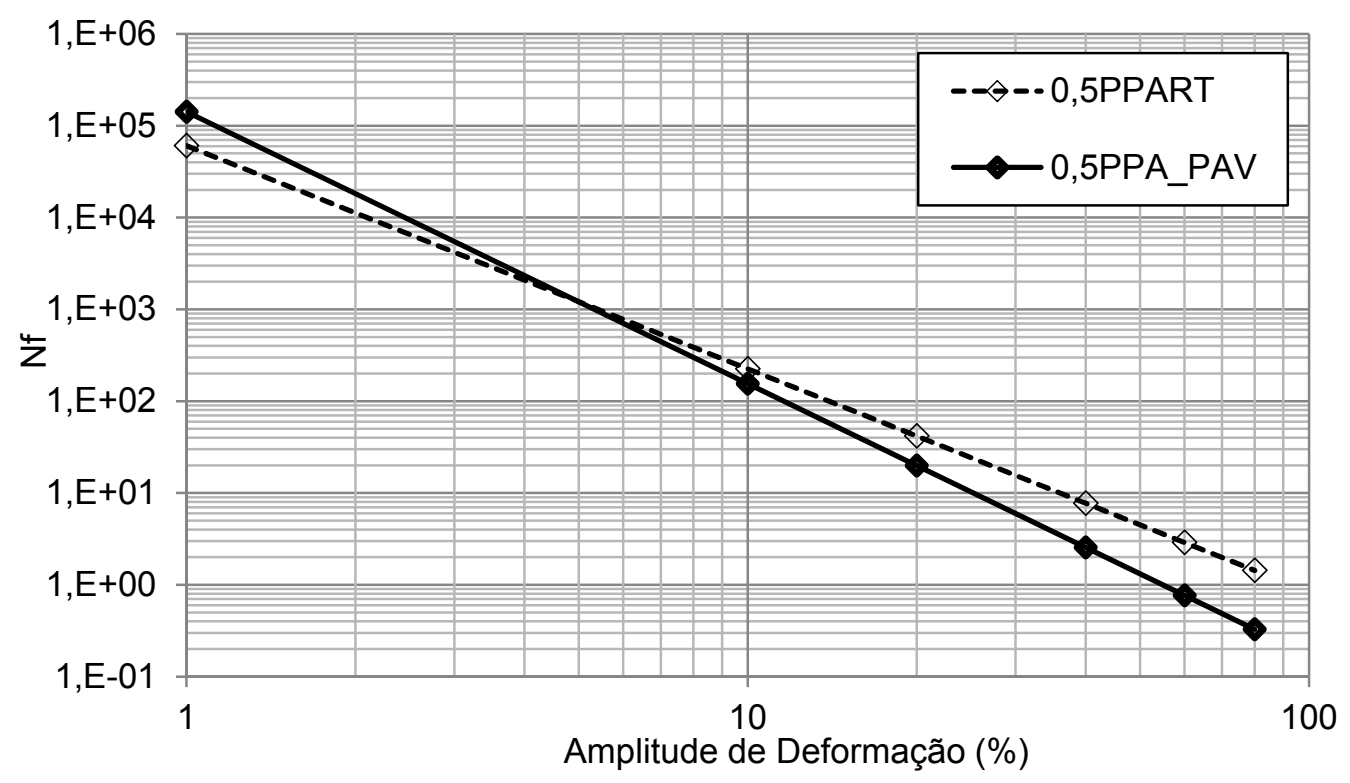

Figura 155 - Efeito do envelhecimento na variação do número de ciclos na ruptura em função da amplitude de deformação para o LUBNOR + 0,5\%PPA.

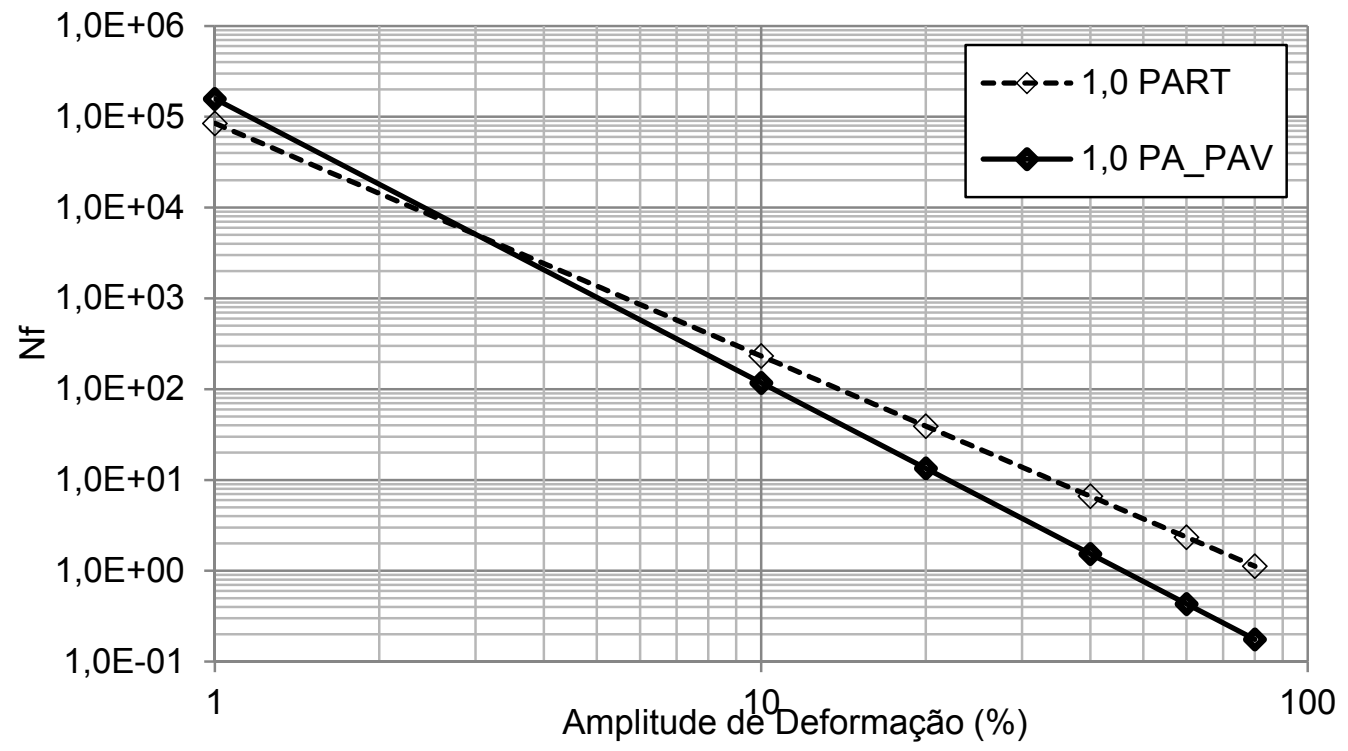

Figura 156 - Efeito do envelhecimento na variação do número de ciclos na ruptura em função da amplitude de deformação para o LUBNOR + 1,0\%PA85. 


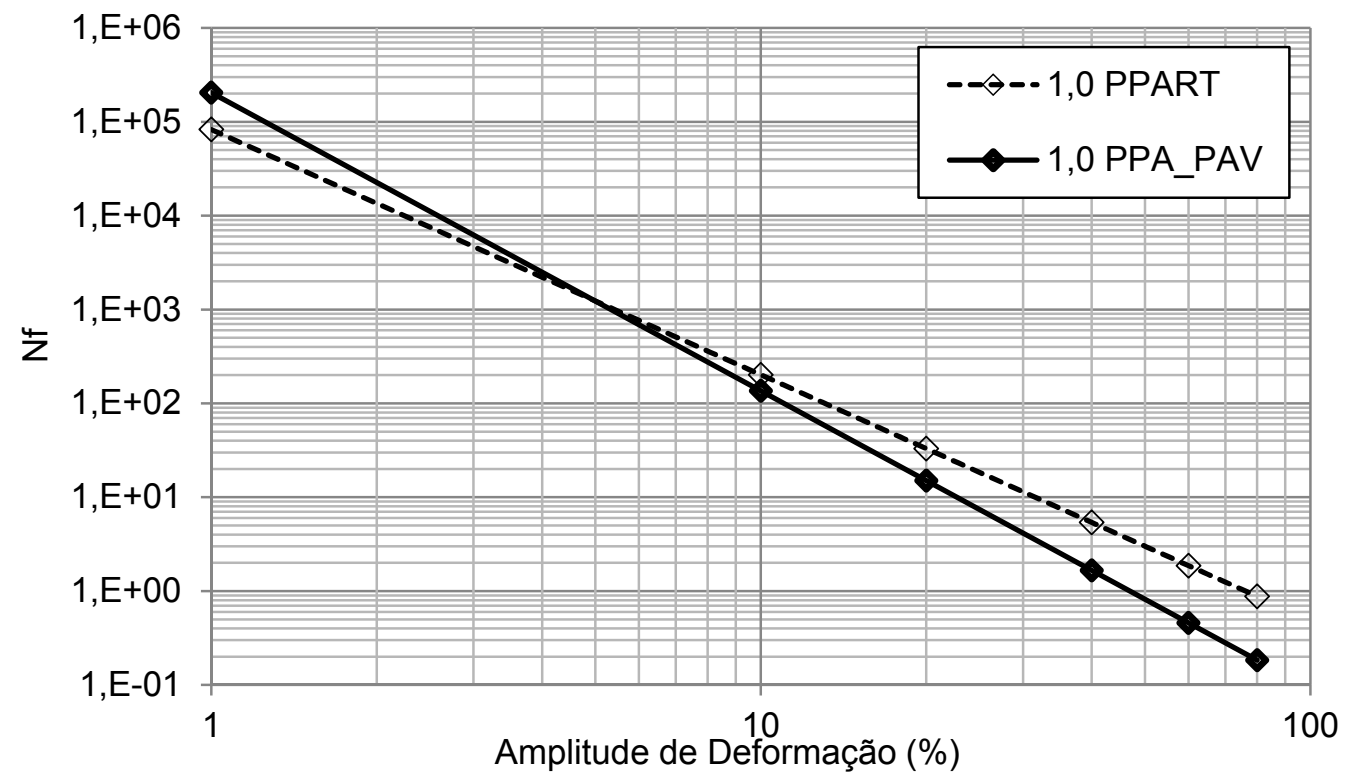

Figura 157 - Efeito do envelhecimento na variação do número de ciclos na ruptura em função da amplitude de deformação para o LUBNOR + 1,0\%PPA.

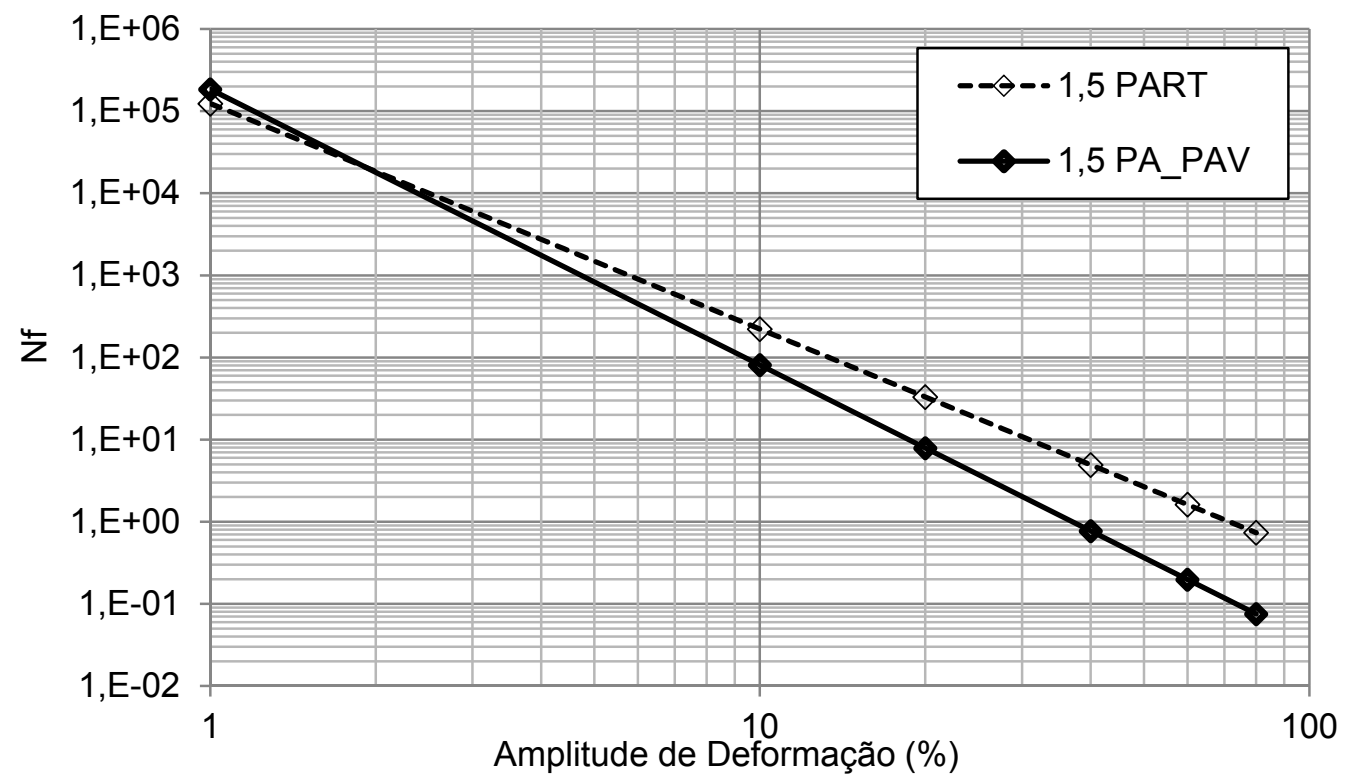

Figura 158 - Efeito do envelhecimento na variação do número de ciclos na ruptura em função da amplitude de deformação para o LUBNOR + 1,5\%PA85. 


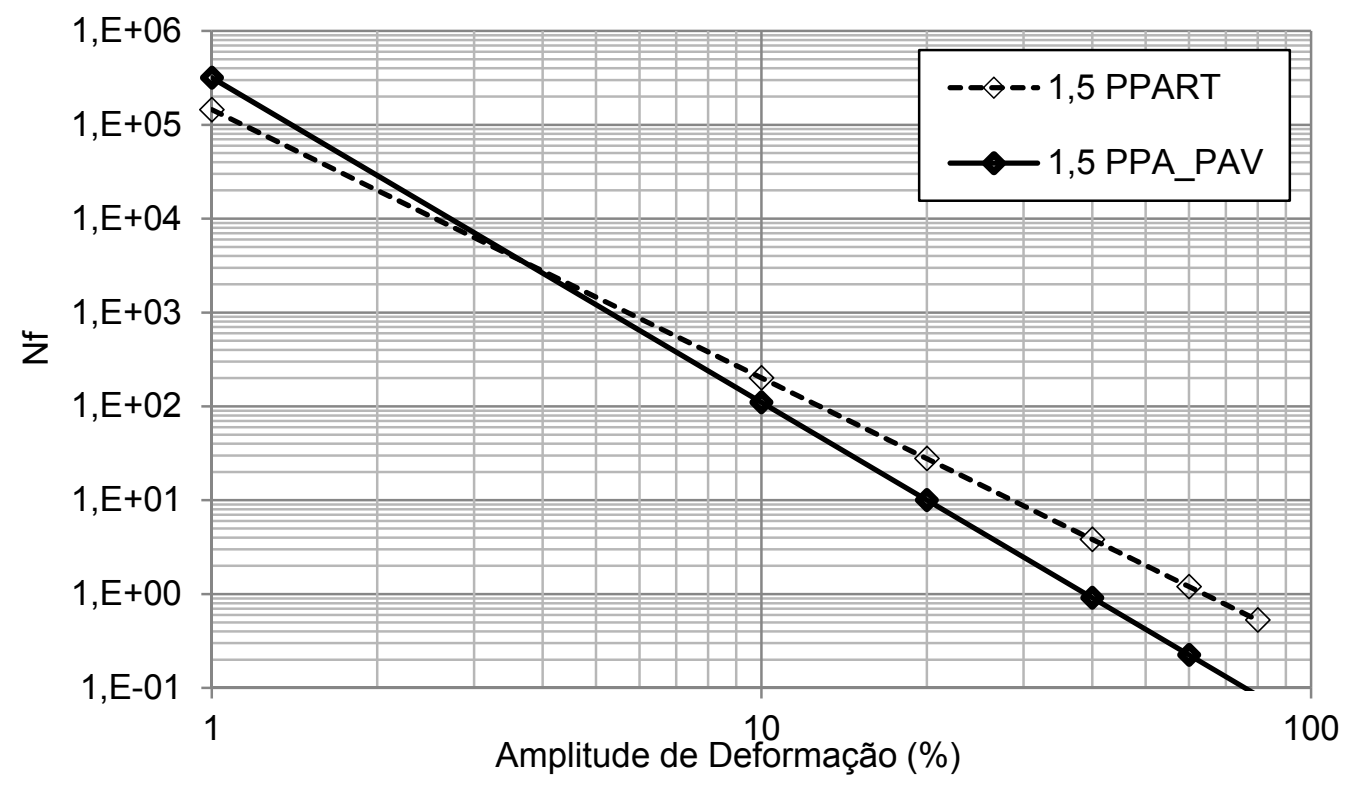

Figura 159 - Efeito do envelhecimento na variação do número de ciclos na ruptura em função da amplitude de deformação para o LUBNOR + 1,5\%PPA. 


\section{Apêndice H-Gráfico de Superfície e Efeito de Componentes (Replan e Lubnor).}

\section{Viscosidade $143^{\circ} \mathrm{C}$}
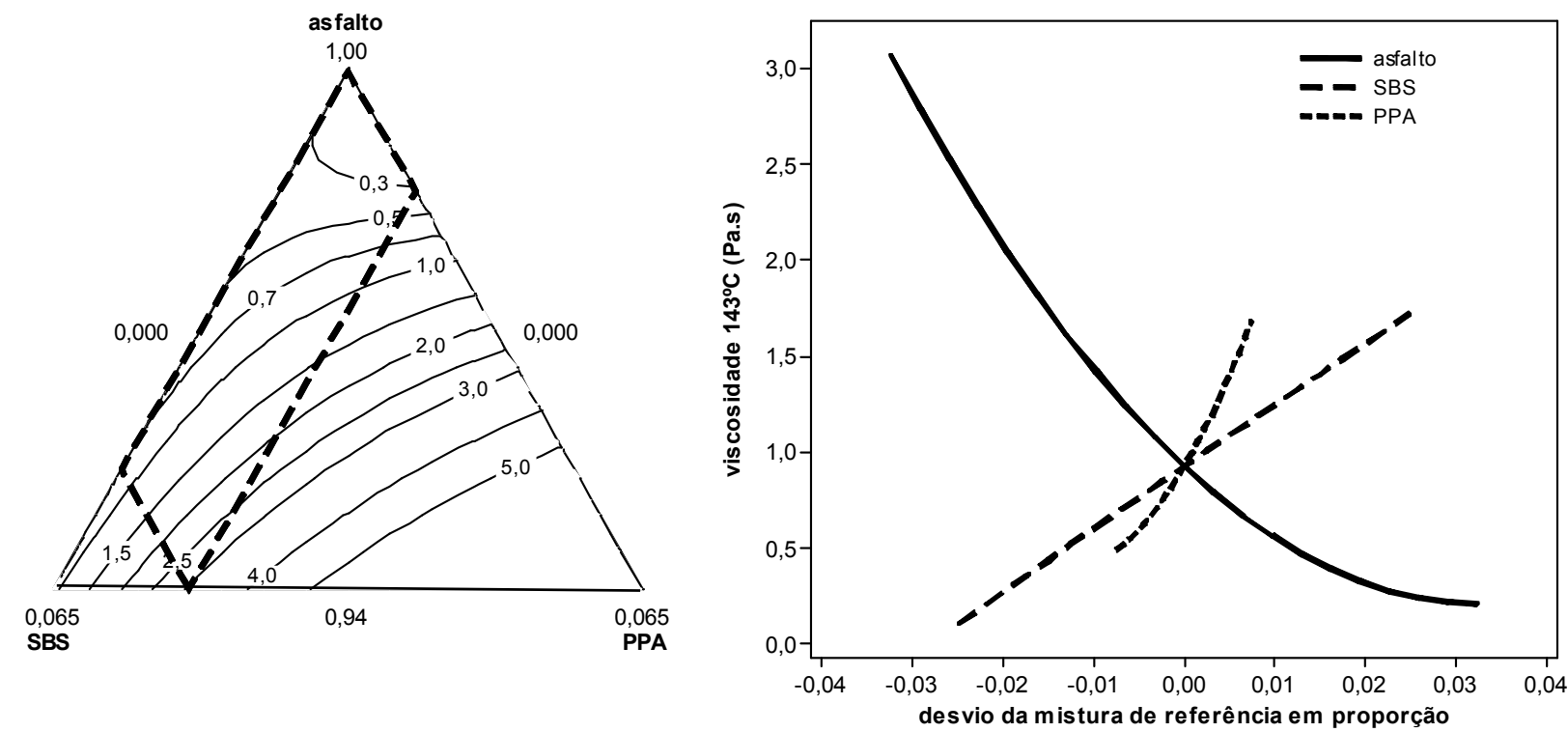

(a)

(b)

Figura 160 - Superfície de Resposta (a) e efeito de componentes (b) para Viscosidade à $143^{\circ} \mathrm{C}$ na condição virgem para misturas com PPA.
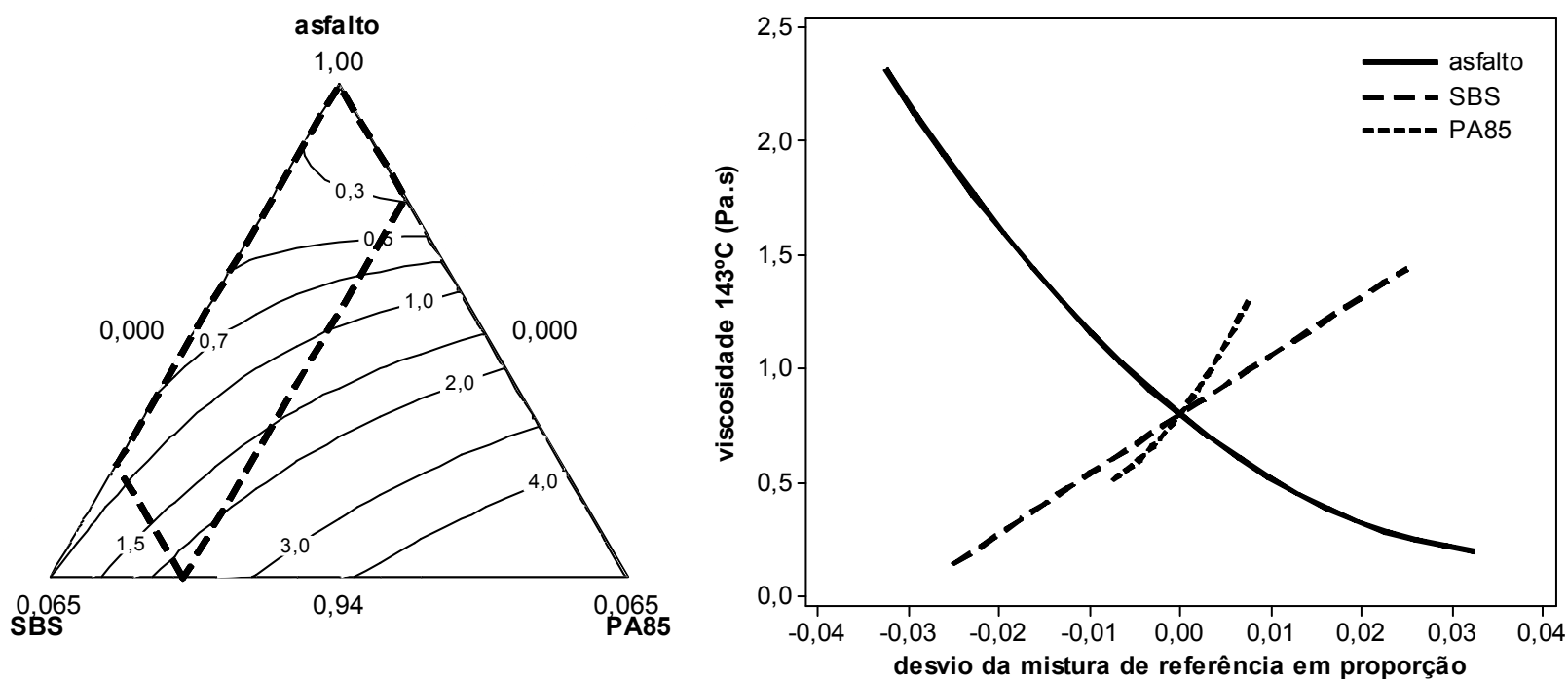

(a)

(b)

Figura 161 - Superfície de Resposta (a) e efeito de componentes (b) para Viscosidade à $143^{\circ} \mathrm{C}$ na condição virgem para misturas com PA85. 


\section{Viscosidade $143^{\circ} \mathrm{C}$ RTFOT}

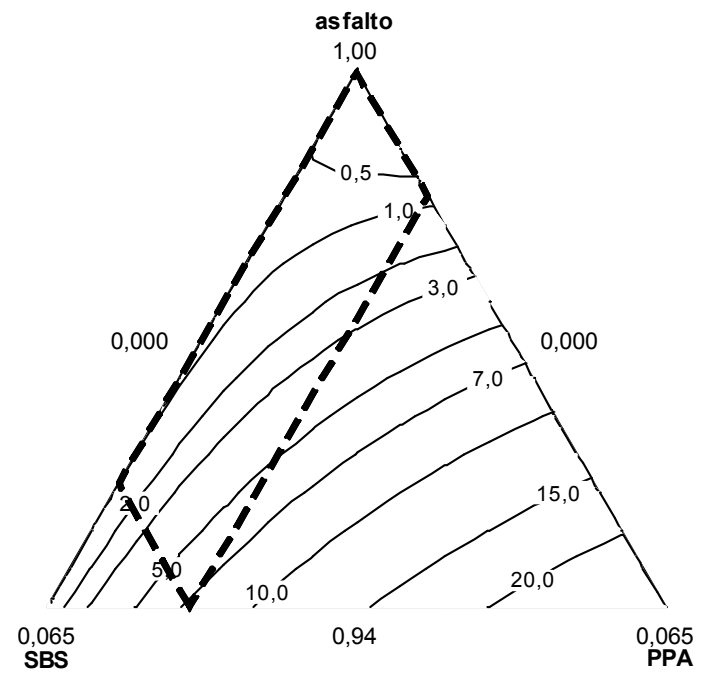

(a)

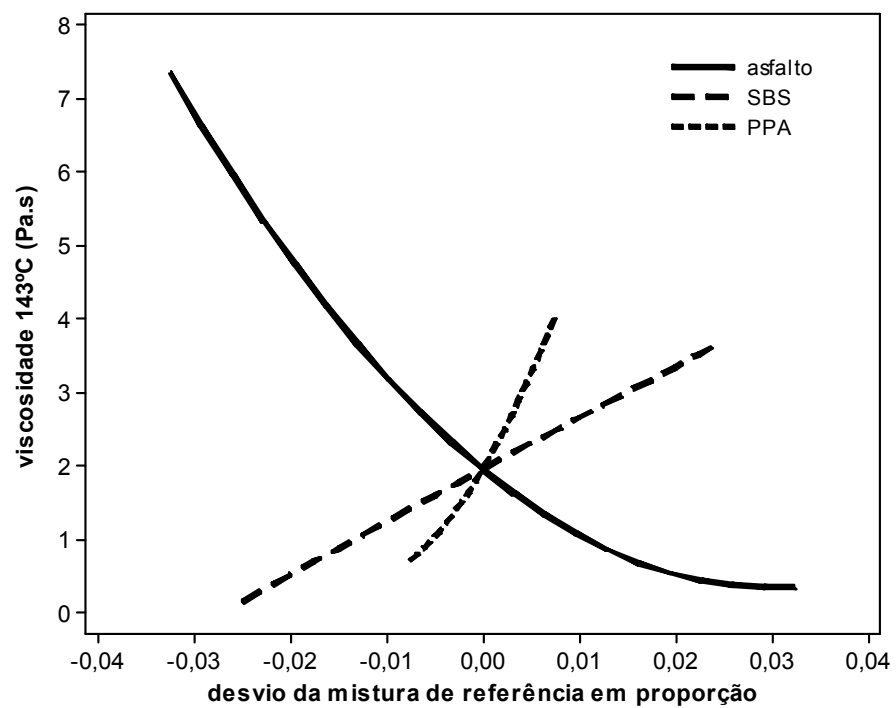

(b)

Figura 162 - Superfície de Resposta (a) e efeito de componentes (b) para Viscosidade à $143^{\circ} \mathrm{C}$ na condição RTFOT para misturas com PPA.

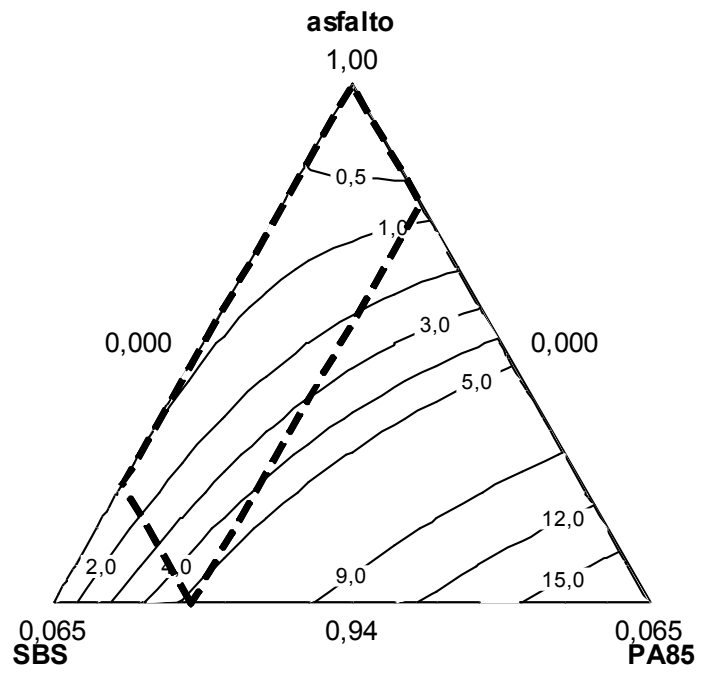

(a)

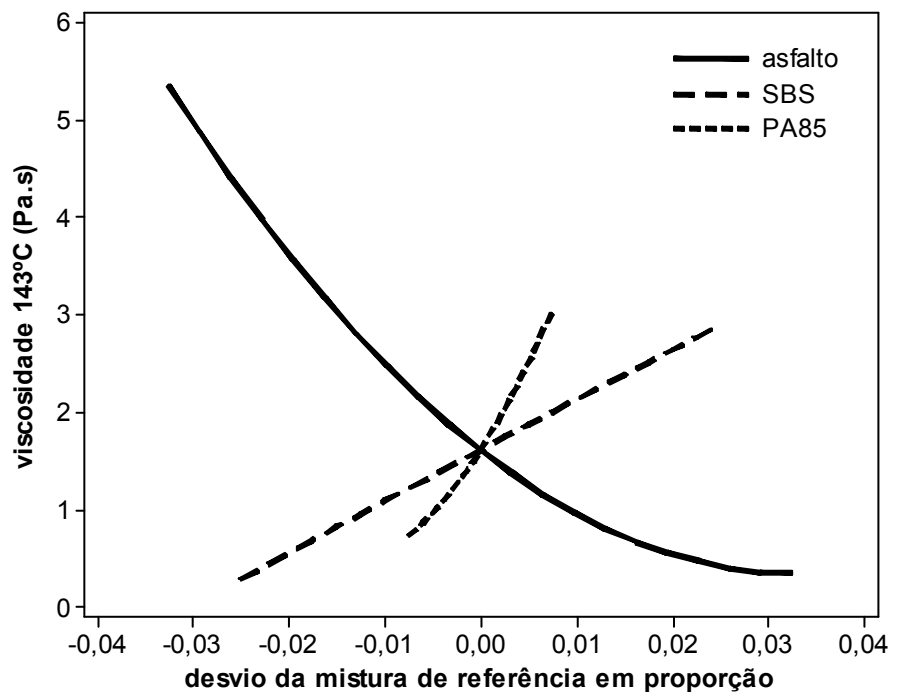

(b)

Figura 163 - Superfície de Resposta (a) e efeito de componentes (b) para Viscosidade à $143^{\circ} \mathrm{C}$ na condição RTFOT para misturas com PA85. 


\section{Viscosidade $155^{\circ} \mathrm{C}$}

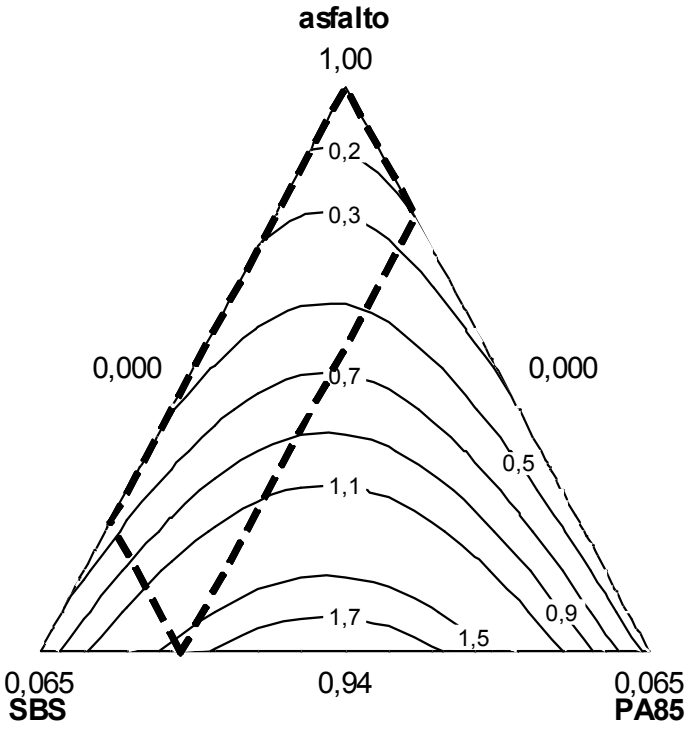

(a)

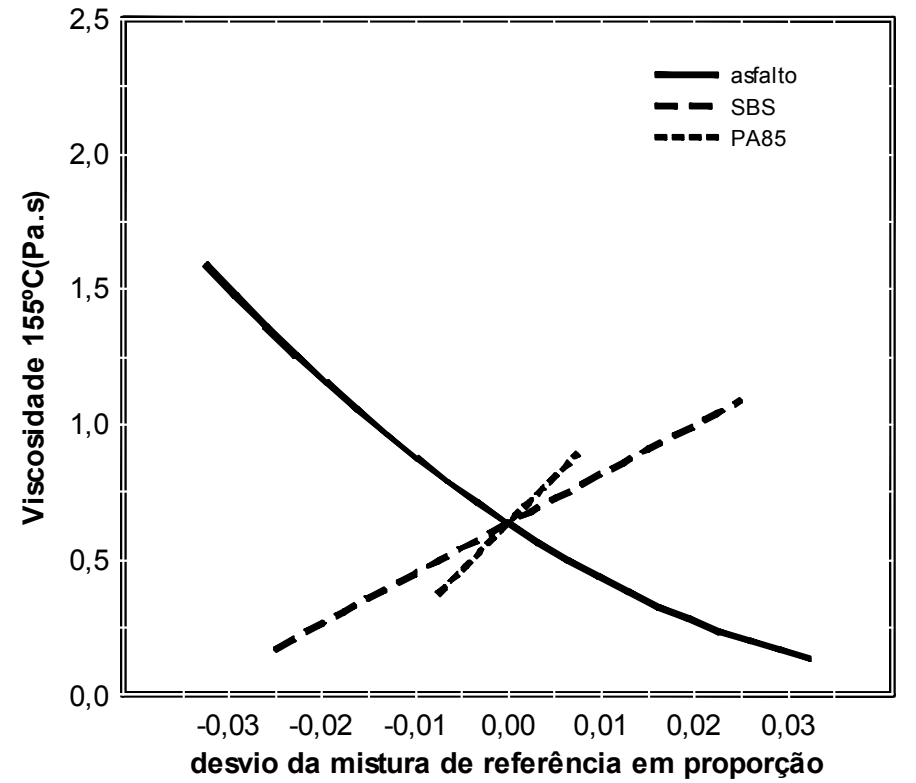

(b)

Figura 164 - Superfície de Resposta (a) e efeito de componentes (b) para Viscosidade à $155^{\circ} \mathrm{C}$ na condição virgem para misturas com PA85.

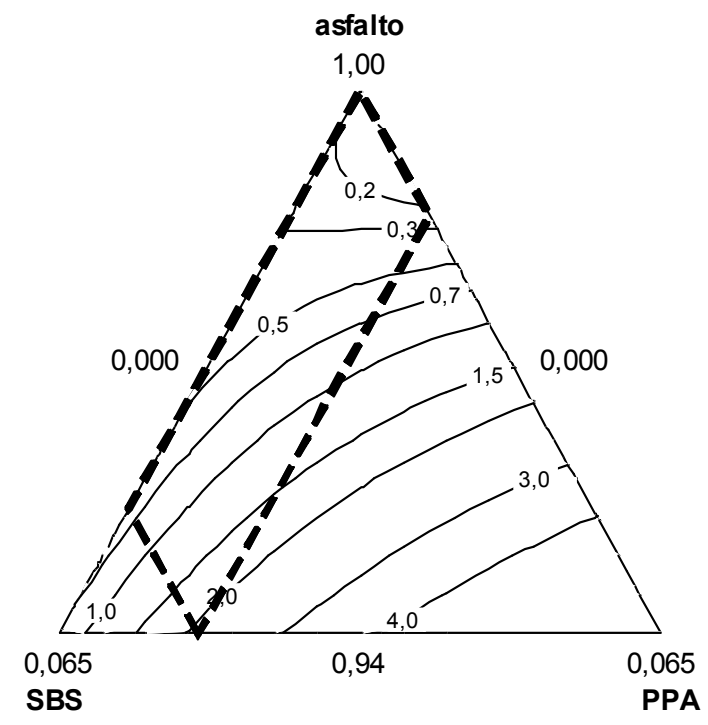

(a)

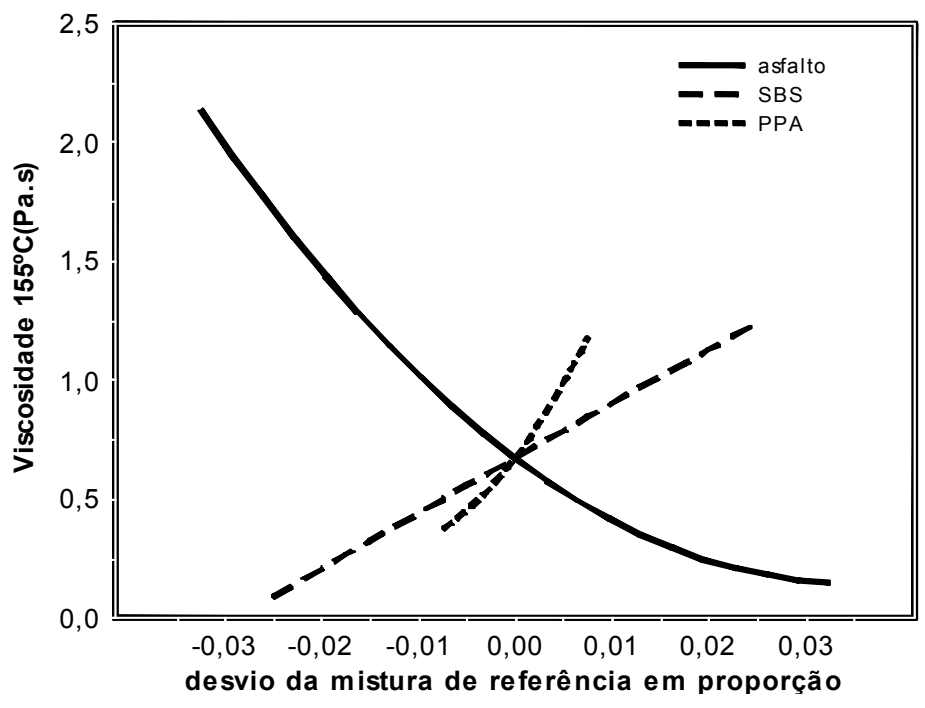

(b)

Figura 165 - Superfície de Resposta (a) e efeito de componentes (b) para Viscosidade à $155^{\circ} \mathrm{C}$ na condição virgem para misturas com PPA. 


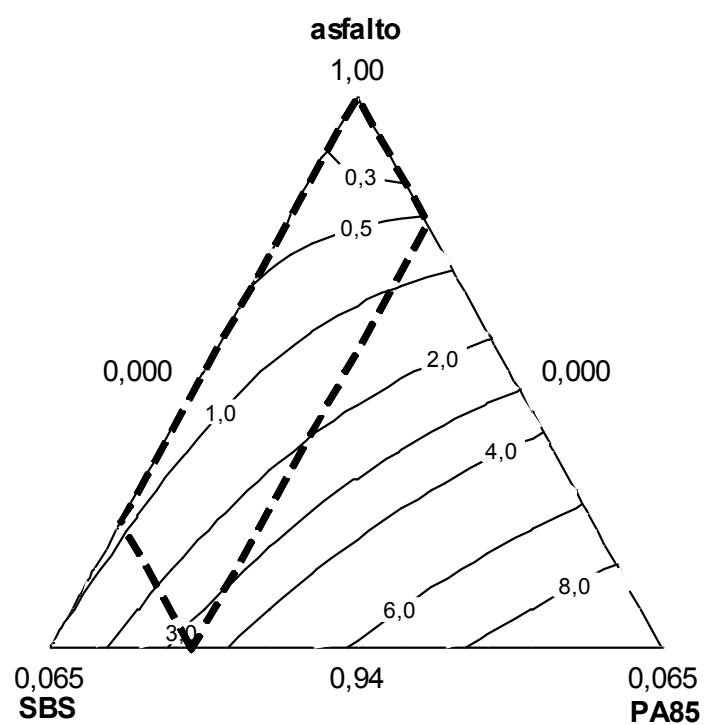

(a)

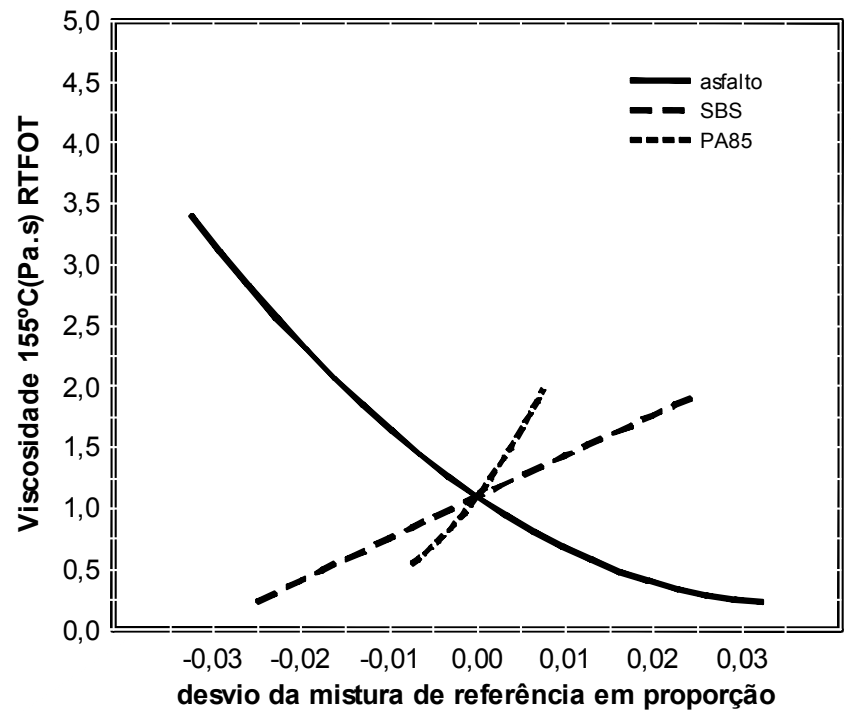

(b)

Figura 166 - Superfície de Resposta (a) e efeito de componentes (b) para Viscosidade à $155^{\circ} \mathrm{C}$ RTFOT para misturas com PA85.

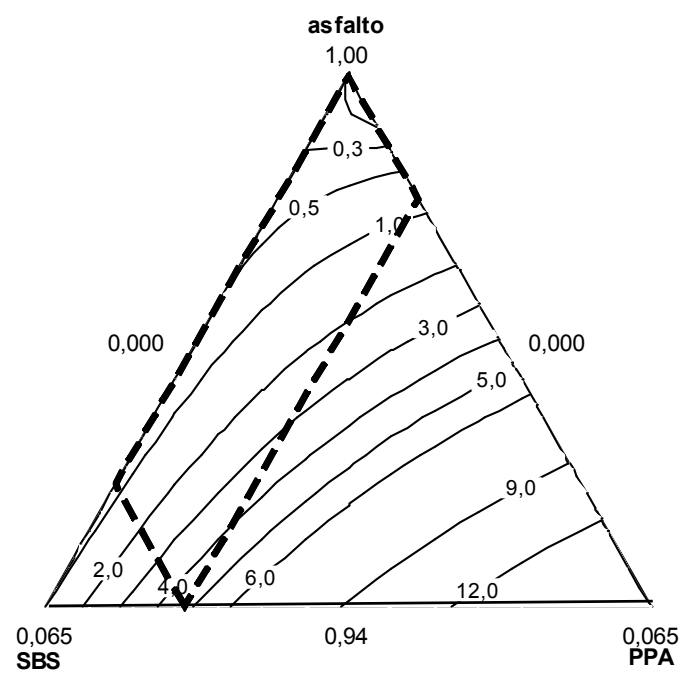

(a)

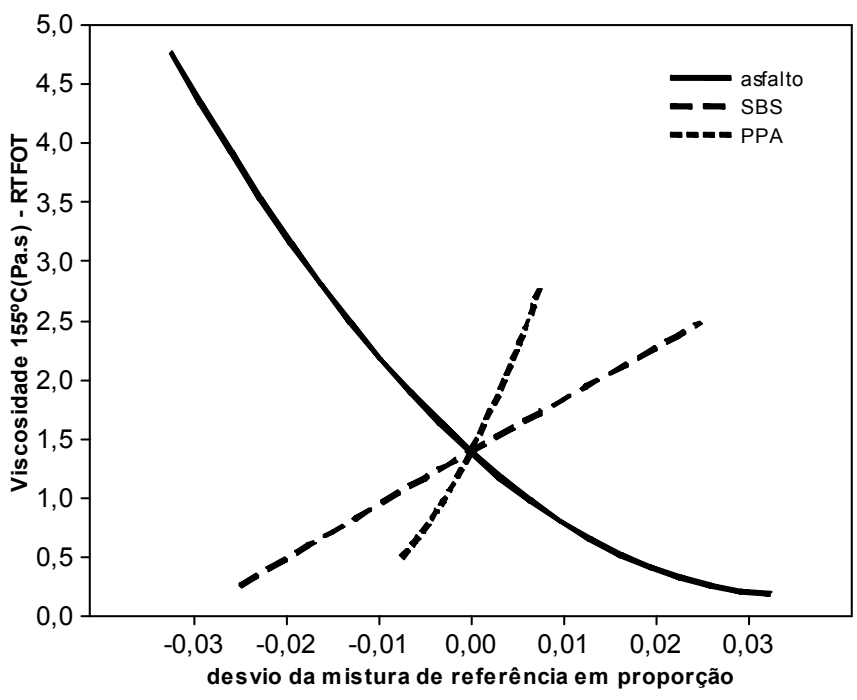

(b)

Figura 167 - Superfície de Resposta (a) e efeito de componentes (b) para Viscosidade à $155^{\circ} \mathrm{C}$ RTFOT para misturas com PPA. 


\section{Viscosidade $163^{\circ} \mathrm{C}$}

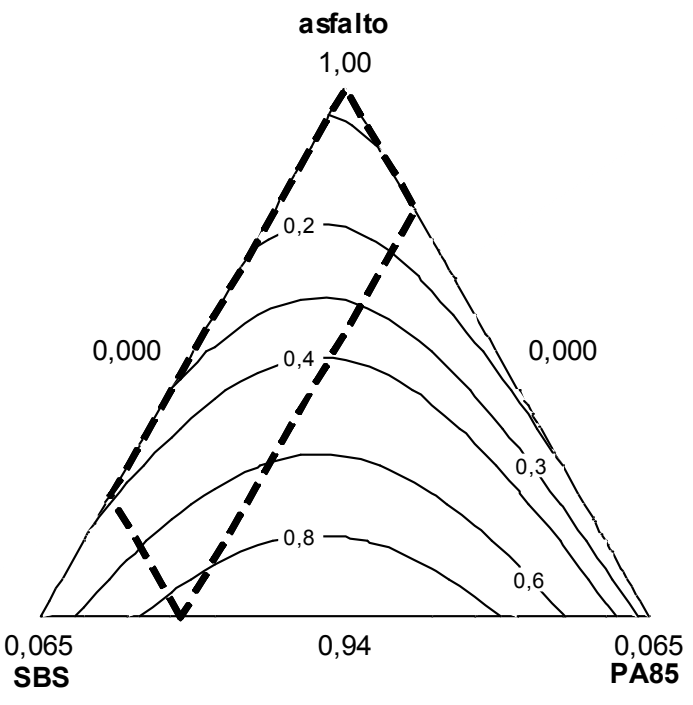

(a)

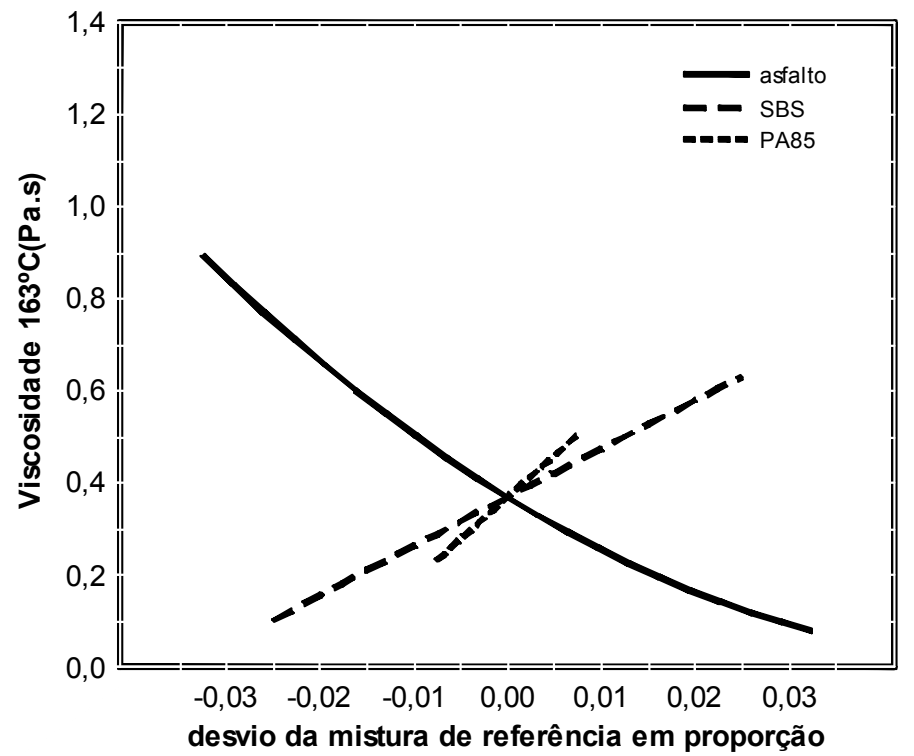

(b)

Figura 168 - Superfície de Resposta (a) e efeito de componentes (b) para Viscosidade à $163^{\circ} \mathrm{C}$ para amostras virgens das misturas com PA85.

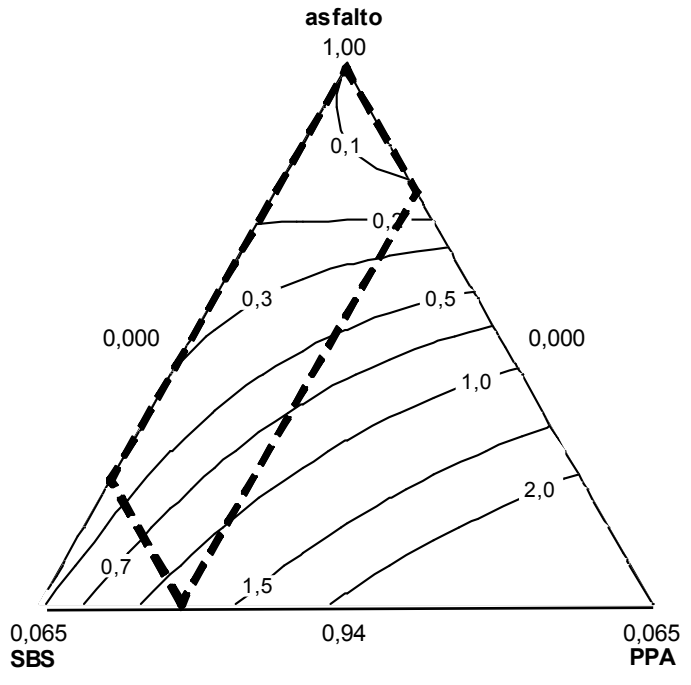

(a)

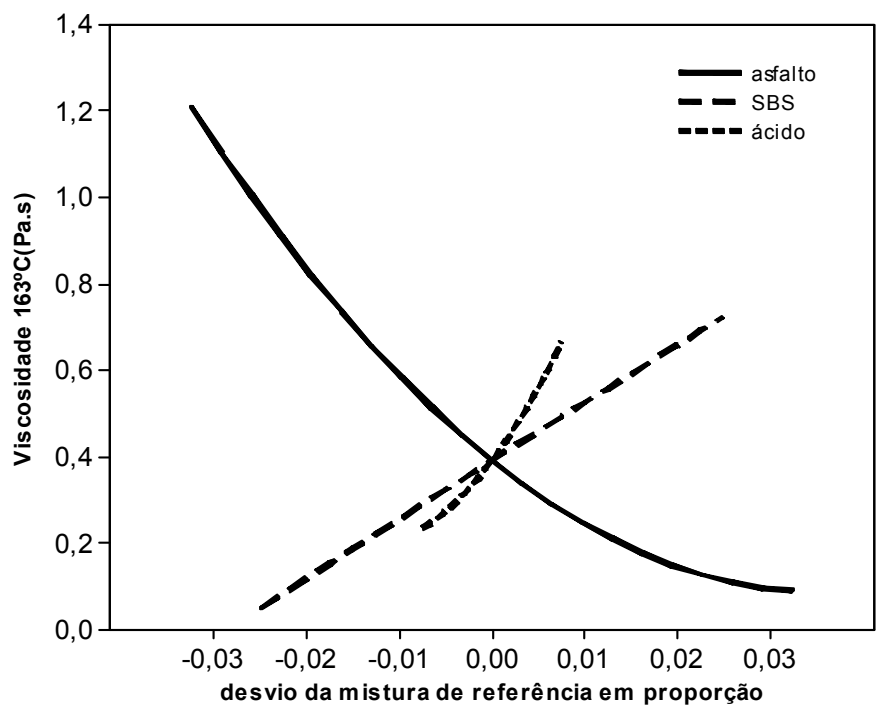

(b)

Figura 169 - Superfície de Resposta (a) e efeito de componentes (b) para Viscosidade à $163^{\circ} \mathrm{C}$ para amostras virgens das misturas com PPA. 


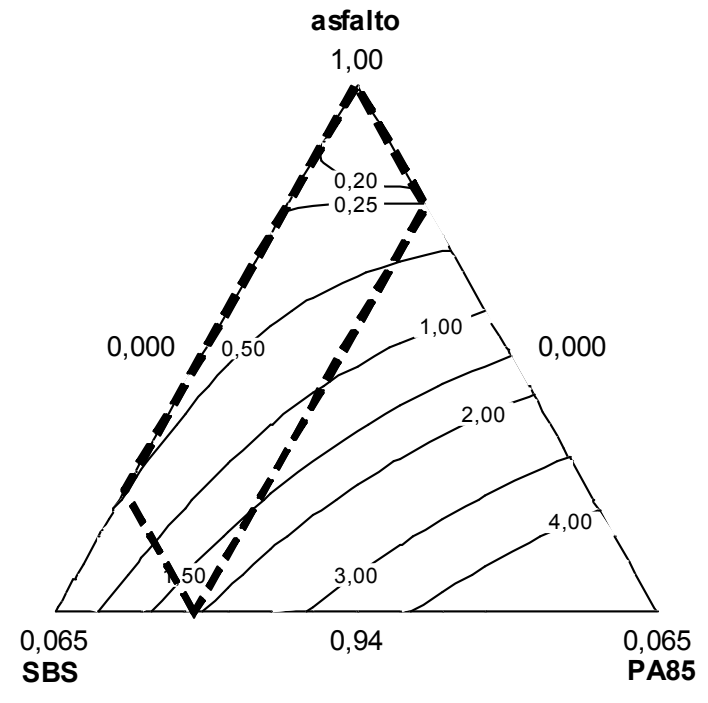

(a)

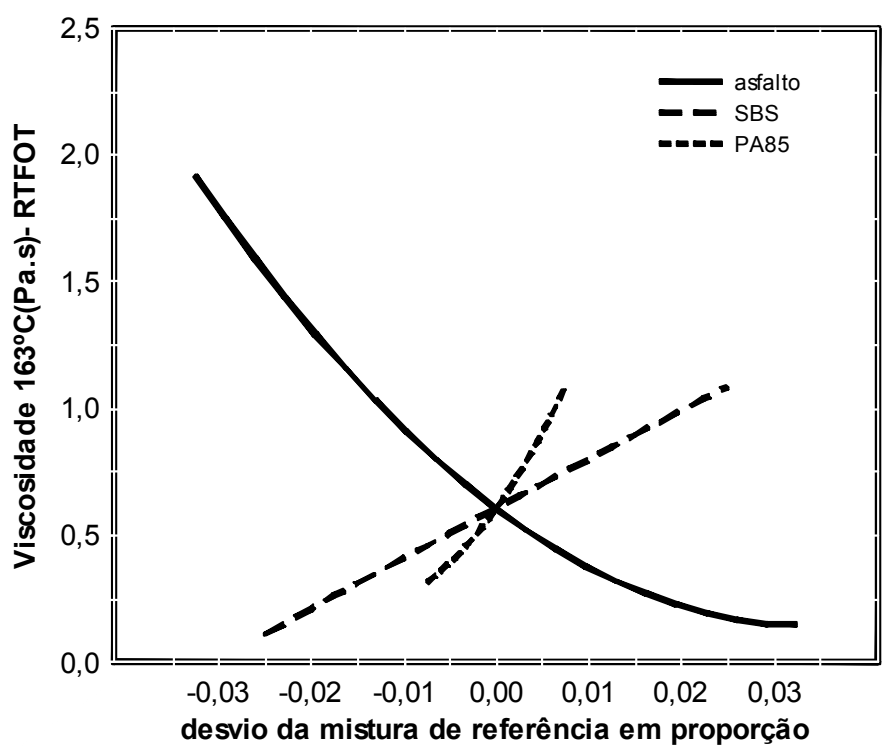

(b)

Figura 170 - Superfície de Resposta (a) e efeito de componentes (b) para Viscosidade à $135^{\circ} \mathrm{C}$ RTFOT das misturas com PA85.

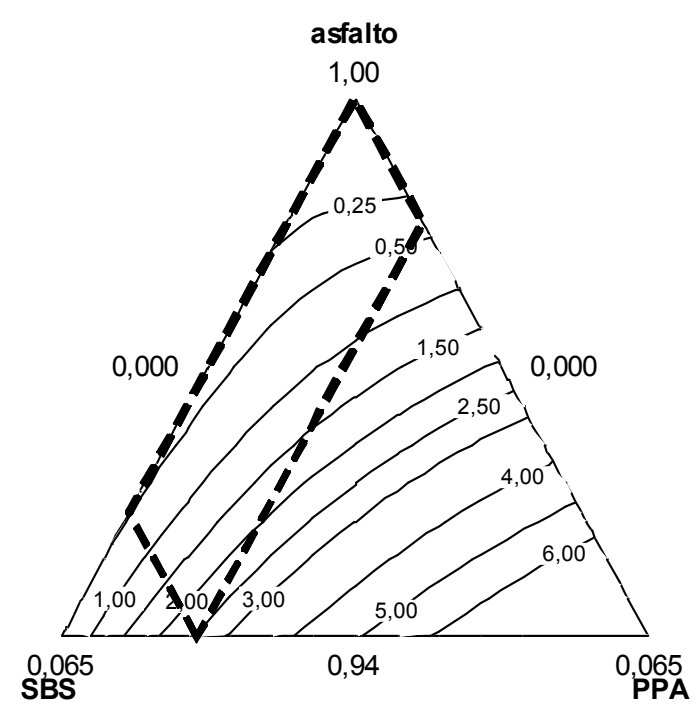

(a)

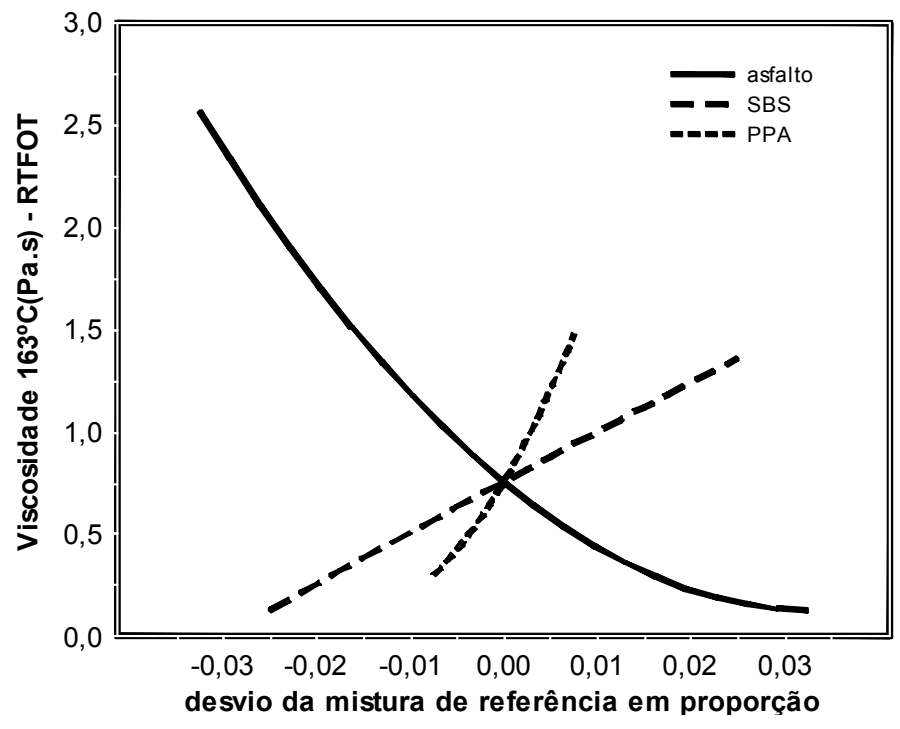

(b)

Figura 171 - Superfície de Resposta (a) e efeito de componentes (b) para Viscosidade à $135^{\circ} \mathrm{C}$ RTFOT das misturas com PPA. 


\section{Viscosidade $177^{\circ} \mathrm{C}$}

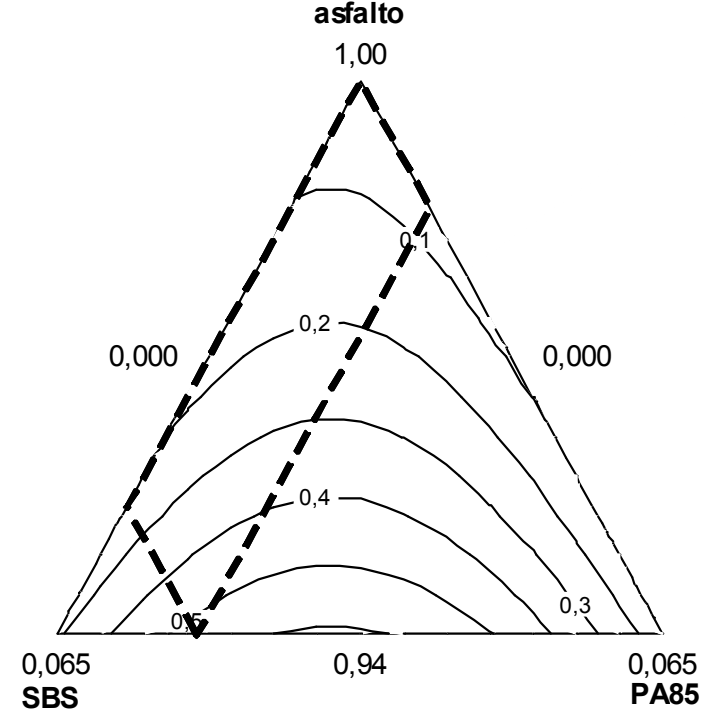

(a)

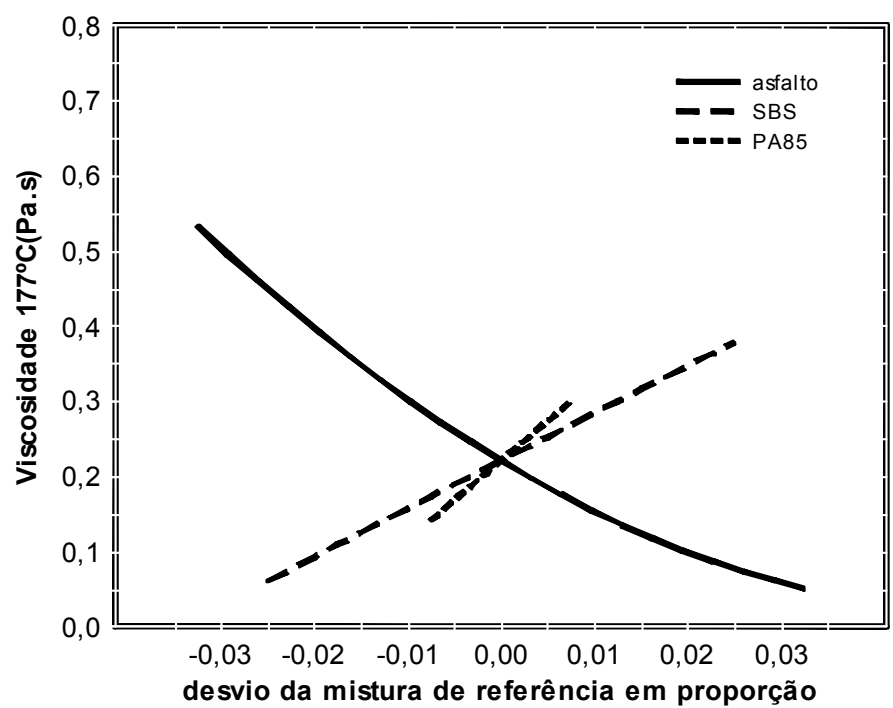

(b)

Figura 172 - Superfície de Resposta (a) e efeito de componentes (b) para Viscosidade à $177^{\circ} \mathrm{C}$ para amostras virgens das misturas com PA85.

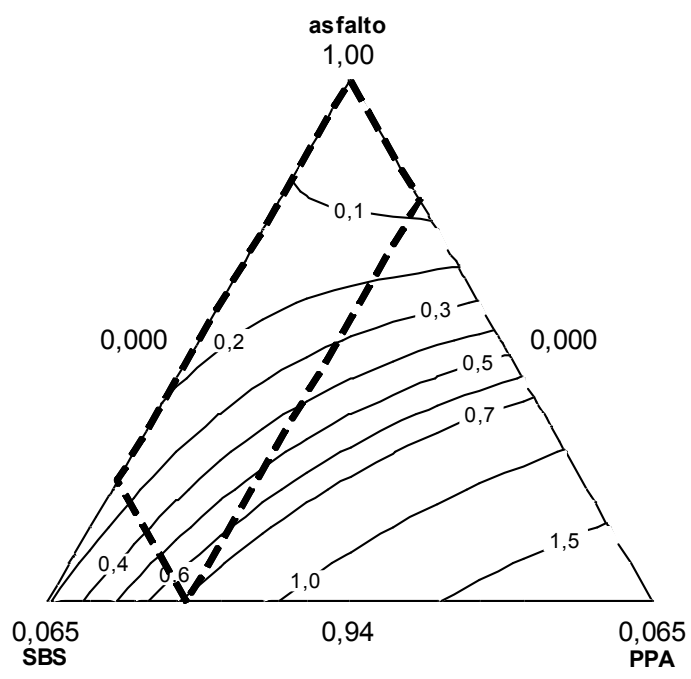

(a)

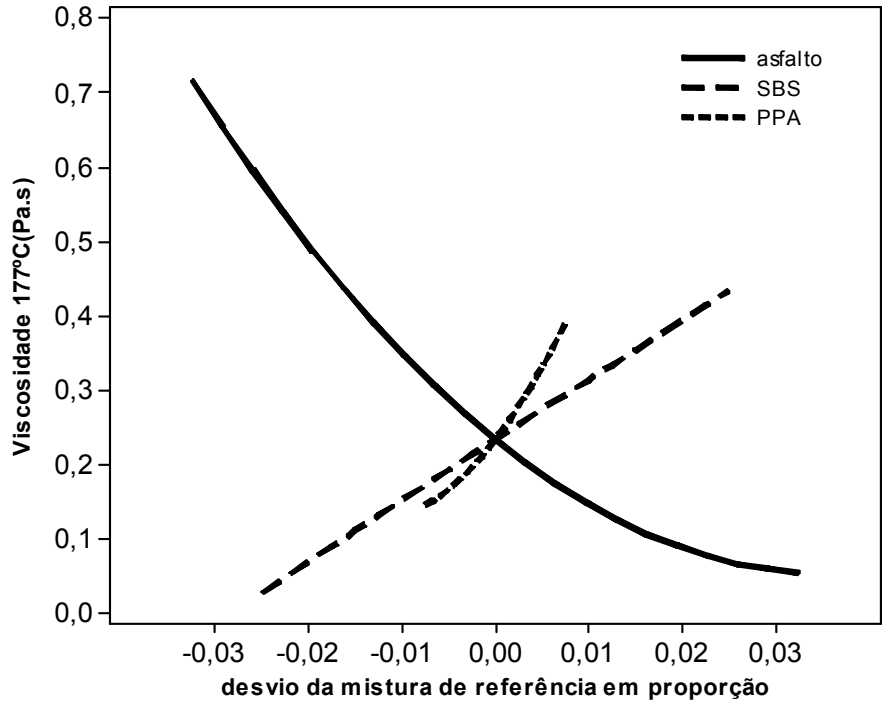

(b)

Figura 173 - Superfície de Resposta (a) e efeito de componentes (b) para Viscosidade à $177^{\circ} \mathrm{C}$ para amostras virgens das misturas com PPA. 


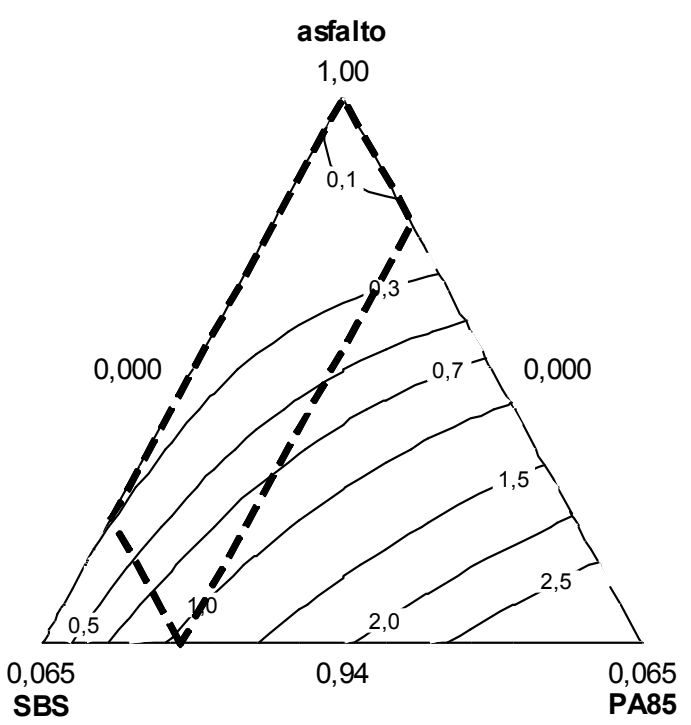

(a)

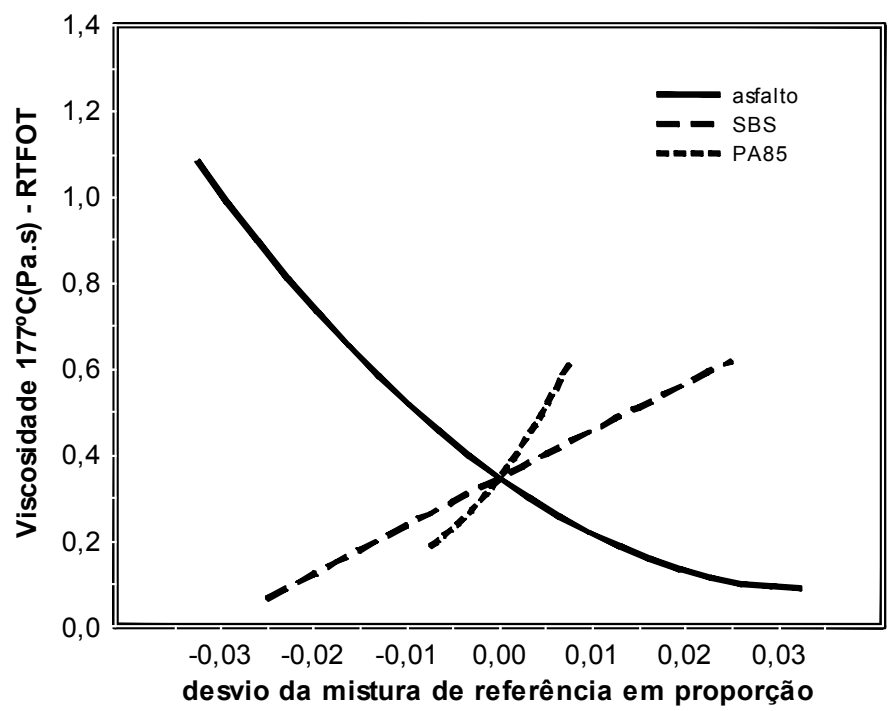

(b)

Figura 174 - Superfície de Resposta (a) e efeito de componentes (b) para Viscosidade à $177^{\circ} \mathrm{C}$ RTFOT das misturas com PA85.

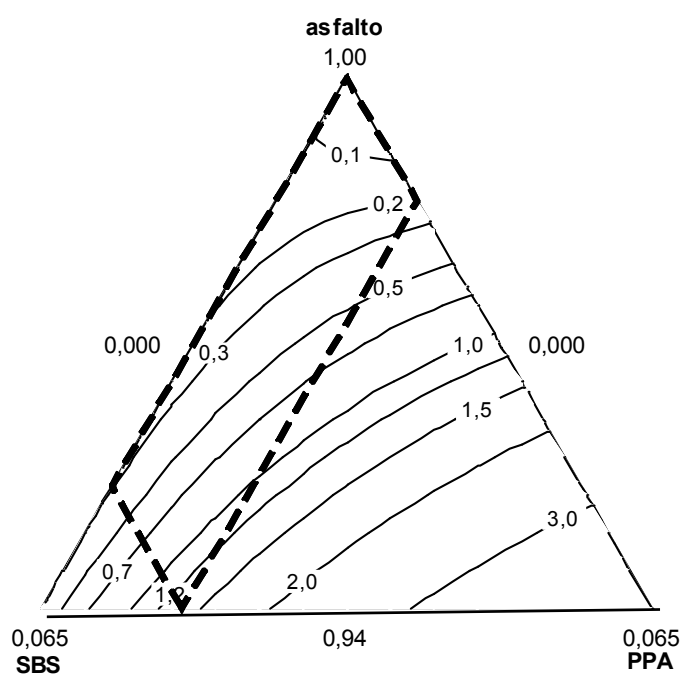

(a)

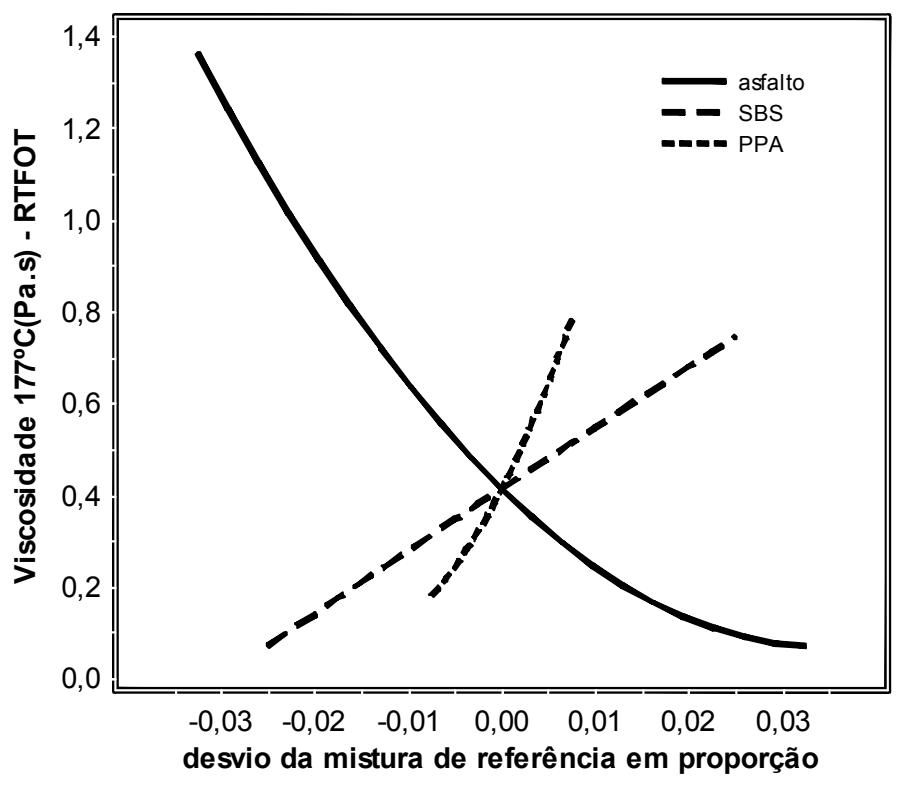

(b)

Figura 175 - Superfície de Resposta (a) e efeito de componentes (b) para Viscosidade à $177^{\circ} \mathrm{C}$ RTFOT das misturas com PPA. 


\section{Perda de Massa}

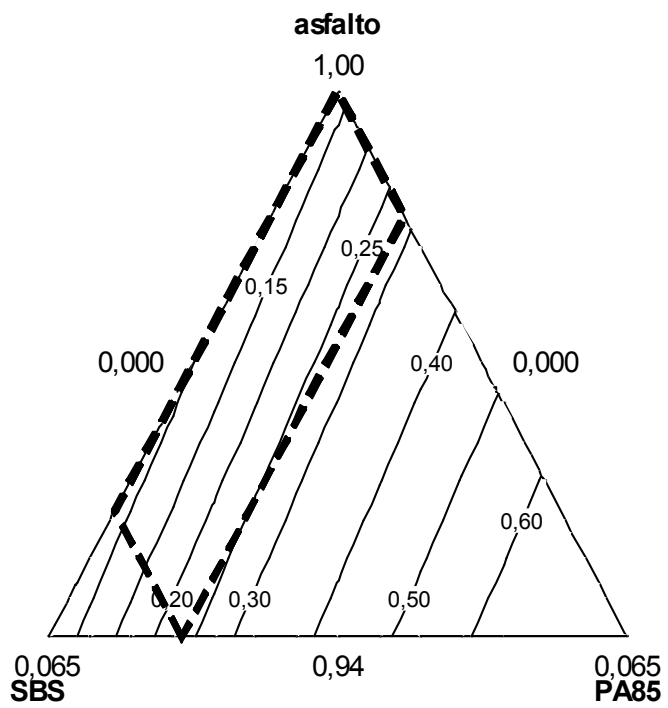

(a)

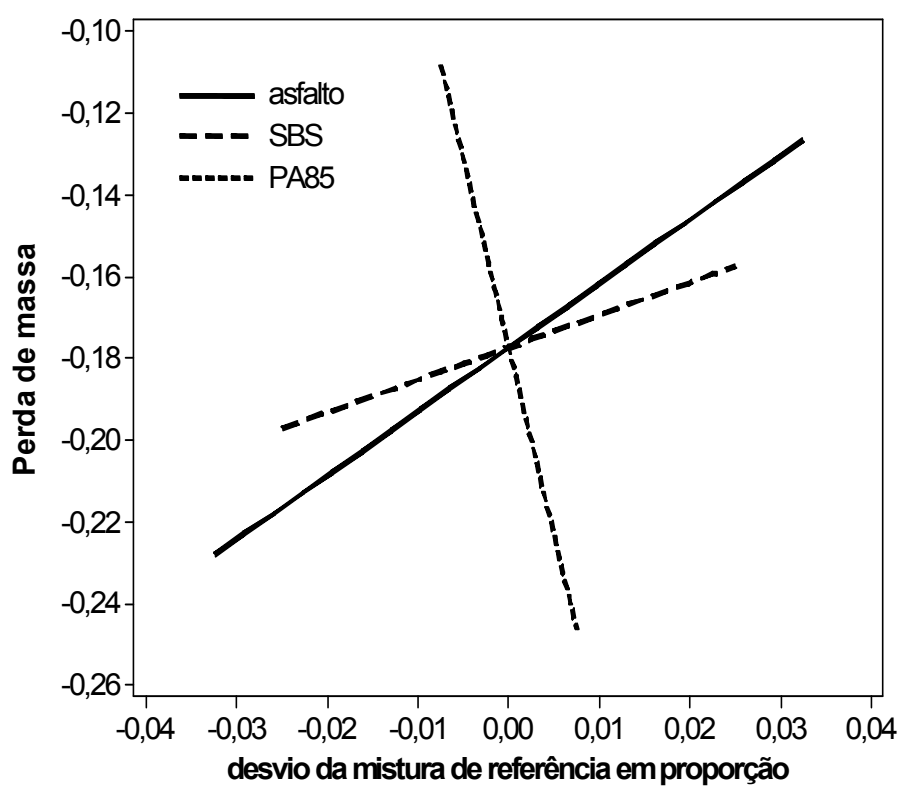

(b)

Figura 176 - Superfície de Resposta (a) e efeito de componentes (b) para perda de massa das misturas com PA85 (Replan).

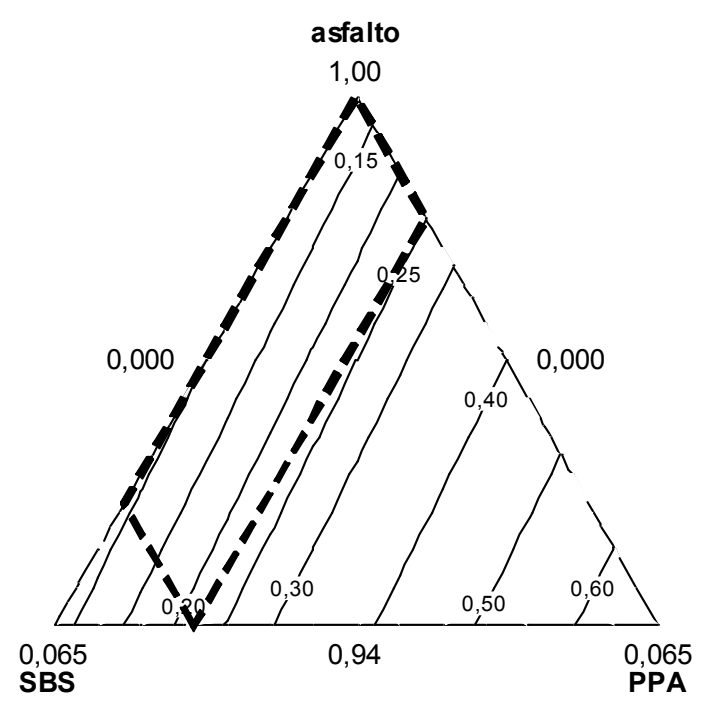

(a)

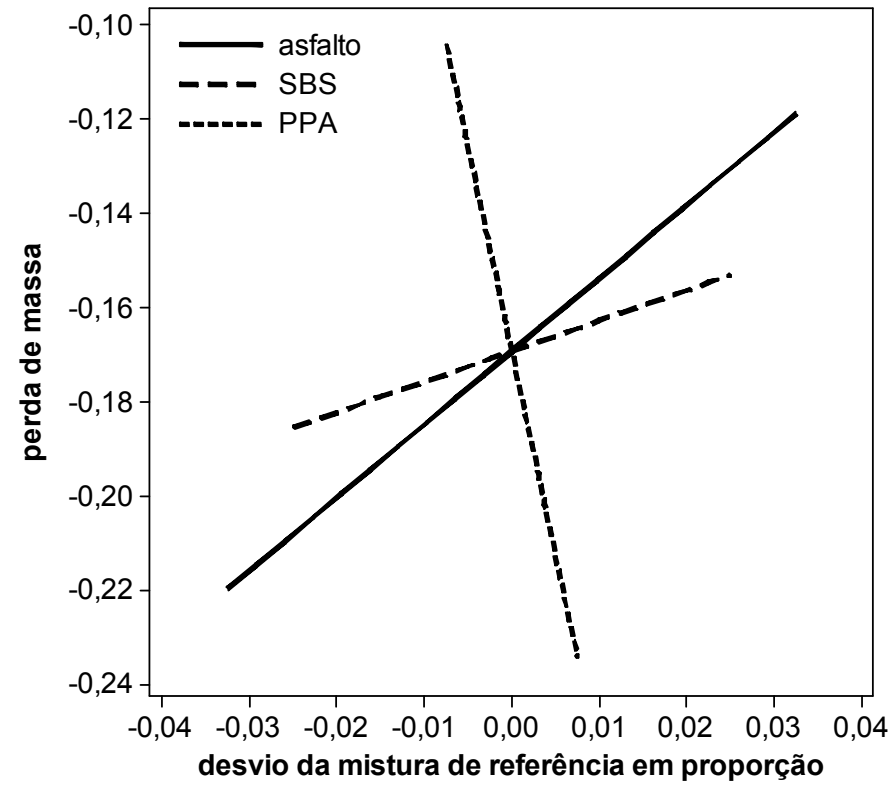

(b)

Figura 177 - Superfície de Resposta (a) e efeito de componentes (b) para perda de massa das misturas com PPA (Replan) 
Temperatura de $52^{\circ} \mathrm{C}$

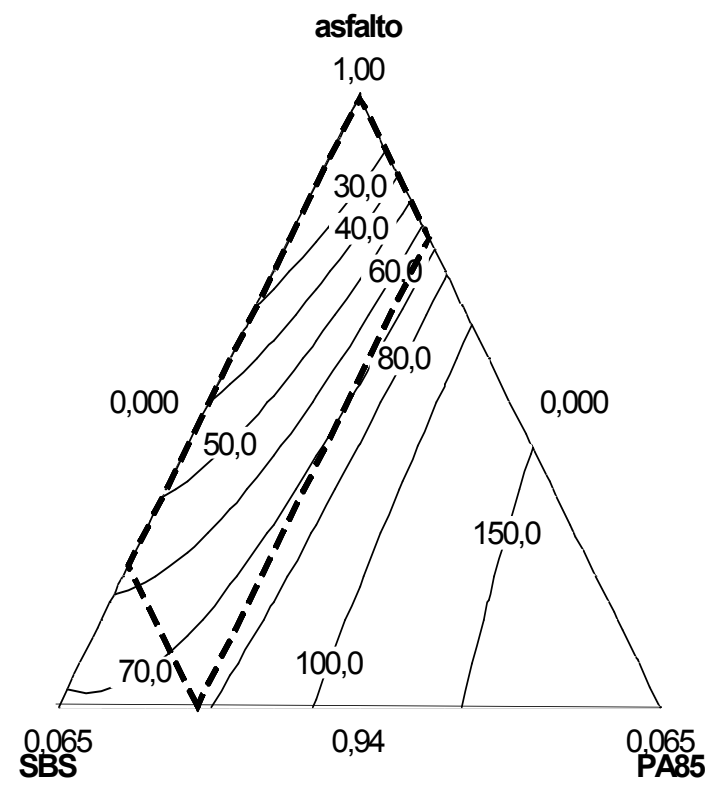

(a)

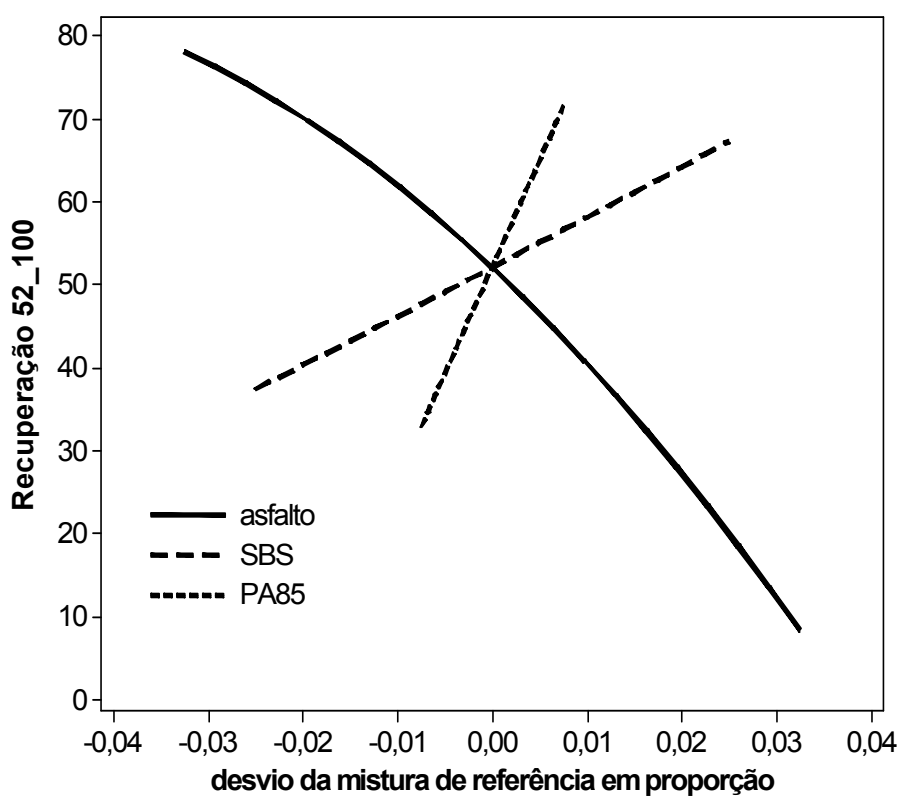

(b)

Figura 178 - Superfície de Resposta (a) e efeito de componentes (b) para a Recuperação (\%) à $52^{\circ} \mathrm{C}$ na tensão de 100PA das misturas com PA85.

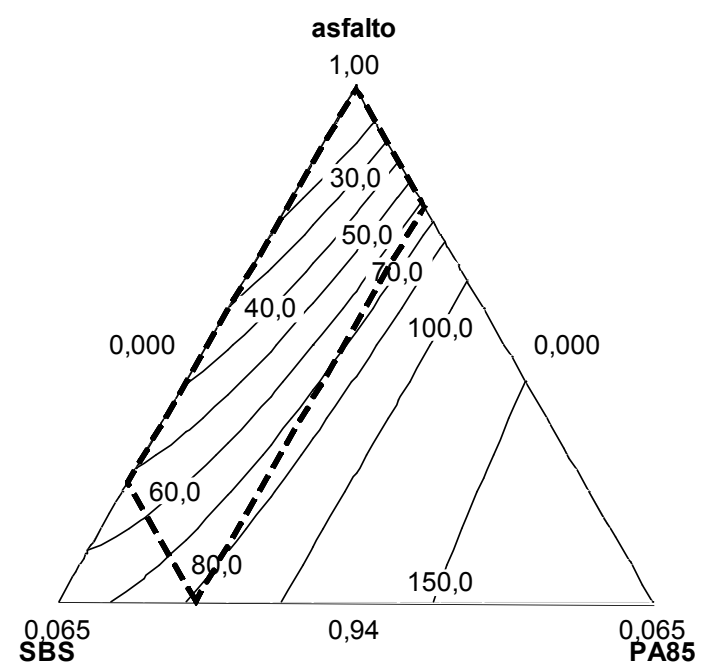

(a)

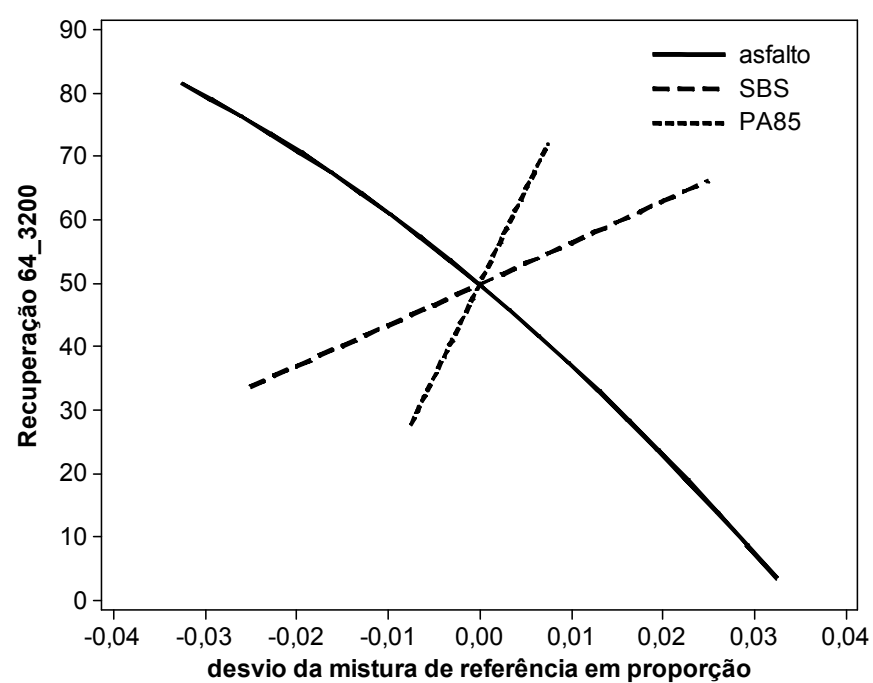

(b)

Figura 179 - Superfície de Resposta (a) e efeito de componentes (b) para a Recuperação (\%) à $52^{\circ} \mathrm{C}$ na tensão de 3200PA das misturas com PA85. 


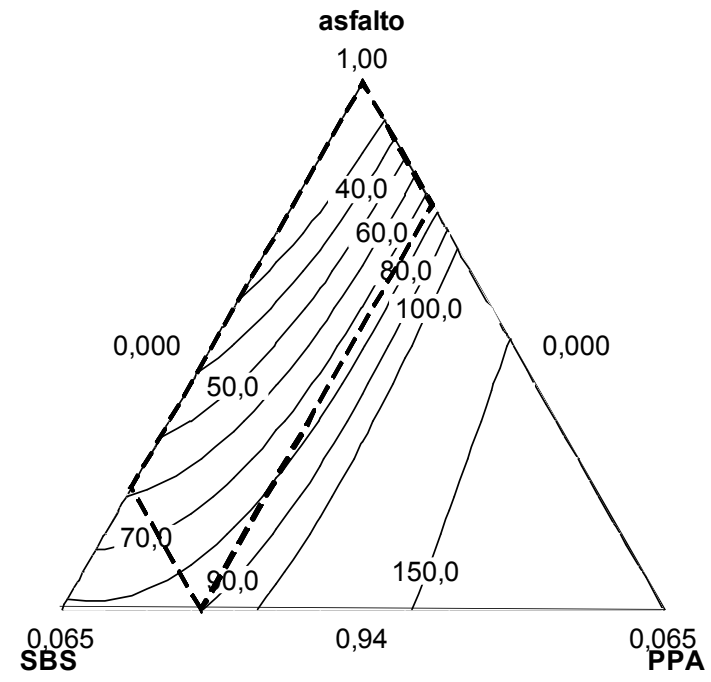

(a)

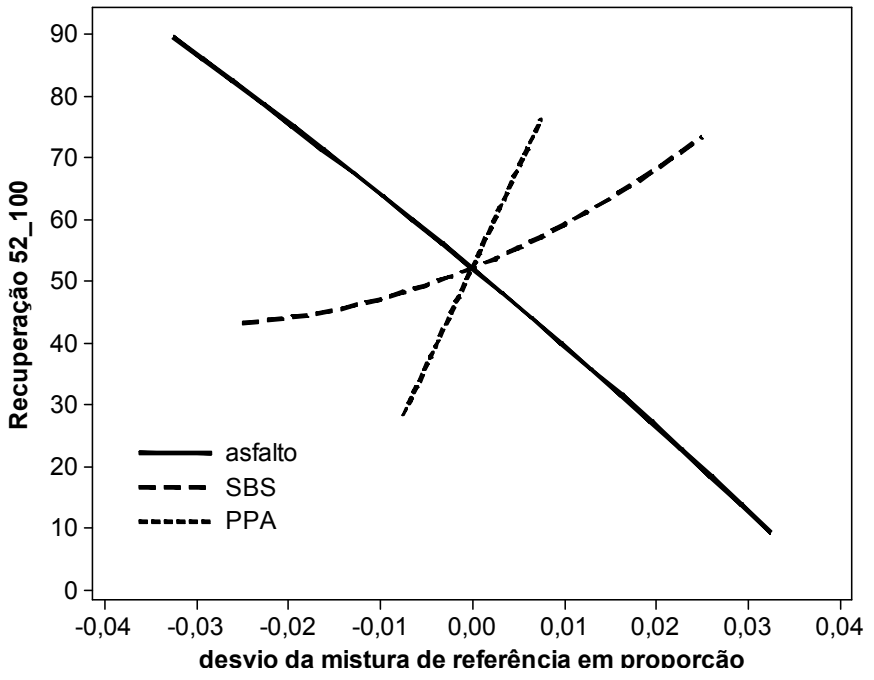

(b)

Figura 180 - Superfície de Resposta (a) e efeito de componentes (b) para a Recuperação (\%) à $52^{\circ} \mathrm{C}$ na tensão de 100PA das misturas com PPA.

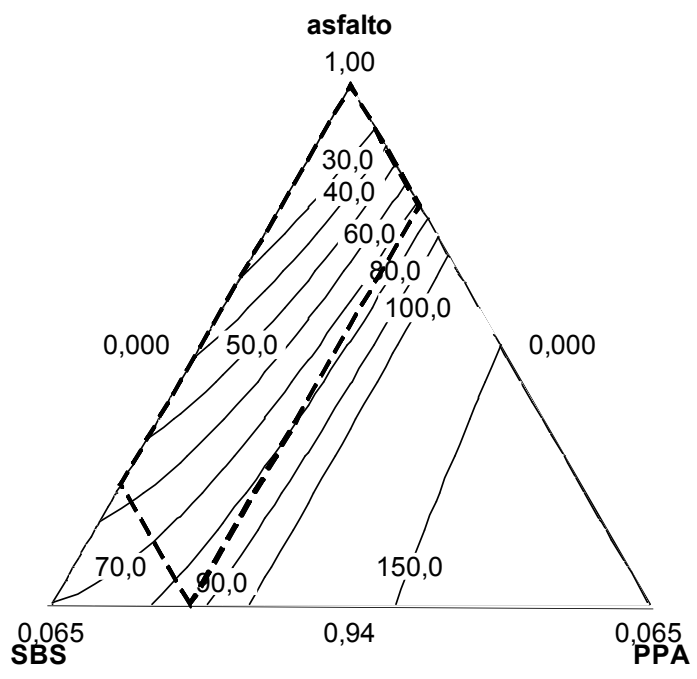

(a)

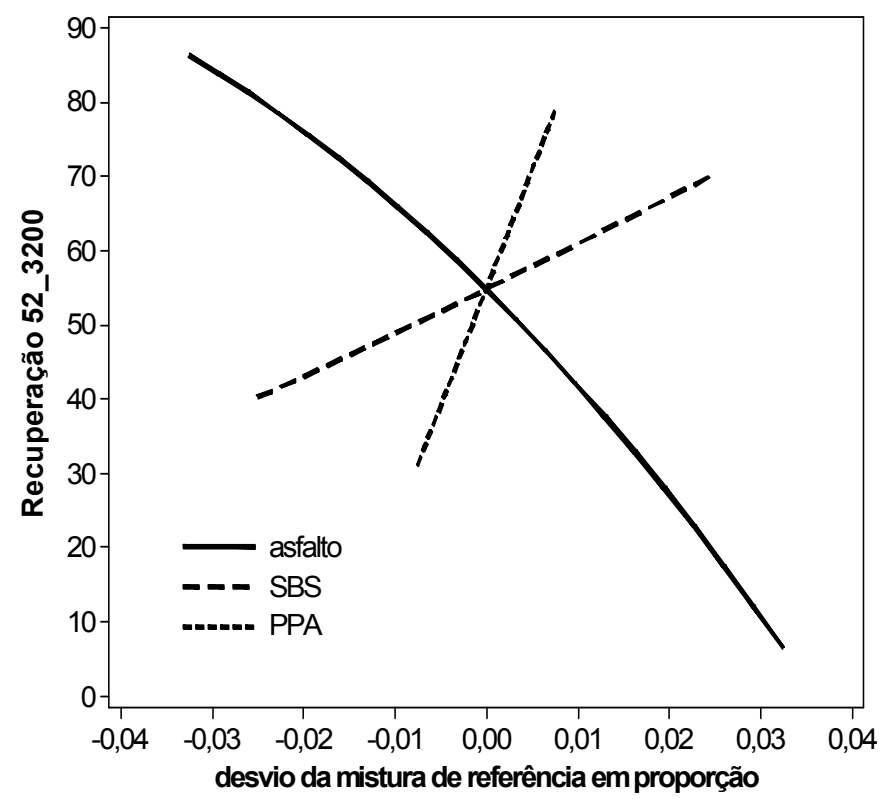

(b)

Figura 181 - Superfície de Resposta (a) e efeito de componentes (b) para a Recuperação (\%) à $52^{\circ} \mathrm{C}$ na tensão de 3200PA das misturas com PPA. 


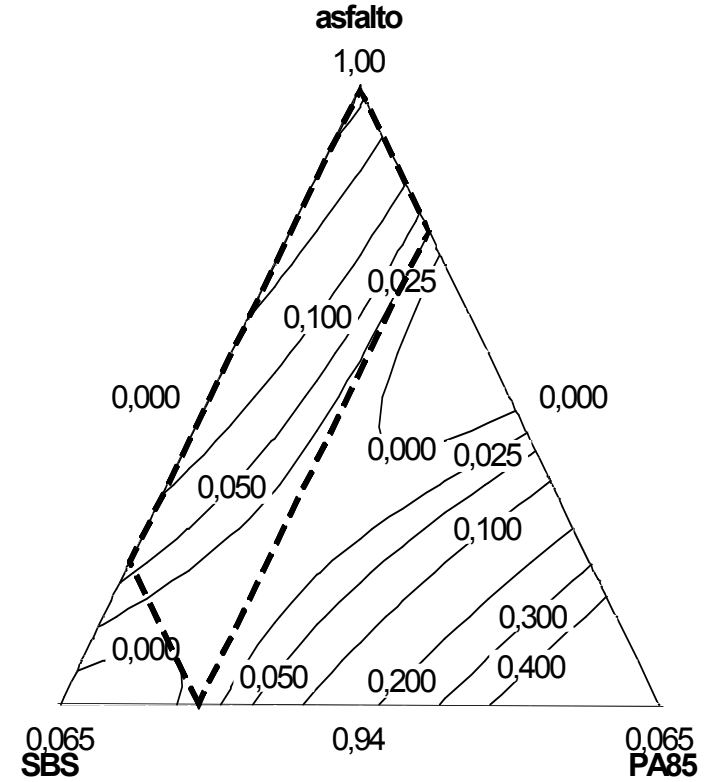

(a)

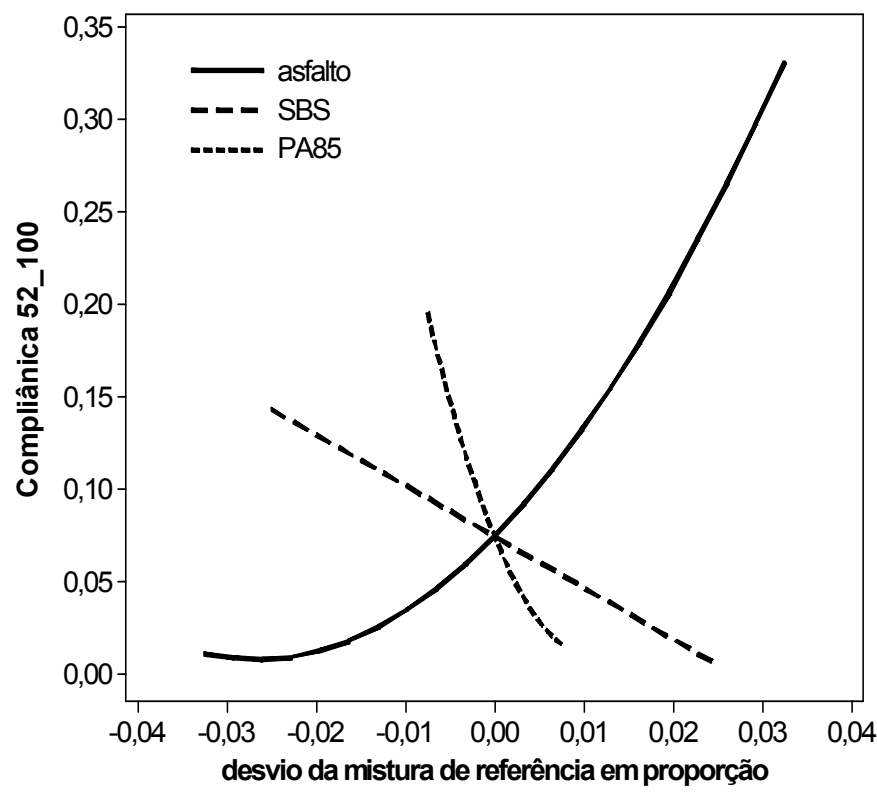

(b)

Figura 182 - Superfície de Resposta (a) e efeito de componentes (b) para a Compliância não recuperável $\left(\mathrm{kPa}^{-1}\right)$ à $52^{\circ} \mathrm{C}$ na tensão de $100 \mathrm{~Pa}$ das misturas com PA85.

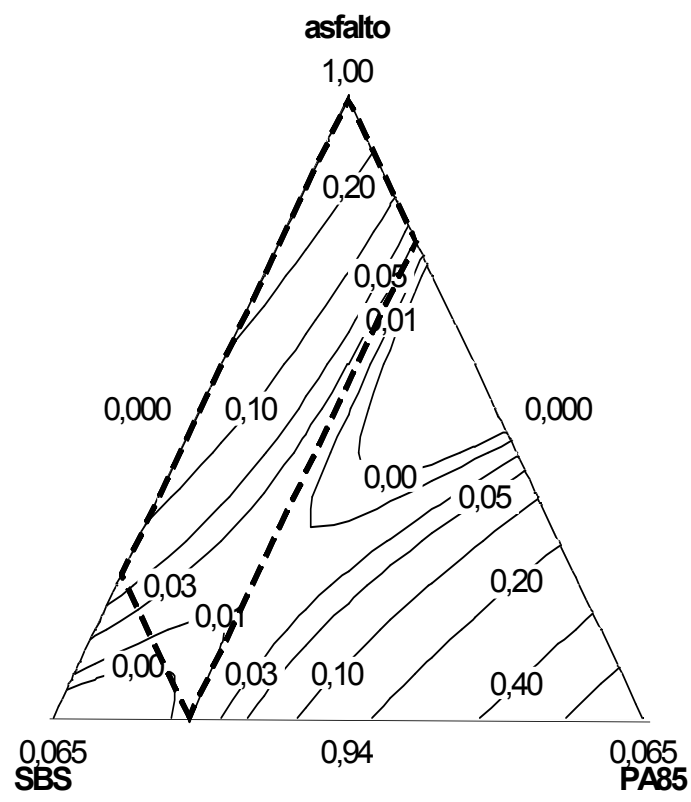

(a)

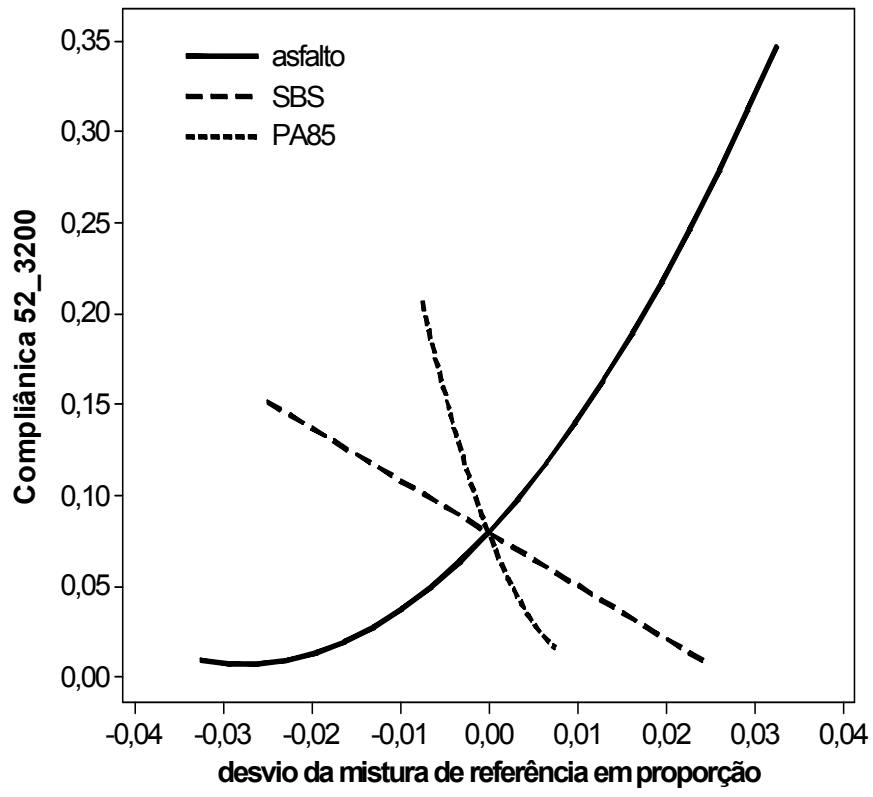

(b)

Figura 183 - Superfície de Resposta (a) e efeito de componentes (b) para a Compliância não recuperável $\left(\mathrm{kPa}^{-1}\right)$ à $52^{\circ} \mathrm{C}$ na tensão de $3200 \mathrm{~Pa}$ das misturas com PA85. 


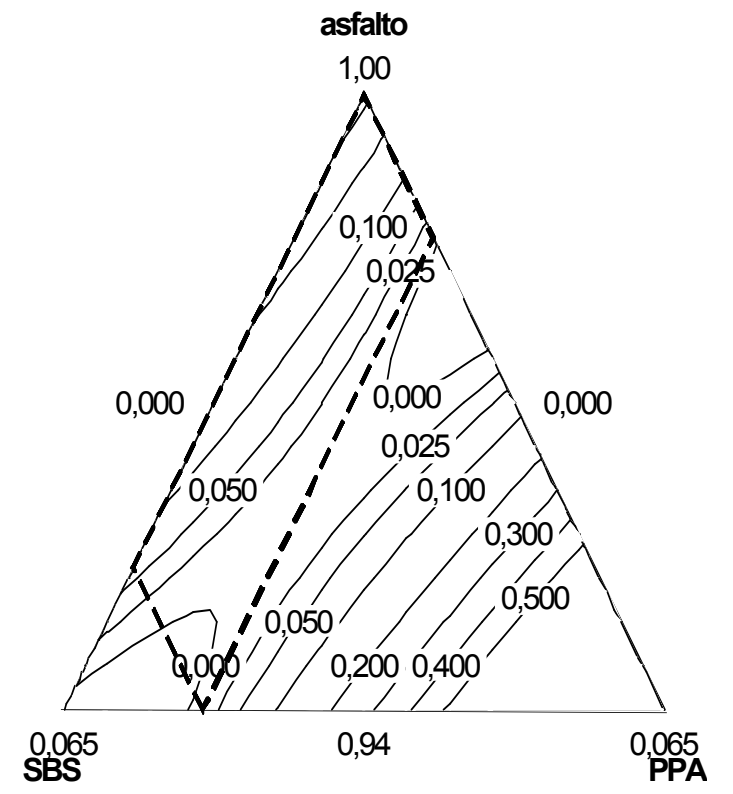

(a)

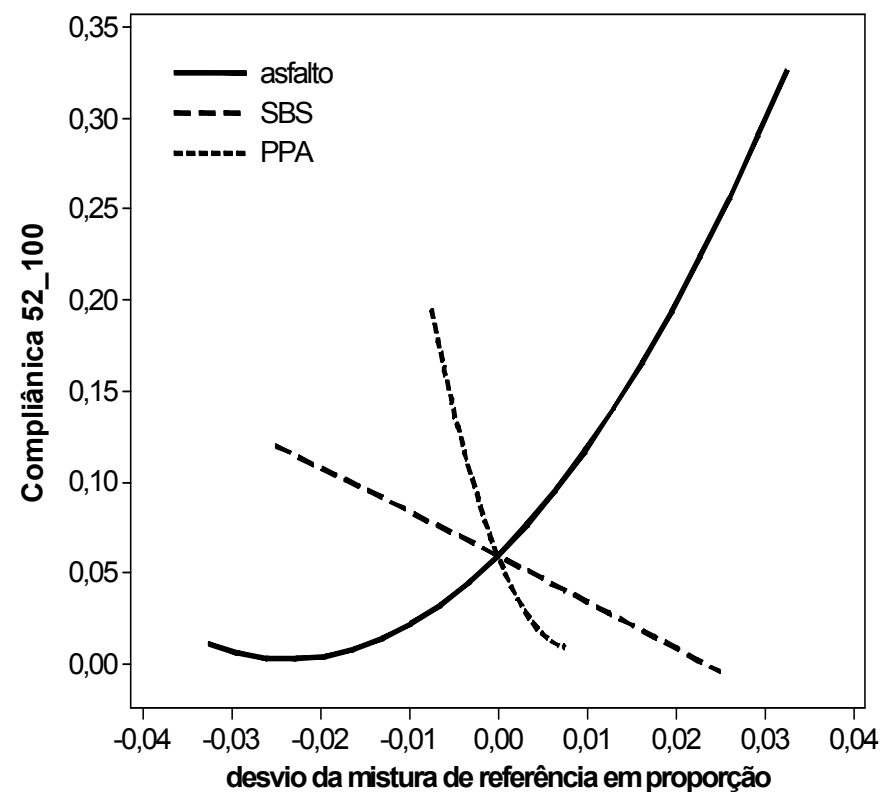

(b)

Figura 184 - Superfície de Resposta (a) e efeito de componentes (b) para a Compliância não recuperável $\left(\mathrm{KPa}^{-1}\right)$ à $52^{\circ} \mathrm{C}$ na tensão de 100PA das misturas com PPA.

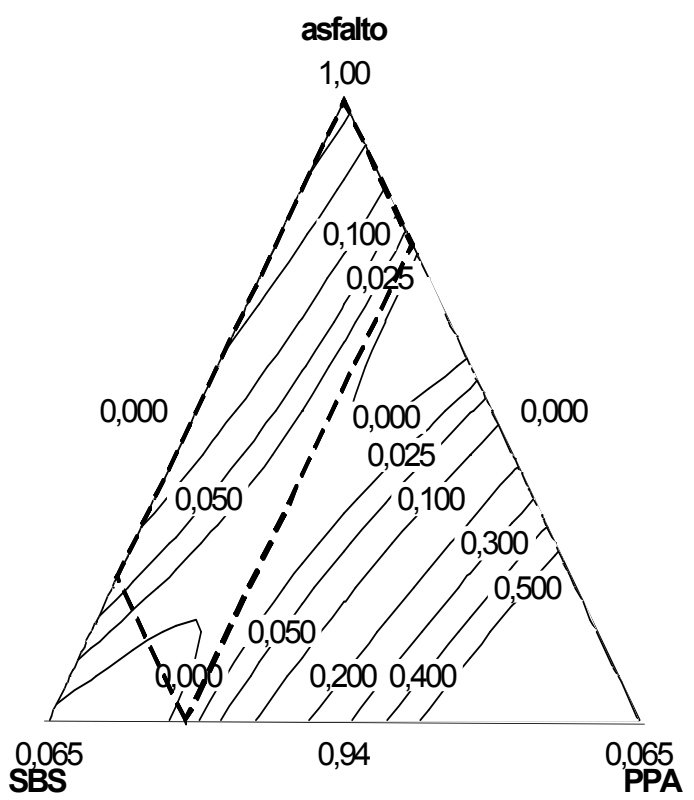

(a)

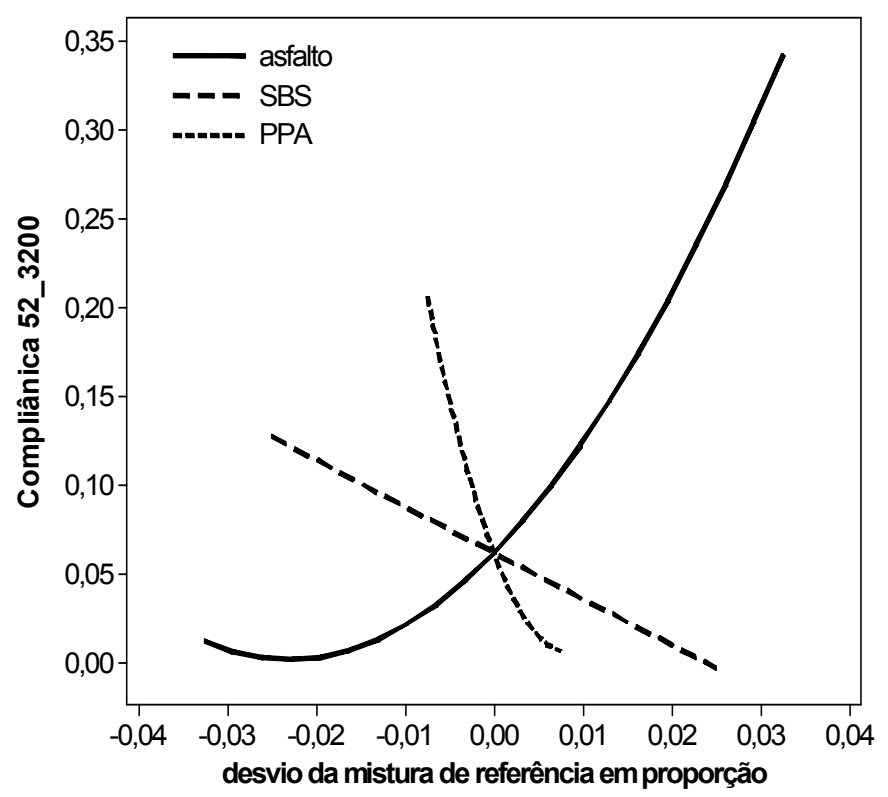

(b)

Figura 185 - Superfície de Resposta (a) e efeito de componentes (b) para a Compliância não recuperável $\left(\mathrm{kPa}^{-1}\right)$ à $52^{\circ} \mathrm{C}$ na tensão de $3200 \mathrm{PA}$ das misturas com PPA. 


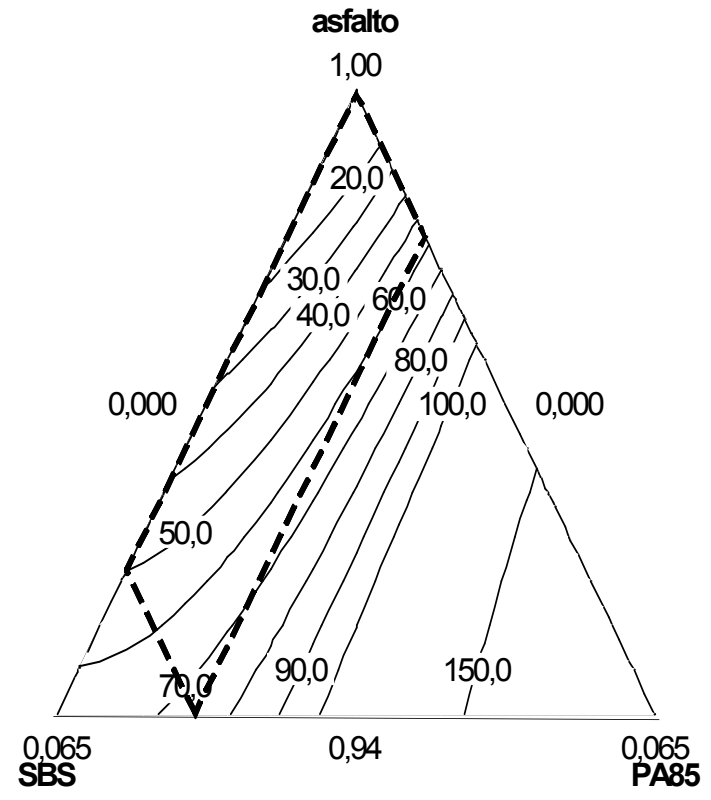

(a)

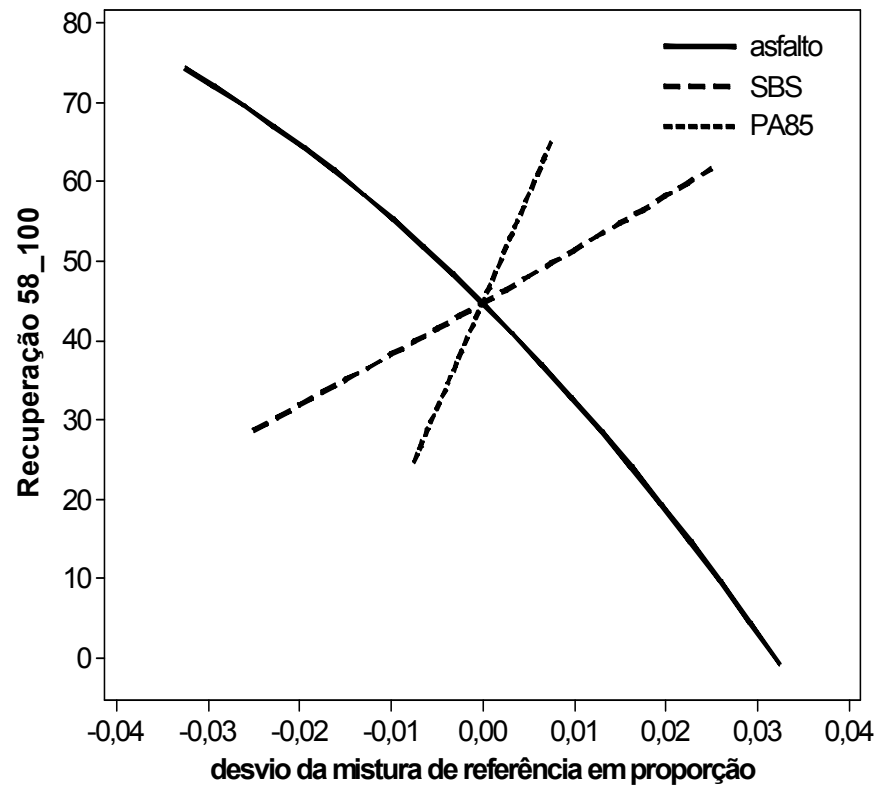

(b)

Figura 186 - Superfície de Resposta (a) e efeito de componentes (b) para a Recuperação (\%) à $58^{\circ} \mathrm{C}$ na tensão de 100PA das misturas com PA85.

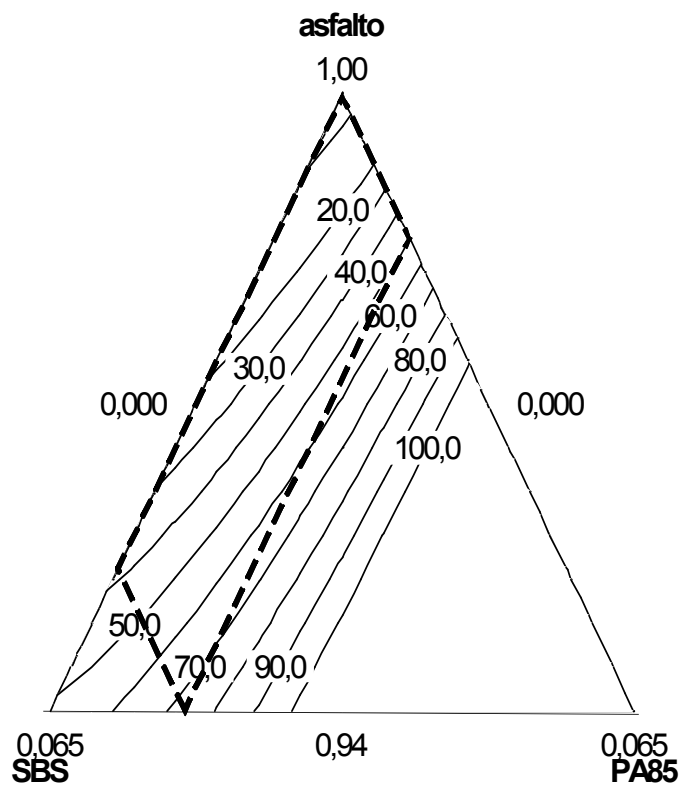

(a)

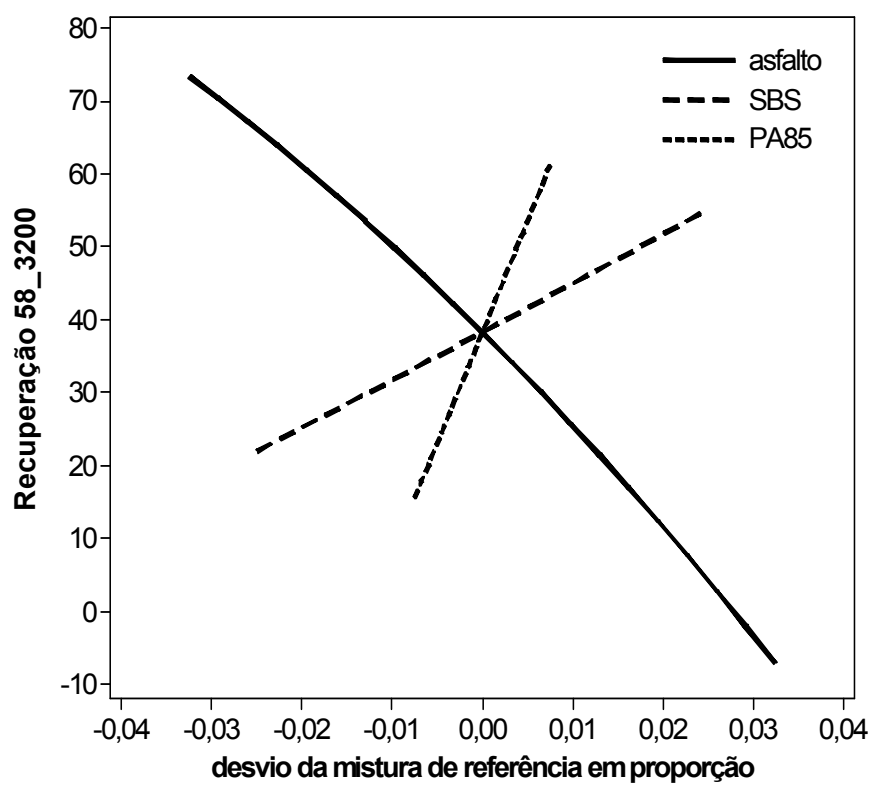

(b)

Figura 187 - Superfície de Resposta (a) e efeito de componentes (b) para a Recuperação (\%) à $58^{\circ} \mathrm{C}$ na tensão de 3200PA das misturas com PA85. 


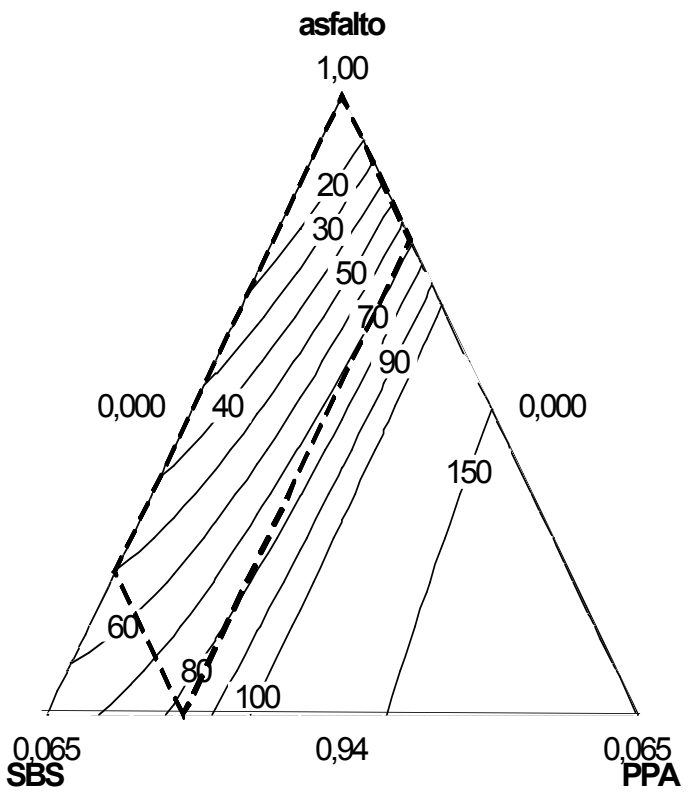

(a)

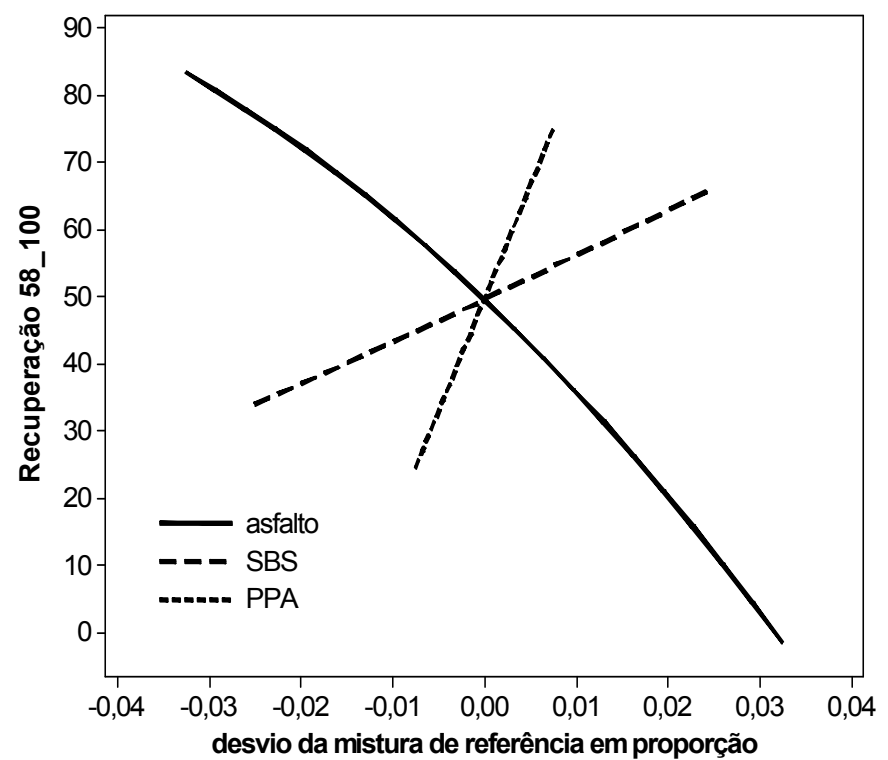

(b)

Figura 188 - Superfície de Resposta (a) e efeito de componentes (b) para a Recuperação (\%) à $58^{\circ} \mathrm{C}$ na tensão de 100PA das misturas com PPA.

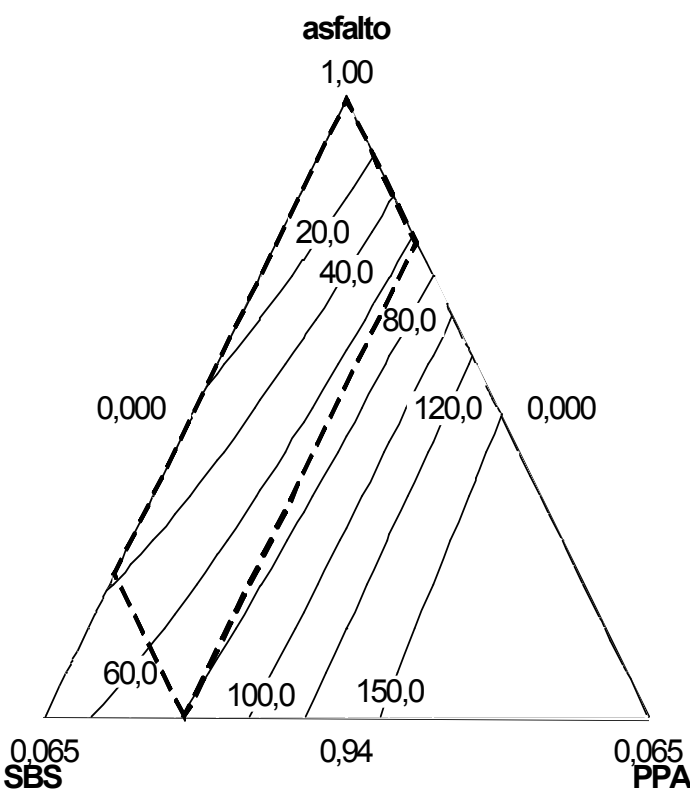

(a)

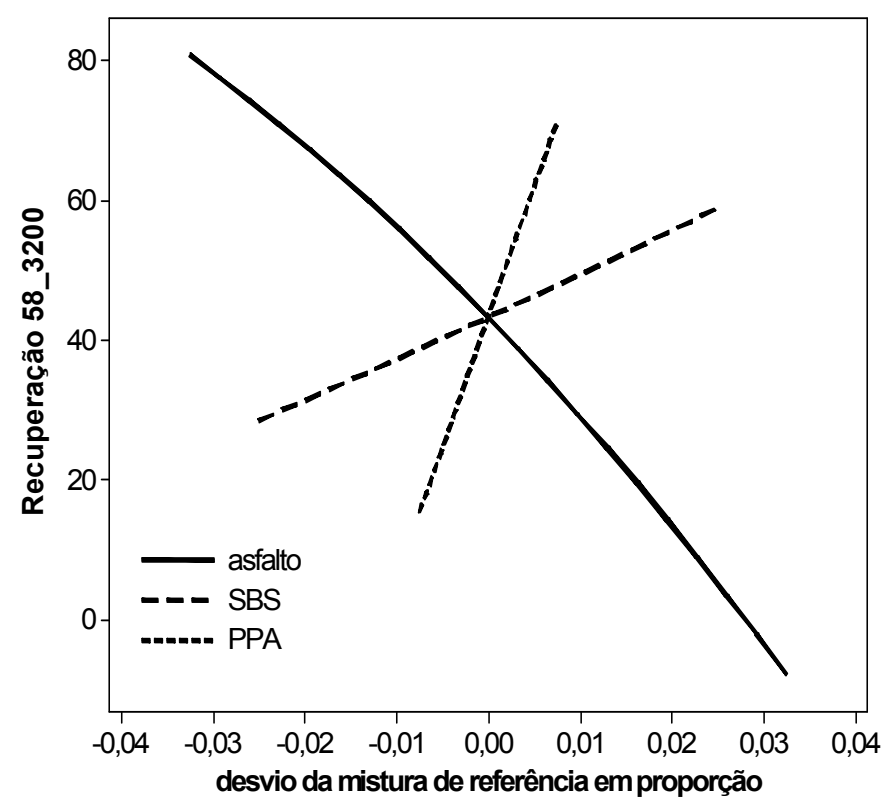

(b)

Figura 189 - Superfície de Resposta (a) e efeito de componentes (b) para a Recuperação (\%) à $58^{\circ} \mathrm{C}$ na tensão de 3200PA das misturas com PPA. 


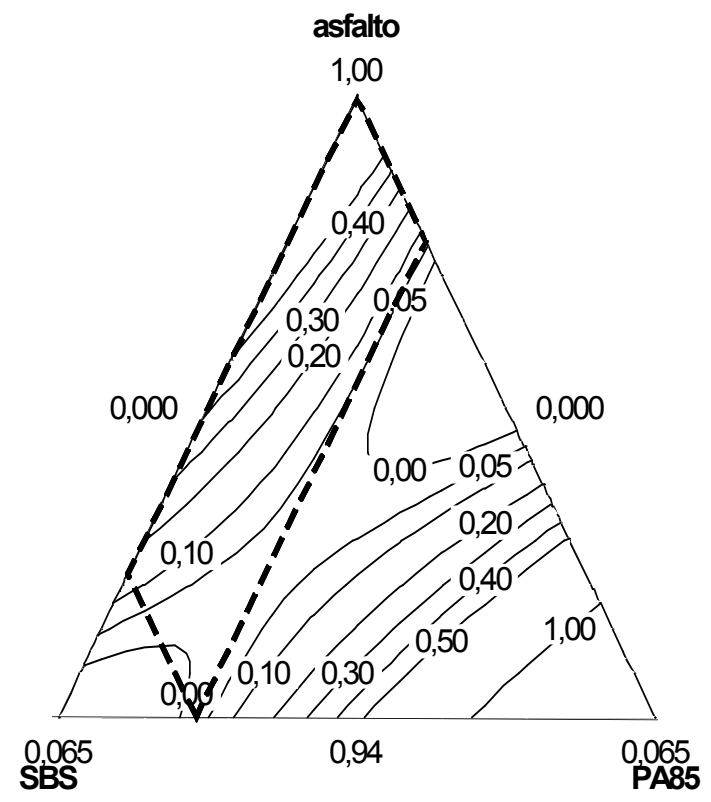

(a)

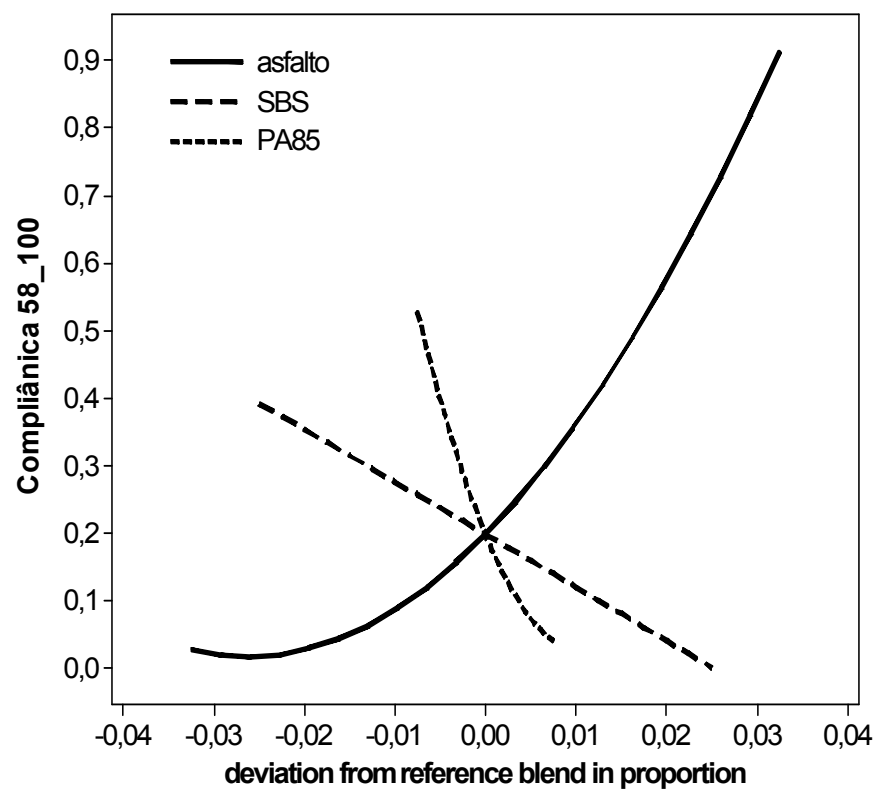

(b)

Figura 190 - Superfície de Resposta (a) e efeito de componentes (b) para a Compliância não recuperável $\left(\mathrm{kPa}^{-1}\right)$ à $58^{\circ} \mathrm{C}$ na tensão de $100 \mathrm{~Pa}$ das misturas com PA85.

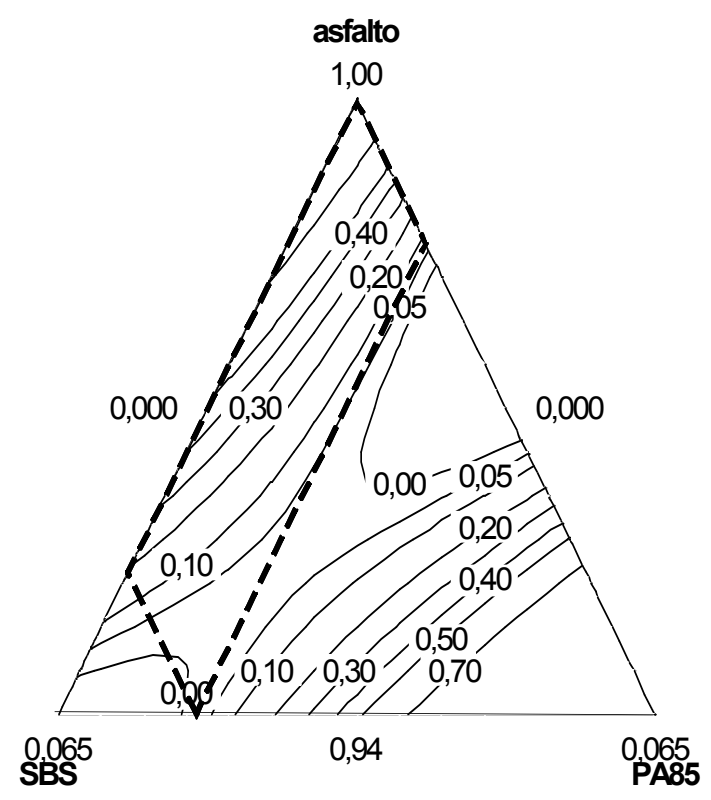

(a)

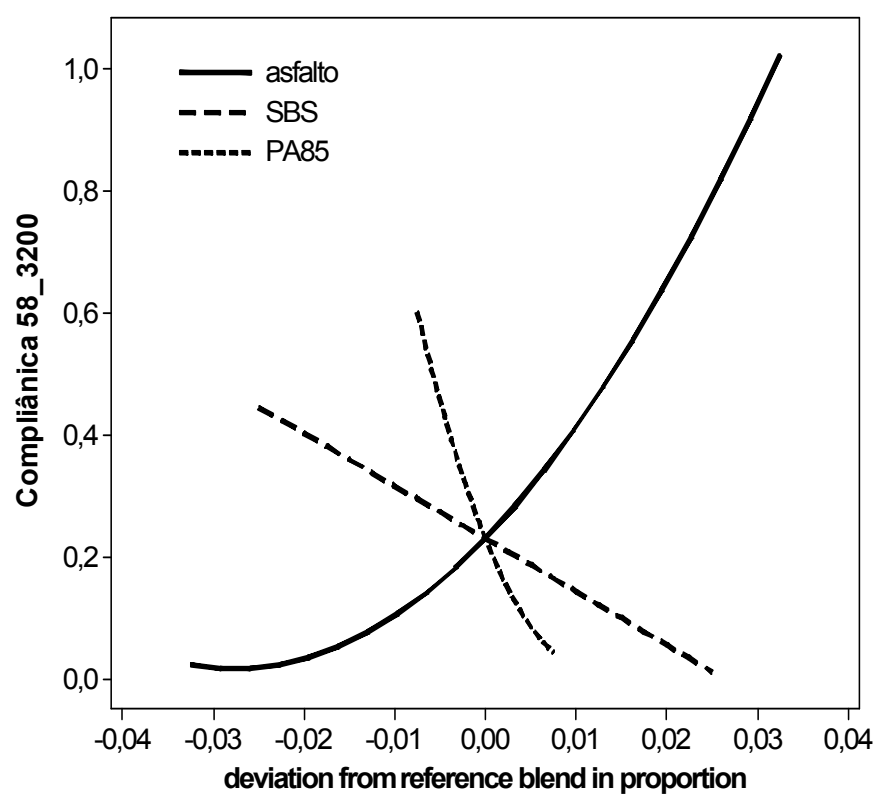

(b)

Figura 191 - Superfície de Resposta (a) e efeito de componentes (b) para a Compliância não recuperável $\left(\mathrm{kPa}^{-1}\right)$ à $58^{\circ} \mathrm{C}$ na tensão de $3200 \mathrm{~Pa}$ das misturas com PA85. 


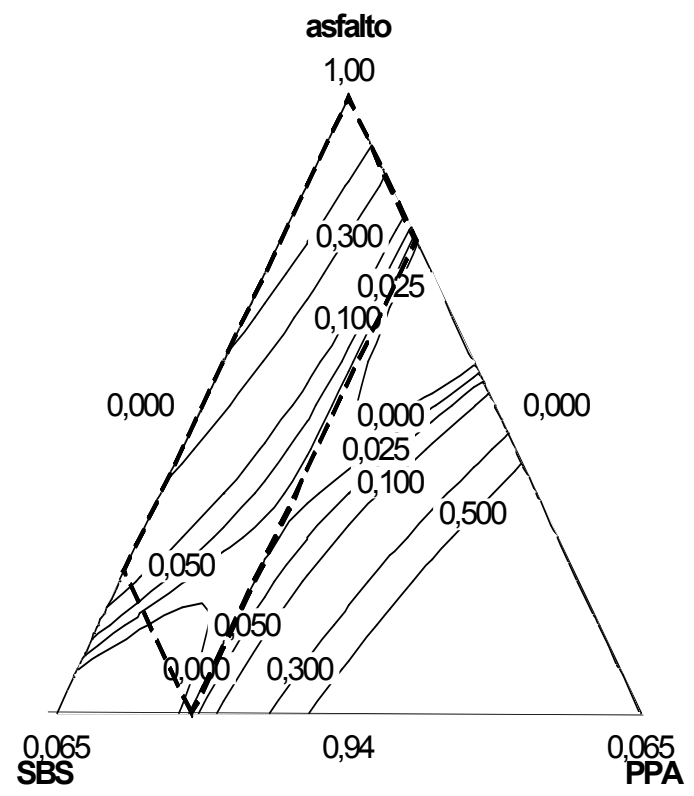

(a)

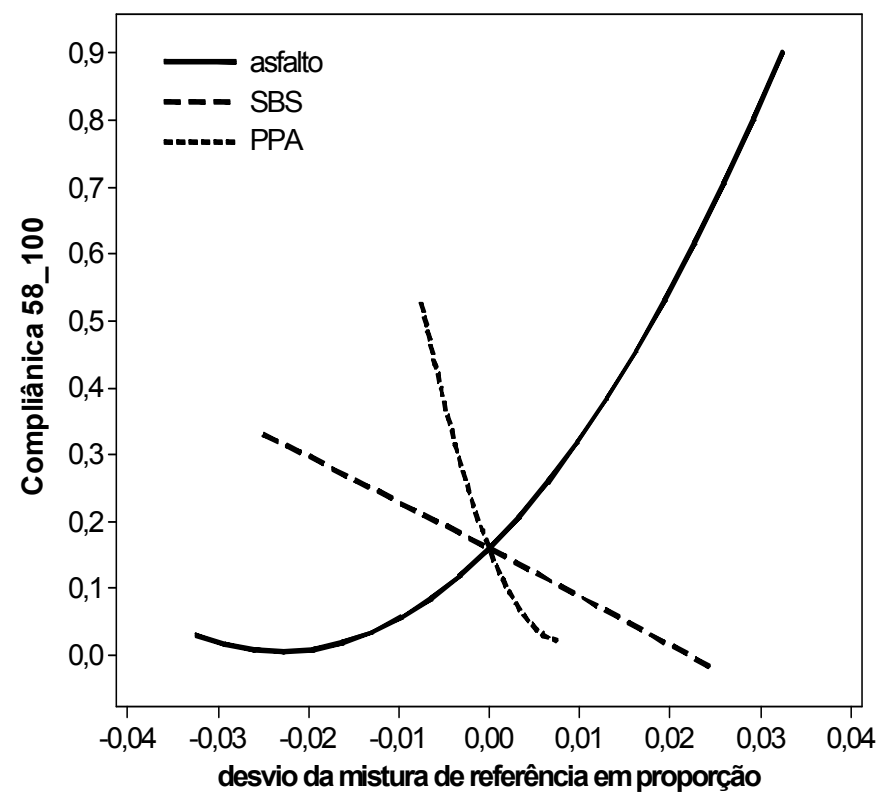

(b)

Figura 192 - Superfície de Resposta (a) e efeito de componentes (b) para a Compliância não recuperável $\left(\mathrm{kPa}^{-1}\right)$ à $58^{\circ} \mathrm{C}$ na tensão de $100 \mathrm{PA}$ das misturas com PPA.

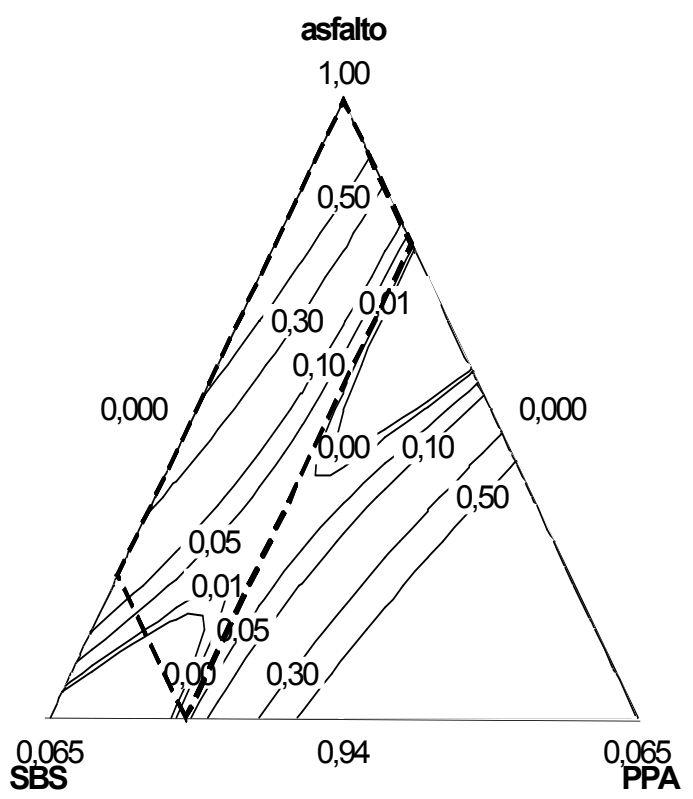

(a)

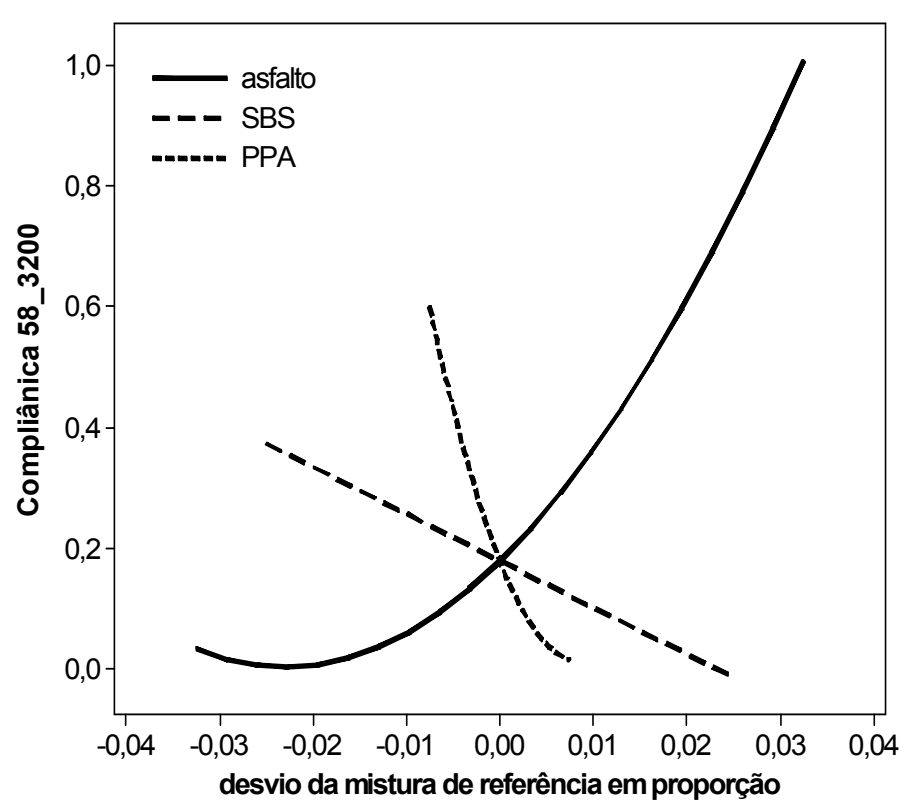

(b)

Figura 193 - Superfície de Resposta (a) e efeito de componentes (b) para a Compliância não recuperável $\left(\mathrm{kPa}^{-1}\right)$ à $58^{\circ} \mathrm{C}$ na tensão de $3200 \mathrm{PA}$ das misturas com PPA. 


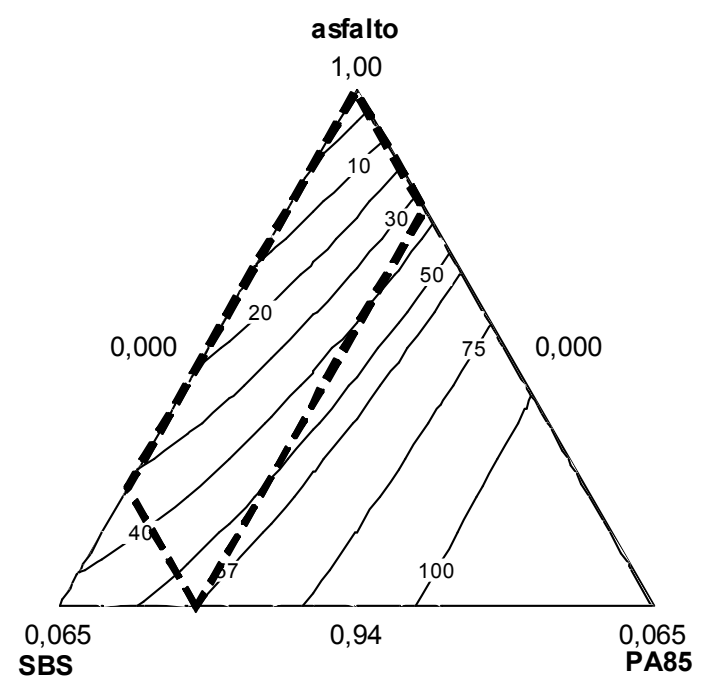

(a)

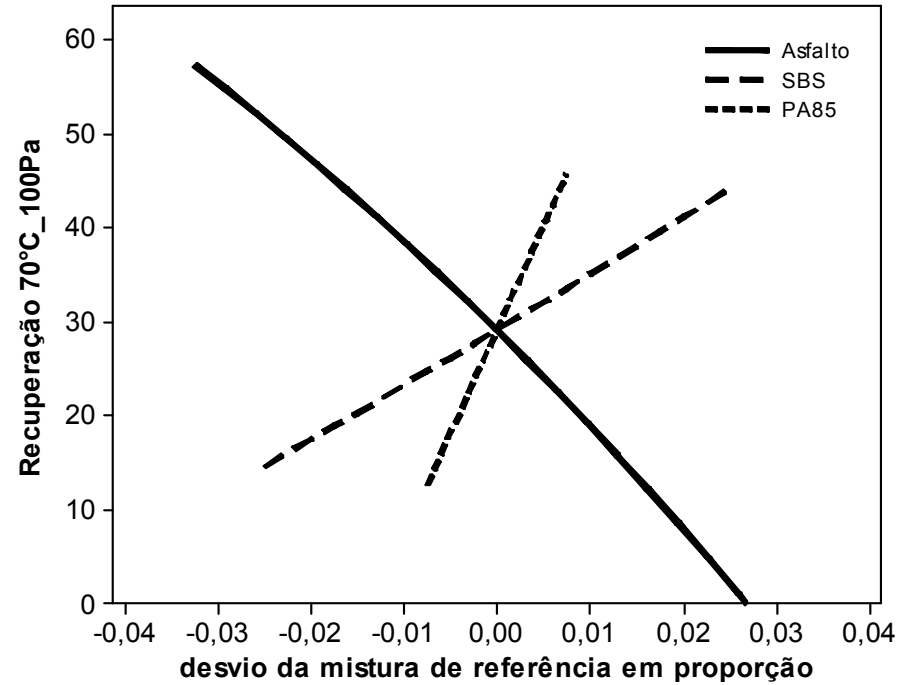

(b)

Figura 194 - Superfície de Resposta (a) e efeito de componentes (b) para a Recuperação (\%) à $70^{\circ} \mathrm{C}$ na tensão de 100PA das misturas com PA85.

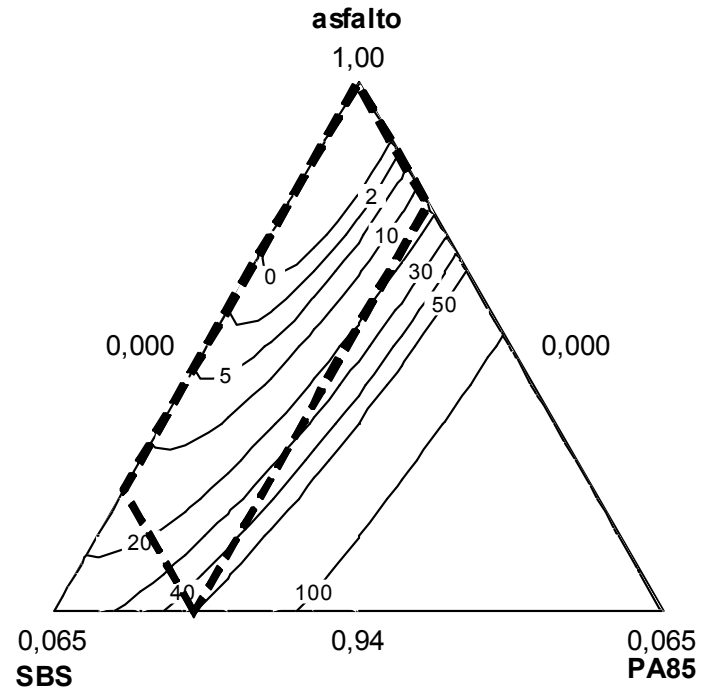

(a)

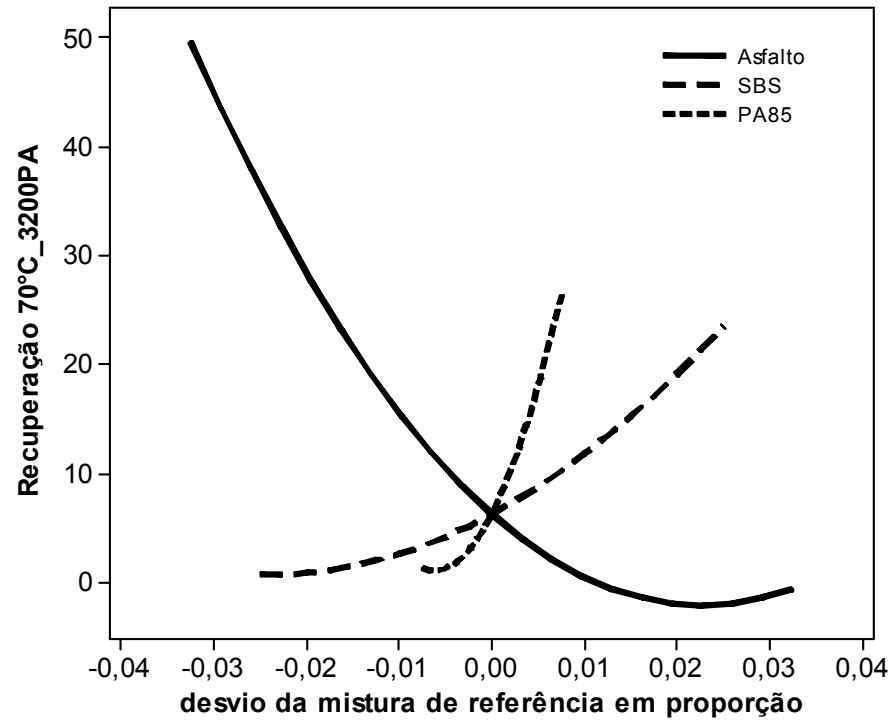

(b)

Figura 195 - Superfície de Resposta (a) e efeito de componentes (b) para a Recuperação (\%) à $70^{\circ} \mathrm{C}$ na tensão de 3200PA das misturas com PA85. 


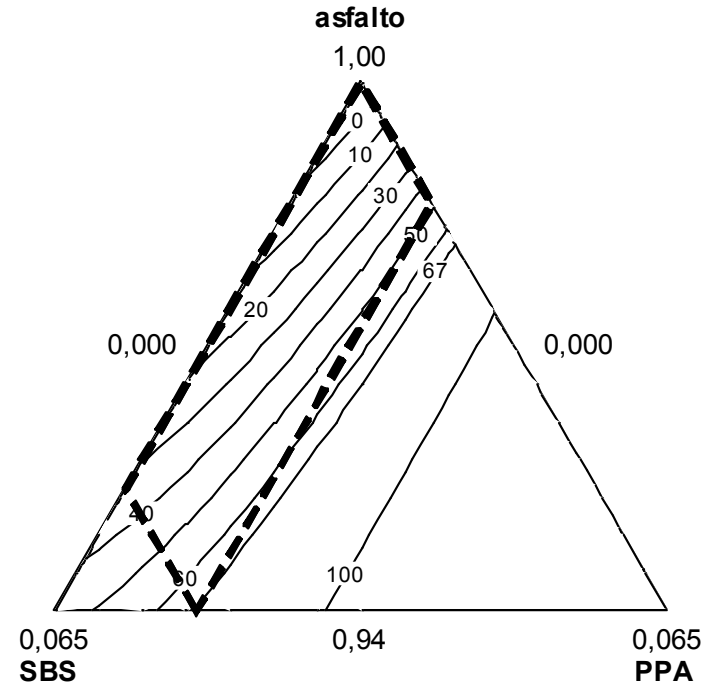

(a)

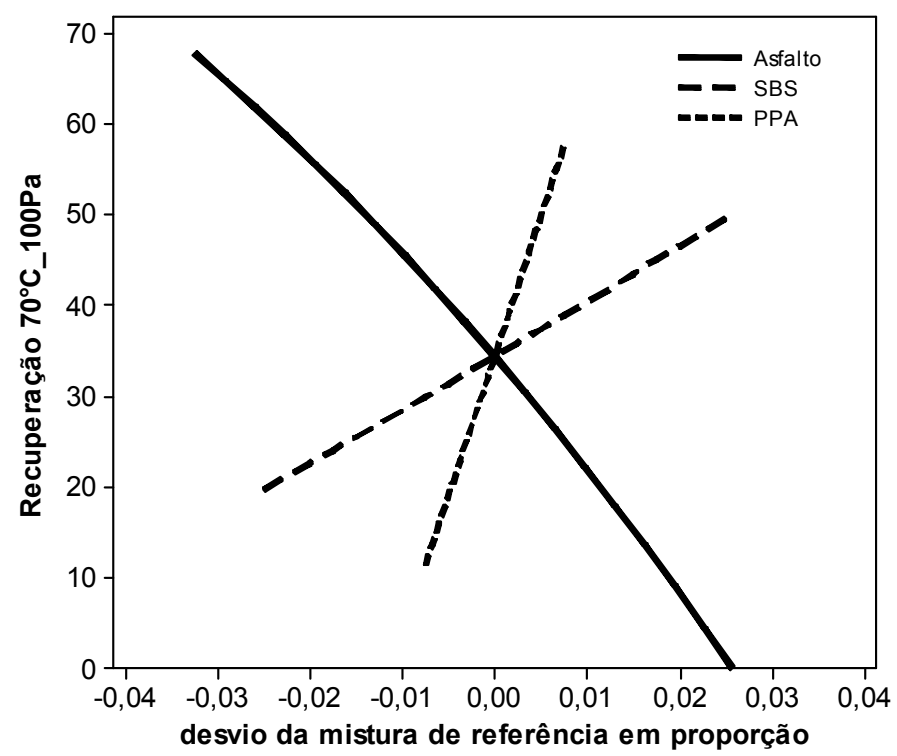

(b)

Figura 196 - Superfície de Resposta (a) e efeito de componentes (b) para a Recuperação (\%) à $70^{\circ} \mathrm{C}$ na tensão de 100PA das misturas com PPA.

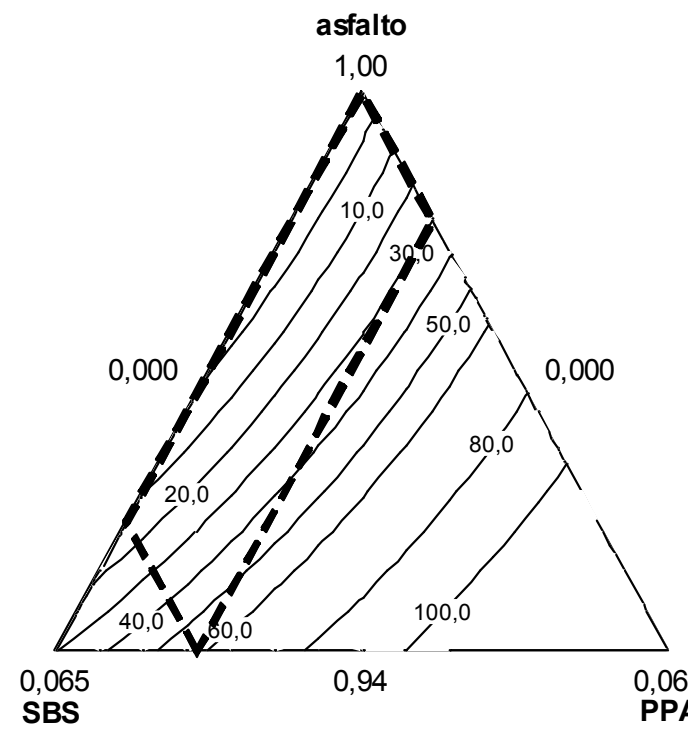

(a)

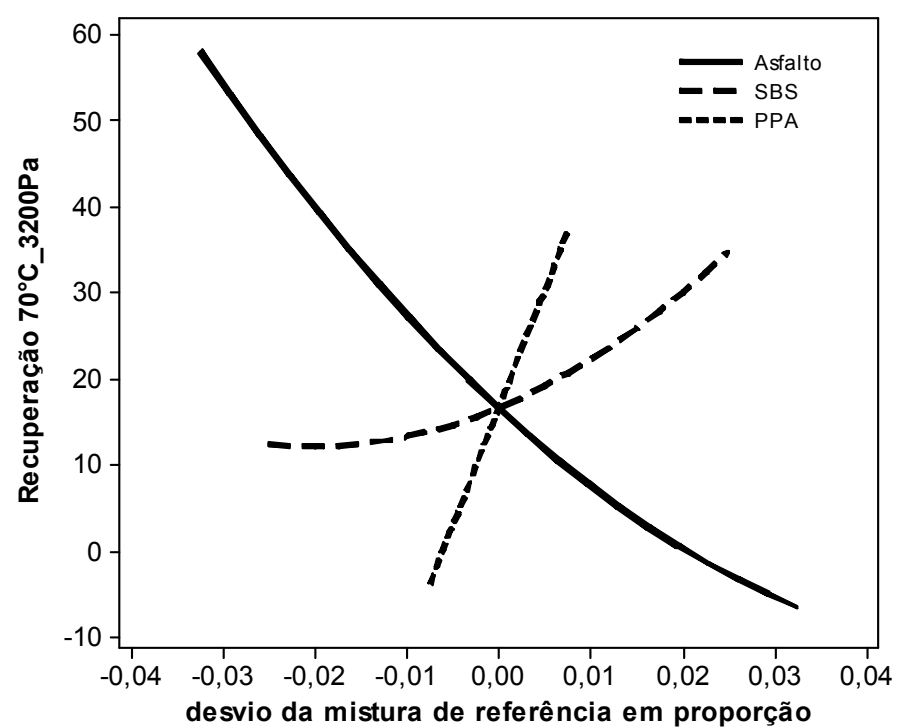

(b)

Figura 197 - Superfície de Resposta (a) e efeito de componentes (b) para a Recuperação (\%) à $70^{\circ} \mathrm{C}$ na tensão de 3200PA das misturas com PPA. 


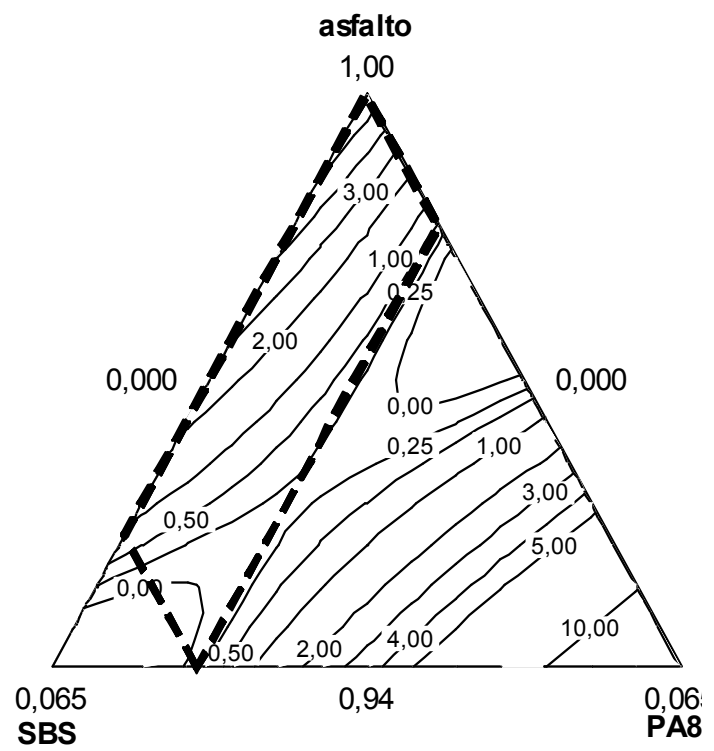

(a)

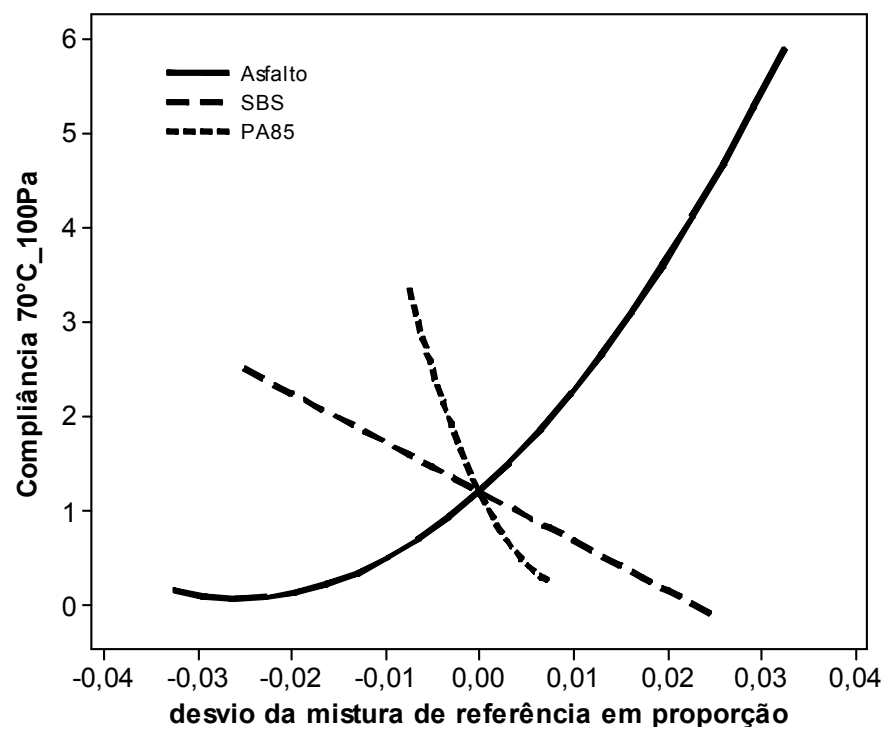

(b)

Figura 198 - Superfície de Resposta (a) e efeito de componentes (b) para a Compliância não recuperável $\left(\mathrm{kPa}^{-1}\right)$ à $70^{\circ} \mathrm{C}$ na tensão de 100PA das misturas com PA85.

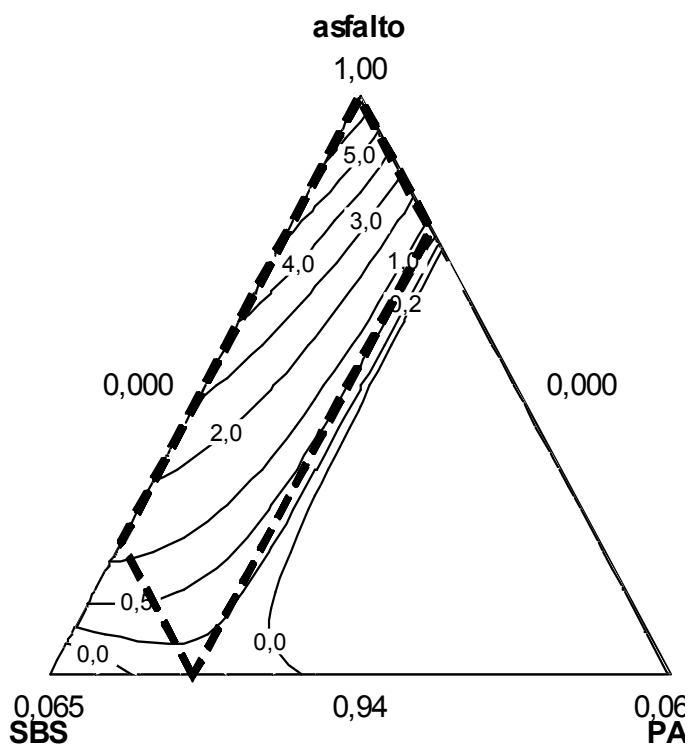

(a)

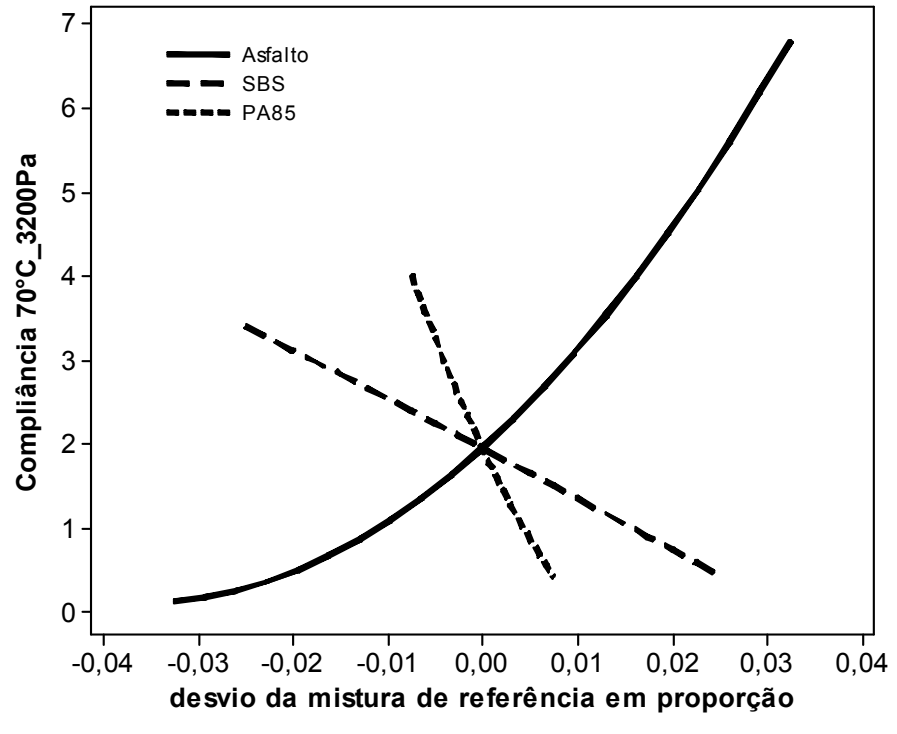

(b)

Figura 199 - Superfície de Resposta (a) e efeito de componentes (b) para a Compliância não recuperável $\left(\mathrm{kPa}^{-1}\right)$ à $70^{\circ} \mathrm{C}$ na tensão de 3200PA das misturas com PA85. 


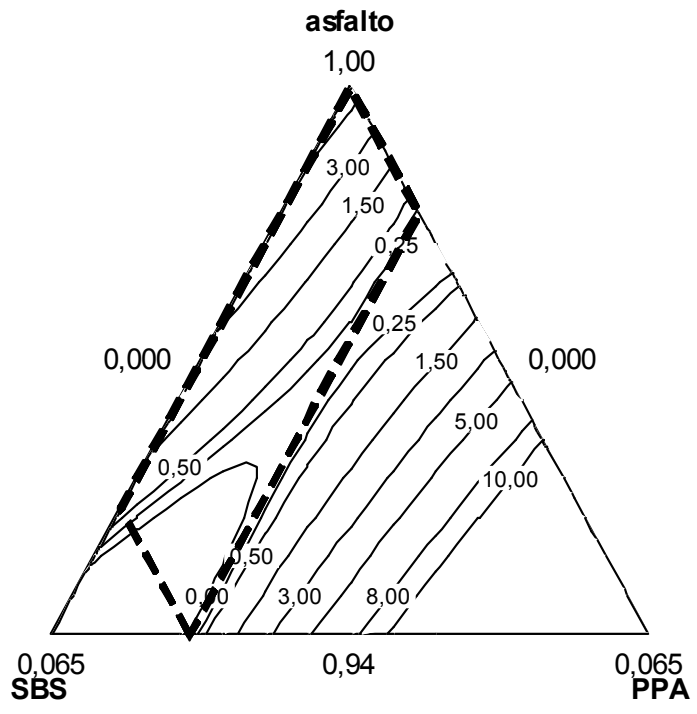

(a)

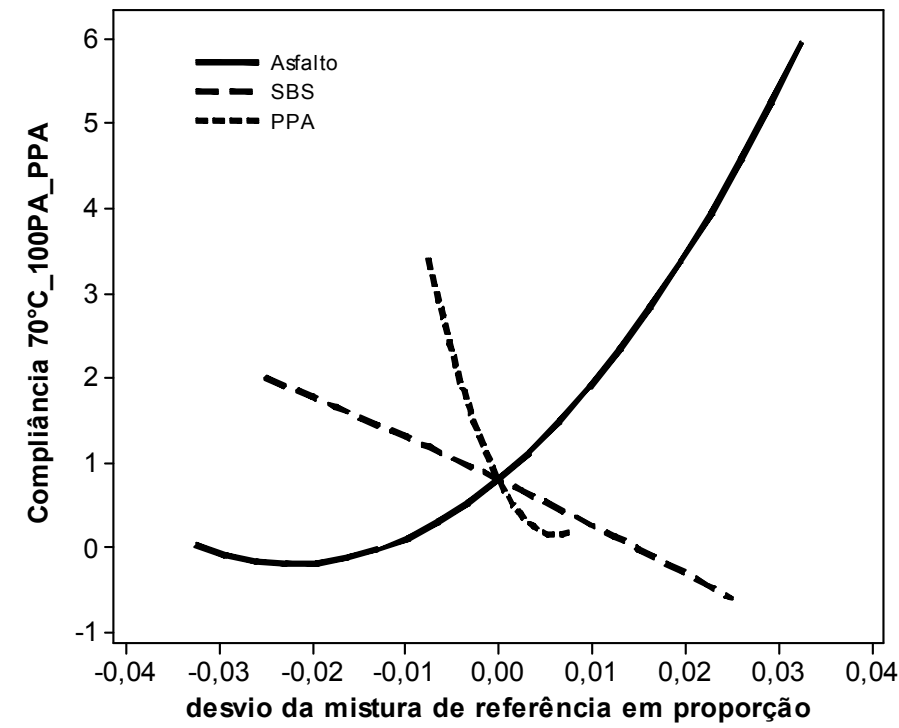

(b)

Figura 200 - Superfície de Resposta (a) e efeito de componentes (b) para a Compliância não recuperável $\left(\mathrm{kPa}^{-1}\right)$ à $70^{\circ} \mathrm{C}$ na tensão de 100PA das misturas com PPA.

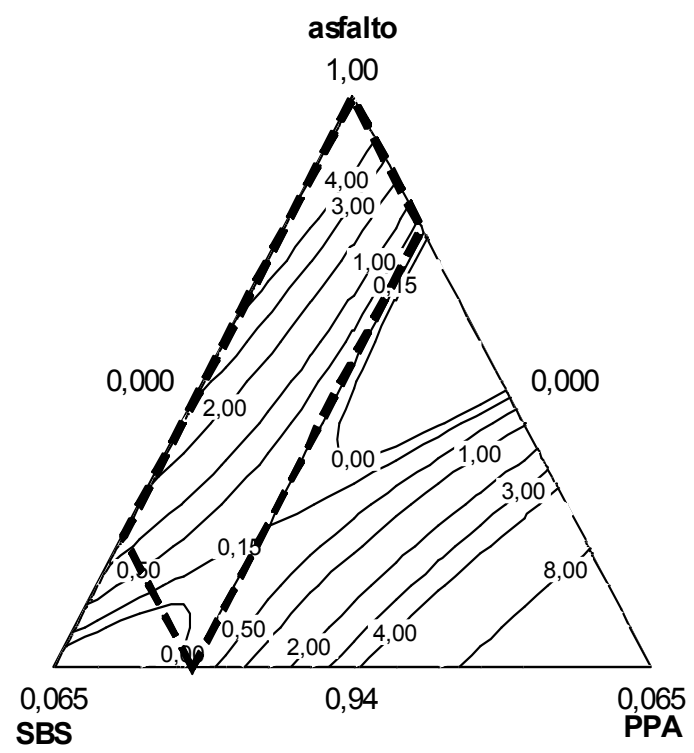

(a)

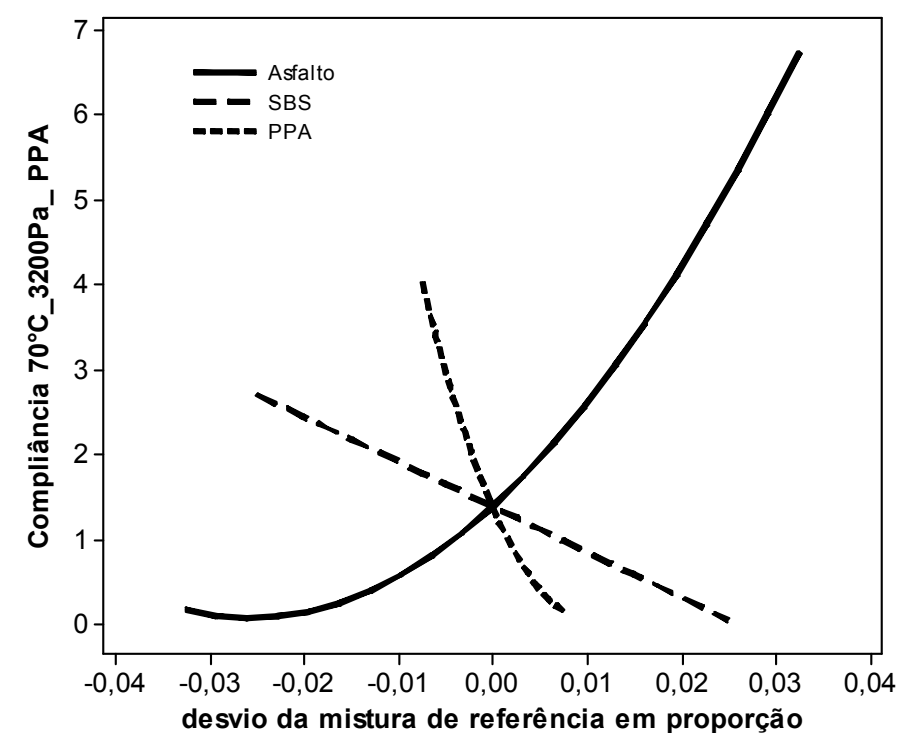

(b)

Figura 201 - Superfície de Resposta (a) e efeito de componentes (b) para a Compliância não recuperável $\left(\mathrm{kPa}^{-1}\right)$

à $70^{\circ} \mathrm{C}$ na tensão de 3200PA das misturas com PPA. 


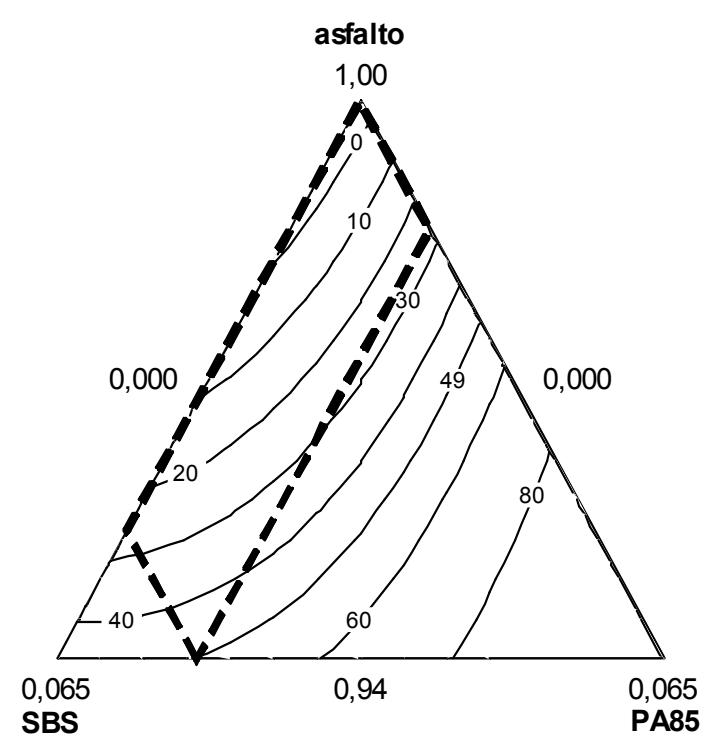

(a)

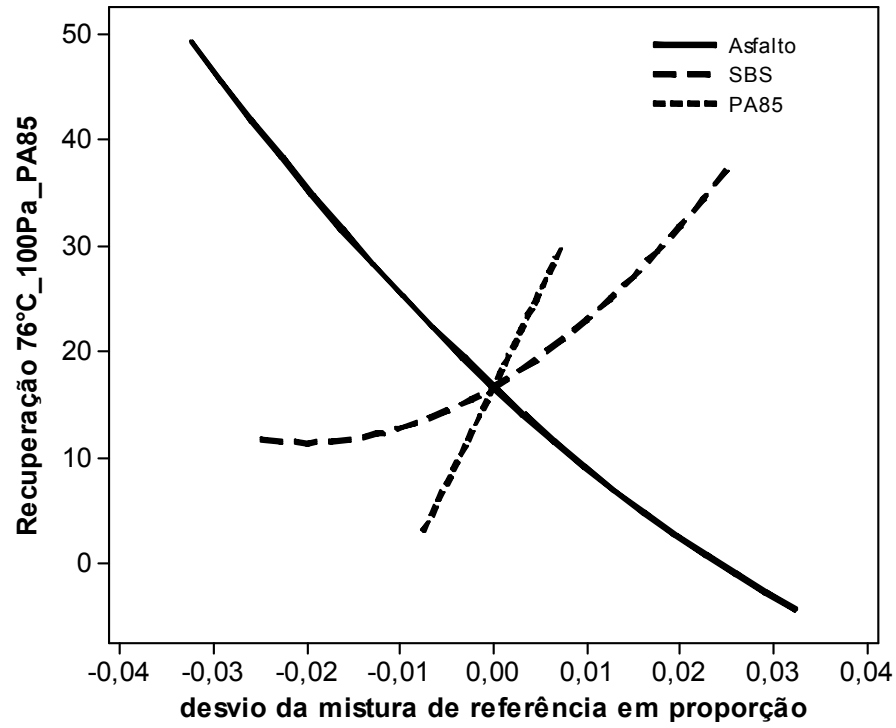

(b)

Figura 202 - Superfície de Resposta (a) e efeito de componentes (b) para a Recuperação (\%) à $76^{\circ} \mathrm{C}$ na tensão de 100PA das misturas com PA85.

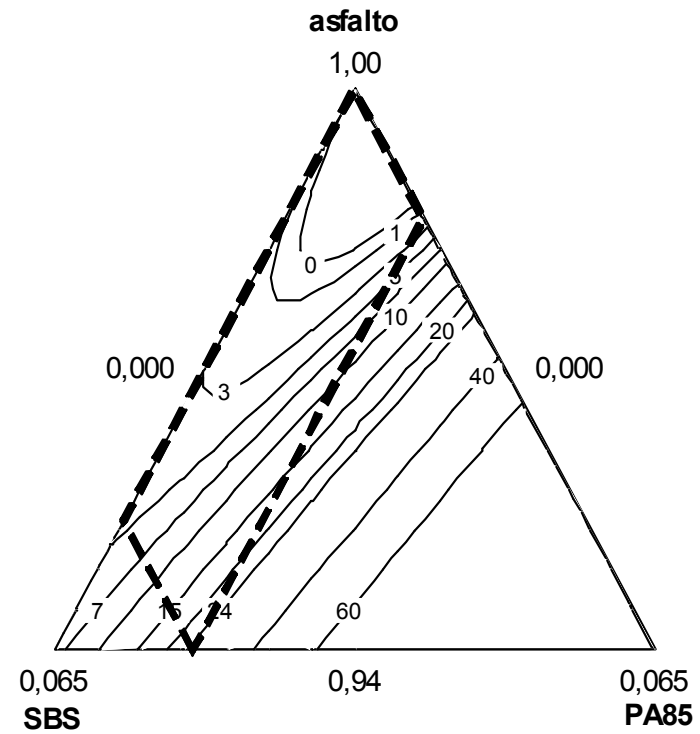

(a)

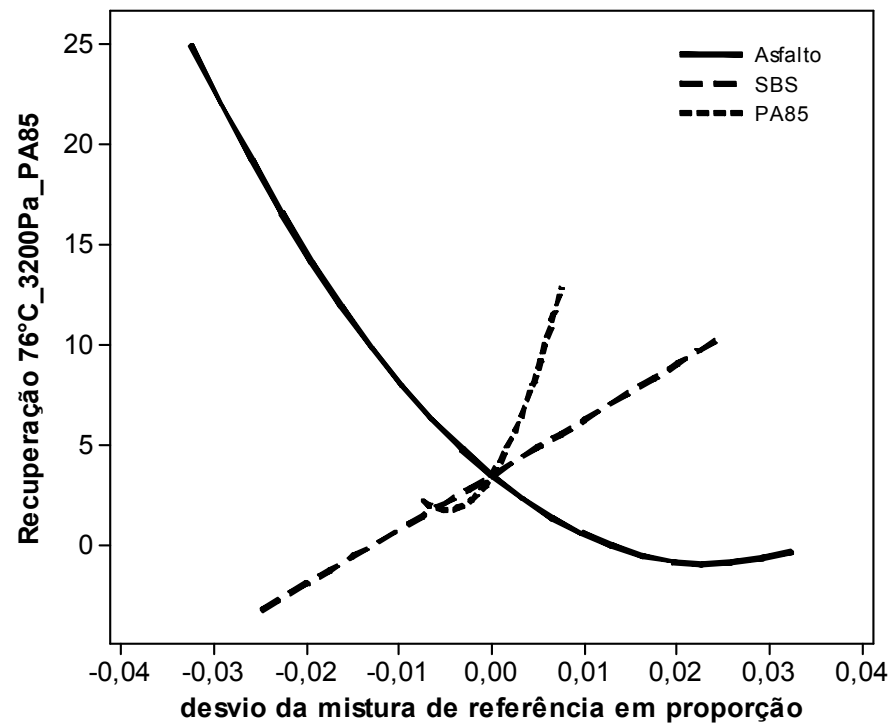

(b)

Figura 203 - Superfície de Resposta (a) e efeito de componentes (b) para a Recuperação (\%) à $76^{\circ} \mathrm{C}$ na tensão de 3200PA das misturas com PA85. 


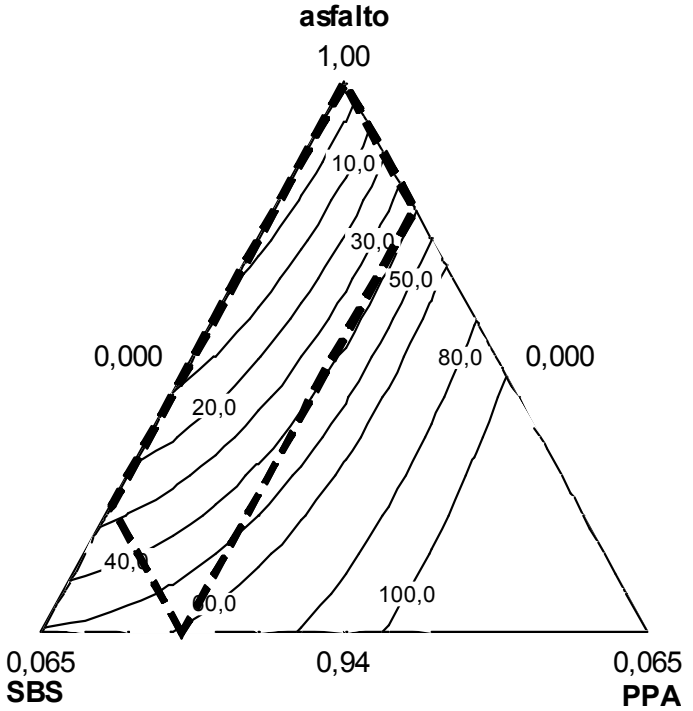

(a)

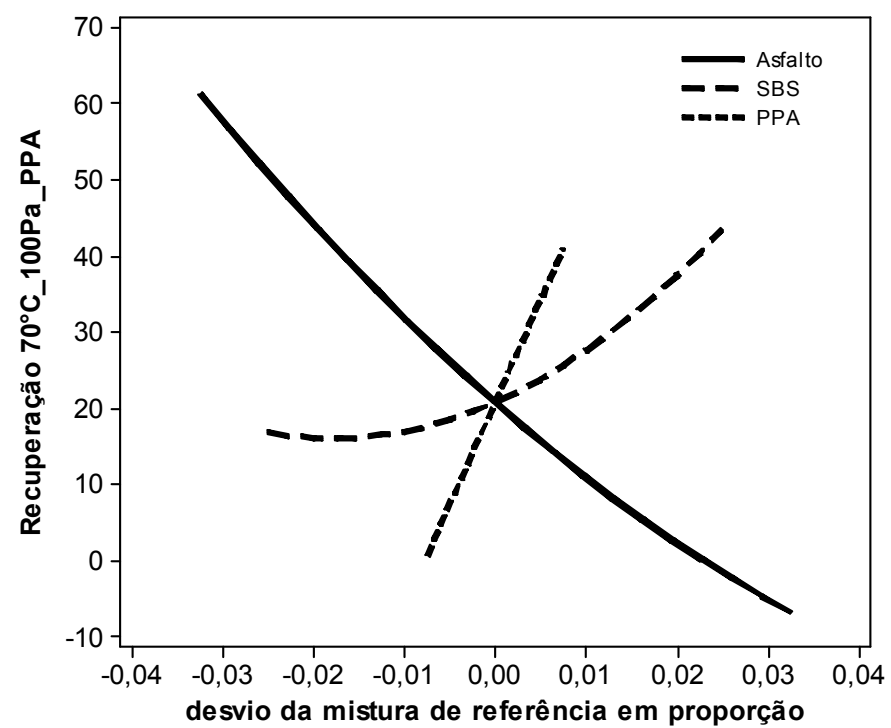

(b)

Figura 204 - Superfície de Resposta (a) e efeito de componentes (b) para a Recuperação (\%) à $76^{\circ} \mathrm{C}$ na tensão de 100PA das misturas com PPA.

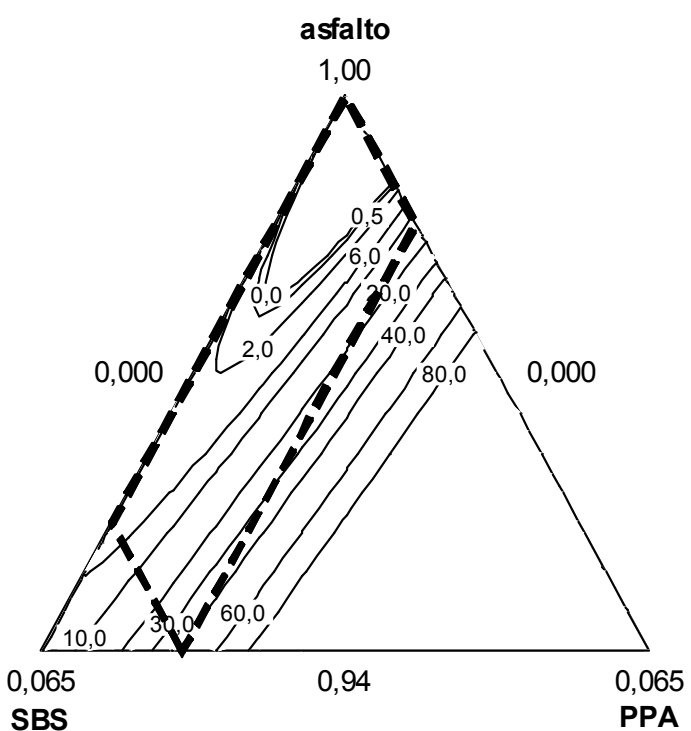

(a)

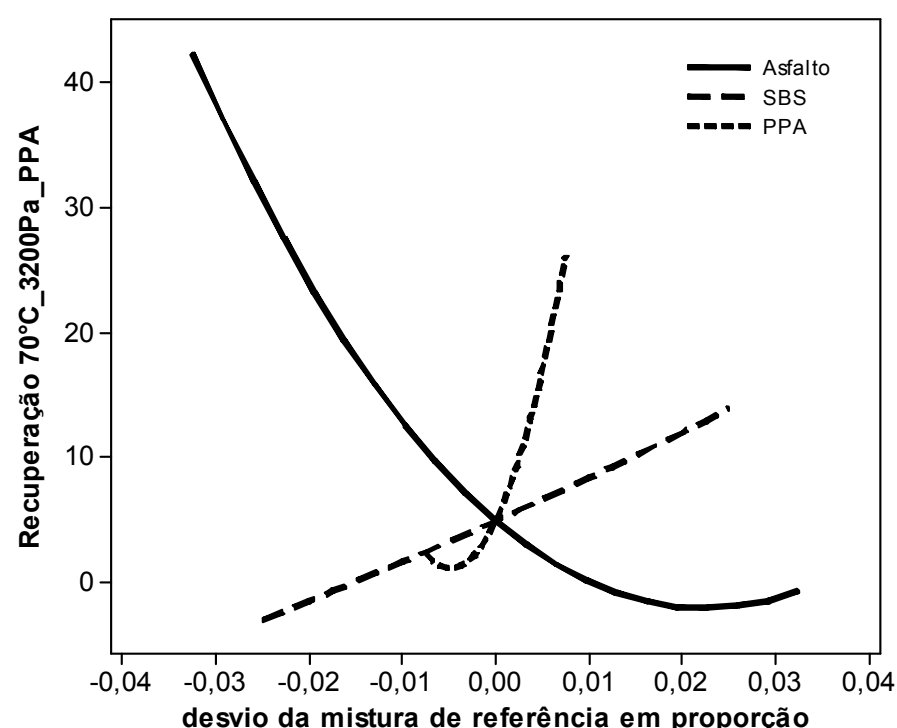

(b)

Figura 205 - Superfície de Resposta (a) e efeito de componentes (b) para a Recuperação (\%) à $76^{\circ} \mathrm{C}$ na tensão de 3200PA das misturas com PPA. 


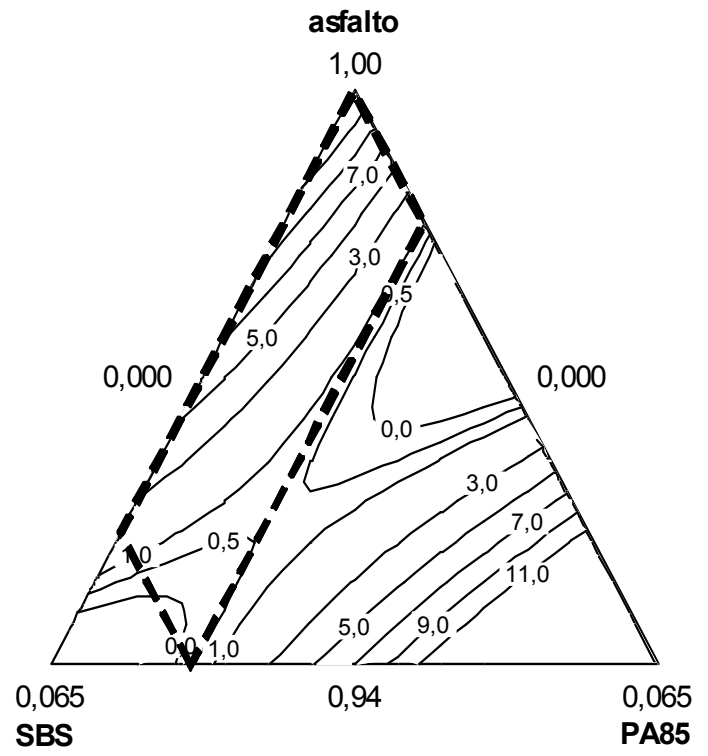

(a)

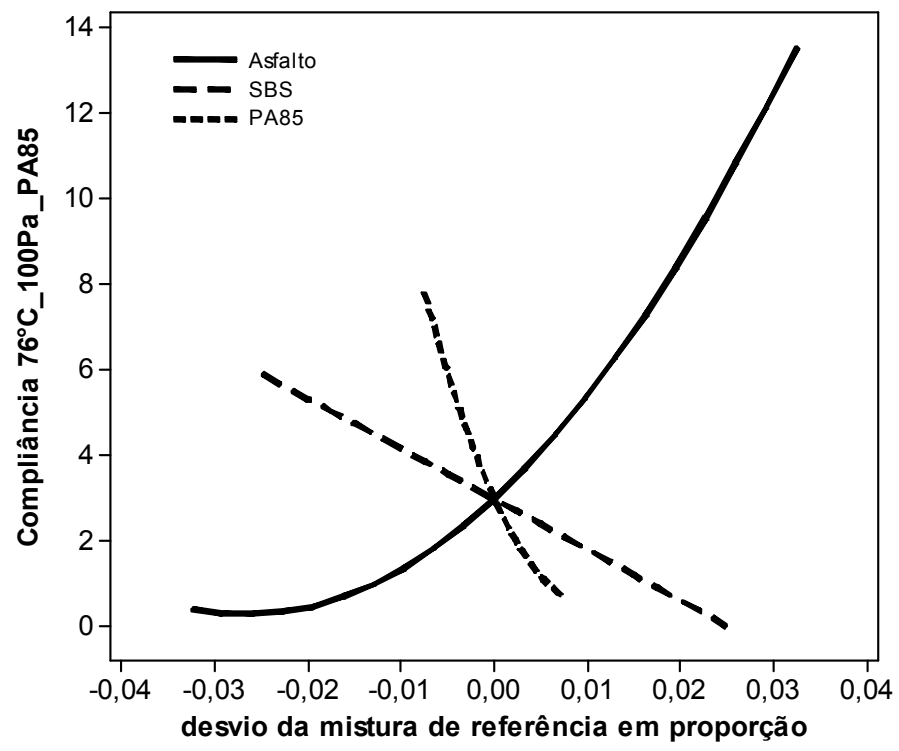

(b)

Figura 206 - Superfície de Resposta (a) e efeito de componentes (b) para a Compliância não recuperável $\left(\mathrm{KPa}^{-1}\right)$ à $76^{\circ} \mathrm{C}$ na tensão de 100PA das misturas com PA85.

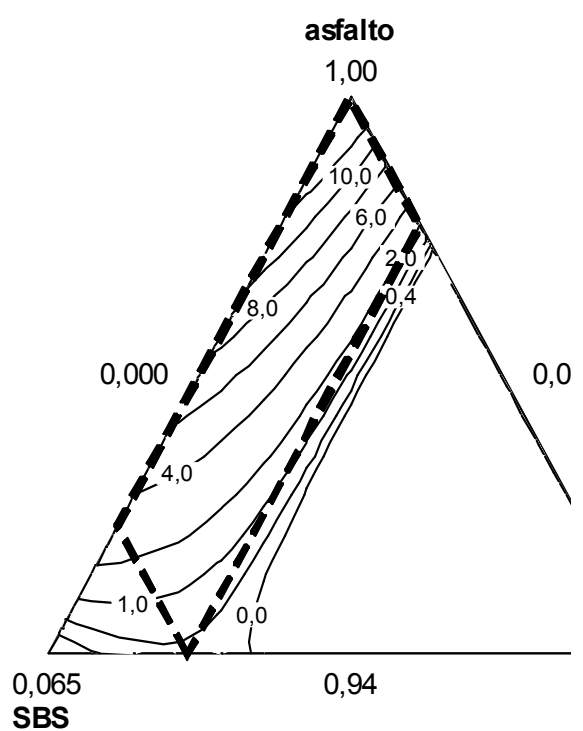

(a)

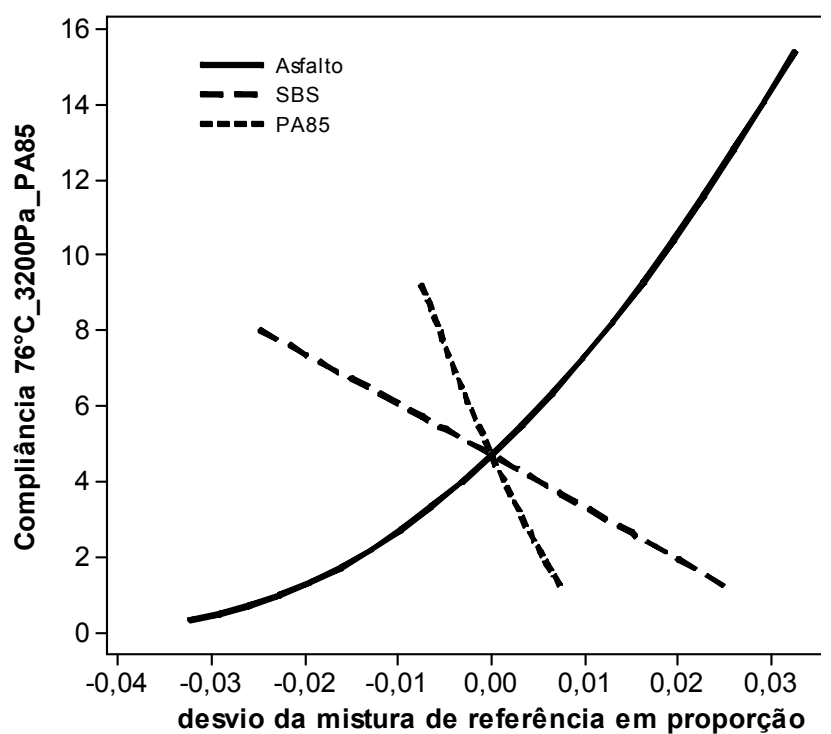

(b)

Figura 207 - Superfície de Resposta (a) e efeito de componentes (b) para a Compliância não recuperável $\left(\mathrm{kPa}^{-1}\right)$ à $76^{\circ} \mathrm{C}$ na tensão de 3200PA das misturas com PA85. 


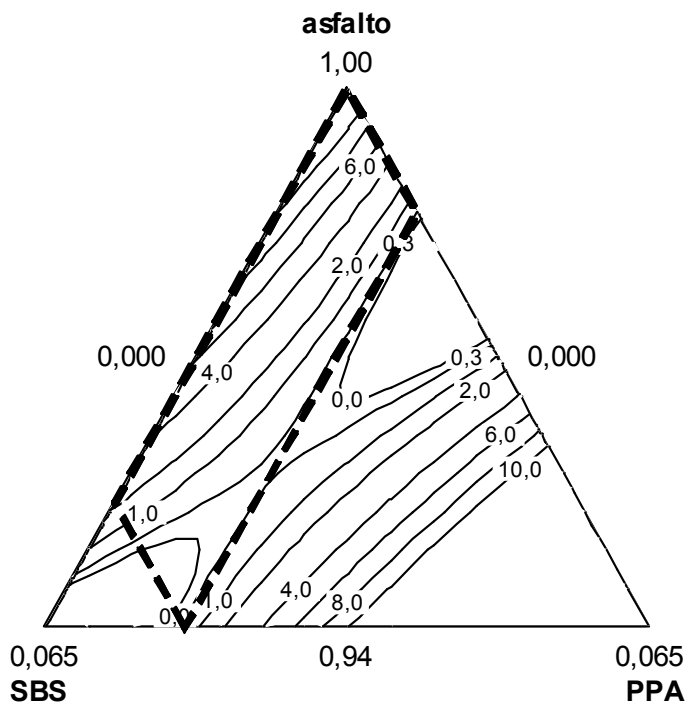

(a)

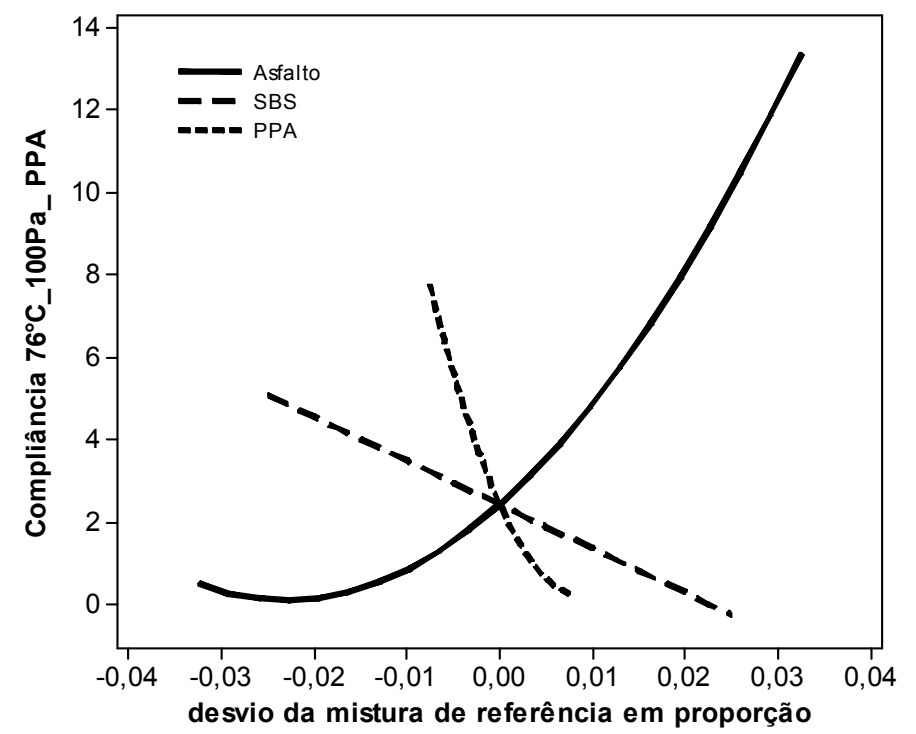

(b)

Figura 208 - Superfície de Resposta (a) e efeito de componentes (b) para a Compliância não recuperável $\left(\mathrm{kPa}^{-1}\right)$ à $76^{\circ} \mathrm{C}$ na tensão de $100 \mathrm{PA}$ das misturas com PPA.

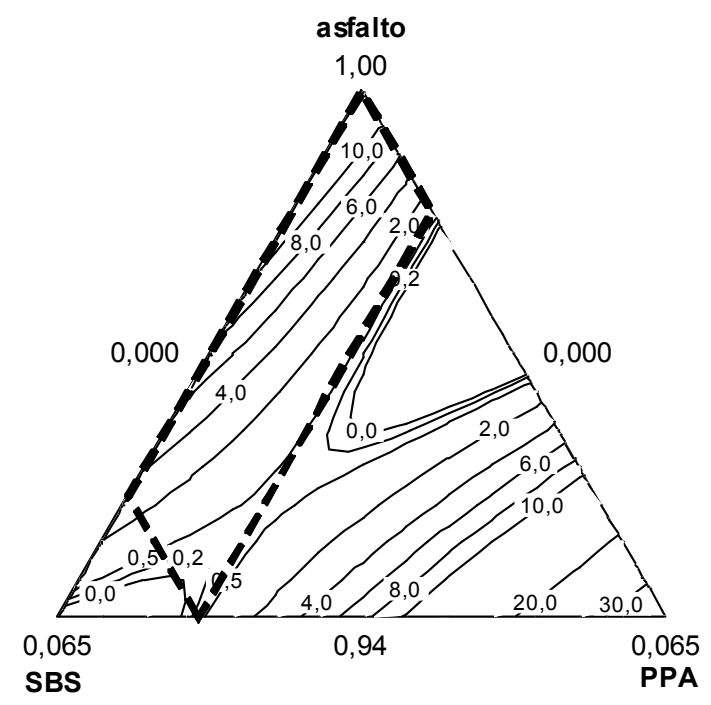

(a)

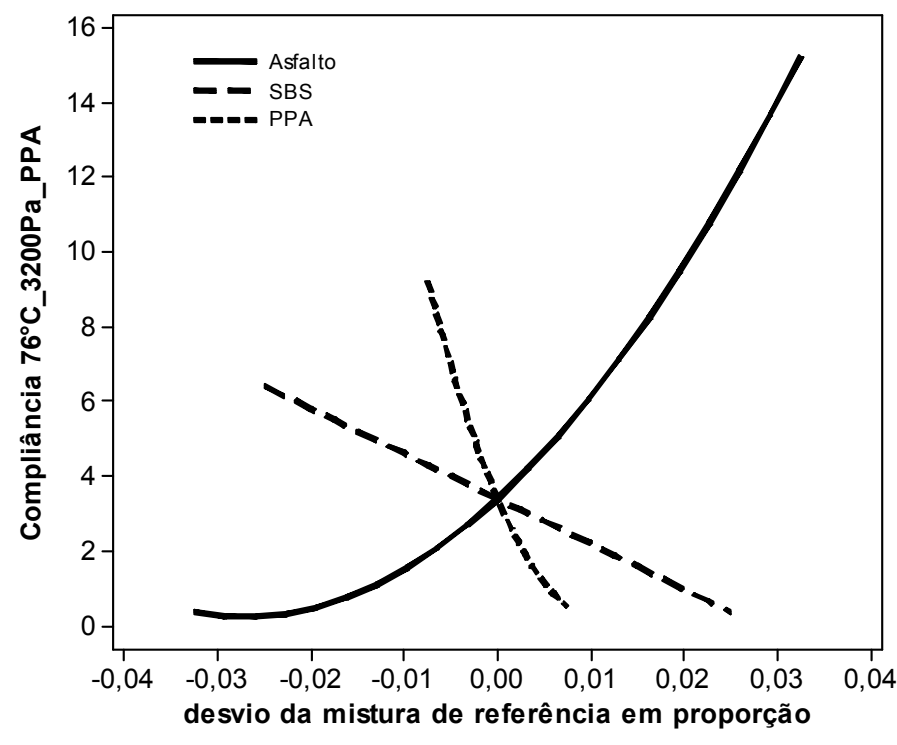

(b)

Figura 209 - Superfície de Resposta (a) e efeito de componentes (b) para a Compliância não recuperável $\left(\mathrm{kPa}^{-1}\right)$ à $76^{\circ} \mathrm{C}$ na tensão de $3200 \mathrm{PA}$ das misturas com PPA. 


\section{Ligante Asfáltico Lubnor}

\section{Viscosidade $143^{\circ} \mathrm{C}$}

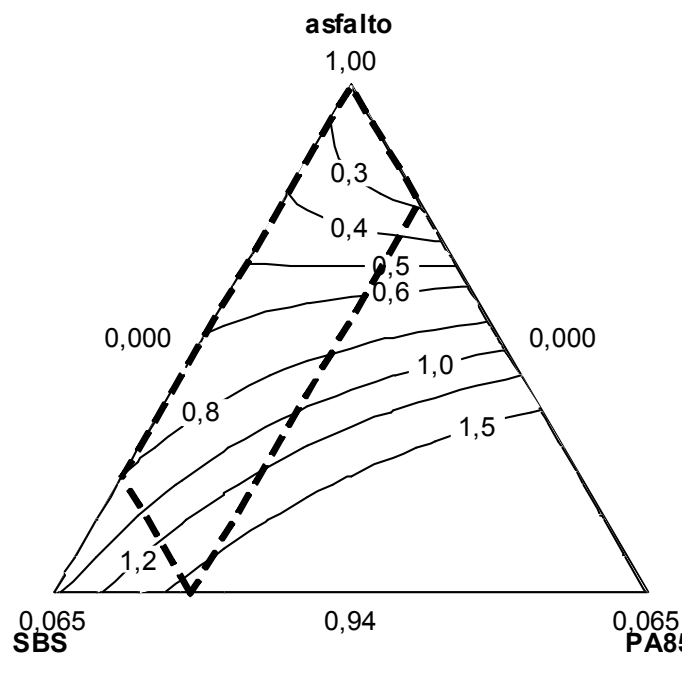

(a)

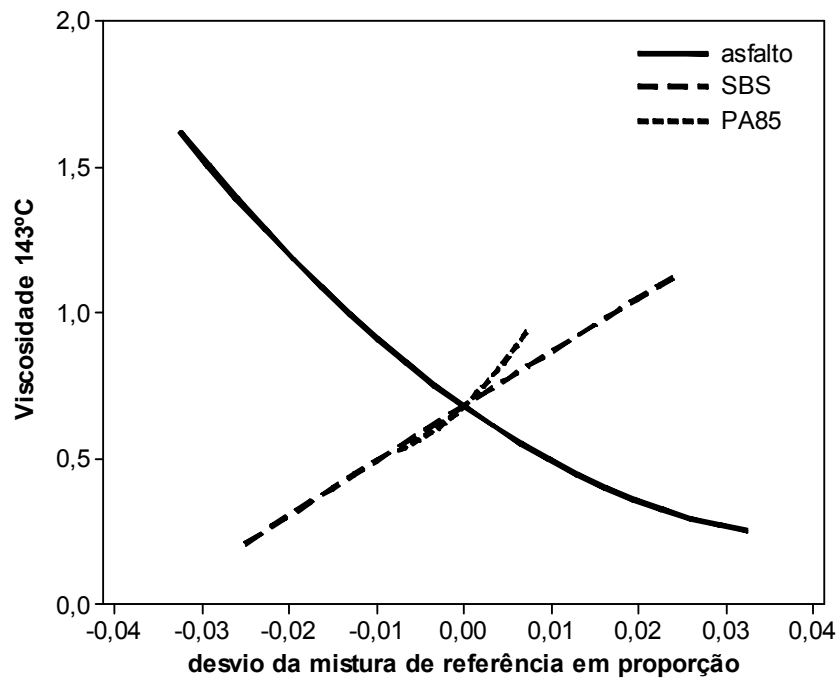

(b)

Figura 210 - Superfície de Resposta (a) e efeito de componentes (b) para a viscosidade à $143^{\circ} \mathrm{C}$ das misturas com PA85.

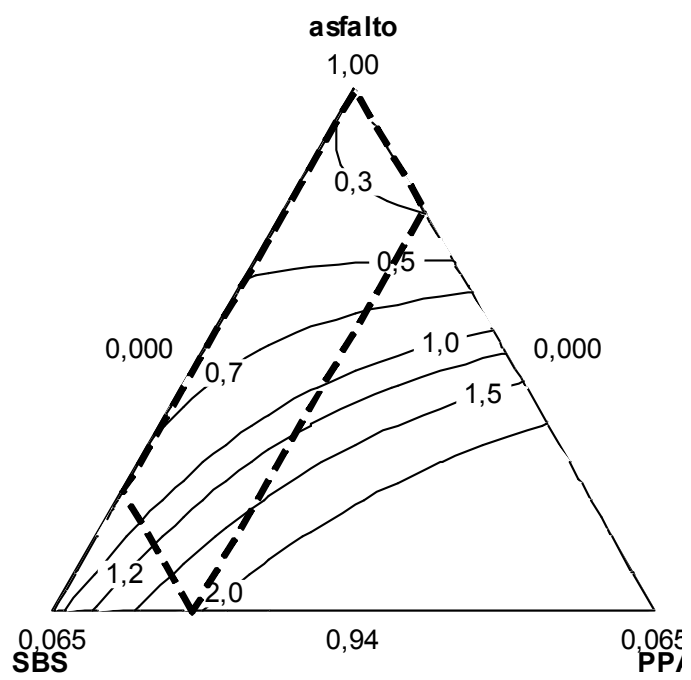

(a)

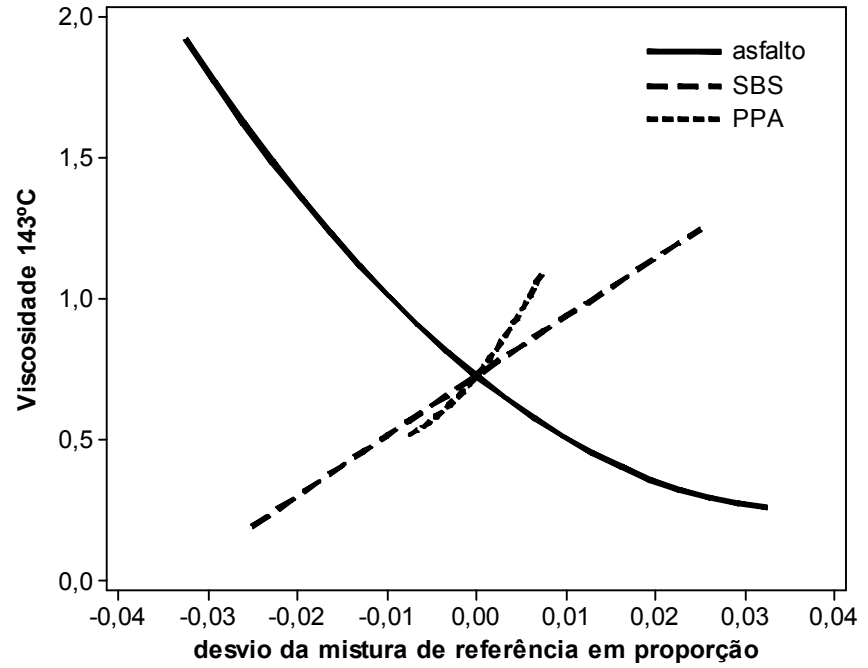

(b)

Figura 211 - Superfície de Resposta (a) e efeito de componentes (b) para a viscosidade à $143^{\circ} \mathrm{C}$ das misturas com PPA. 
Viscosidade $143^{\circ} \mathrm{C}$ - RTFOT

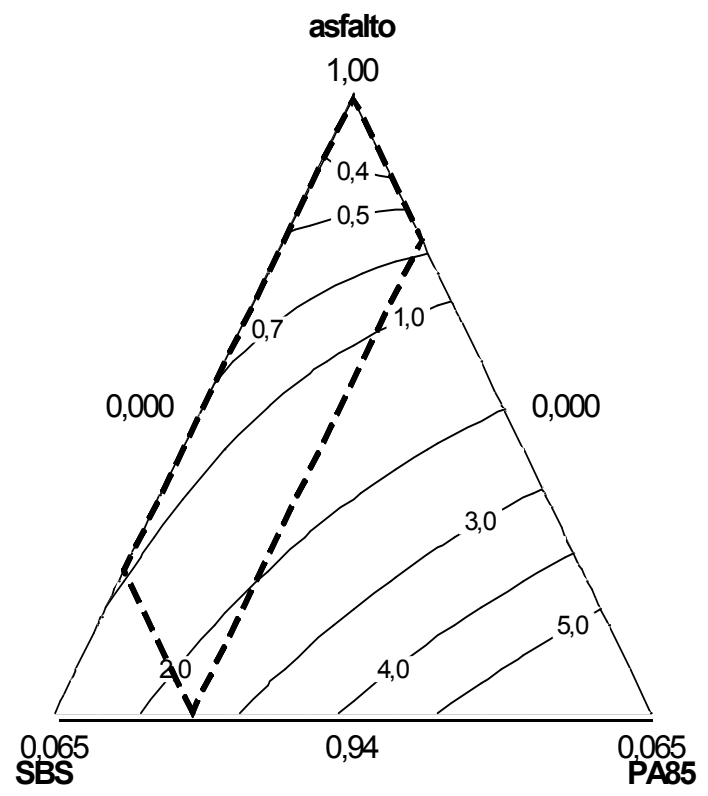

(a)

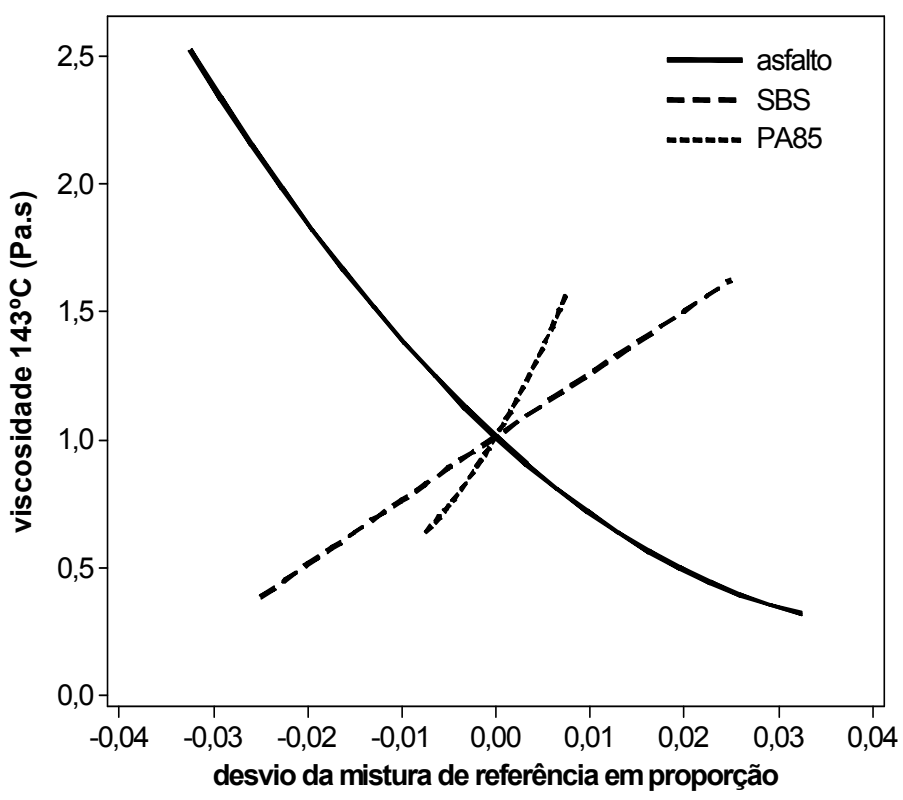

(b)

Figura 212 - Superfície de Resposta (a) e efeito de componentes (b) para a viscosidade à $143^{\circ} \mathrm{C}$ das misturas com PA85.

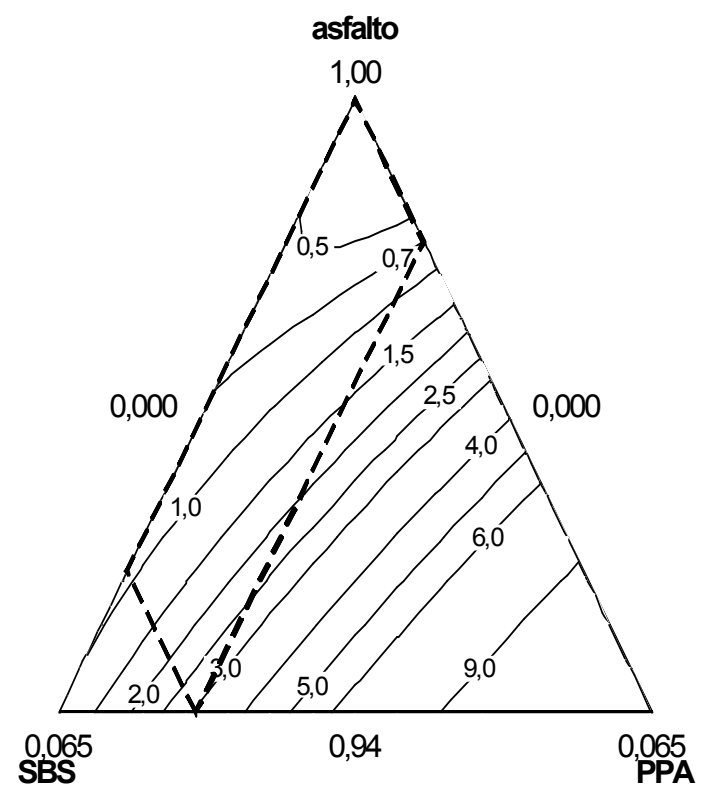

(a)

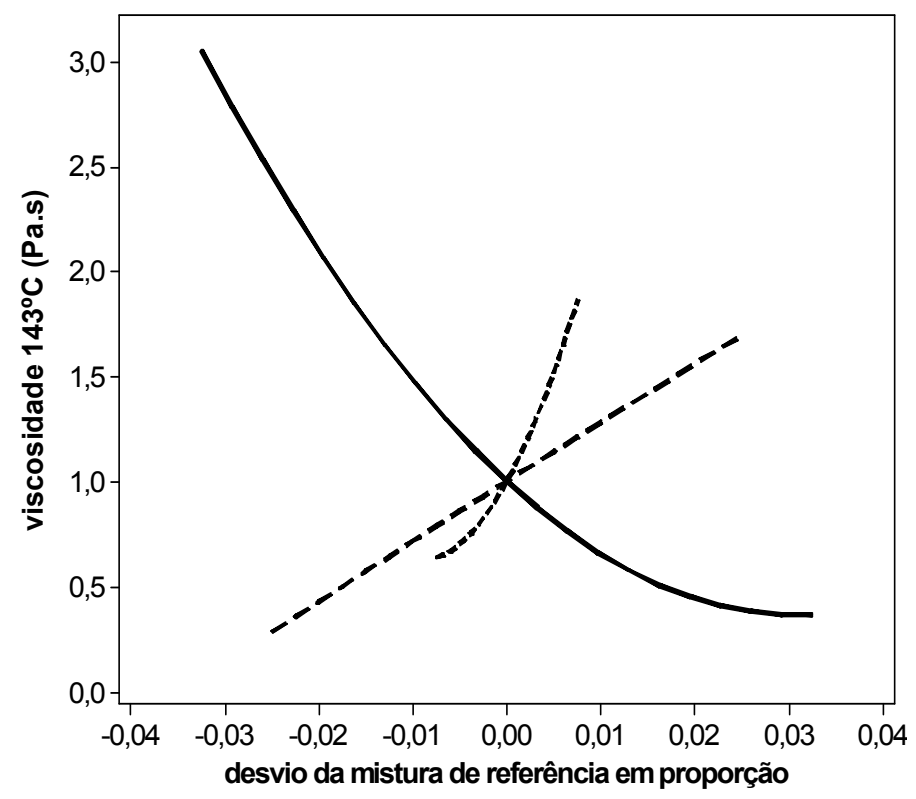

(b)

Figura 213 - Superfície de Resposta (a) e efeito de componentes (b) para a viscosidade à $143^{\circ} \mathrm{C}$ das misturas com PPA. 


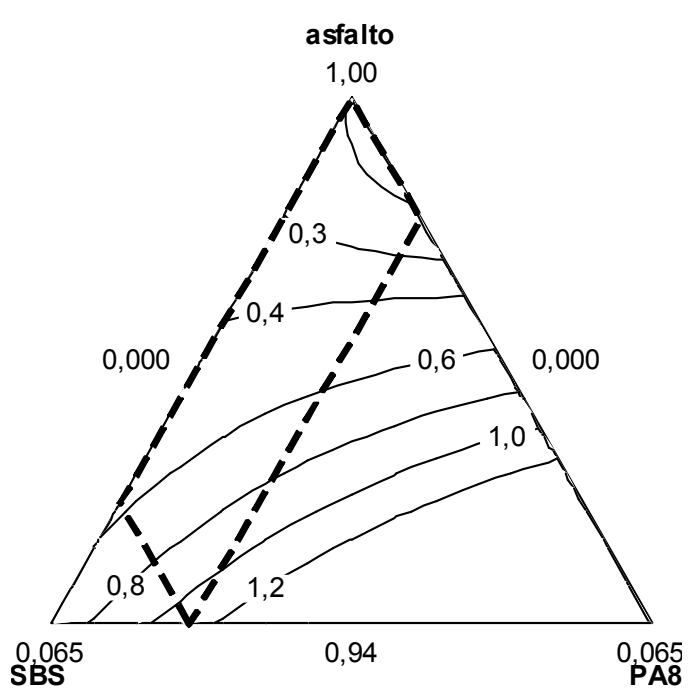

(a)

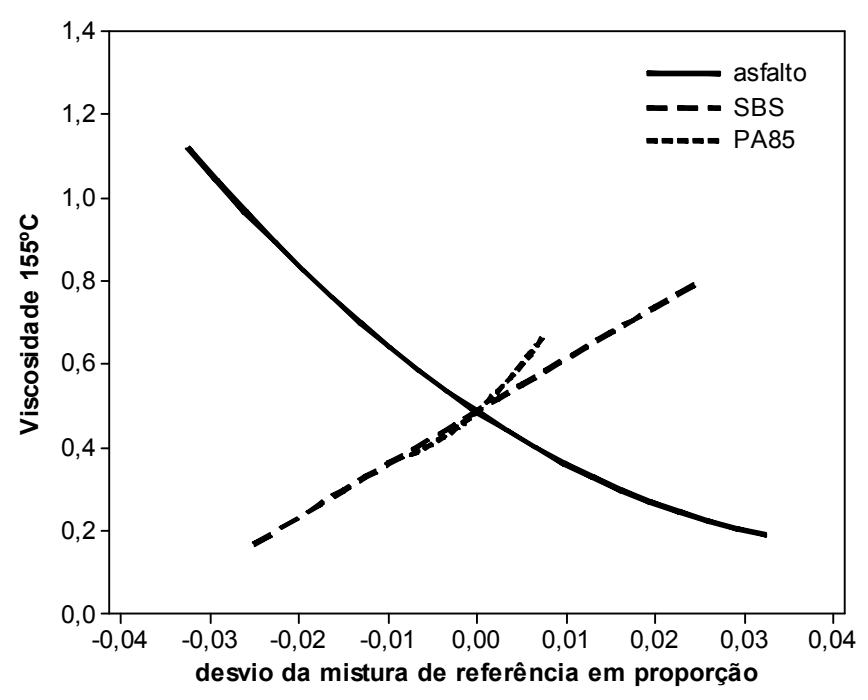

(b)

Figura 214 - Superfície de Resposta (a) e efeito de componentes (b) para a viscosidade à $155^{\circ} \mathrm{C}$ das misturas com PA85.

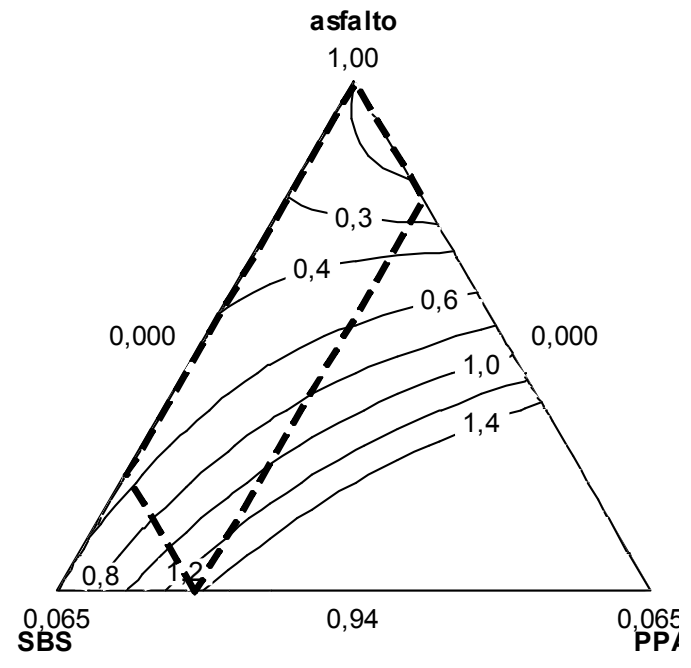

(a)

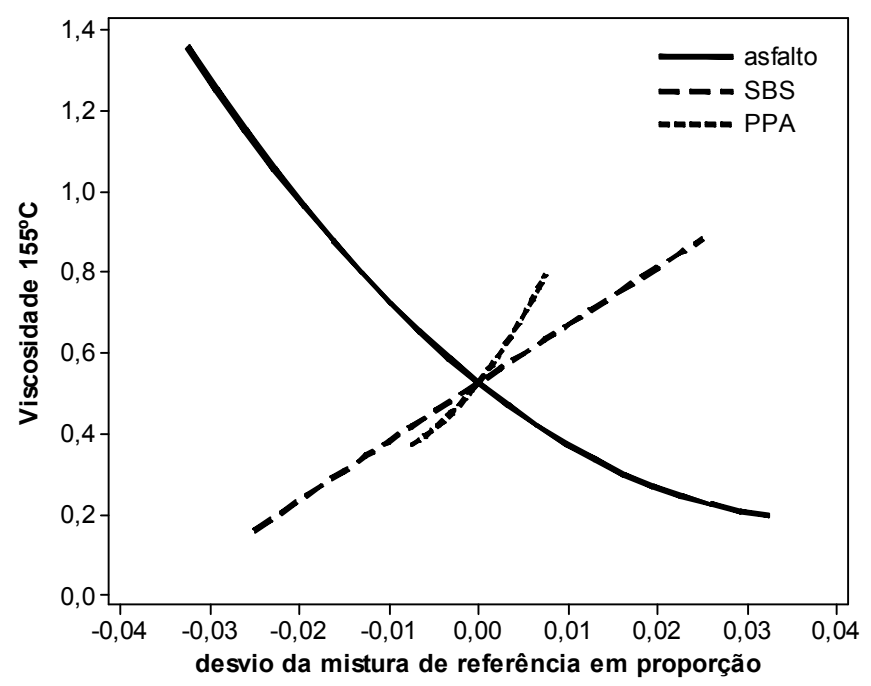

(b)

Figura 215 - Superfície de Resposta (a) e efeito de componentes (b) para a viscosidade à $155^{\circ} \mathrm{C}$ das misturas com PPA. 


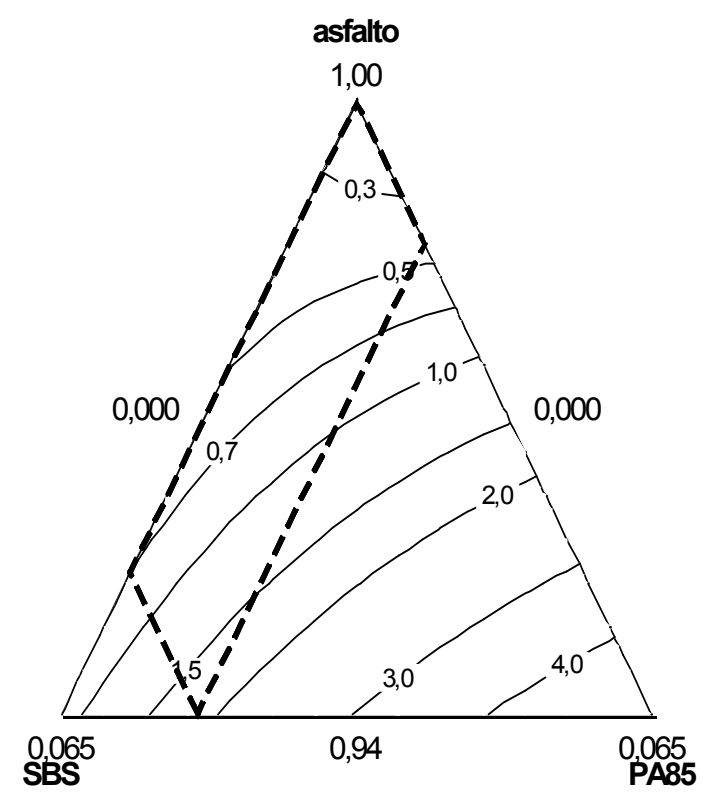

(a)

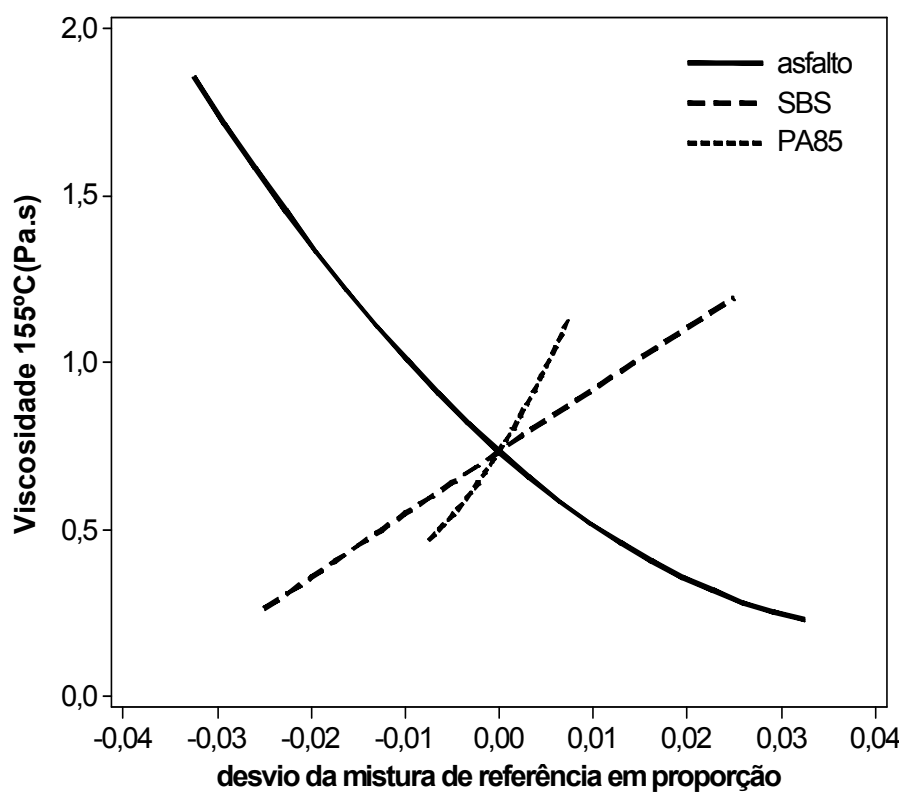

(b)

Figura 216 - Superfície de Resposta (a) e efeito de componentes (b) para a viscosidade à $155^{\circ} \mathrm{C}$ das misturas com PA85.

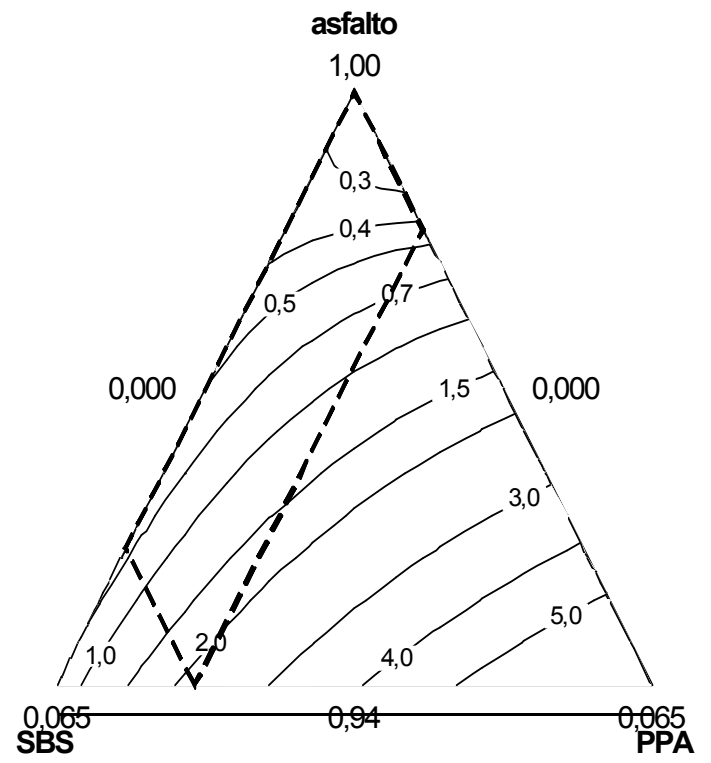

(a)

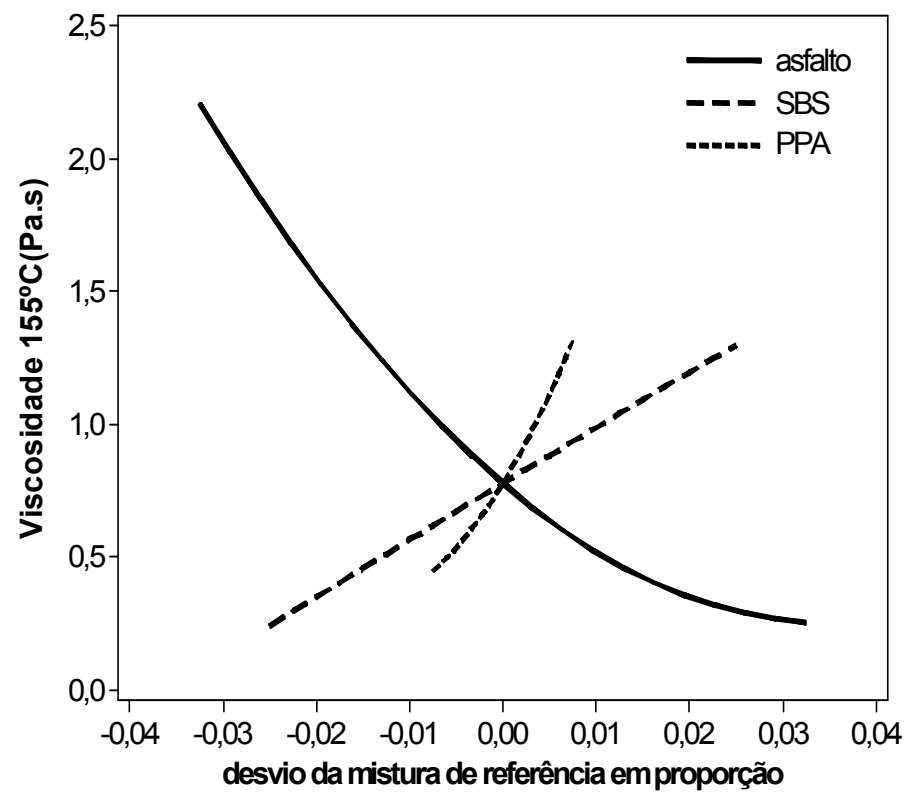

(b)

Figura 217 - Superfície de Resposta (a) e efeito de componentes (b) para a viscosidade à $155^{\circ} \mathrm{C}$ das misturas com PPA. 


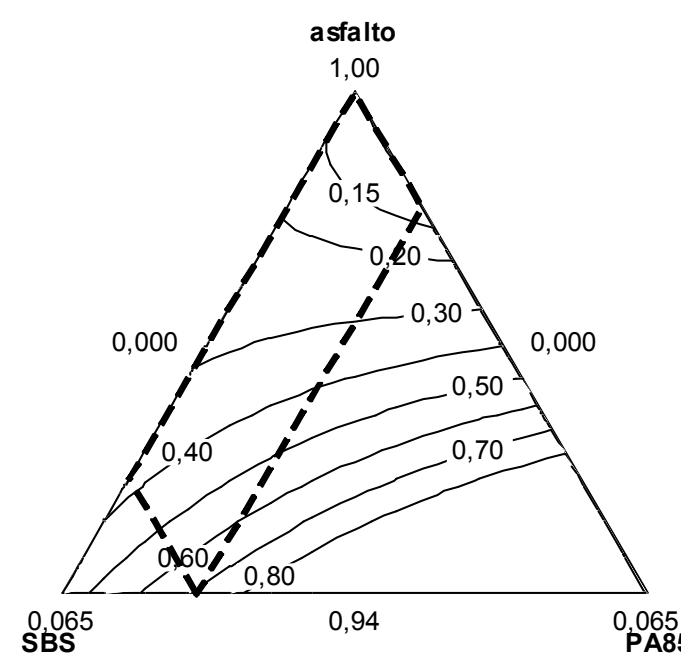

(a)

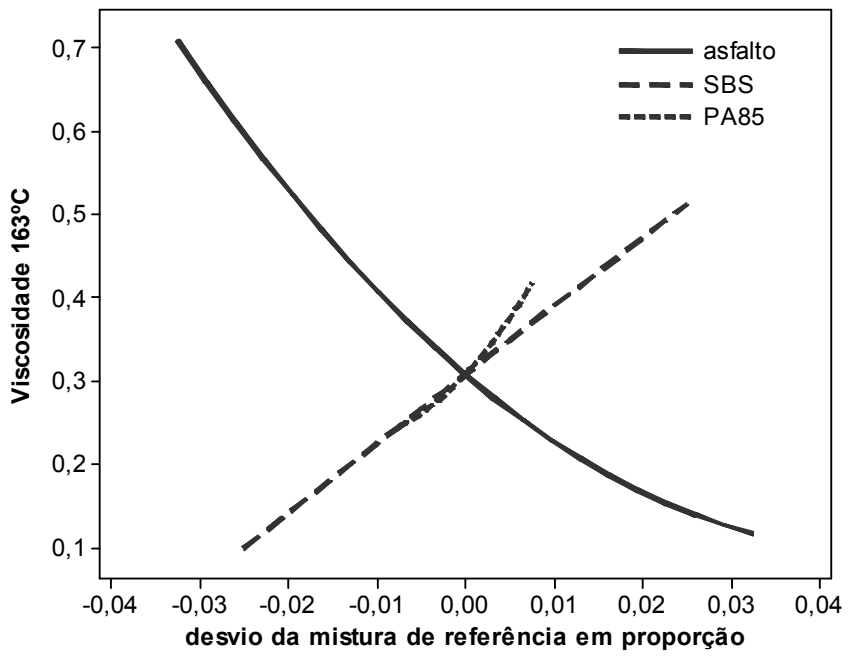

(b)

Figura 218 - Superfície de Resposta (a) e efeito de componentes (b) para a viscosidade à $163^{\circ} \mathrm{C}$ das misturas com PA85.

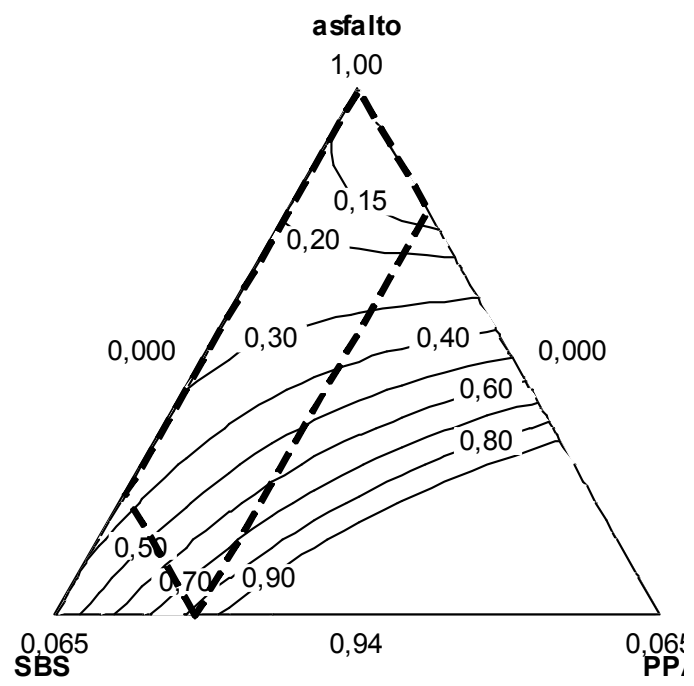

(a)

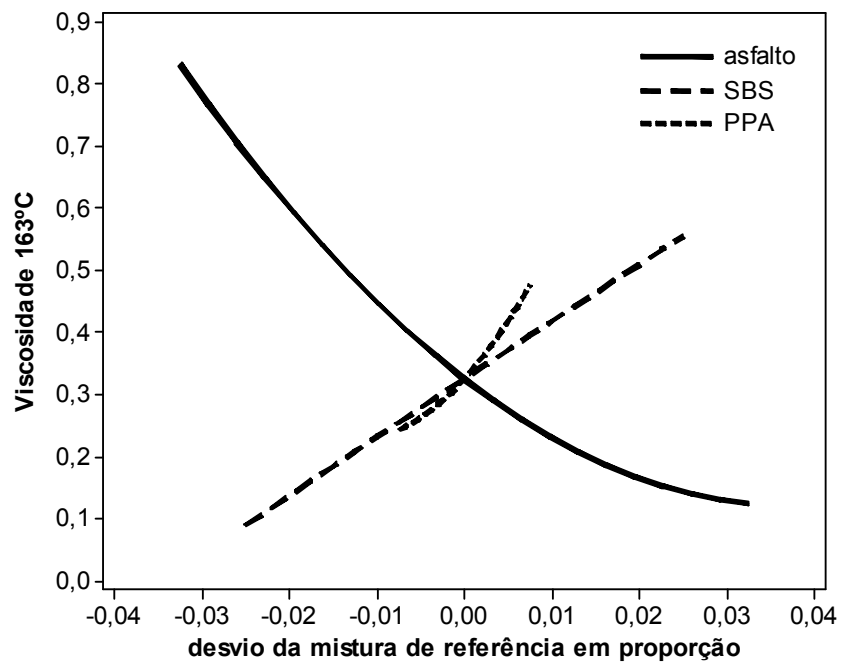

(b)

Figura 219 - Superfície de Resposta (a) e efeito de componentes (b) para a viscosidade à $163^{\circ} \mathrm{C}$ das misturas com PPA. 


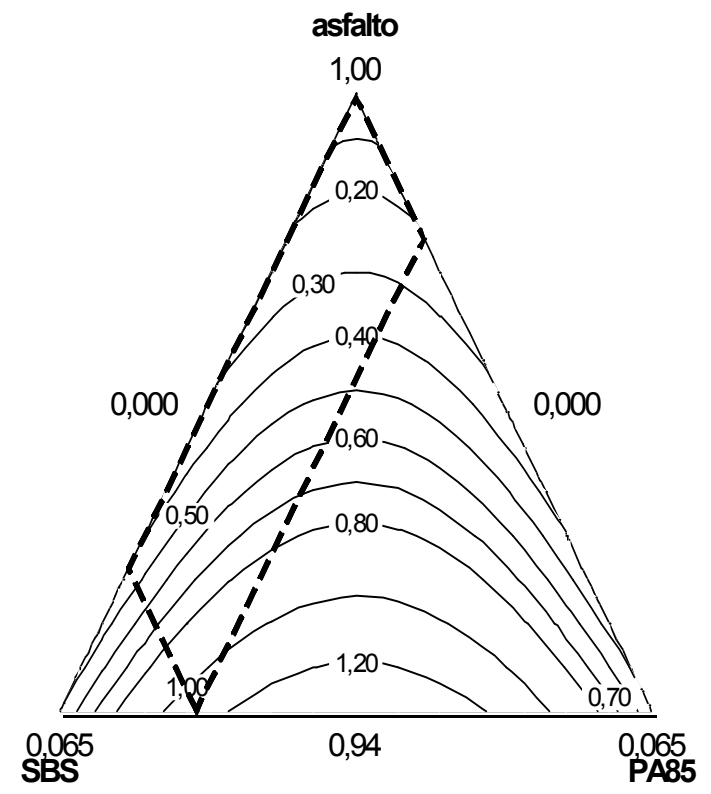

(a)

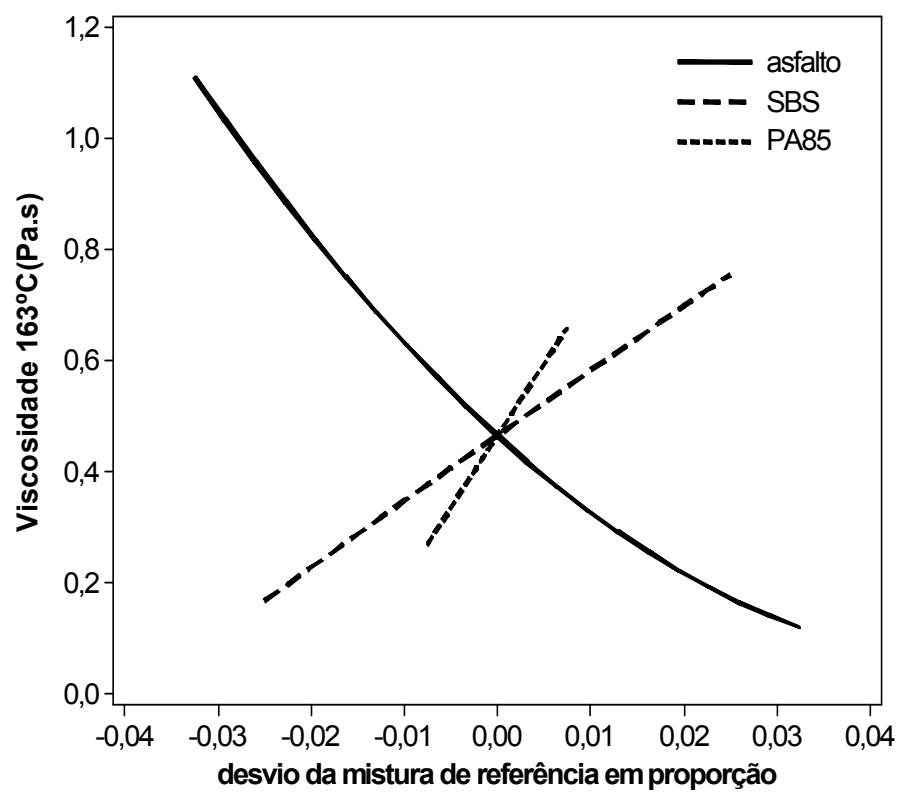

(b)

Figura 220 - Superfície de Resposta (a) e efeito de componentes (b) para a viscosidade à $163^{\circ} \mathrm{C}$ das misturas com PA85.

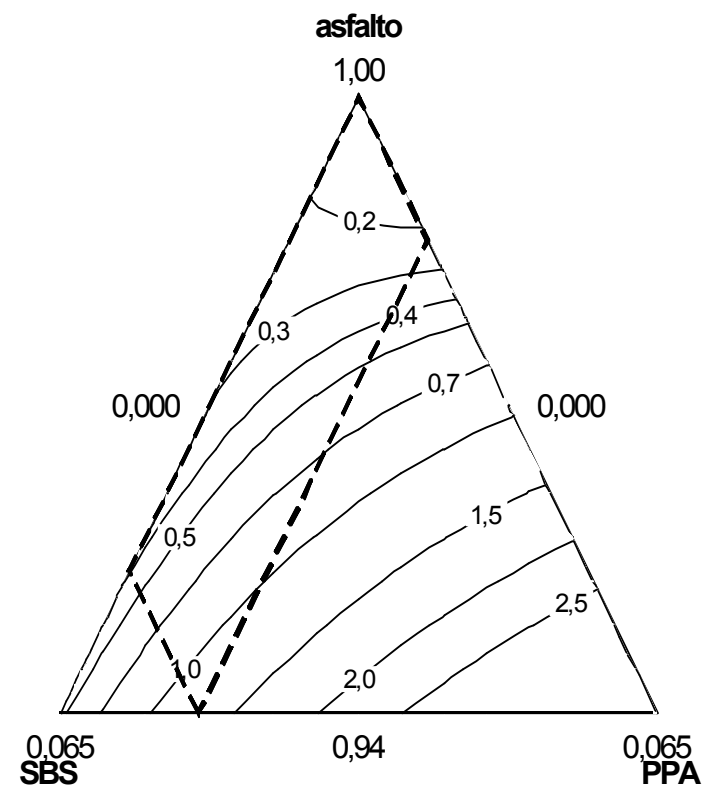

(a)

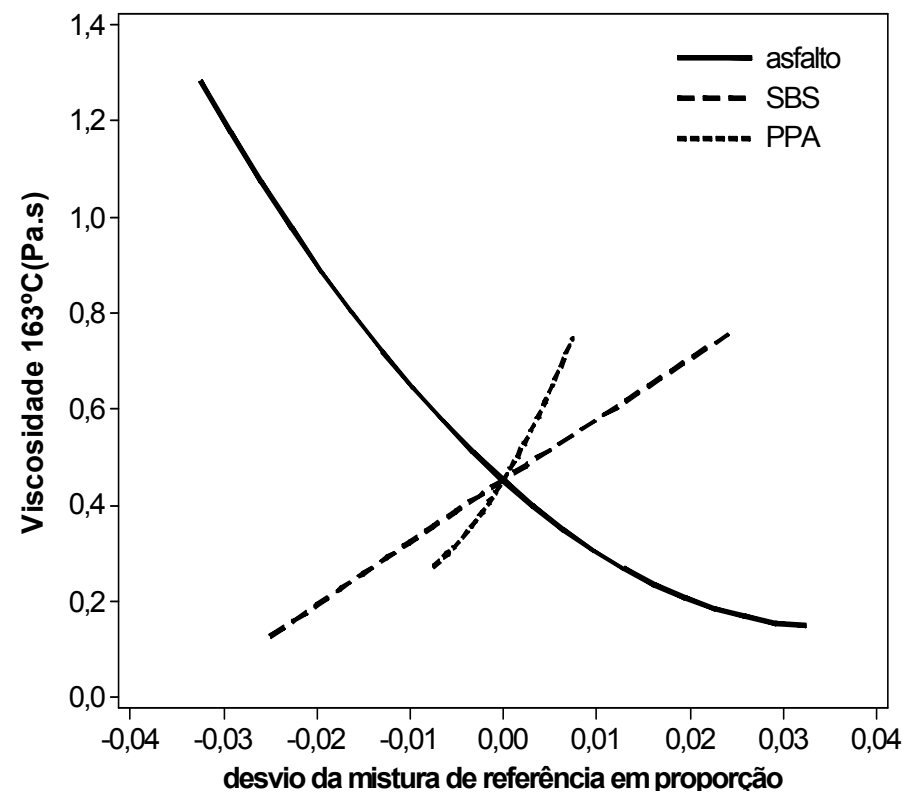

(b)

Figura 221 - Superfície de Resposta (a) e efeito de componentes (b) para a viscosidade à $163^{\circ} \mathrm{C}$ das misturas com PPA. 


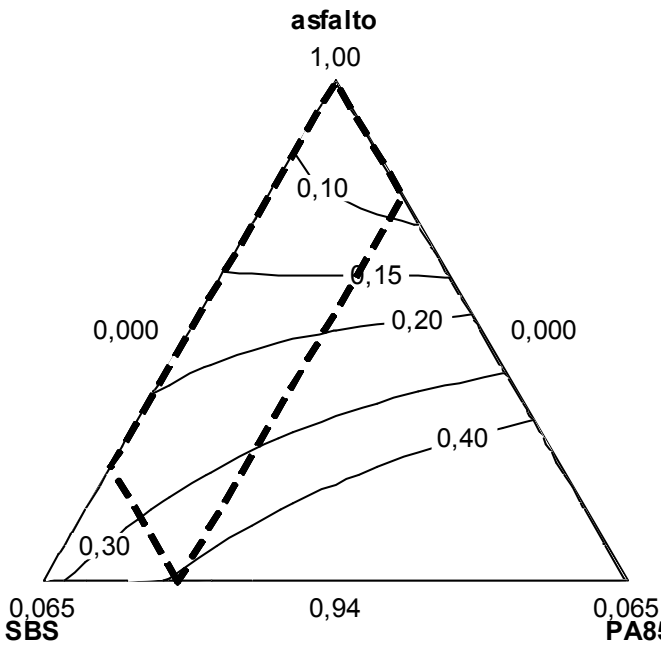

(a)

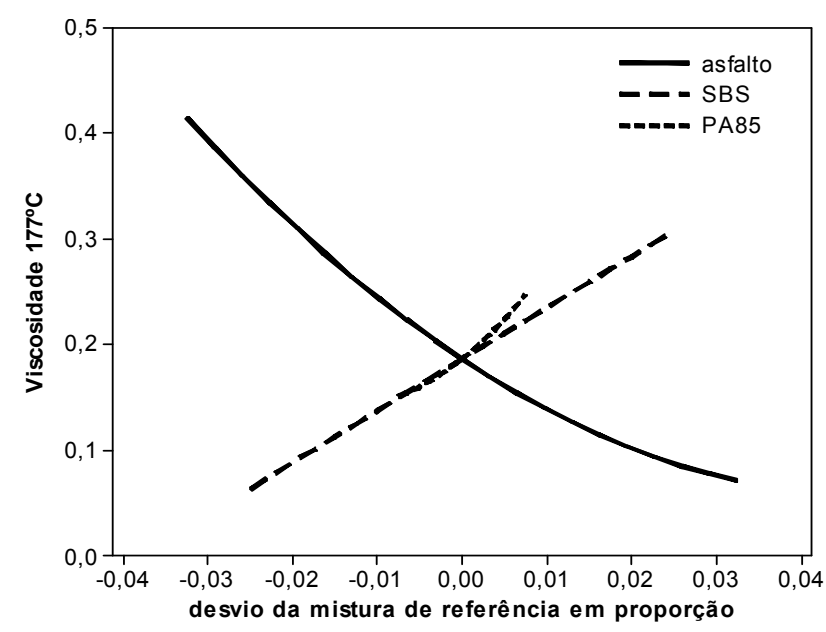

(b)

Figura 222 - Superfície de Resposta (a) e efeito de componentes (b) para a viscosidade à $177^{\circ} \mathrm{C}$ das misturas com PA85.

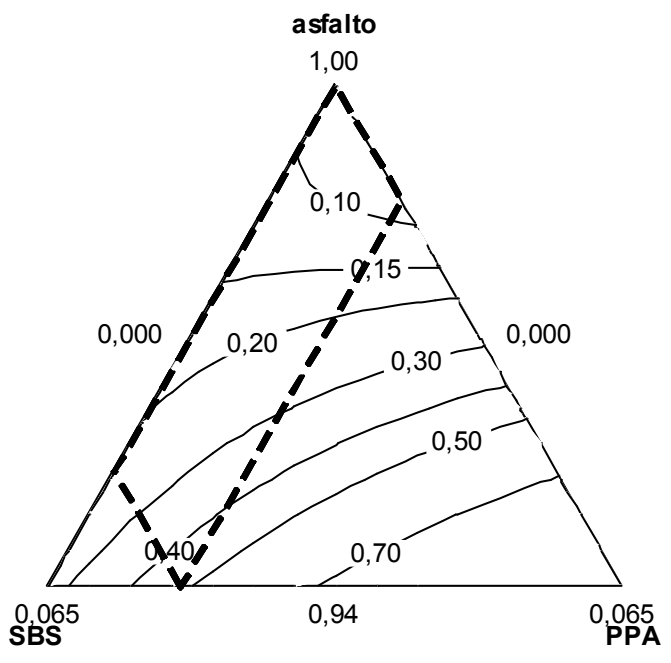

(a)

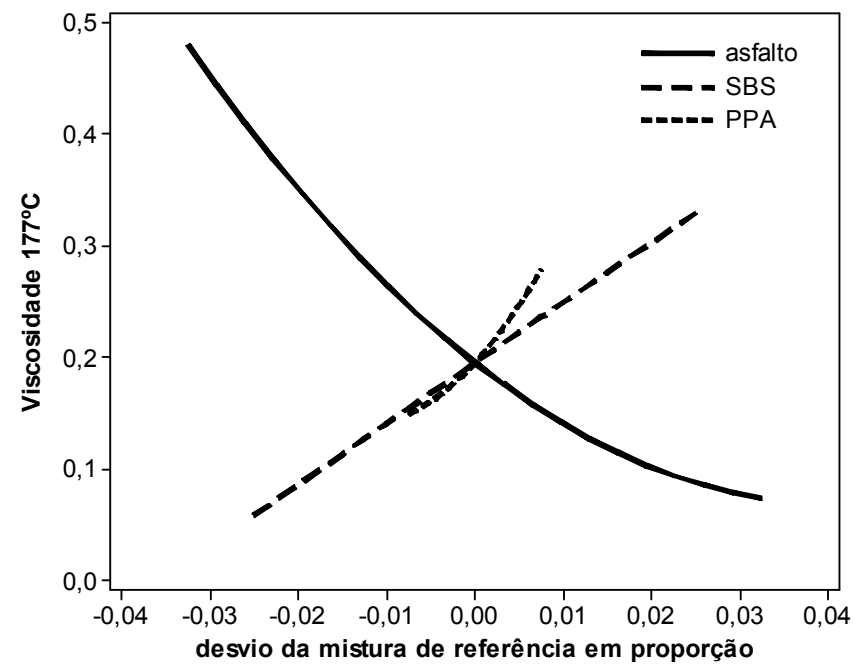

(b)

Figura 223 - Superfície de Resposta (a) e efeito de componentes (b) para a viscosidade à $177^{\circ} \mathrm{C}$ das misturas com PPA. 


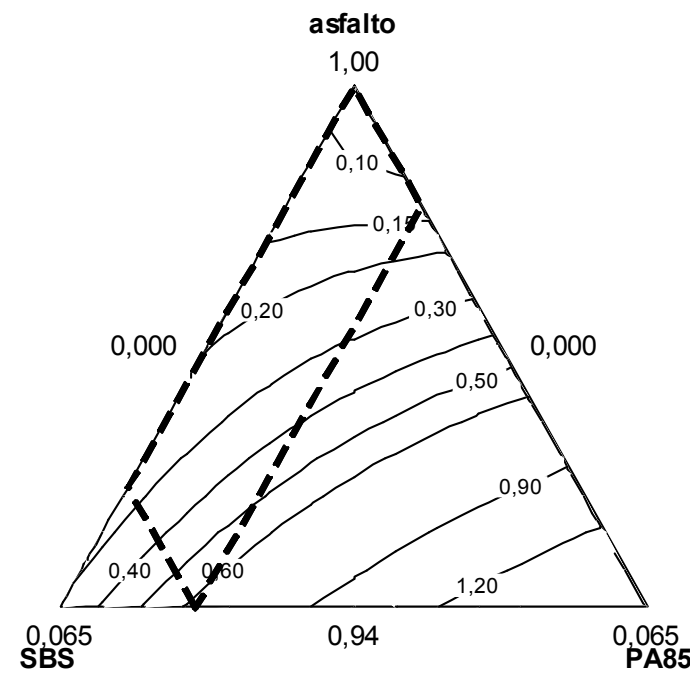

(a)

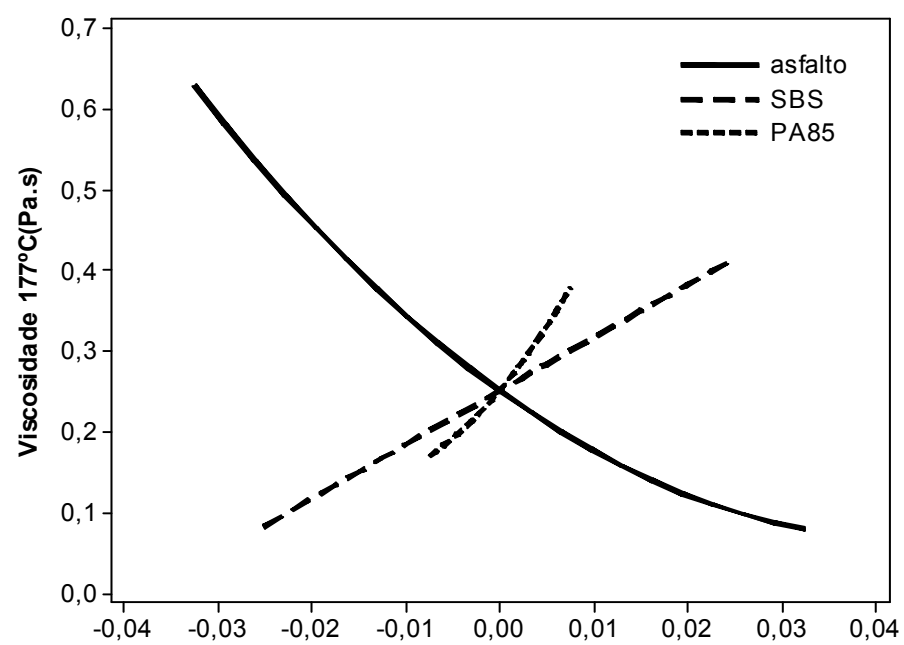

(b)

Figura 224 - Superfície de Resposta (a) e efeito de componentes (b) para a viscosidade à $177^{\circ} \mathrm{C}$ RTFOT das misturas com PA85.

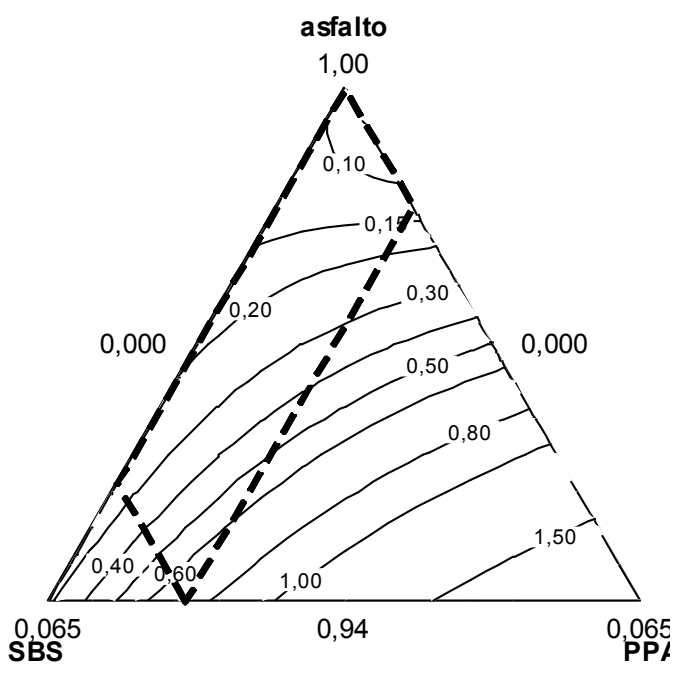

(a)

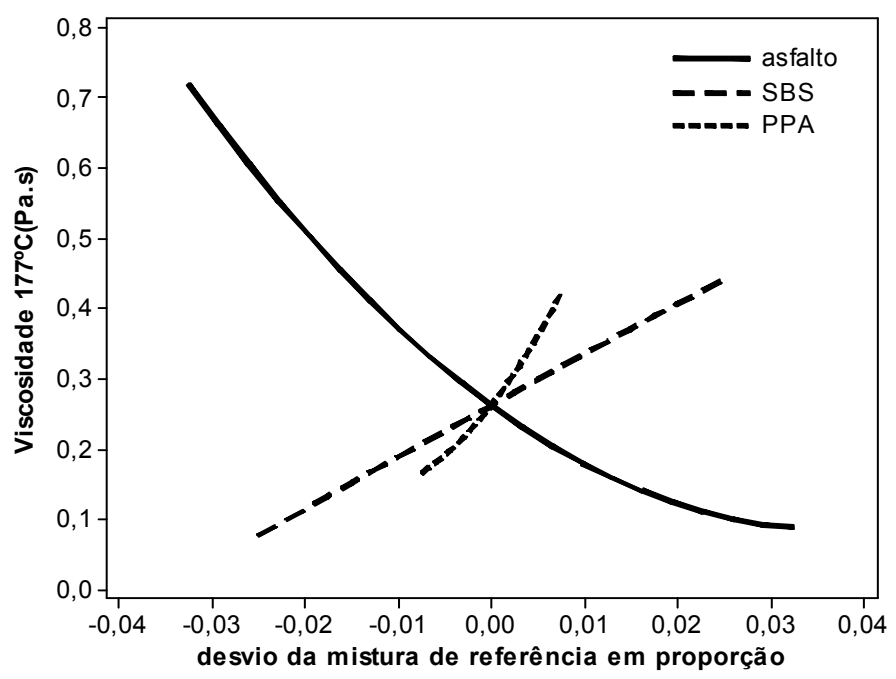

(b)

Figura 225 - Superfície de Resposta (a) e efeito de componentes (b) para a viscosidade à $177^{\circ} \mathrm{C}$ RTFOT das misturas com PPA. 


\section{Perda de Massa}

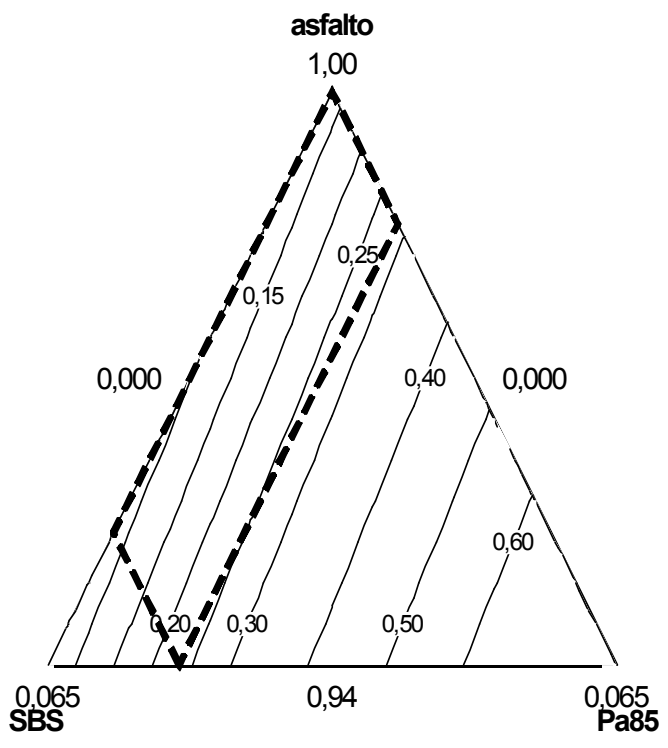

(a)

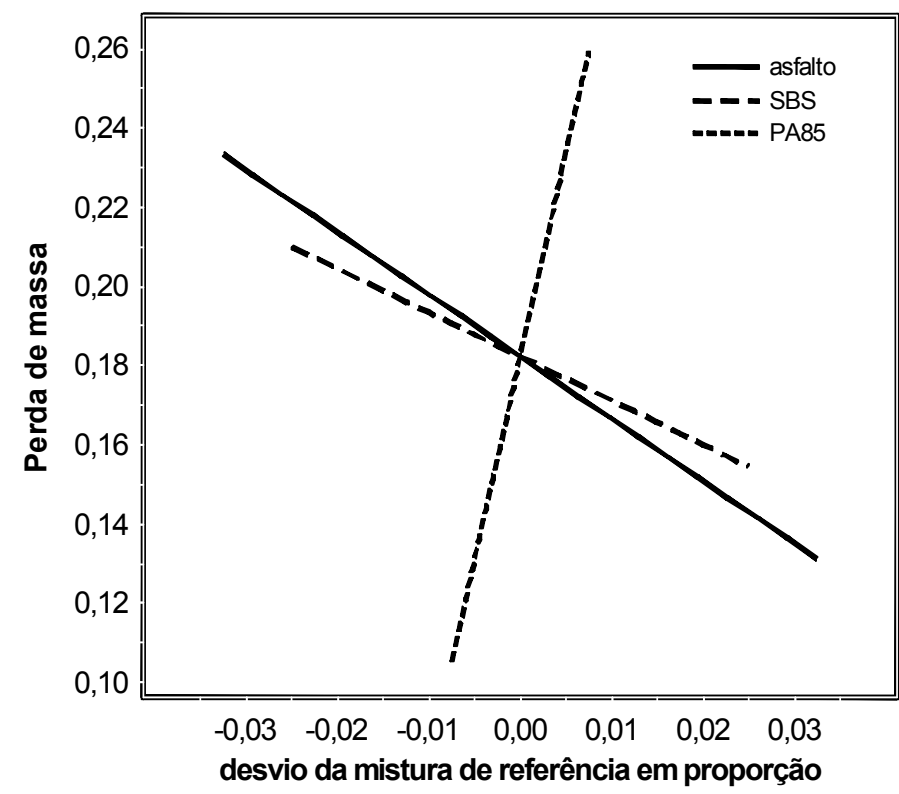

(b)

Figura 226 - Superfície de Resposta (a) e efeito de componentes (b) para perda de massa das misturas com PA85 (Lubnor).

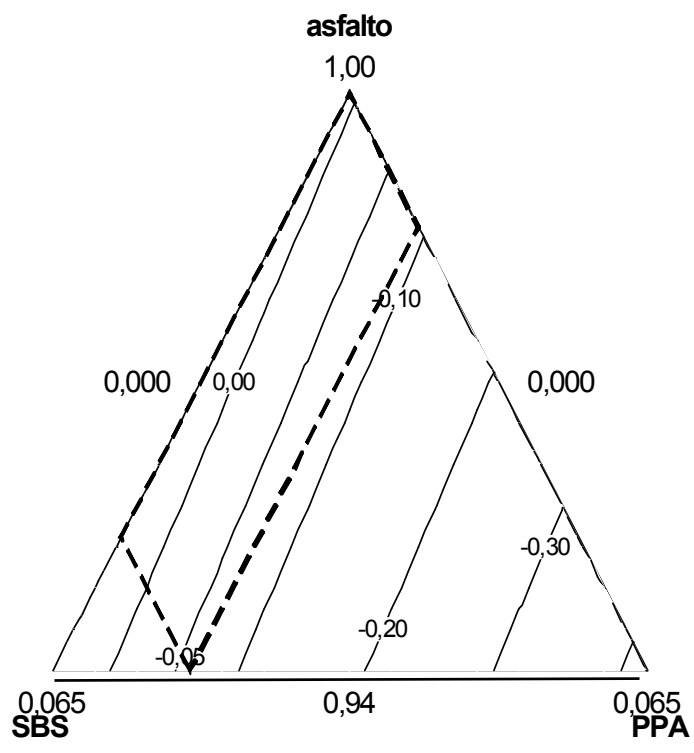

(a)

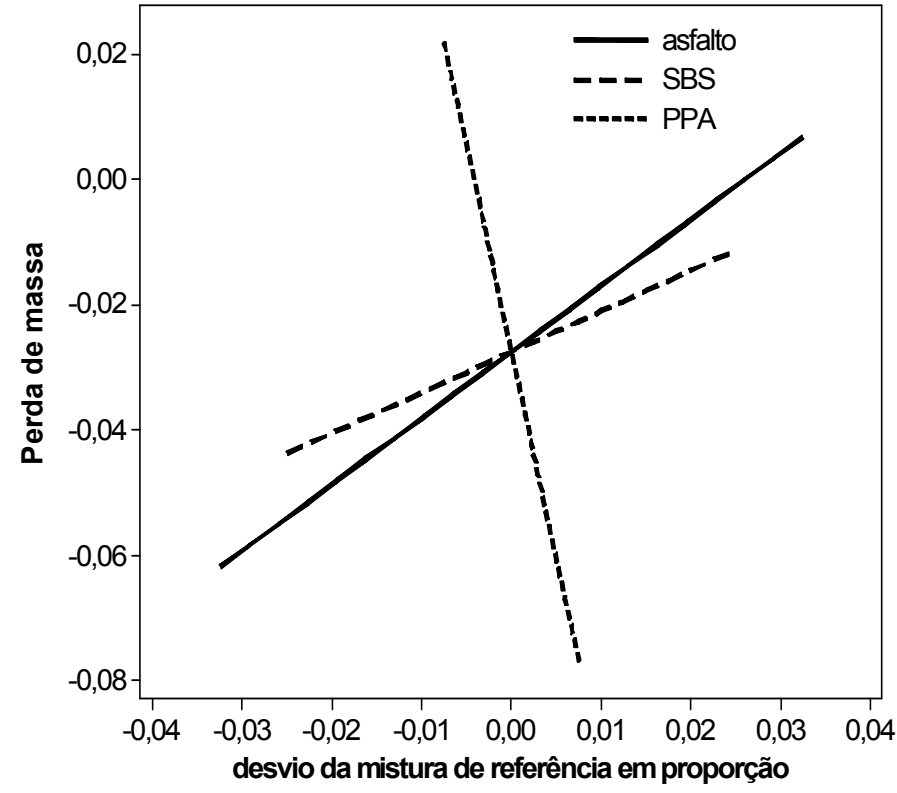

(b)

Figura 227 - Superfície de Resposta (a) e efeito de componentes (b) para perda de massa das misturas com PPA (Lubnor) 


\section{Ensaio de Fluência e Recuperação sob Tensão Múltipla (MSCR)}

Temperatura de $52^{\circ} \mathrm{C}$

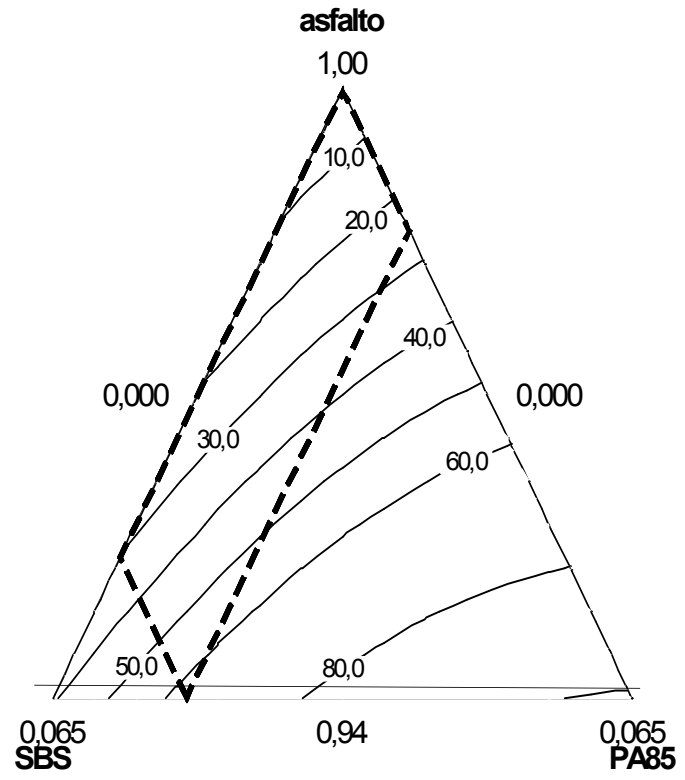

(a)

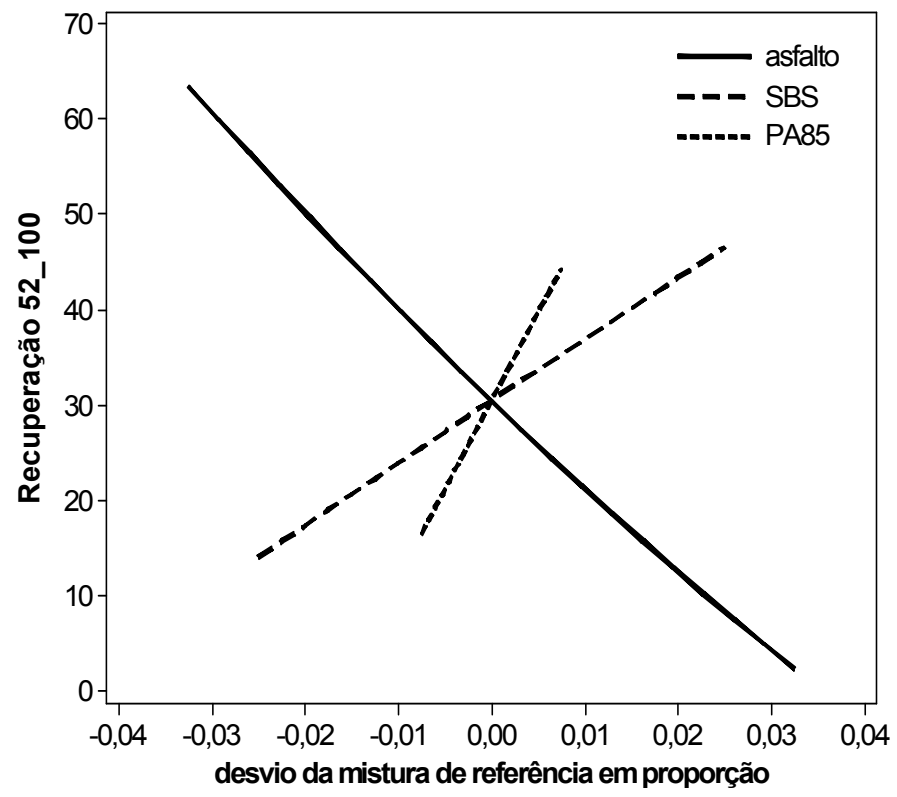

(b)

Figura 228 - Superfície de Resposta (a) e efeito de componentes (b) para a Recuperação (\%) à $52^{\circ} \mathrm{C}$ na tensão de 100PA das misturas com PA85.

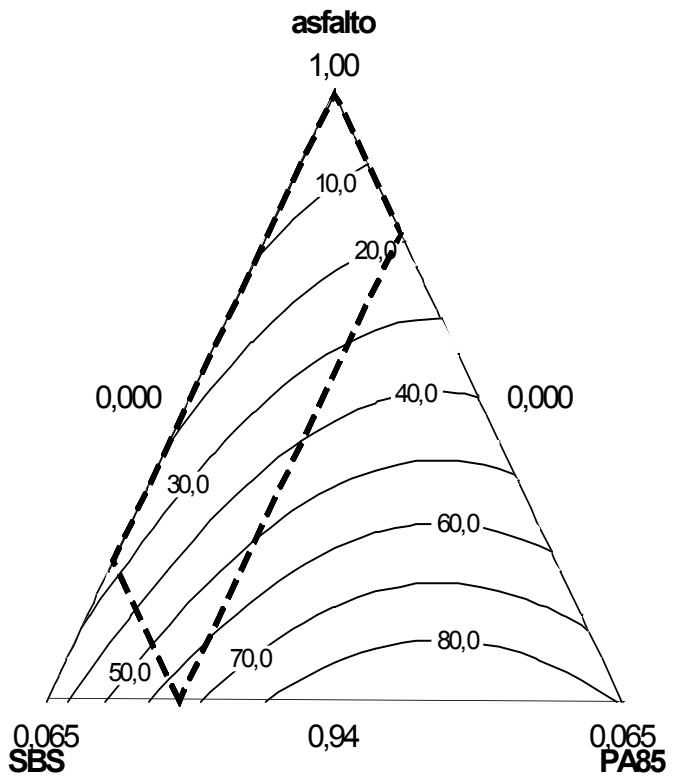

(a)

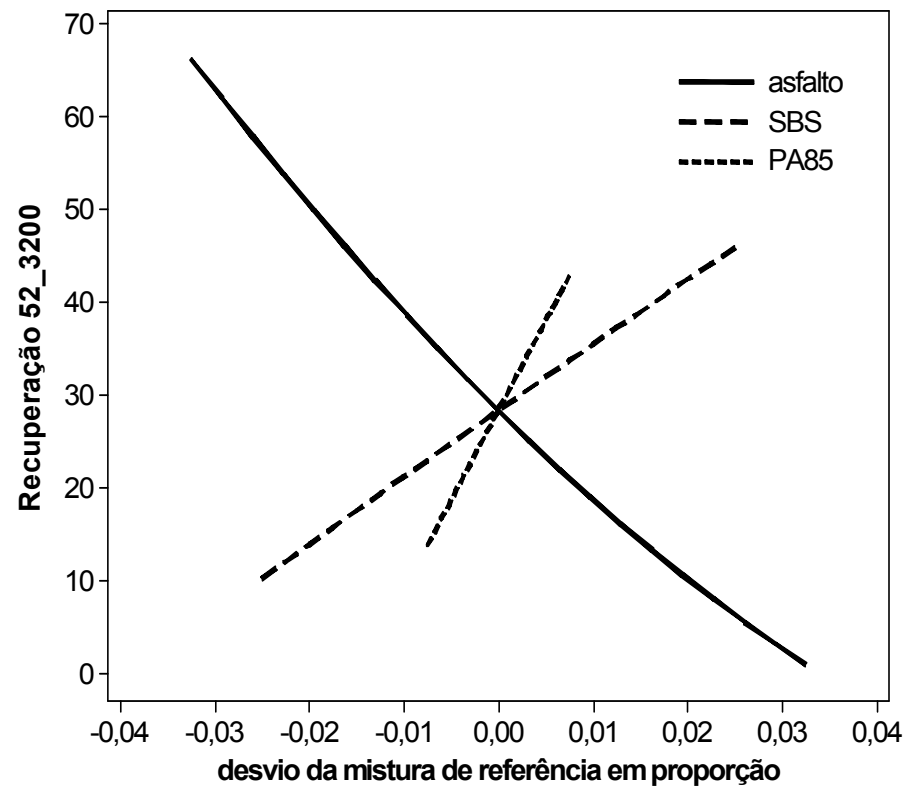

(b)

Figura 229 - Superfície de Resposta (a) e efeito de componentes (b) para a Recuperação (\%) à $52^{\circ} \mathrm{C}$ na tensão de 3200PA das misturas com PA85. 


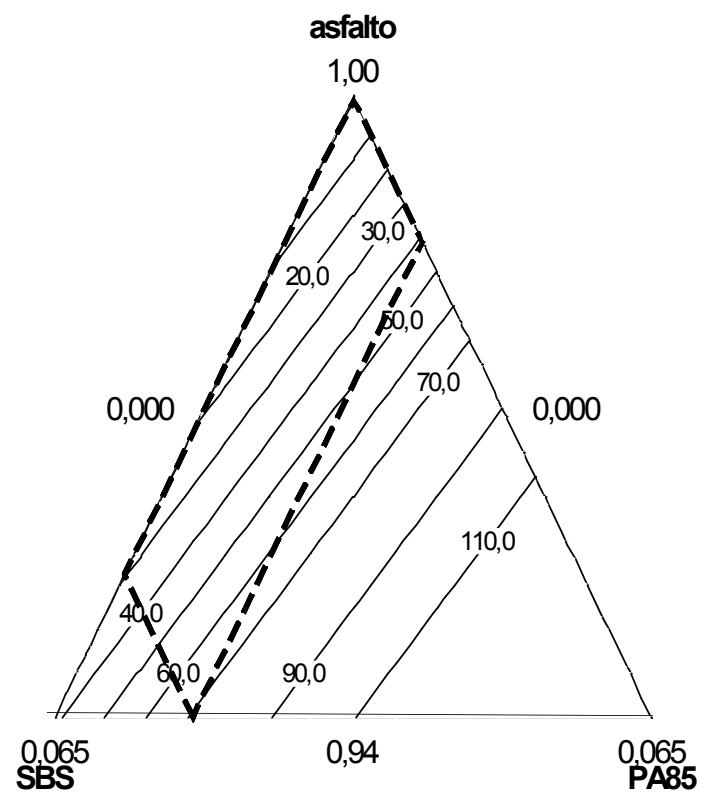

(a)

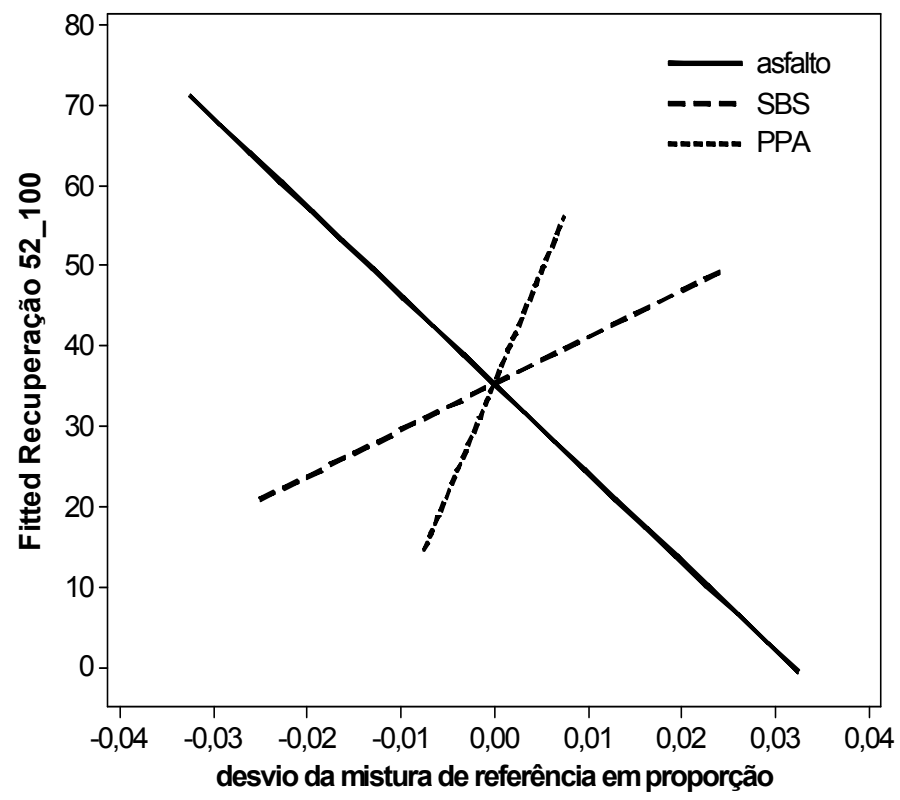

(b)

Figura 230 - Superfície de Resposta (a) e efeito de componentes (b) para a Recuperação (\%) à $52^{\circ} \mathrm{C}$ na tensão de 100PA das misturas com PPA.

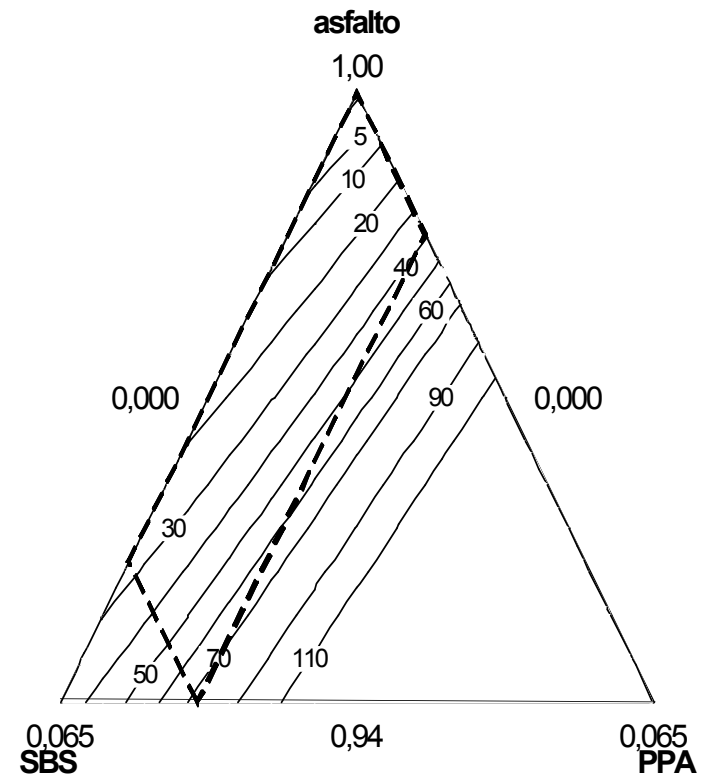

(a)

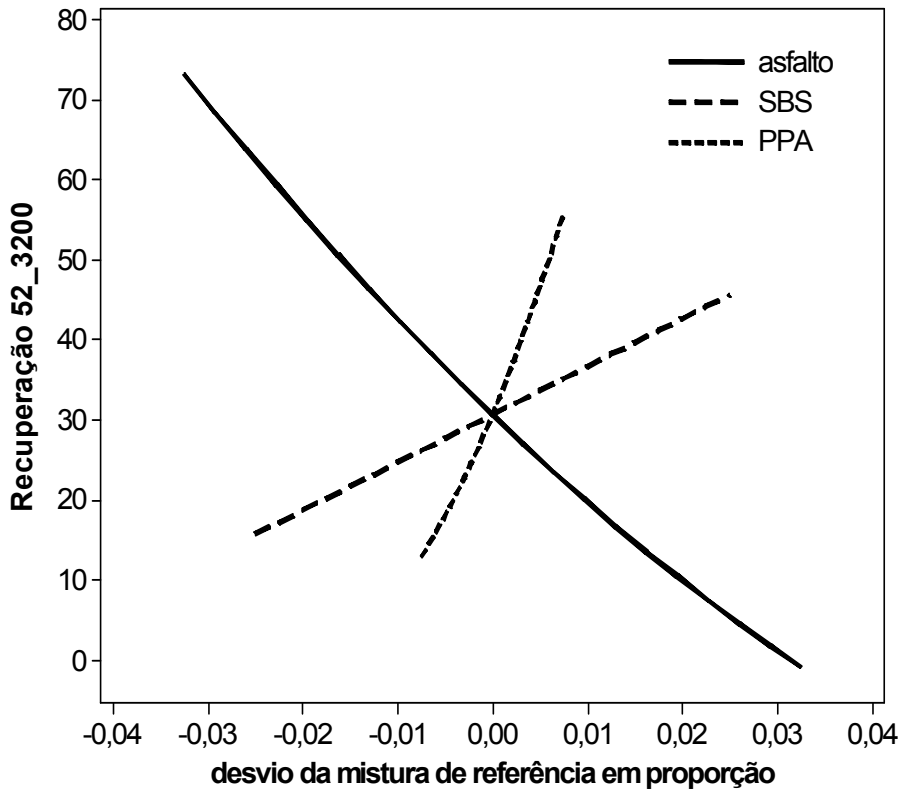

(b)

Figura 231 - Superfície de Resposta (a) e efeito de componentes (b) para a Recuperação (\%) à $52^{\circ} \mathrm{C}$ na tensão de 3200PA das misturas com PPA. 


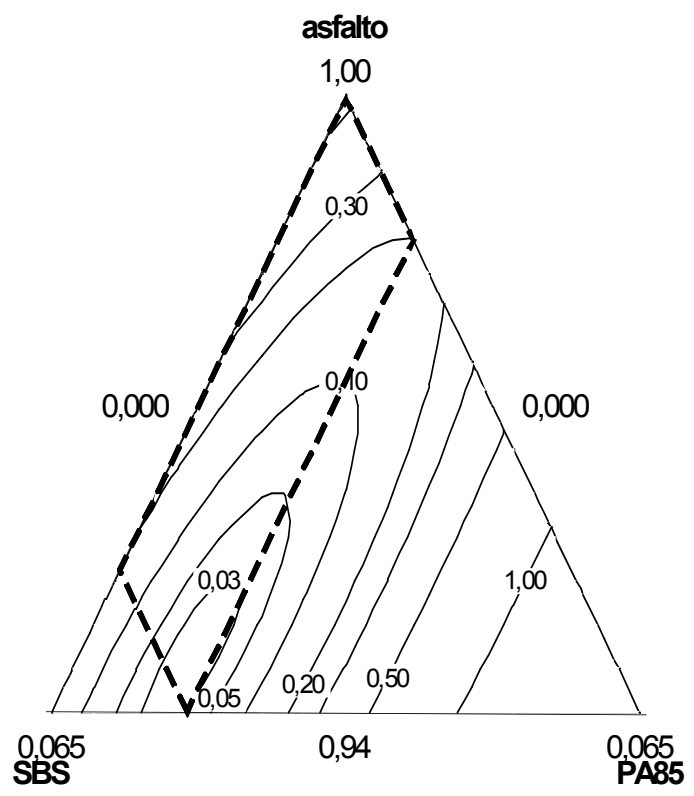

(a)

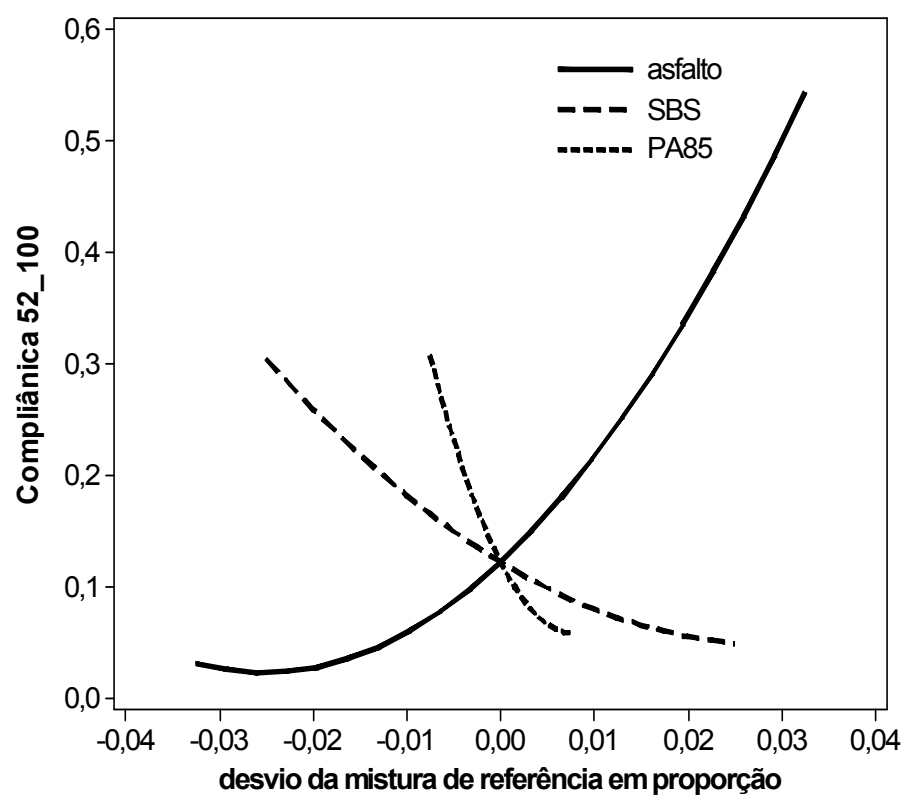

(b)

Figura 232 - Superfície de Resposta (a) e efeito de componentes (b) para a Compliância não recuperável $\left(\mathrm{kPa}^{-1}\right)$ à $52^{\circ} \mathrm{C}$ na tensão de $100 \mathrm{~Pa}$ das misturas com PA85.

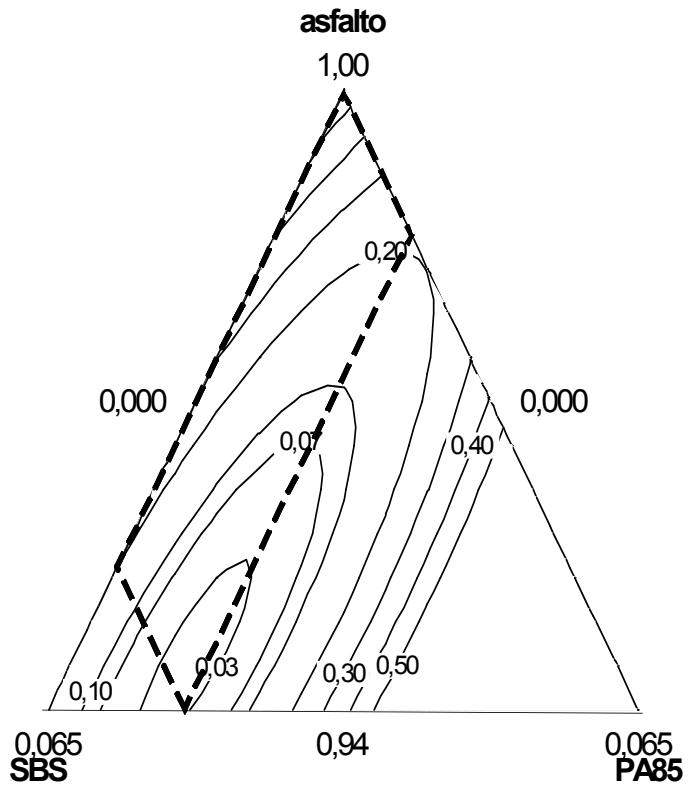

(a)

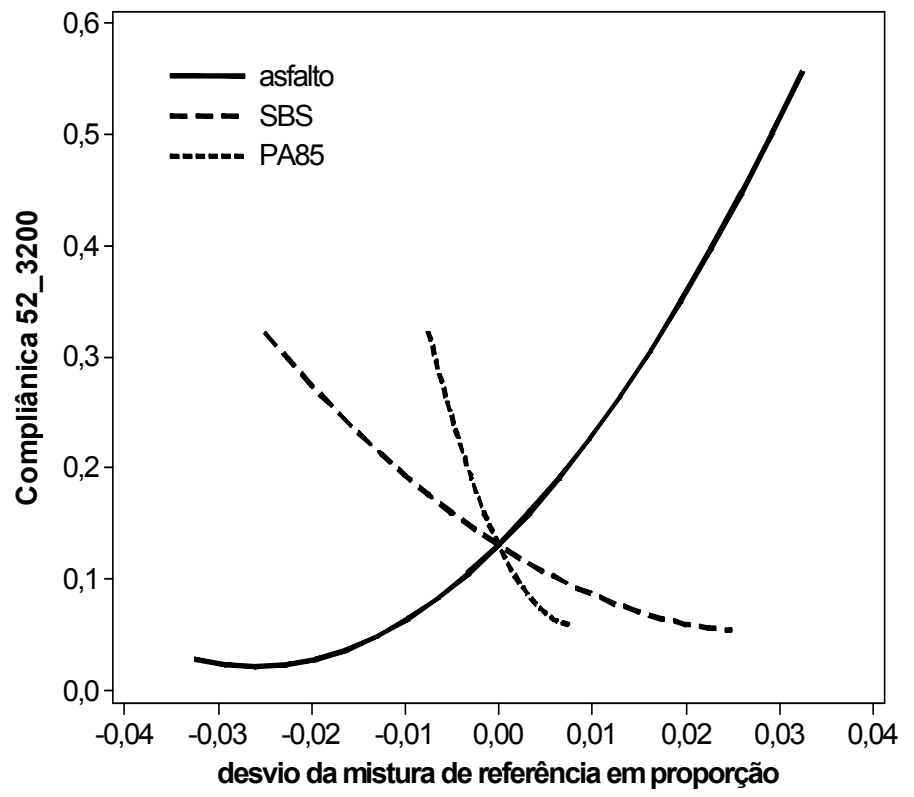

(b)

Figura 233 - Superfície de Resposta (a) e efeito de componentes (b) para a Compliância não recuperável $\left(\mathrm{kPa}^{-1}\right)$ à $52^{\circ} \mathrm{C}$ na tensão de $3200 \mathrm{~Pa}$ das misturas com PA85. 


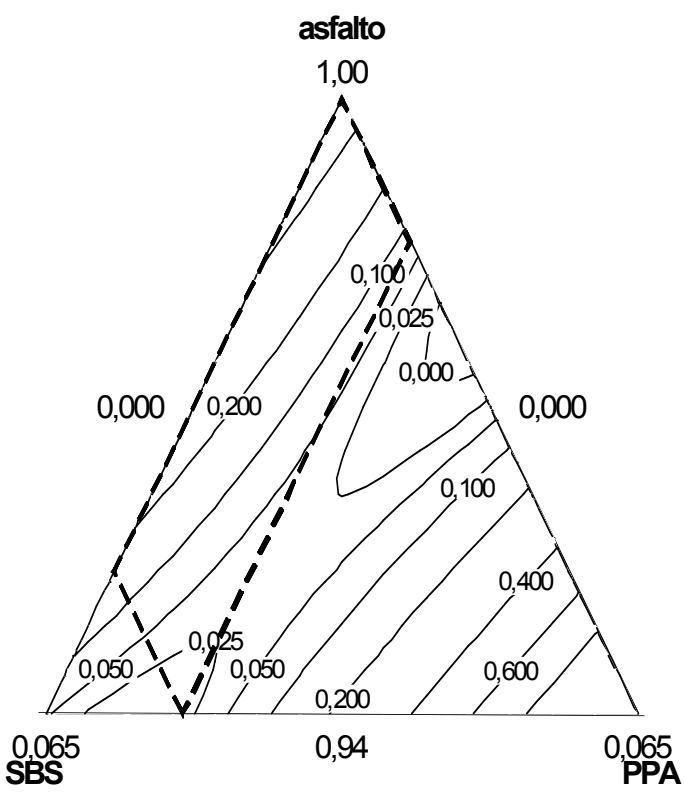

(a)

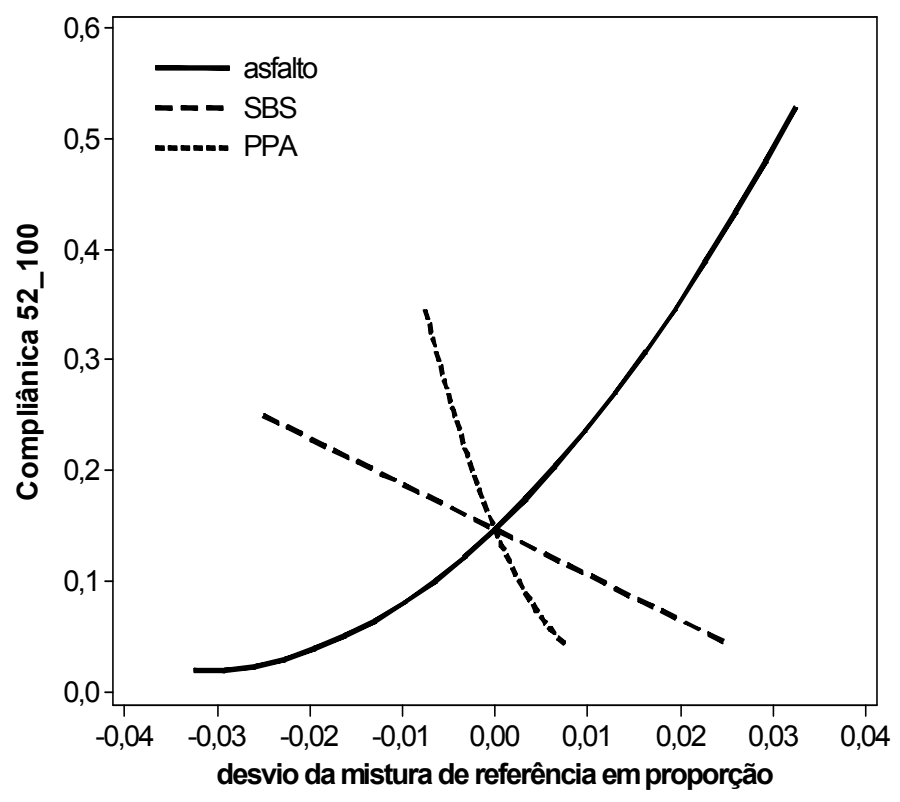

(b)

Figura 234 - Superfície de Resposta (a) e efeito de componentes (b) para a Compliância não recuperável $\left(\mathrm{kPa}^{-1}\right)$ à $52^{\circ} \mathrm{C}$ na tensão de 100PA das misturas com PPA.

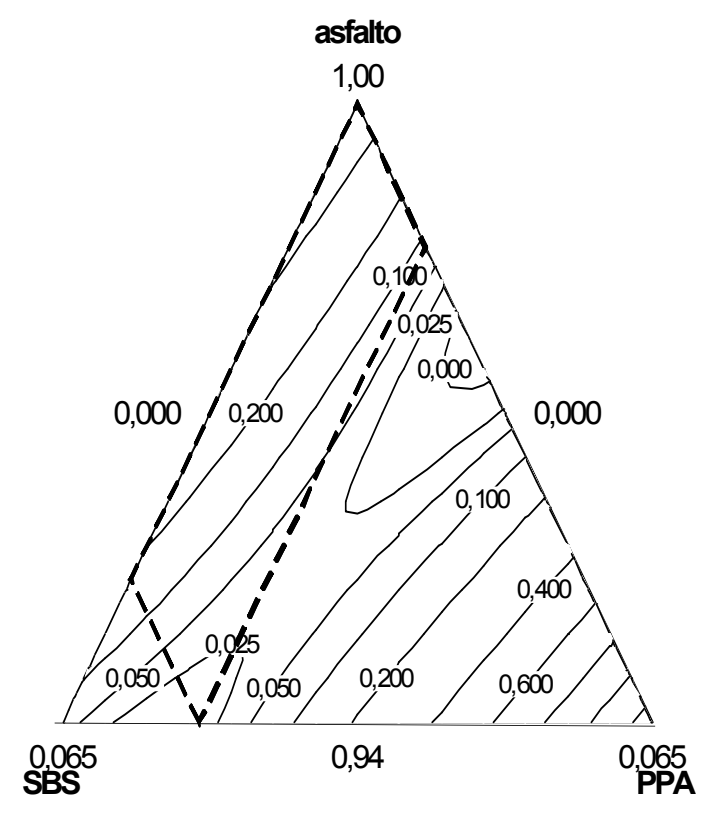

(a)

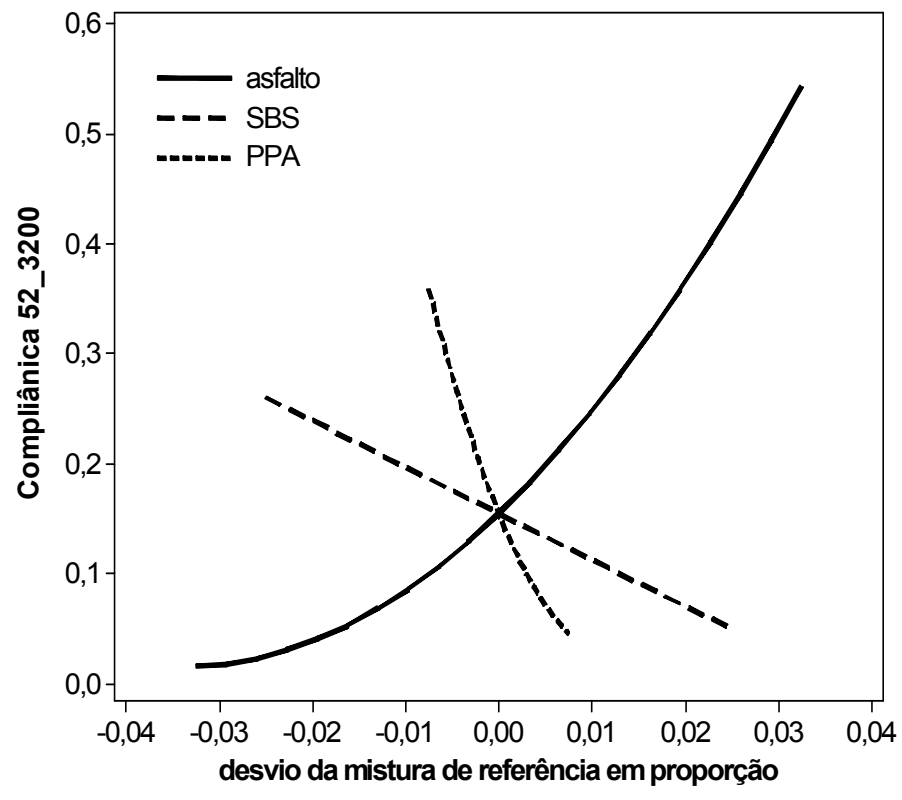

(b)

Figura 235 - Superfície de Resposta (a) e efeito de componentes (b) para a Compliância não recuperável $\left(\mathrm{kPa}^{-1}\right)$ à $52^{\circ} \mathrm{C}$ na tensão de $3200 \mathrm{PA}$ das misturas com PPA. 
Temperatura de $58^{\circ} \mathrm{C}$

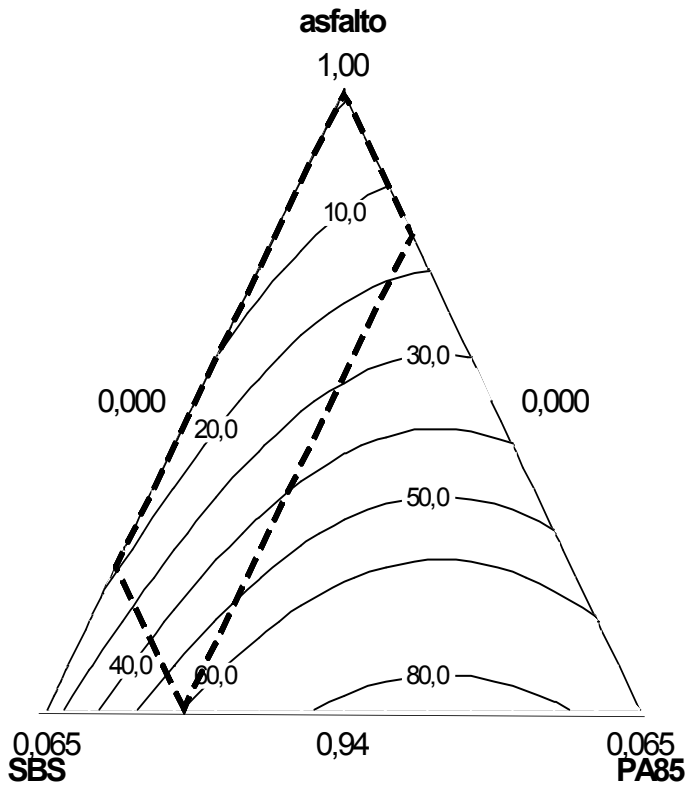

(a)

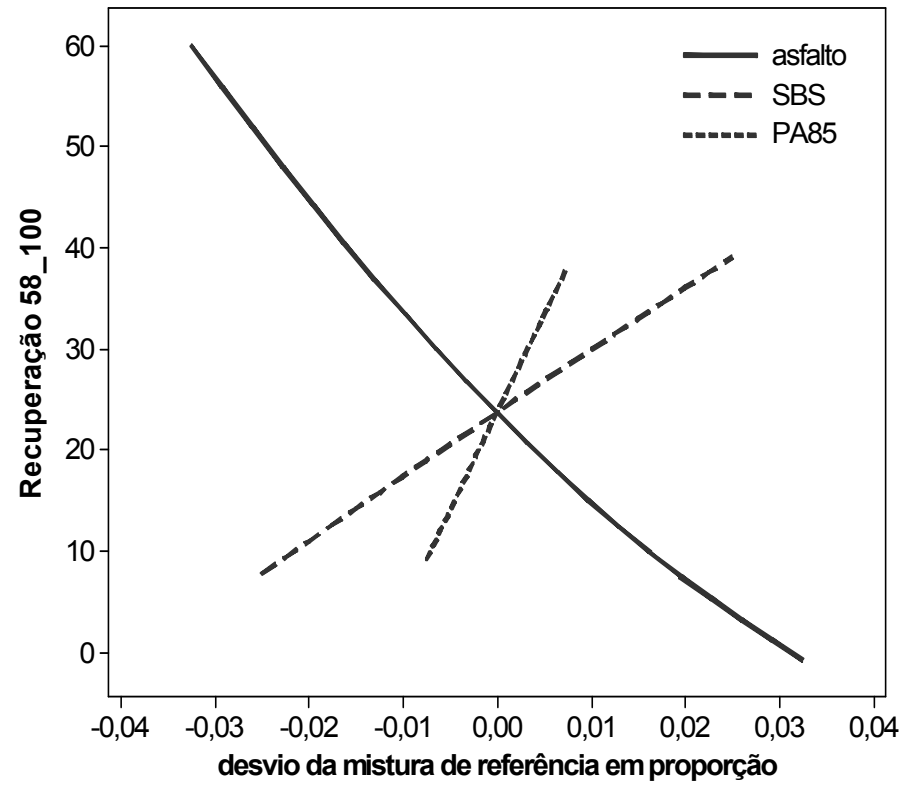

(b)

Figura 236 - Superfície de Resposta (a) e efeito de componentes (b) para a Recuperação (\%) à $58^{\circ} \mathrm{C}$ na tensão de 100PA das misturas com PA85.

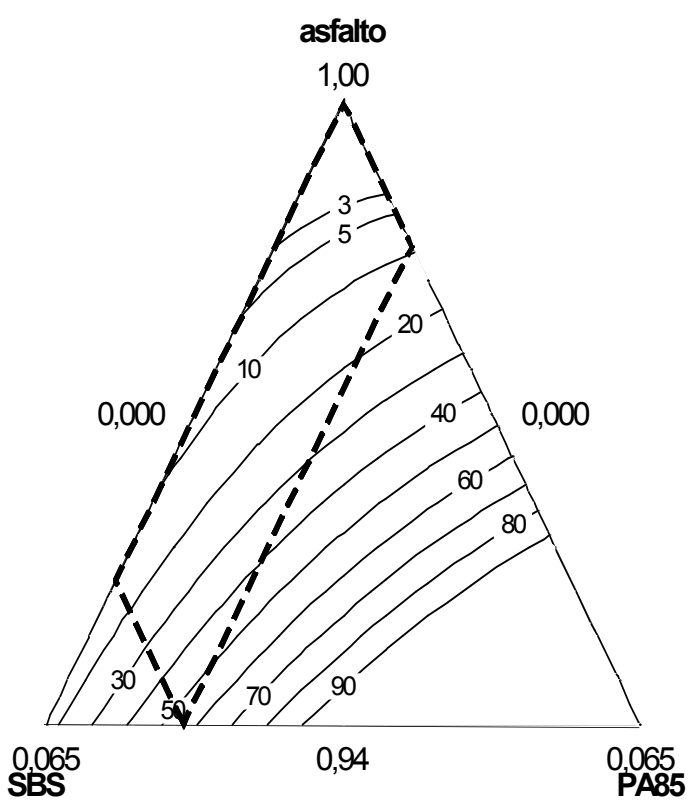

(a)

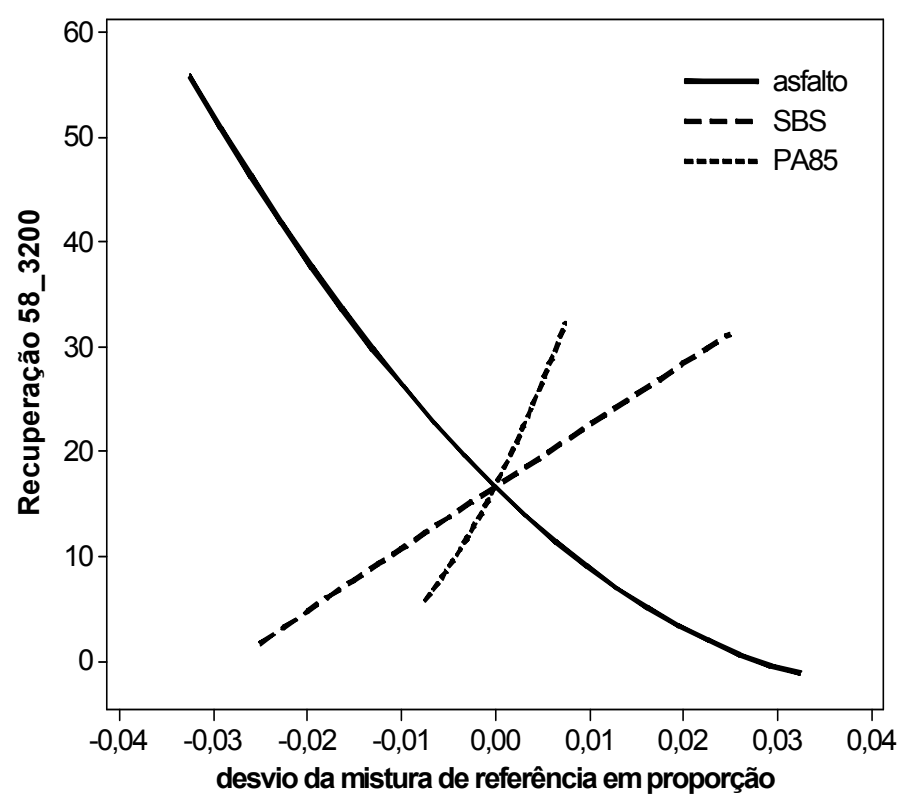

(b)

Figura 237 - Superfície de Resposta (a) e efeito de componentes (b) para a Recuperação (\%) à $58^{\circ} \mathrm{C}$ na tensão de 3200PA das misturas com PA85. 


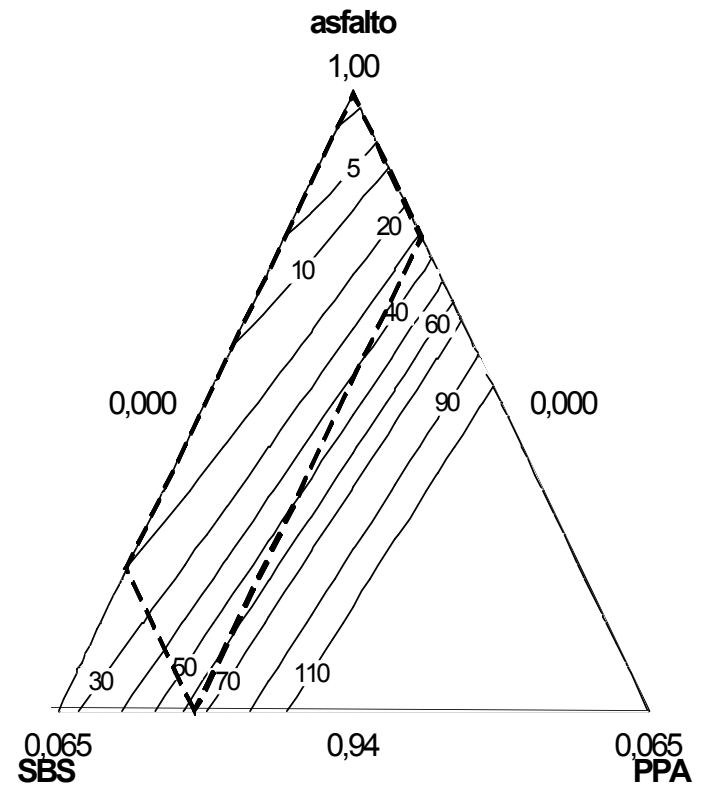

(a)

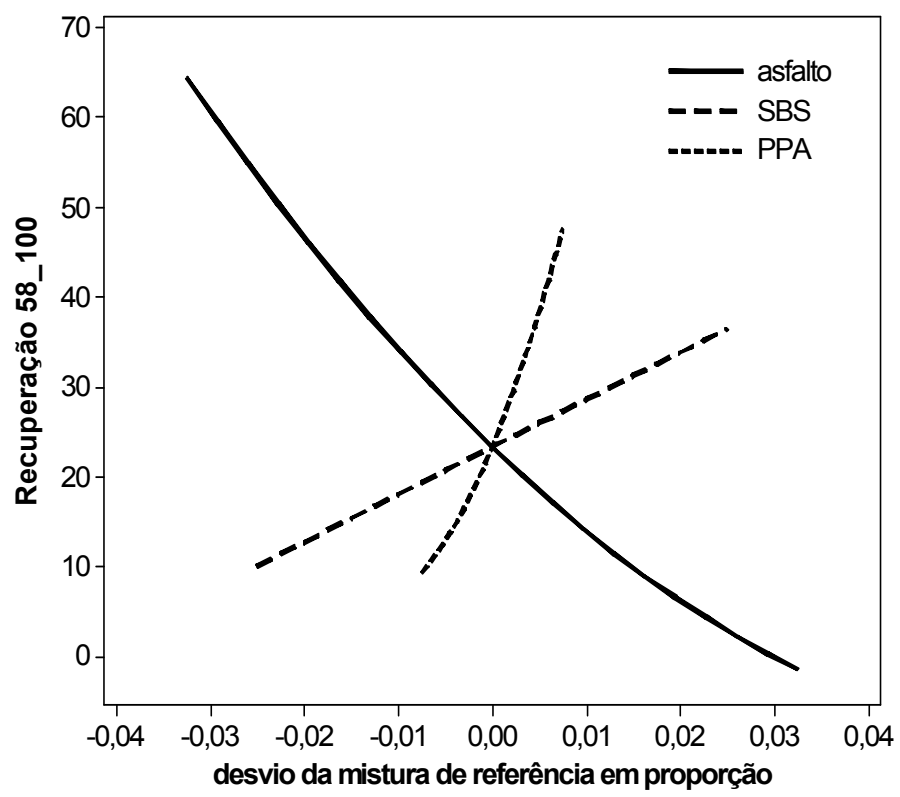

(b)

Figura 238 - Superfície de Resposta (a) e efeito de componentes (b) para a Recuperação (\%) à $58^{\circ} \mathrm{C}$ na tensão de 100PA das misturas com PPA.

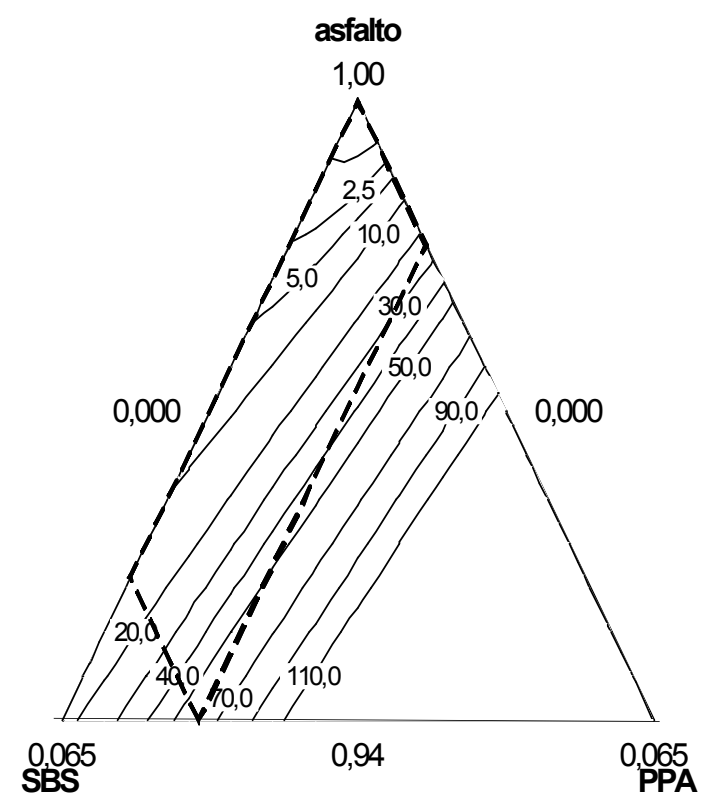

(a)

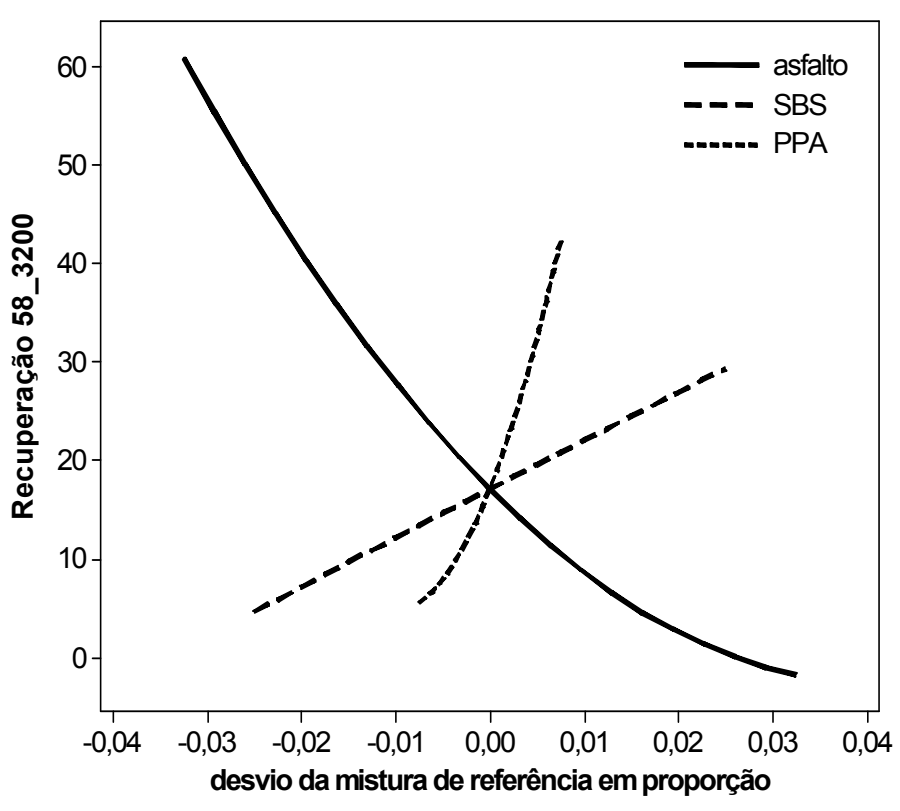

(b)

Figura 239 - Superfície de Resposta (a) e efeito de componentes (b) para a Recuperação (\%) à $58^{\circ} \mathrm{C}$ na tensão de 3200PA das misturas com PPA. 


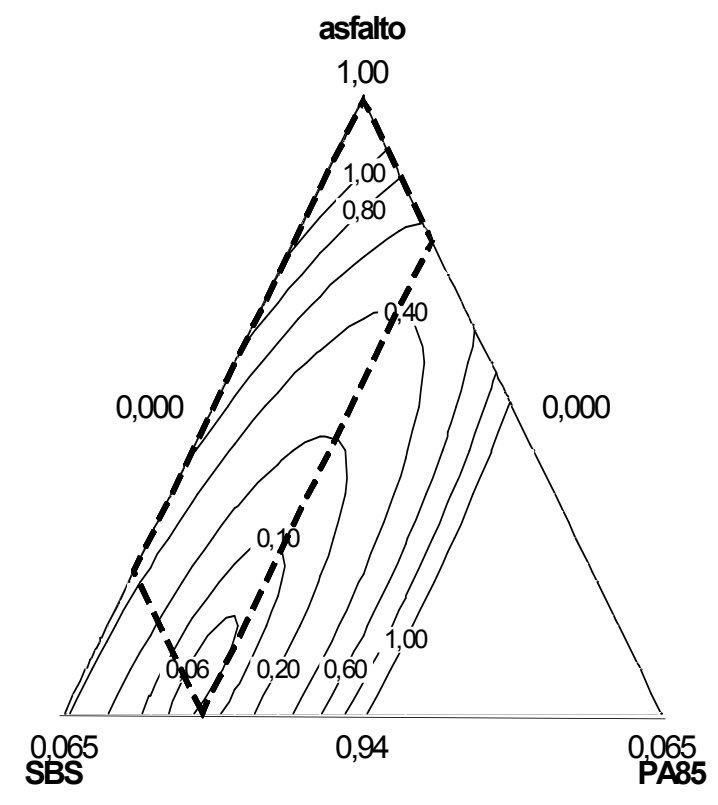

(a)

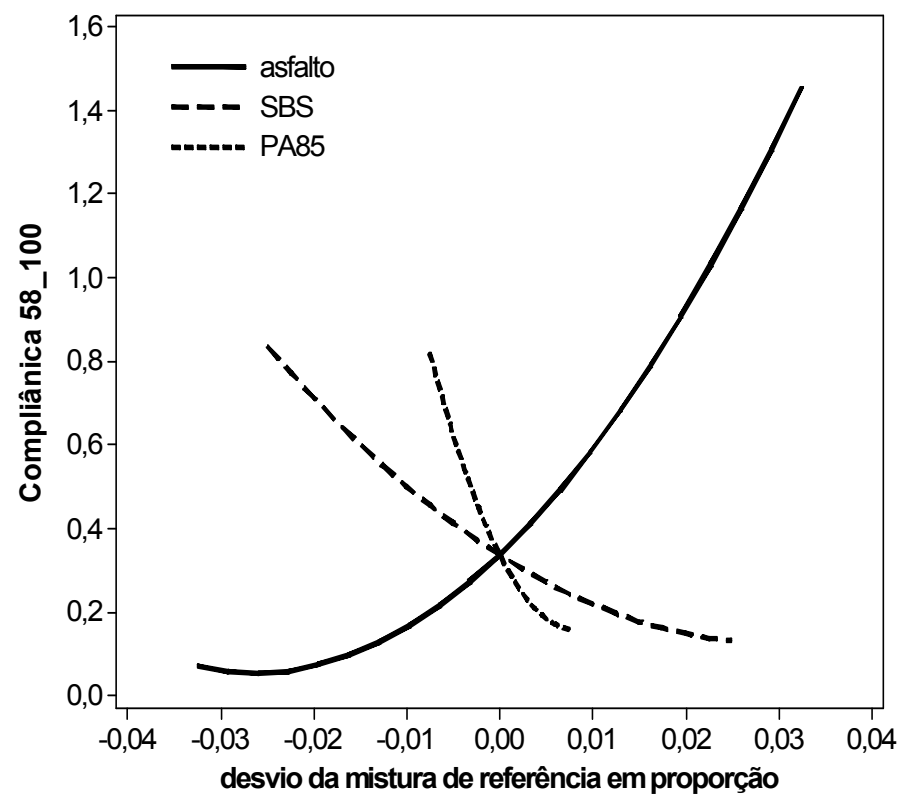

(b)

Figura 240 - Superfície de Resposta (a) e efeito de componentes (b) para a Compliância não recuperável $\left(\mathrm{kPa}^{-1}\right)$ à $58^{\circ} \mathrm{C}$ na tensão de $100 \mathrm{~Pa}$ das misturas com PA85.

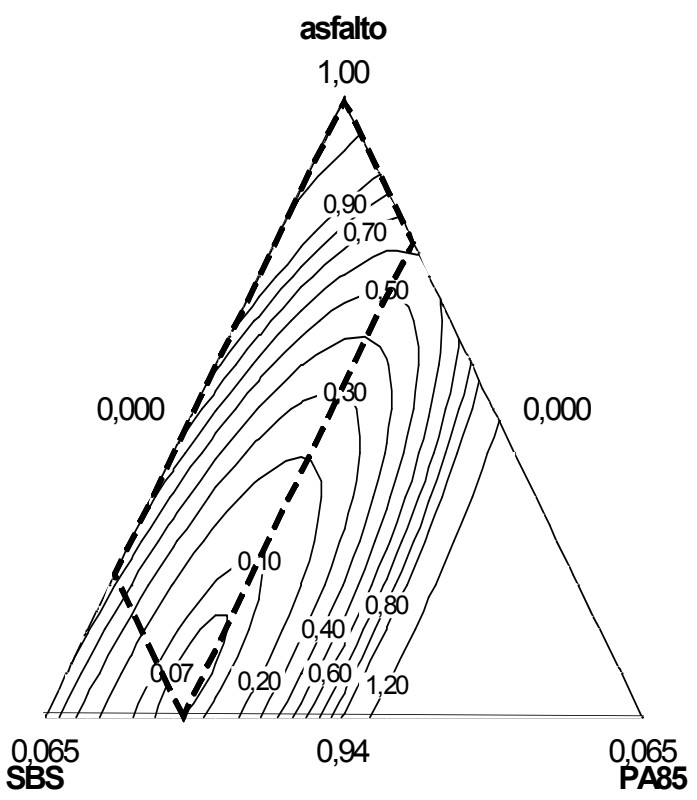

(a)

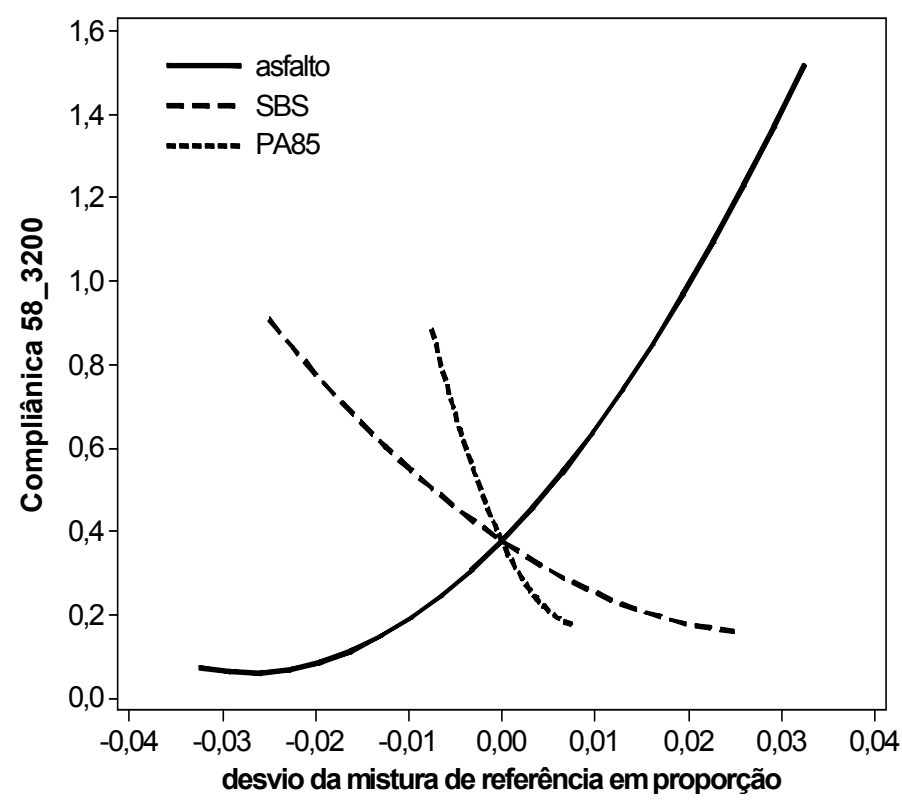

(b)

Figura 241 - Superfície de Resposta (a) e efeito de componentes (b) para a Compliância não recuperável $\left(\mathrm{kPa}^{-1}\right)$ à $58^{\circ} \mathrm{C}$ na tensão de $3200 \mathrm{~Pa}$ das misturas com PA85. 


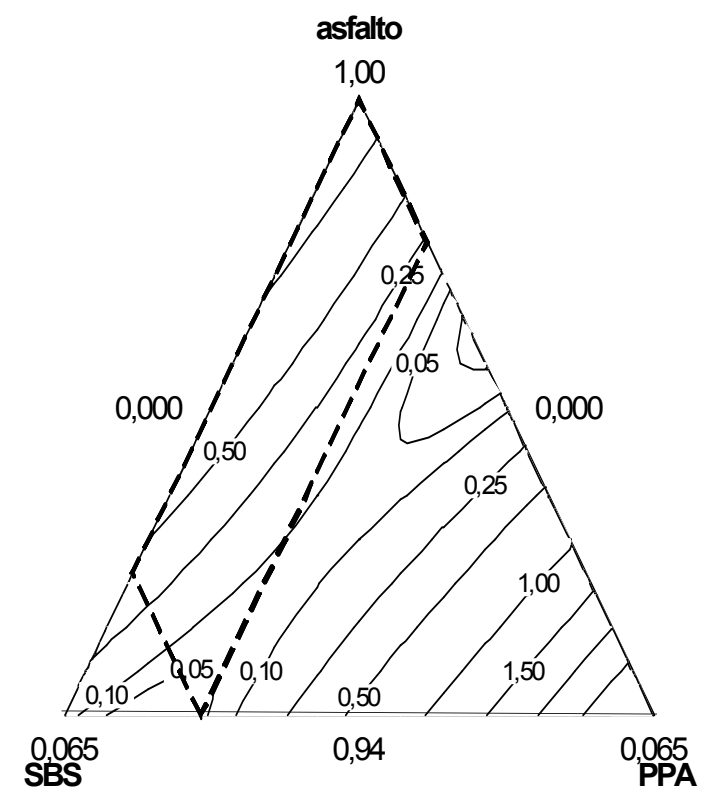

(a)

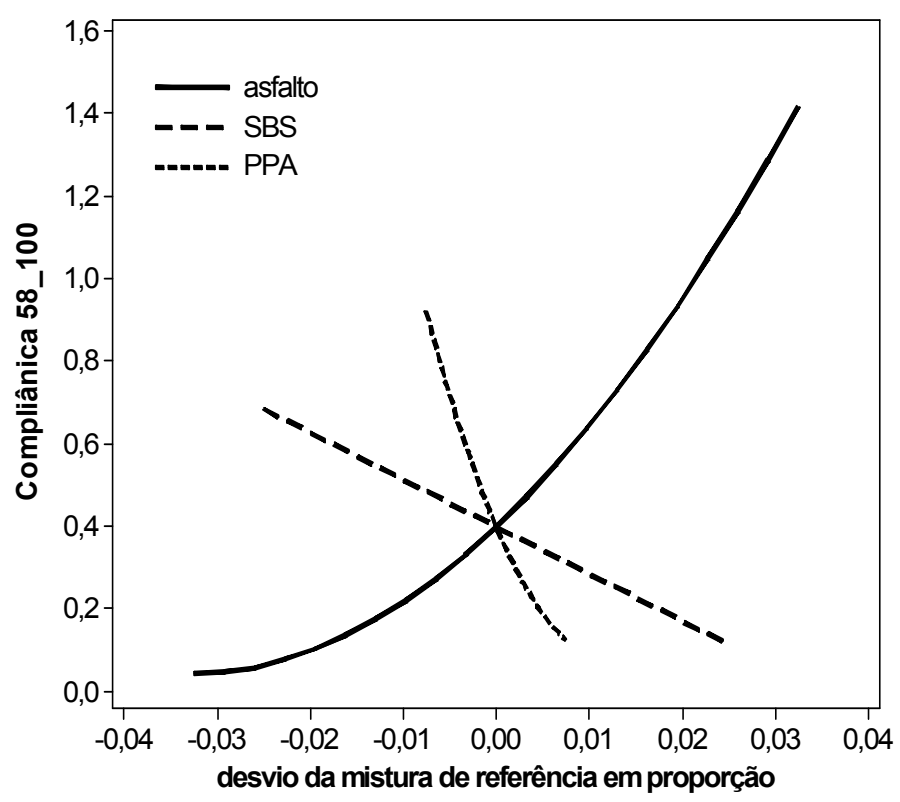

(b)

Figura 242 - Superfície de Resposta (a) e efeito de componentes (b) para a Compliância não recuperável $\left(\mathrm{kPa}^{-1}\right)$ à $58^{\circ} \mathrm{C}$ na tensão de 100PA das misturas com PPA.

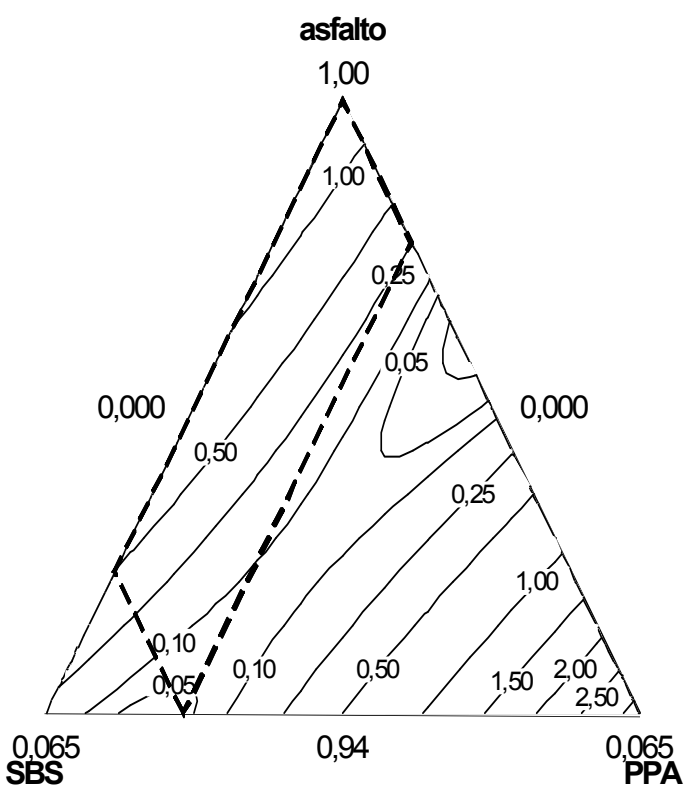

(a)

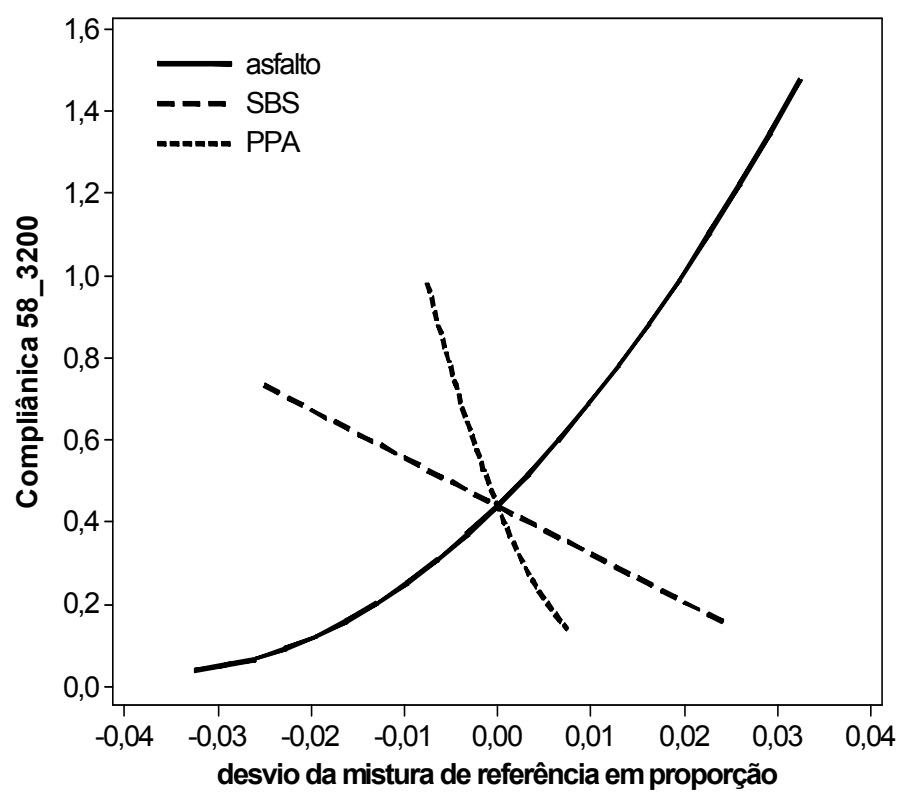

(b)

Figura 243 - Superfície de Resposta (a) e efeito de componentes (b) para a Compliância não recuperável $\left(\mathrm{kPa}^{-1}\right)$ à $58^{\circ} \mathrm{C}$ na tensão de $3200 \mathrm{PA}$ das misturas com PPA. 
Temperatura de $70^{\circ} \mathrm{C}$

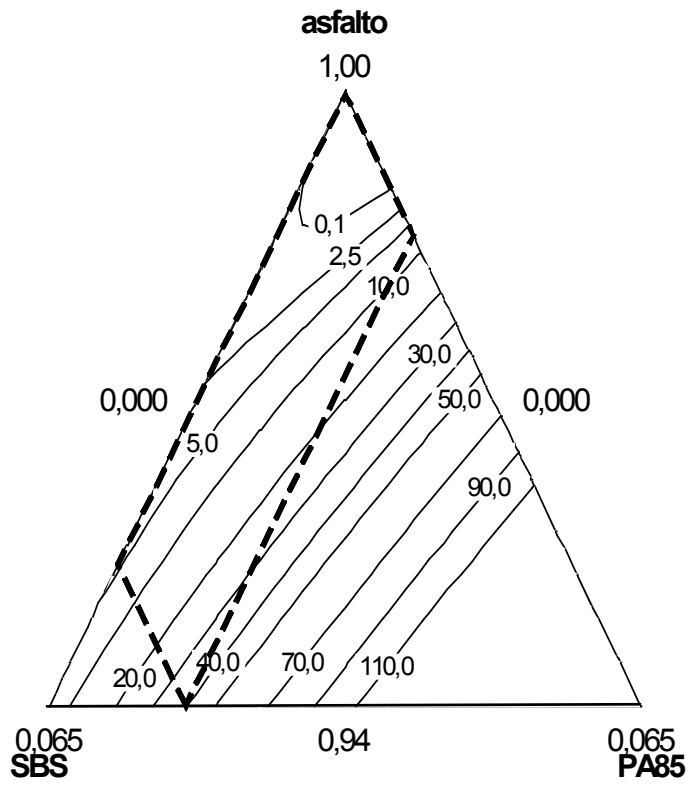

(a)

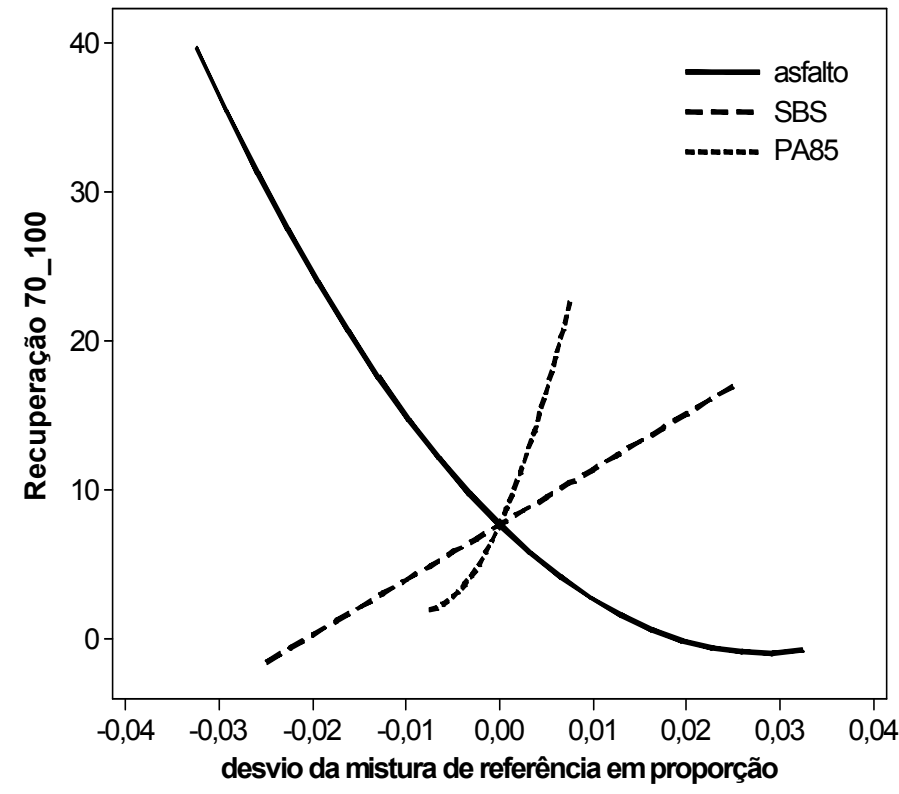

(b)

Figura 244 - Superfície de Resposta (a) e efeito de componentes (b) para a Recuperação (\%) à $70^{\circ} \mathrm{C}$ na tensão de 100PA das misturas com PA85.

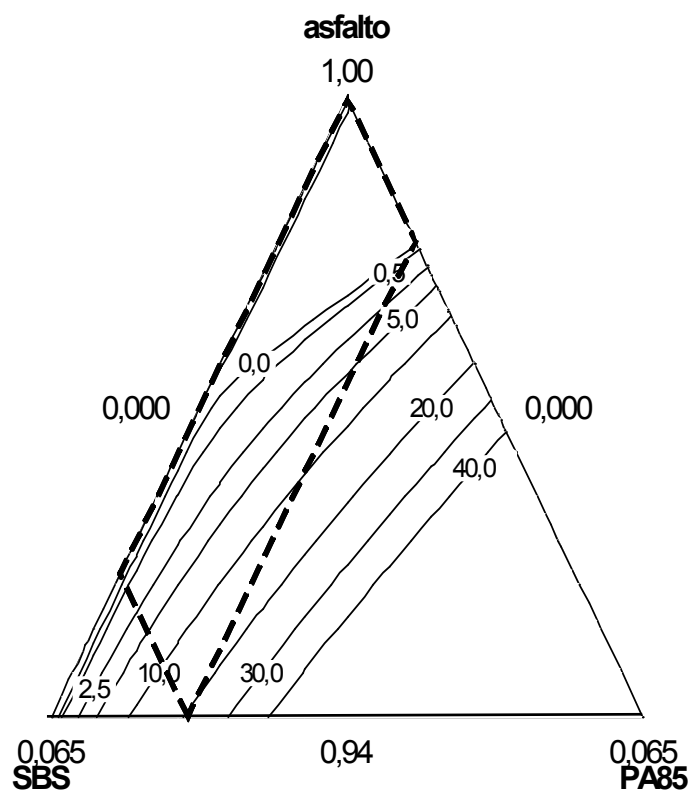

(a)

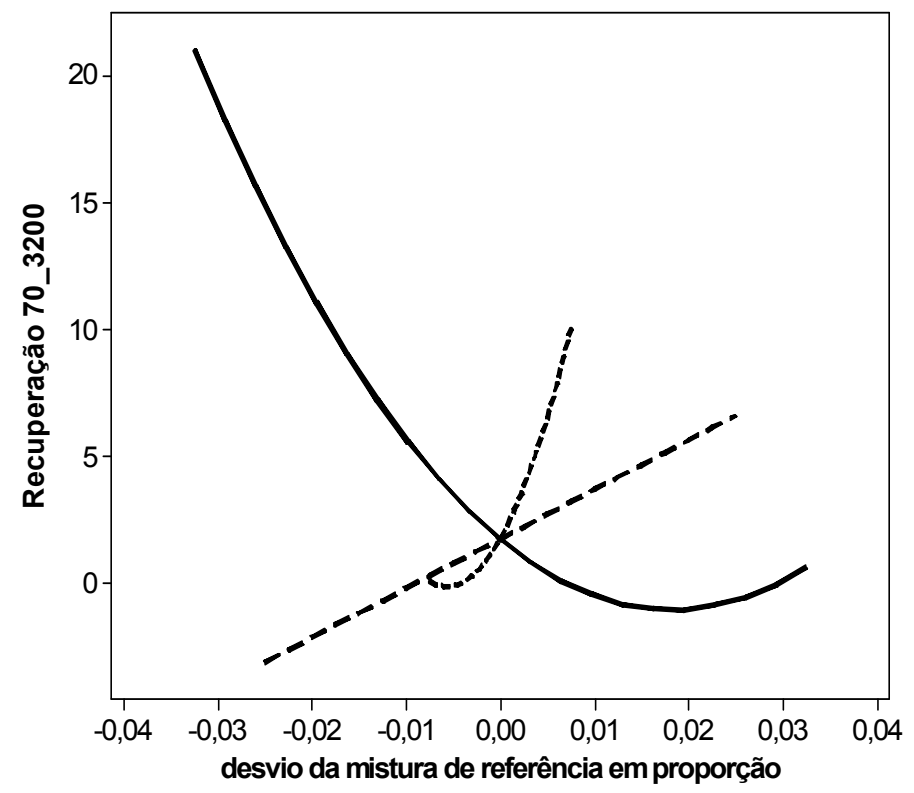

(b)

Figura 245 - Superfície de Resposta (a) e efeito de componentes (b) para a Recuperação (\%) à $70^{\circ} \mathrm{C}$ na tensão de 3200PA das misturas com PA85. 


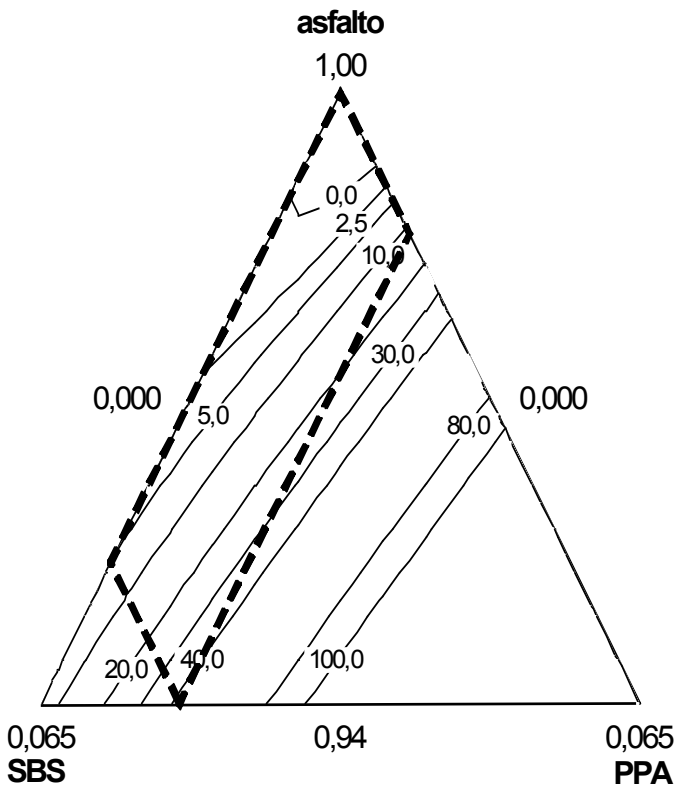

(a)

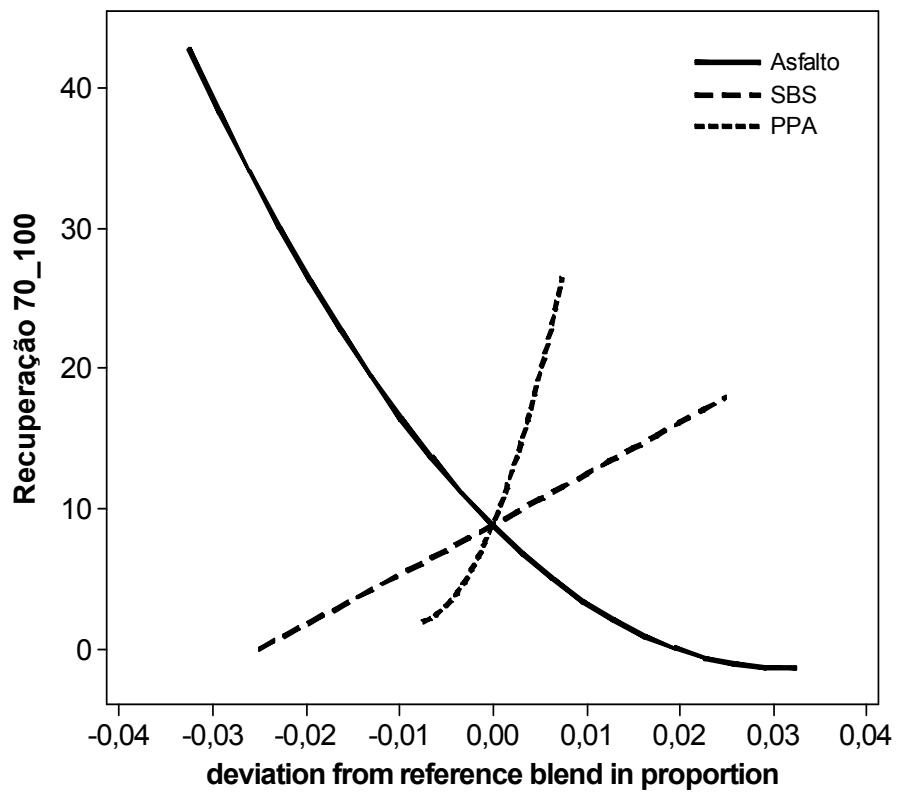

(b)

Figura 246 - Superfície de Resposta (a) e efeito de componentes (b) para a Recuperação (\%) à $70^{\circ} \mathrm{C}$ na tensão de 100PA das misturas com PPA.

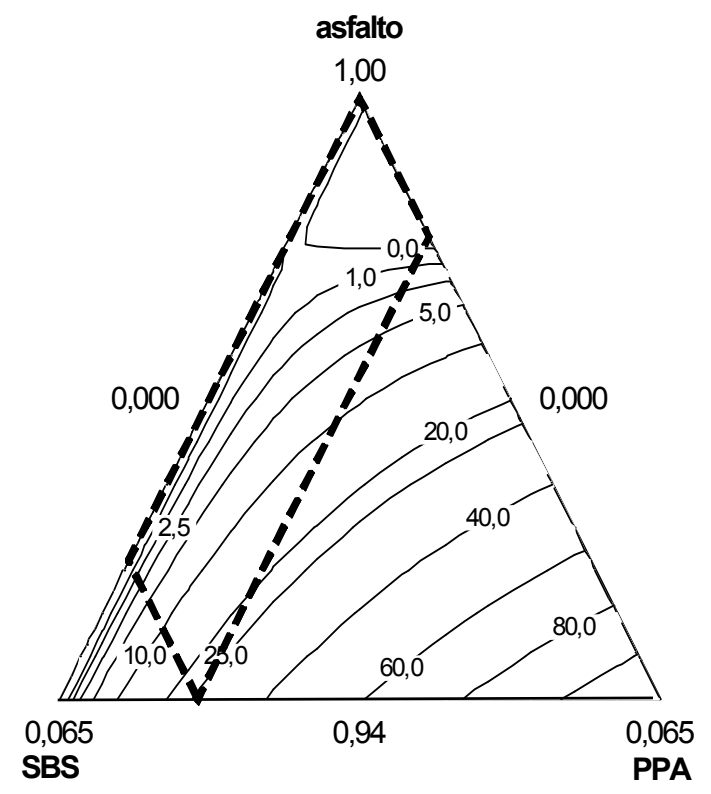

(a)

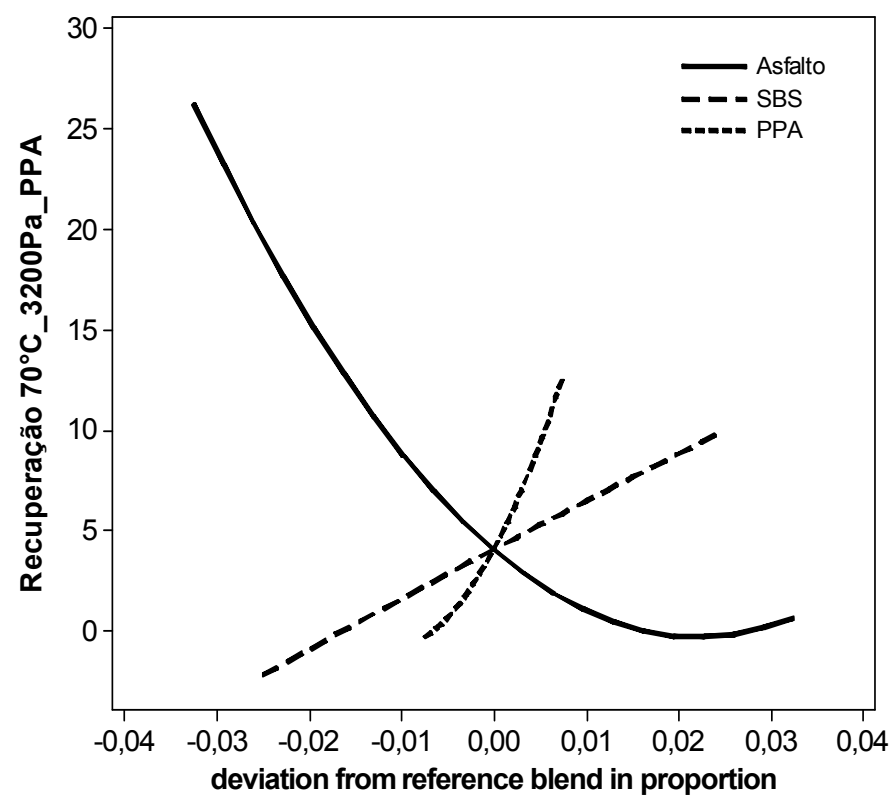

(b)

Figura 247 - Superfície de Resposta (a) e efeito de componentes (b) para a Recuperação (\%) à $70^{\circ} \mathrm{C}$ na tensão de 3200PA das misturas com PPA. 


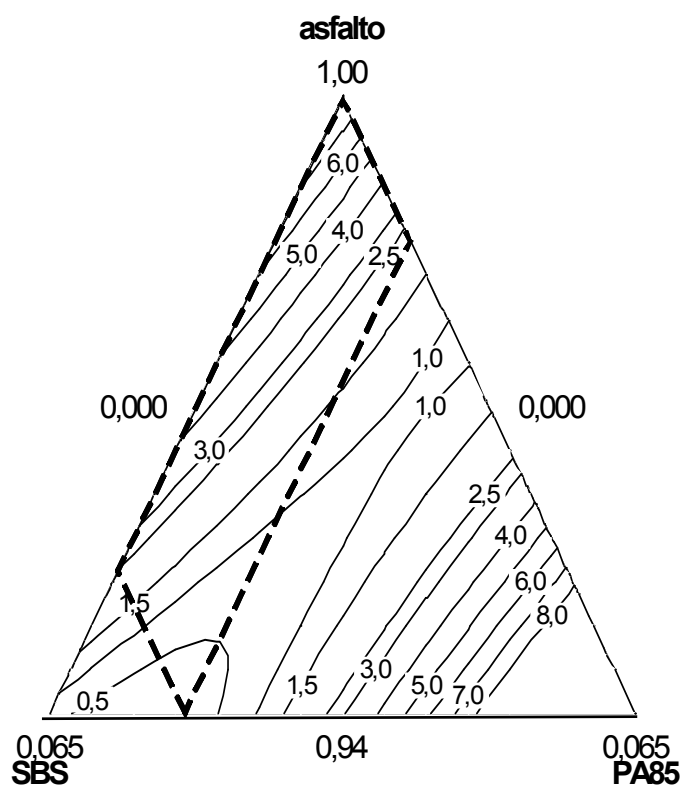

(a)

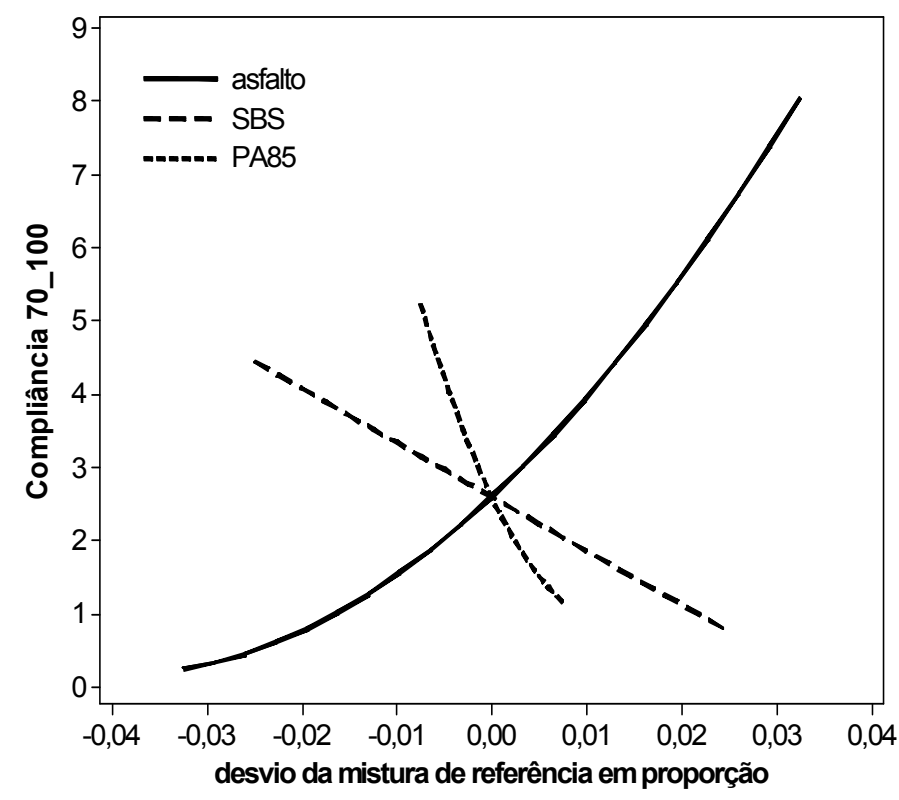

(b)

Figura 248 - Superfície de Resposta (a) e efeito de componentes (b) para a Compliância não recuperável $\left(\mathrm{kPa}^{-1}\right)$

à $70^{\circ} \mathrm{C}$ na tensão de $100 \mathrm{PA}$ das misturas com PA85.

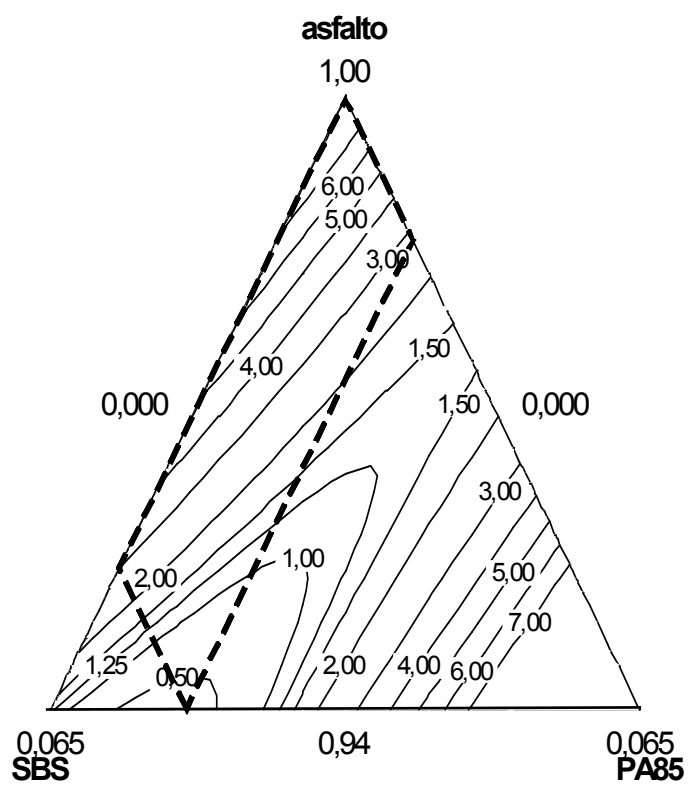

(a)

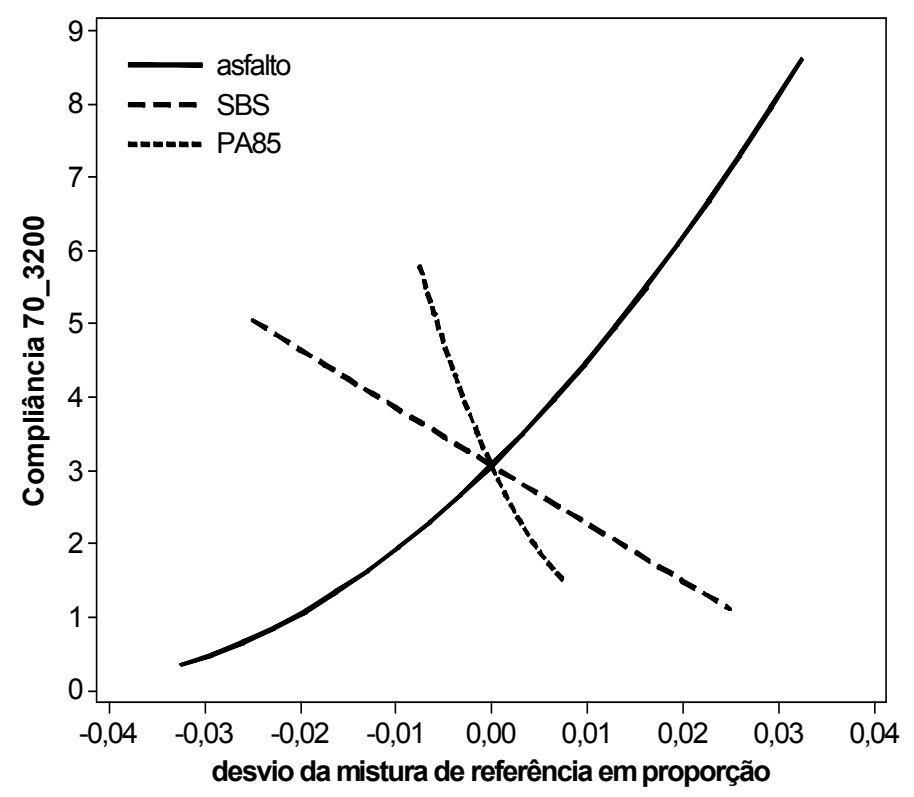

(b)

Figura 249 - Superfície de Resposta (a) e efeito de componentes (b) para a Compliância não recuperável $\left(\mathrm{kPa}^{-1}\right)$ à $70^{\circ} \mathrm{C}$ na tensão de $3200 \mathrm{PA}$ das misturas com PA85. 


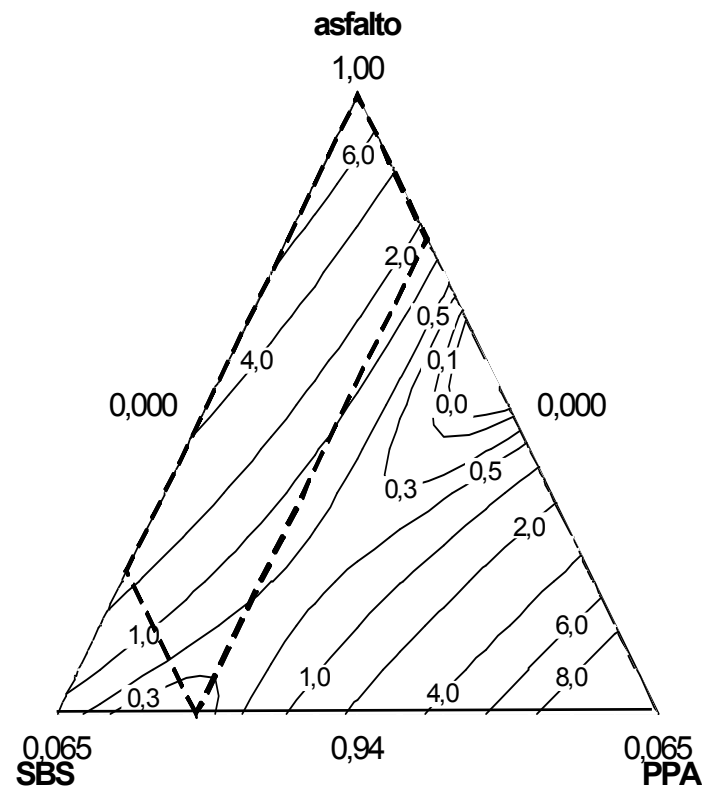

(a)

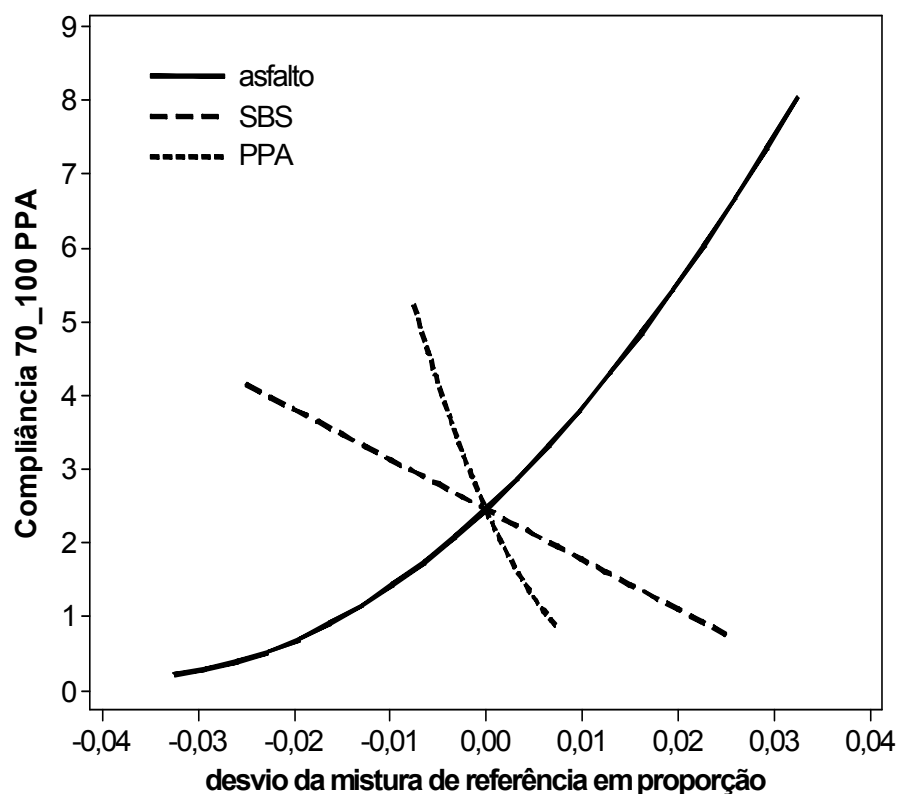

(b)

Figura 250 - Superfície de Resposta (a) e efeito de componentes (b) para a Compliância não recuperável $\left(\mathrm{kPa}^{-1}\right)$

à $70^{\circ} \mathrm{C}$ na tensão de 100PA das misturas com PPA.

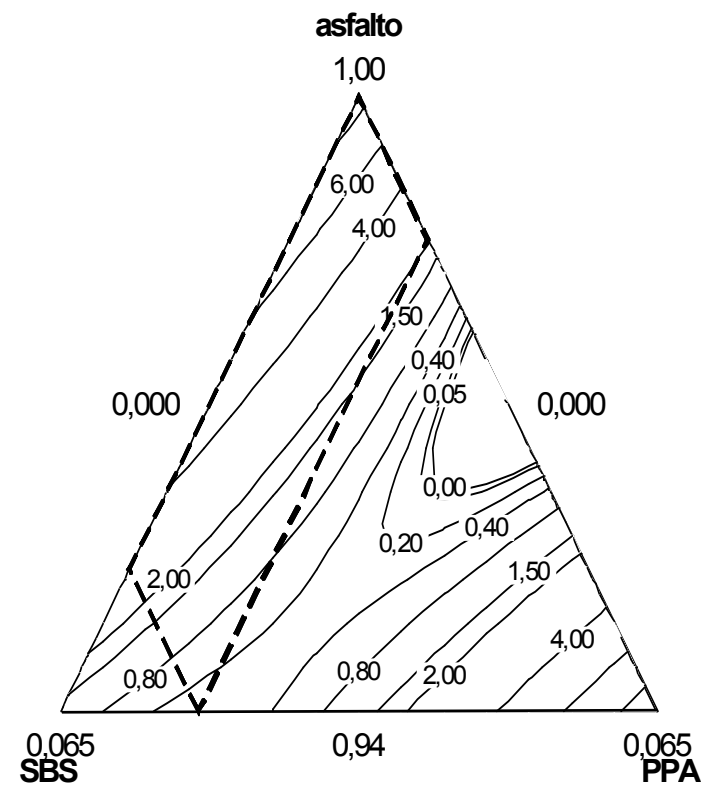

(a)

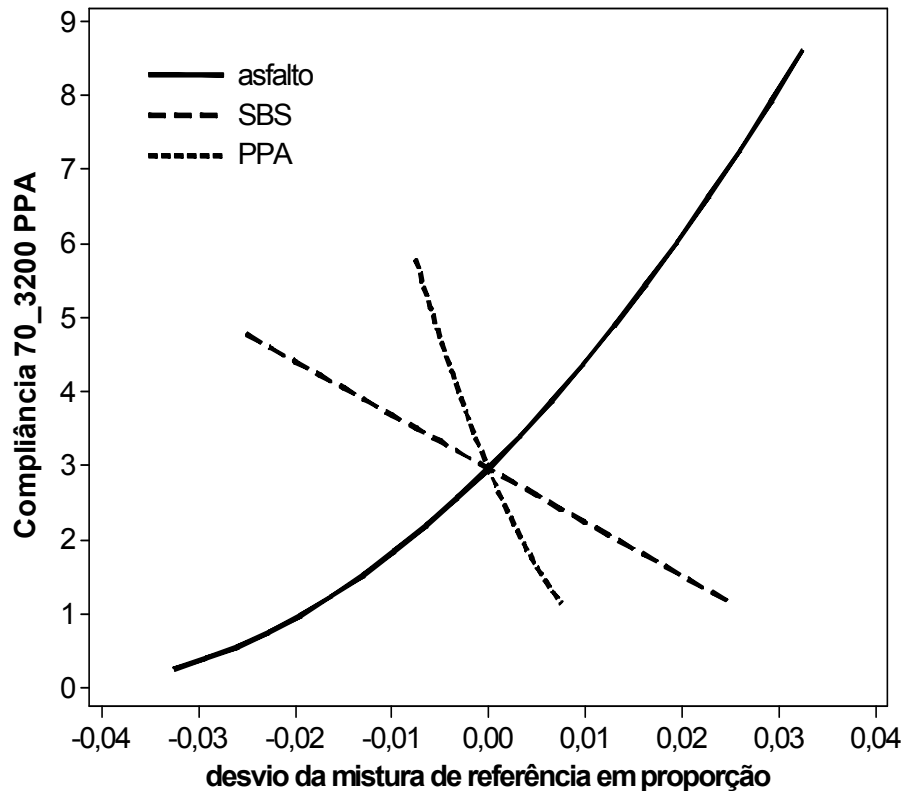

(b)

Figura 251 - Superfície de Resposta (a) e efeito de componentes (b) para a Compliância não recuperável $\left(\mathrm{kPa}^{-1}\right)$ à $70^{\circ} \mathrm{C}$ na tensão de $3200 \mathrm{PA}$ das misturas com PPA. 


\section{Temperatura de $76^{\circ} \mathrm{C}$}

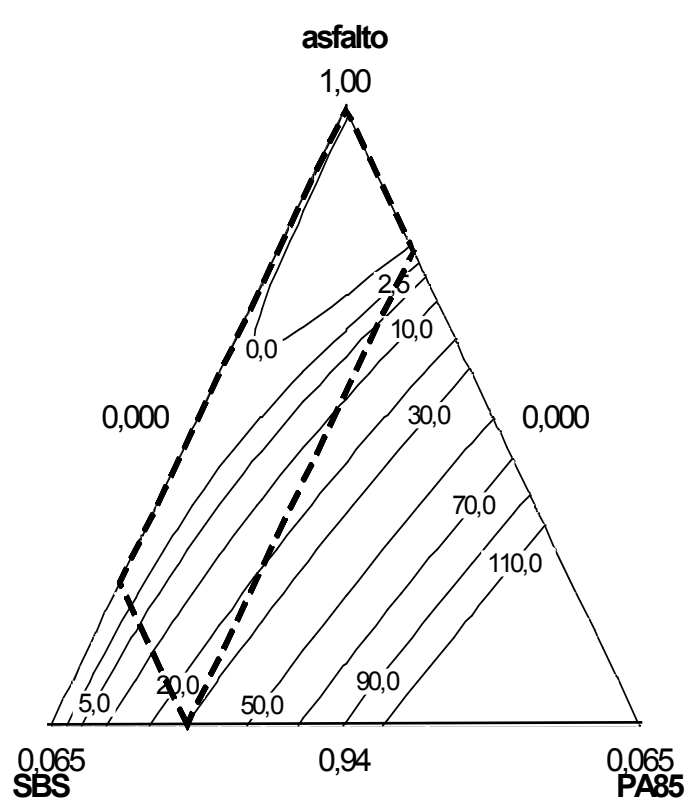

(a)

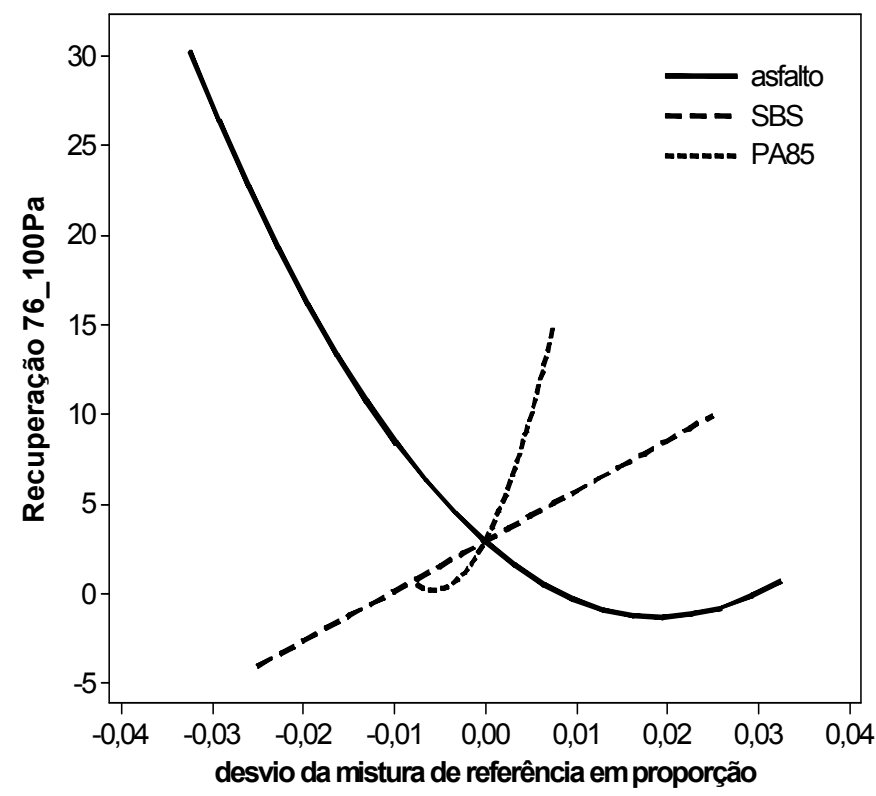

(b)

Figura 252 - Superfície de Resposta (a) e efeito de componentes (b) para a Recuperação (\%) à $76^{\circ} \mathrm{C}$ na tensão de 100PA das misturas com PA85.

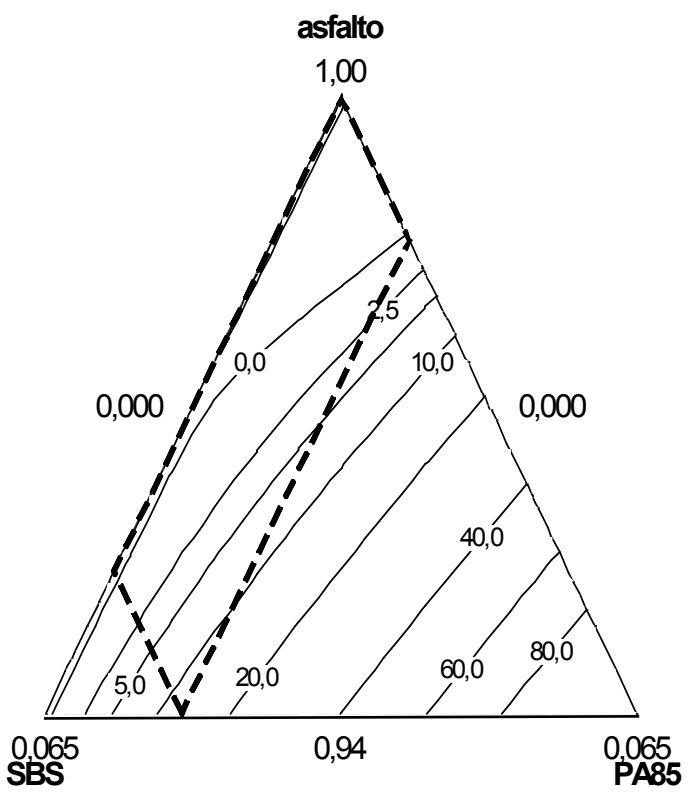

(a)

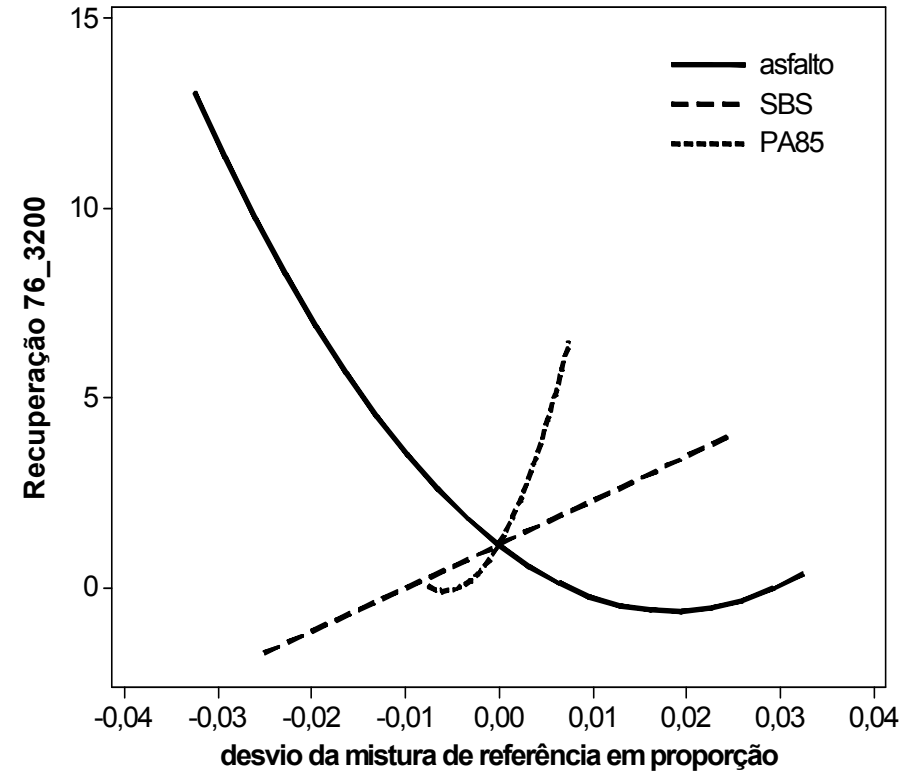

(b)

Figura 253 - Superfície de Resposta (a) e efeito de componentes (b) para a Recuperação (\%) à $76^{\circ} \mathrm{C}$ na tensão de 3200PA das misturas com PA85. 


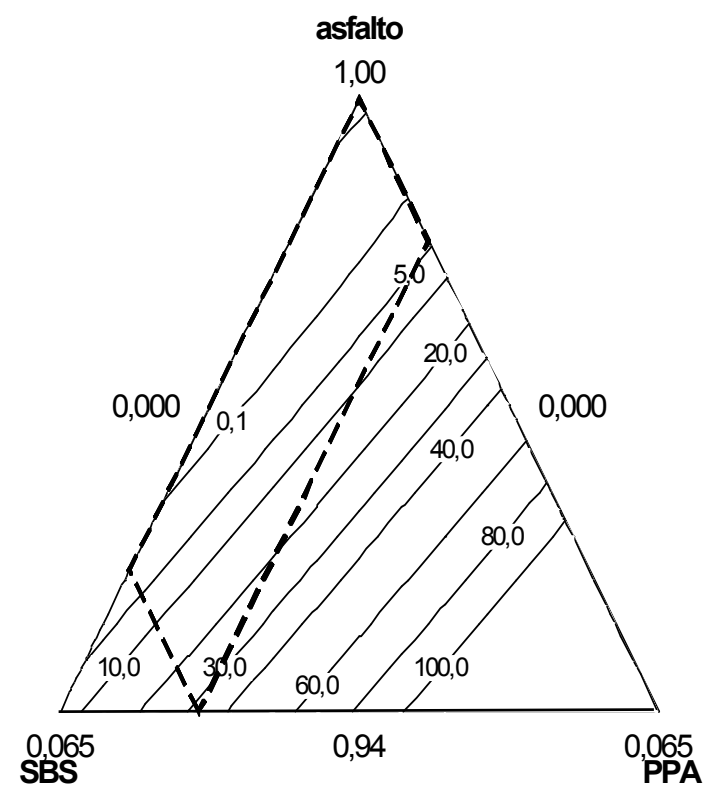

(a)

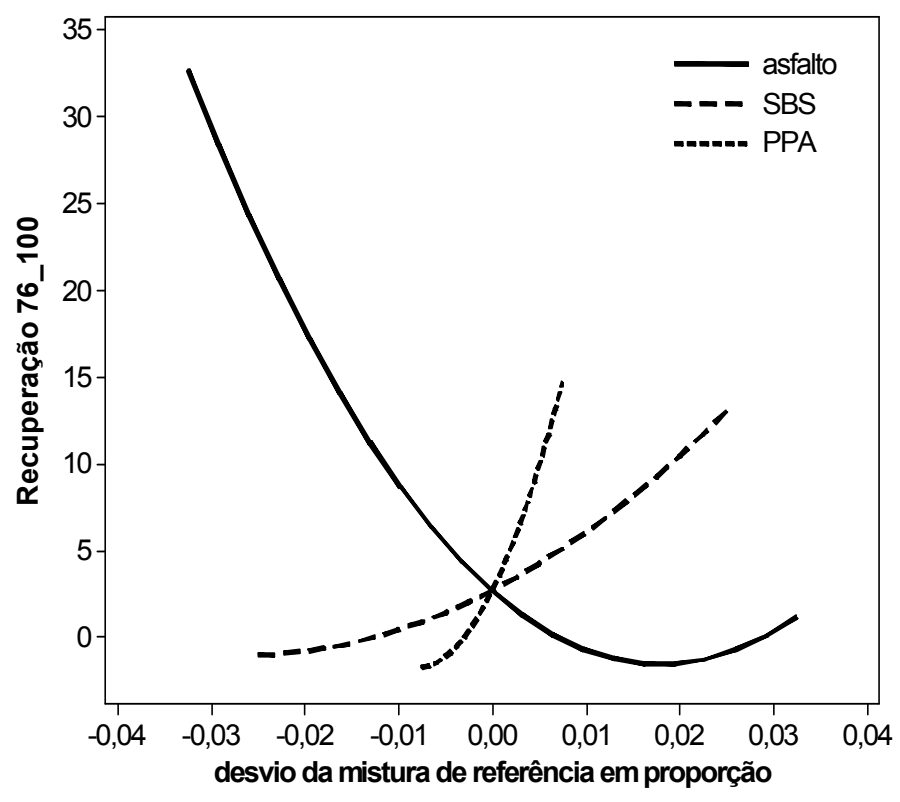

(b)

Figura 254 - Superfície de Resposta (a) e efeito de componentes (b) para a Recuperação (\%) à $76^{\circ} \mathrm{C}$ na tensão de 100PA das misturas com PPA.

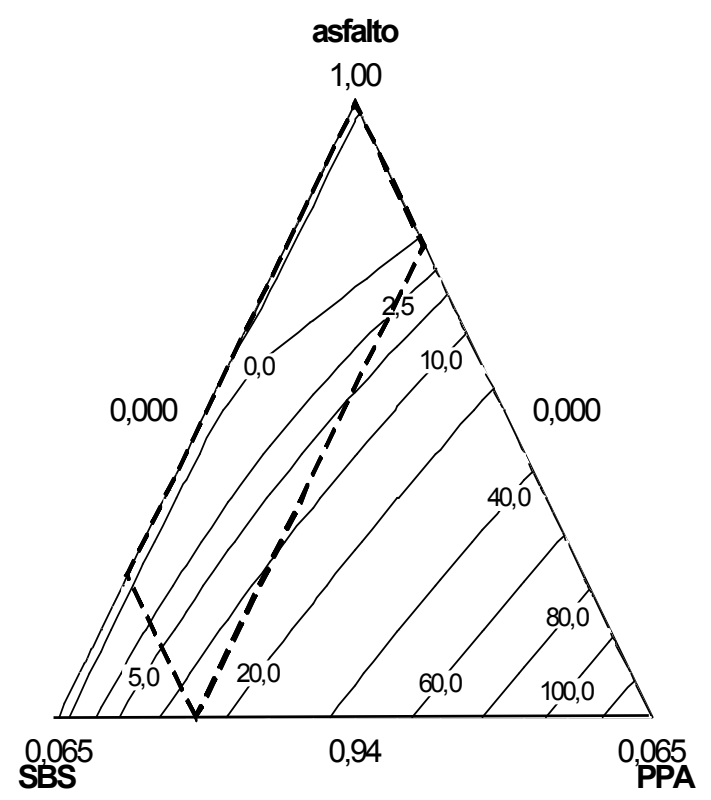

(a)

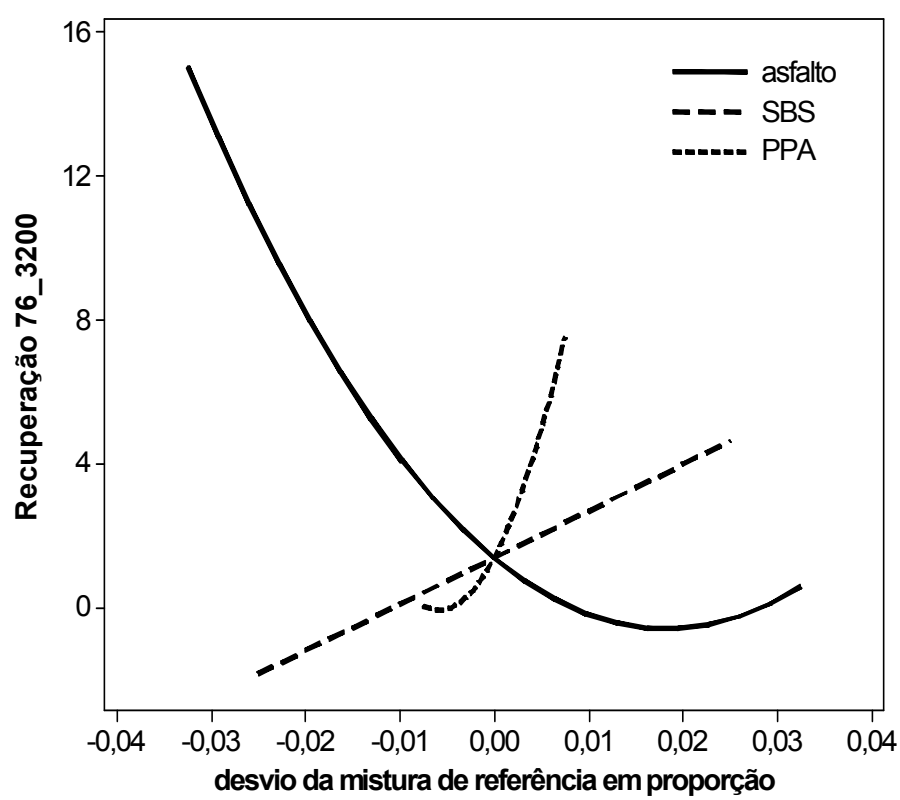

(b)

Figura 255 - Superfície de Resposta (a) e efeito de componentes (b) para a Recuperação (\%) à $76^{\circ} \mathrm{C}$ na tensão de 3200PA das misturas com PPA. 


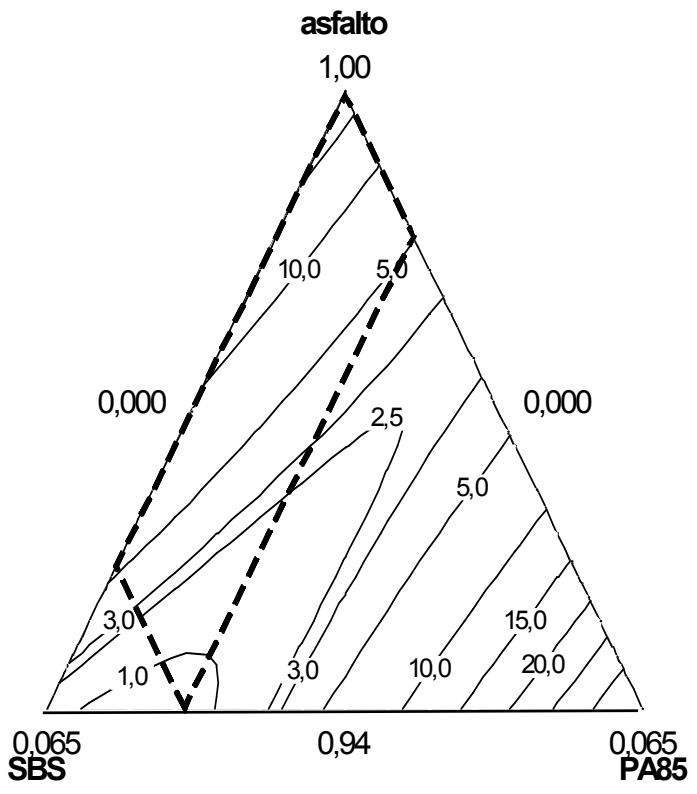

(a)

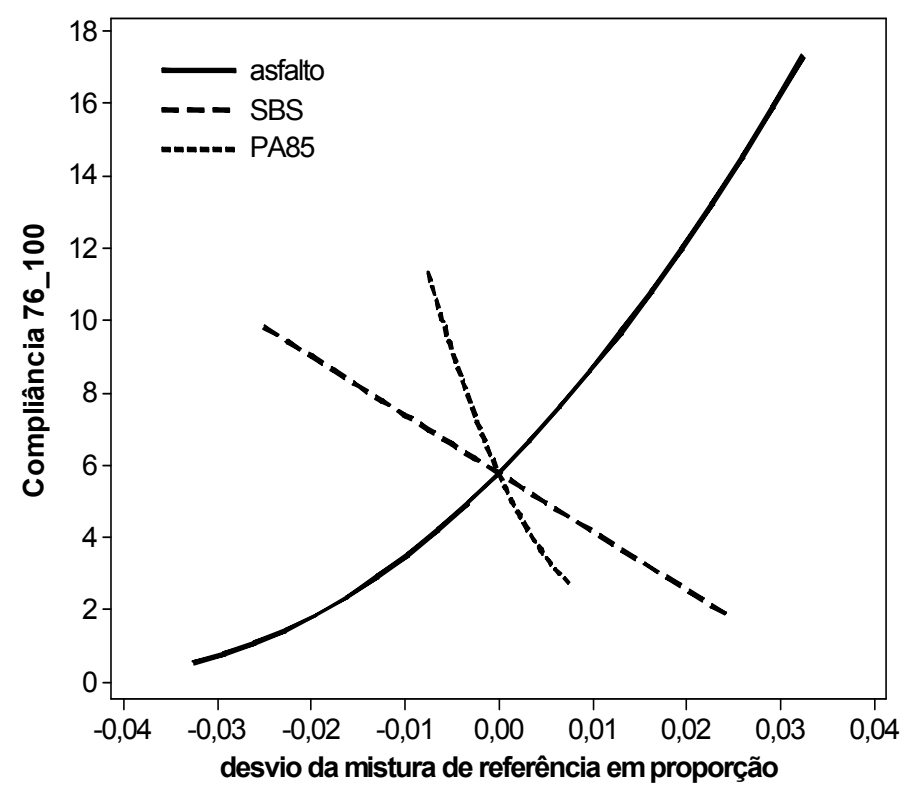

(b)

Figura 256 - Superfície de Resposta (a) e efeito de componentes (b) para a Compliância não recuperável $\left(\mathrm{KPa}^{-1}\right)$ à $76^{\circ} \mathrm{C}$ na tensão de $100 \mathrm{PA}$ das misturas com PA85.

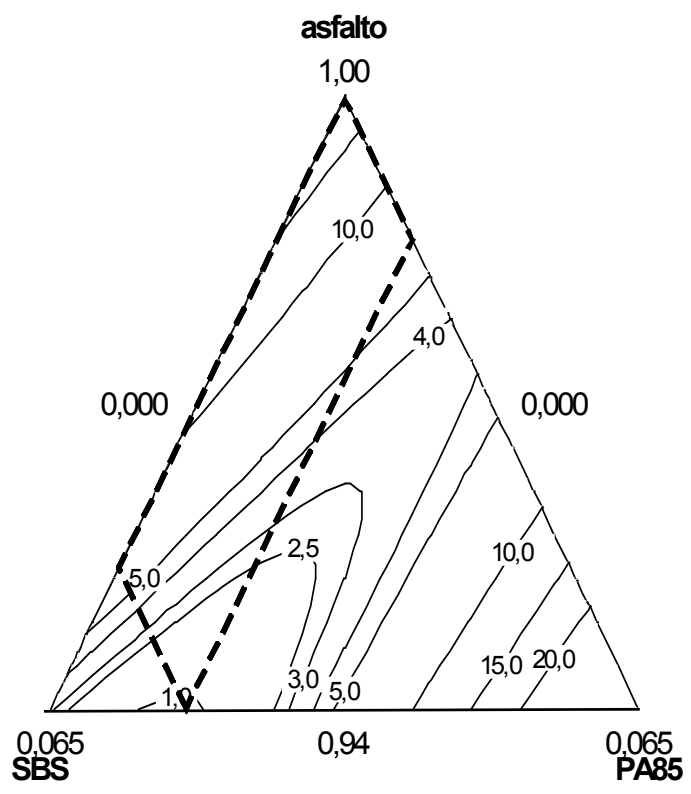

(a)

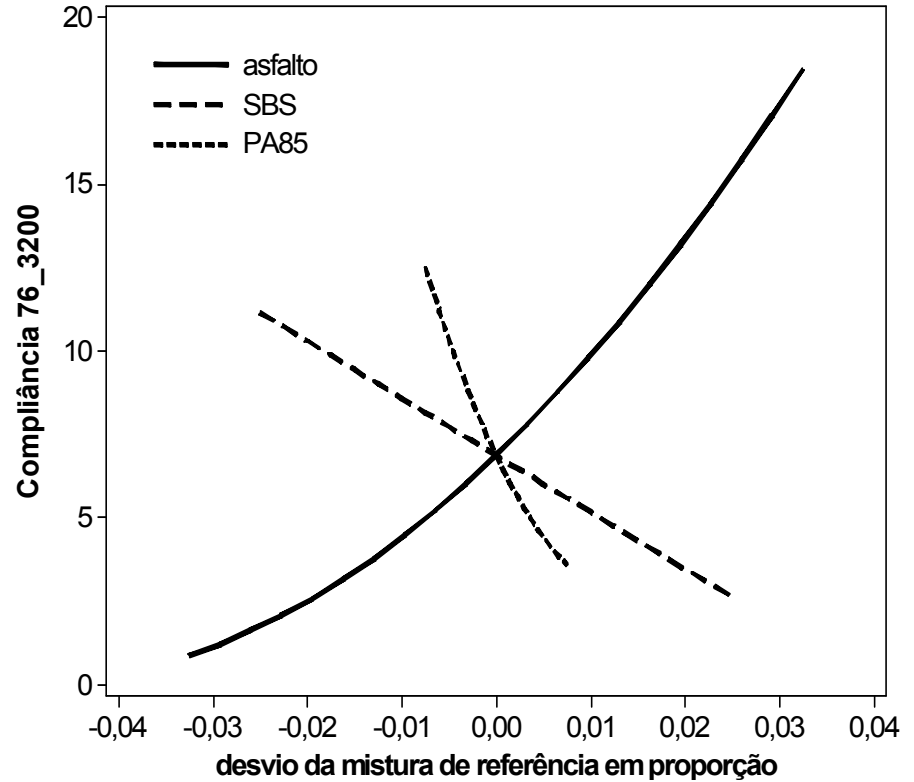

(b)

Figura 257 - Superfície de Resposta (a) e efeito de componentes (b) para a Compliância não recuperável $\left(\mathrm{kPa}^{-1}\right)$ à $76^{\circ} \mathrm{C}$ na tensão de 3200PA das misturas com PA85. 


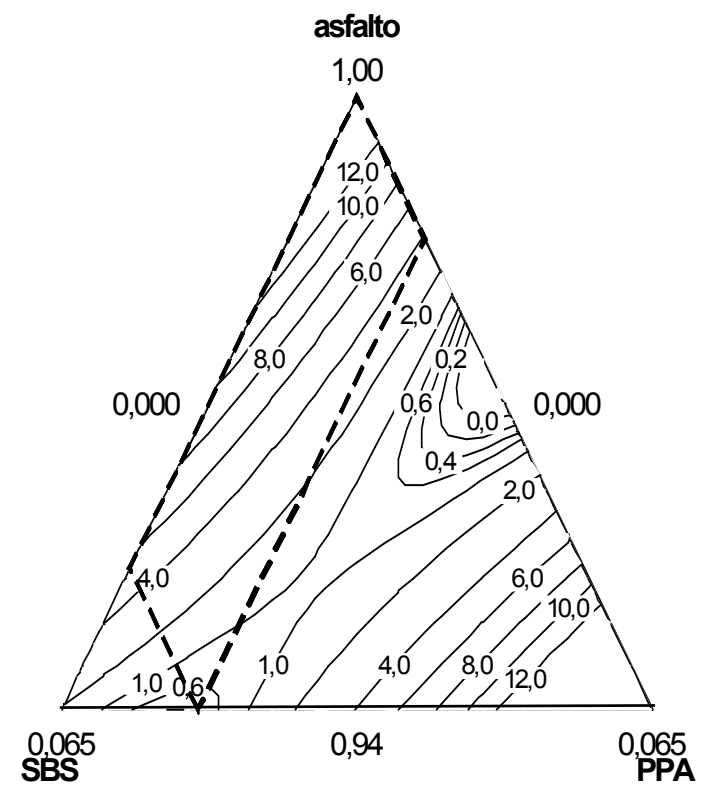

(a)

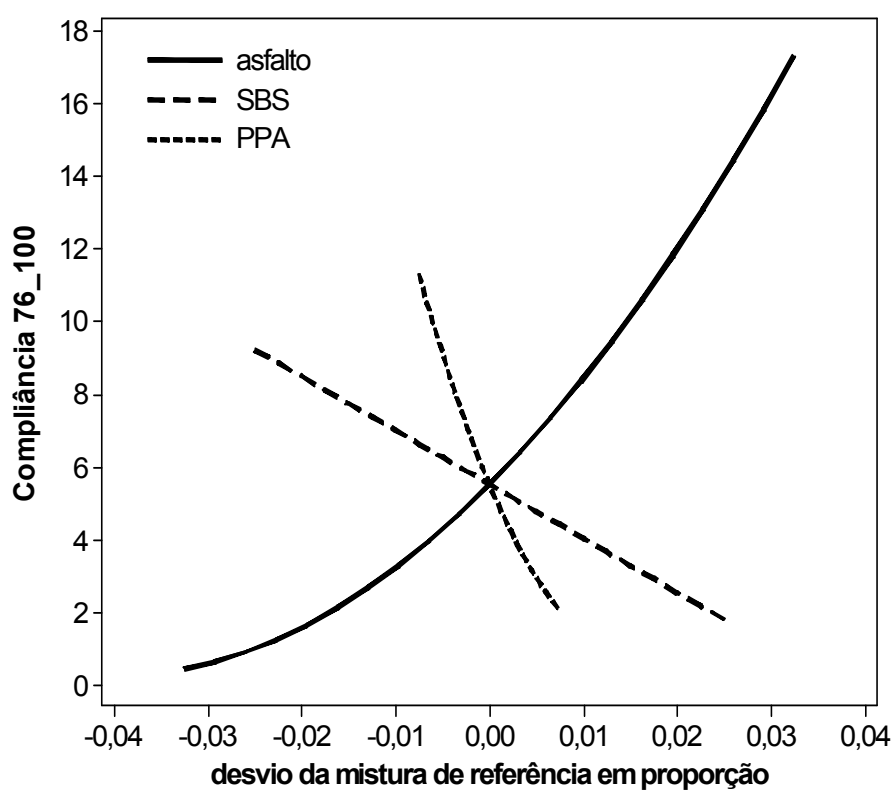

(b)

Figura 258 - Superfície de Resposta (a) e efeito de componentes (b) para a Compliância não recuperável $\left(\mathrm{kPa}^{-1}\right)$ à $76^{\circ} \mathrm{C}$ na tensão de 100PA das misturas com PPA.

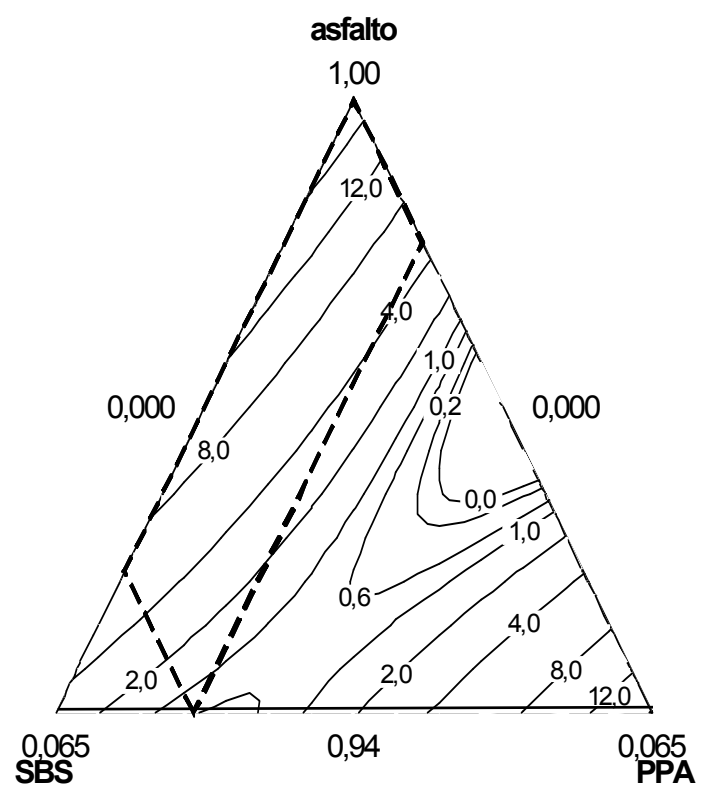

(a)

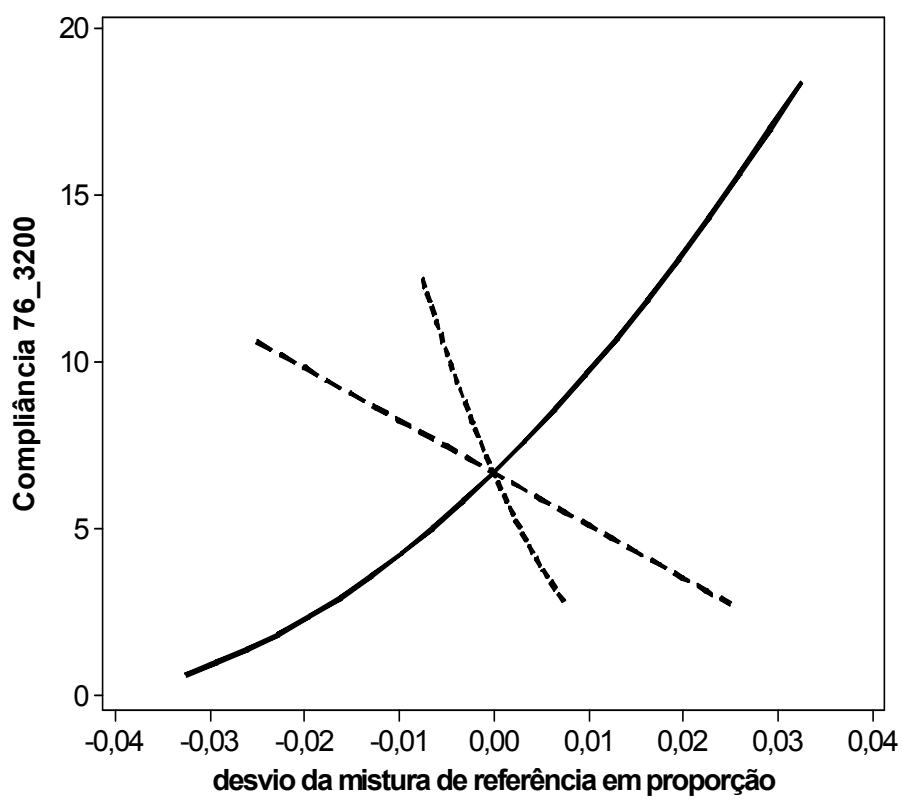

(b)

Figura 259 - Superfície de Resposta (a) e efeito de componentes (b) para a Compliância não recuperável $\left(\mathrm{kPa}^{-1}\right)$ à $76^{\circ} \mathrm{C}$ na tensão de $3200 \mathrm{PA}$ das misturas com PPA. 